

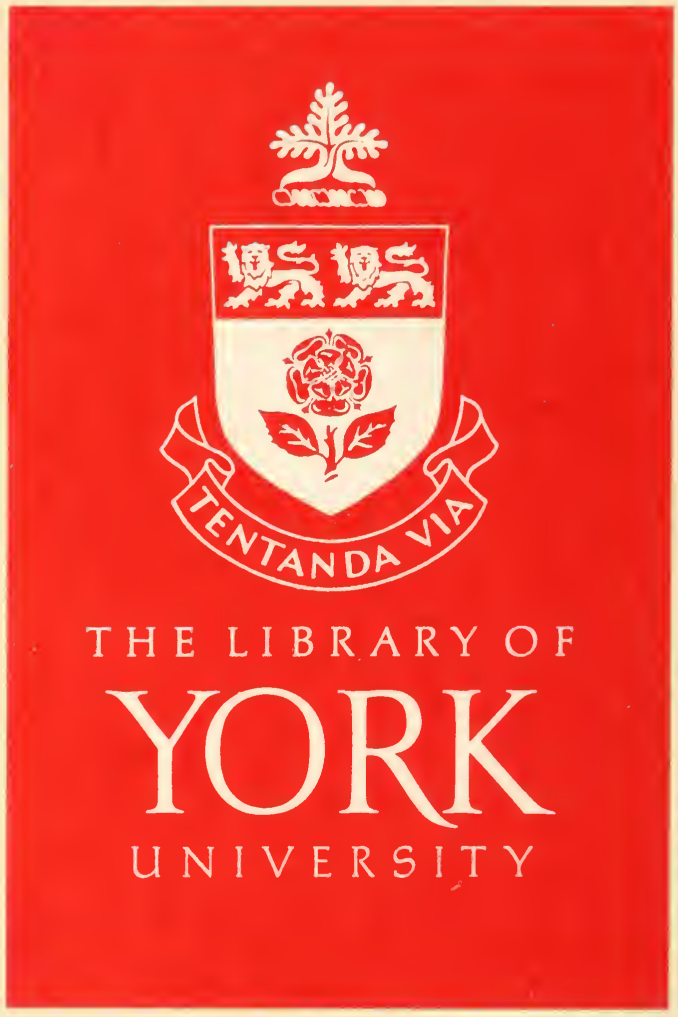


Date Due

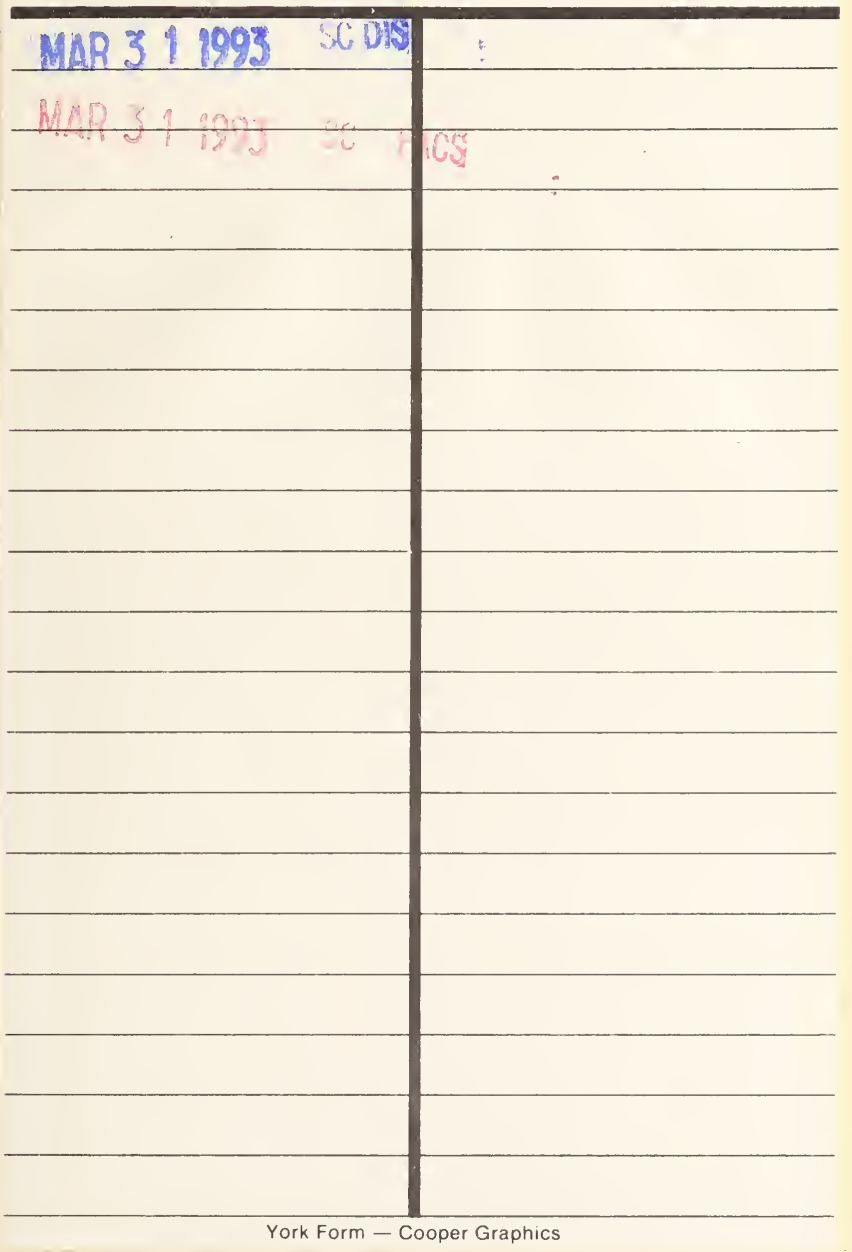


Digitized by the Internet Archive in 2014 



\title{
THE PLEISTOCENE OF THE MIDDLE REGION OF NORTH AMERIGA AND ITS VERTEBRATED ANIMALS
}

\author{
$\mathrm{BY}$ \\ OLIVER P. HAY \\ Associate of the Carnegie Institution of Washington
}

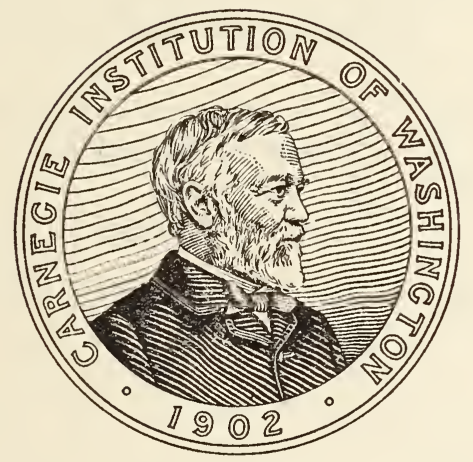

Published by the Carnegie Institution of Washington Washington, OCtoBer, 1924 


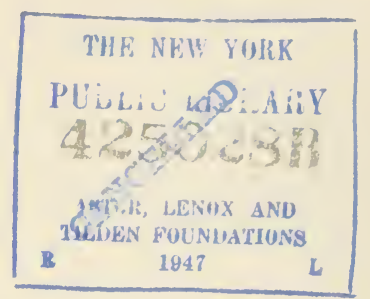

CARNEGIE INSTITUTION OF WASHINGTON Publication No. 322 a

\section{Copies of this book first icciad OCT 151924}




\section{CONTENTS}

Finds of Xenarthra in middle region of North America...... 1-9

Iouisiana .............. 1

Texas ................. 1

Oklahoma ............. 4

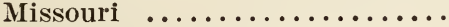

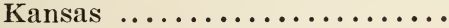

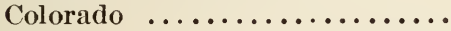

Iowa $\ldots \ldots \ldots \ldots \ldots \ldots \ldots \ldots$

Nebraska ...............

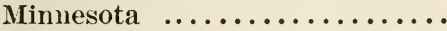

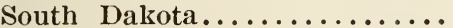

Finds of mastodons in middle region of North America..... 10-46

Louisiana ............... 10

Texas .................. 12

Arkansas .............. 22

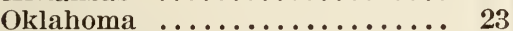

New Mexico.............. 24

Missouri ............... 24

Kansas ................ 33

Colorado ............... 35

Iowa .................. 36

Nebraska .............. 43

Mimmesota .............. 44

South Dakota............. 45

Montana ............... 46

Finds of Elephas boreas in middle region of North America 47-56

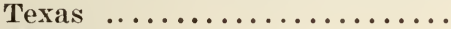

Missouri ............... 47

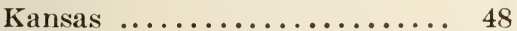

Iowa ................ 49

Nebraska .............. 55

Mimnesota .............. 56

Finds of Elephas columbi in middle

I Louisiana

region of North America 57-84

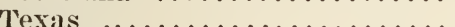

Oklahoma $\ldots \ldots \ldots \ldots \ldots \ldots \ldots \ldots 66{ }_{6}$

New Mexico.............6 67

Missouri . . . . . . . . . . . 69

Kansas ................ 69

Colorado ............... 72

Iowa ................ 74

Nebraska .............. 78

Wyoming .............. 81

South Dakota............ 82

Montana ............... 83

Alberta ................. $8 t$

Saskatchewan .............. 84

Finds of Elephas imperator in middle region of North America ............. 85-101

Texas ................. 85

Oklahoma .............. 94

Kansas ............... 95

Colorado ............... 96

Iowa $\ldots \ldots \ldots \ldots \ldots \ldots \ldots \ldots \ldots . \ldots 9$

Nebraska .............. 98

Wyoming ................ 101

Montana ................ 101
Finds of undetermined species of elephants in middle region of North America... 102-121

Louisiana ................ 102

Texas ................ 102

Oklahoma ................ 108

New Mexico.............. 108

Missouri ............... 109

Kansas ................ 110

Colorado ................ 111

Iowa $\ldots \ldots \ldots \ldots \ldots \ldots \ldots \ldots \ldots . \ldots \ldots$

Nebraska ............... 117

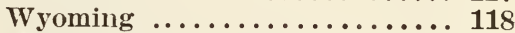

Minnesota .............. 118

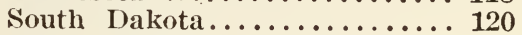

North Dakota............ 120

Montana ............... 120

Saskatchewan ............ 121

Alberta ................. 121

Melville Island, Franklin....... 121

Finds of Equidx in middle region of North America...... 122-154

Iouisiana ................ 122

Texas ................. 123

Arkansas ............... 134

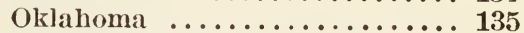

New Mexico.............. 137

Missouri ................ 137

Kansas ................ 140

Colorado ............... 143

Iowa ................... 145

Nebraska ............... 150

Wyoming ............... 152

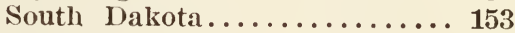

Montana ...............153

Alberta .................. 15

Manitoba ................. 154

Finds of Tapirida in middle region of North America.... 155-156

Louisiana ............... 155

Texas ................. 155

Oklahoma .................. 156

Finds of peccaries, Tagassuida, in middle region of North America ......... 157-159

Texas ................ 157

Arkansas .............. 157

Missouri ................ 157

Kansas .................. 157

Iowa $\ldots \ldots \ldots \ldots \ldots \ldots \ldots \ldots \ldots$

Nebraska ................ 159

Finds of camels, Camelidae, in middle region of North America ............. 161-169

Texas ................ 161

Oklahoma ............... 163

New Mexico................ 164

Missouri .............. 164

Kansas ................... 165

Colorado ................ 166

Iowa $\ldots \ldots \ldots \ldots \ldots \ldots \ldots \ldots \ldots$

Nebraska .............. 168 
Finds of camels, Camclidae. in mirldle region of North America-continued.

Soutl Inikota.............. 169

Montana ............... 16!)

Finds of deer, Odocoileus, in midlle region of North Amerieal ........... 170-171

Inolisiana .............. 170

Texas ................ 170

Arkansas ................ 170

Oklahomil .............. 170

Missouri ................ 171

Kansas ................ 171

Iowa .................... 171

Finds of the wapiti, Cervus, in midlle region of North America ............ 173-17t

Arkansas ............. 173

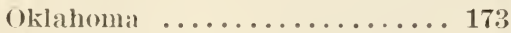

Missouli .............. 173

Kilnsas ................ 173

Iowa $\ldots \ldots \ldots \ldots \ldots \ldots \ldots \ldots \ldots$

Finds of reindeer, Rangifer, in middle region of North Americat ........... 176-177

Iowa $\ldots \ldots \ldots \ldots \ldots \ldots \ldots \ldots \ldots \ldots$

Minnesota ............. 177

Finds of musk-oxen, ovibovina, in midllle region of North America .......... 17S-185

Arkansas ............. 178

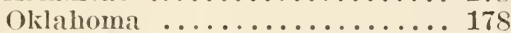

New Mexico.............. 179

Missouri ............... 179

Kausas .................... 181

Colorado ................ 182

Iowa ................. 182

Nebraska .............. 18t

Minmesota ............... 185

Alberta ................ 185

Finds of extinct species of bison in middle region of North America .......... 186-200

Louisiand ............. 186

Texas ................. 186

Oklahoma ............... 19n

Missouri ................. 191

Kilnsas . . . . . . . . . . 192

Colorado ............... 19.
Finds of extinct species of bison in midale region of North America-Continued.

Iowa .................. 196

Nebraska ............... 198

Minnesota ................. 199

Manitoba ............... 200

Finds of Bison bison in midale region of North America 201-209

Texas ................. 201

Oklalıma .............. 203

Missouri ................. 203

Kansas ................. 203

Colorado .................. 204

Iowa .................. 204

Nebraska ............... 207

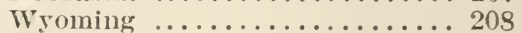

Minmesota ................ 208

South Dakota............. 209

Alberta .................. 209

Finds of the giant beaver, Castoroides, in middle region of North America... 210-212

Texas ................. 210

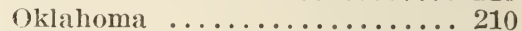

Kansas ................ 210

Iowa ................... 210

Nebraska ................ 211

Minnesota ............... 212

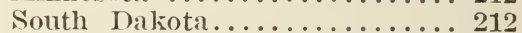

The Pleistocene of the middle region of North America and the rertebrate remains occurring in it........213-317

Iouisiana .............. 212

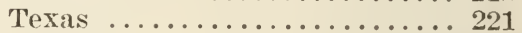

Arkansas ............... 249

Oklahoma ................ 253

New Mexico................ 256

Missouri .............. 259

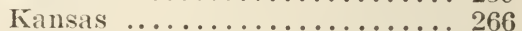

Colorado ................. 271

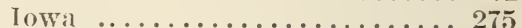

Nebriskat ............... 301

Wyoming ............... 305

Minnesota ................. 306

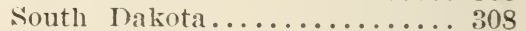

North Dakota............. 310

Montana ................... 311

Manitoba, Saskatchewan, Alberta ................ 313 


\section{ILLUSTRATIONS}

\section{Plates}

MaP 1. Pleistocene Xenarthra in middle region of North America.

2. Pleistocene mastodons in middle region of North America.

3. Pleistocene mastodons in Texas.

4. Pleistocene mastodons in Iowa.

5. Elephas boreus in middle region of North America.

6. Elephas boreus in Iowa.

7. Elephas columbi in middle region of North America.

8. Elephas columbi in Texas.

9. Elephas columbi in Iowa.

10. Elephas imperator in middle region of North America.

11. Elephas imperator in Texas.

12. Elephas sp. indet. in middle region of North America.

13. Elephas sp. indet. in Texas.

14. Elephas sp. indet. in Iowa.

15. Pleistocene horses in middle region of North America.

16. Pleistocene horses in Texas.

17. Pleistocene horses in Iowa.
MaP 18. Pleistocene tapirs in middle region of North America.

19. Pleistocene peccaries in middle region of North America.

20. Pleistocene camels in middle region of North America.

21. Pleistocene species of deer, Odocoileus, in North America.

22. Pleistocene reindeer, Rangifer, in middle region of North America.

23. Pleistocene deer, Cervus, in middle region.

24. Pleistocene musk-oxen in middle region of North America.

25. Extinct bisons in middle region of North America.

26. The existing bison in middle region of North America.

27. Giant beaver, Castoroides, in middle region of North America.

28. Geological map of Louisiana.

29. Glacial map of Minnesota.

\section{Text-Figures}

Fig. 1. Geological section in Louisiana.......................... 214

2. Geological section across Tule Canyon, Texas.................. 232

3. Geological map of region between Pecos River and Rio Grande....... 235

4. Map of region along Brazos River near Bryan, Texas............ 244

5. Part of plastron of box-tortoise, Terrapene impressa ............245 



\section{PREFACE.}

In a previous publication, Carnegie Institution of Washington (No. 322), issued February 24, 1923, the writer dealt with the Pleistocene and its vertebrated animals of the region east of Mississippi River and northward. The present volume relates to the vertebrate palæontology of the region west of the Mississippi, including the States of New Mexico, Colorado, Wyoming, and Montana and the British Provinces lying northward. The Pleistocene geology of the various sections is dealt with as far as it has seemed likely that the geology might throw light on the palæontology or that the palæontology might throw light on the geology.

The writer's acknowledgments are due to many institutions and persons. First of all, he acknowledges his debt to the Carnegie Institution of Washington for its support. Two States, Texas and Iowa, have furnished numerous remains of Pleistocene vertebrates. The Pleistocene geology of both States is extremely interesting and their geological surveys are being actively prosecuted. Dr. E. H. Sellards has read the manuscript on the Pleistocene geology of Texas, with benefit to the writer and to the manuscript. To Dr. W. C. Alden, of the U. S. Geological Survey, Dr. G. F. Kay, state geologist of Iowa, Dr. James H. Lee, assistant state geologist, and Professor A. C. Trowbridge, the writer's thanks are due for reading portions of the manuscript on the Pleistocene geology of Iowa. Dr. Willis T. Lee, of the U. S. Geological Survey, perused the pages on which is discussed the geology of New Mexico; and W. A. Johnston, of the Geological Survey of Canada, gave the writer the benefit of his wide knowledge of the glacial geology of Manitoba, Saskatchewan, and Alberta. Dr. C. L. Baker, formerly connected with the Geological Survey of Texas, has furnished the writer much information regarding the Pleistocene of Texas.

It seems proper that mention should be made here of two errors in the writer's former volume (publication 322 of the Carnegie Institution of Washington) to which his attention has been called. On the base map used to display the distribution of certain vertebrate species and genera, as Map 1, etc., the writer failed to have represented the very old drift lying south of the Wisconsin moraine in Pennsylvania and New Jersey. This old drift is, however, represented in figure 10, on page 308, and on Map 6A.

A more serious error occurs on Map 38. In northwestern Illinois the Wisconsin drift is represented as continuing to the Mississippi, from the middle of Henry County northward. The Illinoian drift occupies this region from the Mississippi and the driftless area to the Bloomington moraine. The drift there ought to have been represented by small crosses. A correct statement regarding the drift of the area in question is made on page 335 of the volume referred to.

Oliver P. Hay.

OCtober 1, 1924. 



\section{THE PLEISTOCENE OF THE MIDDLE REGION OF NORTH AMERICA AND ITS VERTEBRATED ANIMALS.}

\section{FINDS OF XENARTHRA IN THE MIDDLE REGION OF NORTH AMERICA.}

\section{LOUISIANA.}

(Map 1.)

(Petite Anse, Iberia Parish (1).*-In the salt mines at this place have been discovered many remains of Mylodon, and a claw of Megalonyx has been reported. Mylodon appears to have been first announced by Doctor Leidy (Proc. Acad. Nat. Sci. Phila., 1884, p. 22). In 1889 (Trans. Wagner Inst., vol. II, p. 33, pl. v, figs. 1-4), he described and figured remains of Mylodon harlani. From the Joor collection, made in 1890, Cope, in 1895 (Proc. Amer. Philos. Soc., vol. xxxiv, p. 458), described two new species, M. sulcidens and M. renidens. Since that time, Stock (Bull. Dept. Geol. Univ. Calif., vol. vIII, p. 319), who has had abundant materials obtained from the asphalt deposits at La Brea, California, has concluded that Cope's species were not well founded and are variations of Mylodon harlani. The materials collected by Joor belong to Tulane University, New Orleans, where the writer was permitted to see such portions as were accessible at that time.

In 1895, Dr. Joseph F. Joor (Amer. Naturalist, vol. xxix, p. 397) stated that, at an earlier date, Captain Dudley Avery, of Petite Anse, had sent to the Smithsonian Institution a claw found at the salt mines. This was identified as belonging to Megalonyx.

\section{TEXAS.}

(Map 1.)

Wheeler County (1).-The U. S. National Museum contains a skull of a species of Nothrotherium, which was secured from Baylor University, having been presented by some one now unknown. It is reported to have been found, at a depth of 40 feet, in digging a well somewhere in Wheeler County. The skull has been described by the writer (Proc. U. S. Nat. Mus., vol. LI, p. 10\%, pls. vi, vII) under the name Nothrotherium texanum. The animal undoubtedly belonged to the Pleistocene and to an early stage.

Rock Creek Canyon, Briscoe County (2).-In 1893 (4th Ann. Rep. Geol. Surv. Texas, p. 78), Cope announced that he had secured a part of a femur of a species of Mylodon from the Equus beds of the Staked Plains of Texas. This was certainly at Rock Creek, or thereabout. The bone was referred with doubt to Mylodon sodalis. In 1915 (Amer. Jour. Sci., vol. xxxix, pp. 614, $616)$, Troxell reported that the Yale expedition into the Panhandle region of Texas had secured remains of Mylodon harlani at the head of Rock Creek

* Numbers in parentheses after the italic headings indicate the numbers on the map, and point out the provenance of the specimens. 
Canyon. Doctor 'Troxell informed the writer that the locality is in the southwestern quarter of section 20\%. It is probable that the femur secured by Cope belonged to $M$. harlani. A list of the species of vertebrate fossils obtained in the Rock Creek region will be found on page 239.

Professor Lull, in 1915 (Amer. Jour. Sci. ser. 4, vol. xxxix, p. 328), reprinted 'I'roxell's list of vertebrates from the hearl of Rock Creek and stated that at least four individuals of Mylodon harlani had been found. He revised the species and described and figured many parts of the skeleton.

T'erlingua, Brewster County (3).--In 1917 (Bull. Dept. Geol. Univ. Calif., vol. x, p. 138) Stock stated that bones of Nothrotherium had been sent to Dr. J. C. Merriam from this place. With these bones were some sparse remains of a fossil horse (p. 134).

Hawley, Jones County (12).-From Dr. Mark Francis the writer received, for examination, about 15 plates of the carapace of a glyptodon, which were found in Hawley. These had been sent to Doctor Francis by R. J. Magee. of the same place. They appear to have belonged to the species Glyptodon petaliferus, but the animal seems to have been larger than the one mentioned below. One plate has a diameter of $60 \mathrm{~mm}$. and a thickness of $25 \mathrm{~mm}$.; another has a diameter of $50 \mathrm{~mm}$. and a thickness of $44 \mathrm{~mm}$. Naturally, the specific identification is doubtful. Some of these plates were sent to the U. S. National Museum. All were found in digging a well and at a depth of 56 feet. It is possible that a Pliocene deposit had been reached.

Wolfe City, Hunt County (4).-The U. S. National Museum has part of a skeleton of a species of Glyptodon, found near Wolf City. It has been described by the writer (Proc. U. S. Nat. Mus., vol. LI, p. 10\%, pls. III-v) under the name of Glyptodon petaliferus Cope. The finder, O. S. Shelton, states that the skeleton was found in 1908 on the bank of Middle Sulphur Creek, about 9 feet from the surface. The bones lay on a bed of gravel and were overlain with clay. Quite certainly the deposits belong to the Sheridan or Equus beds.

Near Quinlan, Hunt County (15).-From D. A. Saunders, of Greenville, Hunt County, the U. S. National Museum received in 1923 a well-preserved proximal phalange of the left index digit of Megalonyx jeffersonii, found about 3 miles north of Quinlan, in a locality described as "locality No. 3, some 12 miles south and 2 miles east of Greenville, on the H. T. Weathers farm, in the bed of a nameless creek, midway between the Wieland road and the Weathers oil-well."

The bone is slightly smaller than that described and figured by Leidy (Smithson. Contrib. Knowl., vol. vir, p. 32, pl. x, figs. 15, 16, 17). The length is 3 inches and the other dimensions are in proportion. At the same locality were found fragmentary and water-worn teeth of an undetermined species of horse.

Speegleville, McLennan County (5).-The collection of Baylor University, Waco, Texas, contains the distal end of a femur of Mylodon, found by J. K. Prather near Hog Creek, 3 miles northwest from Speegleville. The animal probably belonged to $M$. harlani.

Temple, Bell County (14).--Some unimportant remains seen by the writer, belonging to a species of Mylodon, were unearthed by W. F. McGregor in the 
gravel-pits along Leon River. A list of the associated species is given on page 228.

Bastrop, Bastrop County (13).--In October 1922, Mr. Hugh H. Duval sent to the U. S. National Museum part of a bone of a ground-sloth, which was identified by J. W. Gidley as that of a Mylodon. With this was a hindmost molar of Mammut americanum. The Mylodon bone and mastodon tooth were found at a depth of 6 feet in a gravel-pit on the second terrace at Bastrop. This terrace is about 50 feet above ordinary low water.

Pittbridge, Burleson County (6).--In July 1899, Mr. Dansby located near Pittbridge a part of the left ramus of the lower jaw of a megatherium found in the bank of Brazos River just after a time of high water. The jaw presents the base of the hinder, or fifth, tooth, the inner faces of the two teeth next in front, and a little of the socket of the second tooth. The following measurements are given in millimeters:

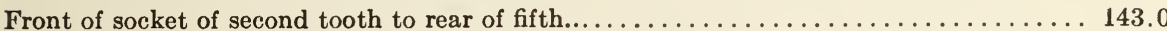

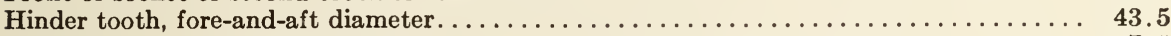

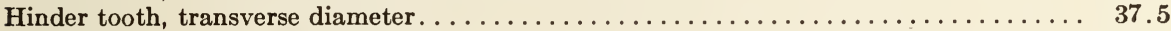

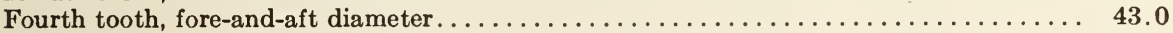

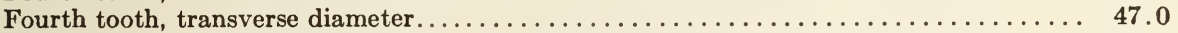

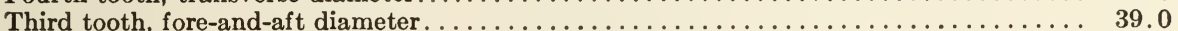

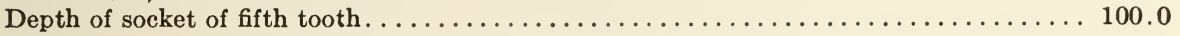

Near this jaw was found the lower end of the radius of Megatherium. In February 1921, Doctor Francis sent the writer a part of a dermal scute which was recognized as having belonged to a species of Chlamytherium. In March he sent photographs of a right ramus of a lower jaw which had been found at Pittbridge. A comparison of this with figures of the one described by Dr. E. H. Sellards, from Florida, showed that the Texas specimen belonged to $C$. septentrionale. The bone is complete, but all of the teeth except two are missing. See Journal Mammalogy (vol. 3, Feb. 1922, p. 22, pl. II) for an account of the jaw, by Professor A. R. Cahn.

Hidalgo Falls, Washington and Brazos Counties (7).-B. F. Shumard, the geologist, reported (Trans. St. Louis Acad. Sci., vol. II, p. 141) that remains of Megalonyx had been found at this place, associated with Mastodon, Elephas, Equus, Crocodilus (probably Alligator), and Testudo. The geology of the locality is discussed on page 245 .

Sour Lake, Hardin County (8).--In 1868, Leidy (Proc. Acad. Nat. Sci. Phila., vol. xx, p. 174) reported the discovery here of a fragment of a tooth of Megalonyx validus. For a list of other vertebrates and a discussion of the geology, see page 242 .

San Felipe, Austin County (9).-W. M. Carpenter, in 1846 (Amer. Jour. Sci., vol. I. p. 249), reported the finding at this place of two claws of an animal belonging to the Megatheriidas. He thought they might belong to Oryctotherium, which is now regarded as a synonym of Mylodon. Leidy (Jour. Acad. Nat. Sci. Phila., vol. vir, p. 413) regarded the animal as probably a Mylodon. For a list of the species found at this locality, see page 246.

"Fifty miles above Mouth of Brazos River," Fort Bend County (10).- - In 1856 (Proc. Bost. Soc. Nat. Hist., vol. vi, pp. 51, 53), Wyman gave an account of fossil remains found about 50 miles above the mouth of Brazos River and presented to the society. The fossils included 2 molars of Mammut ameri- 
canum, a tibia of Megatherium and a molar and symphysis of the lower jaw, and a femur of an elephant. $\Lambda$ description and measurements of the tibia were given. These remains were found in the bed of Brazos River at a stage of low water. It is unfortunate that the locality was not more exactly reported. We do not know whether the distance was taken in a straight line or along the windings of the river. In either case the bones were probably located within the area occupied by the Beaumont formation. One can not now be certain whether or not the river had cut down through this into the older Lissie.

Nueces County (11).-In 1888 (Amer. Naturalist, vol. xxir, p. 345), Cope described a species of Glyptodon as $G$. petaliferus, found in Nueces County by William Taylor. The specimen which formed the type was only half of one of the plates which compose the armor of the animal. This was figured in 1889 (Amer. Naturalist, vol. xxiII, p. 662). The half scute had been found in the beds which furnished Equus crenidens $(=E$. giganteus) and E. barcenci $(=E$. tau) ; but the exact locality is not known.

For (12) see page 2 ; for (13) page 3 ; for (14) and (15) page 2.

\section{OKLAHOMA.}

(Map 1.)

Mulhall, Logan County (1).--In 1917 (Bull. Geol. Soc. Amer., vol. xxviri, p. 212), Troxell stated that he had found remains of a giant sloth in a deposit near Mulhall. Nothing has been published on the collection since that time. For the associated genera, see page 255.

\section{MISSOURI.}

(Map 1.)

Pomme de Terre River, Benton or Hickory County (1).-In 1843, Harlan (Amer. Jour. Sci., vol. XLIV, p. 69, pls. I-III) described the remains of a large ground-sloth, to which he gave the name Orycterotherium missouriense. This was afterwards found to be the same animal as Mylodon harlani. The bones formed a part of the collection which Albert Koch stated he had gathered on the Pomme de Terre River in Benton County. The position of this locality, which appears to have been possibly in Hickory County, is discussed on page 25. Statements by other observers are referred to in connection with Koch's discoveries in Gasconade County, which call in question the correctness of some of his utterances. The materials which Harlan described consisted of $2 t$ teeth, fragments of 2 maxillæ, 2 mandibles, 2 humeri, an ulna, 2 radii, 5 wrist-bones, 4 claw-phalanges, 2 tibiæ, an astragalus, parts of 2 or 3 clavicles, parts of ribs, 4 elements of the sternum, and a considerable part of the pelvis. The writer does not know what has become of these bones. Harlan stated that this collection included remains of the ox (probably Bison), deer, elk, and Megatherium. The last-named genus occurs in South Carolina, Georgia, 'Texas, and New Jersey. It may, of course, have made its way north into Missouri; but it would be interesting to have additional materials from this State. Its occurrence on the Pomme de Terre was not mentioned by Leidy in his monograph (Smithson. Cont. Knowl., vol. vir., 
art. 3). The discovery of Mylodon at the locality mentioned suggests that a part of the deposits belonged to the middle or early part of the Pleistocene. Unfortunately we do not know on what parts of each species the determinations were based.

Kimmswick, Jefferson County (2).-Professor W. C. Mills, of Ohio State University, has shown the writer two teeth of Megalonyx jeffersonii, which he obtained at Kimmswick. Both of the teeth belong to the upper jaw, one being the front tooth, the other the third or fourth. The front tooth had a height of $61 \mathrm{~mm}$, a fore-and-aft length of $39 \mathrm{~mm}$., and a thickness of $17.5 \mathrm{~mm}$. The other tooth was $54 \mathrm{~mm}$. high, $27 \mathrm{~mm}$. wide, and $18 \mathrm{~mm}$. fore-and-aft. Mastodon bones in great numbers have been found here, probably elephant remains; also a horse tooth, and a horn-core resembling that of Boötherium bombifrons. 'The locality had probably been a resort for various species during a large part of the Pleistocene epoch. Although it has been worked for specimens by various people, nobody appears to have thought it worth while to keep accurate records.

From Dr. W. F. Parks, of St. Louis, Missouri, the U. S. National Museum, in July, 1921, received 8 upper teeth of Megalonyx jeffersonii, found at Kimmswick, including both of the large anterior teeth. It is probable that the teeth did not all belong to the same individual. A list of species from this locality is given on page 263 .

\section{KANSAS.}

\section{(Map 1.)}

Seneca, Nemaha County (1).-In 1895 (Kansas Univ. Quart., vol. III, p. 175, figs. 1, 2), Williston figured and described a xenarthran fibula which had been found, as reported, in a well dug in Seneca. The bone was referred with doubt to Mylodon harlani. It was again mentioned by Williston in 1897 (Univ. Geol. Surv. Kansas, vol. II, p. 304, figs. 12, 13) as Mylodon. In 1913 (Mem. Mus. Comp. Zool., Harvard, vol. xL, p. 339, pl. Iv, fig. 21), Dr. G. M. Allen described and figured the fibula of his Mylodon garmani, found somewhere in the region of Hay Springs, Nebraska. He called attention to the bone described by Williston and showed that it was about $25 \mathrm{~mm}$. longer than the largest fibula of $M$. garmani. However, there was a difference of $31 \mathrm{~mm}$. between the right and left fibulæ of the type specimen of Allen's species. At any rate, it is impossible to say at present to what species the Seneca specimen belonged. This fibula is different from that of Megalonyx. Williston reported that the bone had been discovered at a depth of 30 feet below the surface. This locality is within the area of the Kansan drift, and it seems probable that this drift sheet had been penetrated and that the Aftonian had been reached.

Harper Township, McPherson County (2).-In 1892 (Trans. Amer. Philos. Soc., vol. XvII, pp. 1-10, pls. I-v), Josua Lindahl described a fine skull of a species of Megalonyx, which he named M. leidyi. This was found in a sandpit in Harper Township. The writer has not been able to ascertain the locality more definitely. The skull is now in the collection of Bethany College, 
Lindborg, Kansas, where the writer has seen it. According to statements made, a tooth of a horse was found at the same point. The locality is within the area described by Haworth and Beede (Univ. Kansas Geol. Surv., vol. II, pp. 285-296) as belonging to the Equus (Sheridan) beds.

Meade (or Clark) County (3).-Professor F. W. Cragin, in his account of the geology of Meade and Clark Counties (Colorado Coll. Studies, vol. vi, p. 53), reported that the Meade gravels contained, among other species, Megalonyx leidyi. The writer has studied Cragin's collection, but did not find any remains of this species. He found, however, teeth which do not seem to differ from those of Mylodon harlani. For a discussion of the character and age of the deposits and a list of the species found, see page 270 .

\section{COLORADO.}

(Map 1.)

Walsenburg, Huerfano County (1).-In 1909 (Univ. of Colorado Studies, vol. vI, p. 309, pls. I, II), Dr. T. D. A. Cockerell described a fine skull of a ground-sloth, which he referred to Mylodon, but did not determine specifically. This skull was found by E. A. Lidle on his farm one mile south of Walsenburg. It was presented to the University of Colorado, where it still remains. This specimen, as well as the one from Nebraska, described by Barnum Brown as Paramylodon nebrascensis, is referred by Dr. Chester Stock to Mylodon harlani.

\section{IOWA.}

(Map 1.)

Mills County (1).-At the Cleveland meeting of the American Association for the Advancement of Science, in 1888, Professor J. E. Todd exhibited a claw phalange of a large mammal which had been found in this county. It was afterward determined by Doctor Leidy to be a claw of Megalonyx. The claw was discovered in a deposit of sand which underlies the drift; the exact place where it was found has not been given. Calvin (Bull. Geol. Soc. Amer., vol. $\mathrm{xx}, \mathrm{p} .353)$ stated that these sands belong to the Aftonian interglacial. It is impossible to say to which species of Megalonyx this specimen belongs.

Avoca, Pottawattamie County (7). - In the collection of fossil vertebrates in the University of Iowa, with catalogue No. 396, is the distal two-thirds of the right humerus of Megalonyx jeffersonii, which was found by Ray Leonard in the dump of a dredging-machine at work in the East Branch of Nishnabotna River, in the southeast quarter of northeast quarter of section 10, township 77 north, range 39 west. This is near Avoca.

Missouri Valley, Harrison County (2). -From the Cox gravel-pit at Missouri Valley, Calvin reported a damaged right tibia, which he referred to Megalonyx jeffersonii. The writer published a description of this bone in 1914 (Iowa Geol. Surv., vol. xxir, p. 130, fig. 30). If the section taken at the middle of the length is compared with that of the species just named (op. cit., p. 123, fig. 20), it will be seen that they are very different and probably do not belong to the same genus; nor does the tibia belong to Mylodon. From this pit was obtained a large ungual phalange of Mylodon harlani, later figured and described by Calvin (Bull. Geol. Soc. Amer., vol. xx. 
p, 353, pl. xxvi) and the writer (Iowa Geol. Surv., vol. xxiII, p. 142, pl. vIII, figs. 1, 2, text-figs. 40-42).

From the same pit was obtained by Professor Shimek a lumbar vertebra, which appears to belong to a species of Megalonyx. This has been described by the writer (op. cit., p. 130, pl. vi, figs. 1, 2). On page 296 the location and geology of this pit are described, and a list of the species of mammals found there, about 17 in number, is given.

Turin, Monona County (3). - In the Elliott gravel pit was found a complete right radius of Megalonyx. This appears not to differ from that of $M$. jeffersonii. It has been described and figured by Calvin (Bull. Geol. Soc. Amer., vol. xxir, p. 215, pl. xxiv) and the writer (Iowa Geol. Surv., vol. xxIII, pl. v, figs. 3, 4). The deposits at Turin in which vertebrate remains were found are regarded as belonging to the Aftonian. For a brief description of the pit and a list of the species obtained, reference is made to page $29 \%$.

Sioux City, Woodbury County (4).-The Aftonian deposits at this place have furnished various remains of Megalonyx. An ungual phalange now at the State University of Iowa was secured by Professor Shimek at the Anderson pit, at North Riverside, near Sioux City. This was described and figured by the writer (op. cit., p. 128, pl. v, figs. 1, 2, text-figs. 25-27) as M. jeffersonii. A bone found in this pit and identified as possibly a patella of Megalonyx (Iowa Geol. Surv., vol. xxIII, p. 129) is certainly not a patella. A description of the pit and a list of the species of vertebrates collected from it are given on page 298 .

Akron, Plymouth County (5).-From the Jensen well, near Akron, there was obtained the ankylosed first and second phalanges of the third digit of the hinder foot of a species of ground-sloth, probably Megalonyx. This is the well from which were collected the molars and some other remains of Stegomastodon mirificus (Mammut mirificum). The well is noticed here on page 299.

Dubuque, Dubuque County (6).-In 1862 (Geol. Surv. Wis., vol. I, p. 135), J. D. Whitney reported that some peccary-teeth of apparently the living species had been found associated with teeth of an undetermined species of Megalonyx, embedded in clay, at a depth of 10 feet from the surface, in a flat crevice in the Galena limestone near Dubuque. Dubuque is situated in the driftless region and hence we have no guidance from the drift-sheets. Whether the animals of the lead crevices belong to the close of the Wisconsin stage or to an earlier one is not yet determined. The association of the pec-' cary and the megalonyx testifies to the prevalence of a mild climate when they lived there.

For (7) see page 6 .

Wayland, Henry County (8). - In the palæontological collection of the University of Iowa, with catalogue No. 398, is a right tibia of Megalonyx jeffersonii, which was found somewhere near Wayland. It is reported to have been discovered in the bed of Sugar Creek, north of Wayland. The locality may therefore be in the southern part of Washington County. The stage of the Pleistocene to which it belongs is not known. 


\section{NEBRASKA.}

(Map 1.)

Tecumseh, Johnson Counly (1).-'J'he State Museum at the University of Nebraska contains an ungual phalange which is identified as having belonged to some species of the genus Mylodon. The length of the bone is $140 \mathrm{~mm}$. It is not known exactly where this claw-bone was found. 'The town is on Nemaha River and within the area of the Kansan drift. It is safe to assume that it was found in an Aftonian deposit, especially as from this same county, a tooth of Elephas imperalor has been reported.

Red Cloud, Webster County (2).-The State Museum at the University of Nebraska, at Lincoln, has a large part of a left humerus of a species of Mylodon, found near Red Cloud. 'The more exact location is given as the Rocky Dell farm, belonging to the Amboy Milling Company, situated 3 miles east and 1 mile north of the town named. The bone was secured by Professor I. 'T. Frisbee, principal of the public school at University Place, near Lincoln, who presented it to the university. It is reported to have been found at a depth of 5 feet from the surface. A portion of the shaft of this humerus is missing. The head and trochanters form one fragment. The lower fragment has a length of $285 \mathrm{~mm}$. The humerus as restored is 520 $\mathrm{mm}$. long, but this may be more or less inexact. The following measurements (in millimeters) are given; the corresponding measurements were obtained by courtesy of Dr. J. C. Merriam, from a specimen of Mylodon harlani at the University of California.

\begin{tabular}{|c|c|c|}
\hline & $\begin{array}{c}\text { Mylodon } \\
\text { harlani. }\end{array}$ & $\begin{array}{c}\text { Red Cloud } \\
\text { mylodon. }\end{array}$ \\
\hline Total length of humerus................. & 430 & $520 \pm$ \\
Distance through head and trochanter..... & 152 & 150 \\
Width of bone through epicondyles........ & 250 & 260 \\
Width of ulno-radial articular surface..... & 127 & 150 \\
\end{tabular}

The measurements appear to indicate that the Red Cloud humerus has been made considerably too long in the restoration. If the lengths of the two bones compared above were in the same ratio as the epicondylar widths, the Red Cloud humerus would have a length of about $450 \mathrm{~mm}$. It is possible that the latter-mentioned bone belonged to the species of Mylodon described by Dr. G. M. Allen as M. garmani. In this species the total length of the humerus was about $430 \mathrm{~mm}$. and the width of the lower articular surface 125 mm. The width across the condyles is not given. Red Cloud is situated on Republican River and far outside of the glaciated area. It appears probable that the bone above described should be referred to the Sheridan epoch.

Grayson, Sheridan County (3). - Somewhere in the region about Hay Springs, probably near Grayson, Professor Samuel Garman, in 1880, secured, for Harvard University, a well-preserved skull and many parts of the skeleton of a species of Mylodon. This specimen was described in 1913 (Mem. Mus. Comp. Zool., Harvard, vol. xL, pp. 319-346, pls. 1-1) by Dr. Glover M. Allen under the name of Mylodon garmani. Besides the skull and the lower jaw, 
there are preserved more or less completely the cervical vertebræ, 16 dorsals, a portion of the pelvis, fragments of ribs, most of the sternum, parts of both scapulæ, a humerus, a part of an ulna, a radius, and some foot-bones, including several ungual phalanges. The American Museum of Natural History at New York (fide Matthew in 1902 Bull. Amer. Mus. Nat. Hist., vol. xvi, p. 31\%), contains a complete skull and jaw and a large part of the skeleton of a sloth allied to but distinct from M. harlani. This collection was described in 1903 by Barnum Brown (Bull. Amer. Mus. Nat. Hist., vol. xix, pp. 569-583, pls. L, LI) under the name Paramylodon nebrascensis, but the characters supposed to distinguish the genus Paramylodon are sometimes found in Mylodon harlani (Stock, C., Bull. Dept. Geol., vol. virr, p. 319), and Stock regards the species as identical with $M$. harlani.

Boxbutte Creek, Sheridan County (4).-In 1918 (Bull. Amer. Mus. Nat. Hist. vol. xxxvin, p. 229), Dr. W. D. Matthew reported the discovery, at the mouth of Boxbutte Creek, of a few bones which he referred provisionally to Megalonyx leidyi.

\section{MINNESOTA.}

(Maps 1, 29.)

Minneapolis, Hennepin County (1).-From Professor Charles E. Johnson, of the University of Minnesota, the writer received, for examination, a caudal vertebra of a xenarthrid which in all probability is Megalonyx. The bone was found in a gravel-bed within the limits of Minneapolis, at a depth of 25 feet. It can not be compared directly with the caudals of Megalonyx, because these are not known. It does not belong to Mylodon or any other ground-sloth whose caudals are known. Found in such a situation and deposit, it certainly lived after the retirement of the Wisconsin glacier; and this fact makes it likely that it was a species of Megalonyx, probably $M$. jeffersonii.

\section{SOUTH DAKOTA.}

(Map 1.)

Philip, Stanley County (1).-In the Morrill collection of the University of Nebraska is a fine complete femur of a Megalonyx, not improbably Megalonyx jeffersonii. This was found near Philip in 1908 and sent to the museum of the University of Nebraska in 1910. The number given it in the catalogue is 47-16-6-10. No details are known to the writer regarding the finding of the specimen. Philip is situated on Bad River, in the northern part of township 1 north, range 22 east. 


\title{
FINDS OF MASTODONS IN THE MIDDLE REGION OF NORTH AMERICA.
}

\author{
LOUISIANA.
}

(Maps 2, 28.)

Head of Bistineau Late, Webster Parish (1).-An account of the Bistineau salt works has been given by Veatch (Geol. Surv. La., pt. vi, 1902, p. 81). The location is in sections $25,26,35$, and 36 , township 18 north, range 10 west, and therefore near the former head of Bistineau Lake. One of the wells is known as the Frenchman's. Out of this well (Veatch, op. cit., p. 8, pl. XxII) were obtained at one time "several vertebræ, the leg-bones, and a portion of the tusk of some large animal, probably a mastodon." There is nothing to show that these bones did not belong to one of the extinct elephants.

Castor, Bienville Parish (2).-Near this place are the salt works known as King's, in section 35, township 15 north, range 8 west. This locality is near Castor Bayou (Harris and Veatch, Geol. Surv. La., pt. v, pp. 63, 123; Veatch, Geol. Surv. La., pt. vi, 1902, p. 79). There is no assurance that any mastodon remains have been found here; but certainly a tusk of some one of the proboscideans was met with. Veatch quotes statements made to him about the discovery of horns and bones of some very large animal. One object was supposed to be a true horn and not a tusk, inasmuch as it was hollow and retained its horny laminations and its odor. The fragment was 3 feet long and 13 inches in diameter. It is far more probable that it was the basal end of a tusk, showing the pulp-cavity, which on drying separated into its layers. Nor is it probable that the sheath of a bison horn would be preserved or that it would have the diameter given.

Rayburn's Salt Works, Bienville Parish (3).-These salt works are in section 31, township 15 north, range 5 west (Harris and Veatch, Geol. Surv. La., pt. $\nabla, 1899$, pp. 52, 122). The works are about 10 miles south-southeast of the town of Bienville and on Brush Creek. A description of the locality will be found on page 220. These mastodon bones were reported by F. V. Hopkins in 1872 (3d Ann. Rep. Geol. Surv. La., p. 528). They are said to have been found in the laminated clay.

Price's Salt Works, Winn Parish (4).-Price's salt works are in section 25 , township 13 north, range 5 west, about 12 miles in a direct line southsoutheast from Rayburn's works (Harris and Veatch, as cited abore, p. 55). The Price works are on a branch of Dugdemona Creek. A brief description of the geology of the locality will be given in the discussion of the Pleistocene geology of Louisiana. Mastodon bones were reported from this place by $\mathrm{F}$. T. Hopkins in his report of 1871 (1872), cited abore. Teatch (Geol. Surv. La., pt. VI, 1902, p. 68) stated that "big bones" had been reported from a well just west of Rayburn's furnace, at a depth of from 8 to 10 feet. Undoubtedly bones of proboscideans have been found here, but there is no certainty that they belonged to the mastodon.

Drake's Salt Works, Winn Parish (4).-According to Harris and Veatch (as cited above, pp. 55, 121), the location of these salt works is in section 21, township 12 north, range 5 west, 6 miles southwest of Price's and near 
Saline Bayou. We have the same authority for the occurrence of mastodon remains here as for those at the salt works mentioned above. There is no certainty in any of these cases that the remains belonged to the mastodon and not to one or both of the elephants which might be found there.

Opelousas, St. Landry Parish (5).-Goddard (Amer. Nat. Hist., vol. II, p. 248) stated that Doctor Griffin, in 1804, saw mastodon bones exhumed somewhere in the vicinity of Opelousas. W. M. Carpenter, the geologist, in 1839 (Amer. Jour. Sci., vol. xxxv, p. 345), reported finding a skull and other remains of a mastodon about a mile east of this town; only some teeth were saved, their present whereabouts unknown.

Petite Anse, Iberia Parish (6).-This place is in the southeastern corner of township 13 south, range 5 east, extending into the next township east. It is distant about 10 miles south-southwest from New Iberia and 3 miles from the north shore of Vermillion Bay. There is here an extensive deposit of salt, which was worked by the Indians even in prehistoric times. Apparently the first notice published of the finding of fossils here was by Doctor Leidy, in 1866 (Proc. Acad. Nat. Sci. Phila., 1866, p. 109). He stated, on the authority of T. F. Cleu, that a piece of Indian basket-work had been found lying on the rock salt and 2 feet beneath the remains of an elephant. How it was known that the remains belonged to an elephant rather than to a mastodon was not explained.

In 1883 a collection of fossil bones from Petite Anse was sent to the Smithsonian Institution by William Crooks, of the company then exploiting the salt mines. These fossils were first described briefly by Leidy (Proc. Acad. Nat. Sci. Phila., 1884, p. 22), but more fully in 1889 (Trans. Wagner Inst., vol. II, pp. 33-39, figs. 1-4). Among other species he recognized Mammut americanum, it being represented by two teeth, fragments of vertebræ, and some other bones. The teeth have been examined by the present writer in the collection of the U. S. National Museum catalogue Nos. 213, 214. One is an upper last molar with 5 cross-crests; the other a lower left second true molar. Leidy regarded both these teeth as being lower molars. In the collection of Doctor Joor (Amer. Naturalist, vol. xxIx, p. 39\%), 2 teeth of mastodon were recognized. He referred an atlas and some other bones to the mastodon with doubt. The other species found here are listed on page 215.

Côte Blanche, St. Mary's Parish (7).-About the middle of the north shore of Côte Blanche Bay are some salt deposits and salt works. Veatch (Geol. Surv. La., pt. v, 1899 (1900), p. 230) gives the location of these as being in township 15 south, range 5 east. This would be in Vermillion Bay. The range appears to be really 7 east.

In 1872, F. V. Hopkins (Ann. Rep. Geol. Surv. La. for 1871, p. 188) stated that mastodon bones were common in that region. Here again, however, there does not appear to be either description or any specimens preserved to confirm the identifications. Hopkins reported that these bones were found in deposits with fresh-water shells, Paludina, Melania, Unio, and Cyclas. Hilgard (Smithson. Contrib. Knowl., vol. xxII, No. 248, p. 12) stated that mastodon bones had been found on the island, but he could not ascertain precisely the place, and he probably did not see the bones. 
Little Bayou Sara, West Feliciana Parish (8).-W. M. Carpenter in 1838 (Amer. Jour. Sci., vol. xxxiv, p. 202) reported that mastodon remains had been found along this small stream, which is situated between Bayou Sara and Mississippi River. He stated that the place was about 25 miles from Jackson. It seems, therefore, that the locality must have been near the northern border of the parish. One tooth was said to resemble a tooth of Mammut americanum, which is figured by Cuvier. The identification was doubtless correct and the statement that the tooth weighed $61 / 2$ pounds is reasonable. About a mile away was found a part of the jaw of what was supposed to be a young mastodon, with two unworn teeth in it. The whole weighed 8 pounds. About 2 miles from the locality of the first tooth another was found, which weighed 12 pounds. The four cross-crests had been worn down smooth. Certainly no mastodon tooth weighed that much, especially after it had suffered so much wear. It is equally certain that the tooth was from an elephant. In immediate association with this tooth was found one of Equus complicatus, described in its proper place. Carpenter stated that these teeth had been deposited in the College of Louisiana.

Port IIudson, East Baton Rouge Parish (9).-Hilgard, in 1872 (Smithson. Contrib. Knowl., vol. xxıI, No. 248, p. 5), presented a geological section found along Mississippi River, at Port Hudson. The same section and statement were published in 1869 (Amer. Jour. Sci., vol. xLVII, p. 79). In one stratum, composed of miscellaneous fluviatile materials, at a depth of about 35 or 40 feet, bones of a mastodon were found. Why these were thus identified is not explained. They may have been bones of an elephant.

Alsworth's, East Feliciana Parish (10).-At this place, 6 miles above Baton Rouge, mastodon remains have been found, according to Hopkins (Ann. Rep. Geol. Surv. La. for 1871 (1872), p. 188); but the information is not definite.

Baton Rouge, East Baton Rouge Parish (11).-From D. R. Weller, president of the Standard Oil company of Louisiana, through the kindness of Professor W. H. Gates, of Louisiana State University, the U. S. National Museum has received some fragments of bones and teeth of Mammut americanum, accompanied by a tooth of Equus complicatus and some fossil wood. These remains were found about 2 miles north of the city and at a depth of 8 feet. The deposit belongs to the Port Hudson.

\section{TEXAS.}

\section{(Maps 2, 3.)}

Tascosa, Oldham County (50).-Doctor Francis informed the writer that in $1915 \mathrm{~J}$. D. Cooper, of Tascosa, sent him fragmentary bones of an elephant and that among these were some pieces of mastodon teeth.

Palo Duro Canyon, Randall County (1).-Cummins (3d Ann. Rep. Geol. Surv. Texas, p. 149) reported that he found teeth of a fossil horse and of a mastodon on the south side of the canyon, opposite the falls.

Benjamin, Knox County (2).-Cummins (4th Anu. Rep. Geol. Texas, pp. $182,183)$ reported that he found, at Mr. Green's place, 14 miles east of Benjamin, a few fragments of mastodon and of Equus, in deposits which he re- 
ferred to his Seymour beds. A large femur, over 4 feet long, had previously been found at the same place.

Knox City, Knox County (3).-C. H. Gordon (Water-supply Paper 31\%, p. 31) stated that he had seen a mastodon tooth from a well at Knox City at a depth of 40 feet. A femur of a proboscidean was found in a ravine in the vicinity.

Gainesville, Cooke County (4).-R. T. Hill, in his report of 1901 (21st Ann. Rep. U. S. Geol. Surv., pt. \%, p. 360), stated that remains of the mastodon had been found in surficial deposits at Gainesville.

Dallas, Dallas County (5).-Doctor Francis states that a tooth of a mastodon was found within the city limits of Dallas some months before May 2\%, 1913. Probably the same discovery was reported by the Dallas News, December 4,1912 . The tooth was found on the site of the building of that newspaper, at a depth of 23 feet. In the autumn of 1923, Professor E. W. Shuler informed the writer that a jaw of a horse and a fine lower jaw of a mastodon had been discovered in a new Lagow gravel-pit, a mile north of the old one and within the city limits. In the old Lagow gravel-pit were found the species recorded on page 241 .

The writer has seen in the collection of Doctor Francis a palate of Mammut americanum, which was found south of Dallas in the fall of 1920 . This palate contains the two last molars of the right side. They are white and thoroughly fossilized, and show little wear; the roots are in fine condition. The second molar is $120 \mathrm{~mm}$. long and $90 \mathrm{~mm}$. wide. The third is $195 \mathrm{~mm}$. long and 105 wide. It has 5 cross-crests and in the first and second valleys there is much cement; only a little in the third valley. The tusk of this specimen was secured by Doctor Francis, and was restored for him by the Ward Establishment at Rochester, New York. Following the convexity of the curve the length is 8.8 feet. The distance from the base to the tip in a straight line is 7.3 feet. The circumference at the base is 21 inches; at the middle of the length, 18 inches. The tusk is somewhat spirally curved. These remains were found in a gravel-and-sand pit about 5 miles south of Dallas, in a terrace situated about 50 feet above the river. The pit is on the farm of Drs. A. E. and G. R. Flowers, and just west of the Missouri, Kansas \& Texas Railway. In the last gravel-pit was found, in January, 1923, a tusk 8 feet long and a lower jaw of Elephas columbi (p. 58).

Doctor Francis has reported the possession of a mastodon tooth found in February 1923, in Zang's gravel-pit, at the west end of the viaduct in Dallas.

Wilmer, Dallas County (6).-Doctor Mark Francis reported that, in 1922, a tooth of a mastodon was found near Wilmer, on the farm of Mrs. M. A. Tresp, under a bridge over a stream. This was possibly Trinity River, which is not far away. The tooth was broken and soon began to crumble.

Fort Worth, Tarrant County (Y).-Mrs. Jennie Scheuber, of the Carnegie Public Library in Fort Worth, some years ago had an upper left hindmost molar of a mastodon which was found in the vicinity of Fort Worth and which belongs to Anancus gratus. This tooth is worn only on the first crest and there slightly. The length is $200 \mathrm{~mm}$; the width at the first crest is 95 $\mathrm{mm}$. and it increases slightly to the fourth, $97 \mathrm{~mm}$. There are 4 cross-crests and a rather large heel. On the inner ends of the crests are buttresses which 
join and obstruct the first and second valleys. As in the type of the species found by Doctor Mark Francis at Pittbridge, Burleson County, Texas (Bull. No. 71, Univ. 'T'exas, p. 18, pls. III, Iv) the third valley is little obstructed. The tooth is somewhat larger than the hindmost molar of the type.

Professor W. M. Winton, of the Texas Christian University, at Fort Worth, sent the present writer a photograph of a lower jaw of a mastodon, which is in his institution and which was found near Fort Worth. The exact locality is on the north side of 'Trinity River, north of the city. The jaw contained no teeth. This jaw and one of Elephas columbi appear to have been discovered in a gravel-pit about 45 feet above high water.

In January 1924, the writer received from Dr. Mark Francis a photograph of teeth of Mammut americanum, the first and second right lower molars, which had been found 5 miles east of Fort Worth, in the valley of Trinity River, at the junction of this river with Little Fossil Creek. 'These teeth are now in the Francis collection.

Lipan, Hood County (8).-From Dr. J. A. Udden, of the University of Texas, the U. S. National Museum received a part of an upper right molar of Mammut americanum, which had been sent to him by W. H. Roach, of Lipan. The tooth was found near that village, which is on the western boundary of Hood County and on Kickapoo Creek. It was discovered in a ravine about 6 feet deep. The banks of the ravine appear to be composed of a sandy loam and rediclay. The front crest of the tooth is missing, the second is little worn. The tooth is remarkable for its great width, being $106 \mathrm{~mm}$. at the second crest. It is well fossilized and white in color.

Granbury, Hood County (9).- In the collection of the University of Texas, at Austin, is a palate of Mammut americanum from Granbury. Of the first and second molars the former is little worn, the latter not at all. The specimen is labeled as having been found in the "drift," doubtless the gravels, of Brazos River, and is credited to J. A. Taff, who was on the Texas Geological Survey from 1889 to 1894 . Dr. R. T. Hill referred probably to this specimen (2d Ann. Rep. U. S. Geol. Surv., pt. 7, p. 360).

Indian Creek, Comanche County (10).- In his report of 1901 (21st Ann. Rep. U. S. Geol. Surv., pt. 7, p. 360) Dr. R. T. Hill stated that remains of Mastodon had been found in surficial deposits at Indian Creek. This creek is a small tributary of Leon River, in the southern part of the county.

San Angelo, Tom Green County (11).-Dr. Mark Francis informed the writer, January 10, 1916, that he saw in the store of Fred Schmidt, in San Angelo, a tooth of Mammut americanum, and he inclosed a sketch of it. The tooth was found near the town named.

Oatman Creek, near Llano, Llano County (12).-From somewhere along Oatman Creek, Hill (21st Ann. Rep. U. S. Geol. Surv., pt. 7, p. 360) reported remains of a mastodon. Whatever was found appears to have been discovered in surficial materials. Oatman Creek is a small tributary opening into Llano River, on the south side.

Marble Falls, Burnet County (13).--In July, 1919 there was sent to the U. S. National Museum, for identification, an upper right second molar of a mastodon, found in a small creek near Marble Falls. It was sent by George Harwood, M. D., of the town named. 
Kendalia, Kendall County (14).--In the San Antonio Express, of December 13, 1913, there was published an account of the finding of remains of a mastodon near Kendalia. A half-tone reproduction of a hindmost molar makes it certain that the animal was Mammut americanum. The remains were found on the ranch of $\mathrm{Mr}$. John Kreupper. The writer has been unable to learn the exact location of the farm. Men had been engaged in making drainage-ditches, one of which had been converted by heavy rains into a deep gulley, in which a boy found a jaw with teeth in it. It appears that a skull (or a part of one) and a tusk were discovered. The bones were at a depth of 7 feet in a bed of sand; above the sand was about 5 feet of gravel and over this 2 feet of surface soil.

Cibolo Creek, Kendall County (15).--In the collection of Professor Atwater, at Houston, the writer saw an upper right hindmost molar of Mammut americanum, which was found on Cibolo Creek, in Kendall County. This creek forms the boundary between Bexar and Kendall counties.

Northern part of Medina County (16).-In 1905 (Bull. Sci. Soc. San Antonio, vol. I, No. 1, pp. 3-10, pls. I-IV, text-fig. 1), Professor Bernard Mackensen gave an account of the excavation of some mastodon remains at a place about 14 miles north-northeast of Hondo, Medina County. The distance was probably not measured in a direct line. The locality was on the ranch of O. H. Brucks and on the border of what is called the Edwards Plateau. There is here a flat which is sometimes a pond. This is near Verde Creek, which empties into Frio River. On the west the locality is bounded by an escarpment of Cretaceous rocks from 200 to 300 feet in height. The bones of the mastodons were found at a depth of about 9 feet, lying in a stratum of grayish clay 2 feet thick. Underneath this was a layer of gravel several inches in thickness, which contained specimens of Exogyra arietina, derived from the neighboring Cretaceous deposits. Over the gray clay which inclosed the mastodon bones is a layer of black muck $y$ feet thick. The mastodon remains were much injured in getting them out. Some portions of tusks were secured. Parts of two jaws were exhumed and a third had previously been taken out. A lower jaw was figured by Mackensen, which had in it a tusk. The writer has examined this and found the diameter to be $23 \mathrm{~mm}$. It projects $34 \mathrm{~mm}$. beyond the jaw, with a part broken off. The socket extends backward $130 \mathrm{~mm}$. It seems not improbable that this species is Mammut progenium.

Helotes?, Bexar County (17).--In 1885 (Proc. Amer. Philos. Soc., vol. XxII, p. 8), Cope reported that he had a specimen (what part he did not say) of Mammut americanum, which had been found near San Antonio. This had been secured from G. W. Marnock, who lived at Helotes, about 15 miles northwest of San Antonio; but the specimen may have been found elsewhere. The same part of the animal was probably referred to later by Cope (Amer. Naturalist, vol. xIx, p. 1208 ; vol. XxIII, p. 164, Feb.).

Bulverde, Bexar County (18).-From a cave near Bulverde the writer had collected by D. V. Shuhart, of San Antonio, a part of a lower left third milkmolar. The hinder crest is gone. The width is $59 \mathrm{~mm}$. From the same cave have been obtained remains of 18 species of fossil vertebrates which are listed on page $24 \%$. 
San Antonio, Bexar Counly (47).-T'eeth of Mammut americanum have been reported from the gravels along San Antonio River at San Antonio, at a depth of 15 feet. At Bethany College, Lindsborg, Kansas, the writer has seen a palate of a mastodon having a right hinder molar $230 \mathrm{~mm}$. long. It is much damaged, so that it is not certain that it belonged to Mammut. It seems to have 6 crests. It may belong to Stegomastodon. The specimen is said to have been found at San Antonio.

New Braunfels, Comal County (19).-In the American Museum of Natural History, New York, is a lower right second molar of this species, which is labeled as having been found on the bank of Guadalupe River, 5 miles above New Braunfels, July 18\%3. It was buried in yellow clay at a depth of 75 feet from the top of the bank.

Cedar Crech, Travis County (20).- In the collection of the State University of Texas is a much-worn lower left hindmost molar of Mammut americanum, labeled as having been found, in 18\%0, somewhere along Cedar Creek, in this county. On a card accompanying the specimen is the name J. H. Hutchins. Cedar Creek crosses the southern corner of Travis County. Bastrop, Bastrop County (21).-In October 1922, Hugh H. Duval, of Bastrop, sent to the U. S. National Museum an upper hindmost molar of $M$. americanum, found in Bastrop. The front crest and root were gone. The crests were flat as compared with the usual type of molar. The tooth was discovered in a gravel-pit on the second terrace of Colorado River. From the same pit have been collected Mylodon and Bison.

The U. S. National Museum has received from Dr. J. A. Udden, from near Bastrop, an upper left hindmost molar of Mammut americanum. This lacks one or two hinder cross-crests. The molar was sent to Doctor Udden by C. E. Lutz, who found it in a sand-bar in Colorado River, 8 miles northwest of Bastrop, on the road from this town to Austin.

Speegleville, McLennan County (22).-In the collection of Baylor University is a fragment of a tooth of Mammut americanum, consisting of 2 crosscrests, which was found on Hog Creck, 3 miles northwest from Speegleville. Here may be recorded an upper left third molar of a mastodon owned by the wife of Dr. H. C. Black, of Waco, and found in a gravel-pit, along Bosque River, about 15 miles from Waco. This would apparently be not far east of Crawford.

In the collection of Baylor University is an upper right second molar of a mastodon, which the writer has described (Proc. U. S. Nat. Mus., vol. LIII, p. 221, pl. xxvi, fig. 3) as Gomphotherium elegans. The tooth which forms the type of the species was discovered at MePherson, Kansas. Is now regarded as belonging to Anancus mirificus. The tooth at Baylor University was found on Hog Creek, not far from Speegleville. Inasmuch as this tooth possesses only 3 cross-crests it probably belongs to Anancus brazosius.

Sparta, Bell County (23). - In the collection of Baylor University there is a lower right last molar of Mammut americanum, which is reported to have been found in the hills near Sparta. This village is situated on Cowhouse River, a tributary of Iscon River. The length of the tooth is $155 \mathrm{~mm}$., the width $105 \mathrm{~mm}$. 
Belton, Bell County (24).-From Miss Lula L. Taylor, of Belton, the writer received a description, sketch, and photograph of a second true molar of Mammut americanum, found near Belton. The tooth has a length of 109 $\mathrm{mm}$. There are no roots preserved; and as the crown shows no wear, the tooth had not yet come into use. It was discovered in a gravel-pit belonging to I. B. Warner and situated east of Leon River, about half a mile distant. It is also about a mile and a half due east of Belton. The height of the gravel-pit above the river is about 100 feet.

Denny, Falls County (25).-Dr. Mark Francis informed the writer of the discovery of remains of a mastodon near Denny. No details are known. The writer has seen this tooth, an upper left last molar, $180 \mathrm{~mm}$. long. It is unworn and has a large pulp-cavity.

Cameron, Milam County (51).-From the region about Cameron, Dr. Mark Francis has secured important remains of mastodons. A tooth of Mammut americanum was discovered on the farm of Frank Schreiber, about 8 miles west of Cameron. It was found in a ditch at a depth not greater than 8 feet, in a soil described as black waxy. Under this number must be mentioned a fragment of a mastodon molar which, in 1924, was found near Buckholts, about 20 miles west of Cameron and not far from Little River. The information was sent by Dr. Mark Francis.

A more important specimen is the horizontal portion of a left ramus of a lower jaw, found in a gravel-pit on Little River, about 2 miles north of Cameron. This jaw, found in 1897, apparently by J. D. Heeley, was presented to Dr. Francis by Henry Reaves. The gravel-pit, as the writer is informed by Judge Kemp, of Cameron, is between 40 and 50 feet above high water in the river. The jaw presents the socket for the penultimate molar and most of the crown and roots of the hindmost one. This tooth is worn so that the place of the first crest is occupied by a concavity. Besides this, the hinder crest and the talon have been destroyed and the inner ends of the second and third crests are badly injured.

This tooth is $212 \mathrm{~mm}$. long and $90 \mathrm{~mm}$. wide in front. It has 3 crests and a part of a fourth. Evidently there was a large hinder talon. The roots are in the finest condition. The great fang supporting the first crest is curved backward and is $1 \% 0 \mathrm{~mm}$. long. A smaller fang supports the inner end of the second crest and is $100 \mathrm{~mm}$. long. The great hinder root is $100 \mathrm{~mm}$. long and $110 \mathrm{~mm}$. from front to rear at the crown and $72 \mathrm{~mm}$. at the distal end.

In 1886, Lydekker (Cat. Foss. Mamm. Brit. Mus., pt. Iv, p. 46) recorded a mastodon tooth in the British Museum, which was found in Texas and which he identified as the third upper true molar of Mastodon cordillerum, otherwise known as $M$. andium. Fortunately, the U. S. National Museum has a well-made cast of this tooth. An examination shows that it is not an upper molar, but the lower right third molar, there being under the front crest only a single fang. The tooth is slightly worn and shows plainly the structure. A comparison of this cast with the tooth from Cameron shows that the two in all probability belonged to the same species. That this species is Mastodon andium (Anancus hyodon) the writer regards as very doubtful. In length, width, and arrangement of the trefoils it resembles more closely $M$. humboldtii. It 
differs from both of the South American species in the greater height of the columns of the crests. Besides, it is improbable that the same species existed in both North America and South America. We know nothing about the upper and lower tusks of the Texas specimen and nothing about its skull. The tooth in the British Museum and the one just received from Cameron agree in their characters with the one described by the writer (PanAmer. Geologist, vol. xxix, pp. 112-114, pl. viII, figs. 1, 2) as Anancus brazosius, and to this they are referred.

Munson Shoals, Brazos County (26).- In the collection of Dr. Francis is an upper second left molar of Mammut americanum, found on Munson Shoals, in Brazos River, about 2.5 miles below Pittbridge.

Pittbridge, Brazos and Burleson Counties (27).-The collection of Dr. Francis contains the left side of the palate of Mammut americanum, which was found at Pittbridge, in Brazos River, August 9, 1899. This specimen has the second and third molars, the latter with 4 crests and a small heel. 'This may belong with the lower jaw, to be described below. Like the lower teeth, these upper ones are white. The second molar is $112 \mathrm{~mm}$. long and $87 \mathrm{~mm}$. wide; the third, $172 \mathrm{~mm}$. long and $104 \mathrm{~mm}$. wide. A lower jaw collected here during a flood in July 1899 (of which jaw Doctor Francis has sent a photograph) contains a large socket for a tusk. The diameter of the socket is $50 \mathrm{~mm}$. The length of the fragment present is $85 \mathrm{~mm}$. The distance from the angle of the jaw to the front is $830 \mathrm{~mm}$. The ascending ramus has a width of $370 \mathrm{~mm}$. The condyle rises $510 \mathrm{~mm}$. above the lower border of the jaw. The second molar is $118 \mathrm{~mm}$. long and $97 \mathrm{~mm}$. wide; the third molar is $200 \mathrm{~mm}$. long and $97 \mathrm{~mm}$. wide. This jaw is referred to $M$. progenium. Doctor Francis has a mastodon jaw with a 3-ridged tooth, which was found on a gravel-bar 2 miles below Pittbridge; also a molar found opposite the same place.

A beautiful upper last milk-molar, which had just begun to be worn, was found at Pittbridge and is in Doctor Francis's collection. There is a large pulp-cavity and the roots had not yet been formed. The enamel is corrugated and there is a strong cingulum along the inner border. The length is $76 \mathrm{~mm}$., width $65 \mathrm{~mm}$.

Here may be mentioned the discovery, at Pittbridge, of a species which the writer described (Bull. No. 71, Univ. Texas 1916 (191\%), p. 18, pl. Iv, figs. 1, 2) as Gomphotherium gratum. It is now referred to Anancus. The type specimen is owned by Dr. Francis and consists of a maxilla which contains the second and third molars. With this comes a third molar of the left side, evidently belonging to the same individual.

The remains of Mammut progenium and of Anancus gratus, above described, were found in 1899, in Brazos River, a mile below Pittbridge, after a heavy flood, during which a part of the bank fell, exposing the bones.

Hidalgo Falls, Washington County (28).-In 1863 (Trans. St. Louis Acad. Sci., vol. II, p. 141), B. F. Shumard, then on the Geological Survey of Texas, reported that he had found, in gravels overlying Miocene rocks at Hidalgo Falls, remains of Equus fossilis, Mastodon, Elephas, Megalonyx, Crocodilus, and Testudo. 
In 1874 , S. B. Buckley (1st Ann. Rep. Geol. and Agric. Surv. Texas, p. $64)$, referring probably to the same discoveries, stated that, about 15 years before he wrote, bones of the mastodon and of the mammoth in great abundance had been found in the banks of Brazos River. In 1893 (4th Ann. Rep. Geol. Surv. Texas, p. 44) Wm. Kennedy stated that numerous fossil remains had been reported from clays and conglomerates overlying sandstones in the neighborhood of Hidalgo Falls, but he obtained only a mastodon tooth. Doctor Francis has shown the writer a much-worn upper left second molar found in Brazos River, opposite Navasota, in 1918, on the Walker-Moore farm. The locality would be very close to Hidalgo Falls and is in Brazos County. A list of the species found here is given on page 245 .

Chapel Hill, Washington County (29).-The writer has seen a beautifully preserved upper right second molar of Mammut americanum, which was found, in November 1915, by T. B. Lipscomb, in Washington County, opposite Hempstead, and probably picked up on Brazos River. The tooth is now owned by Doctor Francis. Its length is $115 \mathrm{~mm}$., width $89 \mathrm{~mm}$. The enamel is rough and wrinkled. The roots were pretty well developed, but are broken off near the bases. There is yet a large pulp-cavity. Scarcely any wear is visible. The enamel is reddish brown, yellow, and whitish.

Leota, Madison County (30).-From Doctor Francis the writer received, for examination, a beautifully preserved tooth of Mammut americanum, found in 1915 by B. H. Lander, supposed to be of Madisonville, but a letter addressed to him there was returned, stamped "unknown." The tooth is a lower hindmost molar, with 4 cross-crests and a heel. Such parts of the roots as were developed are broken off. The tooth is $207 \mathrm{~mm}$. long and 102 $\mathrm{mm}$. wide. In the valleys is a little cement. The pulp-cavity contains some pebbles and some greenish sand, cemented together. The tooth is labeled as found in Trinity River, opposite Madisonville. It may therefore have been picked up in Houston County.

Clapps Ferry, Trinity County (31).-In 1922, Dr. Mark Francis secured a 3-ridged tooth of Mammut americanum, which was found in Trinity River, near Clapps Ferry, 10 miles west of Trinity.

Drew's Landing, San Jacinto County (49).--In 1920 (Univ. Texas Bull. No. 1869, p. 269) Professor E. T. Dumble reported that he had discovered, a mile below Drew's Landing, on the west bank of the Trinity, remains of mastodons, consisting of limb-bones, lower jaw-bones, and 19 teeth. They were found near the base of a deposit of sandy alluvial clay 30 feet thick.

Post, Garza County (32).-Dr. Mark Francis informed the writer that in 1916 a mastodon tooth was found near Post and came into the possession of George Doughty.

Denning, San Augustine County (33).-Doctor Francis's collection contains an upper left third molar of a mastodon, which he received, in November 1912, from T. J. Miles, of Denning. The roots are not developed and the pulp-cavity is large. The length is $178 \mathrm{~mm}$., the width $100 \mathrm{~mm}$. There is no talon.

Port Arthur, Jefferson County (34).-Dr. Mark Francis informed the writer in June 191\%, that he had lately received a very fine molar of a mas- 
todon, which was found at Port Arthur. It had evidently been washed ashore. 'The tooth is a lower left hindmost molar, worn on 3 crests. The talon is almost a fifth crest. The tooth has on it patches of marine bryozoa. Port Arthur is situated on the western shore of Sabine Lake and apparently on deposits belonging to the Recent epoch; but it is evident that deposits of Pleistocene age are present at no great depth below the alluvium. Naturally, it is impossible to say to what stage of the Pleistocene the tooth in question belonged.

Sour Lake, Hardin County (35).-A fragment of a molar of Mammut americanum was found here in blue clay and sand, beneath a bed of bitumen (Leidy, Ext. Vert. Fauna West Terr., p. 244). For other fossils found at Sour Lake, see page 242.

Harrisburg, Harris County (36).-The writer has seen at Houston, in the collection of Professor E. 'T. Dumble, a fragment of a molar of Mammut americanum, found on the banks of Buffalo Bayou, near Harris Bend. This must be near Harrisburg.

"Fifty Miles above the Mouth of Brazos River" (37).- Jeffries Wyman, in 1856 (Proc. Boston Soc. Nat. Hist., vol. vi, p. 53), described 2 molars of a mastodon, an upper last and a lower last molar, which had been found about 50 miles above the mouth of Brazos River. With these were an uln and part of a humerus supposed to belong to a mastodon; also remains of Megatherium and of an elephant.

McDowell, Austin County (38).-Dr. Mark Francis informed the writer that in 1909 P. M. Cuney, of Brookshire, found in Brazos River some fine mastodon and elephant teeth. These are now in the collection of Doctor Francis. The writer has before him a photograph of a tooth from this place. It is an upper left last molar, with fine roots still held in a fragment of the palate. Inasmuch as these materials were found in Brazos River, the locality was probably not far from McDowell.

San Felipe, Austin County (39).-This locality has long been noted for its fossil vertebrates. The species found here are recorded on page 246 . Remains of Mammut americanus were described from here by W. M. Carpenter in 1846 (Amer. Jour. Sci., vol. I, p. 249). Leidy (Proc. Acad. Nat. Sci. Phila., 1870, p. 97) reports on a specimen from this place which is now in the collection at Harvard College. The collection of Doctor Francis has an upper right last molar, $175 \mathrm{~mm}$. long, found in Brazos River at this place; another much like it is $154 \mathrm{~mm}$. long. His collection also has a large lower right last molar of $M$. americanum from San Felipe, also a palate with upper hindmost molars, right and left, teeth white, length $178 \mathrm{~mm}$., width $107 \mathrm{~mm}$., roots immense, the front root $150 \mathrm{~mm}$. high, the hinder one $160 \mathrm{~mm}$; the hinder talon little developed.

S. B. Buckley (Prelim. Rep. Geol. Agric. Surv. Texas, 1866, p. 44) stated that, many years before he wrote, almost the entire skeleton of a mastodon had been found on the banks of Brazos River near San Felipe. The bones were taken to New Orleans for exhibition and were reported as destroyed in a fire.

At San Felipe has been found a right ramus of a lower jaw with the second and third molars, which the writer described under the name Anancus brazo- 
sius (Pan-Amer. Geologist, vol. xxxıx, p. 112, pl. virI, figs. 1, 2). This jaw is in the Agricultural and Mechanical College at College Station, Texas.

From Professor Taylor White, of Sealy, Doctor Francis received a large upper right second molar, which was found opposite Sealy, in the "big bend" of Brazos River. The length is $116 \mathrm{~mm}$.; width, $92 \mathrm{~mm}$.; there are 3 ridges.

Near Ezzell, Lavaca County (40).-Dr. Mark Francis informed the writer that he secured in January 1922, a right side of the lower jaw of a mastodon, found on Summers Creek, near Ezzell; also 2 molars of a mastodon, discovered on Mixon Creek, somewhere in the same county.

Here may be recorded the finding of mastodon teeth at a point 5 miles west of Hallettsville. Some teeth were sent in January 1922 to Doctor Francis by L. P. Davis. With these were sent likewise 2 teeth which are referred to Elephas columbi.

Cuero, De Witt County (41). - In the U. S. National Museum is a lower last molar, No. 2368, which is recorded as sent to the museum by Lee Joseph, of Cuero. Mr. Joseph informed the writer that the tooth was reported to him as found in Clear Creek. In what part of the county this creek is situated the writer has not learned. The tooth is remarkable on account of the flattened condition of the various cusps. It possibly belongs to Mammut progenium or to an unrecognized species.

For (47) see page 16 ; for (49) page 19 ; for (50) page 12 ; for (51) page $1 \%$. Coleto Creek, Victoria County (48).-Dr. Alexander Deussen reported (Prof. Pap. U. S. Geol. Surv. 126, p. 109) that remains of mastodon had been taken from the banks of Coleto Creek about 8 miles west of southwest of Victoria. He implies that the remains were buried in Lissie deposits.

Keeran Point, Victoria County (42).-From Dr. Mark Francis the writer learns that in December 1919 he visited this locality and found that an enormous mass of the bluff had fallen not long before, and from the fallen materials he secured some fragments of mastodon, of elephant (Elephas columbi), and a vertebra and a part of a metapodial of a camel. Details regarding the geology of the region are given on page 236. The mastodon was later referred to Anancus brazosius (Pan-Amer. Geologist, vol. xxxix, p. $113)$.

Berclair, Goliad County (43). - The collection of St. Louis University, at St. Louis, Missouri, has a well-preserved lower left third molar of an Ameriman mastodon, labeled as having come from Berclair, which is on Blanco Creek.

Beeville, Bee County (44).-Dr. Mark Francis informed the writer that he learned of the finding of remains of the mastodon at this place. No details have been communicated.

Corpus Christi, Nueces County (52).-In October, 1923, A. P. Herndon, editor of the Corpus Christi Caller, sent to the U. S. National Museum a part of a mastodon tooth found at a depth of 16 feet in a clay bank at Flour Bluff, near Corpus Christi. The specimen presents parts of three hinder cross-crests and the small talon of a much-worn right hindmost molar, apparently of the lower jaw. The middle part of the grinding surface is deeply 
hollowed out. 'The outer ends of the crests present well-formed trefoils with folded enamel; the inner ends less well developed trefoils. The enamel of the sides and rear of the tooth is strongly wrinklerl vertically. It seems to the writer that this tooth represents the species Anancus brazosius. 'The Corpus Christi tooth has the catalogue number 10888 in the U. S. National Museum.

Duval, Jim Wells, or Nueces County (45).-In 1885 (Amer. Naturalist, vol. xix, p. 1208), Cope stated that Mammut americanum had been found in southwestern Texas. It is quite certain that he referred to the region about San Diego, but whether the locality was in Duval, Jim Wells, or Nueces County is not known. It was probably on Taranchua Creek, Duval County. Nor did Cope anywhere, so far as the writer knows, state what parts of this species he had in his possession.

El Paso, El Paso County (46).-In 190\%, G. B. Richardson, of the U. S. Geological Survey, sent to the U. S. National Museum some fossil vertebrate remains collected at El Paso. Among these the writer saw a fragment of a tooth of a mastodon belonging to another genus than Mammut. It was probably a species of Anancus, possibly of Gomphotherium.

\section{ARKANSAS.}

(Map 2.)

Helena, Plillips County (1).-The earliest record the writer has found of the occurrence of mastodon remains in Arkansas is of one met with at Helena. Dr. R. E. Call (Ann. Rep. Geol. Surv. Ark., vol. II, p. 39) stated that here bones of a mastodon had, at some time before 1889 , been exhumed. They were buried in a blue-black unstratified carbonaceous clay, at a depth of apparently 50 feet. They were further reported to have been buried in the cliff of loess, about 25 feet back from its face, but not in the loess itself. It is not probable that the remains were seen by Doctor Call; and there is nothing in the account that would exclude the possibility that they belonged to one of the elephants.

Near Trumann, Poinsett County (2).--In April 1921, the writer receired from Frank Janes, of Trumann, a fragment of a tooth and a dorsal vertebra of Mammut americanum, which had been turned out of a drainage-canal west of Trumann. The exact locality has been given by Mr. Janes as in the southeast quarter of section $\%$, township 12 north, range 5 east. The depth was supposed to be about 12 feet. The deposit is said to be a black waxy soil called there "gumbo." The digging was being made in the channel of a small stream, the Little Bay. A few other bones, among them a broken legbone, were found. Others might have been covered up in the dump.

Mississippi River, Chicot County (3).-In 1922, Dr. Clarence M. Pate, of Tutwiler, Mississippi, sent to the U. S. National Museum, for identification and return, an upper second molar of Mammut americanum. It had been found in a carload of gravel dredged up in Mississippi River. In answer to an inquiry Doctor Pate wrote that the gravel had been taken from the river at Greenville, Mississippi. The tooth is here credited to Arkansas. 


\section{OKLAHOMA.}

(Map 2.)

Afton, Ottawa County (1).-In the U. S. National Museum are many finely preserved teeth of Mammut americanum, secured near this place by W. H. Holmes in 1901. His report on his discoveries was first published in 1902 (Amer. Anthropologist, vol. Iv, pp. 108-129, with 2 pls.) and again in 1903, more fully illustrated (Ann. Rep. Smithson. Inst. for 1901, pp. 23\%-252, with 26 pls.). The situation of the spring and an account of the palæontological and anthropological materials discovered there will be found on page 254 , with a list of the species of mammals secured. From this spring Holmes took at least 100 mastodon teeth. Some of these were illustrated on his plates VI and VII of his report of 1903. Figures of others have been published by the present writer (Geol. Surv. Indiana, vol. xxxvi; Iowa Geol. Surv., vol. XXIII). All of these teeth are stained brown or black and appear to have lost practically all of their animal matter; but the vascular canals and the canaliculi are not filled with mineral matter; the freshly broken surfaces adhere strongly to the tongue. The report of Holmes says the mastodon teeth were found at a deptl of 4 feet and downward. The present writer is of the opinion that most of these belong to the Sheridan stage; naturally some may be somewhat older, others younger.

Peno, Le Flore County (2).-Early in 1923, E. V. Lovett, of Peno, sent to the Smithsonian Institution a letter and a photograph of the left ramus of a lower jaw of Mammut americanum, found in Arkansas River, about 2 miles above Peno and 3 miles from Braden. The jaw contained the last and the next to the last molars, little worn and finely preserved. Mr. Lovett has also the skull of a bison, found in the Arkansas River.

In the St. Louis Academy of Science is a mastodon tooth, an upper left hindmost molar, which is labeled as found in Oklahoma, 15 miles above Fort Smith. This would be along Arkansas River, probably not far from the town of Braden; the locality may have been on the north side of the river. Preserved in the same collection and secured in the same region are a part of a skull of an extinct species of bison and a part of a skull of the musk-ox, Symbos cavifrons.

Walker, Cleveland County (3).-Mr. Edward Butts, of Kansas City, Missouri, informed the writer that he has a tooth of a mastodon, found in Cleveland County during the excavation of a caisson for a bridge, for the Gulf \& Sante Fe Railway, over Canadian River. According to the maps this would be between the stations of Lexington and Noble, in township $y$ north, range 2 west. The tooth is stated to have been found at a depth of 30 feet below the water. A sketch of the tooth appears to show that it is a last milk molar.

Citra, Hughes County (4).--At Stanford University, California, the writer saw an upper second right molar and unworn parts of probably a third molar, labeled as found 14 miles northeast of Stonewall, Chicasaw Nation, now Pontotoc County. The locality would apparently be near Citra; it might be in either of the two counties named or in the northern part of Coal County. Mulhall, Logan County (5).--In 1917 (Bull. Geol. Soc. Amer., vol. xxviII, p. 212), Professor Troxell stated that he had collected remains of mastodons 
near Mulhall. Nothing since that time has been published on the collection. For the associated genera, see page 255.

\section{NEW MEXICO.}

(Map 2.)

Taos, Taos County (1).--In 1875 (Append. LL., Ann. Rep. Chief of Engineers, p. 986), Professor E. D. Cope reported that he had been shown a tooth of Mammut americanum, found in the clay along Rancho Creek. Probably this was the same tooth that he mentioned in $18 \% 4$ (Proc. Acad. Nat. Sci. Phila., 1874, p. 221). The exact position of Rancho Creek is not known to the writer, but there is on the maps a village called Ranchos, a few miles south of Taos.

Mastodon, Donna Ana County (2).-In 1907 (Bull. Geol. Soc. Amer., vol. XVIII, p. 215), W. T. Lee reported the discovery of bones of Mammut americanum and of a horse at a siding called (from the discovery) Mastodon. The locality is between El Paso and Noria, about 15 miles south of the Afton volcanoes, where other horse remains were discovered (p. 258). The bones of the mastodon and of the horse were identified by J. W. Gidley. The same species of mastodon had been previously found only at Taos.

\section{MISSOURI.}

(Map 2.)

Galena, Stone County (1).-At a meeting of the Boston Society of Natural History, December 5, 1849, Mr. Desor referred to a fine skeleton of a mastodon which he had lately seen taken from a depth of 70 feet at Galena. He remarked that it had been thought that this specimen occurred in true drift; but it was found in a deposit mixed with drift materials and buried subsequent to the drift. The teeth were fine. The tusks had a diameter of 3 inches; the speaker thought that they must have belonged to a large animal.

This county is in the region affected by the Ozark uplift and lies between 300 and 400 miles south of the border of the region covered by glacial drift. Galena itself is on the James Fork of White River. We do not know exactly where the mastodon was met with nor under what conditions; probably it was buried in alluvial deposits along the James. Under a depth so great the animal may have dated far back in the Pleistocene; of this we can not now be certain.

Near Joplin, Jasper County (2).-From Byron A. Ash, of Carthage, Missouri, the writer learned of the discovery of some remains of mastodons and of Elephas columbi, at a place described as situated 9 miles southwest of Carthage. This would be not far northeast of Joplin. A shaft was being sunk in search of zinc ore. Mr. Ash writes as follows:

"In sinking the shaft we first passed through 12 feet of clay and gravel; then through 45 feet of limestone; then through 30 feet of black loam and into a peat formation. In this the bones were found and also pieces of petrified wood."

The bones and teeth were thus at a depth of nearly 90 feet from the surface. Besides the species mentioned, Mr. Ash stated that bones of a turtle and of a species of Bison, probably extinct, were discorered. These were exam- 
ined and identified at the U. S. National Museum. The supposed petrified wood was probably portions of tusks. It is certain that, in sinking the shaft, one of the caves so abundant in that region had been passed through. In this cave had accumulated soft deposits in which were buried the animal remains. It seems that this cave had been completely hidden from view. While there are no evidences of the age of the remains to enable one to speak with certainty, it appears probable that they date back to early Pleistocene, possibly to the Aftonian. The Joplin Folio (No. 148) of the U. S. Geological Survey describes minutely the geology of this region and discusses the origin of the numerous caves existing there.

Springfield, Greene County (3).--The identity of the tusks here reported is doubtful, as no teeth were found with them. They may belong to one of the elephants. A. M. Stalnaker (Kansas City Rev. Sci. Industry, vol. vir, p. $615)$ reported the discovery of tusks in digging a well. The digger seems to have passed through solid rock, then into mud that filled what is probably a cave. One tusk was, at the time of the report, in possession of the Academy of Sciences at Kansas City.

In 1898, Dr. E. M. Shepard (Geol. Surv. Mo., vol. XII, p. 143) told of the discovery of a well-preserved mastodon tusk about 8 feet long, which lay in a horizontal crevice in the limestone at Springfield. It was met with in excavations made just south of the Kansas City, Fort Scott, and Memphis Railroad. It may be that this refers to the same tusks as those reported by Mr. Stalnaker. Here again it appears that one must attach considerable age to the tusks, probably early Pleistocene.

Papinsville, Bates County (4).--In 1881, G. C. Broadhead, the geologist, reported (Kansas City Rev. Sci. Industry, vol. Iv, p. 521) that a mastodon tusk had been found at Papinsville, in the gravel. The town is on Osage River, and the tusk, whether of mastodon or of elephant, had probably been washed out of the bank of the stream.

On Pomme de Terre River, Benton County (5).-This locality is famous for the remains of mastodons which it has furnished. Besides these, however, there have been found or reported remains of Elephas columbi, Bison, Odocoileus, Cervus, Equus, Mylodon, and Megatherium. In 1842, Richard Owen (Proc. Geol. Soc. London, vol. III, p. 689), in discussing Koch's collection left at the British Museum, stated that in it were remains of Mylodon harlani; also portions of large species of Bos, Cervus, etc.; but the place of their origin is not mentioned.

The occurrence of bones in this region was known to B. S. Barton as long ago as 1806. In the fourth edition of Cuvier's Ossemens Fossiles, 1834, vol. II, page 270 , is an extract from a letter written by Barton to Cuvier in 1806, in which Barton stated that an intelligent traveler had seen in a particular locality near the river of the Osage Indians thousands of the bones of this animal and that this traveler had collected there, among other things, 17 tusks, of which some had a length of 6 feet and a diameter of a foot. However, the majority of these bones were in a bad state of decomposition. Barton sent a molar to Cuvier which appears to have been found in this region. In his Archocologia Americana, 1814, page 26 , Barton speaks of the immense number of bones in 
the country of the Osage Indians; he also stated that he had a molar from there.

It was through the explorations of Dr. Albert C. Koch that the Pomme de T'erre locality became famous. This indefatigable searcher after fossil remains of mastodons and zeuglodons gave a description of his discorery of mastodon bones and teeth in Benton County, Missouri, in 1840. 'These remains are of interest, because from them was restored, by Professor Richard Owen, a skeleton in the British Museum of Natural History. In his "Short description of fossil remains found in the State of Missouri," a pamphlet of 8 pages, printed at St. Louis in 1810 , Koch gave an account of the discovery of the skeleton on which he bestowed the name Missourium. A fifth edition of the sanie work, enlarged to 28 pages, was published in the same year at Dublin, Ireland. An account in different words was presented by Koch in his pamphlet of 99 pages and 8 plates, printed in Berlin in 1845 and entitled Die Riesenthiere, etc. The locality was in the southern part of Benton County, on the Pomme de Terre River, a tributary of Osage River. Broadhead (Kansas City Rev. Sci. Industry, vol. Iv, 1881, p. 520) described the place as being on Pomme de Terre River, 10 miles southwest of Warsaw; but, according to the best maps at hand, a point on Pomme de Terre River 10 miles from Warsaw would be almost due south of this town. Broadhead further stated that the place was on the farm of Alexander Brashears. This information was taken from James H. Lay's History of Benton County, page 14 , published in 1876. Here the name is given as Breshears. Lay stated that a Scotchman named Cott exhumed a large and well-preserved skeleton, which he took east and sold for $\$ 20,000$. This probably refers to Doctor Koch's work. Other persons are mentioned as having unprofitably spent much money at this place in search of bones.

From Mr. J. S. Kidwell, county surveyor and highway engineer at Warsaw, Missouri, the information has been received that the locality is in the northwest quarter of section 9 , township 38 , range 22 west. This would be in Hickory County, not far from the town of Avery.

According to Koch, an attempt had been made by some of the earlier settlers to construct a mill for grinding flour and corn meal. In making the necessary excavation, some bones of young mastodons were met with; but the interest in these was soon lost. In 1839, another tooth was found and the report of this reached Koch early in 1840. On March 31 of that year (Die Riesenthiere, pp. 69, 70) he was at the crossing of Osage River, 24 miles away from his destination. On page 71 of the work quoted he said that he spent 5 months in a cabin there. On the other hand, P. R. Hoy (Amer. Naturalist, vol. v, 1871, p. 14\%) wrote that in March 1840 he "visited the spot on the Pomme de Terre, Benton County, Missouri, where Dr. Koch had recently disinterred the large male mastodon now in the British Museum, which the Doctor mounted and named the Missourium tetracaulodon." Hoy found that the excavation made by Koch was about 15 feet in diameter and 6 feet in depth and was half filled with water. A man who had helped Koch told Hoy that Koch did not get out all of the bones; and Hoy succeeded in finding a molar and some other remains. See also statements made by Dr. Edmund 
Andrews (Amẹr. Jour. Sci., vol. x, 1875, pp. 32-34). It is impossible to reconcile such contradictory statements.

In 1843, Harlan (Amer. Jour. Sci., vol. xliv, p. 69), speaking of Koch's large collection on exhibition in Philadelphia, stated that it contained more than 300 mastodon teeth, with numerous jaws, besides remains of the ox (probably bison), deer, elk, megatherium, and mylodon. Harlan (loc. cit., pls. I-III) described some parts of the skeleton and about 24 teeth (his Orycterotherium missouriense) which is now referred to Mylodon harlani. He believed that the collection was made on the Pomme de Terre.

Koch described quite minutely the character of the deposits met with in making his excavation. Above all was the surface soil, the depth of which was not stated; beneath this from 2 to 3 feet of gravel; beneath this about the same thickness of yellowish clay. Then followed two layers of gravel, each from 9 to 18 inches in depth; below these 3 feet of blue clay. Then came 3 feet of alluvial soil, which contained some of the bones of the Missourium. Under this was the deposit which inclosed most of the skeleton. Besides the bones, this layer contained much other animal material, consisting of the flesh, skin, etc., which had been transformed into a brown fatty mass. Beneath this bone-bearing layer was a deposit of sand. The layer of alluvium contained an abundance of vegetable matter in a wonderful state of preservation. Koch regarded the plants as indicating a warm or tropical climate. He found cypress burrs, and wood which he thought was related to logwood; also a flower of Strelitzia, a genus of African plants; likewise several stems of palmetto. Koch concluded that "a revolution of the earth" had taken place here, between September 15 and October 20 at some time in the past. In discussing the discovery in 185\%, (Trans. St. Louis Acad. Sci., vol. I, pp. 63, 64) Koch affirmed that the layer of vegetable mold was 5 or 6 feet deep and was overlain by 20 feet of alternate layers of sand, clay, and gravel.

From the bones in Koch's possession, no doubt obtained partly on Pomme de Terre River, he reconstructed his Missourium theristocaulodon, of which in 1845 he gave a description and a figure (Die Riesenthiere, pp. 43-53, pl. viII). The tusks were each 10 feet long. The length of the skeleton, from tip of nose to root of tail, is given as 30 feet, height 15 feet. This skeleton was afterwards sold to the British Museum and reconstructed by Richard Owen, being at the same time reduced to more reasonable proportions. Even in its reconstructed form it was composed of bones from several individuals (Lydekker, Cat. Foss. Mamm., pt. IV, p. 16, fig. 3). The price received by Koch for this skeleton was 1,000 pounds sterling (Amer. Jour. Sci., vol. II, 1846, p. 132, fig.).

Besides the bones of the several animals mentioned, which Koch claimed to have found when excavating for his Missourium, he asserted that he took out with his own hand from among the bones 5 stone arrow-heads. One of these lay under the right femur and had left a light-colored spot on the elsewhere brown-colored bone.

We can not form definite conclusions about the age of the fossils found by Koch along Pomme de Terre River. If we were certain that the things which he reported from there were really found there, we would have some founda- 
tion to stand on. If he found there remains of horse, mylodon, and megatherium, early Pleistocene, probably Aftonian, would be indicated.

Tackner, Benton County (6).-At a meeting of the Academy of Natural Sciences, December 3, 1843 (Proc. Acad. Nat. Sci. Phila., vol. I, p. 321), Doctor Chaloner called the attention of the Society to a collection of bones of mastodons and elephants which had been brought from Benton County, Missouri, by S. H. Whipple. The weight of the collection was estimated to be about 2,000 pounds. At a meeting of the American Phiolosophical Society held January 19, 1844 (Proc. Amer. Philos. Soc., vol. Iv, p. 35), this collection of bones was reported as having been purchased of Whipple at the instance of Dr. Isaac Hays. A statement by Whipple accompanied the collection to the effect that it had been made in the county mentioned, at a distance of half a mile from Osage River, and evidently south of it. Broadhead (Kansas City Rev. Sci. Indust., vol. Iv, p. 520) stated that the place was on the farm of the heirs of Charles Wickliffe. Whipple reported that the locality was in latitude $38^{\circ} 10^{\prime}$ and in $16^{\circ} 40^{\prime}$ longtitude west from Washington, which would be $93^{\circ} 41^{\prime} 34^{\prime \prime}$ west from Greenwich. However, the latitude as given would locate the spot about 5 miles south of Osage River, and the longitude as given would locate it in the middle of Henry, the next county west. One can not rely on the statement. Mr. J. S. Kidwell, county surveyor of Benton County, has informed the writer that the locality is in the southeast quarter of section 24, township 40, range 23 west. The description of the character of the country is no doubt correct. South of the Osage it is characterized by its irregular and broken appearance, running up into extensive ridges, rocky cliffs, and flinty knobs. Between these there intervene valleys, through which run streams of water, bordered by alluvial bottoms and lofty forests. In one of these valleys there is a small saline marsh, perhaps an acre in extent. Close to the marsh runs a rocky ridge on which remain columns of limestone, sometimes rising 20 feet above the general level of the ridge. In the soil of the marsh were found the bones, at depths varying from 2 to 12 feet and lying in great disorder. It does not appear that any remains of other animals than mastodons and elephants were secured at this place. The elephant is probably $E$. columbi, inasmuch as specimens from this county are in the Philadelphia Academy collection.

The collections of the American Philosophical Society were many years ago turned over to the Philadelphia Academy of Natural Sciences. In the collections of the Academy are found a considerable number of teeth and bones of mastodons, labeled as having been obtained in Benton County, Missouri, but no definite spot is mentioned; most of them probably belong to the Whipple collection. In the Academy's collections is the type of Dr. Isaac Hays's Tetracaulodon collinsii, now regarded as belonging to Mammut americanum. This specimen is labeled as having come from Benton County. As it was described in 1834 (Trans. Amer. Philos. Soc., vol. IV, p. 326, pl. xxvIII), it appears, if the label is not incorrect, that mastodon materials from Benton County had reached Philadelphia long before Koch and Whipple brought their collections there. Furthermore, the type of Mastodon cuvieri Hays is in the Academy's collections; it, too, is labeled as having been obtained in 
Benton County. It was described in 1834 (op. cit., pp. 322, 334, pl. xxiv). Just where these fossils came from in Benton County it is impossible to determine. As to the geological age of the fossils of the Whipple collection, one can only indulge in surmises.

In James H. Lay's History of Benton County, published in 18\%6, it is recorded that, at the Wickliff farm, Case and Redmond took out a part, perhaps the whole, of a large mastodon skeleton and sold it at Cincinnati.

Osceola, St. Clair County (y).-From Edward Butts, Kansas City, Missouri, the writer received a sketch of a penultimate upper molar of Mammut americanum, which had been dredged up with gravel from the bed of Osage River at Osceola. At the time of writing, it was the possession of Mr. Butts. The little-worn crown had a length of $96 \mathrm{~mm}$.; the roots were well developed. Nothing can be affirmed regarding the stage of the Pleistocene when the animal lived.

Sedalia, Pettis County (8).-The geological collection of the University of Missouri contains a large number of bones of Mammut americanum, which, through the kindness of Professor E. B. Branson, the writer has been allowed to examine. They were obtained near Sedalia by R. A. Blair; they embrace nearly all parts of the skeleton and individuals of different ages. A letter addressed to the writer by N. P. Elmore, county clerk of Pettis County, states that the spring at which these bones were found is in section 25, township 45 north, range 21 west. This would be about 4 miles southeast of Sedalia. The political name of the township is Flat Creek. This collection is obviously the one to which Broadhead referred in 1898 (Geol. Surv. Mo., vol. xII, p. 376). From Broadhead (Kansas City Rev. Sci. Indust., vol. Iv, 1881, p. 519) it is learned that this collection was made by $R$. A. Blair in the winter of 1879-80. The spring where the bones were obtained was about 400 feet distant from the creek, about 15 feet above it and on the opposite side, about 200 feet from the gently rising higher ground. The diameter of the bog surrounding the spring was about 20 feet. The mastodon bones were found in "a light spongy, peaty humus" (and in a space about 15 feet in diameter), together with some pieces of wood resembling cypress. The depth of this humus was about 8 feet, underlain by gravel. It was supposed that remains of about 8 individuals were exhumed. A few flint implements and a stone club were found with the bones; these were probably introduced long after the interment of the mastodons.

It does not appear that any remains of other animals were found with these mastodons and the writer did not observe any in the collection at the University of Missouri; hence there is nothing to indicate the geological age of the mastodons.

Bourbeuse Creek, Gasconade County (9).- In the Philadelphia Presbyterian of January 12, 1839, there appeared an anonymous article concerning the discovery of remains of a mastodon in Gasconade County and of evidences of the existence of man contemporaneously with the mastodon. This article was, on July 1, 1839, reprinted in the American Journal of Science, volume xxxvi, pages 198-200. The discoverer of the remains in question was Dr. Albert Koch, of St. Louis, the finder of the mastodon remains on Pomme de 
'Terre River, in Benton County. The article was acknowledged by Koch in 1857 ('Trans. St. Louis Acad. Sci., vol. I, p. 62), and further description was given of the discoveries. He also gave a picturesque account of his work here, in a pamphlet published at St. Louis in 1840, entitled " $A$ short description of fossil remains found in the S'tate of Missouri."

The exact locality of the exhumation is not known. Bourbeuse Creek runs northeastward across the extreme southern end of the county. Koch's statement as to the longitude and latitude must be disregarded. The investigations were made in 1839. It appears that a farmer, in cleaning out a spring about 400 yards from the bank of the stream, discovered at a depth of 5 feet a part of the back and hip-bone of a large animal. In his excavation for the remainder of the animal, Koch found that it had been mired in a standing position and that its legs were sunken in a layer of clay. Above this clay was a layer of ashes, from 2 to 6 inches thick; in his work of 1840 he stated that the layer of ashes was 6 to 12 inches thick. With these were mingled bones, partly burned, and broken pieces of rock. Koch's conclusion was that human beings had found the great creature helplessly mired and had carried there, from the shore of the stream, rocks to hurl at it. Then these natives had kindled around it, for its destruction, a great fire, which had burned many of the bones and had been especially destructive around the creature's head. The legs sunken in the clay had not been injured. Furthermore, the natives had hurled at the animal many stone arrow-heads, a stone spear-head, and some stone axes. Also between the rocks sunken in the ashes were found large pieces of skin that appeared like freshly tanned leather, strongly impregnated with the lye from the ashes; and a great many of the sinews and arteries were seen, some of which Koch preserved in spirits.

The stratum, which was made up of ashes and stones and bones, was overlain by alluvial deposits of clay, sand, and soil to a depth of 8 to 9 feet. In his first account of this investigation, Koch says that, in case any reader had any doubts about the correctness of the statements, he could be referred to more than twenty witnesses present during the time of digging. Koch included an account of this discovery in his work of 1845 , entitled "Die Riesenthiere der Urwelt oder das neuentdeckte Missourium theristocauTodon," on page $5 \%$.

In $185 \%$, Dr. A. Wislizenus (Trans. St. Louis Acad. Sci., vol. I, p. 168) endeavored to show that the conditions under which Koch had found the remains of the mastodon and the human implements dir not bear out his conclusions. In 1875, J. D. Dana (Amer. Jour. Sci., vol. Ix, pp. 335-3t6) made a careful review of Koch's discoveries, publications, and pretentions, and showed that, even if Koch's honesty were conceded, he was not competent to form correct judgments on anatomical and geological matters. Dr. Edmund Andrews (Amer. Jour. Sci., vol. x, 1875, p. 33) presented an explanation of the matters supposed to have been observed by Doctor Koch. Doubtless something might yet be learned by making careful excavations on that spot, but it would probably not pay for the trouble. It is impossible to say at what time during the Pleistocene the mastodon lived. 
Ste. Genevieve County (10).-In 1873, B. F. Shumard (Geol. Surv. Mo., 1855-1871, p. 291) reported briefly that B. Pratt, of St. Mary's, had obtained in a well, at a depth of 18 feet, a fine molar of a mastodon. This was presented to the Academy of Science of St. Louis; it should now be in the collection. The place where it was found is said to be in the southwest quarter of section 1, township 36 north, range 9 east. This is in the alluvial plane of Mississippi River. A section found near the well mentioned shows at the top 5 feet of soil, with much humus; below this, 30 feet of yellow arenaceous clay; then 15 feet of plastic blue clay. The tooth must have been in the yellow clay.

Kimmswick, Jefferson County (11).-A considerable number of mastodons have been collected at Kimmswick at various times and by various persons. Further details regarding these, the geology of the locality, and the other species obtained there are given on pages 262,263 .

St. Louis, St. Louis County (12).-One might readily suppose that in making innumerable excavations in a great city like St. Louis large numbers of bones and teeth of fossil animals would be brought to light. On the contrary, the writer has found only three accounts of such discoveries; these were made many years ago. In a report by G. C. Swallow, in 1855 (First and Second Ann. Repts. Geol. Surv. Mo., pt. 2, p. 175), in discussing the Bluff or Loess formation, he stated that fossil remains of the mastodon had been found in these deposits in making an excavation for a sewer in the neighborhood of Geyer Avenue and Eighth Street, in what was then the southern part of the city. They were discovered at a depth of about 16 feet and consisted of 2 nearly perfect teeth and fragments of bones. A musk-ox (Symbos cavifrons) and a horse (Equus complicatus) found here will be mentioned on pages $139,181,262$.

Fertile, Washington County (19).-From Mrs. P. G. Higginbotham, of Fertile, the U. S. National Museum has received a brief description and a sketch of a mastodon tooth which was found many years ago. It is reported as dug up from sand in or near Big River. The tooth has 3 crests and is about $110 \mathrm{~mm}$. long and $85 \mathrm{~mm}$. wide. No other details are known.

Arrowrock, Saline County (13).-George P. Purcell, of Arrowrock, states that several years ago he found a mastodon tooth in the northeast quarter of section 36, township 50 north, range 19 west. Mr. Purcell sent a pencil sketch which shows that the tooth was that of Mammut americanum; there were 4 crests and a large crest-like talon. The tooth was 8 inches long. Afterwards another tooth was found near the same place. The locality is very near the right bank of Missouri River. The Kansas drift sheet seems to occupy the immediate vicinity, and probably the teeth were left there at some post-Kansan period.

Under this number 13 must be recorded a mention made in 1873 , by $\mathrm{F}$. B. Meek (Geol. Surv. Mo., 1855-1871, p. 183), of mastodon remains in Saline County. It seems that the bones and teeth had been found south of Blackwater Fork, about 2.5 miles above the mouth of Ferris Creek, hence not far from the south line of the county. Meek saw some of these remains, but was not able to secure them. 
Kansas City, Jackson County (14). - In the Daniel B. Dycr Museum, Public Library building, in Kansas City, the writer saw the lower jaw of a mastodon, which contains the penultimate and the last molars. With this jaw are an upper last molar, some portions of tusk, and the head of a femur. Mr. Edward Butts, interested in the collection of fossils, wrote that these remains were found at a point about 300 fcet west of the intersection of First Street and Lydia Avenue, in the loess formation, and at a depth of about 20 feet below the undisturbed surface. The diameter of one tusk is given as 10 inches.

About 15 years ago Mr. Butts obtained from a brickyard foreman a mastodon tooth which had been found in the locss, about 500 fect south of the spot where the teeth and bones first mentioned were met with. The occurrence of these remains in the loess at the depth given appears to indicate the late Iowan stage or the Peorian stage.

H. H. West reported in 1880 (Kansas City Rev. Sci., Indust., vol. I, p. 336) the discovery, at Kansas City, of a portion of a tusk which he regarded as that of a mastodon. This was found in what he regarded as loess, on Campbell Street, about 150 feet north of Independence Avenue. He furnished a geological section of the locality. Broadhead (same Review, vol. IV, p. 521) mentioned this find and suggested that the tusk might have drifted from deposits a little older, or, more probably been washed into the loess lake from the adjacent shore. It was then supposed that the loess was laid down in water.

In 1880 (Kansas City Rev. Sci., Indust., vol. III, p. 643), Dr. F. A. Ballard, of Independence, recorded the finding of a supposed mastodon tusk in a "lick," in the eastern part of Jackson County. The locality was not more exactly given; it was said to be "twenty miles east of here," meaning probably east of Kansas City. Brothers by the name of Hulse were mentioned as living in the neighborhood. The tusk lay across the rut of a wagon road and was much damaged. A section of this 3 feet long and an ulna were secured and presented to Juadge H. H. West. It is possible that these fragments are yet preserved in some museum.

Line Creek, Platt County (15).--In 1881, G. C. Broadhead reported (Kansas City Rev. Sci., Indust., vol. Iv, p. 521) that J. C. Evans had obtained a large tooth of a mastodon from Line Creek. No other information was furnished. Broadhead thought that the tooth might have been washed out of glacial clay. The exact position of Line Creek is not known to the writer.

Caldwell County (16).- On the page just cited, Broadhead noted that a mastodon tooth had been found in Caldwell County. The information is very vague.

St. Joseph, Buchanan County (17).-The collection of the St. Louis Academy of Science contains a lower right hindmost molar, labeled as found near St. Joseph. No details are given. The outer half of the tooth is split off. The hinder root is extremely long, $150 \mathrm{~mm}$. from the base of the crown to the tip.

Clarksville, Pike County (18).-At a meeting of the St. Louis Academy of Science, held December 20, 1875, Albert Todd exhibited 2 teeth which he supposed belonged to Mastodon angustidens. They had been found in a creek which empties into Mississippi River at the upper end of Clarksville; and 
they were brought to St. Louis by Mr. Jameson, of Louisiana, Missouri. These teeth are well preserved, and doubtless belonged to Mammut americanum.

For (19) see page 31.

\section{KANSAS.}

(Map 2.)

Little Osage River, Bourbon County (1).-The U. S. National Museum contains 2 mastodon teeth recorded as found along Little Osage River in Kansas, but no more exact locality is given. This would be somewhere near the northern boundary of Bourbon County. One tooth, No. 326 of the catalogue, is part of a lower right hindmost molar; the other, No. 336, is part of the upper right last molar. The locality is entirely outside of the glaciated area and it is impossible at present to say in what part of the Pleistocene epoch the animal lived.

Buffalo, Wilson County (10).-The American Museum of Natural History in New York contains a palate and both rami of the lower jaw, with teeth, belonging to Mammut americanum, which were secured somewhere near Buffalo by Charles H. Sternberg. In the lower jaw all three molars, in fine condition, are present. The catalogue number is 1464.

Emporia, Lyon County (2).-In 1866 (First Ann. Rep. Geol. Surv. Kansas, p. 14), B. F. Mudge stated that a large mastodon tooth, the lower last molar, had been found near Emporia and shown to him. Broadhead in 1880 (Kansas City Rev. Sci., Indust., vol. IV, p. 521), in speaking of discoveries of mastodons, made the brief remark that other bones had been found near Emporia. This region is outside of the glaciated area.

Franklin County (3).-Professor William Wheeler, in $18 \% 8$ (Trans. Kan. Acad. Sci., vol. vI, p. 11), reported that a tusk of a mastodon had been found in the bank of Eight Mile Creek and had been sent to the State University. There is no evidence to show that it was mastodon rather than elephant. The same author stated that a mastodon tooth had been found, some years previously, in the same creek, about 5 or 6 miles south of the place where the tusk was discovered. Broadhead, the geologist (Kansas City Review, vol. Iv, p. 521), stated that remains of the mastodon had been found in this county. No particulars were furnished.

Osawatomie, Miami County (4).-In 1866 (First Ann. Rep. Geol. Surv. Kansas, p. 14), B. F. Mudge stated that a few years previously a part of a large jaw-bone of a mastodon, containing 3 teeth, had been fished up from a stream near this town. It was sent to Ohio and all traces of it lost.

Lawrence, Douglas County (5).-J. Savage (Trans. Kan. Acad. Sci., vol. vI, p. 10) told of the discovery of a lower jaw of a mastodon a little below water-level on Wakarusa Creek, southwest of Lawrence, on land then owned by Judge Lawrence. Near the same place were afterwards found bones of bison, elk, and antelope. This jaw is mentioned by Williston (Univ. Geol. Surv. Kan., vol. II, p. 301). It is in the collection of the University of Kansas and has been examined by the writer. He regards it as belonging to the species Mammut progenium. The following are some of the measurements: 
Measurements (in millimeters) of lower jaw of Mastodon.

Length from tip of jaw to rear of ascending ramus at level of teeth........... 812

Width of ascending ramus at level of teeth (outside)................... 284

From tip of jaw to front of second lower molar. . . . . . . . . . . . . . . . 248

Height of jaw at front of second lower molar...................... 192
Length of symphysis..... . . . . . . . 205

Length of second lower molar......... 110

Width of second lower molar......... 87

Length of third lower molar.......... 162

Width of third lower molar. . . . . . . . 96

In the front end of the jaw are two sockets for tusks. The vertical diameter of the right one is $60 \mathrm{~mm}$; the horizontal, $50 \mathrm{~mm}$. The lower floor of the socket is somewhat convex, showing that the tusk would have been bent downward. The jaw had been buried in blue clay and it lay at a level of about 25 feet below the present surface of the ground in the neighborhood. The bones of the other species mentioned were not associated with the jaw. They were found subsequently, evidently at some distance away. They were all in an unfossilized condition and were described as appearing to be bones of bison, elk, and antelope. It was concluded by the finders of the more recent bones that the mastodon jaw in a fossilized state had been washed into the old lake-bed in which the bison and elk bones had been covered up. This is not probable.

Professor J. E. Todd (Trans. Kansas Acad. Sci., vols. XxiII, xxIV, 1911, pp. 211-218) has given an interesting account of the history of Wakarusa Creek. According to his view, the Kansan ice dammed Kansas River and directed its waters into the Wakarusa. He doubts that the Nebraskan ice reached that region.

To the present writer it seems reasonably certain that there are Aftonian deposits in the valley of Kansas River, at Lawrence, as shown by the presence of Equus laurentius there. He believes that an old pre-Kansan valley existed where the Kansas now flows and probably another where is found the Wakarusa. These became partially filled during the Aftonian stage; and the deposits of the latter contain the early Pleistocene fossils that turn up there now and then. The Wakarusa mastodon jaw could not have been transported far without serious damage.

Palermo, Doniphan County (6). - The writer has received letters and a photograph showing the discovery of remains of a mastodon, apparently Mammut americanum, near Palermo. The locality was reported as being in the east half of the northeast quarter of section 24 , township 4 south, range 21 east. The bones and teeth were found by Albert Kienhoff, of Wathena, in a small creek on his farm, and were sold to George Groneweg, of St. Joseph, Missouri, from whom a photograph of one of the molars, apparently the lower right last one, has been received. A tooth of Elephas columbi and one of Equus niobrarensis have been found on the same farm. A newspaper account of the discovery of the skeleton states that bones and teeth, weighing all together about 200 pounds, had been taken out. The remains were found in a ravine about a mile from the Missouri River and about 50 feet below what was formerly the surface at that point. The bank had been eaten away by 
the stream and the bones were thus exposed. It appears evident that the remains discovered here were buried in Aftonian deposits.

Manhattan, Riley County (7).-B. F. Mudge, in 1866 (First Ann. Rep. Geol. Surv. Kansas, p. 14), stated that the cabinet of the State Agricultural College contains a femur of a mastodon found at Manhattan. S. C. Mason, in 1883 (Trans. Kan. Acad. Sci., vol. virI, p. 13), mentioned incidentally that remains of elephants and mastodons had been found near Manhattan in the loess and on sand-bars. S. W. Williston, in 1897 (Univ. Kan. Geol. Surv., vol. II, p. 301), stated that he had knowledge of the finding of Mammut americanum at Manhattan. The present writer has seen in the collection of the Agricultural College at Manhattan a finely preserved lower left last molar of $M$. americanum. It has the catalogue No. 1878 and is labeled as found a mile south of Manhattan on a sand-bar in Kaw (or Kansas) River. The tooth is $185 \mathrm{~mm}$. long, has 5 cross-crests and a large pulp-cavity. The tooth had evidently just come into use.

Jewell County (8).-Dr. S. W. Williston, as cited above, stated that he had knowledge that the American mastodon had been found in Jewell County. No particulars were given.

McPherson, McPherson County (9).-This paragraph concerns, not the common mastodon, Mammut americanum, but a bunodont mastodon belonging to the genus Stegomastodon. The writer described this under the name of Gomphotherium elegans (Proc. U. S. Nat. Mus., vol. LIII, pp. 219-221, pl. xxvi). The species was based on a single lower last molar found in a sandpit about 2 miles east of McPherson, at a depth of 35 feet. The sands found here belong to the Sheridan, or Equus, beds, and have been described by Haworth and Beede (Univ. Kansas Geol. Surv., vol. II, pp. 285-296, pl. XLV) and by Beede (Trans. Kansas Acad. Sci., vol. xv, pp. 104-110, pls. II, III, VI). A re-study of this tooth convinces the writer that it does not differ specifically from Leidy's species Mastodon mirificus, the type of which was found in the Pleistocene of northwestern Nebraska. The teeth hitherto referred to this species are much worn. The Kansan tooth had not yet come into use and therefore presented an appearance very different from that of the known worn teeth for study. The species is now known as Stegomastodon mirificus or Anancus mirificus.

For (10) see page 33.

\section{COLORADO.}

(Map 2.)

Fifteen miles northeast of Pueblo, Pueblo County (1).-In the collection of the State Historical and Natural History Society, at Denver, there is a fragment of a mastodon tooth labeled as found about 15 miles northeast of Pueblo. The collector was N. M. Tabor, of Denver, and the year apparently about 1875 . The tooth is that of Mammut americanum.

Golden, Jefferson County (2).-The City Park Museum, Denver, has an upper right second true molar of Mammut americanum, labeled as having been found in "Quaternary drift" at Golden. It is little worn and presents good large roots. 
IOWA.

(Maps 2, 4.)

\section{Within the Area Covered by Kansan Drift.}

Salem, Henry County (1).-In Netta C. Anderson's list of the mastodon and mammoth remains found in Illinois and Iowa (Augustana Lib. Pubs., No. 5), Professor Frank Leverett reported that some mastodon teeth had been found in the vicinity of Salem. He had not himself seen the teeth, and there is the possibility that they belonged to one of the elephants. In the same list, Dr. J. M. Shaffer reported that two mastodon teeth had been dug up near the bank of Skunk River, in this county.

In January, 1924, the writer received from Professor A. O. Thomas, of Iowa University, photographs of an anterior dorsal vertebra of a mastodon, in all probability Mammut americanum, which had been found near Salem. The locality is, more exactly, near the center of section 18, township 70 north, range 7 west. The object was found in a bed of sand on the flood plain and to the north of a little stream, Big Cedar Creek. Professor Thomas cites Savage (Geol. Surv. Iowa, vol. XII, p. 289) for the statement that the deposit is of pre-Kansan age. This would be either Aftonian or Yarmouth. The specimen consists of the dorsal spine, broken at the neural arches and displaying the postzygapophysial surfaces. The length of the specimen is close to 18 inches. The writer finds that these articular surfaces are more widely separated in the mastodons than in at least the existing elephants.

Mount Pleasant, Henry County (2).-In Netta C. Andersons' list, above mentioned, Professor T. A. Savage reported the finding of some bones and teeth of a mastodon in a well near or in Mount Pleasant. These remains are said to have been met with in or immediately below the Kansan drift. They were placed in the collection of the Iowa Wesleyan University, at Mount Pleasant. It is not probable that the bones of this animal were buried in glacial drift; it is more likely that they were lying in a deposit of Aftonian age.

In 1922 (Proc. Iowa Acad. Sci., vol. xxviII, p. 65, fig. 5a), Professor Jaques reported the discovery of a mastodon tooth, an upper hindmost molar, about a mile east of Mount Pleasant. The more exact locality is section 14, township 71 north, range 6 west. It was found in the digging of a shallow well, at what is known as the Roy Spring. The length is 8 inches, the width 4.5 inches. The roots appear to be nearly complete. With it were found a vertebra, a femur lacking the ends, and 2 small tusks. These were 24.8 inches and 26.75 inches long.

Wayland, II enry County (34).--In 1923 Professor A. O. Thomas reported to the writer the discovery of a mastodon tooth in a stream-bed spoken of as Sugar Creek, north of Wayland. The locality is possibly in Washington County. In the same stream-bed was found a tibia of Megalonyx jeffersonii (p. r).

Trenton, Henry County (3).-From Professor H. E. Jaques, of Iowa Wesleyan College, at Mount Pleasant, the writer received information of the finding of a mastodon tooth in a small creek, a tributary of Skunk River, about 10 miles northwest of Mount Pleasant. This would be evidently near Trenton. 
The tooth is said to have a length of about $4 \frac{1}{2}$ inches and a width of about $21 / 2$. It is probably the second true molar. As the height is given as 4 or 5 inches, the roots are probably present. The finder reported that a year or two previously a tusk had been found in the same creek.

Milton, Van Buren County (4).- In the palæontological collection at Iowa University is a lower left last molar, recorded as found in the bed of Chequest Creek, near Milton, by W. B. Bell, about the year 1890. According to Gordon's report on this county (Iowa Geol. Surv., vol. IV, pp. 201-254, map), the point on Chequest Creek nearest to Milton is about 6 miles north. Exactly where the tooth was found is not known. The county is within the area or the Kansan drift; but as there are two kinds of drift, an upper yellow clay and a lower blue clay, the Nebraskan drift may be represented and between them some remains of the Aftonian. Again, there is a covering of loess in the region and the tooth in question may have been derived from this.

Selma, Van Buren County (5).- In the collection of the Iowa Historical Department, at Des Moines, is a right humerus which the writer examined and referred to Mammut americanum, although the side-to-side diameter at the constricted part of the shaft is somewhat greater than it is in either of two mounted specimens of mastodon in the U. S. National Museum. In Elephas primigenius and the existing elephants this diameter is much less than in the Selma humerus. The remarks regarding the mastodon found north of Milton may be applied to this specimen.

Eldon, Wapello County (6).-According to Professor M. F. Arey, of the State Teachers College, at Cedar Falls, there is in the collection of that school a proboscidean femur which was found in the gravels along Des Moines River, near Eldon. From descriptions, the writer regards it as belonging to Mammut americanum. No certain conclusion can be reached regarding its geological age.

Ottumwa, Wapello County ( $(y)$. - In the collection at the Iowa Wesleyan University, at Mount Pleasant, are two proboscidean ribs which the writer has examined and referred to Mammut americanum. They are labeled as found at Ottumwa and as presented by Rev. E. C. Brooks. Portions of the pelvis in the same collection, labeled as found in Des Moines River, in 1859, probably belonged to the same individual mastodon. From some locality about 6 miles south of Ottumwa there was reported, in 1879, (Kansas City Rev. Sci., Industry, vol. III, p. 242) by Mr. Houbler, the discovery of an entire tusk of a mastodon. This, however, may have belonged to one of the elephants.

Mahaska County (8).--In the collection of the Iowa State Historical Department, at Des Moines, is an upper right last molar of Mammut americanum, labeled as found in this county by J. D. Davis, of Des Moines. Unfortunately no more exact information was left on record. A specimen thus collected is not of great scientific value.

New Virginia, Warren County (9).- - In Howe's Annals of Iowa, volume II, 1883, page 102, A. R. Fulton described, under the name of Elephas americanus, a tooth which (as the description plainly shows and as appears to have jeen recognized by Fulton) was that of Mammut americanum. The tooth 
had been found in Limestone Creek, 1.5 miles west of the village of New Virginia.

'The youngest drift in this county is the Kansan. According to Dr. J. L. Tilton's report (Geol. Surv. Iowa, vol. v, pp. 301-359, map), this drift is usually overlain by loess which may attain a thickness of several feet. It shows indications of being composed of an upper and a lower bed. These beds of loess are of course younger than the Kansan drift and may represent the Sangamon, or the Peorian, or possibly both, interglacial stages. Some geologist examining the locality may yet be able to determine the geological age of the tooth.

Clarinda, Page County (10).-In 1870, C. A. White (Iowa Geol. Surv., vol. I, p. 353) wrote: "In the valley of the Nodaway, near Clarinda, some teeth of that huge extinct animal, the mastodon, have been found."

It may be mentioned here that Samuel Calvin reported (Iowa Geol. Surv., vol. XI, p. 413) that some large bones which, from the description given, must have belonged to the mammoth or the mastodon were brought up from a depth of 90 or 95 feet, with pieces of bark and wood. This was near or at Blanchard. These things appear to have been buried in an old pre-glacial valley. It is impossible to say to which of the proboscideans these bones belonged; and it is probable that they were not preserved.

The items under this number were omitted in the writer's paper in volume xxiII of the Iowa Geological Survey.

Missouri Valley, Harrison County (11).--In the Cox sand-gravel pit, about 2 miles southeast of Missouri Valley, were found remains of two species of Mammut, M. americanum and M. progenium; see Iowa Geological Survey, vol. XxIII, pp. 54, 383, 384). Associated with these were 17 other species of mammals, a list of which is given on page 296 .

Mount Pisgah, Harrison County (12).--Remains of the genus Mammut have been found in the Peyton sand-and-gravel pit a mile southwest of Pisgah. The lower jaw occurring there (Calvin, Bull. Geol. Soc. Amer., vol. xx, p. 352 , pl. xxv, fig. 2) was referred by the writer to Mammut progenium (Iowa Geol. Surv., vol. xxxiII, p. 372). The associated species are named on page 295.

Denison, Crawford County (13).--In the palæontological collection at the University of Iowa is a tooth of Mammut americanum, discovered in a sandpit near Denison. In 1909, (Bull: Geol. Soc. Amer., vol. xx, p. 35̌2) Calvin reported a tibia and fragments of 2 tusks from Denison. The tusks can only provisionally be referred to the mastodon. It is not known from which of two differently situated pits at Denison these fossils were obtained (p. 298).

Turin, Monona County (14).- Various Pleistocene mammalian remains have been collected at Turin, in the Elliott gravel-pit. The locality and its fossils have been described by Shimek (Bull. Geol. Soc. Amer., vol. xx, pp. 344, 345, and vol. xxi, p. 129; Iowa Geol. Surv., vol. xxi, p. 340) and Hay (Iowa Geol. Surv., vol. xxiII, p. 59). The pit is situated in the northeastern part of the village. According to Shimek, Aftonian sands and gravels are exposed to a depth of about 12 feet. The superimposed formations are the Kansan drift, the Loveland, and the loess. The bones and teeth were found in the lower part of the exposed Aftonian. A list of the associated species may be seen on page $29 \%$. 
Castanea, Monona County (15).--Supposed remains of Mammut have been found in the vicinity of Castanea. The Ordway sand-and-gravel pit is situated on the bluff on the southwest side of Maple River, opposite Castanea, on the southeast quarter of section 13, township 84 north, range 44 west. The following section at this pit is given by Shimek.
5. Loess, abundant on ridge above the pit.
4. Loveland, 5 to 6 feet.
3. Kansan drift, 6 to 18 feet.
2. Aftonian, fine and cross-bedded, 5 to 8 feet.
1. Aftonian, gravel.

No vertebrates are recorded from this pit. In the collection of the Iows. State Historical Department, at Des Moines, is a large tusk labeled as found at Castanea, (Iowa Geol. Surv., vol. xxIII, p. 387) ; it is not certain that it belonged to a mastodon. In the collection at the University of Iowa is a part of a scapula found in another pit not far away from the Ordway; it, too, is not generically identifiable.

Mapleton, Monona County (16).- In the Wilkenson well, near Mapleton, a large tusk, nearly 8 feet long on the outer curve, a molar, and fragments of cranial bones of Mammut americanum were found. These remains are now in the State University, at Iowa City. The well is situated in the northwest quarter of section 6 , township 85 north, range 42 west. The remains were found at a depth of from 35 to 40 feet, in loose sand and gravel. Their age is taken to be Aftonian (Iowa Geol. Surv., vol. xx, p. 343 ; vol. xxIII, pp. 68, $386)$.

Le Mars, Plymouth County (17).- The record from this locality is doubtful. The collection at the State University of Iowa contains an imperfect innominate bone which may belong to Mammut americanum, but more probably to one of the elephants. In a gravel-pit near Le Mars, Professor G. F. Kay secured a large fragment of a limb-bone of a proboscidean; it is not identifiable. The age of the interglacial deposit is probably Aftonian (Iowa Geol. Surv., vol. vIII, p. 336 ; vol. XXIII, pp. 69, 389).

Akron, Plymouth County (18). - The mastodon to be noticed here is the one which bears the specific name, mirificus, referred at various times to the genera Mastodon, Mammut, Rhabdobunus (Hay, Iowa Geol. Surv., vol. xxIII, p. 373), and Stegomastodon (Pohlig, Bull. Soc. belge Geol. Paleont., vol. xxvi, P. v, p. 193) and Anancus.

In a well 2 miles east of Akron, fragments of tusks, 2 teeth, and some fragments of cranial bones were found at a depth of 20 feet. These are now in the collection of the University of Iowa, at Iowa City. This species was originally based on jaws supposed to come from Pliocene deposits in Nebraska, but which are now known to have been collected from the so-called Equus beds. Shimek (Bull. Geol. Soc. Amer., vol. XxI, p. 126) showed that the deposits at Akron belonged to the Aftonian. It thus appears that the genus continued on from the Pliocene (Blanco) into the early Pleistocene. From the same well was obtained a bone composed of the united first and second phalanges of the third digit of the hind-foot of the ground-sloth Megalonyx (p. 7). 
Doon, Lyon County (19).-The writer has recorded (Iowa Geol. Surv., vol. xxin, p. 386) the discovery of 2 large tusks at Doon, on the (ireat Northern Railroad. 'They were unearthed by a steam-shovel at a depth of about 25 feet. These tusks may, however, have been those of an elephant. 'They were much broken up, but the fragments are probably preserved in the Sioux City Academy of Science. 'Their generic identity may at some time be determined by microscopic examination of their structure. The deposit containing these tusks belongs quite probably to the Aftonian.

Clinton, Clinton County (20).- In the collection of the Chicago Academy of Sciences is an upper left last molar of Mammut americanum, said to have been found near Clinton, on the west bank of Mississippi River. It was presented to the Academy by the geologist, J. W. Foster. The area occupied by the town is mostly recent alluvium but there is some Kansan drift. 'The latter is the most recent drift everywhere immediately back of the town; but the Iowan drift, according to J. A. Udden's map (Iowa Geol. Surv., vol. xv), is not far away. Besides these formations, the drifts are capped by loess, which may reach a thickness of 20 feet. The tooth may therefore have been found in the loess or in an interglacial deposit. The only information accompanying the tooth is that it was found near Clinton.

Bryant, Clinton County (21).--From Louis Rockrohr, living near Bryant, the writer received a photograph of a lower left last molar of Mammut americanum unearthed at a depth of 8 feet below the original surface of the ground. The tooth was described by the writer in his paper on the Pleistocene mammals of Iowa (Iowa Geol. Surv., vol. xxiı, p. 381). Bryant is within the area of the Kansan drift. Beneath this drift might occur Aftonian interglacial deposits. It seems not unlikely that a competent geologist might determine the age of the gravels in which the tooth was found. It had not yet been cut and shows no signs of abrasion by transportation. It is not probable that it was carried by water for any considerable distance before it was buried.

Maquoketa, Jackson County (22).-In Netta C. Anderson's list, already referred to, Professor W. H. Norton, of Cornell College, Mount Vernon, Iowa, seported that an atlas and two other vertebræ of some proboscidean had been found near Maquoketa and presented to his college. Maquoketa is on the river bearing the same name and is within the strip of Kansan drift which lies between the Iowan drift and Mississippi River.

Garber, Clayton County (23).-The writer has received from Professor A. O. 'Thomas, of the University of Iowa, a photograph of an upper right second molar of Mammut americanum, found in a gravel-pit 2 miles east of Garber. The exact locality is section 32, township 92 north, range 3 west. According to Professor Thomas the age of the gravels is uncertain, being either Kansan drift or Iowan valley trains.

\section{Within the Area Covered bi Illinolan Drift.}

Fort Madison, Lee County (24).-The collection at Iowa Wesleyan University, at Mount Pleasant, contains a complete last lower molar (with fine roots) of Mammut americanum. Charles Buetner, of Burlington, who presented this tooth, informed the writer that it was found in a creek 3 miles due west from Fort Madison. This would be very close to the western border of the Illi- 
noian drift, possibly beyond it. One might suspect that some Yarmouth interglacial occurs there.

Lost Creek, Lee County (25).-In Netta C. Anderson's list, Professor Frank Leverett reported that he had seen a large leg-bone of a mastodon, found in the valley of Lost Creek, section 3 or 4 of Washington township, and which he thought belonged to Justus M. T. Myers, of Fort Madison. Washington township is No. 68 north, range 4 west. On the same page, Mr. Myers himself reports a leg-bone (probably the same as that mentioned by Leverett), together with a piece of tusk, of a mastodon found in Lost Creek. These bones might well have been those of one of the elephants. The locality is about 2 miles southeast of Denmark. This locality is not far from the western border of the area of Illinoian drift in Iowa; and it seems probable that the creek might there have cut into the Yarmouth interglacial. On the other hand, these bones may have belonged to Elephas primigenius and been buried in the Illinoian drift. It is to be hoped that the bones are yet preserved by somebody, so that they may hereafter be identified with some certainty.

Burlington, Des Moines County (35).- -In the U. S. National Museum is a cast (No. 10939) of a lower right hindmost molar of Mammut americanum found at Burlington many years ago. The cast was given to Professor S. F. Baird by Dr. Charles A. White, once state geologist of Iowa. The tooth was a large one, length $180 \mathrm{~mm}$., width $96 \mathrm{~mm}$., with 5 crests and a small talon and 2 large roots. It was only slightly worn. The number 35 is not on $\operatorname{map} 4$.

Wilton, Muscatine County (26).- In 1899 (Iowa Geol. Surv., vol. Ix, p. $352)$, J. A. Udden quoted a report made by Samuel Calvin, in 1874, to the president of the University of Iowa, on some proboscidean remains found near Wilton. These consisted of 12 vertebræ, 13 ribs, a segment of the sternum, parts of both innominate bones, a femur, a tibia, a scapula, a part of a humerus, and a number of foot-bones. The writer figured the scapula (Iowa Geol. Surv., vol. XxIII, pl. LII, fig. 1) and identified it as belonging to Mammut americanum. Calvin, in the report referred to, gave the dimensions of this bone and of some others. His measurement of 35 inches as the length of the tibia must be erroneous. These bones were found in the south bank of Mud Creek, about half a mile south of Wilton, in probably the northwest corner of section 12, township 78 north, range 2 west. Where the bones were found the bank rose about 30 feet above the water. The several pieces of the skeleton were scattered, but all lay at the same level. Calvin did not state how high above the water they were buried. The deposits containing the bones consisted of alternating strata of very fine sand and clay. It was Udden's opinion that this deposit had been laid down in quiet water during the Sangamon stage; he reported, further, that it underlies the Iowan loess.

Davenport, Scott County (27).-In 1899 (Iowa Geol. Surv., vol. IX, p. 356), J. A. Udden stated that mastodon remains had been taken from the Sangamon soil resting on Illinoian till in the west part of Davenport. The writer has seen no other reference to this discovery and the word mastodon may have been unintentionally used instead of mammoth. Udden, as cited, presented a long list of diatoms found in the mud at this locality. 


\section{Within the Area Covered by Iowan Drift.}

Shellsburg, Benton County (28). - In Netta C. Anderson's list, on page 25, Professor T. E. Savage reported that a mastodon tooth had been found by J. Grubb, in 1903, in the alluvium of Bear creek. J. A. Burns, of Shellsburg, a son-in-law of Mr. Grubb, wrote, on February 11, 1911, that the tooth in his possession, is about 6 inches long, and has 4 cross-crests and a talon. His sketch shows well that the tooth belonged to the mastodon. It was found lying in the bed of a small creek, in section 33, township 85 north, range 9 west. This is about 3 miles northwest of Shellsburg. It seems to be unprofitable at present to speculate on the geological age of this tooth. It belongs more probably to a post-Kansan interglacial stage than to any of the glacial stages. An account of the Pleistocene geology of this county has been given by Professor T. E. Savage (Iowa Geol. Surv., vol. xv, pp. 201-21\%, with map).

Springville, Linn County (29).--In Netta C. Anderson's list, Professor W. H. Norton, of Cornell College, reported that a small molar and the crown of a large molar had been found near Springville, in or on Iowan drift. These teeth are now in the collection of Cornell College, at Mount Vernon, Iowa. Judging from our present knowledge of the mastodon, we may conclude that the animal in question lived in that region more probably after than during the Iowan glacial stage. For an account of the Pleistocene geology of this county, Professor W. H. Norton's report may be consulted (Iowa Geol. Surv., vol. Iv, pp. 168-174). In the same list, Professor F. C. Baker reported that there is in the collection of the Chicago Academy of Sciences a part of a tusk found in a gravel-pit at Bertram, Linn County. This tusk might, however, belong to one of the elephants.

\section{Within the Area of the Wisconsin Drift.}

Des Moines, Polk County (30).-The collection of the State Historical Department, at Des Moines, contains an upper last molar of Mammut americanum, apparently found at Des Moines and presented by L. Hamilton in 1883. The number of the tooth is 4519 . The record as to locality, kind of deposit, and depth is not sufficiently exact to permit a decision as to its geological age. In the immediate vicinity of Des Moines are found Kansan and Wisconsin drifts and loess. Probably also interglacial deposits may be found. Dr. James $H$. Lees sent the information that about 2 years ago 2 mastodon teeth were found in South Des Moines, in the gravel of the Raccoon Valley. They may have been in Wisconsin outwash or in older deposits.

Adel, Dallas County (31).-In 1911 (Bull. Geol. Soc. Amer., vol. xxiI, p. 215), Calvin reported that in $18 \% 6$ a complete skeleton of a mastodon was found at Adel. It was met with in a peat deposit which partly filled a depression on the surface of the Wisconsin drift. It is not known what became of this valuable specimen. In this case one can not be in doubt as to the geological age of the animal. It had undoubtedly lived after the passing away of the last glacial ice sheet.

Rippey, Greene County (32).-In the collection of the Iowa State Historical Department, at Des Moines, there is a right scapula which the writer 
identified as that of a mastodon. It is reported to have been found at Rippey, but no detailed information is furnished. Inasmuch as the whole of Greene County is covered by Wisconsin drift, it is probable that the bone belonged to an animal which lived after the Wisconsin ice sheet had retired from that region.

Boone County (33).-The same collection contains various remains which the writer referred (Iowa Geol. Surv., vol. xxiII, p. 380) to Mammut americanum. There is no record to show from what place in the county they were obtained. It may be regarded as certain that they were found in deposits overlying the Wisconsin drift.

For (34) see page 36 ; for (35) see page 41.

\section{NEBRASKA.}

(Map 2.)

Pender, Thurston County (1).-The C. H. Morrill collection, in the State Museum at Lincoln, formerly contained part of a skull of a mastodon, found at Pender, but this was destroyed in a fire in 1912. The remarkable feature about the skull was the tusks. These had a length of 2,700 $\mathrm{mm}$., somewhat more than 8 feet, and instead of being strongly curved, as they usually are, they were nearly straight. In other respects the skull appeared to resemble that of Mammut americanum. Two feet from the base the diameter of the tusk was $140 \mathrm{~mm}$. The lower jaw was not present. Each side of the upper jaw had all three molars, the first $\left(\mathrm{M}^{1}\right)$ being much worn; the second $\left(\mathrm{M}^{2}\right)$ only moderately so; the third $\left(\mathrm{M}^{3}\right)$ not at all. No information has been obtained regarding the exact place or depth of burial of the animal or character of deposit. The region is occupied by the Kansan drift. It might be supposed that the skull had been found in some Aftonian interglacial deposit, but there is no assurance that such is the case. The region is covered with a deposit of loess and the skull may have been buried in this and hence may have existed at a later stage of the Pleistocene.

Pickrell, Gage County (2). - In the collection of the State Museum, at Lincoln, is an upper left second molar found near Pickrell, on the farm of Wilke Jurgens, 4 miles east and a mile south of the town. The tooth is supposed to be that of Mammut americanum. Nothing is known about the nature of the deposits in which the tooth was buried; one can only surmise that the geological age is post-Nebraskan. The county is within the area occupied by the Kansan drift, but the region about this town is covered with loess.

Sutton, Clay County (3).-The collection of the State Museum also contains a lower jaw of a mastodon supposed to be Mammut americanum and found in a gravel-pit at Sutton. The symphysis of the jaw and the greater part of the ascending rami are restored in plaster. The hindmost milk-tooth is present, with good roots. The first molar, $95 \mathrm{~mm}$. long and $64 \mathrm{~mm}$. wide, had just begun to wear; the second molar is deep down in the jaw. This region is occupied by the Equus, or Sheridan, beds. The animal represented by the jaw probably lived during the Sheridan stage. From the same region has been obtained Elephas imperator.

Buffalo County (4).--In 1866 (Proc. Acad. Nat. Sci. Phila., p. 316), Dr. F. V. Hayden announced the finding of a tooth of a mastodon in the "post- 
Pliocene drift," near Fort Kearney. The exact locality is not recorded and probably never will be known. It may have been in Kearney County, south of Platte River.

Valentine, C'herry County (5).-The Minneapolis Journal of June 4, 1911, announced that during the previous year the head and some cervical vertebræ of a mastodon had been sent from Valentine to the State University of Minnesota. The upper jaw contained teeth and the tusks; lower jaw missing Professor F. W. Sardeson informed the writer that the animal is Mammut americanum and that a compact gray sandstone adhered to the teeth. The animal probably lived during the Sheridan stage.

Seneca, Thomas County (6).--In 1858 (Proc. Acad. Nat. Sci. Phila., vol. x, p. 10), Leidy described briefly his Mastodon mirificus. In 1869 (Jour. Acad. Sci. Phila., ser. 2, vol. vir, pp. 249, 396, pl. xxv) it was more fully characterized and illustrated. The remains appear to have been found on Middle Loup River, probably not far from Seneca. One part of the type specimen is in the U. S. National Museum, the other in the Academy at Philadelphia. Other species collected in the same region are listed on page 304. The species now bears the name Anancus mirificus or Stegomaslodon mirificus.

\section{MINNESOTA.}

(Maps 2, 29.)

Fairhaven, s'tearns County (1).-In 1910 (Bull. Minn. Acad. Sci., vol. 1v, p. 416), Professor N. H. Winchell recorded the finding of what he regarded as a large elephant's tooth in a marsh near Fairhaven. The statement made by Winchell that the tooth had a hard, shining surface awakens the suspicion that the tooth was that of a mastodon. Evidently Winchell had not seen the tooth, but relied on the statements of E. E. Woodworth, of Minneapolis, from whom the writer received a letter, dated September 13, 1912. He was a boy 8 years old at the time of the discovery. His father, a studious and observing man, yet living in 1912, had examined the remains, which included many bones. He was of the opinion that they belonged to a mastodon. The remains were not preserved by the finder and at this day it is impossible to settle the question. The statement made regarding the surface of the tooth does not apply well to the tooth of an elephant, but does apply to the enamel of a tooth of a mastodon.

Stillwater, Washington County (2).--In the Sixth Annual Report of the Minnesota Geological Survey, 187\%, page 61, N. H. Winchell gave an account of the finding, at this place, of a tusk supposed to be that of a mastodon. A later discussion of the discovery was presented in 1888 (Winchell Final Rep. Geol. Nat. Hist. Surv. Minn., vol. II, pp. $39 \%-398)$. This tusk was found near or in the town of Stillwater, in the valley of Brown's Creek. The deposit is referred to by Winchell as "drift deposits and river gravels." They were probably not deposited directly by the glacial ice, but by a stream which flowed from it. Winchell evidently regarded it as belonging to the close of the Wisconsin stage. The tusk may have belonged to an elephant. It was preserved in the St. Paul Academy of Sciences, but later was destroyed in a fire. In 1910 (Bull. Minn. Acad. Sci., vol. Iv, p. 416), Winchell again referred to this tusk and offered the opinion that it might have been that of 
an elephant. The discoverer of the tusk affirmed that in the same deposits were found some specimens of pottery. Winchell did not doubt the correctness of the finder's account and believed that the pottery had been included in the drift gravel as native and constituent parts of it; he conceded that possibly they had fallen down from more recent deposits.

Northfield, Rice County (3).-In 1884 (Final Rep. Geol. Nat. Hist. Surv. Minn., vol. I, p. 6\%0) N. H. Winchell published a letter relating to the discovery, in 1879, at Northfield, of a tusk supposed to be that of a mastodon. It was exposed by some workmen while digging in a drift deposit. The tusk was then in Carleton College. It may have been that of an elephant, and the supposed drift was probably a valley gravel. The town is on Cannon River; and on Winchell's map (pl. xxxI) that valley is represented as being occupied by gravel, sand, and valley drift. In 1910 (Bull. Minn. Acad. Sci., vol. Iv, p. 416), Winchell again mentions the tusk and says that it may have belonged to an elephant.

Mankato, Blue Earth County (4).-From D. L. Rose, of Mankato, the writer received an account of a head of a mastodon, found at Mankato and deposited in the high school of that town. In January 1914 the writer visited the school and found the specimen. It consisted of a piece of a lower jaw containing part of a badly broken tooth. The jaw was found at a depth of 15 feet in digging a sewer, at the intersection of State and Byron streets. The valley of Minnesota River is filled with a modified drift (Final Rep. Geol. Nat. Hist. Surv. Minn., vol. I, p. 444). The animal had probably lived there after the recession of the Wisconsin drift sheet. This is probably the mastodon tooth mentioned by Winchell in 1910 (Bull. Minn. Acad. Sci., vol. Iv, p. $41 \%)$.

Allert Lea, Freeborn County (5).-N. H. Winchell, in 1884 (Final Rep. Geol. Surv. Minn., vol. I, p. 386), reported that according to William Morin the jaw of a mastodon had been found here, some years before that time, in a gravel-bank. In 1881 it was lost in a fire in the capitol at St. Paul. According to Upham (Final Rep. Minn. Geol. Surv., vol. I, p. 526), the whole county is covered with drift deposits of Wisconsin age.

Minnesota City, Winona County (6).-Professor Winchell (op. cit., p. 264 ) stated that at this place the remains of a mastodon had been taken out of the alluvium. This (his p. 261) appears to have been on a terrace elevated about 58 feet above the flood-plain of the Mississippi. Winchell, in 1910, referred to this find, and stated that the remains consisted of a tusk and that this might have belonged to an elephant (Bull. Minn. Acad. Sci., vol. IV, p. 446).

\section{SOUTH DAKOTA.}

(Map 2.)

Pine Ridge, Shannon County (1).-In the U. S. National Museum is an upper right hindmost molar of Mammut americanum, from near Pine Ridge. It was discovered about a mile south of the town, in a gravel ridge. It is in a good state of preservation and is credited to Major William H. Clapp. No details are recorded as to conditions of burial.

Perkins County (2).-From Doane Robinson, superintendent of the department of history, South Dakota, the writer has received a photograph of 
3 teeth of Mammut americanum which were found in the southeast corner of Perkins County, on Moreau River, 4 or 5 miles below the mouth of Rabbit Creek. These appear to be upper grinders, one a hindmost molar; the other two are second molars. The number 2 is not on the map.

\section{MONTANA.}

\section{(Map 2.)}

Pryor Creek, Crow Reservation (1).- The writer has seen a tooth of Mammut americanum, found at some place along Pryor Creek. It was the lower left penultimate molar, moderately worn and furnished with complete roots. It had been met with in a ditch, made for reclamation purposes, at a depth of 18 feet. Exact details regarding the locality are wanting. Pryor Creek is a few miles east of the east line of Carbon County.

Diamond City, Broadwater County (2).- - In St. Louis University, St. Louis, Missouri, is an upper right hindmost molar of a mastodon labeled as found at Diamond City and as presented by Rev. J. G. Venneman; also, from the same place, a tooth of Elephas columbi. 


\section{FINDS OF ELEPHAS BOREUS IN THE MIDDLE REGION OF NORTH AMERICA.}

This is the species of Elephant which in the writer's work of 1923, on the Pleistocene of North America east of Mississippi River, etc., is called Elephas primigenius.

TEXAS.

(Map 5.)

Temple, Bell County (1).-From near this place Mark Francis sent the writer for examination a lower left antepenultimate milk-molar of Elephas boreus, found by W. S. McGregor, in his gravel-pit, on Leon River, 5 miles west of Temple and a mile north of Shallow Ford. In this same pit, 40 feet above the river, were remains of a mylodon (p. 2), a tapir (p. 155), a camel (p. 161), and of Equus semiplicatus (p. 129). The elephant tooth (Proc. U. S. Nat. Mus., vol. LvirI, p. 138, pl. x, figs. 3,4) is only slightly damaged; it presents 7 plates, with front and rear talons; length $62 \mathrm{~mm}$., width $32 \mathrm{~mm}$.

Bulverde, Bexar County (2).-In 1920 (Proc. U. S. Nat. Mus., vol. LvIII, p. 136, pl. Ix, figs. 1-7; pl. x, figs. 3-7 ; pl. xr, figs. 1-6), the writer described remains of elephants found near Bulverde, which he referred to Elephas primigenius but which are now regarded as belonging to Elephas boreus. The animals described were young, one of them retaining the first milk-molar. The second milk-molars, both upper and lower, are beautifully preserved. These remains were found in a large cave about 35 feet under the surface, entered only by a perpendicular shaft. All together, 18 species of vertebrates were discovered. See list of these on page $24 \%$.

\section{MISSOURI.}

(Map 5.)

Osage River, Benton County (1).-In the collection of the Academy of Natural Sciences of Philadelphia is an upper right last molar which the writer identifies as that of Elephas boreus. It is worn down in front to the base and backward to about the sixteenth plate. The length along the base is $235 \mathrm{~mm}$.; height of the sixteenth plate, $120 \mathrm{~mm}$. How this tooth came into the collection is not known. It may have been a part of the collection made by Albert Koch, in which case it was probably found at the Pomme de Terre locality (p. 25) ; more probably it belonged to a collection made about 1843 by S. H. Whipple, along Osage River (p. 28). As to the geological age of the tooth, one can only indulge in surmises. It seems probable, from what is known regarding the habits of the species, that the individual lived in that region during one of the glacial stages. The Kansan drift is not far away.

There is another tooth in the collection of the Academy from this county and probably from the same locality. It is a lower right last molar, in fine condition. Probably one or two plates are missing from the rear. The length along the base is $270 \mathrm{~mm}$.; height of the eleventh plate (the first unworn one), $170 \mathrm{~mm}$.; greatest width, $105 \mathrm{~mm}$. On a lateral face there are 8 plates in a line $100 \mathrm{~mm}$. long. The collection contains still another molar which appears to belong here. There are present 14 plates, but some of the rear ones are missing. The length of the part present, measured at right angles 
with the edges of the plates, is $190 \mathrm{~mm}$. The sixth plate is $200 \mathrm{~mm}$. high. Another fragment of a tooth, with 11 plates, seems likewise to belong to Elephas boreus.

\section{KANSAS.}

(Map 5.)

St. George, Pottawatomic County (1). - In the collection of the Kansas Agricultural College, at Manhattan, the writer has examined a part of an upper right molar found, probably many years ago, at St. George. It is labeled "Drift (Loess), on bank of Black Jack Creek, St. George, Pottawatomie Co., Kan. Wm. I)alton, collector." The tooth has 12 ridge-plates; a few in front are missing. It is probably a second molar. The plates are flat and the hinder ones do not make an angle with those farther in front. There are 10 plates in a $100 \mathrm{~mm}$. line. The enamel is somewhat thicker than usual. The writer identifies the animal as Elephas boreus. Exactly where Black Jack Creek is the writer can not determine. The region north of Kansas River is within the area of the Kansas drift sheet; but the deposits along a stream might belong to a later stage.

Pendennis, Lane County (2).-Among the teeth of elephants, collected by C. H. Sternberg, 7 miles northeast of Pendennis and therefore probably near the line between Lane and Ness Counties, are some which the writer is compelled to refer to Elephas boreus. Among these are two now in the American Museum of Natural History, New York. These appear to be upper second molars, right and left, of the same individual. All the ridge-plates are present and each tooth is worn back to the eleventh plate. The length of one tooth, from the base in front to the base behind, is $250 \mathrm{~mm}$; that of the other tooth is slightly less; thickness $85 \mathrm{~mm}$.; height of eleventh plate $155 \mathrm{~mm}$. There are 18 or 19 plates, besides a front and one or two rear talons; 8 plates are crossed by a $100 \mathrm{~mm}$. line. The plates are not warped, but rise from the base with gentle undulations. The hinder plates make hardly any angle with the anterior ones. The size and structure of this tooth are very much as in the tooth of E. roosevelti, found in Milwaukee, Wisconsin, and figured by the writer in 1914 (Iowa Geol. Surv., vol. XxıII, p. 409, pl. LIx) as E. primigenius. Possibly it belongs to $E$. roosevelti rather than to $E$. boreus.

At the American Museum are other teeth which must be referred to $E$. boreus. Three are lower milk-molars, having 11 plates and anterior and posterior talons. The length is $108 \mathrm{~mm}$; width, about $45 \mathrm{~mm}$. In the University of Kansas are similar teeth. One of the best-preserved appears to be a lower last milk-molar. Its length along the base is $132 \mathrm{~mm}$; there are 12 ridge-plates.

In Ward's Natural History Establishment at Rochester, New York, the writer has seen 2 teeth, a last upper molar, and a lower penultimate, which are labeled as coming from Lane County. They may have been a part of Sternberg's collection. 'They have thin plates, 10 in a line $100 \mathrm{~mm}$. long, and are otherwise not to be distinguished from teeth of $E$. boreus.

Remarks on the geological aspects of this locality are to be found on page $2 \% 0$, where the remains of $E$. columbi from the same place are considered. 
IOWA.

(Maps 5, 6.)

\section{Within the Area of the Kansan Drift.}

Ottumwa, Wapello County (1).-In the collection of the Iowa Wesleyan College, at Mount Pleasant, is an upper first molar of Elephas boreus, found, as reported by Professor H. E. Jaques, about 1900, in Des Moines River, at Ottumwa. The tooth has 12 or 13 plates and front and rear talons. According to A. G. Leonard (Iowa Geol. Surv., vol. XII, pp. 472-475), the only drift materials seen in this county belong to the Kansan; but there are reasons for suspecting that the Nebraskan underlies this. In the vicinity of Ottumwa the Kansan averages a thickness of about 25 feet. This is overlain almost everywhere by a deposit of loess, which in the neighborhood of Ottumwa has a thickness of about 8 feet. Before this was laid down the upper surface of the Kansan had suffered much weathering and probably erosion. It can hardly be supposed that the tooth in question got into the river from the body of the Kansan drift. It is possible that it was derived from materials laid down in some unobserved late Aftonian or early Kansan deposit. It is, however, impossible to determine the geological age of this elephant.

Brighton Township, Washington County (2).- In 1883 (Proc. Davenport Acad. Sci., vol. III, p. 177), J. Gass and W. H. Pratt gave an account of the discovery of some teeth and bones of Elephas primigenius, on the farm of Jerry Hopping (misspelled Hoppin), in Washington County. The location was given as section 14, township 22, range 3 , but this was an error; for this would locate the place near the southern border of Missouri. The writer has learned that the farm occupies the northwest quarter of section 14, township 74 north, range 8 west of the fifth principal meridian. It is in the southern part of the county and north of Skunk River. William Hesseltine, a son-inlaw of Mr. Hopping, has informed the writer that the spot where the bones were found is near the center of the quarter section and near the forks of the east branch of Walnut Creek. Gass and Pratt stated that the scapula and some other bones were found in the bed of the creek; others were secured by digging into the bank; all the bones were found within an area of 15 feet each way, in the black mud (sedimentary deposit, chiefly of vegetable mold with some clay) and about 6 feet below the surface of the level ground. Mr. Hesseltine states that they were found in the creek-bank under 8 feet of loose earth and sand. The stream takes its rise about 2 miles away. The principal portions of the skeleton recovered were 2 upper molars, a considerable fragment of a tusk, a complete atlas and 3 other vertebræ, a scapula somewhat injured, a portion of a humerus, a fibula, and some fragments of ribs.

From Mr. Hopping's hands these remains passed into the possession of James M. Wier, of Muscatine, Iowa, who was gathering curiosities of various kinds. On his death his collection was placed in the Muscatine Public Library. The writer had the opportunity to examine the collection and was able to identify most of the bones of the Hopping elephant. There were no records accompanying either these bones or others acquired by Mr. Wier. The writer gave a brief account of the Hopping elephant in his paper on the 
Pleistocene Mammalia of Iowa (Iowa Geol. Surv., vol. xxiII, p. 418), but he omitted to state that he regarded the animal as belonging to Elephas primigenius, now called $E$. boreus.

It might be thought that the rather loose, sandy, clayey, and muck-like materials forming the banks of Walnut Creek consisted of recent alluvium and that the elephant remains had been redeposited from older beds. This is not probable, since a skeleton would on redeposition inevitably have been widely scattered. 'Those superficial deposits were probably laid down during one of the glacial stages, when the climate was sufficiently cold to attract this species into that region.

The Illinoian stage has strong claims. The locality appears to lie very close to, or within the course taken by, one branch of Mississippi River when the Illinoian drift had forced it out of its old bed. The elephant might have been buried in deposits along this river or near the mouth of a stream opening into it. On the other hand, the possibility exists that the elephant lived there during the Iowan or Wisconsin stages.

Union Township, Louisa County (3).- In the writer's paper on the Pleistocene Mammalia of Iowa (Iowa Geol. Surv., vol. xxIII, p. 438) are described teeth of $E$. primigenius ( $E$. boreus), found in a gulley in the northern part of Louisa County, about 6 miles north of Columbus Junction. The exact locality, as given the writer by E. B. 'Tucker, of Columbus Junction, is the northeast quarter of the southwest quarter of section 34, township 76 north, range 5 west. The Pleistocene geology of the region has been described by J. A. Udden (Iowa Geol. Surv., vol. XI, p. 102). According to his determinations there are exposed in that part of the county Nebraskan drift, Kansan drift, a leached Sangamon soil, and over this a covering of loess. With such exact data as to locality, a competent geologist on the spot might determine from what deposit those teeth were derived.

Grinnell, Poweshiek County (4).-In Science (rol. Iv, 1884, p. 46), Professor H. W. Parker reported the discovery of elephant remains in Grinnell. A tusk was found at a depth of 5 feet and 3 molars at a depth of 8 feet, in yellow clayey loam. The place was at the corner of Main and Fourth Streets. The writer examined the molars and found that two, certainly belonging to this individual, are those of Elephas boreus (Iowa Geol. Surr., rol. XxIII, p. 445). Another tooth, apparently a second lower molar, labeled as belonging to the same specimen, appeared to the writer to belong rather to E. columbi and to be probably a tooth described by Dr. E. H. Barbour. For an account of this, see page 293. From Parker's account it appears quite evident that this elephant had been buried in the loess. Dr. G. F. Kay, director of the Iowa Geological Survey, informed the writer that he was at Grinnell in 1915, when much work was being done on the city sewer system and he obtained good sections to a depth of nearly 50 feet from the surface. He found that the loess has a thickness of about 18 feet. The upper 12 feet is yellowish and highly calcareous; the lower 6 feet, gray and also calcareous. The evidence appears, therefore, to place this animal in either the late Iowan or the early Peorian.

Marengo, Iowa County (5).- In 1912 (Iowa Geol. Surv., rol. xxIII, p. 436 , pl. Lv, fig. 2), the writer reported the finding, at Marengo, of a wellpreserved lower first true molar of $E$. boreus (E. primigenius). This tooth 
was met with in alluvial gravel along Bear Creek, in the northwest quarter of section 25, township 81 nortl, range 11 west. Near the same town, in alluvial materials along Iowa River, was found the lower jaw, with the first true molar of each side, which was described by Calvin (Bull. Geol. Soc. Amer., vol. $\mathrm{xx}, \mathrm{pl}$. $\mathrm{xxv}$, fig. 3) as $E$. columbi. The writer regards the jaw as that of E. boreus.

One can not be certain as to the origin of the tooth found in Bear Creek and of the jaw found along Iowa River. It is most probable that they had been washed out of the loess, which occurs of considerable depth along those streams. They may belong to the late Iowan, the early Peorian, or even to a later stage. Neither the tooth nor the jaw could have been transported far, for they show no abrasion.

West Union, Fayette County (6).-A part of an imperfect upper molar, probably the second, No. 42 of the collection at the Iowa State University, was found somewhere about West Union. It belongs to Elephas boreus (Iowa Geol. Surv., vol. xxıII, p. 433). Possibly this tooth was found within the border of the Iowan drift, but the exact place is not recorded.

Clermont, Fayette County (7).-On the page just quoted is an account of another molar, regarded as belonging to Elephas boreus and reported to be in the possession of C. E. Allen, of Clermont. Professor T. E. Savage informed the writer that it was found in materials which fill the valley of Turkey River. Mr. Allen sends the information that it was found in the gravelpit of the Rock Island Railroad, between Clermont and Elgin, at a depth of about 20 feet. The geology of this county has been described by Professor T. E. Savage (Iowa Geol. Surv., vol. xv, pp. 435-546, with figs. and 2 maps). His conclusions as to the Pleistocene are recorded on pages 439-454; 521-532. He expressed the opinion that the high terrace along Turkey River, where the Allen molar was found, is composed in part of gravels of Iowan age. In this connection it may be noted that a skull of Ovibos moschatus was found just east of Clermont, for an account of which see page 183. Dr. Alden and Dr. Leighton (Iowa Geol. Surv., vol. xxvi, pp. 133-134) discuss the gravel terraces along Turkey River and mention the fossils found there. They wrote that they regard the gravel as of Iowan rather than Wisconsin age.

Missouri Valley, Harrison County (8).--In the Claude Cox gravel-pit at this place was obtained, by Professor B. Shimek, an upper right second molar which the writer refers to Elephas boreus (Iowa Geol. Surv., vol. XxII, p. 435). This important gravel-pit is described on page 296, where a list is given of the species which have been secured in the pit. These species belong to the Aftonian interglacial. Most of them indicate a climate probably not colder than that of the present day; but this mammoth tooth belonged to a species which, so far as known, preferred a cool or cold climate.

Denison, Crawford County (9).-The geological situation at Denison has been briefly set forth on page 298. Calvin described from Denison (Bull. Geol. Soc. Amer., vol. xx, pl. xxiII; vol. xxir, p. 212, pl. xx) 2 teeth which are to be referred to Elephas boreus. These have been described and figured by the writer also (Iowa Geol. Surv., vol. xxmI, p. 431, pl. Lvi, fig. 2, pl. LxIx, fig. 1). The first-mentioned tooth was obtained in the upper pit at Denison; the other tooth in a fragment of jaw was found in this pit about a 
mile below the town. It is impossible to determine with certainty the geological age of the species found at this locality.

Correctionville, Woodbury County (10).- In the collection at the Iowa State University is a much-worn tooth of Elephas boreus, possibly the last milk-molar. It was found in the Gilleas pit and has the catalogue No. 355. From the Welch pit, in the same neighborhood, have been taken remains referred to Bison occidentalis and Rangifer. The age of the sands and gravels of these pits is not well determined. They are without doubt post-Kansan. The presence of Elephas boreus and Rangifer appears to indicate a climate appertaining to a glacial stage. This might be the Wisconsin; and the presence of Bison occidentalis is not opposed to this view. It is probable, however, that the three species here named lived in that region during late Illinoian or early Sangamon times. The writer has discussed this locality and the species occurring there in his paper on the Pleistocene Mammals of Iowa (Iowa Geol. Surv., vol. xxiII, pp. 74, 282, 325, 449). The geology of this county was described by H. F. Bain (Iowa Geol. Surv., vol. v, pp. 243-299, maps) and by Carman (Iowa Geol. Surv., vol. xxvi, pp. 409-414).

From Professor H. W. Norris, of Grinnell College, Grinnell, Iowa, the writer learns that that college has recently received from a sand-pit at Correctionville, a tooth believed to belong to Elephas boreus. Dr. J. E. Carman (Iowa Geol. Surv., vol. xxvi, p. 410) reported that a worn tooth of this elephant had been found in the Gilleas gravel-pit, a few miles south of Correctionville, in the Little Sioux Valley. With it were parts of a bison skull and antlers of a deer. In discussing the age of these river gravels Carman (his page 412) concluded that they were post-Kansan and preloess and deposited long after the Kansan. This appears to confirm the view that they belong to the Sangamon or to the late Illinoian. From the Paul Fleming pit, at the mouth of Pierson Creek Valley, Carman examined a large proboscidean tooth, a horn core, and a horse tooth. The presence of the horse tooth appears to indicate a time not far away from the Sangamon.

Le Mars, Plymouth County (11).-The writer has received from Dr. J. Ernest Carman some enamel plates of Elephas boreus, dredged from the deep pit just northwest of Le Mars (Iowa Geol. Surv., vol. xxvi, pp. 394, 395, 409). The thinness of the enamel indicates that the species is $E$. boreus.

Rock Rapids, Lyon County (12).--In the collection at the Iowa State University is an atlas of a proboscidean, which the writer has referred to Elephas boreus (Iowa Geol. Surv., vol. xxiII, p. 439). It was found in what was supposed to be a train of gravel which had been carried down Rock River from the Wisconsin ice sheet. The geological age may therefore be regarded as Wisconsin. This locality is mentioned by Carman (Iowa Geol. Surv., vol. xxvI, pp. 382, 410). While it is well out on the Kansan drift area, it may, he thought, contain Wisconsin gravel.

\section{Wituin the Area of the Illinolan Drift.}

Burlington, Des Moines County (13).-In the collection of the Iowa State University is a large upper molar of Elephas boreus, No. 22, which is recorded as found at Burlington (Iowa Geol. Surv., vol. xxilI, pp. 59, 432). There were, however, no details furnished, and it is impossible to determine the geological age of this tooth. 
Wapello, Louisa County (14).-In the collection just noted (No. 61) is a tooth of Elephas boreus, apparently the lower second molar, found at or near Wapello (Iowa Geol. Surv., vol. xxIIr, pp. 70, 438). Its geological age is unknown.

Muscatine, Muscatine County (15).-At the Iowa State University, at Iowa City, the writer has seen an upper tooth of Elephas boreus, apparently a second molar, reported to have been found in a railroad cut a mile west of Muscatine. From Professor F. M. Van Tuyl, of the geological department of the University of Illinois, and collector of the tooth, it is learned that, according to his recollection, the tooth was found in the cut of the interurban line running from Muscatine to Iowa City.

Buffalo, Scott County (16). - In the Davenport Academy of Science is a part of an upper molar of Elephas boreus, found on the farm of Mr. Sullivan, near Buffalo. The fragment presents 12 enamel plates of the hinder half of the tooth. Professor J. H. Paarmann, curator of the collection, has furnished the writer with photographs and measurements of the tooth. The plates are flat and rise at right angles with the base. The height of the tooth is $200 \mathrm{~mm}$.; thickness, $92 \mathrm{~mm}$.; length of fragment, $125 \mathrm{~mm}$. Between 9 and 10 plates are in a $100 \mathrm{~mm}$. line. The part preserved had not been subjected to use. The tooth is taken to be the second true molar.

Davenport, Scott County (17).--In 1876, W. H. Pratt (Davenport Acad. Sci., vol. I, p. 96) gave an account of the discovery of some elephant remains in a cut along the Chicago, Rock Island, \& Pacific Railroad, just west of Davenport. A tusk, some molars, and some bones were found, and are now in the collection of the Davenport Academy, where the writer has examined them (Iowa Geol. Surv., vol. xxIII, p. 446). They belong to Elephas boreus. The geological situation at this place is discussed on page 289. The conclusion reached is that the Davenport elephant probably lived there during the Iowan stage.

\section{Within the Area of the Iowan Drift.}

Cedar Rapids, Linn County (18).-The writer has reported (Iowa Geol. Surv., vol. xxiII, p. 438) a tooth of Elephas boreus, found within the limits of Cedar Rapids and in the southwest quarter of the southwest quarter of section $2 \%$, township 83 north, range 7 west. It was brought up from the bottom of the river in a suction-pipe. Although the tooth has some plates missing in front, possibly only one or two, it does not seem to have suffered any important abrasion from transportation. Cedar Rapids is within the area of the Iowan drift; but the tooth may have been geologically older or younger than this drift. In a collection of fossils in the City Hall, Portland, Oregon, the writer saw, in 1915, an upper second molar of Elephas boreus, labeled as having been found in Cedar River, at Cedar Rapids. It had been loaned by H. H. Usher.

Waterloo, Black Hawk County (19).-The writer has described (Iowa Geol. Surv., vol. xxIII, p. 428) some large teeth of an elephant, found in 1897 in a sand-pit at Waterloo, at a depth of 7 feet from the surface. These are large teeth and have some of the characteristics of teeth of Elephas columbi; but the writer regards them as belonging to E. boreus. The region about Waterloo is covered by Kansan drift, overlain in most places by Iowan drift. Over 
this again may oceur loess sometimes reaching a depth of 8 feet (Aubrey, Iowa Geol. Surv., vol. Xvi). Doubtless the geological age of the sands which contained this tooth will some time be determined. J. W. Wilby, the owner of the sand-pit, states that it is situated on the southeast quarter of the southeast quarter of section 24, township 89 north, range 13 west. It is about a mile east of Cedar River and apparently at the eastern edge of its old valley. Close to the sand-pit is a stone-quarry.

Hamplon, Franklin County (20.) - From William Brandt, of Hampton, the writer received photographs of an upper second molar of Elephas boreus, found northwest of Hampton, near Beed's lake. The more exact locality is in section 19, township 92 north, range 20 west. The place is evidently on Spring Creek, one of several streams of that county which take their origin in the moraine bounding on the east the Des Moines lobe of the Wiscosin drift. Williams, in his account of the Pleistocene geology of the county (Iowa Geol. Surv., vol. Xvi, p. 469), says that this stream occupies a preWisconsin depression and its valley is marked by the presence of a Wisconsin train of gravel. It seems probable, therefore, that the animal lived there when the Wisconsin glacier was not far away. The possibility exists that the tooth might have been derived from some part of the Iowan drift; it certainly had not been transported any considerable distance.

Marble Rock, Floyd County (21).- The writer has described and figured (Iowa Geol. Surv., vol. xxıII, p. 434, pl. LIx, fig. 2) an upper hindmost molar of Elephas boreus, found near Marble Rock. It was discovered in a pit in a large gravel deposit which is a valley train formed probably during the withdrawal of the Wisconsin ice sheet from the Des Moines lobe. The geological age of the tooth may be regarded as late Wisconsin.

Mason City, Cerro Gordo County (22).-Through Professor A. O. Thomas, of the Iowa State University, the writer has learned of a tooth of Elephas boreus, a hindmost, probably upper, molar found east of Mason City, in Gabler's gravel-pit, in section 11, township 96 north, range 20 west. This gravel was regarded as a part of the same gravel train that is found lower down on Shell Rock River at Marble Rock. Probably the Wisconsin ice sheet was not far distant when the possessor of this molar lived. The tooth was describer by the writer in 1912 (Iowa Geol. Surv., vol. xxıII, p. 85).

\section{Within the Area of the Wisconsin Drift.}

Des Moines, Polk: County (23). - In the writer's paper on the Pleistocene Mammals of Iowa (Iowa Geol. Surv., vol. xxıII, pp. 31, 4t3), descriptions are given of some teeth found at Des Moines and referred to Elephas boreus. The Pleistocene geology of this county has been described by Calvin (Iowa Geol. Surv., vol. viI, pp. 335-352, map). Inasmuch as Des Moines is situated on the border of the Wisconsin drift it is reasonable to suppose that the teeth were derived from animals which lived there while the front of the Des Moines lobe was not very distant.

Clear Lake, Cerro Gordo County (2t). - In the Iowa State Historical Department is a part of a lower jaw of an elephant ( $E$. boreus), found in 1898 by H. I. Smith, in the vicinity of Clear Lake. In this jaw is inclosed a tooth which may be either the last or the next to the last molar. It is further described in the writer's paper on the Pleistocene Mammals of Iowa (Iowa Geol. 
Surv., vol. xxıII, p. 429). Clear Lake is situated on the eastern border of the Des Moines lobe of the Wisconsin drift sheet. It is probable that the elephant in question lived there shortly after the ice began to withdraw.

\section{Within the Driftless Area}

Center Grove, Dubuque County (25).-The writer has seen, in the possession of Dr. H. G. Knapp, of Dubuque, a small but characteristic fragment of a tooth of Elephas boreus, found in making a drift toward a lead crevice, on land owned by William Brunskill, about half a mile from Center Grove. In the collection of Richard Herrmann, of Dubuque, the writer has seen an upper last molar found in 1896 by David Dawson, at the 11-mile post of the Illinois Central Railroad, west of Dubuque. This was probably not far from Center Grove. The tooth is that of Elephas boreus. Center Grove is in or near to, section $2 \%$, township 89 north, range 3 east, and near Catfish Creek. The border of the Kansan drift is, however, not far away; at a somewhat greater distance are fingers of the Iowan drift. The Pleistocene geology of this county has been described by Calvin and Bain (Iowa Geol. Surv., vol. x, pp. 463-478, map). Chamberlin and Salisbury (6th Ann. Rep. U. S. Geol. Surv., 1885, pp. 199-322) have discussed thoroughly the whole of the driftless region. By consulting their plate $x x v i$ it will be seen that the western part of this driftless region, especially that west of Mississippi River, is covered by a mantle of loess. While, therefore, no certain conclusion can be reached about the geological age of the mammoth teeth here reported, it is probable that they were buried beneath or in the loess and would be, at earliest, post-Kansan in age. One might assign them provisionally to the Iowan stage.

\section{NEBRASKA.}

(Map 5.)

York, York County (1).-In the collection in the State Museum at Lincoln is a lower right hindmost milk molar, referred to Elephas boreus. There are present 10 plates, but apparently one or more are missing in front. The length along the worn face is $105 \mathrm{~mm}$.; width, $52 \mathrm{~mm}$. The enamel is thin. The specimen is designated in the collection by the numbers 3-10-11. The region in which this tooth was found is occupied by the Sheridan beds; these are covered by loess. 'The tooth might have been found in either deposit.

Dannebrog, Howard County (2).-In the collection of the State Museum at Lincoln is a large upper left last molar of an elephant, found at or near Dannebrog. It is one of a pair, the other of which is or was in the possession of Dr. P. Harold Salter, of Norfolk, Nebraska. The one in the museum was deposited by Dr. Franklin Schauffelberger, of Hastings. This tooth was described and figured by Dr. E. H. Barbour (Neb. Geol. Surv., vol. Iv, p. 63, pl. I) as Elephas columbi. The present writer now believes that this tooth belongs to Elephas boreus. He wishes to assume the principal part of the responsibility for the assignment of it to $E$. columbi. The tooth is a large one and as a result the plates are thicker than usual in E. boreus. However, the form of the tooth is that usually assumed by the last-named species; the plates are little warped and run parallel with one another. The writer also made a note to the effect that the enamel is thin, a feature which indicates $E$. boreus. Doctor Barbour records the fact that these teeth were dug out 
of the bank of Middle Loup River, in 1895 , by H. L. Underwood. The farm belonged to Louis Gognemans, and is 4 miles northeast of Dannebrog. 'The animal may have lived then during the time of the Kansan drift sheet.

Hayes Center, Hayes County (3).-In Field Natural History Museum, Chicago, is an upper last molar of Elephas boreus, recorded as No. 6767 and as found about halfway between Hayes Center and the town of Palisade. The latter town is about 12 miles south of southwest of Hayes. There are in the tooth 19 plates, besides front and rear talons. The extreme length is 247 mm.; height of the seventh plate, $145 \mathrm{~mm}$. Nothing is known about the history of this tooth. It appears to have been found in the region between Red Willow and Stinking Water Creeks and therefore probably on high land. It seems probable that it was buried in Sheridan deposits; but we have no proof.

Agate, Sioux County (4).-In 1914 (Nebraska Geol. Surv., vol. vir, pl. I), Harold Cook described and figured a lower tooth found near Agate, which he identified as probably $E$. coiumbi. It was supposed to be a milk-molar. An examination of the description and figure makes the present writer think that the tooth is that of Elephas boreus and that it is the second true molar. There is too high a number of plates (10) in a decimeter line for the tooth to belong to $E$. columbi. There are too many plates in the tooth (15) for it to be a milk-molar. 'The tooth had only just begun to wear; the plates of the hinder end had not become united at their bases. It is probable that one or two are missing. Mr. Cook stated that the tooth had been washed out by a flood and that it had come from the gravels which underlie the surface deposits in the bottom of Niobrara Valley, at Agate. It may be that these gravels belong to the Sheridan stage, but the writer does not know that this is true.

\section{MINNESOTA.}

(Map 5.)

Minneapolis, Hennepin County (1).- In the collection at Yale University is a tooth of this species (Cat. No. 11679), labeled as found at Minneapolis. No details are given. The tooth is an upper left hindmost molar. There are present 20 enamel plates; a few in front had probably been worn off. The length of the fragment is $220 \mathrm{~mm}$. Ten plates occupy a line $100 \mathrm{~mm}$. long. This is probably the elephant tooth to which Professor Lull referred as being from Minnesota (Amer. Jour. Sci., ser. 4, vol. xxv, p. 198). Other supposed elephant remains from the region about Minneapolis were reported by $\mathrm{N}$. $\mathrm{H}$. Winchell in 1910 (Bull. Minn. Acad. Sci., vol. IV, pp. 416-417); but there is doubt regarding the species, or even that they are not parts of the mastodon.

Wabasha, Wabasha County (2).--In Professor Winchell's paper of 1910, on page $41 \%$, with a plate, he recorded the finding of a small elephant tooth in a bed of gravel forming a part of the terrace along Mississippi River. It belongs evidently to Elephas boreus. Winchell regarded it as having lived during the Wisconsin epoch.

Mankato, Blue Earth County (3).-The writer saw, in January 1914, a part of a tooth of Elephas boreus, found on a sand-bar in Blue Earth River, near its junction with the Minnesota. In the high school of Mankato there is a part of another tooth of this species, found near the town in excavating for sand. 


\title{
FINDS OF ELEPHAS COLUMBI IN THE MIDDLE REGION OF NORTH AMERICA.
}

\author{
LOUISIANA.
}

(Map 7.)

Petite Anse, Iberia Parish (1).--In the U. S. National Museum is a lower molar of an elephant, presented, in 1866, by J. F. Clew, of Petite Anse. At the same time he contributed some rock salt, parts of tusks of mastodon or elephant, and some matting, or part of a basket, which had, as reported, been found on the surface of the rock salt. The elephant tooth is a lower molar, probably the penultimate, very much worn, 9 plates are represented. The length of the grinding-face is $150 \mathrm{~mm}$.; width, $83 \mathrm{~mm}$.; 5 plates in a 100 $\mathrm{mm}$. line. Each plate, as shown on the grinding-surface, is much constricted in one or two places and nearly all have an expansion near the middle. The enamel is very thick and much corrugated. The rear shows no indications of there having been another tooth behind it; yet it appears to be quite narrow for a hindmost molar. The tooth was mentioned by Leidy (Ext. Mamm. Dak., Neb., p. 254), who referred it to Elephas columbi. In the determination of the species it must be taken into account that the plates, especially those of the rear of the tooth, may be thicker than the anterior plates; also, that the tooth curves somewhat, so that the length would be less than estimated above.

Dr. Joseph F. Joor, in 1895 (Amer. Naturalist, xxIx, p. 397), stated that he had been shown a tooth of an elephant which he was told had been found in a shaft of a salt mine at Petite Anse. This probably belonged to Elephas columbi. It may well be that some of the remains which have been found in northwestern Louisiana and reported as mastodon were really elephant.

\section{TEXAS.}

(Maps 7, 8.)

Paloduro, Armstrong County (1).-In the American Museum of Natural History, New York, are some remains of one or more individuals of Elephas columbi, collected near Paloduro, in 1911, by Mr. Barnum Brown. Among these is a nearly complete lower right third molar. It lacks a few of the hindmost plates. There are 17 preserved; 6 of these occupy a $100 \mathrm{~mm}$. line. There are present a part of the corresponding left molar and a part of the jaw. The catalogue number is 15539 .

Rock Creek, Briscoe County (2).-In 1884 (4th Ann. Rep. Geol. Surv. Texas, p. 79), under the name Elephas primigenius, Cope reported the presence of elephant remains at this place. He stated that the teeth from Rock Creek were neither thick-plated nor thin-plated, but were much as in the typical variety of Elephas primigenius (E. boreus), and that some plates were slightly crenate, while others were plain. Such teeth could not have belonged to $E$. imperator; and there is no sufficient reason for believing that Elaphas boreus occurred there. The teeth must be referred to Elephas columbi.

Foard City, Foard County (3).-In May 1921, J. W. Beverly, of Crowell, Foard County, sent to the U. S. National Museum the rear part, about 8 
plates, of a large upper hindmost molar of Elephas columbi. This tooth was found near a small stream, Salt Creek, about a mile southwest of Foard City.

Vernon, Wilbarger County (4).-From R. L. More, of Vernon, the U. S. National Museum received a lower left hindmost molar of Elephas columbi, catalogue No. 8873, which was found in a gravel-pit about 2 miles southeast of Vernon. It is considerably worn in front and some plates are missing.

Sweetwater, Nolan County (5).-On November 13, 1913, there were received at the U. S. National Museum, from Thomas L. Hughes, parts of two large elephant teeth found near this place. The fragments had suffered little through wear, the circles of the worn digitations remaining on the surfaces. The ridge-plates are from 14 to $16 \mathrm{~mm}$. thick and about $155 \mathrm{~mm}$. high. There are two plates in each fragment and these belong to corresponding molars of the right and left sides of the jaw. In a letter dated December 3, 1913, Mr. Hughes informed the writer that the teeth had been found in the northwest quarter of section 59, block 22, Nolan County, on a small creek called Icemgood, on land owned by Mr. Grogan. The fragments of teeth were in a bluff at a depth of about 8 or 10 feet from the surface of the ground and 4 or 5 feet above the bed of the creek. They were buried in a stratum of strongly cemented gravel. Besides these fragments of teeth, the jaw-bone and a part of a tusk were dug out.

Tulip, Fannin County (6).-About 1910, near the town of Tulip, not far from Red River, what appears to have been a nearly complete skeleton of an elephant was found. This at length came into the possession of R. E. Medford, of Bonham. At last accounts it was being exhibited in Texas towns. Doctor Francis, who saw the remains in Dallas, states that they are now in very bad condition. He thought the skeleton belonged to Elephas columbi.

Rock Hill, Collin County ( 7$)$. - In the collection of the Texas State University, is a part, 10 ridge-plates, of an elephant upper left molar, found on Panther Creek, 2 miles south of Rock Hill. It is credited to J. A. Taff. While referred to $E$. columbi provisionally, it mayl belong to $E$. imperator, inasmuch as there are only 5 ridge-plates in a $100 \mathrm{~mm}$. line.

McKinney, Collin County (42).-From Dr. Francis the writer received in 1924 a photograph of a molar, perliaps the lower second, of Elephas columbi, which had been found in a gravel pit near McKinney. The tooth is close to $180 \mathrm{~mm}$. long and $75 \mathrm{~mm}$. wide. There are $\%$ of the plates in a $100 \mathrm{~mm}$. line. There appear to be 14 of them in the tooth as preserved and these cross the grinding surface obliquely. This number is not on the maps.

Fort Worth, Tarrant County (8).-At the Public Library in Fort Worth the writer saw a lower apparently third molar of Elephas columbi in a part of the jaw found somewhere about the city, probably in the gravel deposits along Trinity River. From Professor W. M. Winton, of Texas Christian University, Fort Worth, the writer received a photograph of a lower jaw of Elephas columbi, preserved in the collection of the institution named. This was found on the north side of Trinity River, directly north of the city. The teeth appear to be the hindmost molars and there are $\gamma$ of the ridge-plates in a $100 \mathrm{~mm}$. line. The jaw was found in a gravel-pit at an elevation of about 45 feet above high water. At the same place was found a jaw of a mastodon. Dallas, Dallas County (9).--In the collection of the Southern Methodist University, at Dallas, are remains of various elephants, but unfortunately it 
is not known, in all cases, where the remains were found; but all or most of them evidently came from gravel-pits east of the city, along or near White Rock Creek. One piece, which consists of the bases of both tusks and the bones which contained them and of both upper hindmost molars yet in the maxilla, was reported in the Dallas News of May 2, 1914, to have been found at a depth of 10 feet in the Lagow gravel-pit, just east of the Fair Grounds. The remains are those of a very old Elephas columbi. The hindmost teeth are worn so that only 12 or 13 ridge-plates remain. The tusks are large, the diameters near the base being $200 \mathrm{~mm}$. and $190 \mathrm{~mm}$. The distance across the sheaths, where this is least, is $400 \mathrm{~mm}$. The tusks diverge at the base at an angle of about 45 degrees. For a list of the species found in this gravel-pit, see page 241; also Lull (Amer. Jour. Sci., vol. II, 1921, p. 160).

In a small collection at the Central High School in Dallas is an upper right last molar of E. columbi, found in the gravel along Trinity River. The tooth is nearly white. It measures $190 \mathrm{~mm}$. in length and $90 \mathrm{~mm}$. in width.

An elephant found at Dallas and referred (Amer. Naturalist, vol. xxiıI, p. 208) to $E$. columbi is regarded as belonging to $E$. imperator.

Here may be recorded elephant remains found 5 miles south of Dallas, along the Missouri, Kansas, and Texas Railroad. Just west of the railroad is an extensive gravel-pit on the farm of Dr. A. E. and Dr. G. R. Flowers. A fine tusk and some teeth of Mammut americanum had previously been found in this pit. In January 1923 a very large tusk and two molar teeth, upper hindmost molars, were found in the pit. The remains were secured by Doctor Francis and he has sent to the writer photographs of the teeth. These are much worn. There are left only 11 or 12 plates and the plane of wear strikes them obliquely. Five plates are counted in a $100 \mathrm{~mm}$. line. There would apparently be more plates in such a line at right angles to the plates. The writer believes that the teeth and tusk belong to Elephas columbi.

Waxahatchie, Ellis County (10).--In Field Museum of Natural History, Chicago (No. 5930), the writer saw a well-preserved left molar of Elephas columbi, found somewhere in this region. There are present 14 plates.

Corsicana, Navarro County (11).- In the collection of the University of Texas is part of an upper molar, referred to E. columbi and labeled as having been found near Corsicana. No other information is given regarding the history of the specimen.

Trinity, Trinity County (38).-In the collection of Dr. Mark Francis is a part of a lower molar, probably the hindmost one, consisting of 14 plates, which was found near Trinity. A few plates are missing from the front end and a few from the rear end. The hindmost of the plates present is 160 $\mathrm{mm}$. high and $97 \mathrm{~mm}$. wide. The plates are curved in their ascent. The hinder plates are thick, 5 in a $100 \mathrm{~mm}$. line. The enamel is thinner than one expects to find in E. imperator. It possibly belongs to the species last mentioned. The tooth was sent to Doctor Francis by Lewis Runnels, of Trinity. This town is near the western end of the county and near Trinity River. Another lower molar seen by Doctor Francis in the Trinity National Bank had been found in Trinity River, near Trinity. It had about 6 ridgeplates in $100 \mathrm{~mm}$.

Onalaska, Polk County (39).-From F. M. Burks, of Onalaska, the U. S. National Museum received in 1923 an upper left hindmost molar of Elephas 
columbi. He sent likewise a photograph of a lot of bones, consisting of a jawbone with good teeth, portions of other teeth, fragments of apparently the pelvis, and parts of various limb-bones. It is evident that the jaw-bone containing a large hindmost molar belongs to Elephas imperator; it will be recorded in its proper place. All of these teeth and bones were found in a gravel-pit in a terrace 1.5 miles from Trinity River rising from the flood plain and at an elevation of about 35 feet above the river. The tooth received presents only about 13 plates; some gone from in front, a few from the rear. There are 6 plates in a $100 \mathrm{~mm}$. line. Whether the bones shown in the photograph belong to $E$. columbi or $E$. imperator, it is impossible to say.

Paluxy Creek, Hood County (12).- In the American Museum of Natural History, New York, is a remarkable tooth, referred to Elephas columbi. The catalogue number is 8071 . The tooth was collected by W. S. Nehms. It appears to be the upper hindmost molar of the right side. 'There are 14 plates present; several of the front ones, probably about 10, are worn out. The hinder plates are $230 \mathrm{~mm}$. high. The notable feature of the teeth is the extreme thinness of the cement between the enamel plates. The enamel is thick. The plates converge from the base toward the grinding surface. At the middle of the height there are 7 plates in $100 \mathrm{~mm}$. Were the cement of the usual thickness there would be fewer plates in this distance. It is possible that the tooth is one of $E$. imperator.

Clifton, Bosque County (13).- - In 1913, Jacob Olson, of Norse, in Bosque County, sent to the U. S. National Museum a fragment of an upper molar of Elephas columbi, found, as the present writer understands, at Clifton, on Bosque River. The tooth was finely preserved and white in color. It was returned to $\mathrm{Mr}$. Olson.

Waco, McLennan County (14).-In Baylor University, Waco, Texas, are two teeth, the last milk-molars of both sides of the upper jaw, which were found in the White Rock sand-and-gravel pit, 5 miles above Waco, on the left bank and in the third terrace. They are worn on only 4 plates. Of these plates, there are 9 in each tooth. From the base in front to the rear talon the length is $117 \mathrm{~mm}$; width, $58 \mathrm{~mm}$. There are a little more than 4 plates in a $100 \mathrm{~mm}$. line. These teeth are referred to Elephas columbi. From the same pits was obtained a part of the lower jaw of a young $E$. columbi, containing a finely preserved lower hindmost milk-molar. This tooth presents 11 ridge-plates. It is worn on all the plates except the hindmost, but not to the base in front. The length is $143 \mathrm{~mm}$; width, $63 \mathrm{~mm}$. This tooth was presented to the National Museum by Richard M. Cooper, Waco. It has the catalogue number $820 \%$.

In the collection of Baylor University are two finely preserved upper hindmost molars of Elephas columbi, found in a gravel-pit at Third Street in South Waco. This is near the river and in the second terrace. These teeth are worn to the base in front and the front roots are missing. Probably 2 or 3 ridge-plates are missing in front. Dr. Mark Francis reports that he received, in 1923, a tooth of $E$. columbi, found along Brazos River, about 6 miles northwest of Waco. 
Temple, Bell County (40).-A lower hindmost molar found between Temple and Belton is of such a nature that it is doubtful whether it belongs to Elephas columbi or $E$. imperator. A description of it is given on page 104 as Elephas sp. indet.

Marlin, Falls County (15).--In the collection of Dr. Mark Francis at College Station is part of a right molar tooth of Elephas columbi from somewhere about Marlin; it consists of 13 plates, the highest $190 \mathrm{~mm}$. On the convex side of the tooth are only 5 plates in a $100 \mathrm{~mm}$. line; on the concave side are about 6 or 7 .

From Doctor Francis the writer received a sketch of a tooth of Elephas columbi, obtained at Marlin, in 1922, in the gravel-pits of I. H. Parten. The tooth had lost some plates at the rear. About 12 plates were worn, but not to the base in front. The extreme length of the specimen was 12 inches. Eight plates occupy a $100 \mathrm{~mm}$. line. With this tooth were what Doctor Francis identified as a radius of a horse and a tooth of Elephas imperator.

J. M. Kennedy, editor of The Marlin Democrat, reports the finding of a tooth of an elephant in the same gravel-pit in which was found the type skull of Elephas francisi. On one of the faces he counted 8 ridges in a line 4 inches long. This indicates that the tooth belonged to Elephas columbi.

Satin, Falls County (16).-The writer has scen photographs of some teeth of an elephant, found in the bed of Brazos River by W. P. Moore, of Satin. There are 4 teeth and a vertebra. In 4 inches, along the grinding-surface, there are 6 plates. The animal was certainly Elephas columbi.

Pittbridge and Munson's Shoals, Brazos County (17).-From Doctor Francis the writer received a photogragh of a much-worn molar of Elephas columbi, obtained in a store in Bryan, but which was found at Munson's Shoals, 2 or 3 miles below Pittbridge. The tooth is worn to the base in front and no doubt some plates are missing. The length as preserved is $142 \mathrm{~mm}$; the width is about $70 \mathrm{~mm}$. The tooth is probably the lower first molar. The plates cross the grinding-face in a very irregular way. There are somewhat more than 6 plates in a $100 \mathrm{~mm}$. line. In the same collection is a molar found 3 miles below Pittbridge. Near the same place was found, by E. J. Fountain, of Bryan, a lower second molar of $E$. columbi. It belongs in the Francis collection.

Here may be mentioned a fine upper left hindmost molar referred to $E$. columbi, which was found at Pittbridge in 1912 and is owned by Doctor Francis. The front end, with its root, is worn off and some plates with it; 19 or 20 plates remain. Of these, there are 5 in a $100 \mathrm{~mm}$. line. The length from the base in front to the rear is $370 \mathrm{~mm}$; the width $105 \mathrm{~mm}$. The enamel is thick and much folded. Were it not that the number of plates exceed 18 , the tooth might be referred to $E$. imperator.

Doctor Francis has an upper second molar of $E$. columbi, which he reports was found at Pittbridge. There are 16 plates and a hinder talon. This tooth is worn on about 10 plates, but not to the base in front. It shows the base of the front root with a space behind it. The length from the front of the tooth to the rear of the hinder talon is $215 \mathrm{~mm}$.; height of the tenth plate, $205 \mathrm{~mm}$.; width of the grinding-surface, $80 \mathrm{~mm}$. In the rear is a depression for the front of the hindmost molar. In 1924 Doctor Francis received an 
elephant molar, recently found at Pittbridge. It had 9 plates in a $100 \mathrm{~mm}$. line, and is referred to Elephas columbi.

Navasota, Grimes County (18).- In the collection of Doctor Francis is an upper right third molar, found in Brazos River, near Navasota. 'This would be practically the same as Hidalgo Falls. 'The front of the tooth is missing. The width of the grinding-surface is $110 \mathrm{~mm}$. There are 6 plates in a 100 $\mathrm{mm}$. line. On the inner side of the tooth, opposite the edges of some of the median plates, is a row of apparently distinct columns of dentine surrounded by enamel, and some intercalated smaller columns. These appear to form a sort of cingulum. The tooth is referred to Elephas columbi. With this tooth were found 2 large cervical vertebræ, one of them the axis, but there is no assurance that they belonged to the same animal. The axis has a total height from bottom of centrum to top of spine of $290 \mathrm{~mm}$. The width of anterior articular surface is $240 \mathrm{~mm}$. These fossils probably belong to $E$. columbi, but there is some doubt.

Big Spring, Washington County (19). - In the National Museum is a part of a tooth of Elephas columbi, collected on Big Spring Creek, 6 miles southeast of Burton, in 1910, by August Stelter. It was sent to the museum by Dr. Alexander Deussen. With it was found a part of a femur. Nothing else is known about conditions connected with the discovery.

San Felipe, Austin County (20).-On page 246 is described the geology of the region of San Felipe, and a list is given of the species of vertebrates found there. In 1846 (Amer. Jour. Sci., ser. 2, vol. I, pp. 2t4-217), Carpenter described a collection made here by a Mr. Huff (or Hough). This went to the British Museum in London. Among the materials of this collection, Falconer found teeth of Elephas columbi. Two of these are described in detail, a part of a lower last molar and a part of a penultimate lower molar. On page 228 the same author* describes a fragment of a cranium which formed part of the Huff collection. In this fragment was an enormous last true molar, of which there remained 20 plates, some anterior ones having been worn away. The distance in a straight line from the base of the hinder talon to the front of the socket for the anterior root was 18.25 inches. The fourteenth plate from the front was 10.7 inches high. The plates were rertical and averaged only half an inch in thickness. Such a tooth reminds one of the great upper molar figured by the author (Iowa Geol. Surv., rol. xxirr, pl. Lxiv, fig. 2) and found near Mount Angel, Oregon. Falconer referred the tooth to $E$. primigenius, but it is possible that it and the Oregon tooth belonged to a yet unnamed species. According to Deussen's latest map (Prof. Pap. 126, U. S. Geol. Surr.), this locality lies somewhat outside of the Lissie area.

In the collection of Doctor Francis is a fine lower right second molar, found at San Felipe in 1908. It is attached to a fragment of the lower jaw; 6 of the front plates abraded; no roots yet developed. Some plates, apparently one or two, are missing from the rear; 14 plates and the front talon are present. Most of these are concare on the hinder face. There are 6 plates in a $100 \mathrm{~mm}$. line. The length of the tooth as preserved is $242 \mathrm{~mm}$.; thickness, $70 \mathrm{~mm}$; height perpendicular to the base, about $150 \mathrm{~mm}$.

* Falconer, Palæontological Memoirs, volume II. 
McDowell, Austin County (21). -This town is on the west side of Brazos River about 10 miles west of Brookshire. A number of fossils are credited to the place, but some may have been found nearer Brookshire. In the collection of Doctor Francis is an upper left molar, probably the second of Elephas columbi, which presents 15 plates, some being gone from the front. There are 6 plates in a $100 \mathrm{~mm}$. line. The molar was found in Brazos River. Another tooth in this collection, found at Brookshire, is a lower right second molar presenting 14 plates, some from the rear being lost. There are 6 plates in a $100 \mathrm{~mm}$. line. From the front of the tooth to the base of the last plate present, the distance is $240 \mathrm{~mm}$. There is doubt whether some other fine teeth in Francis's collection were found at Brookshire or Pittbridge.

San Leon, Galveston County (22).-On the shore of Galveston Bay, at San Leon, 9 miles east of Dickinson, was found, in April 1921, a skull of an elephant, described on page 242 as Elephas imperator. In examining this collection the writer recognized one or two teeth of Elephas columbi and a few bones of a species of horse. The collection has become a part of that made by Dr. Mark Francis, at College Station, Texas.

Houston, Harris County (41).-From Doctor Francis the writer received in 1924 a photograph of a fragment of an upper hindmost molar which was found at a depth of 18 feet in the excavation for the new Masonic Building in Houston. There are about 8 plates preserved. The height of these is about $150 \mathrm{~mm}$.; 5 or 6 of these are crossed by a line $60 \mathrm{~mm}$. long. The tooth appears to belong to Elephas columbi.

Alvin, Brazoria County (23).-In the collection of Dr. Mark Francis are 5 fragments of teeth of an Elephas columbi, sent to him from Alvin by $J$. A. Froberg, of the same town. Mr. Froberg informed the writer that these teeth were picked up by W. R. Bunch, of Alvin, from materials thrown out of a freshly dug ditch, about 3.5 miles southeast from the town. They had been buried at a depth of from 4 to 5 feet. The earth in which they were inclosed consisted of a whitish sand. There appeared to be some fragments of large bones in the same place, but these were not exhumed. The ditch is one which penetrated Mustang Bayou in several places. The locality is well down toward the southern border of the Beaumont clays. All the fragments belong to 2 lower teeth, which seem to be the right and the left second true molars. The most complete tooth is that of the left side. Perhaps one plate and the talon only are missing in front. Then come 9 plates in two fragments which form accurate contact. A rear fragment presents 4 plates and a part of another. Between this fragment and the one in front, one or two plates are missing. We seem thus to account for at least 16 plates. This number appears to indicate the second true molar, but the width of the tooth is only $78 \mathrm{~mm}$, and the height of the supposed ninth or tenth plate from the front is only $135 \mathrm{~mm}$. The tooth probably belonged to a small individual. The plates are thick, there being 6 in a $100 \mathrm{~mm}$. line. They are much bent as they ascend from the base.

Wharton, Wharton County (24).-The collection of Doctor Francis from Wharton, contains a very complete lower jaw of an elephant, which is referred to $E$. columbi. It was found in Colorado River. Ten plates of each hindmost molar are present, these teeth having been worn considerably. There 
are 6 plates in a $100 \mathrm{~mm}$. line. The enamel is very thick and is crimped. From front to rear the part of the tooth remaining measures $220 \mathrm{~mm}$. From outside to outside of the condyles the distance is $496 \mathrm{~mm}$. From the middle of the line joining the condyles to the top of the chin is $612 \mathrm{~mm}$. The width of the lingual groove at the middle of its length is $68 \mathrm{~mm}$.; height of jaw at middle of tooth, $160 \mathrm{~mm}$.; width, $140 \mathrm{~mm}$. From the front of the ascending ramus, at the level of the teeth, to the rear of the jaw is $250 \mathrm{~mm}$.

Keeran Point, Victoria County (37).- In September 1919 a violent hurricane led to the falling of a large mass of earth along the shore of Lavaca Bay, at Keeran Point. In the fallen mass were discovered bones of Elephas columbi, a mastodon later described by the writer as Anancus brazosius, and a bone of a camel. These specimens were acquired by Dr. Mark Francis. Among the elephant bones was a moderately curved tusk, of which about 6 feet were preserved, in as many pieces; at the base it had a diameter of about $215 \mathrm{~mm}$. Two upper hindmost teeth are present, that of the left side complete, except that the roots are mostly broken. The anterior root is partly retained in the bone of the jaw. It appears to have supported 4 plates. Between it and the small tooth belonging to hinder plates there appears only a short interval. In this tooth are counted 24 plates. Only 8 or 9 plates are worn; the eighth has a height of $260 \mathrm{~mm}$. There are 6 plates in a $100 \mathrm{~mm}$. line on the inner face. Of the left lower tooth are present 11 front plates, of which 10 are affected by wear. The great front root is represented by its base and it supported 3 plates. A notch separates it from the hinder rootlets, which were not yet fully developed. It is remarkable that the plates are thick, there being hardly more than 4 in a $100 \mathrm{~mm}$. line. Were it not for the upper teeth, the animal would be referred to Elephas imperator. These plates are much bent forward. The tooth is $100 \mathrm{~mm}$. thick. The lower right third molar is almost wholly buried in the bone. At the front of this tooth the jaw is $243 \mathrm{~mm}$. high and $174 \mathrm{~mm}$. thick. Its greatest thickness, farther back, is $205 \mathrm{~mm}$. The tooth itself is close to $410 \mathrm{~mm}$. long. A fragment of the right maxilla contains a considerable part of the second molar, 12 plates. It is $135 \mathrm{~mm}$. long. Nearly 9 plates are spanned by a $100 \mathrm{~mm}$. line. This fragment alone would suggest Elephas boreus.

Bastrop, Bastrop County (25).- - In July 1921 there was sent to the U. S. National Museum, by Hugh H. Duval, a tooth of Elephas columbi. It was found at Bastrop, in a gravel-pit, 50 feet above Colorado River. The tooth is white and beautifully preserved. It is an upper left second molar with 11 plates, but some, probably 2 , have been broken from the front end; wear had about reached the base in front and the last plate behind. The plates are flat and the enamel thick. The length is about $225 \mathrm{~mm}$.; width of grindingsurface, $80 \mathrm{~mm}$. There are 7 plates in a $100 \mathrm{~mm}$. line.

Marble Falls, Burnet County (26).-In March 1922, Doctor Francis informed the writer that he had visited Marble Falls, where the skeleton of an elephant was being washed out of a gully. He identified it as $E$. columbi. The lower jaws were in fair condition, but the other bones were badly broken and were not exhumed.

Cherry Spring, Gillespie County (27).- In the collection of the State University, at Austin, is a part of a lower molar, consisting of 6 or 7 plates, 
which is labeled as having been found at Cherry Spring by G. Jermy. Nothing more is known about the specimen. Cherry Spring is situated near the head of Hickory Creek, a tributary of Llano River, which empties into Colorado River. It appears to be on the highest land in that immediate region.

Luling, Caldwell County (28). - In the Francis collection at College Station are 2 molars, a part of a right innominatum, and 2 pieces of tusks, each about 3 feet long, which were found at or near Luling by R. E. Faires. These parts appear to belong to Elephas columbi. A part of the maxilla is attached to the left tooth. The teeth are the upper hindmost molars and are well worn down in front; 16 plates are present; about 8 must have been worn out. The hindmost plates had begun to wear. The present length of the crown is $200 \mathrm{~mm}$. The width is $110 \mathrm{~mm}$., excluding the cement. A 100 mm. line extends across 6 plates. The enamel is thick and somewhat crimped. The acetabulum has a diameter of $215 \mathrm{~mm}$.

Ottine, Gonzales County (29).-In the University of Texas, at Austin, is an upper left last molar of Elephas columbi, found in a spring near Ottine by Professor F. L. Whitney. Ottine is situated on Marcos River. There are present 20 plates and from 6 to 7 of these in a $100 \mathrm{~mm}$. line. The height of the unworn sixth plate from the rear is $230 \mathrm{~mm}$.

Marion, Guadalupe County (30).- In 1922 the writer saw 2 fragments, of 2 plates each, of a molar of Elephas columbi, which Dr. L. W. Stephenson and E. B. Stiles found near Marion. The fragments were discovered in alluvial materials along one of the headwater arroyos of Santa Clara Creek, about 1.5 miles west by south of Marion and south of the Galveston and San Antonio Railroad. They were collected August 28, 1921. There is nothing to indicate the stage of the Pleistocene to which they belonged.

San Antonio, Bexar County (31).- In the U. S. National Museum (catalogue Nos. 4840 and 4841) are 3 fragments of large molars, which were sent there by Frank Grice and which were found at San Antonio. The San $A n$ tonio Daily Express of March 25, 1900, gave an account of the discovery of these fragments. They were found in the great gravel-pits of the San Antonio Street Railway Company, near Riverside Park, about 15 feet from the surface. A fragment of a lower tooth (No. 4840) presents 7 ridge-plates which belonged near the front end of the tooth. There are 6 plates in a 100 $\mathrm{mm}$. line and these are strongly flexed. From this newspaper account it is learned that in $1853 \mathrm{C}$. F. Beitel found in a well, at a depth of 16 feet, some large bones, among them a jaw in which were several teeth. These appear to have been preserved; and on comparison with the teeth found near Riverside Park they were regarded as being the same. The U. S. National Museum (No. 8867) has received from Dr. Charles L. Baker a lower right molar, probably a penultimate, which is referred to this species. It was found, according to Doctor Baker's label, in 1917, in Pleistocene gravels and silts, on the east bank of Salado Creek, south of the crossing of the Sutherland Springs road, probably about 5 miles east of San Antonio. Counting from the rear, there are 9 ridge-plates remaining, about 6 of which occupy a line $100 \mathrm{~mm}$. long. The large hinder root, $120 \mathrm{~mm}$. long, is present, behind which there is a depression for a succeeding tooth. Probably as many as 7 ridge-plates were worn away. Were not the plates so thick, the tooth might 
be taken as that of Elephas boreus. Sellards (Univ. Texas Bull. 1932, p. 73) refers to this specimen as occurring on the lower plain along Salado Creek.

Leon, Bexar County (32).-The American Museum of Natural History, in New York, has some remains of an elephant, mostly bones of the skull, found somewhere along Leon River, southwest of San Antonio. Five ridge-plates of a lower molar indicate that the animal belonged probably to Elephas columbi.

Becville, Bee County (33). - In the collection of Dr. Mark Francis is a part of an upper molar of Elephas columbi, found somewhere about Beeville. It was evidently a very large tooth. There are 7 plates in a $100 \mathrm{~mm}$. line. There is also present a part of a lower molar of the same species.

Under the same number may be mentioned an elephant tooth received by Doctor Francis from V. F. Kessler, of Skidmore, and regarded by him as belonging to Elephas columbi. From Mr. Kessler the writer learns that this tooth was found 3 miles northwest from Skidmore, in the bank of a creek, under about 5 feet of ground.

Alfred, Jim Wells County (34).--Dr. Mark Francis received from Alfred 3 ridge-plates of a molar, probably the upper hindmost, of Elephas columbi. The height is $195 \mathrm{~mm}$; ; width, $81 \mathrm{~mm}$. The three occupy a thickness of 42 mm. No details are known about the geological relations of the specimen. Two short pieces of tusk were with the piece of tooth; all were found on the Pease ranch and sent by A. A. Wright.

San Diego, Duval County (35).-In 1889 (Amer. Naturalist, vol. XxIII, p. 209), Cope reported a fragment of a tusk of an elephant from southwestern Texas (meaning doubtless the San Diego region). This had a diameter of $210 \mathrm{~mm}$. at the base. There is no evidence that this was not a tusk of $E$. imperator. The American Museum of Natural History, New York, has part of a molar and a leg-bone, which is referred by the writer to $E$. columbi. It was collected by William Taylor, of San Diego. Dumble (Trans. Amer. Inst. Min. Engineers, vol. XxxıII, p. 984) stated that most of the fossils sent to Cope by Taylor were found on Tarancahaus Creek.

El Paso, El Paso County (36).-In 1907, George B. Richardson (Science, vol. Xxv, p. 32) reported the finding of Elephas columbi in a gravel-pit at El Paso. With it were Equus complicatus and a tapir. The identifications were made by James W. Gidley. In Richardson's materials the writer saw a fragment of a tooth of a species of a mastodon other than Mammut, probably Anancus.

For (37) see page 64; for (38) and (39) page 59 ; for (40) page 61 ; for (41) page 59 ; for (42) page 58.

\section{OKLAHOMA.}

(Map 7.)

Afton, Ottawa County (1).- In the department of palæontology in the U. S. National Museum are about a dozen teeth of $E$. columbi, which were obtained in a spring near Afton. These, with remains of 18 other species of mammals and many flint implements, were secured in 1901 by Professor W. H. Holmes. An account of the spring and its contents will be found on page 254. The teeth of this species include upper and lower ones of both milk and permanent series. Some of these are finely preserved. They are usually 
stained black and show the presence of but little animal matter. Some of them are so well mineralized that they ring on being struck. One of these teeth was figured by Holmes (1903, pl. Ix, lower figure) and by Lucas (Maryland Geol. Surv., Pleistocene vol., pl. xxxviII). Others have been illustrated by the present writer (Indiana Geol. Surv., vol. xxvi; Iowa Geol. Surv., vol. XXIII). Judged by the condition of fossilization of these teeth, they are to be referred to the Sheridan or Aftonian stage.

Avery, Lincoln County (2).--On December 9, 1912, U. S. National Museum received from E. S. Rice, connected with the Atchison and Santa Fe Railway, an upper molar found near Avery; it has 11 ridge-plates; some are missing from the front end. The present writer has received a letter from F. M. Rice, who states that the elephant tooth was dug up in the northwest quarter of section 11, township 16 north, range 5 east, on the right-of-way of the railway mentioned above, at a depth of 8 or 9 feet; it was buried in what is described as soft, sandy clay. The ditch being made was 8 to 10 feet wide, and bones were seen and left undisturbed on both sides of it. A femur dug up is described as being 5 feet or more in length.

Hennessey, Kingfisher County (3).-In 1894 (Proc. Acad. Nat. Sci. Phila., p. 68), Cope reported that he had visited Hennessey and had found some elephant remains in the possession of a rancher by the name of Painter, who lived 8 miles west of the town. There were 4 molar teeth, and these Cope referred to an adult Elephas primigenius, of the coarse-plated variety; they evidently belonged to $E$. columbi, unless, indeed, they were teeth of $E$. imperator. Cope did not say that he secured these teeth; but he probably did and they may now be at the Academy in Philadelphia. With these mammothteeth, Mr. Painter found some teeth and bones of a saber-tooth tiger; these were later described by Cope under the name of Dinobastis serus. These bones and teeth, as well as those of the elephant, were stained red by the iron of the Permian clay and were covered by a thin layer of it. This deposit of clay, derived from the Permian, had probably been laid down during the earlier part of the Pleistocene. In the Journal of the Philadelphia Academy (vol. Ix, p. 453), Cope refers to these elephant teeth and says that they were found 50 miles west of Hennessey. This statement of distance is evidently an error. On April 21, 1913, the author received a letter from R. A. Hamilton, Hennessey R. F. D. No. 2, and there was inclosed a photograph of a tooth of Elephas columbi, which had been found somewhere in that region.

Norman, Cleveland County (4).- In the Oklahoma State University is a lower right last molar of Elephas columbi, found in loose sand in Canadian River, just south of Norman; there are 9 plates, occupying a length of 6 inches; the plates are much curved.

\section{NEW MEXICO.}

(Map 7.)

Sacramento Mountains, Otero County (1).--In 1919, O. L. Tinklepaugh, of El Paso, Texas, sent to the U. S. National Museum a large lower left hind. most molar of an elephant, which had been found somewhere in the Sacramento Mountains. On the label "The Rincon" is mentioned, and this may be a creek. The tooth is nearly complete, the anterior roots and plates being 
represented. There are 20 ridge-plates present and apparently 2 or 3 are missing from the rear. 'The length from the base in front to rear is 412 $\mathrm{mm}$; ; width, $102 \mathrm{~mm}$. The plates are strongly bent, so that the hinder faces are very concave. There are 5 plates on a $100 \mathrm{~mm}$. line. It is possible that this tooth belongs to $E$. imperator, but the writer believes that it is an unusually large molar of $E$. columbi.

Capitan, Lincoln County (2).-In the U. S. National Museum are 2 teeth of Elephas columbi, which came from the vicinity of Fort Stanton. One of these has the catalogue No. $23 \% 0$ and was sent in 1903 by Dr. P. M. Carrington, of Fort Stanton. It was found about 5 miles north of Capitan by a Mexican in digging a well. It appears to be a first true molar. About 10 feet of a tusk was found, as well as some bones, but these were kept by the finder. Apparently the locality was in township 8 south, range 13 east. In the Museum is also another tooth of the same species, sent apparently in 1871, by Governor Arny, from the vicinity of Fort Stanton; but he had received it from W. F. Holmes. No details were recorded.

Albuquerque, Bernalillo County (3).-Through Professor R. W. Ellis, of the State University of New Mexico, the writer received notes and photographs of a tooth of $E$. columbi, which belongs to the university collection. The tooth was found about 30 feet below the surface in a gravel terrace, in the Rio Grande Valley, near Albuquerque. The top of the terrace is about 75 feet above the flood plain. The tooth is the upper left hindmost molar and had been worn to the base in front. About 14 plates are represented. There are 7 plates in a $100 \mathrm{~mm}$. line, and these are little curred. The enamel is thick and considerably crimped.

Pena Blanca, Sandoval County (8).-In 1903 (Amer. Geologist, vol. xxxr, p. 89), Reagan reported that teeth and bones of Elephas primigenius (doubtless E. columbi) and other Pleistocene animals had been found in Pleistocene marls at Pena Blanca. This locality is on the Rio Grande, about 40 miles above Albuquerque. It is in township 16 north, range 6 east.

Placita, Sandoval County (4).-In 1877 (Geogr. Surv. West of 100th Merid., vol. IV, p. 25, pl. Lxx), Cope mentioned and figured a molar of Elephas columbi, which he found along Placita Creek, or possibly one of its tributaries. The village of Placita is about 20 miles east of north of Albuquerque. The hills consist of Cretaceous materials; a deposit of indurated clay about 40 feet thick was found in the valleys. In such a bed, Cope found the tooth referred to. It is now in the U. S. National Museum and has the catalogue No. 4180. Other elephant bones were found in place in the banks of the arroyo. Shells of Planorbis and Pliysa were observed. Cope named these deposits the Placita marls. This tooth is evidently the one mentioned by Cope in $18 \% 4$ (Proc. Phila. Acad., p. 221) as having been found at the base of the Sandia Mountains. It is possible that the tooth was found somewhat farther south, in Bernalillo County.

Las Vegas, San Miguel County (5).--In the American Museum of Natural History, New York, there is a fragment of an upper hindmost molar, which the writer refers to E. columbi. The catalogue No. is 15514 ; the tooth was presented by H. P. Frambly in 1911. It consists of the front 10 plates and retains the base of the large anterior double root. There are 7 plates in a $100 \mathrm{~mm}$. line. 
Santa Fe, Santa Fe County (6).--In 1873 (Contrib. Ext. Vert. Fauna Terrs., p. 238), Leidy reported a tooth of E. columbi from near Santa Fe. This tooth is in the U. S. National Museum and has the catalogue No. 286.

Black Rocks, McKinley County (7).-In making excavations at Black Rocks, about 5 miles east of Zuni, in 1908, some fossil bones were found and sent to the U. S. National Museum. Those to whom credit is due for this are F. E. Leupp, Commissioner of Indian Affairs, John B. Harper, Superintendent of Irrigation, and Frank Mead, Supervisor. No details, however, have been secured as to the depth and kind of deposit in which the remains were found. The species represented are Elephas columbi, Equus sp. indet., camel, sp. indet., and the musk-ox, Gidleya zuniensis. Of Elephas columbi, there are in the U. S. National Museum an upper left hindmost molar and a lower right hindmost molar.

\section{MISSOURI.}

(Map 7.)

Near Joplin, Jasper County (1).- The writer received from Byron A. Ash, of Carthage, Missouri, a photograph of a lower molar, probably the second or third, which was found about 9 miles southwest of Carthage. For an account of the situation, reference may be made to page 24 . The tooth is well worn down, with probably some plates gone in front; 11 are yet present. The tooth is Elephas columbi. In the same situation, probably an old cave, were found a tooth of Mammut americanum, a bone of a species of bison, and some remains of a turtle otherwise unidentified. The age of the remains cannot be determined from the species present.

Tackner, Benton County (2).-In the collection of the Academy of Natural Sciences of Philadelphia are various remains of Elephas columbi, labeled as having been found in Benton County. These are probably a part of a collection made about 1843 by S. H. Whipple. This collection is discussed on page 28. Among the specimens at Philadelphia is a part of a lower jaw of a young elephant, with the third and fourth milk-molars.

Rockport, Atchison County (3).--In 1911 (Bull. Geol. Soc. Amer., vol. xxIr, pp. 211, 212), Professor Calvin stated that a molar of Elephas columbi had been found near Rockport, in section 22, township 64 north, range 41 west. In the same pit were a foot-bone of a horse (Equus), a tooth of a species of Hipparion, and a premolar of a species of large camel, probably Camelops. Calvin regarded the deposits as belonging to the Aftonian stage.

Jackson County (4).--In Popular Science (vol. xxxiv, on pages 198, 199), Dr. T. R. Thornton reported that a tooth of a mammoth had been found about 30 miles southeast of Kansas City. A number of bones were found along a gully in an abandoned public road, in yellowish clay. The bones on drying went to pieces. Three teeth were preserved, one of which Doctor Thornton owned. Inasmuch as there appear to have been about 5 plates in a $100 \mathrm{~mm}$. line, the teeth were probably those of Elephas columbi.

\section{KANSAS.}

(Map T.)

Palermo, Doniphan County (1).-In 1912, Albert Kienhoff, living near Wathena, found on his farm a mastodon tooth, some teeth of Equus niobra- 
rensis, and a part of a tooth of Elephas columbi. The exact locality and conclusions about the age of the remains are given on page 268 .

Hammond, Bourbon County (2).-At Kansas City, Missouri, the writer saw, in the collection of Rev. John Bennett, the front half, presenting 7 ridgeplates, of a molar of Elephas columbi, which had been found near the KansasMissouri line, somewhere between Fort Scott and Fulton, probably in the vicinity of Hammond; but no more exact record had been preserved.

Ottawa, Franklin County (9).- In 1904, as the writer learns from Professor A. R. Bell, some elephant remains were found in the bank of Marais des Cygnes River, about 4 miles west of Ottawa. Some of these remains passed from the hands of J. U. Gill, of Ottawa, into those of C. H. Sternberg, and then into the possession of George Langford, of Joilet, Illinois. From the latter the writer has received measurements and photographs of a tooth in the right ramus of the lower jaw, and another, lacking some hinder plates, free from all bone. Both are hindmost molars and well preserved. They are undoubtedly teeth of Elephas columbi.

Rantoul, Franklin County (10).--In 1890 (Trans. Kan. Acad. Sci., vol. XII, p. 74), Professor O. C. Charlton gave an interesting account of finding remains of elephants in Franklin County. It appears that at intervals during many years bones and teeth had been washed out of the bank of Osage (Marais des Cygnes) River, just above Rantoul. The exact locality was given as being in the northeast quarter of the northeast quarter of section 1\%, township 17 south, range 21 east. One of the teeth weighed 9 pounds; the diameter of the glenoid cavity of a shoulder-blade measured 11 inches. At this point the river-bed is formed by shale, on which rests a foot of gravel. Then come 6 feet of a whitish, friable clay and above it 12 feet of brittle clay and the surface soil. The elephant remains appear to have been at the bottom of the whitish clay.

Professor W. B. Wilson, of Ottawa University, Ottawa, Kansas, has sent to the writer a photograph and measurements of a large lower molar, one of those found at Rantoul, and these show that the animal was Elephas columbi. The molar is in fine condition and had just begun to wear.

Burlington, Coffey County (3).- In the collection of the Philadelphia Academy of Sciences is a single ridge-plate of a tooth of Elephas columbi, which is recorded as having been found near Burlington, at a depth of 30 feet. This fragment was mentioned by Leidy in 1870 (Proc. Acad. Nat. Sci. Phila., 1870, p. 69). It had been presented to the Academy by Dr. IV. F. McAllister, of Burlington. With it, and also found in gravel at a depth of 30 feet in digging a well, was a part of the lower jaw of a bison, which Leidy thought might belong to the existing species. It is more probable that the species is an extinct one.

Arkansas City, Cowley County (4).-The writer received from Louis S. Crouse, of Arkansas City, a letter and a small photograph of an upper hindmost molar which appears to belong to Elephas columbi. It was discovered by Mr. Crouse in a gravelly deposit, under 3 feet of water, in Walnut River, about 1.5 miles east of Arkansas City. Evidently the tooth had recently been washed out of a bank of Pleistocene materials. The tooth has attached to it a fragment of the jaw. There are apparently about 16 ridge-plates; some may be worn off in front. 
From T. F. Schmitt, of Arkansas City, the writer received a letter and photograph of a tooth found by him in Arkansas River, near the place named. This was brought up from the bottom of the river where it is 50 feet deep. The length of the tooth is given as 9.75 inches, and there appears to be 12 plates present.

Argonia, Sumner County (11).-From R. S. Hammond, of Argonia, the writer received word, in 1923, of the finding of 2 teeth of an elephant near Argonia. The exact locality is in section 3, township 32 south, range 4 west. The teeth had been washed out of a sandy bank along a creek. The writer has not seen these teeth, but one was reported as weighing 17 pounds 9 ounces, the other 15 pounds 9 ounces. They were certainly hindmost molars, either lower or upper. The information has been sent that one lateral face of a tooth has 6 ridges on a 4 -inch line. They no doubt belonged to Elephas columbi.

McPherson, McPherson County (5).-Professor H. J. Hanley, of McPherson College, showed the writer a tooth of Elephas columbi, found in McPherson in digging a well. The tooth was discovered in sand at a depth of 23 feet. It appears to be a worn second molar with 12 plates left; 7 of these occupy a line $100 \mathrm{~mm}$. long. In the same collection is an atlas of probably $E$. columbi, found in the northwest quarter of section 21, Battle Hill township. This is near the northeastern corner of the county. From a sand-pit and a well about McPherson have been taken remains of camels and a tooth of the mastodon Anancus mirificus (Stegomastodon elegans Hay). The deposits belong to the Sheridan beds.

Hutchinson, Reno County (6).-In Ward's Natural History Establishment, Rochester, New York, the writer saw a fragment consisting of 3 ridge-plates of a molar of Elephas columbi, which was supposed to have been found near Hutchinson.

Pendennis, Lane County (7).-In 1909 (Life of a Fossil IIunter, p. 134), C. H. Sternberg wrote that he had collected, at a place in Kansas, over 200 teeth of the Columbian mammoth. In a letter to the writer, in April 1911, he gave the locality as 7 miles northeast of Pendennis, in the northeastern corner of Lane County ; this was probably an estimate of distance along winding roads. Some of these teeth are in the American Museum of Natural History. Mr. Sternberg wrote that at the place where he collected are tons of broken bones and tusks. Williston (Trans. Kan. Acad. Sci., vol. xv, p. 91) stated that 70 or more of these teeth are preserved at the University of Kansas. The present writer has examined some of these and others which belong to the American Museum of Natural History in New York.

Williston, as cited, says that the materials secured by Sternberg were found in a small area, not more than 2 or 3 rods in diameter. At the same place were found remains of a camel, of a horse regarded by him as Equus excelsus, by the present writer as $E$. niobrarensis, and of a dog, Canis occidentalis, as determined by Wortman. As stated elsewhere (p. 48), some of the elephant teeth are referred by the present writer to Elephas boreus. It seems to have been a meeting-place of the two species of elephants. According to Williston, the deposit was in a basin in a small ravine that had been hollowed out of the Niobrara chalk and considerably below Loup Fork beds in the neighborhood. 
Another tooth from Pendennis is a lower right molar with 13 ridge-plates; a few hinder ones have been lost. There were probably originally about 16 , and the tooth is evidently the next to the last. It is wholly unworn. 'The upper border is very concave and the front stands high, forming a kind of boss. The length along the base is $150 \mathrm{~mm}$.; the greatest length is $177 \mathrm{~mm}$. There are 8 plates in a $100 \mathrm{~mm}$. line. The plates are mostly considerably warped. The enamel on broken plates appears to be thin. The tooth has the catalogue No. 8069 and has been labeled as Elephas columbi. It is difficult to decide whether it belongs to this species or to $E$. boreus.

The locality appears to be some miles from the Smoky Hill River and on the high land. The deposit undoubtedly belonged to that known as the Equus beds.

Sharon Springs, Wallace County (8).- In a collection kept in the City Hall, Portland, Oregon, the writer has seen a lower left hindmost molar of Elephas columbi, which was labeled as having been found at Sharon Springs. No other information was furnished.

\section{COLORADO.}

(Map 7.)

Grass Valley, near Cripple Creek, Teller County (1).-In the collection of the State Normal School, at Greeley, is a magnificent lower left last molar of Elephas columbi. This was found in a washout at Grass Valley, at an elevation of about 8,000 feet. It is worn on only 4 plates; the length is 330 mm.; width, $96 \mathrm{~mm}$. There are 20 plates with front and rear talons, and there are 6 of these plates in a $100 \mathrm{~mm}$. line.

Colorado City, El Paso County (2).-Colorado City is situated between Colorado Springs and Manitou. In the Agricultural College, at Fort Collins, is a right upper molar of Elephas columbi, which was found at Colorado City. It was collected by Alva E. Brown, who dug it out of the bank of a creek near the railroad roundhouse, at a depth of about 8 feet. Other teeth and parts of some bones are said to have been associated with the tooth.

Elbert, Elbert County (3).-In Folio 198 of the U. S. Geological Survey, page 9 , Dr. G. B. Richardson reported that 3 vertebræ of an elephant, specifically unidentified, had been found in the bank of Running Creek, 4 miles southwest of Elbert. These vertebræ were identified by J. W. Gidley:

Callian, El Paso County (11).-In one of the collections at the Agricultural College, at Fort Collins, are 2 elephant teeth which were found near Calhan and which are referred to Elephas columbi. These are the lower second molars, right and left. They were taken from a creek bank by J. G. Ross, 4 miles west of Calhan, just below the surface and buried in clay. Besides the teeth, there were some bones and a tusk. The former were evidently not collected and the tusk soon went to pieces. The teeth are worn to the base in front and some plates are missing; 13 plates and the hinder talon are counted; the fourth plate from the rear is $160 \mathrm{~mm}$. high; six plates are found in a $100 \mathrm{~mm}$. line. The length of the tooth, as preserved, from the front to the rear of the base, is $250 \mathrm{~mm}$. The angle included between a plate and the grinding-surface in front of it is somewhat greater than 45 degrees. The enamel plates cross the grinding-surface in a sigmoid curve. There are confluent roots in front and a large root behind. 
Monument, El Paso County (12).--In 1914 the writer saw in the high school, at Castle Rock, Colorado, an upper hindmost elephant molar and a humerus, which he identified as Elephas columbi. These were labeled as found on land of L. H. Overstreet, on Jackson Creek, Douglas County. The tooth was $350 \mathrm{~mm}$. long and had 20 plates. The humerus, lacking a little in the middle, was over $1,050 \mathrm{~mm}$. long. The distance through the head and trochanter was $460 \mathrm{~mm}$; width of lower end, $300 \mathrm{~mm}$. On the Castle Rock folio (198 U. S. Geol. Surv.) the writer does not find a Jackson Creek in Douglas County, but a creek of this name is found in the northern part of El Paso County. If the locality is on this creek, it is in township 11 south, 67 west, and probably in section 25 or 26 .

Parker, Douglas County (4).--In Folio 198 of the U. S. Geological Survey, on page 9, G. B. Richardson stated that a tooth of this species had been found in the southwest quarter of section 34, township 7 south, range 66 west, half a mile west of Cherry Creek. The present writer has not, so far as he knows, seen this tooth. It was identified by J. W. Gidley. The place of burial would be within the area occupied by alluvium, as laid down on Richardson's map.

The collection in the State Historical and Natural History Society, at Denver, contains remains of 3 or 4 animals of this species, which have no other record than that they were exhumed in Douglas County: $(a)$ part of the left ramus, showing the beak and a fine tooth, probably the first molar; (b) another left ramus, much resembling the preceding; (c) 10 plates of an uncut second molar, which probably belonged to $(c) ;(d) 2$ fragments of tusk; $(e)$ parts of the pelvis; $(f)$ part of an upper right molar, 11 plates; $(g)$ part of a right lower molar, probably the hindmost. All these are said to have been sent in together to the collection. The molar referred to under (a) is in a fine state of wear and preservation. Wear had not yet reached the base in front, but had reached the rear plate. The anterior root is present, separated from those behind it by a distinct interval, and is directed downward and backward. The length is rather more than $100 \mathrm{~mm}$. The other more or less coalesced roots are developed. The length of the tooth is 200 $\mathrm{mm}$.; width, $70 \mathrm{~mm}$; 倡ht of the hinder plate, $130 \mathrm{~mm}$. There are 7.5 plates in a $100 \mathrm{~mm}$. line.

In Folio 198 of the U. S. Geological Survey, on page 9, Dr. G. B. Richardson stated that a tooth of Elephas columbi, as identified by J. W. Gidley, had been found in outwash deposits, at the base of the mountains, a few miles south of the Castle Rock quadrangle. This was probably somewhere not far from Palmer or Husted.

Denver, Denver County (5).--In the collection of the State Historical and Natural History Society, at Denver, are 2 lower teeth, a right and a left, which the writer refers to Elephas columbi. These were found, April 12, 1912, in gravel-pit No. 2 of the Denver Pressed Brick Company, at West 16th and Clay streets. Bones and teeth were in a gravel-bed from 5 to 10 feet deep. Over this gravel were 20 feet of clay. About 40 pieces of bones or teeth were met with after a fall of the gravel. One of the teeth is represented by 9 plates, the other by 16 . There are 7 plates in a $100 \mathrm{~mm}$. line. With these teeth were 2 other lower molars, a right and left, which have thicker plates, there being only 6 of them in a $100 \mathrm{~mm}$. line. The better preserved of the 
two has 13 plates represented. How many are missing from the front can not be determined.

In City Park Museum there is a proboscidean lower right molar, found in gravel in constructing the Alameda Street subway in Denver. The length from front to rear, at the base, is $245 \mathrm{~mm}$; the width $93 \mathrm{~mm}$. It is worn to the base in front. There are 8 plates in a $100 \mathrm{~mm}$. line. It is possible that this tooth belongs to Elephas boreus, but the plates are somewhat thicker than usual in that species and the enamel is also rather thick.

Golden, Jefferson County (6).- - In the School of Mines, at Golden, are parts of 2 elephant teeth found about 2 miles north of Golden. No details are recorded regarding the geological conditions. One tooth is a part of a very large last upper molar. Only 9 plates remain. In the collection were the head of a femur and a distal end of probably another. These were found within the limits of Golden. They are supposed to belong to $E$. columbi.

Greeley, Weld County (7).--In the collection of the State Normal School, at Greeley, is a fine upper left second molar of Elephas columbi. It is worn on only 6 front plates; the rear is complete. There are present 16 plates and front and rear talons. The tooth was found in gravel within the limits of Greeley.

Big Thompson Creek, Weld County or Laramie County (8).--In the collection at Fort Collins are 9 plates of a lower molar of $E$. columbi, which is labeled as having been found, in March 1899, by P. H. Boothroyd, in a sand drift at the mouth of a small canyon opening into Big Thompson Creek.

Fort Collins, Larimer County (9). - In the collection of the General Museum of the Agricultural College, at Fort Collins, are some fragments which appear to be the rear of two upper molars of Elephas columbi, found a mile due east of the college. These teeth were buried in gravel at a depth of 15 feet.

Hayden, Routt County (10). - In the collection at the University of Colorado, at Boulder, is a fragment of an elephant tooth collected on Bear Creek, 6 miles east of Hayden; only 6 plates remain. The length of the piece is only 6 inches and there were originally 7 plates in a $100 \mathrm{~mm}$. line. The tooth is that of Elephas columbi. It was collected by A. Dakan, of Longmont, who writes that the tooth was in the cut, 5 feet deep, at the roadside and only 18 inches below the surface.

IOWA.

(Maps 7, 9.)

\section{Within the Area of the Kansan Drift.}

Keokuk, Lee County (1).-At the Colorado Agricultural College, at Fort Collins, Colorado, the writer saw a lower left last molar which is labeled as found at Keokuk, Iowa, and as purchased of Ward and Howell. It is well worn down, but 20 ridge-plates are present, of which 8 are in a $100 \mathrm{~mm}$. line. No conclusion can be arrived at about the geological age of the tooth.

Trenton, Henry County (2).-From Professor H. E. Jaques, of Iowa Wesleyan College, Mount Pleasant, Iowa, the writer received photographs of 2 teeth of Elephas columbi, found about a mile southwest of Trenton, along a little stream. The exact locality is given as in section 10 , township 72 north, range 7 west. One of the teeth is an upper one, apparently of the right side, the other is a lower right tooth. Both are hindmost molars, with apparently 
24 ridge-plates each. They are not worn to the base in front; the lower one is worn nearly to the rear, but the upper one, due to its different shape, is not worn halfway to the rear. They were certainly teeth of one individual. These teeth were described and figured by Professor Jaques in 1922 (Proc. Iowa Acad. Sci., vol. xxviII, pp. 66-68, figs. 5b-5d.)

Grinnell, Poweshiek County (3).-The collection at Grinnell College has an elephant tooth, apparently a lower second molar, which appears to belong to Elephas columbi. The front portion had disappeared before the death of the animal. The width is $86 \mathrm{~mm}$. There are 8 plates in a $100 \mathrm{~mm}$. line and the enamel is thick.

In 1890 (Science, ser. 1, vol. xvI, p. 263), Erwin H. Barbour reported the discovery of remains of an elephant near Grinnell. A good molar, some limb. bones, ribs, a scapula, and a small tusk were found at a depth of 20 feet, in digging a large well for the Iowa Central Railroad. All the bones were badly broken in getting them out. The writer suspects that the tooth referred to above is the one described by Barbour. This writer thought that bones were in, and had been transported by, the drift; but in that case the bones would probably have been widely scattered.

From Dr. G. F. Kay, director of the Iowa Geological Survey, who has had the opportunity to study the geology at Grinnell, the writer learns that there the loess has a thickness of about 18 feet. It seems, therefore, that the skeleton in question was at or very near the junction between the Kansan drift and the loess. Kay states that the lower 6 feet of the loess is gray and calcareous. It seems possible, therefore, that the elephant lived during the Yarmouth interglacial stage. However, there are Aftonian deposits along Iowa River not far from Tama. Savage (Iowa Geol. Surv., vol. XIII, p. 231, fig. 28) gave a geological section in section 19 of Toledo township, about 5 miles west of Tama. This section is mentioned by Calvin (Bull. Geol. Soc. Amer., vol. xx, p. 136, fig. 2). Above the level of the railroad is a thin soil band between the Kansan and the Nebraskan. For the present, however, the age of the tooth must be regarded as doubtful.

Clinton, Clinton County (4).--In the collection of the Davenport Academy of Science is a lower molar, apparently the second, which is labeled as found at Clinton and presented by T. J. Frazier (Iowa Geol. Surv., vol. xxiII, p. 130). The tooth is referred to Elephas columbi.

An examination of J. A. Udden's description of the Pleistocene geology of this county (Iowa Geol. Surv., vol. xv, pp. 415-423, map) shows that Kansan drift underlies the region. North of Clinton this is concealed by loess, which may reach a thickness of 25 or more feet. Not far away and west of the town the Kansan is covered by the Iowan drift. It is possible that Illinoian drift enters the county. The thick deposit of loess may represent Sangamon and Peorian interglacial stages. Where the geology is so complex, changing from mile to mile horizontally and possibly from foot to foot vertically, there is need that every fossil be accompanied by exact information. In this case all that is known is that the tooth was found somewhere about Clinton.

Red Oak, Montgomery County (5).--In the collection of the Iowa His. torical Department, at Des Moines, is a much-worn lower right second molar, found at Red Oak and referred to Elephas columbi. William Boll and Sons, 
of Red Oak, informed the writer that the tooth was brought up, in 1912, by persons pumping sand from the bottom of Nishnabotna River. The exact locality is given as lot 3 of the south half of the southwest quarter of the northeast quarter of section 29 , township 71 , range 38 west.

It is probably useless to speculate on the geological age of a tooth which has been found as was this one. The drift of the region belongs to the Kansan; but this is undoubtedly underlain by Nebraskan; and between them may be Aftonian interglacial deposits, which might furnish fossils. Over the Kansan drift is a great thickness of loess, and the tooth might easily have found its way from this into the sands of the river. Probably the best idea of the Pleistocene geology of the region about lied Oak may be found in J. A. Udden's description of the geology of Pottawattamie County (Iowa Geol. Surv., vol. xi, pp. 248-256, map).

Henton, Mills County (6).- In the collection of the Iowa State University is an upper molar, probably the second but possibly the first, which was obtained from the high school at Council Bluffs and was supposed to have been collected near that place. Professor B. Shimek, however, informed the writer that it was found near Henton, in Mills County. This the writer stated in his paper on Iowan Pleistocene Mammals (Iowa Geol. Surv., rol. XXIII, p. 83) ; but the correction was not made on page 444 , where it is credited to Council Bluffs. It is believed to belong to the Aftonian interglacial, but its history is perhaps not well enough authenticated to justify certainty.

No. 300 of the State collection at Iowa City is an elephant tooth which Calvin regarded as the fourth of the series (doubtless meaning the first molar) of Elephas imperator (Bull. Geol. Soc. Amer., vol. xxIr, p. 212). The writer has expressed his opinion (Iowa Geol. Surv., vol. xxIII, p. 41) that it belonged to $E$. columbi. The first molars of $E$. imperator are not well known. They had probably about 10 ridge-plates. That is the number present in the Henton speciden; but undoubtedly some plates are missing in front. The tooth is worn to the base in front and the large anterior root is missing, showing the loss of probably 3 plates. Possibly the tooth is that of $E$. imperator. This tooth was regarded by Calvin as having been derived from the Aftonian interglacial deposits at Henton. In the same locality and apparently from the same deposits have been collected remains of camel and of Equus complicatus and $E$. laurentius.

Missouri Valley, Harrison County (7).-In the author's paper on the Pleistocene mammals of Iowa, page 435, is described a lower jaw, without teeth, which was referred to Elephas imperator by Calvin (Bull. Geol. Soc. Amer., vol. xx, p. 351, pl. xxv, fig. 2). Inasmuch as there appeared, from the ridges on the walls of the sockets, to have been 6 ridge-plates in a line $100 \mathrm{~mm}$. long, the writer concluded that the jaw had belonged to $E$. columbi. A description of the geological situation at Missouri Talley is given on page 296 ; also a list of the species discovered there in the Aftonian.

Logan, Harrison County (8).-On page 436 and plate LxIII of the author's paper just referred to, a fine upper second molar of Elephas columbi is reported, which was found in the Peckenbaugh sand-pit at Logan. At Logan 
the Aftonian sands and gravels rest on limestone and have a thickness of 9 feet. Overlying the Aftonian is Loveland clay 6 feet thick; and this supports about 20 feet of loess. Besides the elephant here recorded the Aftonian has furnished a supposed undetermined horse. The locality has been noticed by Calvin, Shimek and Hay (Calvin, Bull. Geol. Soc. Amer., vol. xx, p. 355 ; Shimek, vol. cit., p. 405 ; pl. xxxv, fig. 2 ; vol. xxI, p. 137, Iowa Geol. Surv., vol. xx, pp. 335, 336 ; Hay, vol. xxIII, p. 54).

Mount Pisgah, Harrison County (9).- In the State University of Iowa is a part of a large tooth collected in the Kress pit and referred (Iowa Geol. Surv., vol. xxIII, p. 5\%) to Elephas columbi. It was collected by Professor B. Shimek and is believed to be the second upper true molar. The deposits are regarded as belonging to the Aftonian.

Turin, Monona County (10).-In 1911 (Bull. Geol. Soc. Amer., vol. xx, p. 212), Calvin mentioned some characteristic teeth of Elephas columbi, found at Turin. These were located in the Elliott sand-pit and are referred to on page $29 \%$, where also a list of the vertebrate species found there has been presented and references to Shimek's descriptions of the pit and its fossils. The beds are undoubtedly of Aftonian interglacial age.

Cherokee, Cherokee County (11).--The collection of the Iowa State University contains an elephant tooth, No. 325, found in 1909 in the Turner sand-pit, about 3 miles north of Cherokee, at a depth of 16 feet. The deposit is known as the Cherokee sands; the same tooth is mentioned by Carman (Iowa Geol. Surv., vol. xxvi, p. 409). Turner's pit in this report is designated as that of the Cherokee Sand and Gravel Company. The tooth is regarded as the lower second true molar of Elephas columbi. The length is $305 \mathrm{~mm}$.; width, $90 \mathrm{~mm}$. There are 6 or 7 plates in a $100 \mathrm{~mm}$. line, and the enamel is thick (Iowa Geol. Surv., vol. xxIII, pp. 76, 429).

Hartley, O'Brien County (1\%).-Professor A. O. Thomas, in 1923 reported to the writer an elephant tooth, which had been found about 4 miles east of Hartley, in a sand-pit, in the valley of Ocheyedan River. The tooth was identified as the left upper second molar of Elephas columbi. There are counted 15 plates and 9 of them in a $100 \mathrm{~mm}$. line. The region is covered by Kansan drift, but the age of the particular deposit is not known.

\section{Within Area of Illinoian Drift.}

Burlington, Des Moines County (12).-In the collection of the Iowa Wesleyan College is an elephant tooth which was presented by Charles Buetner, of Burlington, who informed the writer that the tooth was found in Flint Creek, about 2 miles from Burlington (Iowa Geol. Surv., vol. xxıII, p. 432). It is not possible at present to arrive at any conclusion about the geological age of this tooth, except that it belongs to the Pleistocene. The geology of the county was described in 1895 by Charles R. Keyes (Iowa Geol. Surv., vol. III). On his page 454 is presented a section of Pleistocene deposits at the mouth of Flint Creek. It shows 49 feet, mostly of drift. A mile north of this the deposits amounted to 60 feet, of which from 6 to 8 feet belonged to the loess. The age of the drift deposits was not determined. There are probably to be found there both Illinoian and Kansan deposits, with probably some interglacial. 


\section{Within the Area of the Iowan Drift.}

Big Rock, Scott County (13).-In the collection of the Davenport Academy of Science is a tooth of an elephant, which the author has referred (Iowa Geol. Surv., vol. xxin, p. 447) to $E$. columbi. The exact place of disinterment is not known. Big Rock is situated near Wapsipinicon River, in the northwestern corner of the county. The country about is covered by loess, which may reach a thickness of 20 feet or more; but beneath this is Kansan drift. 'Toward the east the Iowan drift is not far away, and within 10 miles toward the south is found the border of the Illinoian drift. This indicates with what exactitude records of all fossils should be kept.

Marble Rock, Floyd County (14).-The collection of the State University of Iowa contains some imperfectly preserved molars, Nos. 17 and 299, which the writer (Iowa Geol. Surv, vol. xxIII, pp. 60,434) has with some doubt referred to $E$. columbi. The enamel is thicker than that of $E$. boreus. Teeth of the last-named species have been found here in a gravel-pit sunk in a train of outwash from the Wisconsin ice lobe. It is probable that the borders of the habitats of the two species might have overlapped in the wake of the retreating glacier.

Tama, Tama County (15).- In the U. S. National Museum is a lower right second molar received from Fred Herschel, of Tama, which was found sticking in the bank of Iowa River, about half a mile south of the town. This tooth has been further described by the writer (Iowa Geol. Surv., vol. xxiII, p. 447). It is referred to Elephas columbi.

On consulting Savage's description of the Pleistocene deposits of this county (Iowa Geol. Surv., vol. xIII, pp. 230-247, map) it will be seen that Kansan drift is found on both sides of the river at Tama, while the Iowan overlies this a little farther away. Both are covered with a mantle of loess.

\section{Within the Area of the Wisconsin Drift.}

Des Moines, Polk County (16).--In the Iowa Historical Department, at Des Moines, is an elephant tooth, No. 4526, which is referred to Elephas columbi (Iowa Geol. Surv., vol. xxIII, p. 443). It is labeled as found in the vicinity of Des Moines and as presented by L. Hamilton in 1883 . It is to be regretted that the record is so meager. While it may very well be that the particular elephant lived there in post-Wisconsin times, there exists the possibility that the tooth was derived from the loess overlying the Kansan drift.

\section{NEBRASKA.}

(Map 7.)

Pawnee City, Pawnee County (1).-In the collection at the University of Nebraska is a fragment of a lower molar of Elephas columbi, found near Pawnee City. It consists of 2 ridge-plates only. It is recorded as having been found in glacial drift, on the farm of Herbert Brown, 4.5 miles south of Pawnee City and 40 rods east of the bridge over Chattawa Creek. Mr. Brown informed the writer that his farm consists of the west 100 acres of section 14, township 1 north, range 11 east. This is within the area covered by Kansan glacial drift. It is not stated at what depth the tooth was met with. It is not probable that it was originally buried in the drift, but most 
probable that it was either found below the Kansan drift or had been gathered up by the drift from underlying Aftonian deposits; or it may have been met with in the loess.

In G. F. Kunz's Ivory and the Elephant (p. 396, with a figure) the author tells of a very large pair of tusks of $E$. columbi that were found near Campbell, Franklin County, 121/2 feet long on curve, 21/2 feet circumference at base.

Fairbury, Jefferson County (2). - In the collection at the University of Nebraska is a lower right second true molar which is recorded as found 3 miles west of Fairbury. It has the catalogue designation 19-12-04. There are plates missing in front and behind; 10 are present. The length of the fragment is $175 \mathrm{~mm}$. There is no information regarding the conditions under which the tooth was found. Another tooth, found somewhere about Fairbury, has the catalogue No. 22-3-94. It has a part of the jaw attached and it appears to be a second lower molar. It is accredited to Dr. M. L. Eaton. With it and supposed to belong to the same individual is an upper tooth of Elephas columbi. No information is furnished regarding the depth at which the tooth was found and the kind of matrix inclosing it.

Jefferson County.-In the collection at the University of Nebraska is a well-weathered second molar in a part of the lower jaw, and labeled as Elephas columbi; it appears to be this species. The length of the tooth is $195 \mathrm{~mm}$.; width, $75 \mathrm{~mm}$. Some of the front plates are damaged, but there were originally probably 16 , of which 7 are found in a $100 \mathrm{~mm}$. line. With this tooth is an upper second molar supposed to have belonged to the same individual, but its width is much greater, being $98 \mathrm{~mm}$., and the enamel is thicker. These teeth are recorded as found in Jefferson County, but there is no more exact information. According to Barbour's geological map of Nebraska (Neb. Geol. Surv., vol. I, pl. x), the whole of Jefferson County is within the area of the Kansan drift. The elephant teeth found there might have been buried in Aftonian interglacial deposits. Remains of Elephas imperator have been discovered near Fairbury, and camel remains at Reynolds. The remains of $E$. columbi might, however, occur in the loess overlying the drift or in alluvial deposits along the stream.

Wilber, Saline County (3).- In the Nebraska University collection is a large upper right hindmost molar found 4 miles southeast of Wilber, probably somewhere near Big Blue River. Only the anterior 10 plates are present. There are 8 plates in a $100 \mathrm{~mm}$. line. No information is furnished regarding its manner of burial. Wilber is within the area of the Kansan drift.

Lincoln, Lancaster County (4).- - In the State University Museum is a much-weathered tooth of Elephas columbi, which was found in a clay-pit near Lincoln. Its catalogue number is 1-10-08.

Martel, Lancaster County (5).--In the State University Museum are 3 fragments of a lower molar, probably the hindmost, which was found on Charles Krull's place 1.75 miles east of Martel. The catalogue number is 6-1-4-03. Eight of the rear plates are present. Nothing is known about the conditions under which it was found. The whole county is within the area of the Kansan drift. This is probably underlain by Aftonian and is overlain by loess.

Seward, Seward County (6).- In the State University Museum are fragments of a molar of Elephas columbi, found near Seward. These have the 
number 27-8-12 and are credited to J. E. Wallace. The town of Seward is within the area of the Kansan drift. 'This and the part of the county west of it are covered with loess.

Grafton, Fillmore County ( 7 ).--In the State University Museum, with the catalogue designation 11-1-11, is a lower molar, believed to be the penultimate, which is said to have been found at Grafton. There are 11.5 plates present. 'The great anterior root is missing; hence a number of plates, probably about 5, are missing. These plates are unusually thick, there being 5.5 in a $100 \mathrm{~mm}$. line. There is a possibility that the tooth belonged to $E$. imperator, but it is thought not.

Oxbow Creek, Nuckolls County (8).- - In the State University Museum is a fragment of a molar of Elephas columbi, which is recorded as obtained at a depth of 20 feet below the bed of Oxbow Creek. Where this creek is in Nuckolls County, the writer does not know.

Brickton, Adams County (9).--In the State University Museum is a wellfossilized tooth of Elephas columbi, recorded as found in a sand-pit, 2 miles north of Brickton, owned by E. A. English. This is about 4 miles south of Hastings. The tooth was presented to the museum by A. M. Brooking, of Inland, Nebraska, and is designated by the numbers 11-3-13. There are present 8 ridge-plates; but the tooth is worn down to its base in front and some plates and the large front root are gone. It is probably the lower first true molar. The width of the grinding-surface is $83 \mathrm{~mm}$. The record states that with it were found the front of the skull and the palate with teeth. Mr. Brooking informs the writer that the skull lay in sand, below gravel, at a depth of 10 feet. The region is enveloped by loess; but as the specimen lay in sand below gravel it is probable that it was in Sheridan deposits.

From a sand-pit situated near the town of Pauline was obtained a lower hindmost molar of Elephas columbi. It was found at a depth of 7 or 8 feet. This tooth has been described and figured by Dr. Erwin H. Barbour (Neb. Geol. Surv., vol. I, p. 64, pl. II, fig. 3). About 6 of the rear plates are missing. This tooth was lent to the State University Museum by Dr. Franklin Schaufelberger, of Hastings, Nebraska. Pauline is situated on Little Blue River. Doctor Schaufelberger informed the writer that the sand-pit is located in the northeast quarter of section 5, township 5 north, range 9 west. Elephant teeth are frequently found in the sand-pits of the vicinity. It appears probable that these elephant remains belong to the Sheridan.

Ravenna, Buffalo County (10). - In the State Museum (No. 24-9-0\%) is a moderately worn lower left hindmost molar which is recorded as receired from Ravenna in 1907; there is no other information.

Furnas County (11).-The State University Museum has 3 ridge-plates of probably a lower molar of Elephas columbi, which was presented by Mrs. Jennie Ball and is recorded as having been picked up in a canyon in Furnas County. The writer has been unable to gain any additional information.

Medicine Creek, Frontier County (16). - In the collection at Yale University is a fine lower jaw of an elephant, which is recorded as coming from Medicine Creek, Nebraska, but no more accurate information is given. The catalogue No. is 11719. The specimen is labeled as Elephas primigenius, but the writer is inclined to believe that it is $E$. columbi. There are 2 teeth on each side of the jaw and $\% .5$ or 8 plates in a $100 \mathrm{~mm}$. line. The geological 
age of the animal can not be determined with certainty except that it belonged to the Pleistocene.

Broken Bow, Custer County (12). -The State University Museum has a remarkably fine pair of hindmost molars of Elephas columbi, obtained from some place about Broken Bow by Hon. Charles H. Morrill. These specimens have the Nos. 22-11-94. The symphysis of the lower jaw is present. The length of the right molar is $340 \mathrm{~mm}$.; width, $100 \mathrm{~mm}$. There are 22 plates, but probably 2 are missing from the rear.

An injured tooth of $E$. columbi is in the State University Museum from a locality 10 miles west of Broken Bow. It is designated in the catalogue by 6-1-4-03 and was presented by R. W. Buckner. The tooth belonged to the lower jaw and is either the last milk-molar or the first molar. It is entirely unworn.

Benkelman, Dundy County (13).--In the C. H. Morrill collection in the State University Museum is a ramus of the lower jaw, with the last milkmolar and the first molar, which was found near Benkelman. It was brought to the museum by Dr. A. Meese. The milk-molar is much worn; the molar only on 5 or 6 plates. The molar has a length of $155 \mathrm{~mm}$.; width, $50 \mathrm{~mm}$. There are 8 plates in $100 \mathrm{~mm}$. The enamel is thick and considerably crimped.

Sidney, Cheyenne County (14).-The State University Museum, at Lincoln, has a fragment of a tooth of Elephas columbi, reported by E. A. Carey, of Sidney, to have been dug up from a well at a depth of 56 feet, at a point some miles north of Sidney.

Peters, Sheridan County (15).-The fossil-producing locality near the former site of Grayson has hitherto been referred to Hay Springs, but this town was about 15 miles in a direct line west of north from the fossil quarry, while the post-office of Peters is 3 or 4 miles distant. The quarry is on the south side of Niobrara River and appears to be in township 29 north, range 45 west. In a paper published in 1915 (Proc. U. S. Nat. Mus., vol. XuviII, p. 568) it is erroneously given as township 47 west. A list of the numerous vertebrates discovered here will be found on page 305 . The sands and gravels from which the fossils were unearthed have been made by W. B. Scott (Introduc. to Geol., ed. 1909, p. 782) the type of his Sheridan beds.

In the American Museum of Natural History, New York, are some elephant remains which in 1897 were collected in the region south of Hay Springs by Albert Thomson. There are 2 upper right last molars, some vertebræ, an immense atlas, and some portions of tusks. It is not certain that any two parts belong to the same individual. The better tooth is worn only back to the ninth or tenth plate. A few plates are missing from the rear; 17 or 18 are present. The length of the tooth is now $285 \mathrm{~mm}$. along the bases of the plates. The width of the grinding-surface is $90 \mathrm{~mm}$. There are 6 plates in a $100 \mathrm{~mm}$. line. It is possible that these teeth belong to $E$. imperator; but the plates appear to be too thin for this species.

\section{WYOMING.}

(Map 7.)

Caryhurst, Converse County (1).-The U. S. National Museum contains 2 molar teeth and 2 vertebræ of an elephant, which were sent, in 1914, by JIenry Metz, acting for the Copper Bottom Manufacturing and Milling Com- 
pany. 'These remains had been found sticking out from a bank near a washout in a gulch near Caryhurst. Other bones, as those of the limbs and some ribs, were reported but not secured. 'The 2 molars had, after exhumation, been exposed to the weather and had become shattered. The writer regards them as belonging to Elephas columbi. The 2 vertebræ are of different colors and may have belonged to another elephant. 'These remains have the catalogue No. 8080. Mr. Metz has written that the remains were found in the northwest quarter of section 13, township 33 north, range 73 west, on Alkali Gulch, about half a mile from its entrance into Platte River.

Some time before 1911, C. H. Sternberg found in Converse County a tooth of an elephant, which he afterwards sold to George Langford, of Joilet, Illinois, who sent the writer a drawing, from which it is evident that the species represented is $E$. columbi. The tooth was yet in a part of the right side of the lower jaw. Some of the hinder plates seem to be missing; 16 or 17 remain. No information regarding the geological conditions connected with the tooth have been secured nor the exact place of discovery.

Buffalo, Johnson County (2).--In the collection of the State Historical and Natural History Society, in the Capitol, at Denver, Colorado, is a lower left hindmost molar of Elephas columbi, found about 1896 or $189 \%$, at Buffalo, Wyoming. There are present 16 plates, but a few may be missing from the front. The tooth is but little worn. The length at present is $320 \mathrm{~mm}$. No details regarding the conditions under which the tooth was discovered are recorded.

\section{SOUTH DAKOTA.}

(Map 7.)

Sioux Falls, Minnehaha County (1).-On May 1, 1912, the writer received from M. J. Moyer, Sioux Falls, a photograph of an elephant tooth which is identified as that of Elephas columbi. It was much worn and showed 13 enamel plates. The length was said to be close to 8 inches. A little later Mr. Moyer wrote that the tooth had been dug up by a construction company in making a street through a hill and that it had been found in the dump in a mixture of sand and gravel. The depth could not be determined. The place was on the side of a hill, about 3 blocks away from the river.

Yankton, Yankton County (2).- In the U. S. National Museum (No. 303) is a fragment of a tooth consisting of 2 enamel plates, which is identified as bclonging to Elephas columbi. It was collected many years ago and is credited to George H. Propper. No details have been preserved.

Along Cheyenne River, southeast of Black IIills (3).-From Dr. C. C. O'Harra, president of South Dakota School of Mines, the writer has received a photograph of a tooth which is recognized as a molar of Elephas columbi. The locality is indefinite, but Mr. O'Harra regards it as pretty certain that the tooth was found in the vicinity of Cheyenne River, southeast of the Black Hills. The length of the tooth is close to $140 \mathrm{~mm}$.; there are 6 plates in a $100 \mathrm{~mm}$. line.

Pierre, Hughes County (4).-In 1909 Doane Robinson, of the department of history of South Dakota, sent to the U. S. National Museum a photograph of an elephant tooth which he had found at Pierre. In this are counted 13 or 14 plates, but it is probable that the front end of the tooth is missing. There 
are 7 plates in a $100 \mathrm{~mm}$. line. It is regarded as belonging to Elephas columbi. No number for this specimen appears on the map.

MONTANA.

(Map 7.)

Axtell, Dawson County (1).-The writer has seen a large lower left hindmost molar of Elephas columbi, owned by Jay Lunde, of Vida, McCone County. It was found along Red Water Creek, somewhere below Axtell, 15 or 20 miles above the entrance of this creek into Missouri River. There were 6 enamel plates in a $100 \mathrm{~mm}$. line; the plates were considerably bent. It was a typical tooth of Elephas columbi.

Glendive, Dawson C'ounty (2).-The U. S. National Museum (No. 6052) has a part of the distal end of a humerus and 2 fragments of a lower jaw, found at Glendive. The jaw fragments contain the right and left hindmost milk-molars. They were sent, in 1908, by C. H. Paul, acting engineer of the Lower Yellowstone project conducted by the U. S. Reclamation Service. The remains were discovered during the excavation of a canal, but the exact locality and other details were not communicated. The teeth are much worn.

Kimball Post-office, or Hocketts, Custer County (3).-The writer received from T. E. Smith, of Miles City, photographs of an elephant tooth which he reports was found on a sand-bar along Powder River, near one or both of the places mentioned above. The more exact locality is given as township 4 north, range 53 east. The tooth is evidently a lower hindmost molar, worn about to the base in front. At least 20 plates appear to remain. The tooth is referred to Elephas columbi. Its extreme length is 15 inches. On the side, at half the height, are 5 ridge-plates in a $100 \mathrm{~mm}$. line; at the base of are crown are only 4 of these in that distance. It is not improbable that this tooth belongs to $E$. imperator.

Ashland, Rosebud County (4).-First from Thomas E. Smith the writer received notice and photographs of elephant teeth in the possession of $\mathrm{D}$. W. Hogan, of Ashland. On request, Mr. Hogan sent larger photographs of the teeth. There are 5 teeth, all apparently belonging to Elephas columbi; one is an upper hindmost molar, worn at nearly right angles with the base of the tooth. The number of plates can not be determined from the photograph. The height of the crown is nearly 6 inches. A lower hindmost molar is worn to the base in front, with probably some plates missing, and a few plates are gone at the rear; 18 are present. There are 6 plates in a $100 \mathrm{~mm}$. line. It is possible that these 2 teeth belonged in the same skull. All of the teeth are reported as having been picked up by Indians along Tongue River, probably in township 2 south, range 44 east, below Ashland.

Rosebud, Rosebud County (5).-In 1882 (10th Ann. Rep. Geol. Surv. Minn., p. 146), N. H. Winchell recorded the presentation to the State Museum of Minnesota of 2 elephant teeth from the place indicated. His description shows that they belonged to Elephas columbi. In each tooth there were about 6 enamel plates in a $100 \mathrm{~mm}$. line. No details were recorded.

Havre, Hill County (6).- - Some years ago the writer saw a tooth of Elephas columbi which had been forwarded from Havre to the U. S. National Museum for identification. It appeared to be the lower last milk-molar. Only 
7 of the front enamel plates were present in the fragment. The seventh is $111 \mathrm{~mm}$. high and $67 \mathrm{~mm}$. wide. The tooth was said to have been found at a depth of 20 feet, associated with fragments of bones.

Diamond Cily, Broadwater County (7).--In St. Louis University, St. Louis, Missouri, the writer has seen an imperfect and much-worn tooth of this species, found at Diamond City. It appeared to be a last milk-tooth or the first permanent molar. No details had been recorded. In the same museum is a tooth of Mammut americanum from the same region. Both teeth were probably presented by Rev. J. G. Venneman.

Virginia City, Madison County (8).-In the Fifth Annual Report of the United States Geological Survey, on page 43, Dr. F. V. Hayden reported the finding of some elephant teeth and bones at a point near Virginia City. They were met with at a depth of 25 feet. Three teeth were sent to the U. S. National Museum, where they have the catalogue Nos. 195, 290, and 42\%. No. 195 is a nearly complete tooth, worn on only a few of the front enamel plates. It is $320 \mathrm{~mm}$. long. The other teeth are much worn. They belong to Elephas columbi.

Helena, Lewis and Clark County (9).-George Langford, of Joilet, Illinois, has informed the writer that he has 3 teeth of one individual elephant, found in the early seventies near Helena. His uncle, connected with the Washburn expedition, was present when the teeth were taken from what was then supposed to be drift. Mr. Langford believed the teeth to belong to Elephas columbi.

\section{ALBERTA.}

Edmonston (1).-In 1898 (Bull. Geol. Soc. Amer., vol. Ix, p. 372), Sir Robert Bell reported that a mammoth-tooth which appeared to belong to Elephas columbi had been found in superficial deposits in one of the banks of North Saskatchewan River, about 6 miles above Edmonston, but no particulars regarding the discovery were available. The surrounding country has a deep covering of till. This tooth was apparently first mentioned by G. M. Dawson (Ann. Rep. Geol. Surv. Canada, for 1898, p. 19 A), who referred it to Elephas primigenius or E. americanus, and stated that it was found in the Saskatchewan gravels. L. M. Lamb mentions the same tooth and refers it to $E$. primigenius. The number (1) does not appear on map \%.

\section{SASKATCHEWAN.}

\section{(Map 7.)}

Moose Jaw (1).-In 1920 a letter was received at the U. S. National Museum from C. Clay, of Moose Jaw, in which he reported the finding of 2 large elephant teeth. The locality is near Moose Jaw and the teeth were buried only a foot below the surface. Sketches sent by Mr. Clay show that the teeth are upper hindmost molars of large size. The length from the base in front to the rear is about $365 \mathrm{~mm}$. The crown is worn back on about 16 plates, but not to the base in front. The width is $95 \mathrm{~mm}$. The height of the crown at the rear of the worn surface is $210 \mathrm{~mm}$. There are 7.5 plates in a $100 \mathrm{~mm}$. line; the enamel appears to be thick. The teeth are believed to belong to Elephas columbi. Efforts to learn particulars about the locality were unsuccessful. 


\title{
FINDS OF ELEPHAS IMPERATOR IN THE MIDDLE REGION OF NORTH AMERICA.
}

\author{
TEXAS. \\ (Maps 10, 11.)
}

Tule Canyon, Swisher County (1).--In 1903 (Bull. Amer. Mus. Nat. Hist., vol. XIx, p. 618), J. W. Gidley reported that he had found, at the head of Tule Canyon, some remains of Elephas imperator. His map (op. cit. pl. LVIII) shows that the locality is near the eastern border of Swisher County. The portions found consist of a complete fore-limb, part of a fore-foot, the lower jaw and upper teeth, and some vertebræ and ribs. These are now in the American Museum of Natural History at New York. The locality, its geology, and the species found are desccribed on pages 232, 239. The left last upper molar presents 18 ridge-plates and front and rear talons. The length of this tooth is close to $340 \mathrm{~mm}$; width, $93 \mathrm{~mm}$. The lower right last molar is in the jaw. Sixteen plates are counted, but there seem to be two others. The part of the tooth seen measures $300 \mathrm{~mm}$. in length and $105 \mathrm{~mm}$. in width. On the outer face of the tooth are 4 plates in $100 \mathrm{~mm}$. The fore-leg has a length of 11 feet 5 inches; that of the elephant Jumbo had a length of 10 feet.

Fort Worth, Tarrant County (2).--In the Carnegie Public Library at Fort Worth is a considerable part of a skull and some other parts of the skeleton of Elephas imperator, found in 1910 near Fort Worth. Mrs. Jennie S. Scheuber informed the writer that the remains were discovered in the gravel-pit of H. B. Church \& Co., about 1.5 miles southwest of the city at a depth of 12 feet. This pit is doubtless along the southern branch of West Fork of Trinity River, about 3 miles west of the city. The tusks, which are now in several pieces and badly crumbled, are said to have had a length of 12.5 feet and 10.5 feet, respectively. The circumference at the base is given as 36 inches. The skull is broken into fragments of various sizes. The lower jaw was not found. The upper teeth were worn down so that only about 6 or 8 plates remained of each and these were worn nearly to the roots. The animal was evidently very aged. An account of this discovery was published in the Galveston (Texas) News of September 16, 1910. Each tusk was said to be about 9 feet long.

Dallas, Dallas County (3).--In Princeton University is a great upper last molar which is labeled as found at Dallas, but the exact locality is not given ; catalogue No. 8183 ; 17 plates are present, but one or two are missing from the rear. The length in a straight line from the anterior talon to the base of the sixteenth plate is $375 \mathrm{~mm}$.; the greatest width $106 \mathrm{~mm}$.; height of sixth plate is $250 \mathrm{~mm}$.; of the sixteenth, $150 \mathrm{~mm}$. The worn portion of the grinding-surface, extending over 8 plates, makes a nearly right angle with the unworn portion. There are 5 plates in a $100 \mathrm{~mm}$. line.

The collection of the Southern Methodist University at Dallas has a lower jaw of $E$. imperator, which presents both rami. The hindmost molar shows 14 plates, the remainder, probably 4, being yet concealed beneath the bone. There are four and a half plates in a $100 \mathrm{~mm}$. line. This lower jaw is said to have been found in a gravel-pit along Trinity River, about 4.5 miles east 
of Dallas. For this information the writer is indebted to Mrs. M. L. La Mareaux, who was instrumental in securing the specimen.

In the Central High School at Dallas are 4 plates of a lower third molar of the same species; they occupy only $100 \mathrm{~mm}$.; width of the plates $120 \mathrm{~mm}$. 'This fragment was doubtless found somewhere along 'Trinity River.

In the Memorial Museum at San Francisco, California, is a large tooth of this species, labeled as having come from Dallas.

In 1889 (Amer. Naturalist, vol. xxiII, p. 208, pl. xiv, text-fig. 9), Professor Cope wrote that he had in his collection an entire skull of an elephant, found at Dallas; he identified it as that of Elephas primigenius columbi. It had been discovered in what he called the "orange sand." This was probably somewhere along Trinity River. The specimen is now in the American Museum of Natural History, New York, where the writer has examined it. The skull is evidently that of a rather young animal. The upper molars have a length of only $180 \mathrm{~mm}$. and a width of $85 \mathrm{~mm}$. Only 8 or 9 plates are present; there are therefore only 5 or fewer plates in a $100 \mathrm{~mm}$. line. The animal appears to the writer to belong to Elephas imperator. The teeth shown are probably the first true molars. The tusks are those of a young animal, having a diameter at the base of only $110 \mathrm{~mm}$. A description of the skull, with illustrations, was published by the present writer in 1922 (Observations on some extinct elephants, pp. 15, 17, diagrams 3,4).

Professor R. S. Lull (Amer. Jour. Sci., ser. 5, vol. II, p. 176) has reported that a mounted specimen of Elephas imperator is in Yale University; but there is some doubt about the identification. A figure of this specimen was published in 1918 by Professor Shuler (Univ. Texas Bull. No. 1818, pl. XII). The tusks are very long and are spirally curved. In this skull the part in front of the nostrils is restored.

Waxahatchie, Ellis County (11).-From Professor E. IV. Shuler the writer received photographs of a lower jaw of an elephant, discovered in the bed of a stream near Waxahatchie. The photographs show that a part of the left horizontal ramus and nearly the whole of the right horizontal ramus and the symphysis are preserved. In the right ramus is seen the hindmost molar. Apparently the front of the tooth is present and the anterior root. The tooth is worn seemingly on about 8 plates. The plates are thick and it seems evident that the jaw is that of Elephas imperator.

Paluxy, IIood County (4).- In the American Museum of Natural History, New York, is an upper left last molar of $E$. imperator, from near Paluxy. It

- is recorded as found on Paluxy Creek, about 6 miles from Granbury. The Granbury sheet of the United States Geological survey shows that the point on this creek nearest to Granbury is about 14 miles distant. Of this tooth there are 13 plates present, probably about 5 being gone from the rear. The eleventh plate is $250 \mathrm{~mm}$. high. There are 5 plates in a $100 \mathrm{~mm}$. line. The enamel is thick and much crimped. The plates are more or less warped, but the hinder ones are about parallel with the anterior ones.

Blocker, IIarrison County (5).-In the collection of Tulane University, at New Orleans, is a part of a skeleton belonging to Elephas imperator, found near Blocker. These remains were collected, about 1888, by Dr. T. W. Vaughan. 'The locality is on a nameless creek, approximately a mile east of 
the former Blocker post-office and within about a mile of the State line between Texas and Louisiana. Doctor Vaughan informed the writer that the bones were buried at a depth of 3 or 4 feet in a stiff alluvium, in the "second bottom" of the creek. The parts secured are teeth, some fragments of the skull, a humerus, a femur, and some vertebræ. A lower left last molar has 11 plates present, a few being gone from the front end. There are only 4 plates in a $100 \mathrm{~mm}$. line. The length of the tooth, as preserved, is $300 \mathrm{~mm}$.; width only $85 \mathrm{~mm}$. The plane of wear is very oblique to the plane of the plates; consequently the surface shows a series of steps, the outcrops of the enamel. Of the right molar there are preserved only 7 ridge-plates.

Marlin, Falls County (6).-The collection of the Agricultural and Mechanical College, at College Station, contains a large part of a skull of an elephant, found near Marlin in 190\%. It was discovered in a gravel-pit and presented to the college by A. B. Curry, of Marlin. Dr. Mark Francis visited the place and saw the skull in the gravel as it was being taken up. This skull was, on June 12, 1922 (Observations on some extinct elephants, p. 6, pls. III, IV; p. 18, diag. \%, 8), made the type of the species Elephas francisi Hay. There are only fragments of the tusks preserved; two of these are each about 28 inches long; the one belonging near the base is about 9 inches in diameter. The lower jaw was not found. The skull is a large one; distance from crown to front of upper molars 36 inches; width of vertex at least 28 inches; but here the outer plate of the bone is gone, thus exposing the great air-sinuses of this part of the skull. In the midline behind is a great excavation, about 10 inches deep, for the ligamentum nuchæ. By this the vertex is divided into two great lobes. The sheaths of the tusks are about 20 inches long. As far as can be determined, the profile of the face was nearly straight, not concave, as it is in $E$. mammonteus ( $E$. primigenius) and in E. boreus. Two immense molars are present. They appear to have been squeezed nearer each other than in life, the distance between them being only about $55 \mathrm{~mm}$. Length of molar $338 \mathrm{~mm}$., width $105 \mathrm{~mm}$. There are about five and one-half plates in a $100 \mathrm{~mm}$. line; apparently 20 plates in the hindmost molars. $E$. francisi is described here for convenience.

Chilton, Falls County (28).-The Francis collection contains a lower left second molar, said to have come from Chilton, in Falls County, west of the Brazos and opposite Marlin. Probably the tooth was really found in Brazos River. For convenience, it may be noted here. There are 8 plates present, much curved and concave on the hinder fact. A little more than 4 plates are spanned by a $100 \mathrm{~mm}$. line. It is believed this tooth belongs to $E$. imperator.

Temple, Bell County (30).--From Doctor Francis the writer has received, for examination, an upper left molar of an elephant, found at Temple. It is worn to the base in front and a considerable number of plates are missing. There remain 11 and a talon. The length of the specimen as preserved is $130 \mathrm{~mm}$., width of grinding-surface $102 \mathrm{~mm}$. The height of the crown at rear is $140 \mathrm{~mm}$. The grinding-surface is slightly convex from front to rear and quite oblique to the sagittal plane. The slope of the surface is therefore inward and downward. The lower half of the rear of the crown is concave and there is a distinct surface worn by a tooth behind. The one here described is evidently a second molar. Its sides are thickly covered with cement. 
On the rear of the grinding-surface an enamel plate and a cement plate together measure close to $25 \mathrm{~mm}$. It may be taken that there are 5 plates in a $100 \mathrm{~mm}$. line. The enamel is thick and much folded. It appears safe to refer this tooth to Elephas imperator.

Waco, McLennan County ( 7 ).--In the collection of Baylor University are 2 much-worn lower molars of Elephas imperator, which had been found about 5 miles north of the city, in the White Rock sand-and-gravel pit, located in the third terrace of Brazos River. The locality is described on page 60. One of the teeth appears to be the left second molar; it is worn to the base in front and some plates are thereby missing; 7 are present and 4 of these occupy a $100 \mathrm{~mm}$. line. The width of the grinding-surface is $82 \mathrm{~mm}$. The enamel is thick. T'wo upper milk-molars described on page 60 and referred to $E$. columbi belong probably to $E$. imperator.

In the same collection are some fragments of lower molars of this species, found in the Potts-Moore gravel-pits, located on the second terrace, 2 miles from the city.

Dr. Lula Pace, of Baylor University, sent the writer small photographs of a fragment of a tooth which appears to belong to Elephas imperator. It is the rear of a lower apparently hindmost molar. It is said to have 5 plates in a 4-inch line. It was found on the second terrace, on Chestnut Street, north of Paul Quin College.

San Angelo, Tom Green County (8).-Through Dr. Mark Francis the writer learned that F. Schmidt, of San Angelo, had a tooth of an elephant. Mr. Schmidt stated that a 5 -inch line crosses 5 of the ridges of the lateral face of the tooth. The tooth certainly belongs to Elephas imperator. Details regarding the locality and deposit are lacking.

Georgetown, Williamson County (9).-From Professor R. W. Tinsley, of Southwestern University, Georgetown, Texas, the writer received a letter regarding a tooth of an elephant, found near Georgetown. Photographs show distinctly that the tooth is the lower right last molar of Elephas imperator. There appear to be 15 or 16 plates present. It is possible that some plates are missing in front, but the photograph seems to show the presence of the large anterior root. The length of the tooth along the base in a straight line is a foot (304 mm.); height near rear $175 \mathrm{~mm}$.; width of grinding-face 81 $\mathrm{mm}$.; 5 plates in a $100 \mathrm{~mm}$. line. The hinder plates lean strongly forward. The tooth was found in an excavation for a bridge-pier, on the south bank of South Fork of San Gabriel River, where it is crossed by the "Old Lampasas road," just north of Georgetown.

Bandera County (10).-The collection of the San Antonio Scientific Society has a lower molar of Elephas imperator, from an unknown locality in Bandera County. There are 16 plates present and 5 plates in a $100 \mathrm{~mm}$. line. A part of the anterior root seems to be present. The plates are much warped in ascending. The enamel is thick.

Northeast of Elmendorf, Bexar County (27).-From Dr. C. L. Baker the writer learns that a large but badly decomposed tooth of an elephant, which he regarded as Elephas imperator, had been found about 1.33 miles above the highest bridge-crossing on the main eastern tributary of Parita Creek. The grinding-surface was more than a foot long. It was met with in calcareous clays referred by Doctor Baker to the Port Hudson. 
Onalaska, Polk County (17).-From F. M. Burks the writer has received a photograph of elephant bones found in a gravel-pit near Onalaska. Among the bones is a left side of a lower jaw, with part of the ascending ramus and a nearly complete hindmost molar of Elephas imperator. In the same gravelpit were found teeth which belong to Elephas columbi; also various skeletal bones. Two femora appear to be nearly 5 feet long. Whether these bones belong to Elephas columbi or to E. imperator can not now be determined. The gravel-pit is in a terrace about 35 feet above the river and about 1.5 miles away from it. The flood plain extends from the base of the terrace to the river.

Bryan, Brazos County (12).-The collection of Dr. Mark Francis contains the anterior half of a lower left molar, probably the hindmost, found somewhere near Bryan. It was discovered in digging a well, at a depth of from 25 to 30 feet. Ten plates are present. It is worn to the root in front, but the base of the anterior root is present and also the notch between this and the succeeding roots. The hindmost plate present is $150 \mathrm{~mm}$. high and $100 \mathrm{~mm}$. wide. There are hardly more than 4 plates in a $100 \mathrm{~mm}$. line.

Pittbridge, Brazos County (13).-The Francis collection also contains a very large tooth found at Pittbridge, about 1910, and which the writer refers to Elephas imperator. There are present 18 ridge-plates, but whether or not any are missing in front is uncertain. There are 5 of these plates in a 100 $\mathrm{mm}$. line. The plates are not greatly warped in proceeding from the base to the apex, nor do the hinder ones lean considerably forward. The length along the base, in a straight line, is $375 \mathrm{~mm}$., width $105 \mathrm{~mm}$. The enamel on the grinding surface is thick and crimped. The height of the tenth plate is $205 \mathrm{~mm}$.

Doctor Francis has a pair of large upper last molars from Pittbridge, the one of the right side being best preserved. These were found about half a mile below the bridge. Probably a few plates are missing from the front on account of wear. From the base in front to the rear, in a straight line, is $370 \mathrm{~mm}$. The width of the grinding-face is $120 \mathrm{~mm}$. The plates are very coarse, only 4 or 5 in a $100 \mathrm{~mm}$. line. The plane of wear on these upper teeth slopes from within outward and upward.

In the Francis collection, and from Pittbridge, is a lower last molar which belonged to a very old animal, there being left only 8 ridge-plates and a hinder talon. There are only three and one-half plates in a $100 \mathrm{~mm}$. line. The enamel is thick and crimped. Doctor Francis has another pair of upper last molars found at Pittbridge. The one of the right side is in a part of the maxilla. It does not appear that any ridge-plates are missing in front. There are 2 roots in front; the bone has no scar for more anterior roots. There are 17 plates present, somewhat thinner than usual, there being nearly 6 in a $100 \mathrm{~mm}$. line. Width of tooth $100 \mathrm{~mm}$. The eleventh plate is 190 $\mathrm{mm}$. high. A tooth of this description might belong to Elephas francisi.

Doctor Francis has sent the writer a photograph of a part of the left side of the lower jaw of an elephant, found in 1921 at Pittbridge by J. J. Massini. Nearly the whole of the inner face of the tooth is exposed. There are present 15 or 16 plates. Some are gone from the front, but how many the writer can not say. The tooth is worn back to about the sixth plate from the rear. There appear to be 5 plates in a $100 \mathrm{~mm}$. line. They are strongly bent for- 
ward at the middle of their height. The tooth appears to belong to Elephas imperator.

Doctor Francis has also the front part of a lower right second molar, found in Brazos River somewhere not far from Pittbridge. Five plates and a talon of 2 plates are present. 'There are hardly 5 plates in a $100 \mathrm{~mm}$. line. The plates are concave on their hinder faces. 'The height of the fragment is 155 mm. No roots had yet been developed.

East of Lyons, Burleson County (14).--From Dr. Mark Francis the writer has received, for examination, a dorsal vertebra, apparently the nineteenth, of an elephant, found in Brazos River, opposite Lyons, by Bruno Fahnert, of that town. This vertebra is certainly that of an elephant, and because of its size the writer refers it to $\mathrm{E}$. imperator. The following measurements in millimeters have been secured:

Height of centrum in front, at midline . . . . . . . . . . . . . . . . . . . . . . 140

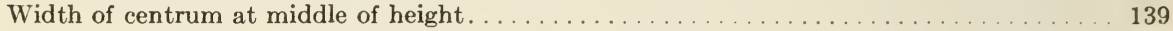

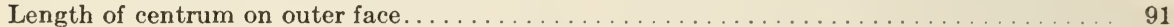

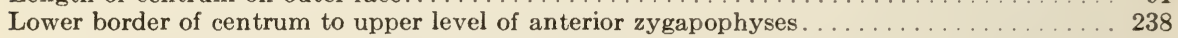

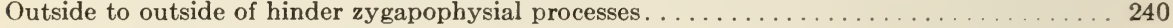

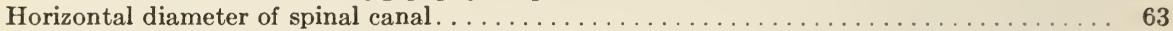

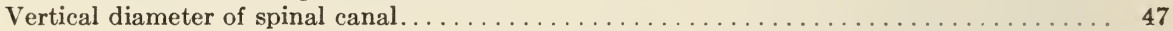

Cameron, Milam County (15).--In the collection of the University of Texas is a lower left hindmost molar found in a gravel-pit, on Little River, near Cameron. It is credited to R. F. Poole and is said to have been found in the Cameron cut of the Santa Fé Railway. There are preserved 14 ridgeplates. As the anterior large root is missing, it is judged that some plates are gone from the front. The length of the part present is $280 \mathrm{~mm}$; width $85 \mathrm{~mm}$. The narrowness suggests a more anterior tooth, but there is nothing in the form of the rear of the tooth and no attrition area to suggest that there was another one behind it. The tooth is worn back to the sixth plate present, and this has a height of $115 \mathrm{~mm}$. There are 6 plates in a $100 \mathrm{~mm}$. line. This tooth possibly belongs to $E$. columbi or $E$. francisi, but more probably to a small individual of $E$. imperator. Robert T. Hill (21st Ann. Rep. U. S. Geol. Surv., pt. 7, p. 356) stated that a tooth of Mammut americanum had been found in sand in a railroad cut at Cameron, at a depth of 10 feet.

Brenham, Washington County (16).-In the collection of Professor Dumble, at Houston, is a fragment of a left lower molar of Elephas imperator, consisting of 9 plates, found near Brenham. It is possible that it is a first or second molar.

Millican, Brazos County (29).--Here may be mentioned, for convenience, a large tibia in the Francis collection, labeled as found in Brazos River, near Millican, Brazos County. The actual place of finding was about 5 miles west of the town. It is credited to H. P. Eaves, 1895. The bone is somewhat water-worn. The length is close to $790 \mathrm{~mm}$; the side-to-side width at the middle of the length, $120 \mathrm{~mm}$; the fore-and-aft width, $118 \mathrm{~mm}$. The bone is referred to Elephas imperator.

Sulphur Creek, Live Oak County (26).-The writer has received photographs and a letter from L. S. Elwell, of Fant City, Cass County, Texas, in regard to a part of a skeleton of Elephas imperator, found on his place, along 
Sulphur Creek, in Live Oak County. The photographs of the teeth indicate plainly the species. Tusks and other parts are preserved but have not been excavated. The property is described as being in the northwest corner of the William Rosenberg survey, abstract No. 415 of Live Oak County; Sulphur Creek runs through the property and the skeleton was found in a gully opening into the west side of the creek, about three-quarters of a mile south of the north line of the property mentioned. The jaws were found near the surface. The tusks had broken from the jaws and were in a horizontal position. It was supposed that the rest of the skeleton was more deeply buried.

Beeville, Bee County (18).- In the American Museum of Natural History at New York are some remains of Elephas imperator, discovered somewhere about Beeville, and consisting of a palate with teeth and both of the tusks. This portion of skull and the tusks were found many years ago and were in possession of Hon. E. D. Linn, by whose widow they were sold to the American Museum of Natural History. It has sometimes been referred to as the Victoria elephant, as in Kunz's Ivory and the Elephant, page 392 ; but it was found near Beeville. It is reported to have been found in an embankment at a depth of 30 feet. On the outside of the curve the tusks are 13 feet long. The portion of an upper molar exposed to view is $295 \mathrm{~mm}$. ; breadth, omitting the cement, $103 \mathrm{~mm}$. 'The palate is $75 \mathrm{~mm}$. wide in front; $125 \mathrm{~mm}$. in rear.

In the Francis collection at College Station is a ramus of Elephas imperator, which was bought from Ben Mattingly, of Beeville. It had been found somewhere in that region. In it are a part of the second true molar and all of the third, except a few of the rear plates. Of the second molar only 4 ridge-plates and the-talon remain. The width of the tooth is $88 \mathrm{~mm}$. The plates run diagonally across the grinding-surface. The third molar presents 15 plates, of which the front ones lean backward, while the hinder plates lean forward, inclosing an angle of more than $90^{\circ}$. About 3 or 4 plates are missing; behind there are 4 plates in a $100 \mathrm{~mm}$. line. Width of tooth $105 \mathrm{~mm}$. It appears to have come into use at a late stage of wear of the second molar.

Doctor Francis obtained from Mr. Mattingly also a palate of $E$. imperator with the left hinder molar. This molar is worn to the base in front; but whether any plates are missing or not is uncertain. There are 14 present, so that probably 4 are gone. The length of the base of the tooth, in a straight line, is $300 \mathrm{~mm}$. The fifth plate from the rear is $205 \mathrm{~mm}$. high; width 100 $\mathrm{mm}$. There are 5 plates in a $100 \mathrm{~mm}$. line. The maxilla presents a part of the sheath of one tusk. From the same place Doctor Francis has a large part of a lower right last molar of Elephas imperator.

Ottine, Gonzales County (20).-The collection of the University of 'Texas has the right side of a lower jaw found in a spring at Ottine and secured by Dr. F. L. Whitney, of the University. The last molar is in its place in the jaw. The anterior roots appear to be present. In front is the first ridgeplate, slightly injured. Probably 2 plates are missing from the rear; 16 are present. The tooth is worn back to the sixteenth. The length of the part present is $340 \mathrm{~mm}$; the width of the grinding-face is only $82 \mathrm{~mm}$. There are 5 plates in a $100 \mathrm{~mm}$. line. The ridge-plates, in crossing the worn surface, are concave in front. The spout of the lower jaw is short. From 
the same place are 2 other rami. In the same spring was found an upper last molar of E. columbi. Ottine is on Marcos River.

San Leon, Galveston County (19).-San Leon is at present a small settlement about 9 miles east of Dickinson, on the west shore of Galveston Bay. Here, in April 1921, were discovered the tusks, teeth, and some bones of what is identified as Elephas imperator. The skull was present, but in such a soft and decayed condition that only parts of it were secured. The tusks were sawn into sections and recovered in pretty good condition. The remains were owned by Mr. Roye and a partner in Houston, but are now the property of Dr. Mark Francis. The writer examined these remains and found that they include teeth of two specimens that are to be referred to Elephas imperator and 1 or 2 teeth of Elephas columbi; also a few bones of a species of horse. The tusks seem to belong to $E$. imperator; they were nearly 12 feet long. They diverged strongly at their bases and curved upward and outward. These remains were found at about the level of the bay. Before the waves had eroded the coast back a few feet, they were buried under about 12 feet of sand and gravel. About three-fourths of a mile farther south was later found a skull of an undetermined elephant, which had been buried under very similar conditions (p. 105). Published photographs of these tusks showed that they diverged rapidly at the base and curved upward and outward.

Gallinas Creek, Atascosa County (21).- In the Industrial Exhibit, in the Auditorium, at Houston, the writer has seen three fragments of molar teeth of Elephas imperator, recorded as having been obtained somewhere along Gallinas Creek, in Atascosa County. There is a town Gallinas in the northwestern part of the county and probably Gallinas Creek is thereabouts.

Buckeye, Matagorda County (22).-From Dr. Mark Francis the writer received for examination a right ramus of the lower jaw of Elephas imperator, which, together with the left ramus and some parts of tusks, had been found near Buckeye. They were encountered in making excavations, but the writer has not been able to learn at what depth or in what kind of deposits. Of this tooth, 13 plates remain, but probably about 5 are missing from the front. Of these ridge-plates, there are only 4 in a $100 \mathrm{~mm}$. line. The distance from the summit of the most anterior plate present to that of the hindmost is $240 \mathrm{~mm}$. The distance across the hindmost 6 plates, at the middle of this height, is $135 \mathrm{~mm}$. The height of the jaw at the middle of the tooth is $170 \mathrm{~mm}$; thickness, $185 \mathrm{~mm}$. If this tooth had belonged to Flephas columbi it would be necessary to suppose that about 10 plates are missing and that the length of the complete tooth was about $550 \mathrm{~mm}$., nearly 2 feet.

Buckeye is on the western bank of Colorado River and about 20 miles from the northern shore of Matagorda Bay. It lies within the area of the Beaumont formation and about 30 miles south of its northern boundary. It is therefore quite certain that the remains were buried in the Beaumont clays.

San Felipe, Austin County (23).-A description of this locality and a list of the species found there are on page 246. In 1861 (The Geologist, vol. IV, p. 469), Charles Blake announced the discovery of an elephant tooth found at San Felipe, and to this he gave the name Elephas texianus. In the same journal (vol. v, 1862, pp. 5\%, 58, pl. Iv) he described the tooth further and gave an excellent figure. It was supposed by Falconer (Palæont. Memoirs, 
vol. II, p. 216), and apparently by Blake himself, that this tooth belonged to the same species that Falconer had previously named $E$. columbi. The propriety of the name $E$. texianus was further defended by Blake in the next year (The Geologist, vol. vi, p. 56). The tooth is in the British Museum and is known as the Bollaert tooth, from the man who presented it. After an examination of the descriptions and the figure the present writer is of the opinion that the tooth in question belongs to $E$. imperator. This name, proposed by Leidy, antedates Blake's $E$. texianus by about 3 years.

In the Francis collection is part of a lower left molar, consisting of 12 plates, which was found by Dr. C. H. Farrington, at Wallis, in the southern part of Austin County. The enamel is thick and much folded. On the inner face are 5 plates in a $100 \mathrm{~mm}$. line; on the outer face only 4 . The tooth is $100 \mathrm{~mm}$. wide. It is referred to $E$. imperator.

San Bernard River, Austin County (31).-From Doctor Francis the writer received in 1924 a photograph of an elephant molar which was found in San Bernard River, between Wallis and Chesterville, being possibly in Wharton County. It is now in the Francis collection. It appears to be an upper molar, possibly the second, $144 \mathrm{~mm}$. long and $90 \mathrm{~mm}$. wide. Four of the plates occupy a $90 \mathrm{~mm}$. line on the grinding surface. The writer regards it as belonging to Elephas imperator. The locality is within the Lissie formation.

McDowell, Austin County (24).-This town is west of Brazos River, just below San Felipe. The specimen described may have been found at San Felipe. It appears to have been collected in 1910 by J. A. Brownlee, of Brookshire. It is now in the Francis collection. An account of it, with a reproduction of a photograph, was published by the Houston (Texas) Post, October 16, 1910. In this account the locality was given as San Felipe. The specimen consists of the greater part of the horizontal ramus of the lower jaw and both hindmost molars. Both teeth have lost the anterior root and the 2 or 3 plates which it supported; but there is in the bone a part of the socket for this root and even the tip of the root. There are preserved 17 plates and the rear talon; hardly 5 ridge-plates are in a $100 \mathrm{~mm}$. line. The plates are very concave on their hinder faces. The base of the tooth, measured in a straight line, is at least $380 \mathrm{~mm}$. long; width $92 \mathrm{~mm}$.; height of fifth plate from rear is $160 \mathrm{~mm}$. The enamel is of moderate thickness and complication. The chin projects much beyond the teeth and is thin from side to side. The lingual groove, measured at extremity of spout, is only $11 \mathrm{~mm}$. wide.

In the Francis collection is a tooth found at Brookshire, which may be the lower last milk-molar or the first molar. It is worn down to the base in front. There is a root in front, but it is somewhat uncertain whether it is the first one. A few plates may be missing; 10 plates and a rear talon are present or represented. Length along base $190 \mathrm{~mm}$; width $75 \mathrm{~mm}$.; height of hinder plates $110 \mathrm{~mm}$. There are in a $100 \mathrm{~mm}$. line 5 plates on the convex side; 6 on the concave side.

Robstown, Nueces County (25). - This place is situated about 15 miles west of Corpus Christi, on the Mexican National Railway. In the collection at Baylor University is a lower right last molar of Elephas imperator, which is labeled as found here. A little is missing from the front, but a part of the anterior root is present. There are 15 plates remaining and the hinder 
talon. The plates are worn back to the sixth from the rear. The length of the tooth is $370 \mathrm{~mm}$.; width $97 \mathrm{~mm}$. There are hardly 5 plates in a 100 $\mathrm{mm}$. line. The hinder faces of the plates are strongly concave.

\section{OKLAHOMA.}

(Map 10.)

Afton, Ottawa C'ounty (1).- In the U. S. National Museum are 3 fine teeth of this species, collected in 1901, near Afton, by Professor W. H. Holmes. A description of the spring excavated and a list of the species of mammals found in it, 19 in number, are given on page 254. One of these teeth, an upper last molar, was figured by Holmes (1903, pl. Ix, upper figure), and a lower last molar was illustrated by two views on his plate virr. The same 2 teeth were described by the present writer in 1914 (Iowa Geol. Surv., vol. xxiII, p. 422, pls. Lxvi, LXviI). Apparently only one other tooth of this species was found by Holmes, these teeth being therefore much rarer than those of $E$. columbi.

In the Dyar Museum, housed in the Public Library at Kansas City, Missouri, is a lower jaw which appears to belong to this species. There is a well-worn molar, apparently the second, in each ramus. This specimen was presented by R. H. Harper, of Afton, and was probably found in the spring mentioned.

Kinlock, Marshall County (2).--In the collection of the department of geology in the State University of Oklahoma, at Norman, is an interesting palate, with both hindmost molars, of Elephas imperator. This was secured by Dr. I. Perrine, in 1914, near Kinlock. With the palate are some fragments of tusks, the largest of which has a diameter of $185 \mathrm{~mm}$. The tusks and probably some other parts of the skeleton accompanied the skull, but were broken up by the workmen. The teeth are remarkable because of their abnormal structure. The hinder third or more of each is folded forward closely against the inner face of the anterior portion, and the plates of the folded portion are directed fore-and-aft. The front of the tooth is close to $100 \mathrm{~mm}$. wide. Posteriorly, the width is little greater. As a result of the confined space, the part of the tooth carried forward is very narrow, only about $35 \mathrm{~mm}$. wide, and the middle part of the tooth is also narrowed. Naturally, this folding existed in the pulp of the tooth hefore calcification began. The length of the tooth is $235 \mathrm{~mm}$.; if it had normally developed, the length would have been about 340 . There appear to be present 17 plates, and, as the anterior root is present, the original number was little greater. There are between 4 and 5 of the plates in a $100 \mathrm{~mm}$. line. From James A. Cotner, Ardmore, Oklahoma, the information has been received that the skull was found in the southeast quarter of the southeast quarter of section 4, township 6 south, range 6 east. It was met with in a deposit of gravel, at a depth of 15 feet. Some teeth and a portion of the tusk were carried off by the workmen.

Olieene, Blaine County (3).-In the Pleistocene volume of the Maryland Geological Survey, on page 168, Professor F. A. Lucas reported a femur which was supposed, on account of its great size, to belong to Elephas imperator. The length is given as $1,410 \mathrm{~mm}$. It was said to have been found 
at Keene, but there appears to be no town of this name in Oklahoma. Okeene may have been referred to. What became of the femur is not known.

Kingfisher, Kingfisher County (4).--In May 1924, Mr. John H. Camp, Kingfisher, sent to the U. S. National Museum a lower hindmost molar of an elephant found near Kingfisher. The tooth had crumbled somewhat in drying and the front portion is missing. There are about 5 plates in a $100 \mathrm{~mm}$. line. The enamel is thick. The tooth is referred to Elephas imperator. Details as to the occurrence are wanting. This number is not on map 10.

\section{KANSAS.}

(Map 10.)

Wellington, Sumner County (1).-In the collection of the Philadelphia Academy is a large jaw of an elephant, which the writer found to be without any indication of its origin, but which is quite certainly the one reported by Professor Cope in 1894 (Proc. Acad. Nat. Sci. Phila., 1894, p. 68). He there stated that he had obtained at Wellington the entire mandibular arch of Elephas primigenius, with both molars in place. It had been found in a sand-bed on the western edge of the town. This jaw is again mentioned in connection with Cope's description of his Bison crampianus, which appears to have been found in the same sand-pit. The bison remains and the elephant jaw are alike in their color, manner of fossilization, and their matrix, and are repaired in the same manner. A description of this jaw is given elsewhere (Iowa Geol. Surv., vol. XxIII, p. 424). It no doubt belongs to Elephas imperator; and its presence at Wellington seems to prove that those deposits belonged to the lower Pleistocene, the Sheridan beds. The bison described as $B$. crampianus is regarded as being $B$. alleni.

Robert Hay (Bull. No. 57 U. S. Geol. Surv., pp. 39, 40, fig. 19) briefiy described the geology of this region and presented a section shown at Wellington in a railroad cut. There is an immense development of what Hay called the "earlier gravels." They appear in the section shown to occupy an old river valley and are overlain by loess.

Ness City, Ness County (2).--In his Life of a Fossil Hunter (p. 268, fig. $44)$, C. H. Sternberg gave an account of the discovery of a lower jaw of an elephant, which he identified as Elephas columbi. This is now in the Museum of Natural History in New York and has been shown to be $E$. imperator. This fine jaw was found near Ness City; but no details are known. The deposits are probably equivalent to the Aftonian beds.

Russell, Russell County (3).-In May 1924, W. W. Rubey, of the U. S. Geological Survey, sent to the U. S. National Museum for identification a lower left second molar of Elephas imperator which had been found about 5 miles south of Russell. The exact location is the southeast quarter of section 25, township 14 south, range 14 west, and on the west side of Fossil Creek. The tooth is worn to the base in front and some plates are missing; 9 are present. Measured on the convex side there are 4 plates in a line about 0.85 $\mathrm{mm}$. long. The width of the worn face is $75 \mathrm{~mm}$. The enamel is thick and considerably folded. With this tooth was found a metatarsal bone of a horse. These fossils are believed to belong to the Aftonian stage. It is understood that these fossils are to be placed in the University of Kansas. This number is not on map 10 . 


\section{COLORADO.}

(Map 10.)

Laveta, Huerfano County (1).-The collection of the University of Colorado, at Boulder, contains the palate of an elephant, referred to $E$. imperator. It was discovered at Laveta. Both hindmost molars are present and worn, so that only 10 ridge-plates remain. There are hardly 5 plates in a $100 \mathrm{~mm}$. line. The enamel bands cross the tooth in a sigmoid curve. The width of each tooth is $83 \mathrm{~mm}$. These teeth are rather thin for the third molars of this species, but there are no cavities behind them for succeeding molars. This palate was collected by Professor R. D. George and E. A. Strange, on the J. J. Armington ranch, 4.5 miles northeast of Laveta.

Colorado Springs, El Paso County (2).- In the collection of Colorado College is a good lower left last molar of Elephas imperator, which was probably, but not certainly, found somewhere in the vicinity of Colorado Springs. There are present 14 plates. Because of its great size, the length being $380 \mathrm{~mm}$., it is regarded as being the hindmost molar. Originally it was probably 450 $\mathrm{mm}$. long. About 4 plates are missing from the front. In front there are the bases of a pair of roots, and behind these, on the inner side, is the base of another. These three support only 3 plates. Behind these roots the others are all confluent and directed backward. The width of the grinding-surface is $116 \mathrm{~mm}$. On the outer concave side of the tooth are 4 plates in a little more than $100 \mathrm{~mm}$.; on the inner, or convex, side 4 plates in a little less than $100 \mathrm{~mm}$.

In 1916 (U. S. Geol. Surv. Folio 203, p. 11), George I. Finlay recorded the discovery of a tooth, identified as Elephas columbi, near Colorado Springs. It had been found near the base of the deposit known as "The Mesa," west of the northern part of the town. The tooth is a foot long and 5 inches wide and showed 12 ridges. The plates were therefore an inch thick and the tooth was quite certainly that of $E$. imperator. This appears to be confirmed by the great width. The tooth had not been water-worn. It was regarded as fixing the lowest, or youngest mesa gravel, as belonging to the Pleistocene. Quite as certainly it fixes the age as that of the early Pleistocene.

Denver, Denver County (3).- In the collection of the State Historical and Natural History Society, at Denver, is a part of a much-worn lower right molar. All that part in front of the large hinder root is missing. Nine plates and the hinder talon remain. The length along the base is $275 \mathrm{~mm}$.; the width of grinding-surface $86 \mathrm{~mm}$. This tooth appears to be the second true molar. Exactly where it was discovered is not recorded, but it is supposed to have been somewhere within the city of Denver.

In the same collection is a large upper hindmost molar, referred to Elephas imperator. It is worn to the base in front and evidently some plates are missing; 15 are present. Length of base $320 \mathrm{~mm}$.; height of sixth plate from rear $225 \mathrm{~mm}$.; thickness $115 \mathrm{~mm}$. The edge of the plates is gently sigmoid as they rise from the base. There are 5 plates in a $100 \mathrm{~mm}$. line. The grinding-face makes an angle of about 50 degrees with the plates. The enamel is thick and the worn edges of the plates cross the grinding-surface in about three zigzags. This tooth was found in 1875 during excavation for a building on the northeast corner of 16th and Laramie Streets, Denver. 
It was mentioned in 1896 by Dr. S. F. Emmons (Mon. U. S. Geol. Surv., vol. xxvir, p. 260). He stated that it (with other teeth found near by) was discovered in what he called "river drift." This appears to be overlain by Emmons's "fluvial loess."

Boulder, Boulder County (4).- The collection at the University of Colorado, at Boulder, contains a part of an eleplant's tooth found at Lovers' Hill, somewhere in or about Boulder. The tooth appears to be a lower one; 8 plates are present. The length of the fragment is $150 \mathrm{~mm}$.; width $68 \mathrm{~mm}$. One face is flat, the other convex. On the convex face are 5 plates in a 100 $\mathrm{mm}$. line. On the grinding-face the plates cross somewhat obliquely. This tooth appears to the writer to be a lower second molar.

Fort Collins, Larimer County (5).- In the collection at the Agricultural College, at Fort Collins, the writer examined a large left lower hindmost elephant molar which had been found a mile due east of the college. The front of the tooth is missing; about 12 plates are present. The width is 100 $\mathrm{mm}$. There are hardly 5 plates in a $100 \mathrm{~mm}$. line. The enamel is thick. This tooth appears to belong to Elephas imperator. Together with some fragments of a tooth of $E$. columbi, this tooth was found in gravel at a depth of 15 feet.

South Canyon, near Glenwood Springs, Garfield County (6).--In the collection at the State University, at Boulder, is a fragment consisting of 4 ridge-plates of an elephant tooth, found about 8 miles west of Glenwood Springs and half a mile up South Canyon. This, together with a humerus of a bison, was discovered on the east side of the creek, at a depth of 8 feet, in making a tramway. The height of the plates is $110 \mathrm{~mm}$.; width $75 \mathrm{~mm}$. About 5 such plates occupied a $100 \mathrm{~mm}$. line. The tooth belongs apparently to Elephas imperator and may be the penultimate rather than the hindmost molar.

IOWA.

(Map 10.)

Mount Pisgah, Harrison County (1).- In the Peyton gravel-pit at this place was obtained a fine large upper right last molar of Elephas imperator. This tooth was described and figured by Calvin (Bull. Geol. Soc. Amer., vol. xx, p. 351, pl. xxIv) and by the writer (Iowa Geol. Surv., vol. xxiII, p. 426, pl. Lxvir, fig. 2). Besides the tooth, Calvin noted from the same pit (op. cit., p. 351, pl. xxv, fig. 6) a very large femur which is to be referred to $E$. imperator. The geological situation and the species found there are considered on page 295. The deposit containing the vertebrates belongs to the Aftonian interglacial.

Mapleton, Monona County (2).-At a depth of 35 feet, in Aftonian gravel, reached in digging a well on the farm of C. H. Griffin, was found a part of a tooth of Elephas imperator. Reference to this tooth has been made by Calvin (Bull. Geol. Soc. Amer., vol. xxII, p. 212), Shimek (Bull. Geol. Soc. Amer., vol. xxI, p. 131 ; Iowa Geol. Surv., vol. xx, p. 343), and Hay (Iowa Geol. Surv., vol. XxIII, pp. 55, 442). The well is situated on the east side of section 1\%, township 85 north, range 42 west. The writer has not seen the tooth. Besides this specimen of Elephas imperator, Calvin mentioned two others. One is the tooth mentioned on page $\% 6$ and referred to $E$. columbi; it was found at 
Henton Station, Mills County. The other is an imperfect lower jaw found at Missouri Valley and here referred (p. r6) likewise to E. columbi. It is, however, fair to say that in this case there is room for difference of opinion.

The writer erred (op. cit., p. 59) when he stated that Calvin had reported E. imperator from 'Turin, Monona County.

\section{NEBRASKA.}

(Map 10.)

Johnson County (1).-Dr. Joseph Leidy, in 1869 (Jour. Acad. Nat. Sci. Phila., vol. viI, p. 255), wrote that he had seen in the geological cabinet of the General Land Office, at Washington, a penultimate inferior molar of an elephant, which had been obtained by F. V. Hayden in Johnson County, Nebraska. It was, he said, of the coarse-plated variety and its breadth was about a foot. It seems probable that this meant the antero-posterior extent of the tooth. The triturating surface was 8 inches long and exhibited 9 worn plates. In all there were 13 plates and a posterior talon. It seems to the writer that this tooth, with ridge-plates lacking only a little of being an inch in thickness, belonged to Elephas imperator. Nothing is known as to the depth and deposit in which it was found. The region round about is covered by Kansan drift and it appears probable that this had been penetrated to the Aftonian. From Tecumseh, in this county, there has been reported remains of Mylodon.

Holmesville, Gage County (2).--In the State University Museum, at Lincoln, the writer has seen a fragment of a left lower molar, probably the hindmost one, of Elephas imperator. This was received in 1903 from E. E. Blackburn; the collector was Dr. L. L. Noble, of Holmesville. The fragment consists of 4 rear plates. These occupy a line $100 \mathrm{~mm}$. long and are $100 \mathrm{~mm}$. wide. The anterior of the 4 plates has a height of $158 \mathrm{~mm}$. The specimen has the number 17-7-03. Holmesville is on Big Blue River, at the edge of the Kansan drift sheet, and the occurrence of this species here is to be expected. Doctor Noble has informed the writer that the tooth was found in a stone quarry in the northeast quarter of the northeast quarter of section 29, township 3 north, range 7 east. The quarry is in the Permian formation, which is here overlain by about 6 feet of sandy loam. The latter is probably of Aftonian age. The tooth may have been buried in this loam or have fallen into a crevice in the Permian rock.

Fairbury, Jefferson County (3).- In the C. H. Morrill collection at the State Museum is a part of a tooth of Elephas imperator, found somewhere near Fairbury. It was presented to the collection by Charles Kinnamon and Charles Dawson. The specimen presents 11 plates of the lower last left molar. The triturated surface extends back to the tenth plate. There are 4 plates in a $100 \mathrm{~mm}$. line. The enamel is thick. The tenth plate has a height of $160 \mathrm{~mm}$. No information was given about the mode of occurrence of the tooth. It appears to reveal the presence of Aftonian, or Sheridan, beds at Fairbury, which is within the area covered by Kansan drift. Elephas columbi also has been found near this town, where the gravel-pits of the Rock Island Railway are located (Barbour. Neb. Geol. Surv., vol. I, p. 168). The gravel, from 20 to 40 feet in thickness, is orerlain by loess. It is possible that the tooth was found in these pits. 
Reynolds, Jefferson County (4).-In the State University Museum, at Lincoln, is a part of a tooth, consisting of 3 plates, which was found 4.5 miles east of Reynolds, on land belonging to G. W. Simpkins. The 3 plates occupy a thickness of $65 \mathrm{~mm}$. It seems to the writer that this tooth belonged to Elephas imperator. With these there were reported to have been found a phalange and a vertebra of a camel. This tooth was found in a bank of clay in making a cut for a road. Other bones were found, but they were mostly divided among the workmen. A femur found here has a length of 1,450 $\mathrm{mm}$. and a diameter of $180 \mathrm{~mm}$. at the middle of the length. This also probably belongs to $E$. imperator. The clay will quite certainly be found to belong to the Aftonian, or Sheridan, beds.

Hebron, Thayer County (9).--In 1923, Dr. W. G. Classen, of Hebron, sent a photograph and description of an elephant tooth which had been found in a sand-pit near Hebron. The tooth appears to be the left upper molar of Elephas imperator. Doctor Classen says that there are 12 plates and 12 ridges on the sides of the tooth. It is apparently not the hindmost tooth. It is worn on about 10 plates. Whether any plates are missing in front is uncertain. It is said to measure, on its biting-surface, 9 by 3.5 inches. There appear to be 5 ridges in $100 \mathrm{~mm}$.

Sutton, Clay County (10).- - In the State University Museum, at Lincoln, is a fine lower jaw of an elephant, found near Sutton and referred to $E$. imperator. It belongs to the $\mathrm{C}$. $\mathrm{H}$. Morrill collection and has the catalogue designation 29-1-10. The tooth in this jaw is evidently the last molar. It has only 18 plates, of which the anterior 12 have undergone wear. The length of the tooth on the upper face is $320 \mathrm{~mm}$.; at the base it would be greater. The width of the worn face is $110 \mathrm{~mm}$. There are not quite 5 of the ridge-plates in a $100 \mathrm{~mm}$. line; on the inner face of the tooth are only 4 plates in that length. The enamel is thick and much crimped. The following measurements, in millimeters, were taken of this jaw and the one designated by Barbour as the type of $E$. hayi:

\begin{tabular}{|c|c|c|}
\hline & E. hayi. & E. imperator. \\
\hline 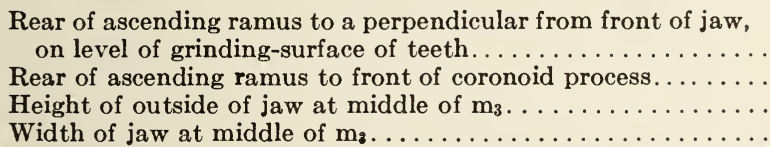 & $\begin{array}{l}725 \pm \\
310 \\
160 \\
160\end{array}$ & $\begin{array}{l}580 \\
280 \\
170 \\
175\end{array}$ \\
\hline
\end{tabular}

No details have been preserved regarding the exact place of discovery of this jaw, kind of deposit, and depth. We can safely assume that it was derived from the Sheridan beds. Somewhere near Sutton was found a lower jaw of Mammut americanum. It was met with in a gravel-pit and may likewise be of Sheridan age.

Wauneta, Chase County (5).--In the State University Museum, at Lincoln, is a lower left molar, apparently the penultimate, which was found, some time before 1898, in the ballast-pit of the Burlington \& Missouri Railroad, at Wauneta. It was presented by T. E. Calvert. The tooth is designated in 
the museum's catalogue as 14-2-98. It is worn down to the bottom of the plates in front, but the base of the anterior root seems to be present. There are represented 13 plates and one or two may be missing from the rear. The extreme length of the tooth is $330 \mathrm{~mm}$. The grinding-surface is worn back to the twelfth plate. The width of this face is $85 \mathrm{~mm}$. The enamel is thick and considerably crimped. Wauneta is on Frenchmans Creek. Doubtless we have here deposits belonging to the Sheridan beds.

Seneca, Thomas County (6).--Somewhere along Middle Loup Fork River, probably in Thomas County, was found, by F. V. Hayden's party, the tooth which forms the type of Elephas imperator. A more exact locality has not been determined. In the region about Seneca, as reported to the writer by Dr. W. D. Matthew, were found, in 1916, remains of Equus, Camelops, Platygonus, Canis, etc. Here, too, Hayden probably found the type of Stegomastodon mirificus.

Cody, Cherry County ( 7 ).- - In the Sioux City Academy of Sciences are two large femora, part of a radius, many foot-bones, and 3 or 4 vertebræ, which the writer refers to Elephas imperator. These bones are reported to have been found in Niobrara Valley. One large vertebra is labeled as having come from near Cody, and probably the other bones were found in the same locality. The following measurements (in millimeters) were taken from one of the femora:

Total length. . . . . . . . . . . . . . . . . . . . . . . . . . . . . . . . . . . . . . . 1468

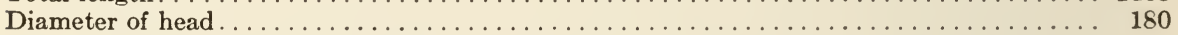

Greatest diameter at middle of length................................ 190

Least diameter at middle of length............................... 118

Distance across distal articular surfaces............................. 275

It will be observed that these femora are close to 5 feet in length.

Grayson, Sheridan County (8).-In the collection of Princeton University are some remains of an elephant, collected in 1893 by $\mathrm{J}$. B. Hatcher, in the quarry which has furnished so many vertebrate fossils. The locality has usually gone under the name Hay Springs (p. 304). The remains consist of a lower jaw containing a last molar, an upper last molar, the radius, fibula, pelvis, several ribs, and foot-bones, said to be nearly all from one individual. Of the jaw, both condyles and much of the right ramus are missing. The beak is somewhat longer than usual. The lingual groove is $76 \mathrm{~mm}$. wide and about $115 \mathrm{~mm}$. deep. At the middle of the tooth the jaw is $200 \mathrm{~mm}$. high and about $165 \mathrm{~mm}$. thick. At the front of the tooth the jaw is 220 $\mathrm{mm}$. high. The ascending ramus at the level of the worn surface of the tooth is $275 \mathrm{~mm}$. wide, and the distance from its front border to the front of the jaw at the lingual groove is also $275 \mathrm{~mm}$. The width of the jaw at the coronoid processes is $490 \mathrm{~mm}$. The lower tooth is cemented in the jaw with plaster. About 12 or 13 plates can be counted and there are apparently 18. There are 5 plates in a $100 \mathrm{~mm}$. line. The width of the grinding-surface is $96 \mathrm{~mm}$. The right upper molar seems to have belonged to the same individual as the lower jaw. There are present 18 plates, including the talon. The length along the base of the tooth is $325 \mathrm{~mm}$.; the width of the grindingsurface, $106 \mathrm{~mm}$. There are 6 plates in a $100 \mathrm{~mm}$. line, being somewhat thinner than usual. At present the post-office nearest the quarry is Peters. 
Here may be noticed the elephant jaw which forms the type of Professor E. H. Barbour's Elephas hayi (Neb. Geol. Surv., vol. 1v, 1915, p. 32\%, pl. I, text-figs. 1, 3, 4). The jaw was discovered in the Hurlbert sand-pit at Crete, Saline County. This place is on Blue River and at the western edge of the Kansan drift. It appears to be pretty certain that the animal lived during the Aftonian stage. It is most closely related to $E$. imperator, but has a much smaller number of cross-crests in the last molar, 10 or 11 instead of 18. It is in this respect like $E$. meridionalis of Europe.

\section{WYOMING.}

\section{(Map 10.)}

Powder River, Johnson? County (1).-In the American Museum of Natural History, New York, is a well-worn tooth of an elephant, probably the lower second true molar, which is labeled as having been found on Powder River. It forms a part of the Cope collection. The locality is indefinite, but it was probably in Johnson County. The length of the tooth is $215 \mathrm{~mm}$.; the width, $73 \mathrm{~mm}$. The edges of the plates, of which there are 8, run diagonally across the worn surface of the tooth. The enamel is thick. There are about 4.4 plates in a $100 \mathrm{~mm}$. line. It is believed that the tooth belongs to Elephas imperator. No details regarding its discovery are recorded.

\section{MONTANA.}

(Map 10.)

Helena, Lewis and Clark County (1).- In his great work on Elephas antiquus, etc. (Nova Acta Acad. Leop.-Carol., vol. xLvir, 1889, p. 248), Pohlig stated that in the museum at Bonn was an elephant's lower molar which had been found in the region of the headwaters of Missouri and Yellowstone Rivers. The locality (given in parentheses) is Sponambar, Helena, Montana. The signification of Sponambar is unknown to the present writer. The tooth was referred by Pohlig to $E$. columbi or E. imperator. The statement is made that there are 13 plates and a talon in $290 \mathrm{~mm}$. This would be a little more than 4 in a $100 \mathrm{~mm}$. line. This appears to make it pretty certain that the animal was Elephas imperator. The width of the tooth is given as $92 \mathrm{~mm}$; height $145 \mathrm{~mm}$.

Valier, Pondera County (2).-In June 1923 a letter was received from R. A. Wood, of Valier, in which were included a drawing and measurements of an elephant tooth. This he had found in a bed of sand at a depth of about 30 feet. The tooth is described as being about 10 inches long and 4 inches wide. On the grinding-surface are indicated 9 or 10 ridge-plates. There appears to be no reason why the tooth should not be referred to Elephas imperator. It appears to be an upper hindmost molar with some front plates worn out and gone. 


\title{
FINDS OF UNDETERMINED SPECIES OF ELE- PHAN'TS IN THE MIDDLE REGION OF NOR'TH AMERICA.
}

\author{
LOUISIANA.
}

(Map 12.)

Little Bayou Sara, West Feliciana Parish (1).-In 1838 (Amer. Jour. Sci., vol. xxxiv, p. 202), W. M. Carpenter reported the discovery of teeth of mastodons and of a horse somewhere along this little stream, which drains the country between Bayou Sara and the Mississippi. Among the teeth which Carpenter referred to the mastodon was one which weighed 12 pounds. This tooth must have belonged to one of the elephants. He stated that the 4 crosscrests had been worn down smooth. It seems not unreasonable to suppose that 4 of the ridge-plates of an elephant were represented, possibly of Elephas imperator. The thick plates of this elephant might have suggested the worndown transverse ridges of a mastodon. The teeth described by Carpenter were deposited in the College of Louisiana.

\section{TEXAS.}

(Maps 12, 13.)

Tascosa, Oldham County (1).-From J. D. Cooper, of Tascosa, Doctor Francis received, for identification, in 1915, some fragments of an elephant, presumably found at the place named. Doctor Francis regarded the specimen as being $E$. imperator. With this were fragments of teeth of Mammut.

Running Water, Hale County (2).-Dr. Charles L. Baker, of the Texas Bureau of Economical Geology, has sent the information that he collected remains of Elephas at Running Water. This is in the northwestern part of the county, on the Blanco, or White Fork of Brazos River. At this place the stream is a kind of "draw," not more than 20 to 25 feet deep, cut in the surface of the Staked Plains.

Plainview, Hale County (3).-Dr. Charles L. Baker reported elephant remains from Plainview. The town is some miles farther down the canyon than Running Water.

McDonald's Creek, Crosby County (4).-In 1893 (4th Ann. Rep. Geol. Surv. Texas, p. 185), Cummins stated that he had discovered a fragment of a tooth of an elephant in a bed of coarse quartz sand at a height of about 20 feet above the present bed of McDonald's Creek. In the same bed were shells of Vallonia gracilicosta and Patula striatella.

Colorado, Mitchell County (5).-Doctor Francis has in his collection at College Station, Texas, a humerus and a lower molar, with 8 plates, of an elephant, which were sent to him in 1916. These had been found in a creek on the farm of Judge Earnest. The remains probably belonged to Elephas imperator.

Tell, Childress County (6).-In the Francis collection are various elephant remains received from $H$. R. Pool, Tell, Texas, about 10 miles from Childress. The remains consist of 2 molars, a femur, several vertebra, and fragments of ribs. One of the molars is in a fragment of the maxilla. There were counted 18 enamel plates, and 6 of these occupy a $100 \mathrm{~mm}$. line. These plates are 
0.5 inch thick, but there is between the successive plates little or no cement. If the cement layers were as thick as usual there would be 4 plates only in a $100 \mathrm{~mm}$. line. It is very probable that the animal belonged to Elephas imperator. The enamel is thick and much plicated. It is not certain that any enamel plates are missing in front, although the tooth is there worn to the base, nor is it certain that the anterior roots are present. On the lingual side of the tooth there appears a notch which may separate one of the anterior roots from the hinder ones. The length of the tooth is $275 \mathrm{~mm}$.; thickness $100 \mathrm{~mm}$. The lower right molar is present, free from the jaw, but a part of the side which contained it is preserved. Sixteen plates were counted; probably a few are missing, as the tooth is worn to the base. The anterior root is missing. There are on the outer face 5 plates in a $100 \mathrm{~mm}$. line. The enamel is thick and folded. The femur likely belonged to the same elephant. Its length is $1,290 \mathrm{~mm}$. ( $4 \mathrm{ft}$. 2.5 inches); the diameter of the head of the femur is $190 \mathrm{~mm}$. ( 7.5 inches); the breadth of the distal end is $270 \mathrm{~mm}$. (10.5 inches). An anterior dorsal vertebra of probably the same animal has the centrum $140 \mathrm{~mm}$. high in the midline and $195 \mathrm{~mm}$. wide at the lower ends of the coalescent cavities for the rib-heads. The spinal canal is $78 \mathrm{~mm}$. wide and $45 \mathrm{~mm}$. high. The distance between the ends of the somewhat eroded transverse processes is $250 \mathrm{~mm}$.

Quanah, Hardeman County (7).-In 1893, W. F. Cummins reported (4th Ann. Rep. Geol. Surv. Texas, p. 184) that he had found on Groesbeck Creek, about 3 miles west of Quanah, remains of an elephant, a horse, and a beaver. They were found at the top of the old flood plain, now about 25 feet above the flood plain of to-day.

Burkburnett, Wichita County (8).-From this town also Dr. C. L. Baker has reported to the writer the finding of Elephas. The remains, whatever they were, were discovered in the second terrace. In the same situation were. found bones of Bison.

Denton, Denton County (9).-From Dr. Mark Francis the writer learned that the head of an elephant was found, on January 20, 1920, 5 miles from Denton. The tusk and a tooth crumbled from lack of attention.

McKinney, Collin County (36).-From Doctor Francis the writer received a photograph of a lower left, probably hindmost, molar which was collected; in 1923, in a gravel pit near McKinney. There remain about 13 plates. The tooth probably belongs to Elephas columbi.

Dallas, Dallas County (10).-The writer has learned from Professor Ed. W. Brigham, curator of the museum of the High School at Battle Creek, Michigan, that about 1885 he found within the limits of Dallas the lower jaw of an elephant with teeth in it. This jaw was in Albion College, Albion, Michigan. The writer has not seen it. The information has been received that the museum of the college was wholly destroyed by fire in December 1922.

Dawson, Navarro County (11).-In the Francis collection at College Station is a part of a skull of an elephant, which was dug up some years ago at Dawson. The right and left upper hindmost molars are present. The animal was an old one, for only 8 of the hindmost plates of the molars were left. There are about 5 plates in a $100 \mathrm{~mm}$. line, but the cement plates are very thin. The enamel is thick and much folded. The outer layer of the 
bone is gone in places, thus exposing the air-sinuses over and behind the palate. 'T'he remains of the sockets of the tusks show that the latter had a diameter of at least $172 \mathrm{~mm}$. With the palate just mentioned and probably belonging to the same individual are both rami of the lower jaw. Of each of the teeth there are remaining 9 or 10 plates only. These must be the hindmost teeth, for there is no trace of another tooth behind them. The enamel is very thick and much crenated. 'The rami are much shortened. The chin projects but little and the spout is short. The jaw is $210 \mathrm{~mm}$. thick and about $190 \mathrm{~mm}$. high near the rear of the teeth. It appears probable that the animal was Elephas imperator.

Granbury, Hood County (3\%).--In the autumn of 1923 Professor E. W. Shuler informed the writer that half of a lower jaw and one tooth of an elephant had been found 4 miles east of Granbury, on Stroud Creek. Inasmuch as the writer has not seen the specimen he does not attempt to identify it. Professor Shuler regarded it as Elephas imperator.

Hubbard and Mount Calm, Hill County (12).- The writer has been informed by Dr. Mark Francis that he has knowledge of the discovery of elephant remains at both Hubbard and Mount Calm. At Mount Calm, J. C. Wollard found a tusk, some teeth, 2 humeri, and a tibia. He would not sell them to Doctor Francis.

T'emple, Bell County (13).--In 1914, W. S. McGregor found some elephant remains in a gravel-pit about halfway between Temple and Belton, along Leon River. These are now in the Francis collection, at College Station. The principal specimen is the rear of a left lower hindmost molar. It consists of 10 enamel plates, white and well fossilized. There are only 5 plates in a $100 \mathrm{~mm}$. line and the plates are much curved. The writer is in doubt whether this tooth belongs to $E$. imperator or $E$. columbi. With the tooth came some vertebræ, which, from the high cordate form of the centrum, seemed to the writer to belong to $E$. imperator.

Liberty Hill, Williamson County (14).-The U. S. National Museum contains a head and a small part of the shaft of a proboscidean femur, which in 1896 was sent from Liberty Hill by Dr. H. H. Thorpe. He reported that it had been dug from the bank of the Gabriel, by which was probably meant the South Fork of San Gabriel River. On this branch is situated Liberty Hill. The femur has the catalogue No. 2098. The diameter of the head is 7.5 inches (192 mm.) and belonged probably to either Elephas columbi or E. imperator.

Austin, Travis County (15).- - In 1876 (2d Ann. Rep. Geol. Surv. Texas, p. 29), Buckley reported that remains of a mammoth had been found in Austin, in digging a cellar, at a depth of 5 to 6 feet. Nothing more is known about this discovery. In 1904 (Scient. American, vol. xc, p. 119), J. S. Brown reported that he had a mammoth-tooth which had been discovered at Austin, in digging a well, at a depth of 45 feet. It weighed 12 pounds; it was 13 inches long, 7 inches high at the center, and 4 inches thick.

Bastrop, Bastrop County (16).-In 1842, J. E. DeKay (Mammalia of N. Y., p. 101) stated that from the Houston Telegraph of April 1840 he learned that a large collection of molars, tusks, and bones had been taken from a ravine about 2 miles below Bastrop, on Colorado River. These valuable fossils have probably long ago been lost to science. Doctor Francis informs the 
writer that Dr. S. R. Dunn, of Bastrop, sent him, in 1922, the left side of a lower jaw which had been found by a negro in Colorado River, near Bastrop. Doctor Francis identified it as Elephas imperator.

Kerrville, Kerr County (17).-Dr. Mark Francis informed the writer that he examined elephant remains which had been found at or near Kerrville. Fragments of the tusk and teeth were secured. The skull was not exhumed. Doctor Francis regarded it as belonging to Elephas columbi.

White Rock Shoals, Trinity County (33).- In 1920 (Univ. Texas Bull. No. 1869 , p. 268), Dumble recorded the finding of remains of a mammoth at White Rock Shoals, on Trinity River. A tusk measured $91 / 2$ feet in length and 14 inches in circumference at the base. Teeth, limb-bones, foot-bones, ribs, and scapula were exhumed, but all crumbled on exposure. These remains, together with the tooth of a horse (p. 126), were buried in the first bottom, the flood plain, of the river. Dumble noted that this discovery indicated that this bottom was neither older nor younger than the stage of the Pleistocene in which the mammoth and the horse lived.

Pittbridge, Brazos County (32).- In the Francis collection, at College Station, are many elephant bones which can not be referred with certainty to their species. Among these are many remarkable limb-bones.

Iola, Grimes County (18).-In 191\%, Doctor Francis received from J. W. Malone, of Iola, a plate of a tooth of a mammoth. It has not been identified.

Drews Landing, San Jacinto County (19).-From Dr. Charles L. Baker the writer has received the information that remains of an elephant had been found a mile below Drews Landing, on Trinity River, some time before 1915. There were present limb-bones, lower jaw-bones, and 19 teeth. If there were really 19 teeth and not so many parts of teeth, more than one elephant is indicated. These remains were found near the base of a deposit, 30 feet deep, of what Baker correlates with the Port Hudson. This lies on a 4-foot bed, which is referred to the Lafayette.

Navasota, Grimes County (31).-From Dr. Mark Francis the writer learned that J. E. Cuthrell, of Navasota, had several molars of an elephant, found in Brazos River, near Hidalgo Falls. Dr. Francis identified these as Elephas columbi and they are probably such.

San Leon, Galveston County (20).- In the summer of 1921 a skull of an elephant was dug up at the settlement of San Leon, on Galveston Bay, about 20 miles north of Galveston. It had been discovered at tide level, and was exhumed by Dr. Mark Francis and a force of men from the college at College Station. When found, both tusks were present and apparently in good condition. About 2 nights before the excavation began, some vandals greatly damaged one tusk. The skull appeared to be quite complete. The writer wished to secure measurements and photographs, but as the sand and clay were removed the bones had to be inclosed in plaster, so that he was not wholly successful. The skull has not yet been prepared. The following measurements (in millimeters) were secured:

Length of left tusk............. 1700

Diameter of tusk at base.......... 200

Vertex to end of sheath, direct....... 1450

Foramen magnum to notch in front of teeth where sheath turns downward (palatal notch) ..............
Foramen magnum to vertex......... 600

Vertex to palatal notch............ 1030

Foramen magnum to postorbital process 680 Palatal notch to postorbital process.... $\quad 570$

Length of last molar. . . . . . . . . . . . 280

Width of last molar.............. 105 
In the upper teeth were counted 18 enamel plates, but some in front may have been worn out. In a $100 \mathrm{~mm}$. line were counted 7.5 or 8 plates. This number appears to indicate that the species is Elephas columbi, but the height of the skull (vertex to foramen magum) is less than the distance from the foramen to the palatal notch, whereas in $E$. columbi the height is considerably greater (Hay, Observations on some extinct elephants, 1922, p. 18, fig. 9). The form of the skull agrees better with that of Elephas francisi (op. cit., fig. \%), but the skull of the San Leon specimen appears to be relatively broarler. Possibly some of the measurements are not exact.

Fort Bend County (21).--In 1856 (Proc. Bost. Soc. Nat. Hist., vol. vi, pp. 51-53), Dr. Jeffiries Wyman reported that a symphysis of a lower jaw, an upper molar, and a femur of an elephant, with remains of mastodon and megatherium, had been found at some point on Brazos River, 50 miles above its mouth. A place thus described is rather vaguely located. It is, however, within the area of the Beaumont formation. Unfortunately, nothing is known about the depth at which the bones were found. They had probably been washed out of the banks of Brazos River.

Richmond, Fort Bend County (22).-The Francis collection, at College Station, contains a very large femur of an elephant, found in Brazos River, at Richmond. The length is $1,372 \mathrm{~mm}$. (5t inches). The length of the femur of the large mammoth (Elephas boreus) in the American Museum of Natural History, New York, is 1,240 mm. The distal epiphysis of the Richmond specimen had not yet become ankylosed to the shaft. The locality falls within the area of the Beaumont formation, but the femur may have been buried deep enough to be in the Lissie. It seems to the writer that this femur belongs to Elephas imperator.

Eagle Lake, Austin Counly (23).-Dr. Mark Francis informed the writer that he had knowledge of the discovery of elephant remains at or near Eagle Lake. In his collection is a large left femur, represented by the upper end only. It was presented by G. R. Abney. The width through the great trochanter is $305 \mathrm{~mm}$. The diameter of the head is $192 \mathrm{~mm}$.

San Bernardo Creek?, Brazoria County (24).-In the U. S. National Museum are a vertebra, the head of a femur, and a part of the right, ischium, which were collected a number of years ago by some member of the U. S. Geological Survey. The head of this femur has a diameter of $150 \mathrm{~mm}$.

Bay City, Matagorda County (25).--In the Francis Collection, at College Station, is a right tibia of a proboscidean, which was found at Bay City by J. H. Freemar. This belongs possibly to a mastodon. However, a section taken at the middle of the length seems to be too nearly triangular for this. It is referred provisionally to Elephas. The total length is $600 \mathrm{~mm}$.

Buckeye, Matagorda County (25).-In September 1923 the writer received from Doctor Francis an account of the finding and collecting of elephant remains near Buckeye. A skull had been observed, during a stage of low water in Colorado River, lying just above the water level. Doctor Francis went there with assistants and found that the skull, tusks, teeth, and many limb-bones were exposed. The top and rear of the skull had been washed away. Two upper molars and both halves of the lower jaw were secured. The tusks broke into pieces about 2 feet long, but these were saved. Such 
of the limb-bones as the party attempted to exhume were very soft and readily broke into fragments. Work was stopped by rain. The exact locality is on the east side of Colorado River, southeast of the village of Buckeye, a short distance below the railroad crossing. The bank is steep and about 25 feet high. The approach from the east is across a marsh, apparently an old river channel.

Doctor Francis sent a carefully prepared sketch of the worn surface of a hinder upper molar. This surface, which appears to extend from the front to the rear of the tooth, is $220 \mathrm{~mm}$. long and on it are shown 9 enamel plates. The animal appears to have been a very old one and many plates were worn out and lost before its death. There are somewhat more than 5 plates in a $100 \mathrm{~mm}$. line. As the surface is doubtless a sloping one, there are to be counted about 6 plates in a $100 \mathrm{~mm}$. line perpendicular to the plates. The tooth is very wide, $120 \mathrm{~mm}$., including the cement. One tusk was about $y$ feet long, the other 6.5 feet. The sheath, where the tusks emerged, was 22 inches wide. The tusks diverged abruptly and curved outward and upward. A cross-section at the base of one is oval, possibly on account of pressure, and measures 205 by $165 \mathrm{~mm}$. It is difficult to determine the species to which this specimen belongs. It may, so far as the writer can now judge, be either Elephas imperator, E. columbi or E. francisi.

About 0.25 mile below this spot, Doctor Francis found another molar tooth which he thought belonged to Elephas columbi; also a humerus which probably belonged to a bison.

On page 92 is described the finding of remains of Elephas imperator near Buckeye and immediately across the river from the place where the elephant was found in 1923. A resident who has lived in the neighborhood many years reported that remains of elephants are washed out nearly every year.

Inez, Victoria County (26).-Doctor Francis has likewise reported the finding of a part of an elephant molar at Inez. He regards it as being $E$. columbi.

Hallettsville, Lavaca County (34).-In January 1922, Dr. Mark Francis received from L. P. Davis, of Hallettsville, remains of some mastodons and 2 molar teeth of elephants, found 5 miles west of Hallettsville. The elephant teeth probably belonged to Elephas columbi, as identified by Doctor Francis. From the northern part of the county, Francis received from Mrs. J. E. Lay a lower jaw of an elephant.

Parita Creek, Bexar County (27).-Dr. Charles L. Baker informed the writer that he discovered a tooth of an elephant in calcareous clays on a branch of Parita Creek. He thought that it belonged perhaps to Elephas imperator. The creek is in the southeastern part of the county.

Medina River, at crossing of Frio road, Bexar County (35).-Dr. E. H. Sellards (Univ. Texas Bull., 1923, p. 73) reported that many years ago C. H. Vogt collected a number of teeth of elephants on Medina River where the Frio road makes a crossing. This is in the southwest corner of the county. Some large bones were collected at the same time.

George West, Live Oak County (28).-In the Francis collection the writer saw a fragment of a skull of an elephant and a single enamel plate, sent by William Skaloud, of George West. In a letter Mr. Skaloud says that these 
were found along a dry creek, about 400 yards from the railroad station at George West. 'This town is the county seat.

Beeville, Bee County (29).-From Beeville the Francis collection has a lower jaw with most of both rami, that of the right side having the condyle. In front the spout is present. The third molar has only 7 or 8 plates remaining. At the middle of the tooth the jaw is $170 \mathrm{~mm}$. high and $195 \mathrm{~mm}$. thick. On the outer face of the jaw are 3 foramina.

Brownsville, Cameron County (30).-Dr. Mark Francis states that in March 1923 he secured a part of an elephant molar which had been found near Brownsville.

\section{OKLAHOMA.}

(Map 12.)

Mulhall, Logan County (1).-About the middle of June 1911 the writer received a letter from Professor Charles N. Gould, of Norman, Oklahoma, together with a large photograph showing the bones of an elephant, found near Mulhall by H. F. Sears. Later two letters were received from Mr. Sears, stating that the bones were considerably scattered and were buried at a depth of from 4 to 6 feet. There appeared to be various teeth and bones in the ground, but they had not been taken out.

In 1917 (Bull. Geol. Soc. Amer., vol. xxviII, p. 212), Troxell reported that he had collected remains of mammoth near Mulhall. For the associated genera, see page 256 .

Lawton, Comanche County (2).-In 1911, Professor Erwin H. Barbour showed the writer a letter dated September 30, 1908, sent him by A. J. Burton, relating to a skull of an elephant found near Lawton. With the skull were secured the tusks, but the photograph gave no view of the teeth. The species is not identified. Two letters sent to Mr. Burton brought no reply. Lawton is situated on Cache Creek, in township 2 north, range 11 west.

\section{NEW MEXICO.}

\section{(Map 12.)}

Deming, Luna County (1).--In the U. S. National Museum (No. 8089) is a dorsal vertebra of an elephant, found probably in the vicinity of Deming. It was sent to the Museum, in 1914, by the Chamber of Commerce of Deming, at the request of Dr. J. W. Fewkes. No details regarding the finding have been recorded.

Bernalillo, Sandoval County (2).-In 1900 (Bull. Denison Univ. Labs., vol. XI, p. 224), C. L. Herrick and D. W. Johnson stated that in the flood plain of the Rio Grande several teeth of elephants had been found and that one fine specimen was in the collection of the University. This is probably the specimen described on page 68 as $E$. columbi.

Datil, Socorro County (3).-The authors just mentioned stated that, in depressions of the great San Augustine plains east of Datil, large numbers of teeth and bones of elephants had been found.

Albert, Harding County (4).-In the summer of 1922 Mr. C. W. Gilmore, of the U. S. National Museum, visited Roy, Mora County, to investigate some elephant remains found in that region. A fine tusk and two teeth had already been taken from the ground when he arrived. An area 10 by 20 feet 
was then excavated to the depth of 4 or 5 feet, but nothing more was found, except broken fragments of the skull. The Mexican farmer who had discovered the tusk and teeth refused to sell them for a reasonable price. The writer received letters from Dr. Carus Plumlee, of Roy, saying that the locality is about 17 miles east of Roy and on Carriso Creek, near Albert. Whether the remains belonged to Elephas columbi or to $E$. imperator is uncertain.

\section{MISSOURI.}

(Map 12.)

Kimmswick, Jefferson County (1).-This locality is on Mississippi River, about 20 miles below St. Louis. In 1840, W. E. Horner (Proc. Amer. Philos. Soc., vol. I, p. 279) made a report on a collection of mastodon and elephant bones which Albert Koch had obtained, partly in Gasconade County and partly at Rock Creek, 20 miles south of St. Louis. Horner did not say at which place the elephant bones had been found, and Koch does not mention having obtained elephant remains at either of these places. It seems more probable, from Koch's various statements, that the elephant bones were found at Kimmswick, if at either place. Of what these remains consisted we are not informed, nor do we know whether they belonged to Elephas columbi or Elephas boreus, nor what became of them.

The geological collection at Washington University, St. Louis, has a large scapula found at Kimmswick. It measures $850 \mathrm{~mm}$. along the spine. The edges of the bone are extensively broken away, but the supraspinous portion appears to have been rather narrow, hence, the bone is believed to have belonged to one of the elephants rather than to the mastodon.

The locality at Kimmswick is described on page 263, and a list is there given of the various species which have been found; also the geological age of the deposits is discussed.

Bonne Femme Creek, Howard County (2).--In 1858 (Proc. Amer. Assoc. Adv. Sci., vol. xI, pt. II, p. 35), G. C. Swallow stated that he had found, on Bonne Femme Creek, Boone County, in the loess, his "bluff formation," 2 teeth of Elephas primigenius; but he gave no details as to locality and depth of burial. As the difference between the teeth of Elephas primigenius (=E. boreus) and $E$. columbi were not then recognized, one can not be certain which species was represented, and it is not known what became of these teeth. When Broadhead (Missouri Geol. Surv., vol. xII, p. 3\%6) stated that bones of Elephas primigenius had been found on Bonne Femme Creek, he probably had in mind the teeth mentioned by Swallow. Howard County has been cut off from Boone since the above announcements were made.

New Madrid, New Madrid County (3).-In a letter written to Rev. Elias Cornelius, in 1820, and published in the American Journal of Science, volume III, 1821, pages 15-46, L. Bringier mentioned (p. 22) that he had seen in New Madrid a grinder of a mammoth which had been found, with several other teeth belonging to the same jaw, about 3 miles below that village. In a footnote the editor stated that he was unable, from the manuscript, to ascertain the weight, but that it appeared to be "from eleven to seven ounces." The present writer interprets it to have been eleven pounds seven ounces, instead of "eleven to seven ounces." The tocth was probably a large molar of 
Elephas columbi, weighed in a wet condition. We have no means for determining its geological age.

Wellington, Lafayette County (4).-In December 1915, Dr. E. Nasse wrote to the U. S. National Museum, inquiring about some bones found at Wellington, in an abandoned bed of Missouri River. His sketch and photographs showed that a part of a skull had belonged to Symbos cavifrons. A right humerus seemed to be that of a rather large elephant. In what stage of the Pleistocene these animals had lived it is impossible to say. The Kansan drift is mapped as having crossed the river for a short distance.

\section{KANSAS.}

(Map 12.)

Ottawa, Franklin County (1).-Professor O. C. Charlton (Trans. Kansas Acad. Sci., vol. XII, p. 74) reported that remains of a mammoth had been found, about the year 187\%, at Ottawa. In digging a well, at a depth of 22 feet, a skeleton was discovered and about 300 pounds of bones were removed. It is said that a part of a tooth, presented to the museum of Ottawa University, weighed 22 pounds. This was probably weighed in a wet condition, but it must have been a very large molar. A part of another molar weighed 17 pounds. The bones are said to have been embedded in gravel and clay. Fragments of other bones had been taken out of the river-bank above Ottawa, at a depth of 18 feet. Wood, not badly decayed, had been obtained at a depth of 22 feet in Forest Park.

Hiawatha, Brown County (2).--In 1918 (Trans. Kansas Acad. Sci., vol. xxvir, p. 45), Professor J. E. Todd made the statement that a mammoth-tooth had been found in Aftonian gravels near Hiawatha.

Attica, Harper County (3).- - In 1890, Professor Robert Hay stated (Bull. No. 57, U. S. Geol. Surv., p. 40) that good specimens of teeth of Elephas had been taken from what he called "earlier gravels" at Attica. No description was given of the teeth, nor is it known what became of them.

Medicine Lodge, Barber County (4).- In the paragraph quoted above, Robert Hay stated that teeth of Elephas had been found likewise at Medicine Lodge. He presented a section of these gravels as exposed in a railroad cut at Wellington, Sumner County. They occupy hollows in the underlying shales and are overlain by a thick deposit of loess. Between Harper and Medicine I رodge similar gravels occupy large areas and form the tops of the high prairie at Attica and east of that place. They attain a depth of 5 to 25 feet. There can be little doubt that they belong to the Sheridan beds.

Vanhem, Clark County (5).--In 1896 (Colorado Coll. Studies, vol. vi, p. 54), Professor F. W. Cragin reported that he had found remains of Elephas in the Kingsdown marls, near Vanhem. The results of the present writer's inquiries lead him to believe that these specimens have been lost.

Meade County (6).-Among the species collected by Cragin from the Meade gravels he mentions, with doubt, Elephas imperator. The elephant materials appear not to be among the fossils of the Cragin collection in Colorado College, at College Springs, Colorado. Inasmuch as Cragin was doubtful as to which species his elephant remains belonged, the species might have been $E$. columbi. The accompanying fauna is listed on page 270 . 
Rush Center, Rush County (7).-The Topeka (Kansas) Journal, of May 15, 1913, published an account of the discovery of a large tooth near Rush Center, in the valley of Walnut Creek, a tributary of Arkansas River. It was found by Robert Kennedy. This gentleman has sent to the writer a small photograph of the tooth, which shows that it is a hindmost upper molar of either Elephas columbi or $E$. imperator. The ridge-plates have a very coarse appearance. The extreme length of the tooth is said to be 15 inches; height, 10 inches; weight, about 18 pounds.

Russell Springs, Logan County (8).--In 1902, Professor S. W. Williston (Amer. Geologist, vol. xxx, p. 313), in discussing the occurrence of a flint arrow-head in association with a skeleton of Bison occidentalis, stated that he had found, in similar marls of the plains, "not far distant," remains of Elephas primigenius. In his work, Age of Mammals, on page 463, Osborn stated that the remains belonged to $E$. columbi. It appears that Williston at that time did not recognize the latter species as distinct from $E$. primigenius ( $=E$. boreus). The animal was probably $E$. columbi, but the writer has not seen the materials.

Manhattan, Riley County (9).- - In Bulletin No. 137 of the United States Geological Survey, on page 34, Robert Hay reported that, some years before he wrote, he had found at Manhattan, under 35 feet of loess, remains of an elephant, a tusk 10 feet 6 inches long, a tooth 15 inches long, 8.5 inches high, and 4.5 inches wide, together with fragments of other teeth. These remains probably belonged to Elephas imperator.

Twelve Mile Creek, Smith County (10).-From Professor J. I. Lush, of College Station, Texas, the writer received two photographs of a tooth of an elephant, found in Smith County in 1923. From Fred H. Hull, of Portis, Osborne County, Kansas, the owner of the farm on which the tooth was found and the owner of the tooth, the writer learns that the locality is in Lincoln Township, in the southeast corner of Smith County. More exactly, the spot is in section 31, township 5 south, range 11 west. Furthermore it was along a stream, apparently Twelve Mile Creek. The tooth lay in a gravel bed between 3 and 4 feet thick, 14 feet below the top of the bank, and approximately 50 feet above the creek-bed. The soil over the gravel-bed is a yellowish clay. The tooth is evidently an upper hindmost molar, worn nearly to the base in front and lacking some hinder plates. There appear to be 20 plates present. The length is reported to be 12 inches, width 3.75 inches. The number of plates in a $100 \mathrm{~mm}$. line is close to $\%$. The tooth is referred to Elephas columbi.

\section{COLORADO.}

(Map 12.)

Old Fort Lyon, Bent County (1).--In 1872 (Amer. Jour. Sci. ser. 3, vol. III, p. 374), A. A. Woodhull reported that 2 teeth of "Elephas americanus" had been found at Old Fort Lyon, within a few yards of Arkansas River. The teeth were preserved at the fort, but it is unknown where they are now. The fort was on the north side of Arkansas River, in township 22 south, range 48 west.

Dawson Butte, Douglas County (2).--In Folio 198 of the U. S. Geological Survey, on page 9, Dr. G. B. Richardson recorded the finding of various 
elephant remains in the region about Castle Rock. In section 26, township 8 south, range 68 west, in the valley of West Plum Creek and on the farm of Upton Smith, some tusks and teeth of an elephant had been discovered. The locality is about 2 miles northwest of Dawson Butte and must be near the Lonetree schoolhouse. From A. Dakan, of Longmont, Colorado, the writer learned that the tooth was found in cutting an irrigating-ditch along West Plum Creek, at a depth of 4 feet, in the older, not the recent, wash of the stream. He reports also the discovery of bones, apparently of an elephant, in section 28 , in a deposit along a stream cut in the Pierre shale. They were buried at a depth of about 4 feet.

Melvin, Arapahoe County (3).- In the folio above cited, Doctor Richardson noted the finding of a part of an elephant skeleton 8 miles north of Castle Rock. A part of a humerus and a part of a tibia were sent to James W. Gidley for determination. These were found in the bed of Cherry Creek, in section 19, township 5 south, range 66 west, therefore evidently not far from Melvin. The locality lies outside of the Castle Rock quadrangle. The bones are considerably larger than the corresponding ones of the existing elephants.

Golden, Jefferson County (4).-In 1872 (Amer. Jour. Sci., ser. 3, vol. III, pp. 302, 373), Captain E. L. Berthoud and Professor Alfred P. Rockwell reported the finding of a part of a tusk of a proboscidean along Clear Creek, 5 miles above Golden. The fragment of tusk was 2 feet 8 inches long and 8 inches in diameter. It was buried under 10 or 15 feet of gold-bearing gravel, at a level of about 25 feet above the bed of the creek. The elevation above the sea is 5,675 feet. The tusk is said to be in the Institute of Technology, Boston. While the tusk is possibly that of a mastodon the probability is strongly in favor of its being that of one of the elephants.

Denver, Denver County (5).--In 1896 (Mon. U. S. Geol. Surv., vol. XxviI, p. 260), Dr. S. F. Emmons reported that molars of a species of elephant had been met with in excavating cellars for some large buildings in Denver. $\mathrm{He}$ mentioned buildings at the corner of Lawrence and Eighteenth Streets and at the corner of Larimer and Sixteenth Streets. The teeth were found in what Emmons termed river drift. Other elephant bones had been discovered in the overlying finer deposit, which Emmons called the "fluvial loess." On his page 264, Emmons stated that bones of two species of elephant had been found in the loess within the limits of the city of Denrer.

\section{IOWA.}

(Maps 12, 14.)

Sugar Creek, Lee County (1).-In Netta C. Anderson's "List of Mastodon and Mammoth Remains in Illinois and Iowa," page 28, Justus M. T. Myers, of Fort Madison, reported that he had found, on Sugar Creek, the molar of an extinct elephant which he could not determine. The present writer has not been able to learn anything more about this tooth. On the same page, Mr. Myers reported that in 1896 he found a molar of Elephas primigenius in a creek below Montrose.

Walnut Township, Jefferson County (2).-Dr. J. A. Udden (Iowa Geol. Surv., vol. XII, p. 428) reported that a well-preserved lower jaw of an elephant had been found in the bed of Walnut Creek. This locality is in the north- 
west quarter of section 28, township 73 north, range 8 west. The name of the finder was given as Josia Bates. In a letter to the present writer, dated February 2\%, 1911, he gave his name as Josia Bales and stated that he still had the specimen. Udden remarked that it was not evident to what part of the drift the jaw belonged.

Floris, Davis County (3).-.In Netta C. Anderson's paper just quoted, un page 26, J. M. T. Myers stated as follows: "In 1862 I found in Des Moines River, near Floris, 2 mastodon teeth, 1 weighing 14 pounds, the other 4 pounds." The larger tooth, and probably the smaller also, must have belonged to one of the species of Elephas, for no mastodon tooth would weigh 14 pounds.

Oskaloosa, Mahaska County (4).-The collection at the State University contains the right innominate bone, which appears to have belonged to a species of Elephas. The writer has described and figured this (Iowa Geol. Surv., vol. xxiı, pl. Lxix, figs. 4, 5). As reported by Dr. M. F. Boyd, of Oskaloosa, the bone was found in Skunk River, 3.25 miles east of the bridge of the Minneapolis and St. Louis Railroad. It seems useless to speculate as to what stage of the Pleistocene this individual belonged.

Near Iowa City, Johnson County (23).-From the bed of Iowa River, in Lucas Township (township 79 north, range 6 west, section 27 ), was taken, at a stage of low water, many years ago, a nearly perfect tusk apparently belonging to Elephas boreus (Iowa Geol. Surv., vol. xxiI, pp. 67 and 43\%, pl. LVII, fig. 1). The writer was informed that in 1913 a molar tooth of an elephant was found in nearly the same spot.

River Junction, Johnson County (24).-At this town, in section 12, township $7 \%$ north, range 6 west, on a sand-bar in Iowa River, Professor Shimek found the tip of a proboscidean tusk. It may be that of an elephant. It is No. 158 of the Iowa University collection.

Albion, Marshall County (5).--In Netta C. Anderson's list, on page 29, Professor W. H. Norton reported that a large molar of a mammoth, in a perfect state of preservation, had been found in Iowa River, near Albion, and presented to the museum of Cornell College at Mount Vernon. Albion is on the border between the Iowan and the Kansan, but Professor Beyer's section (Iowa Geol. Surv., vol. vir, p. 231) taken at Albion shows that some Iowan is there. It is overlain by 20 feet of loess, while below are Kansan and Aftonian. One can say with some degree of assurance that the tooth is of post-Kansan age.

Indianola, Warren County (6).-Through the kindness of Professor J. L. Tilton, of Simpson College, Indianola, the writer has been allowed to examine a large lumbar vertebra which certainly belonged to a species of Elephas. It was found at a depth of 6 feet below the bed of a ravine, 1.5 miles east of Indianola, by workmen digging for the foundation of a railroad bridge. The height of the centrum, to bottom of the spinal canal, is $125 \mathrm{~mm}$; the width at the upper part of the centrum, $115 \mathrm{~mm}$.; length $63 \mathrm{~mm}$. With this vertebra was an atlas which measured about $150 \mathrm{~mm}$. from side to side. It was at one time supposed by Professor Tilton that the deposits containing these bones belonged to the Aftonian (Pleistocene deposits in Warren County, p. 26), but later (Proc. Iowa Acad. Sci., vol. XxIr, pp. 233-236) he concluded 
that the terrace involved belongs to the Wisconsin. There is a possibility, however, that it is of intermediate age.

Osceola, Clarke County (25).-In 1921 (Bull. Geol. Soc. Amer., vol. xxxir, pp. 80-83), Dr. G. F. Kay reported the finding of 2 tusks, a scapula, a limbbone supposed to be a humerus, and fragments of ribs of a proboscidean, near Osceola. The exact locality is section 3, township 71 north, range 25 west (Greenbay). There being no teeth preserved and the bones and tusks being perishable, it is impossible to determine whether the animal was one of the elephants or a mastodon. One tusk was 9 feet 7 inches long, the other 11 feet 4 inches long. The bones were extremely soft and showed no signs of mineralization. At this locality was found the following geological section:

Glacial deposits.

4. Glacial till (Kansan).

feet.

$\ldots \ldots \ldots \ldots$ about 4

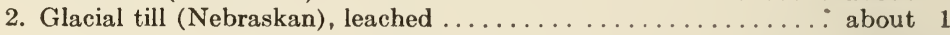

1. Glacial till (Nebraskan), unleached .................... about 40

Deposit 4 contains inclusions of Nebraskan gumbotil. The proboscidean remains were embedded within the lower 10 feet of the Kansan till. Doctor Kay concluded that the skeletons had been lying on the surface of the Nebraskan gumbotil, that they were picked up by the advancing Kansan ice, transported a short distance, and had become embedded in the base of the Kansan drift. One cannot question the possibility of such an occurrence but its probability seems remote. For bones to be picked up by an advancing glacier and lifted to a level of 10 feet in the drift, it would require that there should be a very considerable amount of forward and upward movement. It appears extremely improbable that bones and tusks would remain not only entire but in close proximity to one another. It is not improbable that the northern elephant, Elephas boreus, possibly even a mastodon, may have lived not far from the glacial front. Perhaps during a temporary recession of the glacier the animal left his bones on the bare drift. On the return of the glacier, fortune may have favored their preservation and finally their deep interment.

Pacific Junction, Mills County (7).-In 1880 (Proc. Iowa Acad. Sci., 1875-1880), Professor J. E. Todd reported that there had been found, in grading the Chicago, Burlington, Quincy Railroad, between Glenwood and Pacific Junction, various parts-tusks, teeth, jaws, humerus, and other bones-of a young Elephas americanus. In Bulletin 158 of the U. S. Geological Survey, page 90, Todd recorded the geologic section observed at this place. At the top is about 50 feet of loess, then from 3 to 4 feet of chocolate-colored loam, then from 20 to 25 feet of yellow till. The mammoth was found near the junction of the loess and the till. It is understood that these bones are in the collection of Tabor College. The writer has examined the collection, but because of defective labeling he could not satisfactorily distinguish them from other elephant remains. Todd referred to these bones in Netta C. Anderson's list, pages 29-30.

Malvern, Mills County (8).--In grading for the Chicago, Burlington, Quincy Railroad, in 1879, bones of a mammoth were discovered in Malvern, at the crossing of First Avenue and Railroad Street (Udden, Iowa Geol. 
Surv., vol. XIII, p. 170). There were 3 teeth, part of a tusk, and 2 long bones. What was done with these bones the writer does not know.

Washington Township, Pottawattamie County (26).-An elephant has been reported found in section 34 of this township (p. 295; also Iowa Geol. Surv., vol. XxIII, pp. 72, 444; Iowa Geol. Surv., vol. XI, p. 260). It is not certain that the bones did not belong to a mastodon.

Ida Grove, Ida County (9).- In the collection of the Iowa Historical Department, at Des Moines, is a tusk of a proboscidean, found by Henry Crane at Ida Grove. The tusk has the No. B140. It is between 4 and 5 feet long and about 4 inches in diameter, and is considerably curved. These features appear to stamp it as having belonged to one of the elephants, but not certainly.

Le Mars, Plymouth County (20).-Carman (Iowa Geol. Surv., vol. xxvi, pp. 394, 395, 409) wrote that two deep river gravel-pits at Le Mars had yielded elephant teeth, tusks, and part of a pelvis. From the same pits were obtained teeth of deer and horses, and from other pits in the vicinity of Le Mars were taken antlers and bones of deer. These remains belong probably to the Sangamon, but possibly to the Iowan.

Clinton, Clinton County (10).--In the Anderson list F. C. Baker reported that the collection of the Chicago Academy of Sciences contains a tooth and a tusk of Elephas, found at Clinton. They were presented by J. W. Foster. On page 75 will be found an account of remains of Elephas columbi found at Clinton.

\section{Within the Area of Illinoian Drift.}

Morning Sun, Louisa County (11).-J. A. Udden (Iowa Geol. Surv., vol. xI, p. 110) reported that some years previously there had been dug out from the bed of Otter Creek, near the center of the northwest quarter of section 25 , township 73 north, range 4 west, a tooth, a lower jaw, part of a pelvis, several ribs, and a large part of a tusk of an elephant. What became of these valuable remains is not known. The region is occupied by Illinoian drift, but this is covered by a mantle of loess. Udden thought that the remains were buried in Sangamon soil.

Grandview, Louisa County (27).-J. A. Udden, on the page just quoted, stated that an elephant tooth had once been taken out in digging a shallow well in a tributary to Indian Creek, in section 28, township 75 north, range 3 west. This is near Grandview. As in the case at Morning Sun, the drift is Illinoian and overlain by loess. Udden thought that this tooth also was of Sangamon age.

Sweetland Township, Muscatine County (12).-Dr. J. A. Udden (Iowa Geol. Surv., vol. Ix, p. 350) reported that some elephant bones had been taken up near the center of the southwest quarter of section 12 of this township, which is 77 north, range 1 west. These are said to have been put into the museum of Charles Weir, of Muscatine. This, however, is an error, for James M. Weir had a considerable collection of such remains. These are now in the Public Library of Muscatine; but as there were no labels attached to the specimens it would probably be difficult to pick out the Sweetland bones. Udden informs us that at the place where the bones were found is a peat deposit which contains large pieces of gymnospermous wood. 
Muscatine, Muscatine County (21).-In 1892 (Proc. Iowa Acad. Sci., vol. I, pt. 2, p. 67), F. M. Witter reported an elephant tooth found about a mile above the mouth of Mad (or Mud) Creek, in Muscatine. At this point was a nearly perpendicular bank about 40 feet high, capped by loess. About 10 feet below the top was a layer of gravel a foot thick, and in this gravel was found the tooth. This gravel may belong to the Sangamon stage. 'The species is undetermined.

Blue Grass, Scott County (13).--In the Anderson list, page 35, is an account of the finding of elephant remains at Blue Grass. It appears that as early as 1844 tusks and some teeth had been discovered. The tusks soon crumbled. The largest tooth is said to have been about 14 inches long and taken out in three sections. It appears that other parts of the same skeleton were met with in 1858. The locality is said to have been "near Dr. Carpenter's residence." The bones were embedded in yellow clay and lay at a depth of about 10 feet. If the three parts mentioned all belonged to one tooth, the animal was probably Elephas columbi. From the description given, it would appear that the elephant had been buried in the loess and that it had lived during the late Iowan or early Peorian stage.

\section{Within the Area of the Iowan Drift.}

Clarence, Cedar County (14).- In his report on the geology of Cedar County, in 1901 (Iowa Geol. Surv., vol. xI, p. 37\%), Professor W. H. Norton stated that several finely preserved teeth of Elephas primigenius had been found in a washout in a small creek on the farm of A. T. Whitnell. The place is in the southeast quarter of the southeast quarter of section 6 , township 81 north, range 1 west. This is about 4 miles in a straight line southeast of Clarence. Norton stated that above the washout there is a bed of white alluvial clay overlain by gravels. In which of these the teeth occurred it is impossible to say. Two of these teeth are now in Cornell College, at Mount Vernon, Iowa, but the writer has not seen them. It is possible that at that time Professor Norton did not take into consideration the differences now recognized between the teeth of $E$. boreus and those of $E$. columbi.

\section{Within the Area of the Wisconsin Drift.}

Raccoon River, Polk County (15). - In the Anderson list, on page 34, Professor I. S. Ross reported that the femur of a mammoth, in a good state of preservation, had been taken from a sand-bar of Raccoon River, in Polk County.

Polk, Polk County (16).--Professor S. W. Beyer (Iowa Geol. Surv., vol. Ix, p. 211) reported that a perfectly preserved molar of Elephas primigenius was found in 1898, by an employee of the Chicago and Northwestern Railroad. No details were given, and it is not known where the tooth now is. Probably Beyer did not at that time distinguish between $E$. boreus and $E$. columbi. The tooth occurred in the gravels which are present at Polk and which are evidently of late Wisconsin age.

Lake View, Sac County (17).-From this locality was obtained, for the collection at the State University of Iowa, the proximal end of a large proboscidean scapula. Judging from the nearness of the spine to the anterior edge of the scapula the writer is inclined to refer the bone to some one of the 
species of Elephas. It was found in a gravel-pit, south of Lake View, by John A. Spurrell. It probably belonged to the late Wisconsin stage.

\section{Within the Driftless Area.}

Dubuque, Dubuque County (18).-Richard Herrmann, of Dubuque, informed the writer that many years ago a large tooth of a mammoth had been found 3 miles below Dubuque and had been owned by Mr. Bechtel, of the firm of Eichorn and Bechtel. It was sold to some person now unknown.

Early in 1923 a part of a skeleton of an elephant was unearthed in a sand-pit just south of Dubuque, along the Illinois Central Railroad. The exact locality, as reported by $\mathrm{H}$. Rhoads is in section 6 , township 88 north, range 3 east. There were secured a part of the skull, with both hindmost molars in place, and an ulna. A large tusk and several vertebræ were observed, but these were mostly destroyed in getting out sand for ballast purposes. From Professor A. O. Thomas, of the University of Iowa, the writer received photographs of the palate and ulna. 'The teeth are worn to the base in front. About 16 ridge-plates were counted. So far as can be determined from the small but distinct photograph, there are 8 or 9 plates in a 100 $\mathrm{mm}$. line. The enamel appears to be thin and little folded. The grindingsurface is 4 inches wide. The part of the tooth present appears to be 225 $\mathrm{mm}$. long. A considerable part of the front evidently was worn away. The writer is inclined to refer this specimen to Elephas boreus, but he is in doubt. The specimen appears at this writing to be yet in the possession of the finder, L. H. Finch, section foreman. Professor Thomas further informed the writer that the elephant remains were found in the abandoned channel of Catfish Creek, 2 miles south of Dubuque and a mile west of Mississippi River. A "valley-train" had been deposited by the Mississippi in bringing down sands from the Wisconsin ice at St. Paul, Minnesota, and in this the skeleton was buried.

Postville, Allamake County (19).--In Netta C. Anderson's list, on page 25, Thomas French reported that in 1904 he found 4 teeth, the lower jaw, and a portion of the vertebral column of a mammoth, sticking out of the bank of Yellow River, 4 miles north of Postville.

Wagner Township, Clayton County (22).-In 1911, Rev. J. Gass, of Postville, Allamakee County, informed the writer that mammoth-teeth had been found in sections 5, 16, and 23 of Wayne Township. This is by number township 94 north, range 5 west. No details were communicated.

\section{NEBRASKA.}

\section{(Map 12.)}

Gosper County (1).-In 1903 (Neb. Geol. Surv., vol. I, p. 172, fig. 10\%), Professor Erwin H. Barbour reported the discovery of a pair of tusks in the face of an extensive cut along the Burlington and Missouri River Railroad, in Gosper County. The length of a tusk along the curve was 11 feet. At the base the diameter was 7 inches. There appears to have been no teeth present. These tusks were reported as found in the loess. In this case we must conclude that the animal lived after the time of the Kansan drift, possibly after the time of the Illinoian drift. An interesting account of the 
exhumation and preparation of these tusks was given by Miss Carrie A. Barbour in the Proceedings of the Nebraska Academy of Sciences for 1896, issued in 1898.

Indianola, Red Willow County (2).-In the C. H. Morrill collection, in the State University Museum at Lincoln, is a fine, large spirally curved tusk which probably belonged to a species of elephant. The length is 12 feet 2 inches. It is relatively slender. Near the tip is a worn area. About 2 feet farther back, on another side, is a long, flat, worn surface extending along the tusk a distance of about 2.5 feet. These surfaces make it evident that the tusks were not useless encumbrances.

Crawford, Dawes County (3).- Harold Cook (Neb. Geol. Surv., vol. vir, p. 47) stated that he had seen a damaged tooth of an elephant, which had been found in a sand-pit near Crawford.

Omaha, Douglas County (4).--In 1876 (Ann. Rep. U. S. Geol. Geog. Surv., Terrs. for 1874, p. 254-255), Dr. Samuel Aughey reported the discovery of a lumbar vertebra of "Elephas americanus" in loess at a point 2.5 miles southeast of Omaha. It was in the loess in a railroad cut, at a depth of about 19 feet. Whether this belonged to $E$. columbi or to $E$. boreus may be regarded as doubtful. Aughey affirmed that at a distance of 13 inches below this vertebra and about 3 inches to one side he discovered a flint arrowhead. This he figured.

Saline County (5).-In 1876, Aughey (Rep. U. S. Geol. Surv., Terrs., Hayden, for 1874 , p. 251) recorded the information that there was in the museum of the State University a hinder left lower molar of an elephant; length of molar, $1 \%$ inches. This had been found somewhere in Saline County. It belonged probably to either Elephas columbi or E. imperator.

\section{WYOMING.}

\section{(Map 12.)}

Raw Hide Butte, Laramie County (1).-Harold Cook (Neb. Geol. Surv., vol. viI, pt. 6, p. 4\%) stated that about 1908 Professor F. B. Loomis, of Amherst College, found remains of an elephant near Raw Hide Butte. The exact locality may have been in Converse County, as Professor Erwin H. Barbour informed the writer. Only fragments of the animal were secured. The bones did not appear to be fossilized. They were found in what was designated as an alkali pocket.

Caspar, Natrona County (2).--Professor W. C. Knight reported (Science, n. s. vol. XVII, p. 828, 1903) that a tooth which, from the description, was that of an elephant had been found by a stockman somewhere about Caspar. No details are known.

Dover, Albany County (3).--Professor Knight, as cited above, announced that the lower jaw of a small elephant had been discovered in Laramie Canyon by Mrs. Dover, of Dover. A right molar was complete. The jaw is said to be in the University of Wyoming.

\section{MINNESOTA.}

\section{(Map 12.)}

Fairhaven, Stearns County (1).-In 1910 (Bull. Minn. Acad. Sci., vol. IV, p. 416, pl. x), Professor N. H. Winchell recorded the finding of a large 
elephant tooth in a marsh near Fairhaven. This town is in the southern edge of the county. The statement made by Winchell, that the tooth had a hard, shining surface, awakens the suspicion that it might have been a tooth of a mastodon.

Five miles north of Minneapolis, in Anoka County (2).-In 1878 (6th Ann. Rep. Geol. Nat. Hist. Surv. Minn., p. 61), Professor Winchell reported the discovery of a tusk and a tooth of an elephant at a point 5 miles above Minneapolis, on the east side of Mississippi River in sand and gravel. These deposits are said to occupy the same relation to the river and the valley as the terrace at Little Falls.

Stockton, Winona County (3).-In the Thirteenth Annual Report of the Geological and Natural History Survey of Minnesota, 1885, pp. 147 to 149 , plate II, are accounts, given by Professor J. M. Holsinger and Professor N. H. Winchell, of a remarkable elephant tooth found at Stockton about 20 years before that time. This tooth and a part of a tusk accompanying it were discovered in a clay-bank, within 40 rods of the crossing of the highway and the railroad, and at the time of writing they were in the collection of the State Normal School at Winona. The tooth is remarkable on account of the great thickness of the plates of cement and the thinness of the enamel plates. The tooth was figured of the natural size. There are present 8 enamel plates and 7 cement plates. The distance across all of them is $130 \mathrm{~mm}$. The enamel plates made up only a little more than one-fifth of the length of the tooth. The writer has not seen nor learned of a similar tooth. Dr. Robert Bell, in 1898 (Bull. Geol. Soc. Amer., vol. Ix, p. 370), described and figured a tooth found at Isong Island, Hudson Bay. This had relatively thick cement plates, but only about twice as thick as the enamel plates. The Minnesota tooth may have belonged to an undescribed species. The age of the animal was doubtless post-Wisconsin. The eastern part of this county (Final Rep. Geol. Surv. Minn., vol. I, p. 260) is occupied by what Winchell calls loess-loam. In 1910 (Bull. Minn. Acad. Sci., vol. Iv, pp. 415-418), Winchell refers this deposit to the Iowan loess.

Albert Lea, Freeborn County (4).-From C. E. May, in June 1911, the writer received a letter regarding the discovery of some elephant remains at Albert Lea. These remains comprised a tooth, apparently much worn but having the roots, and measuring 5.5 inches in length and 3.5 inches in width; also an atlas, seomingly complete and said to be 18 inches wide. Sketches of these were sent by Mr. May. They were found within the city, at a depth of from 10 to 12 feet, in excavating for a building of the American Gas Machine Company. Apparently the tooth and the bone belonged to Elephas boreus. At Albert Lea the surface is nearly level, and the beds were thought by Winchell (Final Rep. Geol. Nat. Hist. Surv. Minn., vol. I, p. 386) to have originated from floods coming from the retiring glacier. On the page quoted, Winchell stated that a jaw-bone of a mastodon had been found at Albert Lea some years before 1881 .

Nobles County (5).-In 1910 (Bull. Minn. Acad. Sci., vol. Iv, p. 416), Professor N. H. Winchell recorded the finding of a large elephant tooth at some undesignated place in Nobles County. It was discovered in gravel at a depth of 27 feet. The tooth was preserved in the collection of the Min- 
nesota Academy. The whole county is covered with drift of Wisconsin age, and probably in some outwash deposits from the glacier was found the tooth mentioned. The geology of the region is described in the First Volume of the Final Report of the Minnesota Geological Survey, on page 526.

\section{SOU'TH DAKO'TA.}

(Map 12.)

Sioux Falls, Minnehaha County (1).-In 1894 (Bull. No. 1 S. Dak. Geol. Surv., p. 126), Professor J. E. Todd reported the discovery, at Sioux Falls, of remains of a proboscidean which he called Elephas americanus. This may have belonged to either $E$. boreus or $E$. columbi. The remains consisted of tusks, teeth, and some large bones. They were found at a height of about 60 feet above Sioux River. A tusk was over 7 feet long, 6 inches in diameter, and much curved. This specimen was again mentioned by Todd in 1899 (Bull. 158. U. S. Geol. Surv., p. 85).

Black Hills (2).-T. R. Carpenter (Prelim. Rep. Dak. School Mines, 1888, p. 49) reported that bones of the mammoth had been found in the Quaternary of this region, but no definite localities were mentioned. "One large perfect molar tooth is now the property of the Dakota School of Mines."

\section{NORTH DAKOTA.}

(Map 12.)

Ripon, Cass County (1).-In 1896 (Mon. xxv, U. S. Geol. Surv., p. 332), Dr. Warren Upham gave an account of the finding, in 1884, of some remains of an elephant near Ripon, "near the middle of the line between sections 32 and 33, township 141 north, range 53 west." The name of the political township is Empire. The remains were found where the Great Northern Railway cuts the beach of old Lake Agassiz, at a point about 10 rods south of the track, where the beach had been excavated for gravel. They were on the floor of the excavation and in the upper foot of the till or boulder clay. The parts found included a tusk 11 feet long and 9 inches in diameter, 3 teeth, 2 verbetræ, and several smaller bones. What became of this valuable material we are not told, nor are we able to determine to what species it belonged. Its age evidently was post-Wisconsin, but it probably lived there in close proximity to the foot of the glacier. These remains were referred to by N. H. Winchell in 1910 (Bull. Minn. Acad. Sci., vol. IV, p. 417).

\section{MONTANA.}

(Map 12.)

Helena, Lewis and Clark County (1).-It is recorded in the Transactions of the St. Louis Academy of Sciences, volume 3, page xxxIr, that Auguste Steitz spoke of elephant remains found about a mile from Helena, at a depth of 40 feet.

Butte, Silver Bow County (2).--In the Public Museum of Milwaukee is a large axis, found at Butte and presented by J. J. Kinrade. It was considerably worn, as if it had been rolled in a stream. The lateral processes are gone; without these, the width is $225 \mathrm{~mm}$. Nothing is known as to the conditions of its burial. 
SASKATCHEWAN.

(Map 12.)

Region of Pelly, Pelly County (1).-In 1854, Sir John Richardson (Zool. Herald, p. 101) described a pair of shoulder-blades of a proboscidean found in the region of Fort Pelly and which he called Elephas rupertianus. $\mathrm{He}$ stated that it had been discovered at Swan River. Tyrrell (Geol. Surv. Canada, vol. v, part I, p. $129 \mathrm{E}$ ) found that the locality was on Shell River. Later (Zool. Herald, p. 141) Richardson concluded that these bones were those of Mammut americanum. He based his correction on the presence of a depression 4.5 inches long and an inch deep between the lower end of the spine and the border of the glenoid cavity. Richardson has a note on this subject in the American Journal of Science, series 2, volume XIX, p. 131. It appears impossible to determine whether these shoulder-blades belong to Mammut americanum or to an elephant. The writer finds no such depression in shoulder-blades of two mastodons in the U. S. National Museum. It may have been an individual structure. By far the greater probability is that the bones belonged to an elephant.

\section{ALBERTA.}

(Map 12.)

Calgary (1).- - In 1914 the writer received a letter from G. F. Dippie, secretary of the Scientific Society at Calgary, in which he reported that a tooth of a mammoth had been found within the limits of that town, during the making of a cut for the Canadian Northern Railroad. A sketch sent by Mr. Dippie shows that the tooth is that of an elephant, probably Elephas boreus.

Loon River (This locality is not shown on the map)-The collection of the Victoria Museum, at Ottawa, Ontario, contains part of a tooth of an elephant, found in the bank of Loon River, about 40 miles above its mouth. The locality would be approximately latitude $57^{\circ} 41^{\prime}$ north, longitude 115 west. The writer examined this tooth in the Victoria Museum. It is an upper molar, probably the second of the right side. There are about 10 enamel plates present, some being gone from the rear. The width is only $67 \mathrm{~mm}$. The animal probably belonged to the form of elephant which inhabited Yukon and Alaska.

\section{FRANKLIN.}

Melville Island, Dominion of Canada.-From Dr. E. M. Kindle, palæontologist of the Canadian Geological Survey, the writer learns of the discovery of the tusk of an elephant on Melville Island, at the head of Liddon Gulf. This locality is in latitude $75^{\circ}$. The animal probably belonged to the species known as Elephas primigenius, possibly to Depéret's form sibiricus. 


\title{
FINDS OF EQUID E IN THE MIDDLE REGION OH NOR'TH AMERICA.
}

\author{
I.OUISIANA.
}

(Map 15.)

Shreveport, Caddo Parish (1).--In the United States National Museum is a large upper molar, probably the hindmost, which was sent there in August 1909 by the Shreveport Cottonwood Company, of Shreveport. In the letter of transmittal it is stated that the tooth was picked up on a sandbar in Red River. The height of the crown is $78 \mathrm{~mm}$., length $29 \mathrm{~mm}$., width $29 \mathrm{~mm}$. The enamel is considerably folded. The present writer identifies it as Equus complicatus.

Little Bayou Sara, Feliciana Parish (2).-In 1838 (Amer. Jour. Sci., vol. xxxiv, pp. 201-203, with 3 figs.), W. M. Carpenter, the geologist, reported finding an upper tooth of a horse somewhere along the stream just mentioned and about 25 miles from Jackson, Louisiana. This stream flows nearly southward between Bayou Sara and Mississippi River. The distance given indicates a situation near the northern boundary of the county. The tooth had a height of 3.5 inches $(87 \mathrm{~mm}$.) and a length, on the outer border of the crown, of 1.25 inches $(32 \mathrm{~mm}$.). The figure of the grinding-surface indicates a moderate degree of folding. Leidy (Proc. Acad. Nat. Sci. Phila., 1847-8, p. 328) identified the tooth as belonging to his Equus americanus (=E. complicatus) and the author accepts this view. Carpenter stated that the tooth was found at a depth of several feet and closely associated with what he called a considerably worn mastodon tooth, which weighed 12 pounds. It seems certain that this tooth was that of an elephant. In his article, Carpenter describes the geology of the region.

Petite Anse, Iberia Parish (3).- At the salt mines at Petite Anse have been found, in considerable amounts, horse remains and those of several other species of mammals. In 1884 (Proc. Acad. Nat. Sci. Phila., 1884, p. 22), Leidy called the attention of the members to a collection which was put into his hands by the Smithsonian Institution. The collection was received from William Crooks, of the American Salt Company. According to Leidy, the remains consisted chiefly of Mastodon americanus, Equus major, and Mylodon harlani. Of the horse, there were vertebræ, fragments of limb-bones, and a number of teeth. These are now in the U. S. National Museum. Leidy remarked that the molars were characterized by their large size and the complexity of the arrangement of the enamel, especially of the upper grindingteeth. This collection was more fully described in 1889 (Trans. Wagner Inst., vol. II, pp. 35-39, with 4 figs.). Two upper teeth were figured, and all parts were regarded as belonging to Equus major. They are now known as Equus complicatus. Many of the bones were close to, if not in contact with, the salt.

In 1890 , Dr. J. F. Joor, of New Orleans, made a collection at Petite Anse for Tulane University. He gave a brief account of the collection in 1895 (Amer. Naturalist, vol. xxix, p. 394). It was examined by Professor E. D. Cope (Proc. Amer. Philos. Soc., vol. xxxiv, p. 463, pls. x, xI). The horse he called Equus intermedius, basing the new species on a right maxilla which 
has all the grinders except the second premolar; there were other teeth, upper and lower, a mandibular symphysis, and various parts of the skeleton. The present writer found some of these materials in the collection at Tulane University, but not the maxilla which forms the type of Equus intermedius. Cope's species is regarded as a synonym of Equus complicatus. The geology of the locality is discussed on page 215 .

Baton Rouge, East Baton Rouge Parish (4).-From D. R. Weller, president of the Standard Oil Company of Louisiana, through the kind offices of Professor W. H. Gates, of the Louisiana State University, the U. S. National Museum has received an upper right molar of a horse which is identified as Equus complicatus. The tooth is much curved. Accompanied by teeth and bones of Mammut americanum and fossil wood, it was found about 2 miles north of the city, at a depth of 8 feet. At this point, about a mile from the river, the surface is above high water.

\section{TEXAS.}

(Maps 15, 16.)

Palo Duro Canyon, Randall County (1).- In his account of the Staked Plains, in 1892 (3d Ann. Rep. Geol. Surv. Texas, p. 149), Cummins stated that he found at the Falls of Palo Duro Canyon, south of Amarillo, on the south side of the canyon, teeth of a fossil horse and fragments of the skeleton of a mastodon. At this point the Tertiary strata are about 140 feet thick. Near the top of the canyon is often found a bed of white arenaceous hardened clay, there being sometimes more lime than clay. This overlies a white argillaceous sand which contains masses of stalactitic structure and fossil vertebrates. This bed varies from a few inches to 15 feet in thickness. It contained the remains of horse and mastodon.

Rock Creek Canyon, near Silverton, Briscoe County (2).-Professor E. D. Cope was the first to describe vertebrate fossils from the Pleistocene of this region (4th Ann. Rep. Geol. Surv. Texas, 1893, separate, pp. 74-87, pls. XXI-XXIII). Of the horses, he listed (p. 87) 4 species, Equus excelsus, E. semplicatus, E. tau, and E. major. These were all, so far as can be determined, found in the canyon of Rock Creek, which opens into Tule Canyon. Of the teeth of $E$. excelsus from Rock Creek, two figures were presented (Cope's pl. xxII, figs. 4, 5), figure 4 being that of an upper right second molar, figure 5 a right inferior molar. The upper tooth does not resemble much the type teeth of the species, being entirely too large, while the arrangement of the enamel differs from that of the type. The lower tooth belongs probably to $E$. complicatus. $E$. semplicatus is represented by the type of the species (Cope's pl. XxIII, fig. 2). This is a much-worn upper molar, which the writer has seen in the collection of the University of Texas. The height is only $30 \mathrm{~mm}$.; the length of the worn face, $24 \mathrm{~mm}$.; the width $23 \pm \mathrm{mm}$. The length of the protocone is $12.5 \mathrm{~mm}$. The great inner valley reaches nearly to the center of the crown and there is a small re-entering loop at its head. The anterior fossette has no fold in front, but three rather deep folds opposite the head of the inner valley. There is a small loop, or fold, in the front of the rear fossette, but none in its hiuder border. The anterior style is not prominent. The writer has not seen the upper molar 
referred by Cope (op. cit., p. 79) to $E$. tau. It appears to have had the same size as the teeth of $E$. semiplicatus, with the enamel still simpler; but it may belong to $E$. tau.

Two lower teeth in the collection preserved at Austin and found at Rock Creek are to be referred to $E$. complicatus, or to $E$. scotti, in case the latter is different from the former.

In 1900 (Bull. Amer. Mus. Nat. Hist., vol. xıI, pp. 111-116), J. W. Gidley described his Equus scotti, which he had discovered in the summer of 1899. At the head of the canyon of Rock Creek, itself opening into the canyon of T'ule Creek, an affluent of the Southern Fork of Red River, Gidley found the nearly complete skeletons of five horses, the members of a herd of young ones which had not yet shed the last milk-molars. In 1900, additional remains of the same horse were found here by Gidley (Bull. Amer. Mus. Nat. Hist., vol. Xıx, p. 619). All of these remains are in the American Museum of Natural History at New York. They are referred to Equus scotti. These horses were found in a bed of compact sand, which was believed to occupy the middle of the Equus, or Sheridan, beds. The beds at this place are about 100 feet thick. In 1912, the Peabody Museum of Yale University sent an expedition to this region under charge of Professor R. S. Lull. Six weeks were spent at the head of Rock Creek. A list of the species secured was published by Edward L. Troxell (Amer. Jour. Sci. ser. 4, vol. Xxxix, pp. 615-616). In this paper, Troxell described and figured a specimen of Gidley's Equus scotti, which is mounted at Yale University. He also described a new horse, $E$. calobatus, which is characterized by long, slender legs.

The horses, then, which appear to have been found at Rock Creek are as follows: Equus complicatus, E. scotti, E. semiplicatus, E. calobatus, $E$. tau? and $E$. excelsus??

From Rock Creek, Cope reported Equus tau, but he gave no illustration and no measurements of the teeth which he had, so that it is impossible to determine the species to which the teeth belonged.

South Tule Creek, Swisher County (3).-Dr. Charles L. Baker, formerly of the Texas Bureau of Economical Geology, informed the writer that he found a tooth of Equus on South Tule Creek. He wrote that this creek is a shallow "draw," scarcely over 20 to 25 feet in depth. Baker doubtless referred to this tooth in 1915 (Bull. No. 5\%, Texas Univ., p. 34). Gidley, in 1899, found, at the head of Tule Canyon, teeth, lower jaw, vertebræ, and limb-bones of an unidentified species of horse.

White Flat, Motley County (4).-In the collection of the University of Michigan, Ann Arbor, there are 5 lower teeth of a horse which is identified as Equus complicatus. They were probably collected by Dr. E. C. Case and are labeled as having been obtained 6 miles north of White Flat. This is probably on or near Tom Ball Creek. These teeth are yellowish white in color and appear to have been buried in sand. The following are the identifications and measurements, in millimeters, of these teeth: 


\begin{tabular}{|c|c|c|c|}
\hline & Height. & Length. & Width. \\
\hline Second lower premolar.... & 44 & 35 & \\
\hline Third lower premolar.... & 66 & 31 & 16.5 \\
\hline Fourth lower premolar....... & 84 & 29 & 16. \\
\hline First lower molar. . . . . . . . & 70 & 27 & 14.5 \\
\hline Second lower molar. . . . . . . & 96 & 32 & $\ldots$. \\
\hline
\end{tabular}

The deposits in which these teeth were buried belong probably to the so-called Equus beds, but we have no special information regarding them.

Quanah, Hardeman County (5).-In the collection of the University of 'Texas are two lower teeth of a fossil horse, labeled as having been collected by W. F. Cummins and with the locality given as "Forks of the Groesbeck." Cummins (4th Ann. Rep. Geol. Surv. Texas, 1892, p. 182) stated that he made a small collection of fossils on this creek, west of Quanah. On page 184 he further described the locality and stated that he found also remains of elephant and beaver. The teeth are considerably shattered. They belonged to a small horse, the length of the grinding-surface being only $22.5 \mathrm{mn}$.; the width, $135 \mathrm{~mm}$. There is no fold in the outer valley. This valley extends to, but does not enter between, the expansions of the anterior and posterior inner valleys. These teeth agree in size and arrangement of the enamel with the premolars of Equus francisi.

Benjamin, Knox County (6).-Cummins, in his report just cited, and on the same page, states that at a point 14 miles east of Benjamin he collected a few fragments of a mastodon and of a horse. These fossils occurred in what he called the Seymour beds; these beds seem to be found on the higher lands; they are further mentioned on page 233.

Wild Horse Creek, Howard County (7).-In his report of 1893 (4th Ann. Rep. Geol. Surv. Texas, p. 182) Cummins stated that he found, in the canyon of Wild Horse Creek, remains, probably teeth, of two species of horses; but these do not appear to have been described. In the same bed he discovered fragments of a large animal, probably a mastodon or an elephant, and of an animal about as large as a rabbit. The remains were in bed of sandy clay about 20 feet above the present bed of the creek.

Denton, Denton County (8).-In 1915, J. C. Coit sent to the U. S. National Museum, for determination, 2 equine molar teeth which he reported had been found in a gravel-bed about 6 miles northeast of Denton. At the National Museum one of the teeth, at least, was identified as belonging to Equus complicatus. He stated that other fossils, some of them large, had been taken from the same gravels. The height of the identified tooth was $90 \mathrm{~mm}$.; length of the grinding-face, $30.5 \mathrm{~mm}$.; width, $29 \mathrm{~mm}$.; the protocone, $16 \mathrm{~mm}$. Nothing more has been learned about the deposit.

Quinlan, Hunt County (41).-In 1923, D. A. Saunders, of Greenville, Hunt County, sent to the U. S. National Museum some fragments of teeth of an undetermined species of Equus, which he had picked up in the bed of a nameless creek, about 3 miles north of Quinlan. At the same locality was found a phalange of Megalonyx jeffersonii (p. 2). 
Dallas, Dallas County (9).--In 1887 (Monogr. XI, Hayden Geol. Surv., p. 424), Dr. J. A. Allen stated that the Museum of Comparative Zoology, at Cambridge, contains some teeth of Castoroides, which had been found near Dallas and which were associated with remains of an extinct horse and of the mastodon. The writer has not seen this material. In the autumn of 1923 Professor E. W. Shuler informed the writer that in a newly opened Lagow gravel-pit, within the limits of Dallas and a mile north of the old pit, had been found a jaw of a horse; also a lower jaw of a mastodon. A list of the fossil vertebrates found at Dallas is given on page 241.

Palestine, Anderson County (10). - In the American Museum of Natural History is a single tooth, an upper premolar, probably the antepenultimate, which was sent to Professor Cope from Palestine. The tooth was not greatly worn, the height being $68 \mathrm{~mm}$. The length of the grinding-surface is 28 mm., width $24 \mathrm{~mm}$., protocone $11 \mathrm{~mm}$. At a short distance below the grinding-face the width would be only $22 \mathrm{~mm}$. The tooth was regarded as belonging to Equus semiplicatus. The character and extent of the Pleistocene deposits here are not known. Palestine is on the high ground between Trinity and Neches Rivers.

White Rock Shoals, Trinity County (11).-In the American Museum of Natural History, New York, is a lower tooth of a horse, supposed to be a premolar, which was reported by E. T. Dumble as having been found at the base of the river alluvium, in Trinity River, at White Rock Shoals. These shoals are probably at the mouth of White Rock Creek. The tooth is $93 \mathrm{~mm}$. high, $32 \mathrm{~mm}$. long on the grinding-surface, and $17 \mathrm{~mm}$. wide. The enamel of the postprotoconal valley is much folded and the outer valley is broad and provided with a deep accessory fold. It was probably this tooth which Dumble had in mind when he mentioned the discovery of Equus and an unidentified species of mammoth at White Rock Shoals (Uni. Texas Bull., No. 1869, p. 268).

Sour Lake, Hardin County (12).--In 1868 (Proc. Acad. Nat. Sci. Phila., vol. $\mathrm{xx}, \mathrm{pp}$. 174-176), Leidy described some species of fossil vertebrates from this place. Among the materials were 7 horse teeth. These he referred to Equus complicatus. The other species described by Leidy are listed on page 242.

Some of the horse teeth are figured by Leidy on the plate just cited (figs. 3, 4, 7-10, 12, 13). Most of these certainly belong to Equus complicatus. The lower teeth represented by Leidy's figures 9 and 10 seem to be too narrow and too short to belong to this species, but must have been the teeth of a smaller horse. In size they agree with teeth of $E$. leidyi; they are referred to that species provisionally.

In the lot from Sour Lake and now in the American Museum of Natural History is an upper tooth which lacks the front half. It belonged to a very small horse, the width of the tooth being only $20 \mathrm{~mm}$. The protocone is 13 $\mathrm{mm}$. long. The front wall of the hinder fossette is furnished with 5 reentering loops, the hinder border with two loops. This tooth agrees more closely with the teeth found in Florida, which have been named by the writer Equus littoralis (Proc. U. S. Nat. Mus., vol. xLIV, p. 575, text-figs. 17, 18), than with any others. 
Galveston Bay, Galveston County or Chambers County (13).- In Leidy's work entitled "Contributions to the Extinct Vertebrate Fauna of the Western Territories," 1873, page 244, plate xxxıII, figure 11, he reported and figured a second or third upper molar, which he referred to Equus complicatus. According to Leidy's usage, on the page cited he meant that the tooth was either the third or fourth premolar. This was found by Dr. Thomas H. Streets in a gully of Galveston Bay and presented to the Academy of Philadelphia. Unfortunately no more accurate statement regarding the locality can now be secured. The upper half or more of Galveston Bay lies within the area of the Beaumont formation. This belongs, in the writer's opinion, to the early Pleistocene. From what we know of the history of the species along that coast it seems probable that this tooth was washed out of some part of the Beaumont which was laid down about the time of the Aftonian stage. The locality may have been in Galveston County or in Chambers.

Here may be recorded that in a collection of elephant remains, made at San Leon, Galveston County, in April 1921, by R. T. Roy, of Houston, which remains afterward became the property of Dr. Mark Francis, the writer found a few bones of an undetermined species of horse.

Waco, McLennan County (14).-The Francis collection of vertebrate fossils at College Station contains a third metatarsal bone of a fossil horse, found near Waco, in one of the Potts-Moore gravel-pits, on the northeastern side of the river. The length of the bone is $280 \mathrm{~mm}$., greatest width at upper end $55 \mathrm{~mm}$., width of upper articulary surface $50 \mathrm{~mm}$., fore-and-aft diameter at middle of length $35 \mathrm{~mm}$., side-to-side diameter $40 \mathrm{~mm}$. A part of the lower articular surface is gone. The geology of this region is discussed on page 243.

Marlin, Falls County (39). -With elephant remains which Dr. Mark Francis received from gravel-pits at Marlin, in 1922, was a radius of an unidentified species of Equus.

Reagan, Falls County (15).--In the U. S. National Museum (No. 8267) is a considerably worn left upper tooth, probably a third or fourth premolar, which was sent, in March 1915 , by S. P. Hurley, of Mexia. The tooth was found in a well, at a depth of 26 feet, somewhere about Reagan. The basal part of the tooth is missing; only about $40 \mathrm{~mm}$. of the crown is present. The length of the grinding-surface is $26.5 \mathrm{~mm}$.; width, $27 \mathrm{~mm}$.; length of the protocone, $15.5 \mathrm{~mm}$. The postprotoconal valley is narrow and very slightly notched at its anterior end. The arrangement of the enamel of the fossettes is simple, resembling much that of Cope's figures of E. semiplicatus (4th Ann. Rep. Texas Geol. Surv., pl. xxıII, figs. 2-3).

Curley Shoals, Robertson County (40).- This place is 6 miles west of Calvert. Here, in a conglomerate 10 or 15 feet above the river, Kennedy (4th Ann. Rep. Geol. Surv. Texas, p. 66) found fragments of the tibia of a horse.

Opposite Port Sullivan Shoals, Robertson County (16).--In the collection of the University of Texas are 5 lower teeth labeled as having been found at the shoals above the bridge at Port Sullivan. This town is on Brazos River about 10 miles above the southern line of the county. The teeth helonged to a rather young horse of the species Equus complicatus, the hindmost molar not yet being in use. One tooth is damaged. Possibly the teeth are not cor- 
rectly identified as to position in the jaw. The following measurements (in millimeters) were taken:

\begin{tabular}{|c|c|c|c|}
\hline Teeth. & Height. & Length. & Width. \\
\hline Third lower premolar. & 85 & 30 & 15 \\
\hline First lower molar. . . . & 100 & 28 & 15 \\
\hline Second lower molar. . & 100 & 32 & 13 \\
\hline
\end{tabular}

These are probably the ones obtained by W. Kennedy (4th Ann. Rep. Geol. Surv. Texas, p. 6\%). They were in the jaw when found and were buried in a dark bluish-gray, sandy clay 10 feet thick. The bottom of this bed is about 5 feet above the water in the river.

Pittbridge, Brazos County (17).- - In the Francis collection at College Station is an upper left tooth of a horse, found February 2, 1914, at Pittbridge. It is either the third or fourth premolar. The height of the crown is $55 \mathrm{~mm}$., length $30.5 \mathrm{~mm}$., width $29.5 \mathrm{~mm}$. The enamel is considerably complicated. The inner valley lacks much of reaching the center of the tooth. At its head there is a deep reëntrant loop and behind this a smaller one. The tooth is referred to Equus complicatus. In the same collection is a little-worn upper left last molar, which Doctor Francis found, in November 1916, at Pittbridge, in a bed of gravel. The tooth is well fossilized. Its height is about $70 \mathrm{~mm}$. The length of the grinding-surface is $28 \mathrm{~mm}$. near the outer face of the tooth; width $20 \mathrm{~mm}$. This tooth is referred provisionally to Equus complicatus. A third tooth from Pittbridge is the upper left last molar of E. complicatus. The height is $50 \mathrm{~mm}$., length $30 \mathrm{~mm}$., width 23 mm., protocone $14 \mathrm{~mm}$. Notwithstanding the advanced stage of wear, the enamel of the fossettes is considerably folded.

IIidalgo Falls, Washington County (18).-B. F. Shumard, the geologist, reported, in 1863 (Trans. St. Louis Acad. Sci., vol. II, p. 141), the finding at Hidalgo Falls of Equus (E. fossilis), Mastodon, Elephas, Megalonyx. Crocodilus, and Testudo. It appears that the materials on which these determinations were based belonged to the Texas Geological Survey. Shumard stated that Miocene beds at this place are overlain by a pebbly deposit, cemented with ferruginous matter into a coarse pudding-stone or conglomerate. It is this conglomerate which furnished the genera named above. According to Deussen's map (Water-supply Paper 335, pl. I), the Fleming Clay formation of the Oligocene is the Tertiary which is found here. It appears now that the Fleming belongs to the Miocene.

Washington County (19).--In Leidy's Contributions to the Extinct Fauna of the Western Territories, page 246, plate xxxıI, figure 18, is described and figured an upper molar tooth of a horse, sent to him by S. B. Buckley, the geologist. The tooth presented some peculiarities, which may have been due, to some extent, to the early stage of wear. The tooth was reported from Washington County, but the exact locality was not known to Leidy. It had a height of more than $100 \mathrm{~mm}$., length on the grinding-surface $33 \mathrm{~mm}$., width $25 \mathrm{~mm}$. It is quite probable that at a little later stage of wear the 
length of the grinding-surface would have been reduced. Leidy referred the tooth to Equus major (=E. complicatus), and this appears to be justified.

San Felipe, Austin County (20).-From B. Westermann, of Sealy, Dr. Mark Francis, of College Station, received a piece of the right maxilla containing 2 teeth, the last premolar and the first molar, of a horse found at San Felipe and which the writer identifies as Equus leidyi. The teeth are in excellent preservation and but little worn. The height of the premolar is about $75 \mathrm{~mm}$.; of the molar, about $60 \mathrm{~mm}$. The premolar is $27 \mathrm{~mm}$. long and $25 \mathrm{~mm}$. wide, with the protocone $15 \mathrm{~mm}$. long. The molar is $24 \mathrm{~mm}$. long on the grinding-surface and $24 \mathrm{~mm}$. wide. The length of its protocone is $11 \mathrm{~mm}$. The enamel of the fossettes is strongly folded.

Mr. Westermann sent from San Felipe also a well-fossilized equine lower tooth, apparently a first or second molar. The grinding-surface is $27 \mathrm{~mm}$. long and $13 \mathrm{~mm}$. wide, excluding the cement. There is no special complication of the enamel. The tooth probably belonged to $E$. leidyi. The larger part of this tooth, with a polished section, belongs in the Francis collection. A small part of the upper end of the crown, showing a polished cross-section, belongs in the U. S. National Museum; it has the catalogue No. 10,2\%6. At this locality has been found also a fragment of a lower jaw containing the second and third molars of a species of mastodon. This has been made the type of Anancus brazosius (Pan-Amer. Geologist, vol. xxxix, p. 112, pl. viIr, figs. 1, 2).

Brookshire, Waller County (21).-In Water-supply Paper 335, U. S. Geological Survey, on page 80, Dr. Alexander Deussen reported that teeth of a fossil species of Equus had been taken from a well belonging to C. Wilson, at a place 4 miles north of Brookshire.

A section of the well shows: red clay, 52 feet; sand and gravel, 25 feet; clay, 23 feet; sand and gravel, 37 feet; total 137 feet. The teeth were found in the sand and gravel in the bottom of the well, apparently at a depth of over 130 feet. The distance from Brazos River appears to be about 10 miles.

Temple, Bell County (22).--From Dr. Mark Francis the writer received, for examination, an injured upper tooth of a species of extinct horse found near Temple. This had been received from W. S. McGregor, member of a company owning a gravel-pit on the Leon River, who informed the present writer that the pit is situated 5 miles west of Temple and a mile north of Shallow Ford; also that the bones and teeth were met with at an elevation of about 40 feet above the normal water-line in the river. The terrace is the first one above the flood plain. The tooth was found 10 feet below the surface of the terrace. The tooth is an upper molar of the right side, either the second or the third. It presents the outer half of the crown. The height is $40 \mathrm{~mm}$.; length of grinding-surface $24 \mathrm{~mm}$. The outer styles are well developed. The enamel of the fossettes is rather simple. The size of the specimen and arrangement of enamel make the tooth resemble greatly one of Cope's specimens of Equus semiplicatus (4th Ann. Rep. Geol. Surv. Texas, p. 80, pl. xxIII, fig. 3). There appears to be no reason why it should not be referred to this species. From the same pit Dr. Francis received two other teeth, which are referred to E. semiplicatus. This pit has furnished also bones of a tapir and a camel. 
Bartlett, Williamson County (23).-In the collection of the University of 'Texas is a lower molar or premolar of an extinct horse, recorded as having been found by Professor E. 'T. Dumble at Station 85, Nueces Run, a mile from Bartlett, in gravel, with a mastodon tusk. The tooth is not much worn, the height being $80 \mathrm{~mm}$. It is probably the third premolar. 'The tooth is remarkable for the complicated foldings of the enamel and for its large size. It had been split and only the hinder inner quarter, or thereabouts, remains. There are seen the hinder half of the broad anterior inner column, the postprotoconal valley and its expansion, and the hinder inner column. The distance from the enamel of the rear of the tooth to the anterior end of the longitudinal expansion of the inner valley is $23 \mathrm{~mm}$. An estimate makes it appear that the whole length of the tooth must have been between 37 and $40 \mathrm{~mm}$. Judging from the portion present, the width was not greater than in a domestic horse, whose third premolar is only $30 \mathrm{~mm}$. long. Equus giganteus Gidley is the only horse known that could have so large a tooth.

Austin, Travis County (24).-In Professional Paper 126, U. S. Geological Survey, page 110, pl. virI, figure 2, Deussen describes a tooth of a horse, found in the sixth terrace at Austin, Texas. It is a premolar not much worn and resembles most a tooth of Equus excelsus. The length of the grinding-face is 28 $\mathrm{mm}$., width $2 \sim \mathrm{mm}$., height of crown $64 \mathrm{~mm}$. According to Deussen as cited, on his page 116, this tooth was found on the sixth terrace, at Ridge Top.

Delvalle, Travis County (25).-In the collection of the University of Texas is a single lower tooth, apparently a premolar of a horse, which is labeled as having been presented by Clarence Burck, of Delvalle, a place about 6 miles below Austin, in the angle between Colorado River and Onion Creek. Height of tooth $70 \mathrm{~mm}$., length of grinding-surface $30 \mathrm{~mm}$., width $15 \mathrm{~mm}$. The species has not been determined. The tooth is reported to have been found in a well at a depth of 40 feet.

Bastrop, Bastrop County (26).-In 1915, H. H. Duval sent to the U. S. National Museum an equine tooth which was determined by Dr. J. W. Gidley as probably belonging to Equus complicatus. It was found on a gravel-bar in the bed of Colorado River, near Bastrop.

Colorado River, Fayette County (27).-The writer has receired from C. L. Brock, of Houston, Texas, a damaged upper molar of some extinct horse. The tooth was found in a gravel-pit somewhere along Colorado River, in Fayette County, but nothing more definite has been learned about the locality.

Lissie, Wharton County (28).-Near Lissie, in the northern part of Wharton County, were found the skull and part of the skeleton which form the type of Equus francisi (Hay, Proc. U. S. National Museum, vol. xLiriI, p. 535 , pls. xxxv-xxxviII). These remains were discovered, at a depth of 25 feet, by a farmer, G. E. Thomas, in digging a well 0.75 mile west and 0.25 mile north of Lissie. The town of Lissie has given the name to the Lissie formation, further mention of which is found in the discussion of the Pleistocene geology of the State (p. 236).

Egypt, Wharton County (29).-The collection at Austin contains fragments of horse teeth found on a sand-bar of Colorado River, near Egypt. The name of the collector was B. S. Brown. A left lower molar or premolar has a height of $60 \mathrm{~mm}$., a length of $32 \mathrm{~mm}$., and a width of $13.5 \mathrm{~mm}$. The longitudinal expansion of the posterior inner valley is $19 \mathrm{~mm}$. long and its outer 
enamel wall is much folded; the outer valley has two nearly equal reentrant folds. The upper teeth, as far as represented, show that the enamel of the fossettes was considerably folded. These teeth seem to belong to $E$. complicatus.

In 1892 (Proc. Amer. Philos. Soc., vol. xxx, p. 123), Cope stated that he had received from E. T. Dumble several horse teeth found in Wharton County, but the exact locality was not given. The teeth were identified as those of Equus major (=E. complicatus). With these teeth was received a part of the lower jaw of a camel, Camelops hesternus. In a footnote (Cope, 4th Ann. Rep. Geol. Surv. Texas, p. 84) it is stated that the camel jaw was found at Bowie Bend, Austin County.

R. F. A. Penrose (1st Ann. Rep. Texas Geol. Surv., p. 47) determined, on geological grounds, the age of the beds in which these remains were found as late Pliocene and referred them to the Fayette formation. Cope regarded the presence of the horse and the camel as confirming the belief that the Equus beds belonged to the Pliocene.

Seguin, Guadalupe County (30).-From Professor J. F. Saegert, of Seguin, the writer learned that some fossil horse teeth had been found near Seguin, in a gravel-pit, on the banks of Little Walnut Creek. No further information has been received.

"Screw-bean bridge," Guadalupe County (31). - In the collection belonging to Colorado College, Colorado Springs, Colorado, is an upper molar of a horse collected by Professor F. W. Cragin and labeled as above indicated. This tooth is worn down to within about an inch from the roots. The length of the grinding-face is $30 \mathrm{~mm}$.; width only $20 \mathrm{~mm}$. The enamel is pretty strongly folded. It belongs probably to Equus complicatus.

Nine miles southeast of San Antonio, Bexar County (38).-Dr. Mark Francis reported to the writer that he has a part of the lower jaw of a horse, with 3 teeth, found 9 miles southeast of San Antonio, in the Rosillo gravelpit. This is on the Gibler land and on the W. W. White road. The pit is probably near Rosillo Creek.

San Diego, Duval County (32).-Remains of various horses and other extinct vertebrates have been found in this region, but the localities were not definitely indicated. Dr. E. T. Dumble (Amer. Inst. Min. Engineers, vol. XXXIII, 1903, p. 984) stated that the larger number of the fossils sent to Cope from San Diego had been collected on Tarancahaus Creek, Duval County.

In 1885 (Amer. Naturalist, vol. XIX, pp. 1208-1209), Cope reported that deposits which he then regarded as Pliocene, near San Diego, had furnished Mastodon americanus, Cistudo marnockii, Equus barcenci, E. fraternus, $E$. excelsus, E. occidentalis, and E. crenidens. In 1893 (4th Ann. Rep. Geol. Surv. Texas, p. 79), the teeth referred above to $E$. barcenæi, were identified as those of Owen's E. tau. No figures of these were given and they are described as having the "molars $25 \times 25 \pm \mathrm{mm}$. and the enamel borders as simple," differing from those of $E$. semiplicatus in having the enamel borders complicated in the middle of the crown. According to Owen's figures, E. tau had smaller crowns than Cope's description indicates and the width is less than the length (Gidley, Bull. Amer. Mus. Nat. Hist., vol. xIv, p. 120). In the American Museum of Natural History are 3 teeth from New Leon, Mexico, with quite complicated enamel; these were referred by Cope to $E$. tau. 
In the report of 1893 , on page 80, Cope's $E$. fraternus of 1885 and of 1889 (Amer. Naturalist, vol. xxıII, p. 161) was referred to his E. semiplicatus; his $E$. barcenai to E. tau; E. occidentalis probably to $E$. excelsus; while $E$. crenidens is not mentioned.

In the collection at Austin is an upper right third molar which is labeled in Cope's handwriting as Equus barcenai, from San Diego, and credited to E. T. Dumble. The length of the grinding-surface is $23 \mathrm{~mm}$., width $19 \mathrm{~mm}$., protocone $13.5 \mathrm{~mm}$. The tooth is bent considerably inward and backward

\begin{tabular}{|c|c|c|}
\hline & $\begin{array}{l}\text { San Diego } \\
\text { horse. }\end{array}$ & E. francisi. \\
\hline & $m m$. & $m m$. \\
\hline $\begin{array}{l}\text { Distance from incisive border to middle of line joining rear of gle- } \\
\text { noid fossæ } \ldots \ldots \ldots \ldots \ldots \ldots \ldots \ldots \ldots \ldots \ldots\end{array}$ & $380 \pm$ & \\
\hline Width of skull across glenoid fossæ. . . . . . . . . . . . . & $180^{-}$ & 167 \\
\hline Width of skull on maxillary at front of first upper molar. . . . . . . & 145 & \\
\hline 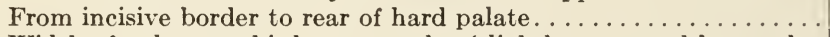 & $235 \pm$ & 210 \\
\hline $\begin{array}{l}\text { Width of palate at third upper molar (slightly narrowed by crush- } \\
\text { ing?) } \ldots \ldots \ldots \ldots \ldots \ldots \ldots \ldots \ldots \ldots \\
\end{array}$ & 60 & \\
\hline Width of palate at middle of second upper premolar . . . . . . . . . & 48 & \\
\hline Width of palate at diastema, least. . . . . . . . . . . . . . & 37 & 39 \\
\hline Width of palate at rear of third upper incisor . . . . . . . . . . & 66 & 68 \\
\hline Vertical diameter of orbit. $\ldots \ldots \ldots \ldots \ldots \ldots \ldots \ldots \ldots$ & 53 & $\ldots$ \\
\hline $\begin{array}{l}\text { Distance from third upper incisor to front of second upper pre- } \\
\text { molar } \ldots \ldots \ldots \ldots \ldots \ldots \ldots \ldots \ldots \ldots \ldots \ldots \ldots\end{array}$ & $98 \pm$ & \\
\hline 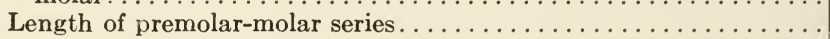 & 153 & 135 \\
\hline 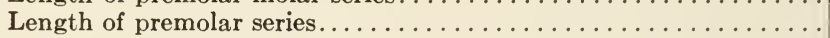 & 83 & 74 \\
\hline Length of molar series $\ldots \ldots \ldots \ldots \ldots \ldots \ldots \ldots \ldots \ldots$ & 70 & 61 \\
\hline Second upper premolar, length. . . . . . . . . . . . . . . & 33 & 28 \\
\hline 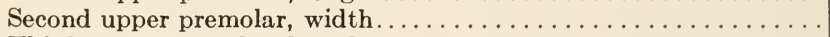 & 24 & 23 \\
\hline Third upper premolar, length $\ldots \ldots \ldots \ldots \ldots \ldots \ldots \ldots \ldots \ldots$ & 27 & 23 \\
\hline 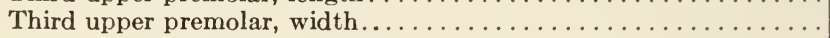 & 26 & 23 \\
\hline Third upper premolar, protocone $\ldots \ldots \ldots \ldots \ldots \ldots \ldots \ldots$ & 11.5 & 10 \\
\hline Fourth upper premolar, length. . $\ldots \ldots \ldots \ldots \ldots \ldots \ldots \ldots \ldots$ & 25 & 21 \\
\hline 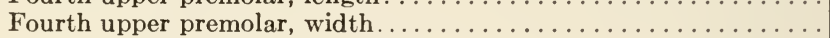 & 26 & 23 \\
\hline Fourth upper premolar, protocone $\ldots \ldots \ldots \ldots \ldots \ldots \ldots \ldots$ & 14 & 10.5 \\
\hline 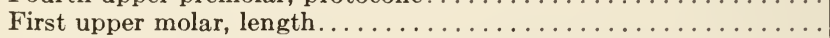 & 25 & 19.5 \\
\hline First upper molar, width $\ldots \ldots \ldots \ldots \ldots \ldots \ldots \ldots \ldots \ldots \ldots$ & 26 & 22 \\
\hline First upper molar, protocone. . . . . . . . . . . . & 14 & 11 \\
\hline Second $u p p e r$ molar, length. $\ldots \ldots \ldots \ldots \ldots \ldots \ldots \ldots \ldots \ldots$ & 23 & 20 \\
\hline 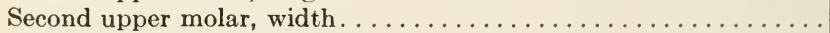 & 23 & 21 \\
\hline Second upper molar, protocone $\ldots \ldots \ldots \ldots \ldots \ldots \ldots \ldots \ldots$ & 14 & 12 \\
\hline 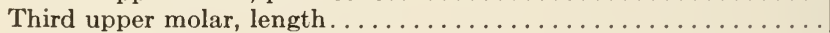 & 23 & 21 \\
\hline Third upper molar, width. . . . . . & 21 & 18 \\
\hline Third upper molar, protocone $\ldots \ldots \ldots \ldots \ldots \ldots \ldots \ldots \ldots$ & 14 & 12 \\
\hline
\end{tabular}

in passing from the summit to the roots. The enamel of the fossettes is simple. The measurements do not agree well with those of the corresponding tooth of Owen's type of the species. It may really belong to $E$. semiplicatus.

In the collection at Austin is a well-worn upper tooth found at San Diego and referred to $E$. semiplicatus. The height is $31 \mathrm{~mm}$., length $25 \mathrm{~mm}$., width $26 \mathrm{~mm}$., protocone $13 \mathrm{~mm}$. The enamel has a very simple arrangement, but this may be due mainly to the advanced stage of wear. There is only a slight notch opposite the head of the great inner valley.

In the collection mentioned is a lower tooth of the right side, supposed to be a first molar, which was found at San Diego. It appears to have been 
regarded as belonging to $E$. semiplicatus. The height is $52 \mathrm{~mm}$., length 22.5 $\mathrm{mm}$., width $13.5 \mathrm{~mm}$. The outer valley approaches closely to the interval between the longitudinal expansions of the inner valleys. It is without an accessory fold. This tooth may belong to $E$. tau or to E. francisci. Another lower tooth, of the left side, regarded as belonging to E. semiplicatus, has a height of $80 \mathrm{~mm}$., a length of $25 \mathrm{~mm}$., and a width of $10.5 \mathrm{~mm}$. A third tooth is present and has the same height and length as the preceding, and a width of $14 \mathrm{~mm}$. The inner anterior column is deeply divided, the inclosed valley ending sharply. The tooth is bent so as to make the front border convex. The tooth, or teeth large enough to be regarded as belonging to $E$. occidentalis may have belonged to $E$. complicatus.

From San Diego, collected by W. Taylor, Cope received a large part of a skull, which is now No. 8600 of the American Museum of Natural History, New York. This was referred to Equus excelsus and described first in 1891 (Amer. Naturalist, vol. xxv, p. 912). A figure of it is presented in Cope's work of 1893 (4th Ann. Rep. Geol. Surv. Texas, pl. xxir, fig. 3) ; it was afterwards figured by Gidley (Bull. Amer. Mus. Nat. Hist., vol. xıv, fig. 21, p. 130). This skull lacks the rear and the base and is crushed somewhat between the orbits. The first incisors, right and left, and the outer right incisor are missing. The following measurements and notes have been secured from this skull. As there is a break at the diastema, the distances from the incisive border to other points are uncertain. Cope's figure purports to be half the natural size, but is only 0.431 of this. (See table on page 132.)

The arrangement of the enamel of these teeth is rather simple; the inner valley is very narrow, while the protocone is wide. The teeth are too small to agree with those of the type of Equus excelsus and the external styles are not so strongly developed. All the measurements common to the San Diego specimen and the type of $E$. francisi show that they belong to distinct species. Gidley referred the San Diego specimen to E. semiplicatus and there appears to be no serious objection to the disposal of it.

The large horse tooth which Cope received from the region about San Diego, and which he referred to Equus crenidens (Amer. Naturalist, vol. xIx, p. 1209, pl. xxxvir, fig. 4 ; vol. xxI, p. 1072, fig. 42), was afterwards made by Gidley the type of E. giganteus (Bull. Amer. Mus. Nat. Hist., vol. xiv, p. 137, fig. 27). It indicates the largest horse known. The height of the tooth is 100 $\mathrm{mm}$., length of the grinding-surface $40 \mathrm{~mm}$., width $39 \mathrm{~mm}$.

In the Wagner Institute at Philadelphia there is a pelvis of a small horse which appears to have been found somewhere about San Diego.

Nueces County or Jim Wells County (33).-Professor E. D. Cope, as cited above, stated that Equus major (=E. complicatus) occurs in the Equus beds of Nueces County, but he does not specify the exact locality. Some of the fossils reported from San I)iego may really have been found farther east, in what was then Nueces County or further west in Duval County. Since that time the western part of Nueces County has become Jim Wells County. San Diego is very close to the eastern border of Duval County.

Nueces County, southern part (34).- The writer was informed by $\mathrm{Dr}$. Mark Francis, of College Station, that he had seen a horse tooth which had 
been brought up by the auger in boring a well on the Ranchos de los Laurelos, a ranch then owned by a Mrs. King. At what depth the tooth was encountered the writer does not know. The place is 20 miles south of west of Corpus Christi and between 10 and 15 miles away from the coast. This region is probably occupied by the Beaumont formation, but the tooth may have been brought up from the Lissie.

Maverick County (35).--From Dr. C. L. Baker, geologist, the writer received parts of 3 horse teeth found 2 miles west of the point where the boundary-line between Zavalla and Dimmit Counties intersects the eastern line of Maverick County and near the northwest corner of section 98. Associated with them were indeterminable bones of a proboscidean. These remains were found in sandy and gravelly clay, weathering yellow. The teeth belong to the right side of the upper jaw. One is the third molar; another is the first or second molar; a fragment of another is probably a premolar. The species appears to be Equus complicatus. At the same locality Doctor Baker found a cannon bone of a horse, but it crumbled on exposure.

Terlingua, Brewster County (36).--In Economic Geology, volume I, page $275, \mathrm{H} . \mathrm{W}$. Turner reported the discovery of bones of a ground-sloth and teeth of a horse in a fissure of a quicksilver mine, the Tierra lode, at the 100-foot and 150-foot levels. These specimens were sent to Dr. John C. Merriam for identification. The species of horse was not determined. It appears probable that these animals lived there during the early Pleistocene. The ground-sloth was identified as belonging to the genus Nothrotherium (Stock, Bull. Dept. Geol. Univ. Calif., vol. x, p. 138).

El Paso, El Paso County (3\%).--At a meeting of the Geological Society of Washington, November 14, 1906 (Science, vol. xxv, p. 32), Dr. G. B. Richardson exhibited some mammalian remains which had been found in Rous's gravel-pit in the northern part of El Paso. Among these was a tooth of a horse, which was identified by J. W. Gidley as that of Equus complicatus. Other teeth in the collection were identified as those of Elephas columbi and Tapirus haysii. These specimens occurred in cross-bedded sands at two horizons, one at 30 feet and the other at 60 feet below the surface of a hill which is an erosion outlier of the bolson plain at the base of Franklin Mountains. These remains were mentioned also by W. T. Lee (Bull. Geol. Soc. Amer., vol. xviri, p. 215). This horse tooth is a left second molar, which has a height of $55 \mathrm{~mm}$. The grinding-surface is $26.5 \mathrm{~mm}$. long and $27 \mathrm{~mm}$. wide. It appears to be too small to belong to E. complicatus. The remains found in this gravel-pit belong probably to the early Pleistocene, most probably to the Sheridan epoch, or thereabouts.

\section{ARKANSAS.}

(Map 15.)

Willcockson, Newton County (1).-At a point 4 miles west of Willcockson, in a limestone fissure known as the Conard fissure, Barnum Brown, in 1903 and 1904, made a large collection of fossil vertebrates. This was described in 1908 (Mem. Amer. Mus. Nat. Hist., vol. Ix). This fissure and the species found there will be discussed on another page. Among these remains was a single upper penultimate milk-molar of a horse, which was referred with doubt to Equus scotti. 


\section{OKLAHOMA.}

(Map 15.)

Afton, Ottawa County (1).-In the U. S. National Museum-some in the department of anthropology and others in the department of palæontologyare many teeth of horses, collected at Afton in 1901 by Professor W. H. Holmes. On page 253 is given a brief account of the spring in which they were found and a list of the 19 species of mammals there secured. The horse teeth are referred to five species, viz., Equus complicatus, E. holmesi, E. hatcheri, $E$. laurentius, and $E$. excelsus. All of these appear to the writer to belong to the Aftonian interglacial stage, except a part of the teeth of $E$. complicatus. These may have belonged to horses which lived as late as the Sangamon stage.

\section{EquUs complicatus.}

The collection made at Afton contains several teeth, upper and lower, which are referred to this species. Among these are three upper second premolars. These have the cement, and to some extent the enamel and the dentine, stained black and brown. Where exposed, the dentine adheres strongly to the tongue. One of these teeth has the grinding-surface $41 \mathrm{~mm}$. long and $30 \mathrm{~mm}$. wide. Many lower premolars and molars must also be credited to this species. Most important are three premolars contained in a fragment of a jaw. Figures of these are to be found in Proceedings of the U.S. National Museum, volume 58,1920 , plate 7 , figure 1 . The bone and surfaces of the teeth are of a reddish-brown color. These measure as follows (in millimeters) :

\begin{tabular}{|c|c|c|c|}
\hline & Height. & Length. & Width. \\
\hline Second lower premolar. & 57 & 38 & 15 \\
\hline Third lower premolar. . & 72 & 33 & 16 \\
\hline Fourth lower premolar.. & 70 & 32 & 16 \\
\hline
\end{tabular}

Among the lower molars referred to $E$. complicatus are some that may belong to one or more of the other large extinct species, as $E$. hatcheri. 'Two lower supposed molars (one right, the other left), are black, heavy, and well fossilized. They are little worn and measure as follows:

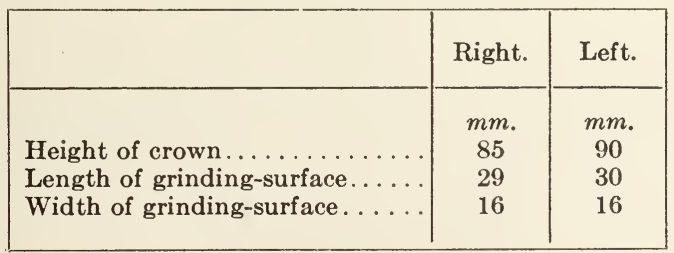

The collection contains 3 upper incisor teeth, which, on account of their size, are referred to $E$. complicatus; 2 of these are the right and the left first incisors of one individual and a second left incisor of another. The enamel is black or mottled black and white. These teeth belonged to horses about 3 or 4 years of age; the cups are yet present and deep. The first incisors measure $22 \mathrm{~mm}$. across the worn surface; the second measures $27 \mathrm{~mm}$. All 
have two shallow grooves in front; the second incisor has a third groove near its outer border.

\section{EQUUS HOLMEST.}

The teeth of this large horse were described by the writer in 1920 (Proc. U. S. Nat. Mus., vol. LviII, p. 119, pl. viI, figs. 9-12). They had previously been regarded as those of the domestic horse.

\section{EquUS Hatcheri.}

A single upper left molar, the first or the second, is referred to Equus hatcheri. It had only just begun to wear. It has been sawn across at the middle of the height. A view of the polished face has been published by the writer (Proc. U. S. Nat. Mus., vol. LviII, p. 119, pl. vir, fig. 2). The outer styles are injured at the level of the section; they are not strongly developed. The following measurements are given in millimeters. Heignt of crown, 75 ; length of crown at section, 28 ; width of crown near section, 26.5 ; length of protocone, 16. This may be compared with the teeth of the type of $E$. hatcheri (Proc. U. S. Nat. Mus., vol. xuviII, p. 531, text-fig. 2). It differs from the upper molars of the type in having a reentrant loop near the head of the post-protoconal valley.

\section{EQUUS LAURENTIUS.}

Six upper teeth, premolars and molars, are referred to Equus laurentius; they are well preserved, with the cement stained mostly reddish brown. Where exposed, the dentine is white and adheres strongly to the tongue. Most of these teeth are in an early or medium stage of wear, and the characters are well presented. Measurements of three of these are here presented. No. 1 is a much-worn left premolar; No. 2 is taken to be a right second molar; No. 3 is a left molar, probably the first.

Measurements (in millimeters) of upper teeth.

\begin{tabular}{|l|c|c|c|}
\hline & No. 1. & No. 2. & No. 3. \\
\hline Height of crown ...... & 55 & 70 & 70 \\
Length of crown ...... & 28 & 27 & 25 \\
Width of crown....... & 30 & 26 & 25 \\
Length of protocone... & 13 & 12 & 12 \\
\hline
\end{tabular}

Tooth No. 2 is strongly bent backward; No. 3 is little bent backward, but bent so that the outer face is convex. The presence of these teeth at Afton was mentioned by the writer in 1920 (Proc. U. S. Nat. Mus., rol. Lvir, p. 119).

\section{EquUs excelsus.}

Three upper grinding-teeth are referred to this species. Two of these are stained black; the other mostly reddish brown. All three are broken teeth. The heights given in the following table are approximate and, as in other cases, are intended only to show the stage of wear. The tooth of the first column is a molar and has the catalogue No. 9105 ; that of the second column is believed to be a last premolar and has the No. 9106; that of column 3, a molar, belongs in the department of anthropology of the U. S. National Museum. 


\begin{tabular}{|l|c|c|c|}
\hline & No. 1. & No. 2. & No. 3. \\
\cline { 2 - 3 } & & \\
\hline & $m m$. & $m m$. & $m m$. \\
Height of crown..... & 60 & 70 & $\ddot{2}$ \\
Length of crown..... & 25 & 27 & 28 \\
Width of crown...... & 27 & 26 & 27 \\
Length of protocone... & 13 & 18 & 17 \\
\hline
\end{tabular}

In the collection are 12 lower grinding-teeth whose identity is uncertain. Their size indicates that they belong to either Equus laurentius or E. excelsus. Lower premolars and molars of E. excelsus have not yet been found in unquestionable association with the upper ones; but it is to be supposed that the lengths of the grinding-surfaces would equal, or more likely surpass, the lengths of the upper ones. On the other hand, while the dimensions of the teeth agree with those of E. laurentius, the enamel is more plicated than in the teeth of the type. Of the teeth in the collection, 6 are stained a chestnutbrown color; 5 are black; and one, almost wholly without cement, is beautifully white. It is not unlikely that the chestnut teeth belonged to one individual. Measurements are given of three of these lower teeth. No. 1 is a right second premolar (Cat. No. 9106); No. 2 is apparently a fourth premolar; No. 3, the white tooth, seems to be a left first molar.

Measurements (in millimeters) of lower teeth.

\begin{tabular}{|l|c|c|c|}
\hline & No. 1. & No. 2. & No. 3. \\
\cline { 1 - 3 } Height of crown...... & 55 & 80 & 85 \\
Length of crown...... & 33 & 26 & 26 \\
Width of crown...... & 13 & 15 & 15 \\
\hline
\end{tabular}

Inasmuch as there are present 6 upper teeth which are referred to $E$. laurentius and 3 to $E$. excelsus, the probability is that the lower teeth belong to the former species. Again, it may be that both species are represented. Mention of some of the teeth here described was made in a paper by the writer in 1920 (Proc. U. S. Nat. Mus., vol. LvIII, p. 119).

\section{NEW MEXICO.}

(Map 15.)

Mastodon Station, Donna Ana County (1).-In 1907 (Bull. Geol. Soc. Amer., vol. xviII, p. 215), Dr. W. T. Lee reported that at the place named, in a railroad cut, bones of a horse and of a mastodon had been found. The horse was identified by J. W. Gidley as Equus complicatus. The present writer has not seen the specimens.

Afton, Donna Ana County (2).-In $190 \%$ (Bull. Geol. Soc. Amer., vol. xvIII, pp. 211-220), Dr. Willis T. Lee described some craters believed to be of volcanic origin, about 30 miles northwest of El Paso, Texas, west of the Rio Grande, and about 8 miles south of Afton. One of the craters, known as the Kilburn, is 2 miles long, 1.25 miles wide, and 250 feet deep below the general surface. The level plain in which these craters are situated is the aggraded surface of the ancient valley of the Rio Grande, and the deposit is of 
Pleistocene age. Over these old beds is an ancient sheet of lava and also later beds of lava. The craters appear to have been produced at the time of the later eruptions. In the sinking of a well in the Kilburn crater, at a depth of 70 feet and 330 feet below the general level of the plain, there was found a part of a lower jaw of a species of Equus. Lee is of the opinion that the horse jaw had been buried in river deposit before the eruption and that it had reached the position where found by the falling of the sides of the crater. His opinion is confirmed by the finding of remains of horses and tapirs in similar deposits near El Paso.

Black Rocks, McKinley County (3).- In the U. S. National Museum are some remains of a horse which were discovered at the place indicated, in making the excavations for the Zuni Reclamation dam. There is a part of a lower jaw without teeth, and a part of a left innominate bone. The species is indeterminable. At the same place were found Elephas columbi, a bone of a camel, and the musk-ox Gidleya zuniensis. In the U. S. National Museum the horse bones have the catalogue No. 5098.

Ildefonso, Santa Fé County (4).--In 1875 (Rep. Wheeler Exped., vol. III, p. 543) G. K. Gilbert reported the finding of some vertebrate remains near this place. His account was in part quoted from Dr. Oscar Loew, who had visited the locality. This is 1.5 miles north of Ildefonso, in some hills of alluvial drift. Loew found there fossil bones of several mammals. A collection had previously been made by Governor W. T. M. Arny. The combined collection was placed in the hands of Professor O. C. Marsh for study. He made a preliminary report, in which he recognized "the presence of Mastodon, Rhinoceros, Equus, and Procamelus." What part of Equus was found is now unknown. It appears safe to credit this genus to the locality. The other genera belonged to late Tertiary deposits.

\section{MISSOURI.}

(Map 15.)

Papinsville, Bates County (1).--In 1869, G. C. Broadhead (Trans. St. Louis Acad. Sci., vol. III, p. xx; Amer. Naturalist, vol. IV, p. 60) reported the discovery of a tooth of a horse at Papinsville, at a depth of 31 feet. This was examined by Doctor Leidy, who pronounced it to be the last upper molar of probably an extinct species. Papinsville is situated on the Marais des Cygnes River. In his report on Bates County (Geol. Surv. Missouri, 1874, p. 15\%), Broadhead again referred to this tooth. He stated that wells dug at Papinsville show 31 feet of yellow clay resting on 4 inches of blue clay and gravel. Beneath this was found a thin sandy stratum which inclosed the tooth of the extinct horse. Underneath this, again, was a gravel bed 5 feet thick. Broadhead recognized the fact that this region had suffered extreme denudation, as one result of which all drift pebbles had been swept away from the surface, except on the higher grounds. He expressed the opinion that this denudation had been due to glacial action. This region is, however, probably 30 or 40 miles away from the border of the nearest drift sheet, the Kansan. It has, therefore, been subjected to erosion during the whole of the Pleistocene. However, from the fact that the horse tooth was buried at such a depth it would appear that a good deal of deposition of materials occurred in the 
valleys. These materials may have been laid down, partly at least, by streams proceeding from the Nebraskan or the Kansan ice sheets. The tooth may belong, therefore, to the Aftonian or to the Yarmouth interglacial stage. Again, it is not impossible that the horse belonged to a hardy species which lived close up to the glacial front. The present writer has examined the tooth in question. It is preserved in the collection of the State University of Missouri, at Columbia. It is worn down to about half an inch from the root. The length of the grinding-surface is $27.5 \mathrm{~mm}$., width $22 \mathrm{~mm}$. It is well fossilized, The species can not be determined with any certainty.

Osage River, Benton County (2).--In 1869 Dr. Joseph Leidy stated (Ext. Mamm. Fauna Dak., Neb., p. 263) that there was in the collection of the Academy at Philadelphia a coronary bone of a horse, found in Benton County, Missouri, in association with remains of Boötherium cavifrons and a great abundance of remains of Mastodon americanus. In treating of the specimens of the musk-ox, now known as Symbos cavifrons, Leidy (Smithson. Contrib. Knowl., vol. v, art. III, p. 16) wrote that they were among a large collection of mastodon bones which had been secured in Benton County and purchased by the American Philosophical Society. This collection is doubtless that made by $\mathrm{S}$. H. Whipple, of which mention is made on page 28 in connection with the mastodons from the Osage River locality. It would be of great interest to know at what levels the horse bone and the musk-ox remains had been found. To the collectors of that day, and to too many of this, it was sufficient to have found all of these bones in the same hole in the ground.

Kimmswick, Jefferson County (3).- In 1840, Albert Koch (Short Descrip. Foss. Remains Found in Missouri, p. 3) stated that he found at Rock Creek, 20 miles south of St. Louis, a tooth of a horse. For a brief description of the locality, see page 262.

In July 1921 the U. S. National Museum received from Dr. W. F. Parks, of St. Louis, Missouri, a finely preserved third or fourth upper premolar of Equus complicatus, found at Kimmswick. A list of the species from this locality is given on page 263 .

On Bluffs near St. Louis (4).-In the collection of the Philadelphia Academy is a large upper right second premolar $\left(\mathrm{pm}^{2}\right)$, found by B. F. Shumard on what was called the Illinois Bluffs. stated to be 6 miles west of St. Louis. It was reported by Shumard as being derived from the "bluff formation." It came, therefore, probably from the loess. The tooth is that of Equus complicatus and may for the present be regarded as belonging to the Sangamon, or possibly the Peorian, interglacial epoch. The writer is informed by Professor W. E. McCourt, of Washington University, St. Louis, that he knows of no Illinois Bluffs west of St. Louis. Evidently, Shumard did say, or intended to say, that the tooth had been found in the bluffs on the Illinois side of the Mississippi, 6 miles east of St. Louis. Inasmuch as the locality is not reported in the writer's "Pleistocene of North America, etc., 1923," it is credited here to St. Louis.

Rockport, Atchison County (5).-In 1911, Dr. Samuel Calvin announced (Bull. Geol. Soc. Amer., vol. xxIr, p. 210) the discovery of horse remains near Rockport. The exact locality was a gravel-pit in section 22, township 64 north, range 41 west. The remains consisted of a metatarsal, 4 lower molars, 
and a worn upper molar. Associated with the horse were Elephas columbi, a camel, and a species of Hipparion resembling $I$. gratum but belonging more probably to $I$. cragini Hay. 'The horse was provisionally identified by the writer (Iowa Geol. Surv., vol. xxIII, p. 201) as Equus niobrarensis. 'The deposit was regarded by Calvin as belonging to the Aftonian.

\section{KANSAS.}

(Map 15.)

Palermo, Doniphan County (1).-From George W. Groneweg, St. Joseph, Missouri, the writer received a lower left second true molar of a horse, found near Palermo. 'I'he exact locality is in the east half of the northeast quarter of section 24, township 4 south, range 21 east. 'The tooth was found by Albert Kienhoff, of Wathena, in a small stream on his farm. At the same place were found a tooth of Elephas columbi and bones and teeth of Mammut americanum. Several other horse teeth are said to have been found here, but the writer has not seen them. The tooth in question is identified as that of Equus niobrarensis. It had just begun to wear. The length is $28 \mathrm{~mm}$; width, $13 \mathrm{~mm}$. It appears quite certain that the deposits containing these remains belong to the Aftonian stage. The geological situation is further explained on page 34 , where the mastodon from the same place is discussed.

Atchison, Atchison County (10).-In 1923 there were sent to the U. S. National Museum by E. Raymond Hall, of Lawrence, Kansas, for determination, 3 horse teeth found on an Indian camp-site 4 miles north of Atchison. With the teeth described below was found a tooth of Protohippus. Under the circumstances, one can not be absolutely certain that the teeth had not been brought there from some distance. The Equus teeth consisted of an upper molar (the first or second) of the left side and both lower hindmost molars. The teeth were in an early stage of wear. Following are the measurements of the upper molar: Height, $75 \mathrm{~mm}$.; length of grinding-surface, $28 \mathrm{~mm}$.; width, $28 \mathrm{~mm}$.; length of protocone, $15 \mathrm{~mm}$. Measurements taken at half the height are: Length, $26 \mathrm{~mm}$.; width, $28 \mathrm{~mm}$; protocone, $15 \mathrm{~mm}$. The inner face of the protocone has a median groove the whole height of the tooth. The tooth is not much curved. The striking feature of this tooth is the extreme complication of the enamel. It equals or excels that of the horse which Cope called Equus pectinatus. Whether $E$. pectinatus is the same as Equus complicatus has not yet been determined. The lower hindmost molars are, as usual, curved backward in passing from the grindingsurface to the root. They are thin. Height, $55 \mathrm{~mm}$.; length of grindingsurface, $32.5 \mathrm{~mm}$.; width in front, $13 \mathrm{~mm}$. The enamel is more complicated than usual in lower teeth. The inlet between the metaconid and the metastylid forms a double loop. The enamel elsewhere is more or less crimped. The writer sees no good reason why these teeth should not be referred to Equus complicatus. 'The 3 teeth here described evidently belonged to one individual, and this fact appears to favor the supposition that they had not been brought from a great distance. The surface deposit at the locality is said to be loess.

Marysville, Marshall County (2).-In 1866 ('Trans. St. Louis Acad. Sci., vol. II, p. 418) G. C. Swallow, the geologist, reported having examined a lower jaw of a horse, which had been discovered at Marysville. It was found by 
Hon. E. C. Manning, in sinking a well, at a depth of 45 feet, in beds of stratified sand, which, as stated by Swallow, lie beneath the Bluff (loess) formation and the drift. Other parts of the skeleton had been met with, but Swallow did not see them. The jaw and teeth reported by Swallow are now in the Kansas Agricultural College, at Manhattan, to which college the specimen was presented by Mr. Manning in 1865 and has been seen by the writer. There are present 3 teeth instead of 2 . These are identified as the second and third premolars of the right side and the second molar of the left side. The teeth are but little worn. The enamel is only moderately complicated. The following are their dimensions in millimeters:

\begin{tabular}{|c|c|c|c|}
\hline & Height. & Length. & Width. \\
\hline Second lower premolar..... & 70 & 38 & 17 \\
Third lower premolar...... & 90 & 32 & 19 \\
Second lower molar...... & 90 & 32 & 15 \\
\hline
\end{tabular}

These teeth are certainly those of Equus complicatus. The teeth bear the number 1983. On the label it is stated that the specimen was found at a depth of 40 feet. Marysville is within the area covered by the Kansan drift, and it seems most probable that the jaw was buried in Aftonian deposits.

Harper Township, McPherson County (3).-In 1897 (Univ. Kan. Geol. Surv., vol. II, p. 303), Williston reported that a tooth of Equus major (= E. complicatus) as identified by Professor Cope, had been found in the vicinity of McPherson, associated with Megalonyx leidyi. Professor E. O. Deere, of Bethany College, Lindsborg, writes that the horse tooth is not in their collection. The type of Megalonyx leidyi was found in Harper Township, but in what part the writer has not been able to learn.

Minneapolis, Ottawa County (4).-In the collection of the Kansas Agricultural College, at Manhattan, is a large lower tooth of a horse, labeled as having been presented by D. M. Dunn and as having come from Minneapolis, Kansas. The tooth is but little worn. The height is $100 \mathrm{~mm}$., length 32 mm., width $17 \mathrm{~mm}$. The enamel is considerably folded. It is identified as Equus complicatus and is probably the third upper premolar.

Russell, Russell County (11).-In May 1924, W. W. Rubey, of the U. S. Geological Survey, sent to the U. S. National Museum the median metatarsal bone of a horse which had been found about 5 miles south of Russell. The exact location is in the southeast quarter of section 25, township 14 south, range 14 west, and on the west side of Fossil Creek. With this bone was found a molar of Elephas imperator. It is stated that these fossils are to be preserved in the collection of the University of Kansas. No number for this locality appears on map 15.

Bluff Creek, Clark County (5).- In his brief paper of 1896, on the geology of Meade and Clark Counties (Colorado Coll. Studies, vol. vi, p. 53), Cragin reported the discovery of Equus curvidens in the Meade gravels. Some of these teeth are mentioned above and are regarded by the present writer as belonging to $E$. leidyi. Among the lot is a part of an upper maxilla which contains 4 teeth and which is labeled as having been found in the Meade gravels at the 
head of Bluff Creek. 'This locality is in the northern part of Clark County. The specimen has been described and figured as E. leidyi (Kansas Univ. Quart., x, 1917, p. 44, pl. II, figs. 2-4; pl. III, figs. 5, 6). For the geology of the region, see page 270 .

Meade, Meade County (6).-Dr. F. W. Cragin's collection of fossil vertebrates contains an upper left premolar and 5 lower premolars and molars. These were found on Spring Creek, about 4 miles southwest from Meade. They have been studied by the writer and referred to Equus complicatus, and descriptions of them have been published (Kansas Univ. Quart., x, 1917, p. 43). Some foot-bones found in the same region belong probably to this species. Cragin found at Meade several teeth, upper and lower, which the writer, as above cited, has identified as Equus leidyi. They were probably regarded by Cragin as those of Equus curvidens. All these remains were found in the Meade gravels. The geology of Meade and Clark Counties, as made out by Cragin, is discussed on page 270 .

In the collection of the Kansas State Agricultural College, at Manhattan, are 2 left lower teeth, third and fourth premolars, which are labeled as found at Big Spring ranch, Meade County, and presented by D. E. Ballard, November 25, 1910. They are only slightly worn and the enamel is but little complicated. The third premolar is $70 \mathrm{~mm}$. high, $32 \mathrm{~mm}$. long, and 17.5 $\mathrm{mm}$. wide; the fourth is $80 \mathrm{~mm}$. high, $29 \mathrm{~mm}$. long, and $17 \mathrm{~mm}$. wide. These teeth are referred to Equus complicatus. They have the catalogue No. 1838. In the same collection is an upper right second true molar which is referred to Equus niobrarensis. It had just begun to wear. A section made about an inch below the grinding-surface shows well the structure of the tooth. The height of the tooth is $87 \mathrm{~mm}$., length of crown on sectioned surface 27 mm., width $29 \mathrm{~mm}$. The parastyle is unusually broad for a molar, $6 \mathrm{~mm}$.; there is no groove in it. The mesostyle is very narrow, $4 \mathrm{~mm}$. The outer face of the tooth is flat, except for the styles mentioned. The protocone, too, is very narrow, $10 \mathrm{~mm}$., and it stands out well from the body of the tooth. The great inner valley sends outward a long process toward the anterior lake. The borders of the lakes adjacent to each other are somewhat more complicated than in the type specimen.

Kiowa Creek, Comanche County (7).-Professor Robert Hay (Bull. U. S. Geol. Surv., No. 57, p. 34) reported that horse teeth had been found on Kiowa Creek, in this county. The more exact location was not stated, but a geological section at the place was given (R. Hay's fig. 11). The teeth occurred in what he called Tertiary marl, under which name he included Cope's Equus beds.

Pendennis, Lane County (8).- In 1897 (Univ. Kan. Geol. Surv., vol. II, p. 303), Doctor Williston reported briefly that a complete upper dentition of Equus excelsus had been found in Lane County by C. H. Sternberg; this gentleman states in a letter that the locality is 7 miles northeast of Pendennis, in the northeast corner of Lane County. Here Mr. Sternberg found many teeth and bones of Elephas columbi and some of $E$. boreus.

In the University of Kansas is a mount, in a plaster base, of 5 horse teeth supposed to be those mentioned by Williston; there are only 2 teeth on the right side and 3 on the left. The teeth are those of an old horse, being much 
worn. A tooth which seems to be the third premolar of the left side is only $32 \mathrm{~mm}$. high, with the grinding-surface $32 \mathrm{~mm}$. long and $29 \mathrm{~mm}$. wide. ' ' 'he postprotoconal valley is large and sends a branch forward. It seems to belong to Equus niobrarensis. A molar is only $25 \mathrm{~mm}$. high, $25 \mathrm{~mm}$. long on grinding-face, and $27 \mathrm{~mm}$. wide, with extremely simple valley. This may be due to the great wear.

Twelve-mile Creek, Logan County (9). - In the American Museum of Natural History, New York, is a single horse tooth which, with other teeth of the same individual, was found by H. F. Martin, of the University of Kansas, at a point 12 miles west of Elkader. This was in the valley of Smoky Hill River and would apparently be in township 14 north, range 34 west. It was about 0.25 mile north of the spot where was found the skeleton of Bison occidentalis, now mounted in the museum of the University of Kansas. At the same place were found teeth of Canis occidentalis and of a small dog and teeth and bones of a camel.

In the University of Kansas the writer has seen 4 teeth and some fragments of others collected by Mr. Martin. Three of these, upper molars, belonged probably to the same horse. The writer regards them as teeth of Equus laurentius. They are worn down so that the second molar has a height of only $35 \mathrm{~mm}$. The following are measurements (in millimeters) taken on the grinding-surfaces:

\begin{tabular}{|c|c|c|c|}
\hline Tooth. & Length. & Width. & Protocone. \\
\hline First upper molar. & 22 & 25 & 11 \\
\hline Second upper molar. . & 22 & 24 & 11 \\
\hline Third upper molar $\pm \ldots$ & 24 & 21 & 14 \\
\hline
\end{tabular}

The enamel is simple in its arrangement. The presence of horse and camel remains indicates early Pleistocene, equivalent probably to the Aftonian.

\section{COLORADO.}

(Map 15.)

Rouse, Huerfano County (1).-In the U. S. National Museum are 3 horse teeth received some years ago, the date and donor unknown. The teeth were found in the slope at the mouth of a coal mine, on the top of a bed of shale and at the base of the deposit of loess, at a depth of about 12 feet. They belong to the left side of the lower jaw and are the second and fourth premolars and probably the second molar. The species has not been determined. The writer understands that the town of Rouse is no longer in existence, but that the name has been given to a new town about 5 miles away.

Near Gardner, Huerfano County (2).--Somewhere along Williams Creek, a branch flowing into Huerfano River, and probably in township 25 south, range 70 west, was found the partial skeleton of the camel described by Dr. F. W. Cragin (Amer. Geologist, vol. Ix, 1892, p. 25\%) as Auchenia huerfanensis. This camel will be mentioned in its proper place. With it was found, as the writer was informed by Professor R. C. Hills, a tooth of a horse. The writer has not seen this tooth, but has seen a photograph of 
it sent him by Professor T. D. A. Cockerell. The deposit consisted of volcanic ash.

Silver Cliff, Custer County (3).- In the U. S. National Museum (No. 10307) are 4 horse teeth found near Silver Cliff in 1898 and sent to the museum by A. H. Henning. 'They were found in a gully or "wash," where the finder was searching for minerals, and consist of the right last premolar, the first and second molar, and the left last premolar, all of the upper jaw. They appear to belong to the species Equus laurentius. On comparing them with the palate described by the writer in 1913 (Proc. U. S. Nat. Mus. xurv, p. 598, text-fig. 27), and referred to E. laurentius, the teeth from Silver Cliff resemble those of this palate more closely than they do those of the type specimen. The teeth are little worn and considerably curved. The inner faces of the protocones are slightly concave.

Colorado Springs, El Paso County (4).- In the collection of Colorado College the writer has seen an upper left hindmost horse molar found about the year 1911, somewhere near Colorado Springs. The tooth is injured, so that it could not be determined specifically.

From Professor Edward R. Warren the writer received a small collection of bones found in gravel-pits about Colorado Springs, including remains of a camel, a bison, a musk-ox (Ovibos\%), a deer-like animal, and an upper tooth, apparently a premolar of a horse. The grinding-surface is covered with a crust of iron oxide; length of grinding-surface $30 \mathrm{~mm}$., width $29 \mathrm{~mm}$. The enamel of the fossettes is little folded. The species has not been determined.

Manitou, El Paso County (5).-In 1899 (Bull. Geol. Soc. Amer., vol. xI, p. 610), Professor F. W. Cragin reported having seen 2 proximal phalanges of a slender-limbed horse, unearthed in the cave in which he found his specimens described as Nomorhedus palmeri.

Calhan, El Paso County (6).-Dr. Willis T. Lee, of the U. S. Geological Survey, showed the writer an equine metatarsal found near Calhan. The exact locality is given as section 13 , township 13 south, range 60 east. The bone is reported to have been discovered at a depth of 60 feet. It appears to be that of a species of Equus.

Elbert County ( $\%)$.- In November 1919 the writer received from Mr. W. L. Burnett, curator of the museum of the State Agricultural College, at Fort Collins, Colorado, part of the left mandibular ramus of a young horse, found somewhere in the county at a depth of 25 feet. The 3 hinder milkmolars are present and little worn. In length they differ little from those of a recent horse; each is about $3 \mathrm{~mm}$. wider than the corresponding teeth of a colt of the domestic horse. The widths of the fossil teeth are, respectively, $16.5,17$, and $15.5 \mathrm{~mm}$.

Littleton, Arapahoe County (8).-In the collection of the State Historical and Natural History Society, at Denver, is a little-worn equine lower premolar or molar, found about 1911, approximately 3 miles northeast of Littleton. The exact location is given as block 266, South Denver Garden. The tooth was met with at a depth of 25 feet, in a gravel formation. The place is stated to be half a mile from Dry Creek. The finder and donor was Gustav Ephriam. The height of the tooth is $95 \mathrm{~mm}$.; length of grindingsurface, $29 \mathrm{~mm}$.; thickness, $12 \mathrm{~mm}$. 
Denver, Denver County (9).- - In the collection of the State Historical and Natural History Society the writer saw in 19143 equine right lower incisors found near Denver. The inner incisor is $20 \mathrm{~mm}$. wide; the next is $21 \mathrm{~mm}$.; the outer one is $23 \mathrm{~mm}$. They certainly belonged to a large horse, but to which species has not been determined. A collection sent from Denver to the U. S. National Museum by Professor G. L. Cannon contains a third metacarpal and a third metatarsal of a horse. These were found in the Pleistocene deposits along Platte River. In the same deposits were found remains of Bison and Camelops. Dr. S. F. Emmons (Mon. U. S. Geol. Surv., vol. XxVII, p. 261) reported the occurrence of horse bones in the fine fluvial loess on the western bank of the Platte at Denver. On page 264 he stated that portions of 6 skeletons of an ancient species of horse had been found in the loess within the limits of the city of Denver.

Longmont, Boulder County (10).- In the collection belonging to Colorado University, at Boulder, the writer found 2 upper teeth of a fossil horse, from Longmont. These had been found at a depth of 15 or 20 feet, on Sugar Factory Hill, in Pleistocene gravel. A left upper tooth, probably a premolar, has a height of $85 \mathrm{~mm}$.; a length, on the grinding-surface, of $32 \mathrm{~mm}$., and a width of $29 \mathrm{~mm}$. A right upper tooth is $50 \mathrm{~mm}$. high, $28 \mathrm{~mm}$. long, and $27 \mathrm{~mm}$. wide. The enamel of the fossettes is considerably folded in both teeth. They are referred to Equus complicatus.

Greeley, Weld County (11).--In the collection of the State Normal School, at Greeley, are two upper molars of a horse, found very near the college, in gravel, at a depth of 19 feet. The teeth are in good condition, being only moderately worn. The following measurements (in millimeters) were secured: Second upper molar: Height 80, length 2\%, width 2\%.5, protocone 15 . Third upper molar: Height 75, length 30, width 23, protocone 15 .

The enamel of the fossettes is considerably folded. The protoconal valley does not reach the center of the tooth. It is probable that the tooth belonged to Equus complicatus. The inner face of the protocone is concave.

South Canyon, near Glenwood Springs, Garfield County (12).-At Boulder, in the palæontological collection of the University of Colorado, is a muchworn horse tooth found near Glenwood Springs. With it were the humerus of a species of Bison and a tooth of Elephas imperator. On account of the worn condition of the tooth, no attempt is made to determine the species. The tooth is worn down to about $35 \mathrm{~mm}$. of the roots; length of crown 27 $\mathrm{mm}$., width $30 \mathrm{~mm}$., long diameter of protocone $16 \mathrm{~mm}$. The fossettes are extremely narrow, the inner and the outer walls being very close to each other. The postprotoconal valley resembles that of Equus laurentius. Dr. T. D. C. Cockerell states that these remains were discovered about 8 miles west of Glenwood Springs, half a mile up South Canyon, at a depth of 8 feet.

IOWA.

(Maps 15, 17.)

\section{Wrthin the Area of the Kansan Drift.}

Montrose, Lee County (1).-The collection of the State University of Iowa contains a horse tooth labeled as taken at a depth of 25 feet, from a well, sunk somewhere near Montrose. One lateral face of the tooth and the grinding- 
surface are covered with a hard incrustation, apparently a part of a calcareous nodule. 'To what species the tooth belonged has not been determined.

This part of Iowa is mapped as having the Kansan as the superficial drift. 'The Pleistocene geology of the county was described by C. R. Keyes (Iowa Geol. Surv., vol. III, pp. 356-369). Two kinds of drift are recognized but not named. The lower consists of a blue boulder clay which occupies an old preglacial valley and attains a thickness of at least 200 feet. At Fort Madison, about 10 miles above Montrose, wood and other vegetable matter are found embedded in this blue clay (in what part is not stated). The thickness of the yellow boulder clay is stated to vary from 30 to 75 feet. It is said to contain calcareous nodules, known as loesskindehen. Orer the yellow clay is found loess not exceeding 15 feet.

It seems probable that the blue boulder clay belongs to the Nebraskan, the yellow to the Kansan. It is not probable that the horse tooth was found in unmodified Kansan glacial drift. Its age is probably post-Kansan. It is not unlikely that it was derived from the loess and belonged to the Sangamon stage or to the Iowan, but want of exact information arrests any certain conclusions. In the writer's paper on the Pleistocene Mammals of Iowa, page 201, the opinion is expressed that it might have been found in Aftonian deposits. In this case the well would have had to pass through both the loess and the yellow boulder clay.

Afton Junction, Union County (2).--This item concerns a species of Hipparion, first mentioned by Calvin, in 1910 (Bull. Geol. Soc. Amer., vol. xx, p. 138), as a small slender-limbed horse. In 1911 (op. cit., vol. XxII, p. 210, pl. xIx, figs. 1-4), it was referred to Hipparion and spoken of as resembling H. gratum Leidy. The present writer (Iowa Geol. Surv., vol. xxIII, p. 149, pl. Ix, figs. 3, 4) described, under the name Neohipparion gratum?, the metatarsal and the phalangeal bones which formed a part of the materials found at the locality. Besides these, there were an astragalus and one or two unerupted teeth. An examination of a section of one of the teeth showed the writer that it belonged to Hipparion. The only reason for not referring it definitely to $H$. gratum is the fact that the type of this species was found in the Upper Miocene, and it is not probable that the species lived on, unchanged, into the early Pleistocene. That these bones belonged to the Aftonian interglacial and had not been redeposited from an older formation is rendered extremely probable from the fact that Hipparion remains have been found in Pleistocene deposits at Rockport, Missouri, and in Clark County, Kansas. It is very probable that the remains found near Afton Junction belonged to an undescribed species, or to Hipparion cragini Hay.

It appears that the materials above referred to were collected between Afton Junction and Thayer, 4 miles east of the former place. Afton Junction is the type locality of the Aftonian formation (Calvin, Bull. Geol. Soc. Amer., vol. $\mathrm{xx}$, p. 136). Here the Nebraskan drift is exposed in the west bank of Grand River and is overlain by more than 30 feet of water-laid gravels. These at one time were worked for railroad ballast. 'These gravels are orerlain by a heavy deposit of Kansan drift and were supposed by Calvin to belong to the Aftonian interglacial stage. For a different opinion the reader may consult page 279 . 
Lyons Township, Mills County (3).- In the collection of the State University of Iowa are the left upper and the right lower cheek-teeth of a horse, found in Lyons Township. The specimens have the catalogue Nos. 220 and 219. They were found by E. L. Gladwin in the east half of section 35, township 71 north, range 43 west. It was stated by Calvin that a considerable part of the skeleton was present, but the bones were too soft for preservation. The matrix was a fine blue clay, a bed of silt, which is regarded as belonging to the Aftonian. From the fact that a considerable part of the skeleton was found, it is certain that the bones were in their original place of burial. The teeth mentioned have been described and figured by Calvin (Bull. Geol. Soc. Amer., vol. xx, p. 344, pl. xvII, figs. 1, 2) as Equus scotti, and by the present writer (Iowa Geol. Surv., vol. XxIII, p. 166, pl. XI, text-figs. 60, 61) as $E$. complicatus.

Hinton Station, Mills County (4).-Having learned from Professor J. E. Todd that the Council Bluffs High School has some fossil horse teeth, the writer got into correspondence with Professor J. E. Marshall, who forwarded the teeth for examination. Two of these are referred to Equus complicatus and one to E. laurentius (Iowa Geol. Surv., vol. xxirI, p. 178). Professor Marshall wrote that these teeth had been found at Hinton. A tooth of Elephas columbi and bones of camels were discovered also at Hinton (p. 294), and doubtless all the species were located in Aftonian deposits.

Missouri Valley, Harrison County (5).-Four species of horses have been found at Missouri Valley, in an opening for sand and gravel known as the Cox pit. The location and the geology of this pit, with a list of the species secured there, are to be found on page 296. The equine remains have been referred to Equus complicatus, E. excelsus, E. niobrarensis, and E. laurentius. These are described in the writer's paper on the Pleistocene Mammals of Iowa (Iowa Geol. Surv,, vol. XxIII). The remains of E. complicatus are treated on pages 166 to 178 of that paper; E. excelsus on page $190, E$. niobrarensis on pages 198 to 201, E. laurentius on page 208. Many of the teeth are figured. The sands and gravels are assigned to the Aftonian.

Logan, Harrison County (6).- The only claim that this locality has for having furnished horse remains is found in a statement made by Shimek (Bull. Geol. Soc. Amer., vol. xxi, p. 137) that a fragment, probably from a limb-bone of a horse, had been located in the lowest gravel-bed of the Peckenbaugh sand-pit. A good molar of Elephas columbi was found in the same pit. The geology of the locality is considered on page 296 .

Pisgah, Harrison County (7).-From a sand-and-gravel pit, southwest of Pisgah, in the northwest quarter of section 26, township 81 north, range 44 west, were secured two teeth which the writer (Iowa Geol. Surv., vol. xxIII, p. 171) has referred to Equus complicatus. On the page quoted, these teeth were wrongly credited to the Peyton pit. From this pit, situated on Soldier River, about a mile southwest of Pisgah, in the northeast quarter of section 23, township 81 north, range 44 west, Shimek (Bull. Geol. Soc. Amer., vol. xxI, p. 133) reported the finding of an acetabulum and a part of a metapodial of a horse. The geological situation in this region is considered on page 295 . The fossils are referred to the Aftonian interglacial. 
Turin, Monona County (8).- Teeth of extinct horses, referred to three species, Equus complicatus, E. excelsus, and E. niobrarensis, were found in the Elliott pit; these teeth have been described by the writer (Iowa Geol. Surv., vol. xxiri, pp. 59, 167, 175, 176, 177, 191, 198, 200). Many of them are figured. The situation of the pit, the geological formations exposed, references to the literature, and a list of species found are presented on page 297. The species belong to the Aftonian.

Sioux City, Woodbury County (9).-The writer has recognized 3 species of horses from the Sioux City locality. These are Equus complicatus (Iowa Geol. Surv., vol. xxıII, p. 177), E. laurentius (p. 207), and E. niobrarensis. The first-named species is represented in the collection at the State University of Iowa by 2 teeth of the right side of the lower jaw. They were found in the Anderson sand-pit, which is located north of North Riverside, near Sioux City. More exactly, the pit is in the southeast quarter of the northwest quarter of section 13, township 89 north, range 48 west.

Shimek (Bull. Geol. Soc. Amer., vol. xxı, p. 128) gave the following description of the section presented in this pit:

Loess, 8 to 12 feet.

The Loveland, an irregular mass of reddish joint clay.

Kansan, typical bluish till, 6 to 8 feet.

Fine laminated bluish or yellowish silt, evidently Aftonian, 5 to 8 feet.

Aftonian sand, cross-bedded and containing mammalian fossils, 22 to 30 feet.

The sand is said to be underlain by larger boulders and gravel resting on the rock. In this same pit were collected an ungual phalange of Megalonyx and the tooth which the present writer has described as Mylohyus? temerarius (Iowa Geol. Surv., vol. XxIII, p. 227, pl. Xxi, figs. 1, 2).

Equus laurentius is represented in the collection of the State University of Iowa by a part of a left maxilla, which contains 5 teeth. The specimen was sent by J. H. Charles, of Sioux City. It is not known exactly where it was found, but it was in the region about Sioux City. It was described and figured by Calvin (Bull. Geol. Soc. Amer., vol. xx, pp. 347, 348, pl. xx) and by the writer (Iowa Geol. Surv., vol. xxiII, pl. xiIn, fig. 3, text-fig. 83). The teeth are much worn.

In the fall of 1919, Dr. W. C. Alden obtained from the Anderson pit a fine upper left first or second molar of a horse. It was but little worn. The length is $31 \mathrm{~mm}$.; width, $31.5 \mathrm{~mm}$. The protocone measures $11.5 \mathrm{~mm}$. from front to rear; $6 \mathrm{~mm}$. from side to side. The adjacent borders of the lakes are considerably folded, but elsewhere are simple. The postprotoconal inlet shows a deep fold at its head. The writer is not able to say to what species it belongs.

Professor J. E. Todd (Proc. Iowa Acad. Sci., vol. vi, p. 124) tells of the finding of a vertebra of a horse in an old soil at Sioux City, together with fragments of a turtle and bones of a small mammal.

Bain (Iowa Geol. Surv., vol. v, p. 27\%) reported that J. C. C. Hoskins found at Sioux City some horse teeth which Cope identified as belonging to Équus major (=E. complicatus). Wilder (Iowa Geol. Surv., vol. x, p. 117) stated that these teeth had been found north of Sioux City, in fine sands which were overlain by gray and yellowish clays containing some pebbles. 
Calvin (op. cit., p. 348) said they had come from a sand-pit along the Big Sioux River. In the collection of the Sioux City Academy of Sciences the writer has seen 3 teeth which are probably the ones referred to by Bain and Wilder. The following are the identifications of the teeth and their measurements (in millimeters) :

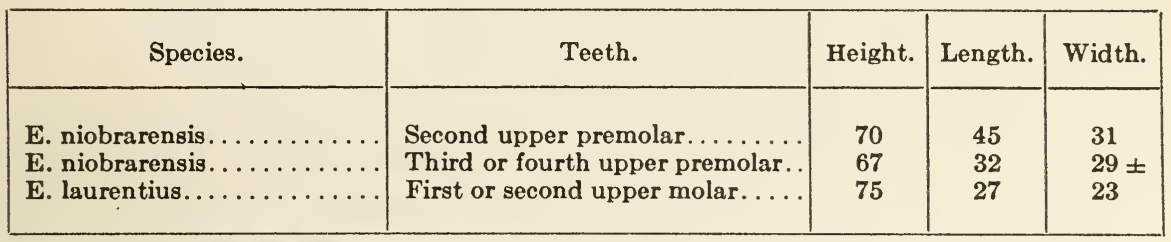

All of the teeth above mentioned are believed to have been found in deposits of the Aftonian interglacial stage.

Le Mars, Plymouth County (13).-Dr. J. E. Carman, in 1917 (Iowa Geol. Surv., vol. xxvi, p. 409), reported that horse teeth had been discovered near Le Mars in two river pits. One pit was in section 10, township 92 north, range 45 west; the other in section 9 . In the same pits had been found remains of elephants, antlers of deer, and teeth of horses. The levels from which the teeth had been dredged could not be determined. The valley gravels were regarded as having been deposited after the Kansan till and probably before the Iowan till.

Granite, Lyon County (10).-A worn fragment of a molar of a horse was found in a gravel-bed in a section described as follows by Shimek (Bull. Geol. Soc. Amer., vol. XxIIr, pp. 141, 151) :

feet.

3. A gravelly yellowish stratum of uncertain age $\ldots \ldots \ldots \ldots \ldots \ldots \ldots$

2. Bed of sand and gravel....................... $3-5$

1. Weathered grayish drift, probably Kansan, exposed.......... 5

No. 2, which contained the tooth, was regarded as belonging to the Aftonian. The species to which the tooth belonged could not be determined.

\section{Within the Area of the Iowan Drift.}

Sandspring, Delaware County (11).-In 1891 (11th Ann. Rep. U. S. Geol. Surv., p. 495), W J McGee stated that the only trace of animal life brought to light in the Pleistocene deposits of northeastern Iowa was a tooth of a horse. To the writer's inquiry about this, Doctor McGee sent a reply, of which the following is a part:

The tooth was picked up on a knoll of cherty Niagara limestone, thinly overspread with loose fragments including glacial pebbles, chert nodules, silicified corals and other paleozoic fossils, with remnants of sandy drift lying in depressions. It was clear to me that the knoll had been thinly mantled with the exceptionally sandy drift prevailing in this region (i. e., in eastern Delaware County) and that this had been largely removed by the winds, leaving the coarser materials, including the tooth. The locality lies within the area overspread by what we now call the Kansan and Iowan drift sheets, and the intercalated forest bed occurs in the neighborhood. Of course the associations were such as to throw no light on the stratigraphic position or geologic age of the tooth; but, so far as I now recall, attendant conditions led me to infer that it probably pertained either to the pre-Kansan time or to the interglacial period. 
'To the present writer it appears necessary to refer this tooth to the preKansan (Aftonian) interglacial. Had it originally lain in any deposit which reposed on the Kansan, it must have been exposed to the weather for a vast period of time, while the containing deposit and the Kansan were being eroded away. Unless it had been thoroughly silicified, it could hardly have endured the exposure. It had probably been buried in an interglacial deposit lying immediately on the Niagara limestone. Doctor McGee thought that the tooth was in his collection, but nothing can be learned about it. The name of the locality, Sandspring, was suggested to the present writer by Doctor McGee. It is a railroad station in the southeastern corner of the county. He wrote also that he thought he had shown the tooth to Professor Calvin.

Ridgeway, Winneshiek County (12).-The writer has learned from Professor A. O. Thomas, of the State University of Iowa, that their collection has received a fossil horse tooth found near Ridgeway. The Professor forwarded the tooth to the writer for examination. It proves to be the upper right second or third premolar of Equus niobrarensis. It is but little worn and the crown had not yet reached its maximum width. The tooth is considerably curved in a plane transverse to the skull and is bent backward toward the root. The height is about $75 \mathrm{~mm}$.; length of worn face, $28 \mathrm{~mm}$., width $25 \mathrm{~mm}$., length of protocone $11 \mathrm{~mm}$. The width of the tooth would, on a little more wear, have been $27 \mathrm{~mm}$. The great inner valley is broad and in front it sends a loop to the center of the tooth. There is a deep reentrant fold. This tooth was found by Charles Hornberger, of Ridgeway, in washedout sand and gravel in Otter Creek, in the southwest quarter of section 28, township 98 north, range 10 west, known as Lincoln township, about 3 miles southwest of Ridgeway. This township, according to Calvin (Iowa Geol. Surv., vol. xvi, pp. 37-146, map), is covered with Iowan drift, underlain by Kansan drift. He concluded that throughout the county there were evidences of two distinct loess deposits; one would be referred to the Sangamon stage, the other to the Iowan or Peorian. Alden and Leighton reported no Sangamon. They recorded (Iowa Geol. Surv., vol. xxvi, p. 200) a geological section found in the same land section that furnished the horse tooth, as follows: feet.

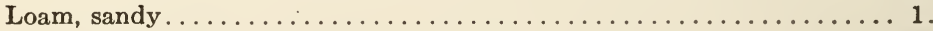

Till (Iowan?), brownish yellow, leached .............. 2.5

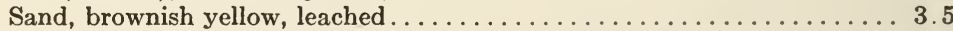

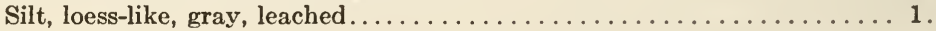

As this silt underlies the till supposed to be Iowan, it may belong to the Sangamon and the horse tooth may have been washed out of it or an equivalent of it. We must not, however, base any certain conclusions on the data furnished us, but so far as the writer knows, no remains of horses have yet been found in deposits more recent than the Sangamon. It is possible, however, that the horse tooth found in Illinois, opposite St. Louis. was buried in loess of Iowan or Peorian age.

\section{NEBRASKA.}

(Map 15.)

Louisville, Cass County (1).- In the collection of the State Museum, at Lincoln, are a palate and teeth of a fossil horse, found in Rand's sand-pit, at Louisville. This town is on the south side of Platte River. The maxilla is 
present up to the bases of the teeth. Of teeth, there are present the worndown second, third, and fourth milk-molars capping the premolars; also the first and second molars. The third molar had not made its way through the bone. The distance from the front of the second milk-molar to the rear of the second molar is $161 \mathrm{~mm}$. The width of the palate between the second milk-molars is $64 \mathrm{~mm}$; ; between the second molars, $71 \mathrm{~mm}$. The teeth furnish the following measurements in millimeters:

\begin{tabular}{|c|c|l|}
\hline Tooth. & Length. & Width. \\
\cline { 2 - 3 } & & \\
Second upper milk molar........ & 40 & 14 \\
Third upper milk molar........ & 29 & 25.5 \\
Fourth upper milk molar....... & 30 & 25 \\
First upper molar............. & 31 & 27.5 \\
Second upper molar........... & 31 & 24 \\
\hline
\end{tabular}

The enamel of the second upper molar is rather simple, that of the posterior fossette being most crimped; the protocone is $13 \mathrm{~mm}$. wide. With this palate are the right and left ulnæ. Judging from the size of these teeth, they belong to Equus complicatus; the enamel is unusually simple. The locality is within the area of the Kansan drift, and the tooth may be provisionally referred to the Aftonian stage; but inasmuch as the locality is on Platte River, the geology ought to be carefully studied.

Crete, Saline County (5).--Professor Erwin H. Barbour sent to the American Museum of Natural History some rather remarkable teeth of a horse, found at Crete, Nebraska. This lot consists of a tooth which is either the first or second lower left molar and 5 lower left teeth, from the third premolar to the third true molar, inclusive. They are remarkable because of their great length and the apparent narrowness of the grinding-surfaces. The single molar is $110 \mathrm{~mm}$. high; length of grinding-surface, $34 \mathrm{~mm}$. ; width, 12.6 mm. However, it is evident that the tooth had just begun to wear and that a little below the present face the length of the grinding-face would be only $28 \mathrm{~mm}$., while the width would certainly be greater.

The following measurements (in millimeters) are taken from Professor Osborn's drawings of the 5 teeth of one individual:

\begin{tabular}{|l|c|c|c|c|c|}
\hline & $\begin{array}{c}\text { Third } \\
\text { lower } \\
\text { premolar. }\end{array}$ & $\begin{array}{c}\text { Fourth } \\
\text { lower } \\
\text { premolar. }\end{array}$ & $\begin{array}{c}\text { First } \\
\text { lower } \\
\text { molar. }\end{array}$ & $\begin{array}{c}\text { Second } \\
\text { lower } \\
\text { molar. }\end{array}$ & $\begin{array}{c}\text { Third } \\
\text { lower } \\
\text { molar. }\end{array}$ \\
\hline Height of crown.............. & 90 & 93 & 98 & 102 & 80 \\
Length of grinding-surface...... & 31.2 & 30 & 27.5 & 29 & 27 \\
Width of grinding-surface....... & 14.6 & 13 & 13.5 & 13.5 & 10 \\
\hline
\end{tabular}

Some of these teeth might, after a little more wear, show considerable differences in the measurements. They are figured by Osborn (Mem. Amer. Mus. Nat. Hist., n. s. vol. II, p. 8, fig. 4a) as those of Equus niobrarensis. They are reported to have been found in glacial drift at Crete. As this place is very near the border of the drift and on Big Blue River, and as the drift is thin, there are opportunities for errors. 
Fullerton, Nance County (2).-The U. S. National Museum contains an upper incisor and part of the enamel of a cheek-tooth of a fossil horse, found at or near Fullerton. They were collected by Professor E. H. Barbour and sent to the museum by N. H. Darton. It is not possible to determine the species. The age is probably Aftonian (Sheridan).

Seneca, Thomas County (3).-At some place along the Middle Loup River was found the type of Leidy's Equus excelsus. 'The locality was probably near Seneca. The specimen was described and figured by Leidy in 1869 (Jour. Acad. Nat. Sci. Phila., vol. viI, p. 268, pl. XIx, fig. 39). On the page mentioned and on the two succeeding pages, Leidy enumerated other teeth, upper and lower, and some bones, which he referred to the same species, some of which he figured. It is, however, by no means certain that all, or even any, of them belong to $E$. excelsus. The deposits found in this locality belong to the Sheridan stage of the Pleistocene, which has furnished camel remains and probably Elephas imperator.

During the summer of 1916, a party from the American Museum of Natural History, New York, explored the region about the head of Middle Loup River, along which Hayden appears to have made a journey. Remains of Equus were found at a point west of Seneca. In the same region were found also remains of Cameiops, Platygonus, Canis, etc. The deposits belong to the Sheridan; no Pliocene was found along the river. This information was furnished the writer by Dr. W. D. Matthew.

Peters, Sheridan County (4).-The fossil quarry near Grayson has hitherto been referred to Hay Springs; but this town is about 15 miles from the quarry, while Peters is not far away. The locality is more particularly described on page -, in connection with the remains of Elephas columbi from that region. In 1868, John Bell Hatcher made here an extensive collection of fossil vertebrates, among which were many bones of horses. Some of these equine remains are now in the U. S. National Museum. In 1893, J. B. Hatcher, J. I. Wortman, and J. W. Gidley collected other remains of horses, some of which are in the American Museum of Natural History, the remainder in the museum at Princeton University. In 1913 (Proc. U. S. Nat. Mus., vol. xLIV, p. 576, pls. LXIx, LXx), the writer described the species Equus niobrarensis, based on a skull discovered by Hatcher, in 1886, in the quarry just mentioned. In 1914 (Proc. U. S. Nat. Mus. vol. XuvII, p. 527, pls. xxxII-xxxIv), the writer described, from Hatcher's materials, another species, Equus hatcheri, based on a quite complete skull. The types of both of these species are in the U. S. National Museum. In the collection at the American Museum of Natural History, New York, and that at Princeton University the writer has recognized from Peters remains which appear to belong to Equus complicatus and $E$. excelsus. For the associated species, see pages $304,305$.

\section{WYOMING.}

(Map 15.)

Bridger, Unita County (1).-In the U. S. National Museum is an equine upper last molar labeled as found at Bridger. It is worn down nearly half of its original height, measuring now $65 \mathrm{~mm}$. The length of the grinding-face is $30 \mathrm{~mm}$.; width in front, $25 \mathrm{~mm}$.; in the middle, $23 \mathrm{~mm}$. The width of the 
protocone is $13.5 \mathrm{~mm}$. It will be noted that, relatively to the length of the grinding-face, the width is small. The metastyle is unusually broad, being $9 \mathrm{~mm}$., as wide as that of the horse which the writer has described as Equus holmesi. The enamel of the fossettes is pretty strongly folded. For the present this species is left undetermined. No details are recorded regarding the geological conditions or the exact place of discovery.

\section{SOUTH DAKOTA.}

\section{(Map 15.)}

Sioux Falls, Minnehaha County (1).-In 1900 (Amer. Geologist, vol. xxv, p. 99), Dr. J. E. Todd reported the discovery of vertebrate remains in an old buried pond in cuts of the Illinois Central Railroad, a mile or more northeast of Sioux Falls. Among the bones was one which Professor W. B. Scott identified as a cervical vertebra of a horse. Other bones were those of an unidentified turtle and of a mammal about as large as a rabbit.

Otis Mill, Union County (2).--In 1908 (Elk Point Folio, No. 156, U. S. Geol. Surv., p. 4), Dr. J. E. Todd reported the discovery of a lower jaw of a horse near Otis Mill. The exact locality is given as the southwest quarter of section 29, township 94 north, range 48 west. It is on the Big Sioux River and opposite Chatsworth, Iowa. The jaw is said to have contained 3 molars; it was identified as belonging to either Equus complicatus or E. scotti. The writer does not know what was done with this specimen.

Dr. N. H. Darton sent to the U. S. National Museum from the same locality, 2 upper teeth of a horse, the left second and third molars. They are worn down to a little more than an inch from the roots. The present writer refers them to Equus laurentius. They have the catalogue No. 9711. All of these horse remains are regarded by the present writer as being of Aftonian age.

Fort Pierre, Stanley County (3).-In 1869 (Ext. Mamm. Fauna Dak. Neb., p. 271), Dr. Joseph Leidy reported that a fragment of a calcaneum and an astragalus had been picked up from the surface of the ground near Fort Pierre. They were thoroughly infiltrated with siliceous matter. Without further details it is not certain that these belonged to the Pleistocene period.

Runkel, Lawrence County (4).- In the U. S. National Museum is a second phalanx of a horse which is labeled as found in Crystal Cave, on Elk Creek, near the present town of Runkel. The bone is heavy, without animal matter, brittle, and incrusted with lime rock. It is credited to Charles Whitney.

\section{MONTANA.}

(Map 15.)

Phillips County, southwest of Lovejoy (1).-In 1918 (U. S. Geol. Surv. Profess. Pap. 108-J, p. 182), Dr. A. J. Collier reported the discovery of a fossil horse tooth in the region indicated above. The exact locality is given as in section 23, township 33 north, range 30 east, and is marked on his map by a cross. In Professional Paper 120-B, p. 35, the locality is erroneously given as in range 35. There appears to be in this region an extensive terrace of early Pleistocene with associated gravels. Near the locality mentioned, the 
terrace, or bench, is capped by about 25 feet of gravel and yellowish silt. From the face of a cliff was obtained a tooth which J. W. Gidley identified as that of a horse resembling the existing species. 'The gravel is reported to be older than the last advance of the ice. The conclusion was reached that the deposit belonged to the late Pliocene or early Pleistocene. Even in case it had been demonstrated (as it has not) that the genus Equus occurs in the Pliocene of North America, the probability remains that the deposit belongs to the Pleistocene.

\section{ALBERTA.}

(Map 15.)

Empress, Redcliffe County-This town is at the junction of Red Deer River with the South Saskatchewan. About the year 1914, W. E. Cutler, of Calgary, Alberta, brought to the U. S. National Museum a much-worn upper left hindmost molar of a horse, found in a gravel-bed in a cut of the Canadian Pacific Railroad, about 200 yards west of the station at Empress. It was worn down to a height of only $30 \mathrm{~mm}$. Length of grinding-surface $30 \mathrm{~mm}$., width $25 \mathrm{~mm}$, protocone $15 \mathrm{~mm}$. long. There was no considerable complication of the enamel. The indications were that it was not a tooth of the existing horse.

\section{MANITOBA.}

(Map 15.)

York Factory (1).-This locality is on Hudson Bay, at the mouth of Nelson River. In 1898, Sir Robert Bell (Bull. Geol. Soc. Amer., vol. IX, p. 373) reported the finding of a horse skull half embedded in the soil. He thought it might be that of a domestic horse, but could hear of none having been brought there. No additional information appears to have been secured on the subject. 


\title{
FINDS OF TAPIRID E IN THE MIDDLE REGION OF NORTH AMERICA.
}

\author{
LOUISIANA. \\ (Map 18.)
}

Southwest Corner of St. Landry Parish (1).-In 1842 (Amer. Jour. Sci., vol. XLII, p. 390, fig.), Professor W. M. Carpenter, of Jackson College, Louisiana, reported the finding of a jaw of a tapir at a point 20 or 30 miles west of Opelousas. This would apparently be somewhere in the southwestern corner of St. Landry Parish, probably not far from Bayou Cane, or possibly near Nezpique River. The jaw was discovered in digging a well, at a depth of 45 feet. The jaw soon crumbled and only a single tooth, a lower molar, regarded as being the fifth, was preserved. Carpenter gives as the length of the tooth 0.94 inch (23.5 mm.); as the width, 0.76 inch $(19 \mathrm{~mm}$.$) . He recognized$ the close resemblance of the tooth to the corresponding one of the tapir now inhabiting South America. In 1849 (Proc. Acad. Nat. Sci., Phila., vol. Iv, p. 180), Leidy referred to this tooth, and identified it as the lower left fourth premolar; he stated that it did not differ from the same tooth of Tapirus americanus ( $T$. terrestris).

\section{TEXAS.}

(Map 18.)

El Paso, El Paso County (1).-Dr. G. B. Richardson, of the U. S. Geological Survey, reported, in 1907 (Science, vol. xxv, p. 32), the finding of Elephas columbi, Equus complicatus, and Tapirus haysii? in a gravel-pit in El Paso. "The bones were found in cross-bedded sand and gravel, at two horizons, 30 and 60 feet below the surface of a hill, an erosion outlier of the bolson plain which lies at the base of Franklin mountains." Doctor Richardson expressed the opinion that the fossils furnish another link in the evidence of a moist climate during the early Quaternary in the Cordilleran region.

Temple, Bell County (2).-Dr. Mark Francis sent the writer, for examination, 3 cervical vertebræ which had belonged to some species of tapir and had been found in a gravel-pit at Temple. W. F. McGregor, the owner of the same pit, sent to Doctor Francis remains of Equus semiplicatus and of a medium-sized camel, possibly Camelops macrocephalus.

The following measurements (in millimeters) have been taken on the fourth cervical and compared with corresponding ones of the fourth cervical of a tapir from Costa Rica:

\begin{tabular}{|c|c|c|}
\hline & $\begin{array}{l}\text { Fossil } \\
\text { tapir. }\end{array}$ & $\begin{array}{l}\text { Tapir- } \\
\text { ella. }\end{array}$ \\
\hline Center of front to center of rear articular surface.. & 44 & 35 \\
\hline Height of anterior ball. . . . $\ldots \ldots \ldots \ldots \ldots$ & 29 & 27 \\
\hline Width of anterior ball.... & 20 & 22.5 \\
\hline Height of posterior cup.. & 34 & 31 \\
\hline Width of posterior cup ............. & 27 & 28 \\
\hline $\begin{array}{l}\text { Outside to outside of anterior zygopophysial proc- } \\
\text { esses } \ldots \ldots \ldots \ldots \ldots\end{array}$ & 60 & 57 \\
\hline
\end{tabular}


For the present the species must remain undetermined.

San Felipe, Austin County (3).- Tapir remains consisting of a part of an upper jaw, with 4 teeth, and part of a lower jaw, with 4 or 5 teeth, formed part of a collection of fossils described by W. M. Carpenter in 1846 (Amer. Jour. Sci., vol. I, p. 247, figs. 3, 4). Remains of elephant, mastodon, Bison latifrons, etc., were also obtained from San Felipe. An account of the locality and a list of species found there are given on page 246. This collection went to the British Museum; but the tapir bones from San Felipe are not men. tioned in Lydekker's Catalogue of Fossil Mammalia in the British Museum, part III.

Doctor Leidy examined and reported on these specimens in 1849 (Amer. Jour. Sci., vol. IV, pp. 180-182). He concluded that the two fragments did not belong to the same individual and probably had not been found near together. He proceeded to give an extended description of the remains. On comparing the bones and teeth with those of Tapirus americanus, he found certain differences; but thought that these might be due to a difference in the ages of the specimens compared.

In 1873 (Contrib. Ext. Vert. Fauna West. Terrs., p. 391), Leidy again referred to Carpenter's specimens under the name Tapirus americanus and expressed the conclusion that they probably belonged to an extinct species.

\section{OKLAHOMA.}

(Map 18.)

Near Mulhall, Logan County (1).-In 1917 (Bull. Geol. Soc. Amer., vol. xxviII, p. 212), Troxell reported that he had found near Mulhall some remains of a tapir. Nothing further has been published. For the accompanying genera, see page 255 . 


\title{
FINDS OF PECCARIES IN THE MIDDLE REGION OF NORTH AMERICA.
}

\author{
TEXAS.
}

(Map 19.)

Rock Creek, Briscoe County (1).-In 1903 (Bull. Amer. Mus. Nat. Hist., vol. XIX, p. 624), Dr. J. W. Gidley reported that his party of the year 1901 had found in the Pleistocene deposits of Rock Creek some remains of an undetermined species of Platygonus. In 1915 (Amer. Jour. Sci., vol. xxxıx, pp. 616, 635, fig. 24), Troxell stated that Platygonus compressus had been collected at Rock Creek by the Yale expedition.

\section{ARKANSAS.}

(Map 19.)

Willcockson, Newton County (1).-In a limestone fissure 4 miles west of Willcockson, Barnum Brown, in 1903 and 1904, found numerous remains of peccaries, all of which he referred to the genus Mylohyus. These were believed to belong probably to three species, but they were not named. About 200 teeth were secured, as well as fragmentary skulls and bones of nearly all parts of the skeleton. Some of the remains were described and figured by Brown in his paper of 1908 (Mem. Amer. Mus. Nat. Hist., vol. Ix, pp. 200-202, pls. XXIII, XXIV). The fissure and its contents will be discussed on another page. A form recognized by Mr. Brown (sp. a) has been described by Gidley (Proc. U. S. Nat. Mus., LVII, 1920, p. 675) under the name Mylohyus browni.

\section{MISSOURI.}

(Map 19.)

Tackner?, Benton County (1).-In 1852, Dr. John L. LeConte (Proc. Acad. Nat. Sci. Phila., vol. vi, p. 5) described a part of a lower jaw of a peccary, which he called Dicotyles costalus. This specimen had been given to Doctor LeConte by Dr. R. W. Gibbs, who reported only that it had been obtained in Benton County, associated with mastodon bones. That it was found along the Osage River is not certain. In 1853, Leidy studied this specimen (Trans. Amer. Philos. Soc., vol. x, pp. 325, 331, pl. xxxvII, fig. 10 ; pl. xxxviII, fig. 3 ) and concluded that it belonged to the earlier described Dicotyles compressus, now arranged under the genus Platygonus. Besides the hinder half of the right side of the lower jaw, Leidy found some other premolars and molars, upper and lower, of probably the same individual.

\section{KANSAS. \\ (Map 19.)}

So far as the writer knows, representatives of the Tagassuidce have been found in Kansas at only one place, Goodland, in Sherman County, a few miles from the western line of the State. Osborn (Age of Mammals, p. 463) indicates that Platygonus compressus has been found with Bison occidentalis and Elephas columbi on Twelve-mile Creek, Logan County, and cites Williston (Internat. Cong. Americanists, 1902, p. 335). Williston, however, informed the writer that he had reference to the specimens found at Goodland. 
Goodland, Sherman County (1).-In 1894 (Kansas Univ. Quart., vol. III, pp. 23-39, pls. vir, vili), Williston reported the discovery of remains of Platygonus at Goodland. In excavating for clay in a brickyard, 9 skeletons were found which belonged to individuals of both sexes and of different ages. Williston described these under the name Platygonus leptorhinus, but they appear not to differ essentially from $P$. compressus. The bones were found, as reported by Williston, in a loose sandy marl at a depth of 9 feet. The different individuals were lying with their snouts all in the same direction and those behind were resting partly on those in front; probably a herd had perished in a storm. Williston, at the time of his description, regarded the deposits as belonging to the Pliocene; but later, as cited above, he recognized them as being buried in the Equus (Sheridan) beds of the Pleistocene.

In order to learn the exact location of the pit which furnished these fine skeletons, the writer communicated with. D. A. Long, of Goodland, who has been for 20 years the county surveyor of Sherman County. He sends the information that the brickyard, now no longer worked, but yet showing the old 12-foot-deep clay-pit, is situated in the southeast quarter of section 19, township 8 south, range 39 west. The railroad machine shops are within about 100 yards of the pit. The surface of the prairie in the vicinity is described as forming a dead level for miles around. There is no sand above the clay; but sand is found in wells dug near there, at a depth of about 60 feet. The clay is described by Mr. Long as being like flour when dug up and dried. Mixed with water and sand, it was once used as a substitute for plaster. From this description of the locality and the material, it is evident that the bones were buried in the loess, so commonly distributed in that region.

In most cases where the geological age of this species can be determined with certainty, the remains belong to the post-Wisconsin stage. However, Dr. W. D. Matthew has identified portions of upper and lower jaws found in Sheridan deposits, at Peters (Hay Springs), Sheridan County, Nebraska, as belonging to Platygonus compressus. If this identification is correct, it must be concluded that the species existed during the whole, or nearly the whole, of the Pleistocene, and this is what one might expect.

IOWA.

(Map 19.)

Sioux City, Woodbury County (1).-In his paper on the Pleistocene Mammals of Iowa (Iowa Geol. Surv., vol. XxIII, p. 22\%, pl. xxI, figs. 1, 2), the writer described, under the name of Mylohyus? temerarius, a tooth of a peccary, secured by Professor B. Shimek in the Anderson sand-pit near Sioux City. The pit is described on page 298. No other parts of the animal are known.

Burlington, Des Moines County (2). - In the report on the geology of the lead region (Geol. Surv. Wis., 1862, p. 135), Whitney stated that remains of the extinct peccary had been found at Burlington. Inasmuch as our Platygonus compressus was the only extinct species of peccary then known, it must be that Whitney believed that the Burlington remains belonged to it.

In 1857 (Trans. Amer. Philos, Soc., vol. xI, pp. 100, 105, pl. vi, fig. 2), Leidy stated that remains of Dicotyles compressus had been found in Iowa 
by Doctor Foster, and he figured a series of upper teeth. The remains were in the hands of Wyman, who proposed to give an account of them, but apparently never finished his task. It seems not improbable that the remains mentioned by Whitney as found at Burlington are the same as those which Wyman had. In any case, there is nothing in the report of the Burlington specimen that gives any clue to its geological age.

Dubuque, Dubuque County (3).-From the rather obscure accounts given, it appears that two species of peccaries have been found in Iowa, near Dubuque. In his report on the geology of the lead region, in 1862 (Wisconsin Geol. Surv., vol. I, p. 135), Whitney stated that he and C. Childs found some teeth and bones of a peccary in a crevice near Dubuque, on the Mississippi, a few rods below Lorimiai furnace. On the same page Whitney had just been discussing the peccary now known as Platygonus compressus, and he then spoke of the remains found near the furnace as those of "the same animal." Nothing else is mentioned as having been found associated with these peccary bones.

In a foot-note on the same page, Whitney stated that other teeth, obtained in a crevice near Dubuque, found in association with Megalonyx, were submitted to Doctor Wyman and were referred by him to the living species. These are probably the 3 teeth which Wyman, on page 422, mentioned as agreeing with Dicotyles torquatus. Leidy (Jour. Acad. Nat. Sci. Phila., vol. vII, p. 384) regarded all such teeth as belonging to his D. lenis (Tagassu lenis). It is probable that he had in mind, when he spoke of teeth from Wisconsin, those mentioned by Whitney in 1866 (Geol. Surv. Ills., vol. I, p. 162). They had been found at Blue Mounds, Wisconsin; for Wyman simply stated that the materials he studied were from the lead region of Wisconsin and Iowa. The reader is referred to page 214 of the twenty-third volume of the Iowa Geological Survey.

\section{NEBRASKA.}

(Map 19.)

"Niobrara River" (1).--In 1869 (Jour. Acad. Nat. Sci. Phila. vol. vir, pp. 200, 389, pl. xxviII, fig. 3), Leidy mentioned and figured an upper canine tooth of a peccary, which he referred to the genus Dicotyles. The tooth was much worn and was thought to be of the size and appearance that a canine of Platygonus compressus would possess under the same circumstances, but he concluded that its reference to any particular species was uncertain. The specimen was collected by Doctor Hayden in sands somewhere along the Niobrara River. The deposits were regarded as belonging to the Pliocene, but they were probably Pleistocene.

Seneca, Thomas County (2).--In a letter from Dr. W. D. Matthew the present writer was informed that during the summer of 1916 a party from the American Museum of Natural History, New York, explored the region about the headwaters of the Middle Loup Fork River, west of Seneca. Some remains of Platygonus were found. In the same region were secured remains of Equus, Camelops, Canis, etc. No Pliocene deposits were found here; but these were observed a little farther south, on Dismal River.

In 1871 (Amer. Jour. Sci., ser. 3, vol. II, p. 41), Marsh described his Platygonus striatus. He had some lower jaws, of one of which he gave several 
measurements. The type of the species must be regarded as a second lower premolar, which, according to a letter from Dr. R. S. Lull, is No. 10018 in the collection of Yale University. This tooth is described as resembling the corresponding one of $P$. compressus; but in addition to its much larger size it is proportionately broader. It is said also to have the basal ridge in front less developed, while that of the rear is expanded into two rudimentary tubercles. The length of the tooth is 6.2 lines $(12.9 \mathrm{~mm}$.), the width 5.8 lines $(12 \mathrm{~mm}$.).

Marsh's specimens are said to have been found near the headwaters of Loup Fork River, in northern Nebraska. Whether this was the North or the Middle Loup Fork, the writer does not know. The deposits were regarded as belonging to the Pliocene, but it is probable that they are Pleistocene. If the locality was on the Middle Loup Fork, it was probably somewhere near Seneca.

Peters, Sheridan County (3).-In 1902 (Bull. Amer. Mus. Nat. Hist., vol. Xvi, p. 317), Dr. W. D. Matthew published a list of the fossil mammals secured near Peters by E. D. Cope and by parties from the American Museum of Natural History. The locality is mentioned as being near Hay Springs. In this list are found the names of 2 species of Platygonus: $P$. compressus and $P$. vetus. The former is represented by upper and lower jaws, the latter by a palate. The writer has not examined these materials. For the associated species, see page 305 . The type of $P$. vetus was found in a cave in eastern Pennsylvania (Leidy, Ann. Rep. Geol. Penn. for 1887, p. 12) and belonged probably to late Wisconsin times. To the same epoch may have belonged the type of $P$. compressus, but this is uncertain. In case both species are confirmed as being found in the Sheridan beds of Nebraska, they will be shown to have continued on from near the beginning of the Pleistocene to its end. As expressed on another page, this conclusion will accord with the history of the other Pleistocene mammals. 


\title{
FINDS OF CAMELID A IN THE MIDDLE REGION OF NORTH AMERICA.
}

\author{
TEXAS.
}

(Map 20.)

Rock Creek, Briscoe County (1).-In 1884 (4th Ann. Rep. Texas Geol. Surv., p. 84, pl. xxıII, fig. 5), Cope described and figured, under the name Holomeniscus macrocephalus, a nearly complete lower jaw of a camel, Camelops macrocephalus, which had been found on Rock Creek, near its entrance into Tule Canyon. From the same locality (op. cit., p. 84, pl. xxin, fig. 4) the same author described his new species Holomeniscus sulcatus. The present writer has referred this provisionally (Proc. U. S. Nat. Mus., vol. Xuvi, p. 275 ) to Camelops huerfanensis. From Rock Creek, in 1915, Lull (Amer. Jour. Sci., ser. 4, vol. xxxix, p. 328) and Troxell (ibid., p. 622) reported Camelops hesternus and Eschatius conidens. There are thus 4 species of camels which are supposed to have lived in that region during the early Pleistocene.

Cope's type of Camelops macrocephalus is in the collection at the University of Texas. His measurement of the length of the jaw, $292 \mathrm{~mm}$., includes the incisors and extends to the rear of the jaw on the level of the teeth. Deducting the length of the incisors, the distance is $285 \mathrm{~mm}$. What Cope calls $\mathrm{pm}_{4}$ is the first premolar, $\mathrm{pm}_{1}$, his reckoning beginning behind. The hindmost molar, not measured by Cope, has a length of $33 \mathrm{~mm}$. and a width in front of $14.5 \mathrm{~mm}$. The writer found the width of the first molar to be 13 $\mathrm{mm}$. (Cope, $14 \mathrm{~mm}$.) and that of the second to be $15 \mathrm{~mm}$. (Cope, $13 \mathrm{~mm}$.) The type of $C$. sulcatus is in the same University collection. Besides these types, there are in the collection mentioned other camel bones, which were collected by W. F. Cummins and labeled found at "Osborn's, Tulea Canon."

Bridgeton, Wichita County (8).-The writer has seen a right upper second molar of a camel, sent, in November 1921, by Professor L. C. Glenn, for identification. It was found at Bridgeton. The locality is described more exactly as being a gravel-pit at an elevation of about 70 feet above the present level of Red River. On comparison with the teeth of Camelops huerfanensis, the writer finds no differences which appear to be important.

Dallas, Dallas County (9).--In 1921 (Amer. Jour. Sci., ser. 5, vol. II, p. 160), Lull reported the discovery, in the Lagow gravel-pit at Dallas, of a camel which he described as Camelops huerfanensis dallasi and of a camel of an unidentified genus and species. The accompanying species are listed on page 241 .

Waco, McLennan County (2).--In the collection of Baylor University the writer saw a metapodial and a part of a lower jaw of a camel, the jaw containing the last premolar and the 3 molars. The lower jaw was referred by the writer (Bull. Univ. Texas, No. 71, 1916, p. 16) to Camelops hesternus. He understands that these remains were found on the highest terrace, 5 miles above Waco.

Temple, Bell County (3).-Dr. Mark Francis sent to the writer, for examination, 3 cannon-bones of a camel, found in a gravel-pit, halfway between Temple and Belton, by W. F. McGregor. In the same pit were found cervical 
bones of a tapir, teeth of the horse Equus semiplicatus and of Elephas columbi, a part of a humerus of Mylodon harlani, and the type of the great land tortoise, Tesludo francisi. One bone of the camel belonged to the right fore-leg; the other 2 to the right and left hind-legs. 'The anterior cannon-bone lacks the distal end, perhaps one-third of the total length. The following comparative measurements are given, the groove in the hinder face being disregarded in taking the fore-and-aft diameter:

Measurements of anterior and hinder cannon-bones in millimeters.

\begin{tabular}{|c|c|c|c|c|c|c|}
\hline & \multicolumn{3}{|c|}{ Anterior. } & \multicolumn{3}{|c|}{ Hinder. } \\
\hline & Fossil. & $\begin{array}{c}\text { Bactrian } \\
\text { camel. }\end{array}$ & Llama. & Fossil. & $\begin{array}{c}\text { Bactrian } \\
\text { camel. }\end{array}$ & Llama. \\
\hline $\begin{array}{l}\text { Total length............. } \\
\text { Side - to - side diameter at } \\
\text { proximal end............ } \\
\text { Side-to - side diameter at } \\
\text { middle of shaft........... } \\
\text { Fore-and - aft diameter at } \\
\text { middle of shaft.......... } \\
\text { Side-to-side at distal end... }\end{array}$ & $\begin{array}{r}255 \\
48 \\
30 \\
26 \\
\cdots\end{array}$ & $\begin{array}{l}330 \\
64 \\
33 \\
31.5 \\
83\end{array}$ & $\begin{array}{l}198 \\
27.5 \\
16 \\
16.5 \\
35\end{array}$ & $\begin{array}{c}55 \\
38 \\
\\
26 \\
\ldots\end{array}$ & $\begin{array}{r}321 \\
70 \\
39 \\
\\
31 \\
94\end{array}$ & $\begin{array}{l}195 \\
29 \\
16 \\
16.5 \\
36\end{array}$ \\
\hline
\end{tabular}

The right anterior cannon-bone is the better of the two, but the distal end is missing. The present length is $240 \mathrm{~mm}$.; it was originally about $255 \mathrm{~mm}$. It seems probable that all these bones belonged to the same individual. The anterior bone was apparently longer than the hinder. On account of the moderate size, the bones are referred to Camelops macrocephalus, an animal smaller than $C$. huerfanensis or $C$. hesternus.

Pittbridge, Brazos County ( 7 ).-Dr. Mark Francis sent to the writer from Pittbridge, for examination, the greater part of a right front cannonbone of a camel. That part which is formed of the two separated metacarpals is missing. The bone is slightly smaller than the corresponding bone of the dromedary. The front surface in the middle third is rounded from side to side, not flattened, as it is in the dromedary. Doctor Francis reported that he had a splendid tooth of a camel, found, December 1922, at Pittbridge.

San Felipe, Austin County (4).- In 1884 (4th Ann. Rep. Geol. Surv. Texas, p. 83, pl. xxI, figs. 3,4 ), Cope reported that a fine mandibular ramus of Camelops hesternus had been found in Austin County. In a foot-note it was explained by J. B. Walker that the locality was Bowie Bend. Professor E. T. Dumble, in the same foot-note, called attention to the fact that here W. M. Carpenter had obtained the materials which he described in the American Journal in 1846. It is at or close to San Felipe. It had previously been said by Cope that the jaw was found in Wharton County (Proc. Amer. Philos. Soc., vol. xxx, p. 123). J. B. Walker also stated that at Bowie Bend the bluff is in two terraces and that the bones, when in place, were at the upper part of the lower terrace. This specimen has been provisionally referred by the writer to Camelops huerfanensis (Proc. U. S. Nat. Mus., vol. xLvi, p. 276).

Richmond, Fort Bend County (5).-In the collection of Professor E. T. Dumble, at Houston, Texas, the writer saw 2 teeth of a camel, a last upper 
molar and what appeared to be a second lower molar. These teeth were found in Brazos River, near Richmond. The locality is near the northern border of the Beaumont formation. This is doubtless very thin at the locality, and the teeth may have been buried in the underlying Lissie. In either case, the writer regards the remains as belonging to the early Pleistocne.

Keeran Point, Victoria County (6).-Dr. Mark Francis, of the Agricultural and Mechanical College, College Station, Texas, sent to the writer, for examination, a cervical vertebra and the distal end of a metapodial bone of a large camel, which, accompanied by remains of a mastodon, Anancus brazosius, and an elephant, were found at Keeran Point. Details regarding the geology of the locality will be found on page 236 .

\section{OKLAHOMA.}

\section{(Map 20.)}

Afton, Ottawa County (1).- Two species of camels have been found in a spring near Afton. An account of the locality and a list of the species found there are presented on page 253. The specimens are in the U. S. National Museum.

\section{Camelops Kansanus? (Leidy).}

To this species are referred 5 teeth or parts of teeth. All of these appear to be well fossilized and are stained blue or black. One tooth is the upper left first molar, which is only slightly worn. It belongs in the department of anthropology. The following measurements are taken from this tooth and from the same molar of the type of $C$. huerfanensis:

Measurements of first upper molars in millimeters.

\begin{tabular}{|l|c|c|}
\hline & $\begin{array}{c}\text { C. huerfanensis } \\
\text { type. }\end{array}$ & $\begin{array}{c}\text { Afton } \\
\text { specimen. }\end{array}$ \\
\hline Height of crown, as preserved....... & 35 & 60 \\
Length of crown at the base....... & 33 & 28 \\
Length of crown 33 mm. above base. & 38.5 & 43 \\
Width posterior lobe at base........ & 30 & 25 \\
\hline
\end{tabular}

It will be seen that, as compared with that of the type, the Afton first molar has a short and narrow base, but that it expands rapidly fore-and-aft toward the summit. Here the length is $53 \mathrm{~mm}$. Another tooth is a littleworn, well-preserved, lower left last molar, also in the department of anthropology. The following measurements are taken, and corresponding ones of the same tooth of the type of $C$. Iuerfanensis, of a tooth from Minidoka, Idaho, and of the same tooth of the type of Cope's Holomeniscus sulcatus, regarded by the writer as probably the same as $C$. huerfanensis:

Measurements of lower hindermost molars.

\begin{tabular}{|c|c|c|c|c|}
\hline & $\begin{array}{l}\text { Minidoka } \\
\text { tooth. }\end{array}$ & $\begin{array}{l}\text { C. huer- } \\
\text { fanensis. }\end{array}$ & $\begin{array}{l}\text { Afton } \\
\text { tooth. }\end{array}$ & $\begin{array}{l}\text { H. sul- } \\
\text { catus. }\end{array}$ \\
\hline Height of crown & 63 & 65 & 50 & \\
\hline Length of crown at middle of height. & 56 & 62 & 51 & 55 \\
\hline Thickness of second lobe.......... & 20 & 21 & 21 & 20 \\
\hline
\end{tabular}


It will be noted that the Afton tooth is somewhat, but not much, snaller than the others. It differs from them in having on the inner face a pronounced groore opposite each of those on the outer face and in haring in front of each groove a pretty strongly developed style. In the department of palæontology there is a part of another lower left last molar of a considerably worn tooth. Only the second and third lobes are present.

In the collection there is an upper premolar (No. 214410, U. S. Nat. Nus. Dept. Anthrop.), which resembles the fourth of C. huerfanensis, but is ton small; it may be the third premolar. The crown is only slightly worn and has a height of $45 \mathrm{~mm}$. At the base the length is $16 \mathrm{~mm}$.; at summit, $20 \mathrm{~mm}$. The thickness at base is $24 \mathrm{~mm}$.

These teeth may belong to Camelops huerfanensis. They were described provisionally by the writer, in 1920 , as those of C. kansanus (Proc. U. S. Nat. Mus., LviII, p. 121).

\section{Camelops nitidus Hay.}

In the collection from Afton are 3 left lower teeth, identified as the left lower premolar and the first and second molars. These were described by the writer in 1920 (Proc. U. S. Nat. Mus., vol. Lvin, p. 122, figs. 3-8).

Measurements of lower teeth of Camelops nitidus in millimeters.

\begin{tabular}{|l|c|c|c|}
\hline & $\begin{array}{c}\text { Fourth } \\
\text { premolar. }\end{array}$ & $\begin{array}{c}\text { First } \\
\text { molar. }\end{array}$ & $\begin{array}{c}\text { Second } \\
\text { molar. }\end{array}$ \\
\hline Length........ & 18 & 23 & 24 \\
Width....... & 9.1 & 23 & 15 \\
\hline
\end{tabular}

The fourth premolar is worn nearly to the base. The first molar is moderately worn and has still a height of $26 \mathrm{~mm}$. The second molar is only slightly worn and has a height of $45 \mathrm{~mm}$. The length of the teeth, as given abore, is taken at the base.

\section{NEW MEXICO.}

(Map 20.)

Black Rocks, McKinley County (1).-On page 259 an account is giren of excavations at Black Rocks, in which were found a part of the skull of a musk-ox, Gidleya zuniensis, some teeth of Mammut americanus, some bones of a horse and a part of a scapula of an undeterminerl camel.

\section{MISSOURI.}

\section{(Map 20.)}

Rockport, Atchison County (1).-In his second communication on the mammals of the Aftonian interglacial stage (Bull. Geol. Soc. Amer., vol. xxil, p. 212, pl. xIx, fig. 10), Calvin reported the discovery of an upper right fourth premolar in a gravel-pit, in section 22, township $6 \pm$ north. range +1 west. In the same pit were found remains of Elephas columbi, Hipparion, and Equus. Calvin regarded the grarels as belonging to the Aftonian stage. The tooth was described and figured by the present writer in 1912 (Iowa (ienl. 
Surv, vol. xxIII, p. 243, pl. xxxI, fig. 4). Its identification is uncertain, but it may belong to Camelops kansanus.

\section{KANSAS.}

(Map 20.)

McPlierson, McPherson County (1).--Professor H. J. Harnley, of McPherson College, has shown the writer a first phalange of a camel, found by Henry Peel in the McGill sand-pit, 2 miles east from the center of McPherson. It was met with at a depth of 35 feet. The length is $100 \mathrm{~mm}$.; width of upper end, $42 \mathrm{~mm}$; side-to-side diameter at middle of length, $25 \mathrm{~mm}$.; width of lower end, $34 \mathrm{~mm}$. It is impossible to determine the species to which this bone belonged. Although the bone is somewhat smaller, the proportions are almost exactly those of an anterior phalange found at Henton, Mills County, Iowa (Iowa Geol. Surv., vol. XxIII, p. 241). In the same collection was seen another camel bone, found at J. H. Parker's place, in a well at a depth of 118 feet. The deposits containing these bones are believed to be equivalent to the Sheridan beds and to the Aftonian.

Meade, Meade County (2).--In 1896, Professor F. W. Cragin made a brief report on the Pleistocene geology of Meade and Clark Counties and recorded various species of rertebrate animals which he collected there. Among these was Auchenia huerfanensis, now called Camelops huerfanensis. The greater part of this collection is in Colorado College, at Colorado Springs, and the writer has examined it. He regards Cragin's identification of the camel teeth and bones as correct. These camel remains, as well as the rest of the collection, were secured from the lowest of the three divisions, the Meade gravels.

Pendennis, Lane County (3).-In the collection of the University of Kansas, at Lawrence, are a fragment of a metapodial and a first phalange, which were found by C. H. Sternberg, among many elephant remains, about 7 miles northeast of Pendennis. The fragment of metapodial is $140 \mathrm{~mm}$. long; the width across the distal articular surface, $65 \mathrm{~mm}$; measured $80 \mathrm{~mm}$. above the ristal end, the width of the shaft is $61 \mathrm{~mm}$. The phalange is $122 \mathrm{~mm}$. long, $45 \mathrm{~mm}$. across the proximal articular surface, $27 \mathrm{~mm}$. fore and aft, and $27 \mathrm{~mm}$. from side to side at middle of length.

Russell Springs, Logan County (4).-At a point near the mouth of Twelvemile Creek, 12 miles west from Elkader, on the south side of Smoky Hill River, were found many bones of Bison occidentalis, among them those forming the complete skeleton mounted at the University of Kansas. H. T. Martin, the collector of these bones, informed the writer that at a place about 0.75 mile north of this he found camel bones and teeth; also teeth of a horse, of a badger, and of a small dog, and of another dog which Mr. Martin determined to be Canis occidentalis.

Leroy, Coffey County (5).- In the U. S. National Museum (No. 2095) is the greater part of the left metacarpal of a camel, sent there in 1869 from Leroy. In a letter written in that year Allen Crocker, the donor, stated that the bone had been found within the limits of Leroy, sticking in the bank of Neosho River, about $y$ feet above low-water mark. It was in a bed of sand and gravel which underlies the town. The bone has lost the lower end up nearly to the top of the split. On comparison with the corresponding bone of 
Camelus dromedarius it appears to have had almost exactly the same length. The other dimensions are different. The following measurements of metacarpals are presented, in millimeters:

\begin{tabular}{|l|c|c|}
\hline & Fossil. & Dromedary. \\
\cline { 1 - 2 } Length from upper end to split............ & 285 & \\
Side to side diameter of upper e nd........ & 72 & 685 \\
Side to side diameter at middle of length... & 44 & 38 \\
Fore-and-aft diameter at top of split....... & 26 & 21.5 \\
\hline
\end{tabular}

While in the dromedary the lateral faces of the bone are nearly parallel, in the fossil they diverge strongly backward. It appears that this camel was a heavier-legged animal than the dromedary.

\section{COLORADO.}

(Map 20.)

Near Gardner, Huerfano County (1).-Somewhere along Williams Creek, probably in township 25 south, range 70 west, as the writer is informed by Professor R. C. Hills, of Denver, was found the camel which was afterward described by Professor F. W. Cragin under the name Auchenia huerfanensis. This specimen is now in the U.S. National Museum. Unfortunately no record has been preserved regarding the geological conditions connected with the burial of the animal. At the same time and place was found a tooth of a horse. Professor Hills has written that the camel and the horse remains were found in volcanic-ash beds west of Williams Creek. These beds are only about 0.25 mile wide and extend westward from the creek 2 or 3 miles.

Colorado Springs, El Paso County (2).-In a small collection of bones made in gravel-pits in or near Colorado Springs was the proximal two-thirds of a metatarsal of a camel. It was $265 \mathrm{~mm}$. long, and apparently belonged to a beast having long and slender legs. The following table gives comparative measurements in millimeters.

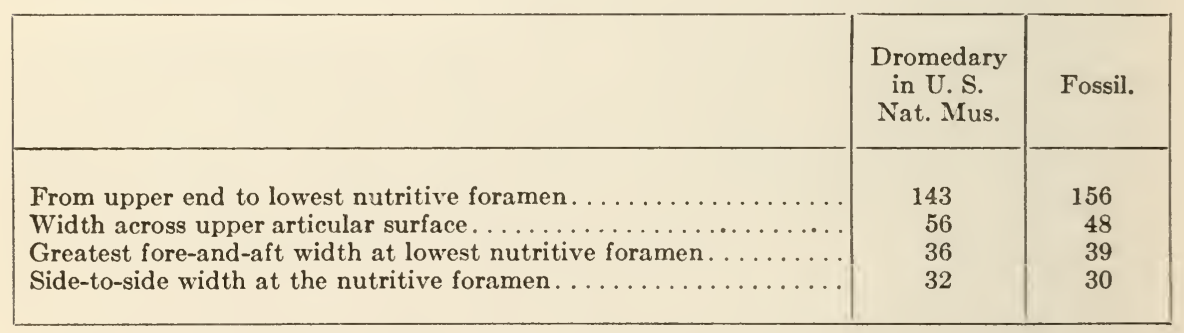

Besides the metatarsal there was included one of the condyles belonging to the distal end of a metapodial. In this same lot of bones were remains of a horse, a bison, a musk-ox (Ovibos?), and a deer-like animal.

Denver, Denver County (3).- There have been sent to the U. S. National Museum, by Professor George I. Cannon, of Denver, teeth and various bones of a camel. These were referred by the writer to Camelops huerfanensis and described in 1921 (Proc. U. S. Nat. Mus., vol. LIx, p. 600, pl. crvi). In the 
same deposits along Platte River were found bones of an undetermined species of horse and an undetermined Bison. In 1896 (Mon. U. S. Geol. Surv., vol. xxvir, p. 264), Dr. S. F. Emmons reported that bones submitted to Professsor F. W. Cragin had been pronounced by him as those of Auchenia. These had been found in river drift and loess, and possibly in fluvial loess. The bones would now be referred to Camelops.

West Cliff, Custer County (4).- In the U. S. National Museum are 3 teeth of a camel, found at West Cliff. They were sent, in 1891, by T. Charlton, and were reported to have been found in digging a well within the limits of the town. They were met with at a depth of between 15 and 25 feet in a mixture of fine sand, clay, and some gravel.

\section{IOWA.}

(Map 20.)

Remains of camels have been found, so far as reported, in four localities in Iowa, all situated along the western border and in all of them the deposits containing camel remains are regarded as belonging to the Aftonian interglacial stage. For a somewhat different view the reader is referred to page 279.

Hinton Station, Mills County (1).-In his second paper on Aftonian mammals (Bull. Geol. Soc. Amer., vol. XxII, p. 212, pl. XIx, fig. 8), Calvin described and figured a proximal phalange of a camel, found in Aftonian deposits at Hinton Station. In the present writer's account of the Pleistocene mammals of Iowa (Iowa Geol. Surv., vol. xxIII, p. 241, pl. xxxi, fig. 1), the measurements of this bone are given and Calvin's figure is reproduced. It is impossible with our present knowledge to say to what species of camel the bone belonged. In the University of Iowa there is the distal end of the humerus of a large ruminant, which the writer (op. cit., p. 242) identified as that of an undetermined species of camel.

In the vicinity of Hinton Station have been found also a tooth of Elephas columbi, teeth of Equus complicatus, and of $E$. laurentius.

Missouri Valley, Harrison County (2).- In his first paper on Aftonian mammals (Bull. Geol. Soc. Amer., vol. xx, p. 351), Calvin mentioned 2 ungulate calcanea. The measurements and a figure of one of them were given by the present writer in 1914 (Iowa Geol. Surv., vol. XxiII, p. 242, pl. XxviII, fig. 6). The figured bone is referred provisionally to Camelops kansanus. The measurements indicate that the two bones did not belong to the same species. They were found at Missouri Valley, in the Cox sand-and-gravel pit. Calvin also figured a large astragalus (pl. xxII, fig. 1), which had been found in the Cox pit. On page 242 of his paper the present writer identified this bone as an astragalus of a camel.

From the Cox pit has been secured a large lower hindmost molar of a camel, which the writer (op. cit., p. 244, pl. xxvirr, fig. 1; pl. Lxxiv, fig. 7) referred to Camelops kansanus. The collection at the Iowa State University, taken also from the Cox pit, contains the distal end of a cannon-bone of a camel. The measurements have been given by the writer (op. cit., p. 244). The geological situation at Missouri Valley is discussed on page 296.

Pisgah, Harrison County (3).-Calvin (Bull. Geol. Soc. Amer., vol. xx, p. 350 , pl. XxI, fig. 1; pl. XxIr, fig. 2) figured a proximal phalange of a large 
ruminant which had been found in the Peyton pit near Pisgah. The measurements have been given by the present writer (op. cit., p. 241) and the bone identified as that of a camel of uncertain species. The situation of the pit, its geological relations, and the species of vertebrates found are presented on page 295.

Turin, Monona County (4).-Calvin (Bull. Geol. Soc. Amer., vol. xxiI, pp. 212, 216, pl. xix, fig. 9) figured a phalange of the second row, which had been found in the Elliott pit, at Turin. The writer has given the measurements of the bone and reproduced Calvin's figure (op. cit., p. 241, pl. XxxI, fig. 2). From the same pit there is, in the collection of the State University of Iowa, the upper end of what appears to be a cannon-bone of a camel (op. cit.. p. 244). From Turin, probably from the Elliott pit, the writer described and figured (op. cit., p. 243, pl. xxvin, fig. 1) a lower right fourth premolar of a camel which may be Camelops huerfanensis. For information regarding the geological situation at Turin and the species of vertebrates found there, see page $29 \%$.

\section{NEBRASKA.}

(Map 20.)

Reynolds, Jefferson County (1).-On page 99 is noticed the finding of part of a tooth of Elephas imperator 4.5 miles east of Reynolds. With this were discovered, as reported, a phalange and a vertebra of a camel. The genus and species are not known. The bank of clay which held these remains is certainly of Aftonian (Sheridan) age.

Seneca, Thomas County (2).-As reported to the writer by Dr. IV. D. Matthew, a party from the American Museum of Natural History, in 1916, found, not far west of Seneca, some remains of the genus Camelops. In the same neighborhood were secured remains of Equus, Platygonus, Canis, etc. The deposits were regarded as belonging to the Equus beds. It was probably in this region that the types of Elephas imperator and Anancus (Stegomastodon) mivificus were found.

Peters, Sheridan County (3).-In 1898 (Bull. Amer. Mus. Nat. Hist., vol. x, p. 133, fig. 21), Dr. J. A. Wortman described a camel to which he gare the name Camelus americanus. The materials consisted of portions of lower jaws with teeth which had been found in the quarry on Niobrara River, which has furnished so many other fossil vertebrates. Besides the species just named, there had previously been recorded from this locality Camelops kansanus and $C$. vitakerianus. For the associated species, see page 305 .

Furnas County (4).- In the collection of the Illinois State Museum, at Springfield, is a ramus of a lower jaw of a camel, recorded as found in a canyon in Furnas County. This jaw probably belongs to one of the species of Camelops, but of this the writer is not now certain.

\section{SOUTH DAKOTA.}

(Map 20.)

Irene, Clay County (1).-The writer has a note regarding a tooth which be identified some years ago as that of Camelops and which was found, in 1904, near Irene. This tooth is in the U. S. National Museum and has cata- 
logue No. 8252. It was discovered by F. A. Sweezey, of Wakonda, Clay County, in a sand-pit on Turkey Creek, at a depth of about 9 feet. Mr. Sweezey wrote that the pit is located in the west half of the southwest quarter of section $\%$, township 95 north, range 53 west. In Bulletin No. 158 of the U. S. Geological Survey, on page 31, is a description of Turkey Ridge and a map of it (pl. XxxII). It is formed by a loop of the outermost Wisconsin moraine and is drained southward by Turkey Creek. From Todd's description it is evident that older glacial deposits may be found along the creek. It is probable that the camel tooth was buried in a deposit of Aftonian age.

MONTANA.

(Map 20.)

Flaxville, Sheridan County (1).-In 1918 (U. S. Geol. Surv. Profess. Pap. $108 \mathrm{~J}$ ), Collier and Thom, on determination made by J. W. Gidley, stated that a camel tooth had been discovered near Flaxville. The report reads: "Camelops sp. (large tooth, last lower molar, wrapped in mud ball). Apparently Pleistocene species." The more exact locality is giren as being in township 35 north, range 50 east, first cut of Great Northern Railway west of Flaxville. The writer has not seen this tooth. In the same cut were found teeth which were referred to Neohipparion (IIipparion) and Procamelus. In other not distant localities were found in these Flaxville beds Hipparion and rhinoceros of unidentified genus and species, Protohippus, Merychippus, Procamelus, Merycodus, and Ceratogaulus. These appear to be Tertiary species, belonging probably to the Pliocene. The geologists at present regard the formation as being of the late Miocene or early Pliocene. There may, therefore, be some error about the specimen of Camelops. 


\title{
FINIS OF DEER OF THE GENUS ODOCOILEUS IN THE MIDDLE REGION OF NORTH AMERICA.
}

\author{
LOUISIANA.
}

(Map 21.)

Petite Anse, Iberia Parish (1).-In his paper of 1895, Dr. Joseph F. Jooe (Amer. Naturalist, vol. XxIx, pp. 394-398) reported that among the fossils collected by him at Petite Anse in 1890 were some bones of a deer. It should probably be referred to Odocoileus virginianus, but the materials have not been described and the writer has not seen them. However, Hilgard (Smithson. Contrib. Knowl., vol. Xxiır, No. 248, p. 14) stated that remains of deer had been found at Petite Anse before he visited the place. There is some uncertainty regarding the depth and the nature of the deposits from which the deer remains were secured.

TEXAS.

(Map 21.)

East Dallas, Dallas County (1).-In 1921 (Amer. Jour. Sci., ser. 5, vol. II, p. 163), Dr. R. S. Lull reported the finding of an antler and a part of a humerus of Odocoileus sp. indet., in the Lagow sand-pit at East Dallas. It was associated with various early Pleistocene mammals. The species was regarded as indeterminable.

ARKANSAS.

(Map 21.)

Willcockson, Newton County (1).-In 1908 (Mem. Amer. Mus. Nat. Hist., vol. Ix, p. 205), Barnum Brown recorded the presence of Odocoileus in the Conard fissure, 4 miles west of Willcockson. The remains secured consisted, in part, of 2 lower jaws and some foot-bones, which were referred, with some doubt, to O. virginianus. Three upper grinding-teeth, a base of a large antler, and various foot-bones were identified provisionally as 0 . hemionus. The species found in this fissure are listed on pages $251,252$.

\section{OKLAHOMA.}

(Map 21.)

Afton, Ottawa County (1).-In 1901, W. H. Holmes made a collection of remains of fossil mammals and many flint implements in a spring near Afton. An account of this discovery and a list of the mammals are given on page 254 . The Holmes collection contains an upper molar, 2 left lower molars in a fragment of the jaw, a part of the left antler about $160 \mathrm{~mm}$. long, 6 anterior cannon-bones and a hinder cannon-bone, a magnum bone, and 6 cubonaviculars, all of which, on comparison with the corresponding parts in $O$. hemionus and $O$. virginianus, are referred to the latter. The bones are but little stained externally. On a fractured surface they are chalky white and adhere to the tongue. In a flame they do not show the presence of any considerable amount of animal matter. Compared with the correspouding bones of the living deer, they are appreciably heavier. While it is impossible to determine their geological age, it seems not improbable that they belong to some one of the Pleistocene stages, perhaps to one of the later ones; but they may be older. 
Mulhall, Logan County (2).--In $191 \%$ (Bull. Geol. Soc. Amer., vol. xxviri, p. 212), Troxell stated that he found remains of a deer near Mulhall. This was probably a species of Odocoileus. For a list of the associated genera, see page 256 .

\section{MISSOURI.}

(Map 21.)

Pomme de Terre River, near Avery, Hickory County (1).-This locality and the nature of the collection made by Albert Koch are considered on page 25 in connection with the mastodons obtained. In 1843, Doctor Harlan stated (Amer. Jour. Sci., vol. xuIv, p. 70) that Koch's collection, then on exhibition in Philadelphia, contained, besides the bones and teeth of mastodons, some remains of the ox (doubtless Bison), deer, elk, and megatherium. Each of these is here considered in its proper place. Unfortunately, Harlan did not indicate by what parts these various animals were represented. The present writer does not know what became of the minor parts of the collection.

Kimmswick, Jefferson County (2).-In a small collection made at Kimmswick and sent, in July 1921, to the U. S. National Museum by Dr. W. F. Parks, of St. Louis, was a second phalange which seemed not to differ from the corresponding bone of Odocoileus virginianus. A list of the species found at Kimmswick is given on page 263 .

\section{KANSAS.}

\section{(Map 21.)}

North Lawrence, Jefferson County (1).-In the collection of the University of Kansas are parts of several antlers found at North Lawrence, which are not distinguished from those of Odocoileus virginianus. They appear to have been found after washouts along Kaw River. Inasmuch as this genus, perhaps this species, has come down to us from the early Pleistocene, it is impossible to say what is the age of these antlers. From the washouts at North Lawrence have been secured a horse, Equus laurentius, belonging to the Aftonian, and bison skulls which appear to belong to the Recent epoch.

\section{IOWA.}

(Map 21.)

Wapello, Louisa County (1).--In his report on Louisa County (Iowa Geol. Surv., vol. xI, p. 110), J. A. Udden stated that George Gresham had found, in what was regarded as Sangamon soil, in the northwest quarter of section 14, township 74 north, range 3 west (Port Louisa), the antler of a deer. Mr. Gresham (Jan. 2\%, 1911) informed the writer that he still had a part of the antler and that finds of that kind were quite common in early days. The writer has, however, been unable to examine the specimen. It is not certain that it belonged to Odocoileus, but may have been an antler of $O$. virginianus.

Eddyville, Mahaska or Wapello County (5).- In the University of Iowa collection of fossil vertebrates is a part of the skull of a deer, Odocoileus virginianus, found in a gravel-pit near Des Moines River, at Eddyville. The catalogue No. is $40 \%$. The bone is labeled as having been found in the gravelpit 20 feet above the river. The age of the gravel is unknown; but it is said by Professor A. O. Thomas that from the general appearance of the 
specimen it may be of post-Pleistocene age. It may, however, have liverl during the late Wisconsin.

Folsom, Mills County (2).--Professor J. L. 'Tilton, of Indianola, now in the University of West Virginia, sent the writer, in May 1915, 2 fragments of antlers and a third cervical vertebra which had been found near Folsom. This is a railroad station, apparently 3 or 4 miles south of Hinton, mentioned on page 294. No differences could be observed between these bones and the corresponding ones of Odocoileus virginianus. The age of the deposits containing the bones is not determined. A photograph of the spot, sent by Professor Tilton, showed a heavy deposit overlying the one containing the remains. The bones were not mineralized.

Turin, Monona County (3).-On page 249 of the writer's paper on the Pleistocene Mammals of Iowa is a description, and on plate xxxi, fig. 5, a figure of a part of a skull of Odocoileus virginianus, found near 'Turin. It is there stated that it was found on Cedar Creek, but this is due probably to an error on the part of Doctor Calvin. It was found on Beaver Creek; the exact locality and a statement about the geological situation are given on page 297 . While the bisons, the elk, and the deer collected probably belong to the Recent epoch, it is not impossible that they lived during the last stages of the Pleistocene.

Le Mars, Plymouth County (4).-Dr. J. E. Carman reported (Iowa Geol. Surv., vol. Xxvi, pp. 394, 395, 409) remains of deer from sand-and-gravel pits in the vicinity of Le Mars. Two deep river pits furnished antlers. In other pits were found antlers and limb-bones. These may have belonged to Odoloileus virginianus. A part of a calcaneum sent the writer is well fossilized and appears to differ somewhat from that of the Virginian deer. The age may be Sangamon or somewhat later.

Both Odocoileus virginianus and O. whitneyi have been found in the lead region of Wisconsin, Iowa, and Illinois; but the describers were not at any pains to specify exact locations. Both species no doubt inhabited all three of the States mentioned.

Correctionville, Woodbury County (6).-Dr. J. E. Carman, as abore cited, on his page 410, reported the finding of antlers of deer in the Paul Fleming gravel pit, at the mouth of Pierson Creek Valley, west of Correctionville, and others in the Gilleas gravel pit, in the Little Sioux Valley, a few miles south of Correctionville. These localities are not represented on map 21 . 


\title{
FINDS OF CERVUS IN THE MIDDLE REGION OF NORTH AMERICA.
}

\author{
ARKANSAS.
}

(Map 23.)

Willcockson, Neuton County (1).-Barnum Brown (Mem. Amer. Mus. Nat. Hist., vol. Ix, p. 204) has referred to Cervus canadensis, with doubt, some bones found in the Conard fissure, 4 miles west of Willcockson. These bones consisted of 2 calcanea and 2 navicular-cuboids. They are all larger than the corresponding bones of Cervus canadensis and presented other differences. 'The accompanying species will be found listed on page 251 .

\section{OKLAHOMA.}

\section{(Map 23.)}

Afton, Ottaua County (1).-For an account of the discovery of Cervus canadensis in a spring near Afton and a list of the 19 species of mammals found there, see page 254 . In the collection is a part of a cast-off left antler of a young elk. It is about $250 \mathrm{~mm}$. long, the distal end being broken off. The bone is spongy and rather brittle, and it shows no long-time burial. It probably belongs to the Recent epoch. There is also present a lower right fourth premolar. It is slightly stained and is heavier than a Recent tooth; but its geological age can not be determined.

Guthrie, Logan County (2).- In the State Historical Society, at Oklahoma City, is the rear of the skull of an elk, labeled as having been found on the farm of B. F. Hubble, near Guthrie. It is said to have been buried "deep under ground." It was presented to the Society by the finder, June 21, 1910. The pedicels of the antlers are present. The skull may belong to the Recent epoch, or it may belong well back in the Pleistocene.

\section{MISSOURI.}

\section{(Map 23.)}

Pomme de Terre River, near Avery, Hickory County (1).-For a discussion of this locality and the collection made there by Albert Koch, see page 25 . In 1843 (Amer. Jour. Sci., vol. xLIv, p. 70), Doctor Harlan stated that in Koch's collection, then being exhibited in Philadelphia, were remains of the ox (doubtless Bison), deer, elk, and megatherium. It is plainly implied that these species, as well as the great quantity of mastodon bones and teeth, had been found at the locality on the Pomme de Terre. Of what parts the elk remains consisted, nothing was said.

\section{KANSAS.}

(Map 23.)

North Laurence, Jefferson County (1).-The collection of the University of Kansas contains the basal portion of an antler, about $200 \mathrm{~mm}$. long, found in Kansas River, about a mile above North Lawrence, in 1903, after a freshet. At about the same time and place were found the type horn-core of McClung's Bison kansensis and some skulls of Bison bison. At a later time were dis- 
covered here the type skull of Equus laurentius and a skull of Bison occidentalis. While the horse skull belongs to the Aftonian stage, it is quite certain that the skull of Bison bison and probably the elk's antler were buried in later deposits. Whether or not they belonged to the late Pleistocene is at present not to be determined.

Wakarusa Creek, Douglas County (2).-J. Savage reported in 1877 ('Trans. Kansas Acad. Sci., vol. vi, p. 10) that he and Professor F. O. Marvin had found, along Wakarusa Creek, a few miles from Lawrence, remains of buffalo, antelope, elk, and some other animals. The jaw of a mastodon (regarded by the present writer as Mammut progenium) had just before been found in the bank of the same creek. The finders of the buffalo, elk, and antelope bones concluded that these had been buried in a lake or estuary formed after the mastodon had lived, and that the jaw of the latter in a fossilized condition had been washed into the lake. It is more probable that the mastodon jaw, at a depth of 25 feet from the surface and a few feet below the surface of the water, lay in Aftonian deposits, while the other animals were buried in comparatively late alluvium.

IOWA.

(Map 23.)

Five miles east of Logan, Harrison County (1).-Our knowledge of the occurrence of the elk at this location is due to Professor B. Shimek (Iowa Geol. Surv., vol. xx, p. 409). The locality is on the farm owned by Lester Adams, in the northeast quarter of the southeast quarter of section 11, township 79 north, range 42 west. The conditions at this place are more fully explained on page 296. Along Hog Creek, sticking in the banks, were seen numerous bones of bison and elk. These remains probably belong to the Recent epoch, but the possibility exists that they may be of late Pleistocene age.

Turin, Monona County (2). - In the State University of Iowa is a large collection of remains of the American bison, obtained near Turin by Dr. Samuel Calvin. Shimek (op. cit., p. 408, pl. xxxII) has described the conditions under which they occurred. These are here considered in more detail on page 297. With the bison remains were found some bones and antlers of the elk and of the Virginia deer, together with remains of an old beaver dam. As in the case of the remains of the elk and the bison found near Logan, it is probable, but not certain, that the finds from near Turin belong to the early part of the Recent epoch.

Henry McCall informed the writer that a number of buffalo skulls and antlers of elk were picked up on his father's farm, on Beaver Creek, 7 miles north of Moorhead, Monona County. This must be very near the Turin locality.

Nevada, Story County (3).--From H. C. Lowrey, of Shadeland farm, near Nevada, the writer received a letter telling of numerous elk antlers found on his farm. In reclaiming a peat marsh, a ditch was made, in which, at a depth of about 3 feet, was found an antler of an elk. Afterwards, in plowing deeply the same ground, 14 other antlers were met with, a number of which were well preserved. Some of these antlers are in the Public Library at Nevada. One pair was found attached to the complete skull. Story County is within the area occupied by the Des Moines lobe of the Wisconsin drift. The peat 
marsh mentioned lies, therefore, on this drift, and the elk remains must be of post-Wisconsin age. Whether they belong to the late Pleistocene epoch or to the Recent may be difficult of determination.

On reading S. W. Beyer's report on the Pleistocene geology of this county (Iowa Geol. Surv., vol. IX), it is learned that (p. 203) "the topographic features of the Wisconsin are remarkably immature. Ponds, undrained basins, and incipient drainage lines are the rule." In such a nearly level region, depressions left in the surface, on the retreat of the Wisconsin glacier, must fill with extreme slowness. Water coming in from the surrounding only slightly higher ground must make its way through vegetation, so that little or no sediments are thus carried in. The pond must become filled principally by the growth of peat and by wind-borne dust. It is probable that the peat itself has for a long time been decaying faster than it grows. To produce a thickness of 3 feet of deposit might have required a time reaching back into the latter part of the Wisconsin stage.

Beyer (op. cit., p. 210) has quoted Stalker's account of the discovery of an undetermined proboscidean in a basin in Washington Township, Story County. This basin comprised 2 or 3 acres. The proboscidean bones were found at a depth of only 4 or 5 feet. Stalker supposed that the basin had received some wash from the surrounding land. No. 6 on the map of Cervus canadensis refers to a bone of this animal which was found somewhere in the lead region, but whether in Illinois, Wisconsin, or Iowa is not known.

Irvington, Kossuth County (4).- In 1923, Professor A. 0. Thomas informed the writer that a fine pair of antlers attached to the frontals of an elk, Cervus canadensis, had been found near Irvington, in the bank of Des Moines River. Professor Thomas presumed that it was a flood-plain deposit. It may, therefore, belong to the Recent epoch. It is No. 408 in the palæontological collection at the University of Iowa. 


\title{
FINDS OF RANGIFER IN THE MIIDDLE REGION OF NOR'I'H AMERICA.
}

\author{
IOWA.
}

(Map 22.)

Muscaline, Musculine Counly (1).-In the writer's paper on the Pleistocene Mammals of Jowa (Iowa Geol. Surv, wol. xxiII, pp. 278-280, pl. xxxiI, fig 1, 2) will be found a description and figures of upper and lower premolars and molars of a Rangifer, to which Leidy (Proc. Acad. Nat. Sci. Phila., p. 32) gave the alternative name $R$. muscatinensis. These teeth, containerl in portions of their respective jaws, were found some time before 1878 , in what was supposed to be loess, in the city of Muscatine, by Professor F. M. Witter. He (Proc. Iowa Acad. Sei., 1875-1880, p. 16) stated that almost the entire remains of the animal were taken from the loess. In his description of 1879 , Teidy, on the advice of Dr. Elliott Coues. referred the animal to $R$. caribou, and stated that other bones found with the jaws were too much decomposed for preservation. The present writer believes that the remains belonged to a species quite distinct from any now living.

While Witter regarded the deposit from which the Rangifer remains were obtained as loess, Professor Shimek takes a different riew, as shown in the following statement, quoted from the present writer's paper referrer to above, page 34 :

In connection with Witter's Rangifer I wish to note that Professor Witter pointed out to me the exact spot from which the bones and teeth were taken. The lower part of the exposure shows a heavy, close-grained deposit not unlike the Loveland in appearance and probably bearing the same relation to the Illinoian which the Loveland bears to the Kansan. Above this is a deposit of true yellow loess. At this point the two are not sharply separated (probably because of local wash and redepюsition) and the bones in question were found in this intermediate portion. It is the only place (and case) where there seems to be a suggestion offered that at the close of (or immediately following) a glacial stage there were Arctic mammals in lowa. These bones are not associated with ordinary loess fossils, for the latter are restricted to the upper part of the deposit-that which is manifestly loess. Neither are they in Illinoian drift, but in a deposit evidently closely following it, and preceding the deposition of the loess proper.

According to the statement the Rangifer must be referred to a time between the late Illinoian stage and the late Iowan. The writer suggests that the deposit in question is the Illinoian gumbotil.

Avon, Poll: County (2).-In Simpson College, Indianola, Iowa, are the hind half of the right ramus of the mandible containing the second molar, and the first dorsal vertebra of a specimen of Rangifer, which the writer refers to $R$. muscalinensis. These bones were found several rears ago in a gravelpit at Aron. The age of these gravels was at one time regarded by Professor Tilton as Aftonian, but later he concluded (Proc. Iowa Acad. Sci., rol. xxir, pp. 233-236) that they belong to the Wisconsin. The writer's view has coincided with this, but the matter has hardly receired a definite solution. The terrace described by 'Tilton may have been, partly at least, laid down somewhere near the middle of the glacial epoch.

Correctionrille, Woodbury Counly (3).-The collection of the State University of Iowa contains some fragments of caribou antlers which were secured 
at Correctionville. These have been described and figured by the writer (Iowa Geol. Surv., vol. xxIII, pp. 281, 282, pl. xxxir, figs. 4, 5), but it is impossible to determine the species. They were found in the Welch gravel-pit in which were found also a horn-core and a part of a skull of Bison occidentalis. The discovery of remains of Bison occidentalis in Minnnesota, as described below, on deposits overlying the early half of the Wisconsin drift suggests that the animals found at Correctionville belong possibly to a late time in the Pleistocene.

Besides the remains of Rangifer recorded above, there is, in the collection of the State University of Iowa, a considerable part of an antler, which has been described by the writer (op. cit., p. 282, pl. xxxıI, fig. 4). Unfortunately, no record was kept of its discovery, but almost certainly it was found somewhere in Iowa.

\section{MINNESOTA.}

(Map 22.)

Crosby, Crow Wing County (1).- In 1921, the U. S. National Museum received from the John A. Savage Company, Crosby, a large lot of bison bones found in a peat bog in section 19, township 46, range 29. This peat overlies about 30 feet of drift of mid-Wisconsin age. In this same peat were found, besides remains of Bison occidentalis and B. bison, 2 antlers of a reindeer, probably Rangifer caribou, and an antler of the moose Alces americanus. The remains referred to Bison occidentalis were described by the writer in 1923 (Proc. U. S. Nat. Mus., vol. LXIII, art. 5, pp. 1-8, pls. I, II). A skeleton, mounted from these bones, is in the U. S. National Museum. 


\title{
FINDS OF MUSK-OXEN, OVIBOVINA, IN THE MIDDLE REGION OF NORTH AMERICA.
}

\author{
ARKANSAS.
}

(Map 24.)

Willcockson, Newton County (1).--In 1903 and 1904, Barnum Brown, of the American Museum of Natural History, found, in a limestone fissure, 4 miles west of Willeocksoll, abundant remains of fossil vertebrates. Among these were teeth and bones of a musk-ox, to which Mr. Brown gave the name Symbos australis (Mem. Amer. Mus. Nat. Hist., vol. IX, p. 203, pl. XXII). His materials consisted of 3 molar teeth, 3 premolars, an atlas, and a proximal and an ungual phalanx. For associated species see pages 251, 252.

\section{OKLAHOMA.}

(Map 24.)

Afton, Ottawa County (1).- In 1901, W. H. Holmes collected, from an excavation near Afton, flint implements and remains of 19 species of fossil mammals. A brief account of the locality and a list of the species are given on page 253. Among these fossils were some remains of a musk-ox, which the writer in 1920 (Proc. U. S. Nat. Mus., vol. LviII, p. 125, pl. vi, figs. 9-10; pl. viII, figs. 1-6) described under the name Symbos promptus. In the collection is an upper left hindmost molar, which was made the type of the species. The tootl is in fine preservation, except that the extremities of the roots are gone. The enamel is yellowish white, and the tooth looks almost as if it belonged to a recently killed animal. The other parts are somewhat blackened. The tooth is worn down so that the crown has a height of about $25 \mathrm{~mm}$. The length of the tooth on the outer face is $38 \mathrm{~mm}$; thickness at base of front lobe $35 \mathrm{~mm}$. The tooth differs from the corresponding one of $S$. cavifrons in sereral particulars. These are specified in the original description.

The collection also contains an atlas, lacking the upper arch, which in all probability belongs to this species. It has been carefully compared with the same bone of a young Oribos moschatus; also with the atlas of Bison bison. From the bone of the latter the fossil difiers greatly. The wings are not so fully developed, having evidently extended out but little beyond the hinder articular surfaces for the axis. The wings are not prolonged behind the surfaces mentioned. In Bison there is, on the under side, around each arterial foramen, a deep excavation. In the fossil atlas these excarations are shallow. The following measurements (in millimeters) have been taken, some of those of the fossil being only approximate:

\begin{tabular}{|c|c|c|c|}
\hline & Bison. & Oribos. & Symbos. \\
\hline Length of lower arch on midline. & 50 & 36 & 68 \\
\hline Horizontal diameter of spinal canal. . & 55 & 35 & $50+$ \\
\hline Horizo ntal extent of hinder articular surfaces. & 118 & 83 & $120 \pm$ \\
\hline 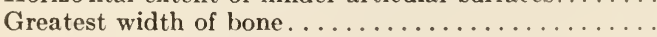 & 210 & 110 & $145 \pm$ \\
\hline Thickness of lower arch at midline..... & 38 & 25 & 42 \\
\hline Backward extension of wings beyond midline at rear. & 35 & 00 & 00 \\
\hline Width across anterior articular surfaces......... & 136 & 85 & $112 \pm$ \\
\hline
\end{tabular}


In both Ovibos and Symbos the front of the bone is far less excavated for the condyles of the skull than in Bison.

Fort Gibson, Muskogee County (2).-In the collection of the Academy of Natural Sciences of Philadelphia is preserved the type of the species Symbos cavifrons. This was first brought to notice at the Cincinnati meeting of the American Association for the Advancement of Science, in 1851, being one of several fossil species which were mentioned by Louis Agassiz. It was first described in 1852 (Proc. Acad. Nat. Sci. Phila., vol. vi, p. 1\%1) by Dr. Joseph Leidy, under the name of Boötherium cavifrons. Later (Smithson. Contrib. Knowl., vol. III, p. 12, pls. III, IV) it was more carefully described. The specimen had been found near Fort Gibson and put into the hands of Leidy by Thomas Kite. It consists of the frontal region and the rear of the skull bearing both horn-cores. It was found in the hut of an Indian, to whom it served as a seat, and it was reported to have been originally discovered in a neighboring gravelly bluff, probably on either Arkansas or Grand River. We may surmise that this animal lived in this region during the Wisconsin glacial stage; but we have no knowledge about the geological age of the Pleistocene deposits about Fort Gibson to substantiate this suppostion. Furthermore, the animal may have lived there long before the Wisconsin stage.

Braden?, Le Flore County (3).- In the collection of the St. Louis Academy of Science are preserved the base and rear of the skull of Symbos cavifrons, having the horn-cores broken off close to the skull. This is labeled as found 15 miles above Fort Smith. This would probably be somewhere near the town of Braden; but the locality might have been on the north side of Arkansas River, in Sequoyah County. The collector is unknown. The bases of the horn-cores and the space between them are smooth. In the same collection is a tooth of a mastodon and a part of the skull of an extinct Bison, which are recorded as secured at the same locality.

\section{NEW MEXICO.}

(Map 24.)

Black Rocks, McKinley County (1).-On page 259 the writer has recorded the circumstances under which were found some fossil remains of a musk-ox, a horse, a camel, and a mastodon. The musk-ox was described by J. W. Gidley, in 1906 (Proc. U. S. Nat. Mus., vol. xxx, pp. 165-16\%, figs. 1-3), under the name Liops zuniensis. The generic name was afterwards found to be preoccupied. The intention was to substitute for this the name Lissops, and somewhere in the literature of the National Museum this name appears, but not in such a way as to associate it definitely with the species. In $190 \%$ (Rev. Crit. Paleozool., Paris, vol. xI, p. 64), Cossman substituted for Liops the name Gidleya. This discovery is of special interest, since it is the first definite association known of musk-oxen with camels and horses, animals of early Pleistocene age. More recently the musk-ox Symbos has been found in the Cox gravel-pit at Missouri Talley, Towa.

\section{MISSOURI.}

(Map 24.)

New Madrid, New Madrid County (1).-In 1828 (Ann. N. Y. Lyc., rol. III. pp. 280-291, pl. vi, figs. 1-3), J. E. DeKay described and figured a skull of 
a musk-ox, found at New Madrid, probably in 1812. According to the label which accompanied the specimen, this had been "ejected by the shock of an earthquake in 1812." At the conclusion of his paper DeKay proposed the name Bos pallasii to designate an Asiatic musk-ox which had been described by Pallas and Ozeretskovsky, and to his species he referred provisionally the New Madrid skull. It is now known as Symbos cavifrons. The writer does not know where the skull now is. One would suppose that it had gone, with "other materials which belonger to the Lyceum of Natural History, to the American Museum of Natural History at New York; but the writer has not seen it there. It was probably destroyed in a fire at that museum.

In 1821 there appeared (Amer. Jour. Sci., vol. III, p. 20) a letter written in 1820 by L. Bringier, in which the writer gave an account of his experiences during the earthquake in 1812 at New Madrid. According to him openings were formed in the ground and from these were ejected water, mud, and carbonized wood. The latter was doubtless wood in the state of lignite. McGee (Amer. Jour. Sci., vol. xxxiv, 1887, pp. 219, 220) concluded that this skull had been derived from what Hilgard had designated the Port Hudson beds. Under the circumstances it seems impossible to determine the exact geological age of the specimen. The lignitized wood which appears to be buried at New Madrid may well belong to an older epoch, probably to Sangamon or Peorian interglacial times, or to the Port Hudson.

Cape Girardeau, Cape Girardeau County (2). - In the collection of the University of Missouri, at Columbia, is the rear portion of a skull, with horncores, of Symbos cavifrons. The writer was informed by both Dr. J. W. Spencer, former professor of geology in the university, and Dr. S. S. Laws, its former president, that this skull was found in a swamp in the region about Cape Girardeau. This must have been many years ago, for Professor Cope at one time wanted to buy the skull. Exactly where it was found and under what conditions is not known. The probability is that the animal lived in that region during the $\mathrm{W}$ isconsin glacial stage, but the border of the Illinoian drift sheet is not far away, and there appears to be no reason why the animal might not have been in that region during the Illinoian glacial stage.

Tackner?, Benton County (3).- In his memoir on the extinct species of the American ox (Smithson. Contrib. Knowl., vol. v, art. III, p. 16), Leidy announced that there were in the collection of the Philadelphia Academy of Sciences the cranial portions of three individuals of Symbos cavifrons, found in Benton County, Missouri. All of these, he said, were much decomposed, friable, and chalk-like. With them were also 2 astragali and a metacarpal which were supposed to belong to the same species. They had all formed a part of a large collection, composed mostly of mastodon bones. Doubtless this was the collection made by $\mathrm{S}$. H. Whipple somewhere along the Osage River, and which is referred to on page 265. It is to be regretted that no exact records were kept to show exact localities and the depths at which each specimen was found. The mastodon and the musk-oxen may have been found at different localities. The crania referred to are yet in the Academy of Natural Sciences of Philadelphia.

Kimmswick, Jefferson County (4).-For a description of this place, see page 262. 
The writer saw at St. Louis, Missouri, in the possession of C. W. Beehler, a part of a horn-core which greatly resembled that of Boötherium bombifrons.

From Dr. W. F. Parks, of St. Louis, Missouri, the U. S. National Museum received, in July 1921, an upper molar tooth which appears to have belonged to Symbos cavifrons.

St. Louis, St. Louis County (5).--In 1869 (Jour. Acad. Nat. Sci. Phila., vol. vir, p. 375), Dr. Leidy stated that Dr. Englemann informed him that a great part of a skeleton of Symbos cavifrons had been recently discovered in making an excavation for the foundation of a building in St. Louis. The writer has had the opportunity to examine the partial skull. It is recorded that it was found in Choteau pond, at the bridge at the crossing of Twelfth Street and Choteau Avenue. No statement has been made regarding the depth at which the skull was found nor as to the kind of soil in which it was buried. The rear of the skull is presented, with the horn-cores. It comes forward to the front of the orbits. 'The horn-cores are nearly complete. The following measurements (in millimeters) were taken.

\section{Skull of Symbos cavifrons.}

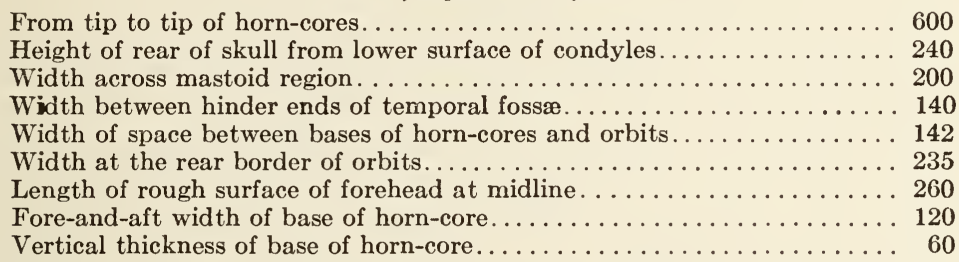

For some reason no other parts of the skeleton have been preserved. Choteau Pond was probably situated on the loess deposits of that region and the skeleton of the musk-ox may have been buried there during the Wisconsin stage.

Wellington, Lafayette County (6).-In December 1915, E. Nasse wrote to the U. S. National Museum about some bones found in a recently abandoned bed of Missouri River at Wellington. He sent a sketch and some photographs of a part of a skull, which was evidently that of Symbos cavifrons. With these pictures were others of a right humerus of an undetermined species of elephant. This was found in the same deposit. It is impossible to say to which stage of the Pleistocene these remains had belonged. The drift is Kansan.

\section{KANSAS.}

(Map 24.)

Wilson, Ellsworth County (1).-In the American Museum of Natural History, New York, is a part of a skull of a musk-ox, found somewhere near Wilson. It was secured for E. D. Cope in $187 \%$ from Jacob Fowler. The specimen is badly damaged and presents only the brain-case. Both horn-cores are broken off close to the skull and with them a part of the occipital crest. The skull is a rather large one. The distance across the constriction of the occiput, below the horn-cores, is $135 \mathrm{~mm}$.; that across the mastoid bones, 205 mm. J. A. Allen (Mem. Amer. Mus. Nat. Hist., vol. r, pp. 203, 214) concluded that the skull was that of Ovibos, but the writer believes that it belonged to Symbos and probably to $S$. cavifrons. It is to be regretted that more information has not been furnished regarding this skull. 


\section{(COLORADO.}

(Map 24.)

Colorado Stprings, El Paso County (1).-In May 1915 the writer received from Professor Edward R. Warren, of Colorado College, some fragmentary bones found in gravel-pits in the vicinity of Colorarlo Springs. Among these bones was the distal end of a right humerus, which in size and structure agreed closely with the corresponding bone of Ovibos moschatus. The fragment was only about 3.5 inches long. It was somewhat water-worn, so that exact measurements could not be taken. However, the distance from the bottom of the pit on the outer epicondyle to the surface of the inner epicondyle was $66 \mathrm{~mm}$. With this bone cane remains of a deer-like animal, a bison, a camel, and a horse. It would be interesting to know whether or not the musk-ox bone came from the same deposit as the horse and camel.

\section{IOWA.}

(Map 24.)

Ottumwa, Wapello County (1).-In the American Museum of Natural History, New York, is a brain-case of a species of Ovibos, which is a part of the Cope collection and which is credited to E. I. Lathrop, of Ottumwa. The specimen consists of the hind part of the skull; this had, before its discovery, been subjected to rough usage, probably in ruming water. As a result, all the prominent processes have been worn down and the horn-cores are eroded off nearly to their bases. Between the exostoses of the two horn-cores there is a narrow groove $147 \mathrm{~mm}$. in length. For the present it is necessary to refer fossil specimens of this genus to $O$. moschatus; but if there were skulls sufficiently complete, it might be found that they belonged to species as yet undescribed. Nothing is known as to the exact place where this specimen was found, nor anything about the geological situation. Inasmuch as Des Moines River formed the principal outlet for water from the Wisconsin ice-lobe, it is easily surmised that the animal lived about the foot of the ice wall and that after death its skull was rolled to the place where it was found.

Indianola, Warren County (2).-Professor John L. Tilton, of Simpson College, Indianola, submitted to the writer an atlas found by H. D. Perry 1.5 miles east of Indianola, at a depth of about 11 feet, in digging a foundation for a pier of a bridge, in section 29 , township 76 north, range 23 west. On a careful comparison it was concluded that the atlas belonged to some species of musk-ox, probably Symbos cavifrons (Iowa Geol. Surv. vol. xxiIr, p. 30\%). The following measurements of the atlas are given in millimeters, and with them the corresponding measurements of Oribos moschatus in the American Museum of Natural History:

\begin{tabular}{|l|r|r|}
\hline & Symbos? & Ovibos. \\
\cline { 1 - 2 } Distance between foramina on lower surface..... & 108 & 108 \\
Length on lower arch..................... & 55 & 47 \\
Distance between foramina on upper face....... & 71 & 61 \\
Side-to-side diameter of spinal canal in front.... & 45 & 36 \\
Vertical diameter of spinal canal in front....... & 25 & 23 \\
Side-to-side diameter of spinal canal behind..... & 47 & 43 \\
\hline
\end{tabular}


Professor Tilton sent the writer also a fragment of a humerus which appears to have belonged to a species of musk-ox. It was found in an old soil at a depth of 38 feet beneath the river flood-plain.

As both of these remains of musk-oxen were found near South River, which flows toward the northeast to enter the Des Moines, it is evident that they could not have been washed down from the Wisconsin ice border. To what deposits they belonged has not been determined. At one time it was thought by Professor Tilton that they were as old as the Aftonian, but he has expressed doubts regarding this. They appear to be older than the Wisconsin.

Council Bluffs, Pottawattamie County (3). - In the collection of the State University of Iowa is a partial skull of Symbos cavifrons, found many years ago within the limits of Council Bluffs. It was first noticed by W J McGee (Amer. Jour. Sci., vol. xxxiv, 188\%, p. 21\%). It was found in loess 12 feet below the surface, at a height of 130 feet above Missouri River. With it were secured half of the lower jaw, the atlas, a femur, and some other bones; but these bones appear to have been lost. It lacks all parts in front of the orbits. The skull has been briefly described and figured by the writer (Iowa Geol. Surv., vol. xxıII, p. 306, pl. xxxviı, fig. 3). While McGee thought that the deposits which contained this skull consisted of loess, Shimek is inclined to believe that they belong to the Loveland. Inasmuch as this Loveland is regarded by Shimek as resulting from materials deposited during the melting of the Kansan ice-sheet, the skull would have to be referred to the late Kansan. This is not to be regarded as impossible.

Woodbine, Harrison County (4).-In $18 \% 0$ (Proc. Acad. Nat. Sci. Phila., p. 73), Leidy reported that there had been sent to him, from the Smithsonian Institution, a part of a lower jaw of an animal which he supposed to be that now called Symbos cavifrons. The present writer has not seen this jaw. According to Doctor Witter's letter, which accompanied the specimen and which is on file in the Registrar's office at the National Museum, the jaw was found in a well, at a depth of 22 feet, a mile north of Woodbine, on the second "bottom," or flood-plain, of Boyer River. According to Shimek (Iowa Geol. Surv., vol. $\mathrm{xx}, \mathrm{p} .288$ ), this bench rises from 40 to 50 feet above the river bottom; and on page 394 he states that these benches are covered with loess, chiefly of the lower yellow type. Probably this musk-ox, if musk-ox it was, dates from the Illinoian glacial stage, if not from an earlier one.

Missouri Valley, Harrison County (5).-Dr. W. C. Alden and Dr. G. F. Kay informed the writer that they had seen in the possession of C. A. Cox, owner of a gravel-pit near Missouri Valley, part of a skull of a musk-ox. It is probable from their description that this is a species of Symbos. The writer has not been able to learn anything from Mr. Cox about the specimen. The occurrence of the skull in the pit indicates that this musk-ox existed there during the Aftonian stage.

Clermont, Fayette County (6).- - In Hay's paper cited above, on page 29\%, he described and figured (pl. xxxvi, figs. 2, 3) the rear portion of the skull of Ovibos moschatus, which was found near Clermont and which is the property of Dr. Frederick Becker, of that town. It was discovered in clay at a depth of about 26 feet, in the northeast corner of the southeast quarter of section 35 of township 95 north, range 8 west. This region is covered by 
Kansan drift; but, according to our present knowledge of this genus, it is not impossible that the skull is as old as the Kansan stage. Alden and Leighton have studied the gravels at Clermont (Iowa Geol. Surv., vol. xxvi, pp. 133134), and they conclude that those filling Turkey Creek, where the Ovibos was found, are of Iowan age.

\section{NEBRASKA.}

(Map 24.)

Wyoming, Otoe Counly (1).--In the collection of the State University Museum, at Lincoln, Nebraska, is the hinder part of a skull of Symbos cavifrons, labeled as found about 15 miles northwest of Nebraska City. The specimen is designated by the Nos. 20-10-04. The donor was Eugene Munn, of Lincoln, on whose farm the skull was found. In this specimen the horncores are nearly complete. It is remarkable for the depth of the cavity between the horn-cores. Some measurements of this specimen were taken by the writer.

\begin{tabular}{|c|c|}
\hline Height of occiput above lower borders of occipital condyles. . & ${ }_{185}$ \\
\hline Width of skull just behind auditory meatus. . . . . . . . . . & 190 \\
\hline Width at hinder end of temporal fossæ. . . . . . . . & 128 \\
\hline Distance between tips of horn-cores, as restored. . . . . . & 450 \\
\hline Width of frontal concavity between bases of horn-cores..... & 115 \\
\hline Depth of concavity between bases of horn-cores........... & 55 \\
\hline Fore-and-aft width of bases of horn-cores. . . . . . . . . . & 115 \\
\hline
\end{tabular}

From O. N. Munn, of Bellingham, Washington, the writer received the information that the skull in question was found in a well at a depth of 32 feet, in the northwest quarter of section 1, township 9 north, range 13 east. This is close to the town of Wyoming. The well is somewhat more than 100 feet from a small stream, and it is thought that the bottom of the well is on about the same level as the bed of the creek. According to the recollection of Mr. Munn there was a surface soil of about 2 feet, then a bed of joint clay (indicated in the sketch as about 2 feet), followed by a loam described as being somewhat mucky and sandy. At 32 feet there was a bed of gravel a foot thick and in this the skull was found. On top of the gravel there were a 12-inch cottonwood log and some sticks.

Endicott, Jefferson County (2).-In the collection of the State University Museum, at Lincoln, is a part of a skull of Symbos carifrons, recorded as found at Endicott. It has the catalogue designation 15-11-00. There is present the much-worn back of the skull, with the horn-cores. The bases of the latter have a fore-and-aft width of $131 \mathrm{~mm}$. The frontal concavity is of moderate depth. Endicott is situated on Little Blue River; the fossil may have been buried in some late Pleistocene deposit along this river, or it may belong to older Pleistocene.

In the geological collection of the State University of Ohio, at Columbus, is an injured skull of Symbos cavifrons, labeled as having been found in the Bad Lands of Nebraska and as having formed a part of the "Rennick collection." The writer was not able to learn anything more about its history.

Cambridge, Furnas County (3).--In the collection last mentioned is another partial skull of Symbos cavifrons. This is recorded as found 2 miles east of Cambridge in making an excavation on the line of the Chicago, Burlington, 
Quincy Railway. It was presented by Dr. G. A. Hobson, of Cambridge. Nothing more is known about its history. It is at about this point that Medicine River enters the Republican, and it is probable that the skull was buried along one or the other of the rivers mentioned. Barbour (Neb. Geol. Surv., vol. III, p. 61) figured a sand-pit near Cambridge. This skull, probably that of an old bull, was larger than the one found at Nebraska City. The height of the occiput is $222 \mathrm{~mm}$.; width at the ear-openings, $222 \mathrm{~mm}$. ; fore-and-aft width of the bases of the horn-cores, $125 \mathrm{~mm}$.

Near Morrill, Sioux County (4).-In the collection of the State University Museum, at Lincoln, is the hind part of the skull of a musk-ox, found on the ranch of Fred S. Young, about 7.5 miles northeast of Morrill. The exact location is in section 30, township 24 north, range 51 west. The skull was found at a depth of 8 feet in digging an irrigation-ditch. It is also reported to have been buried in about $y$ feet of volcanic ash. Through the liberality of Professor Erwin H. Barbour the writer has had the opportunity to examine this skull. Both of the horn-cores are broken off and all the bones in front of the bases of these are missing. The base of one horn-core present has a length of about $95 \mathrm{~mm}$. and a depth of $70 \mathrm{~mm}$. The right and left thickened portions of the frontal and parietal bones which supported the bases of the horns are considerably concave and are separated by a narrow groove. Each is $150 \mathrm{~mm}$. long and $90 \mathrm{~mm}$. wide. On comparison with the corresponding parts of Ovibos moschatus the writer finds no important differences.

\section{MINNESOTA.}

(Map 24.)

Between Wabasha and Theilman, Wabasha County (1).-In 1910, Professor N. H. Winchell (Bull. Minn. Acad. Sci., vol. IV, p. 419, pl. xr, fig. 3) recorded the discovery of a part of a skull of a musk-ox in Wabasha County. It was found in 1903, on the farm of Mr. McCracken, between Wabasha and Theilman, in a gravel terrace (evidently along Zumbrota River), at a depth of 10 feet. Professor Winchell called the animal Ovibos cavifrons, yet the photograph shows that it was not this species, but $O$. moschatus, or a closely related form. The animal was small, probably not wholly grown. The extreme width, including the horn-cores, was 8.5 inches. Winchell found it impossible to determine whether the animal had perished during the late Wisconsin or whether it dated from the time of the Iowan loess. He concluded that the musk-ox had not been forced south by the Wisconsin period of cold.

\section{SOUTH DAKO'TA.}

Sioux Falls.-For skull of musk-ox found here see page 310 .

\section{ALBERTA.}

(Map 24.)

Edmonton, Edmonton County (1).-In 1899 (Summ. Rep. Geol. Surv. Canada for 1898, p. 19 A), Dr. G. M. Dawson reported the discovery of a partial skull of a musk-ox, which he referred provisionally to Ovibos moschatus. It had been found in the roof of a drift run into the bank of Saskatchewan River, about a mile below Edmonton. It was thought to be derived from the Saskatchewan gravels. 


\section{FINDS OH BISONS OF EXTINCT SPECIES IN THE MIDDLE REGION OF NORTH AMERICA.}

\section{LOUISIANA.}

(Map 25.)

Pelite Anse, Iberia Parish (1).-Among the fossil remains which Dr. Joseph F. Joor collected in 1890 at Petite Anse, and which are now in Tulane University, the writer found a single molar tooth of a species of Bison. The length of the crown, taken near the base, is $33 \mathrm{~mm}$, the width $20 \mathrm{~mm}$. It was not possible to determine to what species it had belonged; however, it is smaller than those which appear to belong to Bison latifrons and $B$. regius. Hilgard (Smithson. Contrib. Knowl., vol. xxı1, No. 248, p. 14) wrote that before his visit buffalo bones had been found at Petite Anse.

\section{TEXAS.}

(Map 25.)

Sweetwaler, Nolan Counly (1).- In 1913 a lower right hindmost molar of a bison was sent from Sweetwater to the U. S. National Museum for identification, by 'T'. L. Hughes. In a letter sent in December 1913 this gentleman gave the information that the tooth was found on Icemgood Creek, in the southwest quarter of section 51, block 22, in Nolan County. It was found sticking in the bank at a depth of about 2.5 feet from the surface and about 4 or 5 feet from the bottom of the creek. It appeared to be in a much-decayed jaw, but this was not secured. The tooth is but little worn, white, and evidently fossilized. All the cement is dissolved off. In form and measurements it seems not to differ from the corresponding tooth of $B$. bison, but it belonged probably to one of the extinct species.

Mouth of Fifth Creek, Cooke County (16).-From Dr. Mark Francis the writer has received a sketch of an anterior dorsal vertebra of a bison found in Red River near the mouth of Fifth Creek, in Cooke County. The length of the body of the vertebra is close to $72 \mathrm{~mm}$.; the height of the spinous process, including the epiphysis, is $472 \mathrm{~mm}$.; the width of this process, at the middle of the height, is close to $55 \mathrm{~mm}$. The writer has found a dorsal vertebra of the existing bison which is somewhat higher, but none with so great a width. It is thought that the vertebra belongs to an extinct species. The number 16 is not on map 25.

Dallas, Dallas County (15).-In 1921 (Amer. Jour. Sci., ser. 5, vol. II p. 16\%), Professor R. S. Lull described as belonging to Bison alleni a ramus of a lower jaw, found in the Lagow gravel-pit in East Dallas. A list of the associated species will be found on page 241. The specimen is in the Southern Methodist University. In the same collection is a part of a skull with a horncore, referred to Bison occidentalis. It was discorered in the Vilbig sand-pit, east of Dallas, near Rock Creek.

Crawford, McLennan County (2).-In the collection of the University of Texas are an atlas, 2 cervical vertebræ, and a humerus, recorded as found along a creek near Crawford. They probably belong to an extinct species.

Big Elm Creek, Fa!ls? County (3).-In the collection of the Academy of Natural Sciences, at Philadelphia, is a bison tooth labeled as found by Doctor 
Lincecum on Big Elm Creek, in Falls County. The writer finds on a map of Texas an Elm Creek which flows through Bell County, near the western border of Falls, but no Big Elm Creek in the latter county. The tooth is much worn. The length of the tooth is $35 \mathrm{~mm}$.; width, $27 \mathrm{~mm}$. It is possibly that of Bison bison.

Pittbridge, Brazos County (4).-From Dr. Mark Francis the writer received, for examination, a part of a bison atlas found at Pittbridge. The part preserved belongs to the right half, showing most of the surface for articulation with the right occipital condyle and the surface for union with the right side of the axis. The following comparative measurements (in millimeters) have been secured.

\begin{tabular}{|c|c|c|}
\hline & Fossil. & $\begin{array}{l}\text { Bison } \\
\text { bison. }\end{array}$ \\
\hline $\begin{array}{l}\text { From occipital articulation to that for axis, not far } \\
\text { from midline }\end{array}$ & & \\
\hline Diameter of vertebrarterial canal. & 17 & 15 \\
\hline Thickness of bone on bar just below the canal. & 18 & 16 \\
\hline Thickness of bone of hinder bar on lower surface & & \\
\hline & & \\
\hline
\end{tabular}

Judged from the lengths of these atlasses, the fossil represents an animal nearly one-half larger than the existing bison. It may be provisionally referred to Bison latifrons.

From Doctor Francis the writer received a photograph of a right humerus of a bison, found along Brazos River at Pittbridge. The total length is 412 $\mathrm{mm}$. This is a little greater than the same bone, in the specimen of Bison occidentalis, found in Minnesota (Hay, Proc. U. S. Nat. Mus., vol. LxIII, art. 5).

At the same place and time were found 2 vertebra of Bison. One of these is an anterior dorsal, apparently first or second. The spine has a height of 400 $\mathrm{mm}$. Doctor Francis found at Pittbridge also a part of the pelvis of a bison.

All of these bones belong probably to an extinct species.

\begin{tabular}{|l|r|c|}
\hline & B. alleni. & $\begin{array}{c}\text { Pittbridge } \\
\text { atlas. }\end{array}$ \\
\hline Length of centrum on median line below ... & 56 & $m m$. \\
Length of neural arch on median line...... & 66 & 55 \\
Width of anterior articular surface........ & 135 & 142 \\
Height of anterior articular surface on me- & & \\
dian plane........................ & 58 & 70 \\
Width of notch on front of lower arch...... & 66 & 85 \\
Width of bone on line through hinder bor- & & \\
ders of arterial foramina................. & 235 & 230 \\
Greatest width of atlas.................. & 240 & 255 \\
Height of bone when stood on hinder angles. & 138 & $150 \pm$ \\
Distance from the lower surface of hypophy- & & \\
sis to top of arch..................... & 118 & 125 \\
Lateral diameter of spinal canal in front.... & 50 & 55 \\
Lateral diameter of spinal canal, behind.... & 65 & 70 \\
Vertical diameter of spinal canal, behind... & 60 & 68 \\
& & \\
\hline
\end{tabular}


Doctor Francis sent the writer, for examination, also a very large axis of a species of Bison. It has lost the border of the right wing and the borders elsewhere are somewhat water-worn. It is impossible to refer it definitely to any species, but inasmuch as $B$. latifrons is supposed to have been a large animal the bone is provisionally placed there. The measurements given above (in millimeters) have been taken and compared with those of the axis of $B$. alleni from Alaska (Proc. U. S. Nat. Mus., vol. xuvi, p. 188) :

From the gravel in the west bank of Brazos River, about a mile below Pittbridge, Doctor Francis sent an axis and a lumbar vertebra. The axis is here compared with that of the Alaska specimen of $B$. alleni. Measurements also of the atlas and the axis of $B$. bison are to be found as cited above.

\begin{tabular}{|c|c|c|}
\hline & B. alleni. & $\begin{array}{l}\text { Pittbridge } \\
\text { atlas. }\end{array}$ \\
\hline & $\mathrm{mm}$. & $m m$. \\
\hline $\begin{array}{l}\text { Length from front of odontoid process to } \\
\text { lower border of hinder articular surface.. }\end{array}$ & 133 & 130 \\
\hline Length from lower border of anterior articu- & & \\
\hline $\begin{array}{l}\text { lar surface to lower border of hinder ar- } \\
\text { ticular surface........................ }\end{array}$ & 112 & 109 \\
\hline Width of anterior articular surface.......... & 133 & 118 \\
\hline Height of roof of spinal canal from lower & & \\
\hline $\begin{array}{l}\text { border of anterior articular surface.... } \\
\text { Greatest height of bone near hinder end. }\end{array}$ & $\begin{array}{r}90 \\
186\end{array}$ & 84 \\
\hline From outside to outside of lateral processes. & 160 & $\ddot{13} 0$ \\
\hline From outside to outside of rear of pedicles. & 50 & 55 \\
\hline 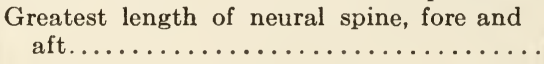 & 108 & \\
\hline
\end{tabular}

On comparing this fossil axis with one of $B$. bison whose centrum is but slightly longer, the base of the pedicle, where most constricted, measures 75 $\mathrm{mm}$. ; in B. bison, $60 \mathrm{~mm}$. The lumbar vertebra has the centrum $77 \mathrm{~mm}$. long, $60 \mathrm{~mm}$. wide, and $49 \mathrm{~mm}$. high in front. The spinal canal is $26 \mathrm{~mm}$. wide and $23 \mathrm{~mm}$. high.

Wallis Station, Austin County (14).- The writer received from Doctor Francis, for examination, a part of a horn-core of a bison, which may be referred to Bison latifrons. The fragment is $230 \mathrm{~mm}$. long and has portions missing at both ends. The diameter at the large end is $95 \mathrm{~mm}$.; $80 \mathrm{~mm}$. farther toward the distal end it is $85 \mathrm{~mm}$. The curvature is slight. On the lower side are 4 or 5 rather deep grooves about $13 \mathrm{~mm}$. wide, separated by flattened ridges of widths about equal to the grooves.

Burton, Washington County (5).- - In the U. S. National Museum are some teeth and fragments of bones of a bison, found near Burton, in a well, at a depth of 14 feet. The well is on the farm of B. F. Elliot, 4.5 miles north of Burton. The remains were sent by Dr. Alexander Deussen, of the U. S. Geological Survey. There is a last premolar and a second molar. These possibly belong to Bison bison, but more probably to an extinct species.

O'Quinn Branch, Fayette County ( 7 ). - In the University of Texas, at Austin, is a part of the left ramus of the lower jaw of a bison, labeled as found in loamy clay in O'Quinn Creek by Dr. F. T. Dumble. It is thoroughly fossilized. There are present 3 teeth, the fourth premolar and the first and 
second molars. The third molar is in another fragment. While the measurements present no important differences when compared with those of Bison bison, the teeth are certainly those of an extinct species. From John Schroeder, of Lagrange, Fayette County, the writer learns that O'Quinn Branch is in the western part of the county and empties into Buckner's Creek.

San Felipe, Austin County (6).-W. M. Carpenter, in 1846 (Amer. Jour. Sci., vol. I, p. 245, fig. 1), described and figured a part of a skull of a fossil bison, found at San Felipe. This skull, with other vertebrate remains found at the same place, was sent to the British Museum at London (Falconer, Nat. Hist. Review, 1863, p. 53 ; Palæont. Mem., 1868, vol. II, p. 223; Lydekker, Cat. Foss. Mamm. Brit. Mus., pt. III, p. 27). The distal ends of the horncores were missing. The remaining portion of one was 2 feet long, that of the other 18 inches. The circumference at the base was 17 inches and at a distance of 18 inches from the head it was still 14.5 inches. Carpenter thought that the length of a horn-core would be about 4 feet and that in life the distance from tip to tip of the horns would have been at least 11 feet. However, he probably did not take into consideration the curvature of the horns. With this skull was found a much-worn upper second molar. Carpenter gave as the length of the worn crown 1.6 inches ( $40 \mathrm{~mm}$.) ; as the width, 1.2 inches (30 $\mathrm{mm}$.). These dimensions, especially the length, considerably exceed those of the existing bison and likewise those of $B$. occidentalis (Geol. Surv. Iowa, vol. XXIII, p. 320).

In 1853, in his work on the Extinct Species of American Ox (Smithson. Contrib. Knowledge, vol. v, art. III, p. 9), Leidy gave a description of this skull, but without having seen the specimen itself. He referred the skull to Bison latifrons. The present writer is inclined to believe that this skull belonged to Bison regius.

Pilot Knob, Travis County (8).-In 1898, Dr. F. A. Lucas (Proc. U. S. Nat. Museum, vol. xxi, p. 768) described a part of a lower jaw of a bison, found by R. T. Hill on Onion Creek, about 2 miles west of Pilot Knob. This is a few miles southeast of Austin. Lucas found that the teeth had a somewhat larger fore-and-aft diameter and were considerably wider than those of the existing bison. He referred them provisionally to B. latifrons. Hill, as quoted by Lucas, stated that this jaw had been found in an extensive formation which he was naming the Onion Creek formation and which had a wide development in Texas. He regarded it as being the equivalent of the Equus beds or early Pleistocene. In 1898 (18th Ann. Rep. U. S. Geol. Surv., p. 252), Hill and Vaughan state that this jaw was found in Onion Creek marls on Rinard Creek. It is mentioned under the name Bos scaphoceras. It was so named by Hill in 1901 (21st Ann. Rep. U. S. Geol. Surv., pt. 7, p. 360). In the U. S. National Muesum this jaw has the catalogue No. $477 \%$.

Oakville, Live Oak County (9).-In the collection of the University of Texas is a fragment of a horn-core of a bison, found by Dr. E. T. Dumble near the mouth of Atascosa Creek. It was discovered in the bank. The fragment has a length of about $185 \mathrm{~mm}$. The core is flattened on the plane of curvature. At the large end of the fragment the greatest diameter is $90 \mathrm{~mm}$., the shortest $77 \mathrm{~mm}$. The curvature suggests the horn-core of Bison occidentalis or that of $B$. antiquus. 
Bulverde, Bexar County (13).-From a cave near Bulverde the writer received a lumbar vertebra of an indeterminable species of Bison. The care and its fossil contents are described on page 24\%. The bison bone is thoroughly fossilized and certainly belonged to an extinct species.

Beeville, Bee County (10).-The writer had the opportunity to study 3 horn-cores found somewhere in the region about Beeville. They are now owned by Dr. Mark Francis, who obtained them from Ben Mattingly, of Beeville. With two of these cores is a part of the skull, but this has been much damaged by weathering. 'The length of each of these horn-cores is about $850 \mathrm{~mm}$., or nearly a yard. The greatest diameter at the base is $165 \mathrm{~mm}$., the smallest about $145 \mathrm{~mm}$. 'This skull is regarded as belonging to Bison latifrons.

Another fragment of horn-core, probably from about Beeville, has a length of $405 \mathrm{~mm}$., starting at the base. The greatest diameter at the base is 175 mm., the smallest $155 \mathrm{~mm}$. Near the distal end the greatest diameter is 132 mm., the smallest $105 \mathrm{~mm}$. This core curves more rapidly than those known to belong to $B$. latifrons, and it is supposed to belong to $B$. regius. If a line is made to join the two ends on the upper surface its middle point will be 46 $\mathrm{mm}$. distant from the upper surface of the core. The radius of the curvature would be about $400 \mathrm{~mm}$.

Burkburnett, Wichita County (11).-Dr. Charles L. Baker, formerly of the Texas Bureau of Economic Geology, informed the writer that he found some bison remains (not designated) on the second terrace along Red River, in the neighborhood of Burkburnett. At the same place and in the same terrace he found Elephas. It is probable that the bison belonged to an extinct species.

Sir miles north of Sherman, Grayson County, Texas (12).-In the U. S. National Museum (No. 10931 is a sixth cervical bone of a bison, collected in $191 \%$ by Dr. L. W. Stephenson, of the U. S. Geological Surrey. It was found 6 miles due north of Sherman, in a ditch along a public road, 0.25 mile north of Iron Ore Creek. It is noted as having been found at the base of a Pliocene or Pleistocene terrace deposit. The latter supposition is more probably the correct one. It is not possible to determune to which species of Bison the bone belonged, but it is thought that it was one of those now extinct.

\section{OKLAHOMA.}

\section{(Map 25.)}

Afton, Ottawa County (1).--On page 253 will be found a brief account of the discovery of flint implements and remains of 19 species of mammals in a spring near Afton. In the collection in the U. S. National Museum are many teeth, upper and lower incisors, premolars, and molars, which belong to species of Bison. Some of these are undoubtedly the teeth of the existing buffalo, others are quite certainly those of one or more extinct species. Among the latter are 8 teeth which belonged to at least two individuals. Of upper teeth there are a right third premolar, a first and a second right molar, and a left third molar. Of lower teeth there are an incisor, a right fourth premolar. and a left second and a left third molar. The upper teeth are worn down to half their original length; the lower teeth are less worn. All of these teeth have the enamel more or less blackened and all appear to be well mineralized. They are fully as large as the largest teeth of the existing bison (Iowa Geol. 
Surv., vol. xxin, p. 312). It is impossible to assign them to any particular extinct species of Bison.

In the department of palæontology of the U. S. National Museum are some teeth which present similar evidences of geological age, together with many which show little indication of this. There is also a left tibia, apparently of a cow bison. Its animal matter is gone and the bone heary and brown externally. There is likewise an anterior left cannon-bone, stained brown and which appears to be well fossilized. These two bones probably belong to one or two extinct species.

Braden?, Le Flore County (2).--In the St. Louis Academy of Science is preserved the rear portion of the skull of an extinct bison, labeled as found in Arkansas River at a point 15 miles above Fort Smith. This would be somewhere near the present town of Braden. The name of the collector is not known. The skull is thoroughly fossilized. The horn-cores are missing, so that the species can not be identified. At this same location have been found and preserved in the same collection a tooth of a mastodon and a part of a skull of Symbos cavifrons.

Mulhall, Logan County (3).-In $191 \%$ (Bull. Geol. Soc. Amer., rol. Xxviri, p. 212), Doctor Troxell announced that he had found remains of bison near Mulhall. The horns measured 3 feet from tip to tip. The species has not been determined. For the associated genera, see page 255.

Fentress, Okfuskee County (4).--In September 1923, Dr. James Gardner, geologist, sent to the U. S. National Museum a second or third dorsal vertebra of a bison, found near Fentress. The exact locality was giren as the southeast quarter of section 19, township 10 north, range 8 east. A section of the locality shows 5 feet of red-colored clay, below which is 6 inches of gravel. Underlying these is a bed of rolcanic ash 18 feet thick. The bank had fallen and Doctor Gardner thought that the bone had come from either the red clay or the gravel. It is of a gray color, not stained with iron. The volcanic ash was supposed to belong to the Pliocene. It seems possible that the ash is Pleistocene and that the bone had been derived from it. The species can not be determined.

\section{MISSOURI.}

(Map 25.)

Near Joplin, Jasper County (1).-At this point, at a depth of $8 \%$ feet, were found a few bones of a bovine animal identified at the U. S. National Museum as a species of Bison. With these bones were found some remains of Mammut americanum and of Elephas columbi. A description of the locality is given on page 24 , together with suggestions as to the age of the remains. They are probably of Aftonian times.

On Pomme de Terre River, Hickory County, near the Benton County line, or vice versa (2).-In 1843 (Amer. Jour. Sci., vol. XLIv, p. 70), Doctor Harlan, in speaking of a collection made by Albert Koch, in Benton County, Missouri, composed mostly of mastodon remains, stated that among the other bones were evidences of the megatherium, elk, and ox. Doubtless by the latter was meant Bison. For an account of the locality, which appears to have been possibly in Hickory County, the reader is referred to page 25. Whether the 
Bison remains were found superficially or deep down we have no means of determining.

Pleasant IIill, Cass County (3).- In 1870, G. C. Broadhead ('Trans. St. Louis Acad. Sci., vol. III, p. XXII) wrote as follows:

From the foundation of a bridge abutment on the Pacific Railroad, 4 miles north of Pleasant Hill, Missouri, I obtained the tooth of an extinct species of ox. The excavation passes through soils and clays, and at 12 feet below the surface of the bottom-lands a bed of gravel containing decomposing remains of fresh-water shells was reached. From the gravel the tooth was obtained.

Pleasant Hill is situated on or very near the border of the Kansan drift sheet. There is little, however, in the account given that aids in forming a conclusion about the geological age of the tooth, which no doubt was that of a species of Bison.

Kimmswick, Jefferson County (4).-The U. S. National Museum received from Dr. W. F. Parks, of St. Louis, Missouri, a small collection of bones secured at Kimmswick. In the lot are 6 teeth of an undetermined species of Bison. These are very solidly fossilized. An upper molar has a width of $32 \mathrm{~mm}$.

Kansas City, Jackson County (5).--In his report on the Quaternary deposits of Missouri (Missouri Geol. Surv., vol. x, 1896, p. 135), Professor J. E. Todd stated that a tooth of a buffalo had been found in the loess, at its base, near the foot of Lydia Street, Kansas City. The tooth was incrusted with calcareous material. In the same loess were fossil shells. The tooth was probably that of an extinct species. If there is a loess belonging to the Sangamon stage the age of the bison probably belonged in that loess.

\section{KANSAS.}

(Map 25.)

Crawford Township, Cherokee County (1).- In the collection at the University of Kansas is a right ramus of a lower jaw of a species of Bison mentioned by Williston (Univ. Geol. Surv. Kan., vol. II, p. 302). The following label appears on the jaw: "Found at strip pit (coal) on S. L. Cherry's place, section 17, Crawford Tp. In blue clay and on top of coal, 6 to 7 feet from the surface. Horns, etc., have been found in the same pit. Peyton York, 4-12-94." The writer has been informed that the locality is not far from Columbus, Cherokee County. The jaw contains all three of the molars. Neither these molars nor the jaw appears to differ from those of Bison bison, but it is probable that they belonged to one of the extinct species.

Oswego, Labette County (2).--In the U. S. National Museum is an astragalus of a bison, received from N. S. Newton, Oswego, in 1894. This is reported as found in a well at a depth of 20 feet. Whether this well was situated near Neosho River or a higher ground is not known. It is impossible to say to what species of bison the bone belonged.

Burlington, Coffey County (3).-In $18 \%$ (Proc. Acad. Nat. Sci. Phila., p. 69), Leidy reported the presentation of 2 fossils, a plate of a large molar of "Elephas americanus" (E. columbi), and the fore part of a ramus of the lower jaw of an ox, perhaps, as Leidy said, of a large individual of the American bison. These remains were found in a well at a depth of 30 feet. The asso- 
ciation of the bison jaw with that of the elephant indicates the Pleistocene age of both. It is not probable that the jaw belonged to the existing species.

North Lawrence, Jefferson County (4).-In 1905 (Trans. Kansas Acad. Sci., vol. xIx, p. 15\%, fig. 10), Professor C. E. McClung described, under the name of Bison kansensis, a part of a skull which, in the spring of 1903, had been washed out of the bank of Kaw (or Kansas) River, near North Lawrence. In this specimen all of the muzzle back to the frontals is missing, likewise the left horn-core and contiguous parts, and only about 3 inches of the base of the right horn-core is present. So far as the present writer can judge, there is nothing that distinguishes the skull from that of $B$. occidentalis.

In the same collection is a nearly complete skull of a bison, found near North Lawrence by L. D. Read. The molar teeth are present, but much worn down. The basilar length of the skull is $512 \mathrm{~mm}$.; distance from the front of the occipital foramen to the rear of the nasals (basinasal length), $275 \mathrm{~mm}$.; width across the mastoids, $275 \mathrm{~mm}$.; width between the bases of the horncores, $347 \mathrm{~mm}$.; width at the rear of the orbits $345 \mathrm{~mm}$. The distance between the bases of the horn-cores is $725 \mathrm{~mm}$.; diameters of the horn-cores at the base, $90 \mathrm{~mm}$. and $85 \mathrm{~mm}$.; length along the lower curve of the core, $323 \mathrm{~mm}$.; along the upper curve $255 \mathrm{~mm}$.; circumference at the base, $290 \mathrm{~mm}$. The horncores sag somewhat and rake somewhat backward. The muzzle is rather narrow. It appears to the writer that the skull belonged to Bison occidentalis. It came possibly from the same deposit that furnished the skull of Equus laurentius, and that, the writer believes, is the Aftonian. Mr. Read informed the writer that this skull was found after the flood of 1903, about 3 miles northeast of North Lawrence and 1.5 miles north of Kansas River.

Manhattan, Riley County (5).--In $187 \%$ (Amer. Jour. Sci., ser. 3, vol. Iv, p. 252), Professor O. C. Marsh described the species Bison alleni, basing it on a horn-core found on Big Blue River, near Manhattan. S. W. Williston (Trans. Kan. Acad. Sci., vol. xv, 1898, p. 92) stated that he purchased it from the finder.

Dr. J. A. Allen (The American Bison, p. 53) reported that he received from Orestes St. John a fossil astragalus of the American bison, found on the banks of Big Blue River, but here again the exact locality is not given. In the U. S. National Museum is a second upper molar, a right tibia, a sacrum, and 2 metacarpals, collected by F. V. Hayden somewhere along Big Blue River. While all of these may have belonged to Bison bison it is quite as likely that they were parts of extinct species.

Atchison, Atchison County (12).--In 1918 (Trans. Kansas Acad. Sci., vol. xxviII, p. 45), Professor J. E. Todd reported that a bison had been found west of Atchison. It appears to have been implied that the remains, whatever they were, had been discovered in Aftonian gravels.

Wellington, Sumner County (6).--In 1890 (Bull. U. S. Geol. Surv., No. $5 \%$, p. 40), Robert Hay stated that a fine skull of Bison latifrons had been found at Wellington in what he called the "earlier gravels." This is probably the skull on which Professor Cope (Proc. Acad. Nat. Sci. Phila., 1894, p. 68; Jour. same Acad., vol. Ix, p. 456, pl. xxıI, figs. 1-4) based his species Bos crampianus. This name is now regarded as a synonym of Bison alleni. The specimen is in the Academy of Natural Sciences, Philadelphia. Apparently 
from the same sand-pit was obtained a fine lower jaw of Elephas imperator, which is also in the collection mentioned. This jaw is described elsewhere (p. 270). 'The deposit apparently belongs to the Equus (more properly called the Sheridan) beds, equivalent to the Aftonian. Robert Hay (Bull. No. 5\%, U. S. Geol. Surv., p. 40) described the gravels at Wellington and presented a section. 'They appear to occupy an old stream-bed and are overlain by loess.

McPherson, McPherson County ( 7 ).-On page 71 has been described a tooth of Elephas columbi, found in a well at McPherson. In the same well was found a lower tooth of a bison, about half worn down. Just at what depth it was found is not known, nor can the species be determined. These beds at McPherson belong to the Sheridan horizon and are described more particularly elsewhere (pp. 26\%, 269).

Ellis, Ellis County (8).--Professor S. W. Williston informed the writer that he had seen remains of a bison regarded as belonging to Bison occidentalis found somewhere near Ellis. The present location of this specimen is not known.

Hoxie, Sheridan County (9). - At some place in the vicinity of Hoxie was found a fine skull, now in the American Museum of Natural History, New York, which is the type of Bison regius. An account of the finding of this skull is given by C. H. Sternberg in his Life of a Fossil Hunter, on page 267; likewise, a figure, under the title of the "giant bison," is furnished. The specimen was afterwards described by the writer as B. regius (Proc. U. S. Nat. Mus., vol. xLVI, p. 192, pl. xviII, figs. 1, 2). The skull was found on Sand Creek, a stream which empties into Solomon River. The Missouri Pacific Railroad cut a new channel for the creek and in doing so came near the skull; afterwards a freshet washed away some of the bank and exposed it. It is said to have been buried at a depth of 35 feet. D. L. Wiggins, of Hoxie, informed the writer that the skull was found on the south part of the southwest quarter of section 14, township 8 south, range 28 west. Whether this specimen was buried in deposits belonging to the Sheridan formation or in some later alluvium along the creek it is at present impossible to say. It is most probable that it belongs to the early or the middle of the Pleistocene.

Twelve-Mile Creek, Logan County (10). - It was near this place that several skeletons of Bison occidentalis were found by H. T. Martin. Mr. Martin, as quoted by Williston (Amer. Geologist, vol. xxx, pp. 313-315), described the locality as being on Twelve-Mile Creek, about half a mile north of Smoky Hill River, in Logan County; also 12 miles east of Russell Springs and 18 miles south of Monument Station, on the Union Pacific Railroad; finally, as being in township 14 south, range 33 west. In his paper just quoted, Williston presents a section of the valley. In this it is shown that the bones were overlain by 20 feet of soil and were at a considerable distance from the surface in other directions. Martin (Kansas Univ. Sci., Bull., vol. IV, p. 250) stated that the bone bed lay at the west edge of a canyon in the Cretaceous, about 200 yards wide, through which flowed a small tributary of Smoky Hill River.

From these bones was constructed the skeleton which is on exhibition in the University of Kansas. Under the shoulder-blade of this skeleton was found, according to the statement of Mr. Martin, a flint arrow-head (Williston, 
Univ. Kan. Geol. Surv., vol. II, p. 302). In a letter to the present writer, dated November 29, 1912, Mr. Martin wrote as follows:

From the first sign of bone on the outer edge of the bed to the position of the large bull bones having the arrow-head, it was fully 12 feet straight back into the bank, and 25 feet from the surface, with absolutely straight steep bank, with no sloping at all. And above all, the arrow was pressed right into the bone, leaving a raised place on the opposite side.

In apparently equivalent deposits, about a mile away, Mr. Martin secured teeth of a fossil horse and some camel remains and a lower jaw of a wolf, Canis occidentalis? If the horse and camel remains were found in deposits of the same age as those inclosing the bison bones it would appear that the latter were as old as the Aftonian.

Cheyenne County (11).-In 1866 (Prelim. Rep. Geol. Surv. Kansas, p. 101), Major F. Hawn reported that bones of a buffalo, including a portion of the upper jaw, with 5 teeth, had been found on the south slope of Republican River, at a depth of 50 feet and at a height of 125 feet above the stream. They were in a deep arroyo, or ravine, evidently exposed on the side of the slope, for no excavations were reported. It is not known what became of these bones. By comparing the bones found here with those of the existing bison, Major Hawn convinced himself that the former were identical with the latter and represented Bison bison. Without the horn-cores this would be uncertain.

\section{COLORADO.}

(Map 25.)

Colorado Springs, El Paso County (1).- In a small collection of bones found in gravel-pits in Colorado Springs and sent by Professor Edward R. Warren the writer recognized some remains of a bison. Inasmuch as the other animals represented were camels and horses, it is concluded that the bison belonged to an extinct species.

Near Parker, Douglas County (2).-In his chapter on the Pleistocene geology of the Denver Basin (Mon. U. S. Geol. Surv., vol. xxvir, p. 260), S. F. Emmons states that a bone was found in a tunnel driven in the ancient drift of Newlin Gulch (section 36, township 6, range 67 west), 47 feet from its mouth and 25 feet below the surface. This bone was sent to Professor O. C. Marsh, who identified it as consisting of vertebræ of a bison, grown together as the result of an injury. Marsh thought it possible, even probable, that the injury was caused by the weapon of a hunter. A description of Newlin Gulch is given by Emmons on page 270 of his paper above cited.

Denver, Denver County (3).--In the U. S. National Museum is a collection of bones, made from the Pleistocene deposits along Platte River, at Denver. This collection was sent by the late Professor George L. Cannon, of Denver. Besides bones and teeth of a camel and a few bones of an extinct horse, there are a few bones, a vertebra, and a metacarpal cannon-bone, that belonged to an extinct species of bison. The cannon-bone presents the distal half. The width of the distal articular surface is $94 \mathrm{~mm}$. The width of unusually broad cannon-bones figured by $\mathrm{J}$. A. Allen in his monograph on American Bisons is $72 \mathrm{~mm}$. The Denver bison was probably either Bison latifrons or B. regius.

S. F. Emmons (Mon. U. S. Geol. Surv., vol. xxvir, 1896, p. 260) reported that a few isolated bison bones had been found in excavating for cellars in 
Denver. He mentioned buildings at the corner of Lawrence and Eighteenth Streets and Larimer and Sixteenth Streets. These bones were met with in what Emmons called the river drift. On page 261, Emmons stated that bison bones had been found also in what he called fluvial loess, which lies on the river drift.

Glenwood Springs, Garfield County (4).- In the collection at the University of Colorado is a humerus of a bison, found about 8 miles west of Glenwood Springs and half a mile up South Canyon Creek. It was discovered in gravel at a depth of 8 feet in making a tramway. The bone appears to differ only slightly from that of the existing bison. Inasmuch as in the same deposit was found the tooth of an extinct horse, the bison also is probably extinct.

IOWA.

(Map 25.)

Avon, Polk County (1).--At Simpson College, Indianola, are a right front cannon-bone and a left astragalus of an undetermined species of Bison, found some years ago in a gravel-pit at Avon. These were submitted to the writer, for examination, by Dr. John L. Tilton. They were mentioned by him in his thesis on the Pleistocene Deposits in Warren County, Iowa (Univ. Chicago, 1911, p. 26). The astragalus is considerably larger than one (No. 35525 of the U. S. National Museum) with which it has been compared and presents some differences in proportion. The measurements, in millimeters, are:

\begin{tabular}{|c|c|c|}
\hline & Fossil. & Recent. \\
\hline Length of bone on outer face........... & 79 & 69 \\
\hline 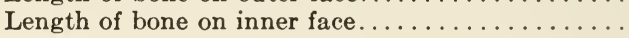 & 74 & 66 \\
\hline Greatest width near upper end... & 49 & 45 \\
\hline Greatest width near lower end........ & 49 & 44 \\
\hline $\begin{array}{l}\text { Fore-and-aft thickness at middle of length, on } \\
\text { outer face } \ldots \ldots \ldots \ldots \ldots \ldots\end{array}$ & 42 & 35 \\
\hline Same thickness on inner face............. & 42 & 37 \\
\hline
\end{tabular}

In the same pit was found a part of a lower jaw, with a molar, of Rangifer muscatinensis.

James Township, Pottawattomie County (2).-Dr. J. A. Udden (Iowa Geol. Surv., vol. xI, p. 260) reported the discovery of a pair of horn-cores of Bison latifrons in James Township. The more exact locality was described as being near the quarter-post of the east line of section 28, township 76 north, range 40 west. This is about 4 miles northwest of Oakland. The horn-cores are said to have been found in the loess in a well at a depth of 14 feet. Udden published various measurements taken from these cores. These show that he used the name latifrons in the broad sense in which Leidy sometimes employed it. These measurements are given also by the writer (Iowa Geol. Surv., vol. xxiII, p. 323). The length of the upper curve exceeded somewhat the circum. ference of the core at the base. The cores belonged to either B. occidentalis or $B$. antiquus; there is nothing to show which of these species was represented. The first named is the commoner species in the eastern half of the United States. 
Judging from Udden's statements as to the thickness of the loess in this region, averaging perhaps 40 to 50 feet, one may conclude that the animal lived during the early Peorian or the late Iowan.

Missouri Valley, Harrison County (7).-From the Cox pit at Missouri Valley (see p. 296) were obtained the distal ends of two cannon-bones of a large ruminant. One of these bones was figured by Calvin (Bull. Geol. Soc. Amer., vol. xx, p. 350, pl. xxir, fig. 3). They belonged almost certainly to some species of Bison. The present writer (Iowa Geol. Surv., vol. xxIII, p. 327) has referred them provisionally to $B$. alleni, because of the association of this species with a camel in Idaho. Camel remains also have been found in the Cox pit.

Denison, Crawford County (3).--In the collection at the State University of Iowa is a large scapula found in deposits of uncertain age in a gravel-pit west of the railroad station at Denison. This pit is the upper one of the two at Denison which have furnished mammalian remains. The bone is rather light in weight, but appears to be mineralized; it rings on being struck. Measurements of this scapula and one of Bison bison have been presented by the writer (Iowa Geol. Surv., vol. xxIII, p. 325). It appears probable that the age of this bone is pre-Wisconsin at least.

Correctionville, Woodbury County (4).--In the collection at the State University of Iowa are some remains of Bison occidentalis, found at Correctionville, in the Welch pit. The part which is assigned definitely to this species is a horn-core having on it the University's No. 350 (Iowa Geol. Surv., vol. xxIII, p. 325). No. 355 is given to the base of a skull which may have belonged to the same individual; No. 354 to a scapula which may or may not belong to the same species. In the same pit were found caribou antlers. Inasmuch as this place is not far from the border of the Des Moines lobe of the Wisconsin drift, it is to be expected that trains of Wisconsin gravel will be found in the valley of the river. As Bison occidentalis has been found in deposits in Minnesota of middle Wisconsin age, the remains discovered at Correctionville are possibly not older.

Des Moines, Polk County (5).- - In the National Museum is a bison tooth (No. 2082) recorded as sent there, by Claude D. Brown, from Des Moines. It is an upper left last molar and only moderately worn. It is heavy, thoroughly mineralized, and of a blue color. Although it shows no characters by which it can be distinguished from teeth of Bison bison, the writer believes that it belonged to a species which became extinct before the close of the Wisconsin stage. No exact statements as to the place where it was found, or the depth and kind of soil, accompany the tooth. It was described by the writer in 1914 (Iowa Geol. Surv., vol. xxIII, p. 318).

Webster City, IIamilton County (6).- - In 1914, the writer described and figured (Iowa Geol. Surv., vol. xxiII, p. 323, pl. XL, figs. 3, 4) a horn-core, with a part of the skull attached, sent to the U. S. National Museum in 1878 by Charles Aldrich. He stated in his letter that it was found on a gravel-bar in Boone River, at Webster. The measurements are given in the paper just cited, also the reasons for referring it to Bison occidentalis. The chief interest in this specimen is found in the fact that the locality is in the heart of the Des Moines lobe of the Wisconsin drift. The writer has held that no remains of 
an extinct bison have been found in deposits overlying the Wisconsin drift sheet. 'This view must be modified somewhat because of the discovery of Bison sylvestris (Proc. U. S. Nat. Mus., vol. XlviI, 1915, p. 515) in postWisconsin deposits in northern Ohio, and because of the discovery of $B$. occi dentalis in peat overlying early Wisconsin drift in Minnesota (see p. 199). According to Macbride's report on the geology of Hardin County (Iowa Geol. Surv., vol. xx, pp. 125, 128), the Wisconsin drift is underlain by Kansan, and this is exposed at places along Boone River, near Webster. Within the limits of the town is an exposure of about 72 feet of Wisconsin, but Macbride concluded that the bed of the river was formed by the blue clay (Kansan). It is possible that the horn-core was washed up out of some as yet unrecognized preWisconsin interglacial deposit at that place.

Galva, Ida County (8).- In 1923 Professor A. O. Thomas reported to the writer the finding of the right half of the face of a specimen (Cat. No. 400) of Bison occidentalis, at Galva, on the Maple River. It is reported as discovered in a "sandy drift," 14 feet from the surface, in the digging of a town well. Professor Thomas stated that the bone is iron-stained, as are many of the Aftonian fossils, but the bone is not mineralized, as are usually the Aftonian bones. The geological age is as yet uncertain.

\section{NEBRASKA.}

(Map 25.)

Richfield, Sarpy County (1).-In the collection at the State Museum at the University, in Lincoln, is a lower last molar of a bison, recorded as found at Richfield. This town is located at about the center of Sarpy County, about 15 miles southwest from Omaha. It is impossible to determine the species to which the tooth belonged, but it was probably one of those now extinct. Nothing more is known about the history of the specimen.

Broken Bow, Custer County (2). - In the State University Museum, at Lincoln, is a part of a skull of a bison which the writer identifies as Bison occidentalis. It is designated on the catalogue as No. 22-5-0\%. The base of the skull is missing. The width of the forehead, taken between the orbits and the bases of the horn-cores, is estimated as $33 \pm \mathrm{mm}$. The circumference of the base of the horn-core is $330 \mathrm{~mm}$.; length of the horn-core measured along the upper curve, $335 \mathrm{~mm}$. The diameters at the base of the horn-core are $108 \mathrm{~mm}$. and $98 \mathrm{~mm}$., the horn-core being thus slightly flattened. The distance between the tips of the horn-cores is nearly $1,000 \mathrm{~mm}$., being thus somewhat more than usual. Nothing is known as to the exact place of discovery of this specimen or the conditions of its burial. The region is covered by loess, but beneath this are doubtless to be found materials belonging to the Sheridan. Teeth of $E$. columbi, from Broken Bow, are in the same museum.

Hitchcock County (3).- In the State Univeristy Museum, at Lincoln, is a bison horn-core, recorded as found in Hitchcock County and presented by Hon. R. W. Furnas. The total length of the fragment is $580 \mathrm{~mm}$. How much of the basal portion is missing is not known. At a distance of $406 \mathrm{~mm}$. from the tip the diameters are $100 \mathrm{~mm}$. and $95 \mathrm{~mm}$. The curvature is such that the middle part of the upper curve is $65 \mathrm{~mm}$. distant from a straight line joining the extremities. As near as can be determined, the index of curvature 
(length along lower curve $\times 100 \div$ the straight line above mentioned) is equal to about 113. It appears to the writer that this horn-core belongs to Bison latifrons. In size and curvature it agrees more closely with that than it does with any other species. It is to be regretted that nothing more is known about the history of this specimen. The statement that it was found in glacial drift is obviously wrong, for no glacial drift exists in that region.

"Niobrara River" (4).-The type of Marsh's Bison ferox was collected in 1870 by Eli Whitney at some point along Niobrara River. It was described by Marsh in 1877 (Amer. Jour. Sci., ser. 3, vol. XIv, p. 252). In 1899, Lucas (Proc. U. S. Nat. Mus., vol. XXI, p. 766, pl. LXXXI), figured the specimen.

In his paper on Fossil bisons of North America, already mentioned, Lucas stated that in shape the horn-core indicates a species more nearly like $B$. latifrons than like any other species. It appears to the present writer that there is no character by which $B$. ferox can be distinguished from B. latifrons. The size and curvature indicate identity. The index of curvature of an equal portion of the distal end of the horn-core of the Cincinnati specimen of $B$. latifrons is almost exactly the same as that of the type of $B$. ferox. In the case of this specimen, as with too many others, our lack of information makes all conclusions uncertain about the geological age of the animal.

\section{MINNESOTA.}

\section{(Map 25.)}

Crosby, Crow Wing County (2).--In the fall of 1921 the U. S. National Museum received from the John A. Savage Company, at Crosby, through F. W. Uhler, chief engineer, a large lot of buffalo bones, found in section 19, township 46, range 29, very close to the eastern shore of Mississippi River. A mine of iron ore here is overlain by about 30 feet of drift and this is covered by from 6 to 8 feet of peat. In hydraulicking off the peat the buffalo bones were discovered at or near the bottom of the peat. Besides 3 or 4 good skulls of Bison occidentalis, there are a skull and a good maxilla of Bison bison. These remains were described by the writer (Proc. U. S. Nat. Mus., vol. LXIII, 1923, art. 5, pp. 1-S, pls. I, II). There were also sent to the museum, from the same peat deposit, some antlers of a reindeer, probably Rangifer caribou, and an antler of a moose, Alces americanus. Professor Frank Leverett informed the writer that the drift belongs to about the middle of the Wisconsin stage. The discovery of these bones shows that $B$. occidentalis was living toward the end of the Wisconsin glacial stage. It is possible that the bones of $B$. bison got into the peat at a later time than those of $B$. occidentalis.

\section{SOUTH DAKOTA.}

Pierre, Hughes County (1).-From Doane Robinson, superintendent of department of history, South Dakota: the writer has received a photograph and measurements of a skull of Bison occidentalis which was found during the construction of a railroad bridge across Missouri River at Pierre. The skull lay on Pierre shale in river sand at a depth of 43 feet below the bed of the river. This skull presents the complete horn-cores and the uninjured face. From the front of the premaxillary bone to the occipital crest is $625 \mathrm{~mm}$. The circumference of the horn-cores is $325 \mathrm{~mm}$.; the length of the lower curve, $400 \mathrm{~mm}$.; of the upper curve $325 \mathrm{~mm}$.; the width at rear of orbits is $285 \mathrm{~mm}$. 
It appears impossible to determine the Pleistocene age of the fossil. Dr. W. C. Alden informs me that the valley was excavated during the Nebraskan stage and refilled during a later, probably Kansan, stage. The animal may have been buried there during the Aftonian. However, as has been shown to be the case farther south (Chamberlin and Salisbury, Geology, vol. I, p. 185, fig. 185), the filling may at times have been reworked by the stream to bedrock; and thus the skull may have been entombed at any time from the Aftonian to late Wisconsin. The locality is not marked on map 25.

\section{MANITOBA.}

(Map 25.)

Aweme, Glenwood County (1).-During the years 1914 to 1916 the writer had correspondence with Stuart Criddle, of Treesbank, Manitoba, about remains of fossil bisons which he was finding along the Assiniboine, near Aweme, about 11 miles northwest of 'Treesbank. Mr. Criddle sent photographs and sketches of the more or less damaged skulls which he had discovered. Associated with these were vertebræ and other bones, but they were usually much decayed and broken. The documents sent by Mr. Criddle make it evident that the remains discovered belong to Bison occidentalis. In one skull, found in 1915, the distance between the tips of the horn-cores is $841 \mathrm{~mm}$.; length along concave curve of the right horn-core, $321 \mathrm{~mm}$.; along convex curve, $395 \mathrm{~mm}$.; circumference at base, $32 \% \mathrm{~mm}$.; distance between the bases of the two horn-cores, $332 \mathrm{~mm}$. These remains were found on Assiniboine River, near Aweme. According to a geological section sent by Mr. Criddle the bones occurred at an elevation of about 40 feet above the river, in a layer of clay and gravel. The 40 feet below this layer is composed of blue clay, with gravel and boulders. Above the bone-bearing layer is fine sandy clay overlain by what appears to be a thin layer of white clay. Over this, sloping back from the river, is about 30 feet of yellow sand. The deposits in which these remains were buried, as pointed out to the writer by W. A. Johnston, of the Geological Survey of Canada, were laid down in the Assinboine delta of the ancient Lake Agassiz and near the base of the lake deposits. The bison remains belong, therefore, to a time after the $W$ isconsin ice had retired north of this delta. Evidently the species Bison occidentalis lived to the end of the Pleistocene. It is possible that it was a species which preferred a cold climate.

Douglas Station, Norfolk County (2).-Mr. Criddle sent the writer a sketch of the base and the front part of a skull of a fossil bison which he reports as found on the Kidd farm, 3 miles south of Douglas Station. This is likewise to be referred to Bison occidentalis. This specimen has the tips of both horncores broken off. Many other bones of bisons were found near by ; also a skull of a wolf and one of a badger. All occurred on a spot from which the wind had blown the sand, and they had been buried at a depth of 3 or 4 feet.

Arden, Beautiful Plains County (3).- The writer received the information from W. A. Johnston, of the Geological Survey of Canada, that in 1918 bison remains had been reported as occurring at Arden. The locality is in township 15 north, range 14 west. The remains were discovered at a depth of 30 feet in gravels at the base of the Upper Campbell beach, described by Upham (Monograph xxv, U. S. Geol. Surv.). The altitude is 1,090 feet and is considerably below the highest beach of the lake. The species is undetermined. 


\title{
FINDS OF THE EXISTING BISON, BISON BISON, IN THE MIDDLE REGION OF NORTH AMERICA.
}

\author{
TEXAS. \\ (Map 26.)
}

Southwest corner of Crosby County (1).-From Roy H. Brewer, of Spur, Dr. Mark Francis, in 1922, received a skull, or a part of one, which he regarded as belonging to Bison bison. Mr. Brewer informed the writer that the skull was found on the "U. S. ranch," between Spur, Dickens County, and Peet City, and about 16 miles southwest of Spur. It was in the gravel of a small stream. A photograph sent by Doctor Francis shows the skull to lack the premaxillæ, the nasalis, and the lower jaw. The distance between the tips of the horn-cores is 24 inches; between the bases of the horn-cores, 12 inches; between the hinder borders of the orbits, 12.75 inches. The skull may belong to Recent times.

Vernon, Wilbarger County (2).-In the American Museum of Natural History, New York, are some remains of a bison, believed to belong to the existing species, which were collected near Ternon by Dr. C. L. Baker, formerly of the Economic Geographical Survey of Texas. The exact locality is a gravelpit on the south side of Paradise Creek, 1.25 miles southeast of Vernon. The deposits appear to form a part of what Dr. E. T. Dumble has called the Seymour formation. The remains consist of 3 upper molars and a hindmost lower molar, 2 calcanea of the same side, the distal ends of the right and left metacarpals, some phalanges, a metatarsal, 2 astragali, a nearly complete tibia, and a fragment of horn-core. The fragment of horn-core is about $175 \mathrm{~mm}$. long and is weathered. It is rather slender and considerably curved; therefore the animal could not have belonged to any of the long-horned species. Bison bison is suggested, but it is thought that the deposits belong to the earliest Pleistocene; it has not yet been shown that the species occurred in such early deposits. Likewise, the teeth are apparently too large. In the fossil the teeth are but little worn. The first molar is $43 \mathrm{~mm}$. high; the second 58 $\mathrm{mm}$.; the third, $65 \mathrm{~mm}$. The following are the millimeter measurements of the teeth and of corresponding ones of Bison bison:

\begin{tabular}{|l|c|c|}
\hline & $\begin{array}{c}\text { Vernon } \\
\text { bison. }\end{array}$ & $\begin{array}{c}\text { B. bison, } \\
\text { 22374 } \\
\text { U.S.N.M. }\end{array}$ \\
\hline Length of three upper molars .......... & 98 & \\
First upper molar, length fore-and-aft.... & 30 & 26 \\
First upper molar, width at base ....... & 27 & 26 \\
Second upper molar, length fore-and-aft.. & 35 & 33 \\
Second upper molar, width at base...... & 28 & 28 \\
Third upper molar, length fore-and-aft... & 35 & 34 \\
Third upper molar, width at base....... & 30 & 27 \\
Third lower molar, length fore-and-aft... & 40 & $\ldots$ \\
\hline
\end{tabular}

San Marcos, Hays County (3).-In the U. S. National Museum are 9 teeth of a bison, which came from San Marcos. The teeth are reported as found in 
excavating fish ponds. 'They are in different stages of fossilization; one is quite unchanged; the others have lost most of their organic matter. Specimens thus collected and not accompanied by proper information are of little value.

Nash's Ferry, Bastrop County (4).-In the U. S. National Museum are 6 vertebræ (of which one is the axis), the sacrum, the right femur minus the lower end, and some fragments of other bones. These were sent by Alexander Deussen; the locality is given more exactly as being 2 miles below Nash's Ferry. From Hugh H. Duval, of Bastrop, the writer learns that Nash's Ferry is about 9 miles above Bastrop. According to information sent by Doctor Deussen the locality is on the lowest terrace along the river, at a height of about 25 feet above low water. Apparently the whole skeleton was present and in a standing position. It was in a sandy clay at a depth of about 10 feet below the level of the terrace and about 15 feet above the water line. The skeleton appears to have been mostly destroyed by the workmen. From the portions present it is impossible to say whether the animal belonged to the existing species or not. In 1924 (Profess. Pap. 126, U. S. Geol. Surv., p. 116) Deussen recorded this locality as being at Hemphill Bend, near Goodman.

Bastrop, Bastrop County (5).-A number of skulls or parts of skulls and some other portions of Bison bison were found at or near Bastrop. From Dr. Mark Francis the writer received 2 photographs showing front and rear views of a skull he received from Dr. S. R. Dunn, of Bastrop, in 1922. The muzzle is missing, but the nasals are preserved. This skull shows the short, stubby horns of Bison bison. In the skull were 2 upper molars. Doctor Francis sent some measurements, in millimeters: Tip to tip of horn-cores, 560 ; distance between bases of horn-cores, 300 ; greatest width at ear-openings, 250 ; greatest width at rear of orbits, 320 .

From Hugh H. Duval, of Bastrop, the writer received photographs of the rear of another skull which is to be referred to Bison bison. This was found in the bluff of the Colorado, about 5 miles above Bastrop. It has very thick horncores. Mr. Duval found other bison bones in what appears to be the first terrace above the present flood plain, 25 feet above low water. The deposit consists of silt and sand. The bones were found at a depth of 20 feet. This position appears to indicate at least a late Pleistocene stage. In July 1921 Mr. Duval sent to the U. S. National Museum a right humerus, most of the left radius, a metacarpal cannon-bone, and an axis of a bison, all of which had apparently been just washed out of the bank of Colorado River as Bastrop. These bones appear to have lost nearly all their animal matter and yet are solid and heavy. They can not be distinguished from those of the existing bison.

Hill Creek, Bosque County (6).-In 1922, Doctor Francis received from E. T. Adams, of Glen Rose, a part of a bison skull found in a gravel-pit near Hill Creek, about 6 miles south of Glen Rose. The depth beneath the surface was about 4.5 feet. The locality appears to be in the neighborhood of IValnut Springs, Bosque County. A photograph of the skull was sent by Doctor Francis. The writer refers the skull to Bison bison. The left horn-core is broken off at about the middle of the length; that of the right side has a little of the tip missing. The distance from the base of the horn-core to tip, straight, 
as reported by Doctor Francis, is $190 \mathrm{~mm}$.; length on concave curve, $20 \% \mathrm{~mm}$.; that on convex curve, $265 \mathrm{~mm}$. These measurements correspond to those of Bison bison and are much below those of $B$. occidentalis.

Cameron, Milam County ( 7 ). - In the Francis collection is a skull of Bison bison, found on a sand-bar in Little River, about 3 miles above Cameron. This came into the possession of Judge Jeff T. Kemp, of Cameron, who presented it to Doctor Francis. He sent the writer photographs of the skull, which show that it is one of the existing species. The age may be Recent.

\section{OKLAHOMA.}

(Map 26.)

Afton, Ottawa County (1).-In 1901, Professor W. H. Holmes made an excavation in a spring near Afton and secured many flint implements, besides remains of 19 species of mammals. T'his locality is described on page 254 . In the spring was found a nearly complete skull which belonged evidently to a cow of Bison bison. The bone is not greatly changed. Among the loose teeth of the collection are some which are white and fresh in appearance and which are probably those of the existing species of Bison. Others more or less stained with iron and more fossilized must for the present remain unidentified.

Pickwick, Bryan County (2).- - In the U. S. National Museum is a tooth of a bison, probably of the existing species, sent to the museum about 1879 by Dr. George H. Horn. It is recorded as found 8 miles north of Dennison, Texas, and 3 miles north of Red River. This would be not far from the present towns of Pickwick and Colbert. The tooth has the No. 656 and appears to be a left first molar. It probably belongs to the Recent epoch.

\section{MISSOURI.}

(Map 26.)

Kimmswick, Jefferson County (1). - In a small collection made at Kimmswick and sent to the U. S. National Museum, in July 1921, by Dr. W. F. Parks, of St. Louis, are 3 teeth of a species of Bison. These resemble so closely the teeth of the existing bison and are apparently so little mineralized that they are referred to $B$. bison.

\section{KANSAS.}

(Map 26.)

Wakarusa Creek, Douglas County (1).-In 1877, J. Savage (Trans. Kansas Acad. Sci., vol. vi, p. 10) reported the discovery of bison bones along Wakarusa Creek, south of Lawrence, in what, according to his description, would be late Pleistocene or early Recent deposits. With these remains were found others which he supposed to have belonged to the elk and the antelope. These deposits and fossils may be older than Savage supposed. On page 233 is described the jaw of Mammut progenium, which was found in the same locality.

North Lawrence, Jefferson County (2).- In 1905 (Trans. Kansas Acad. Sci., vol. xIx, p. 15\%), Professor C. E. McClung reported that in the spring of 1903 heavy floods in Kaw, or Kansas, River had caused numerous washouts near North Lawrence, which is on the north side of the river and opposite Lawrence. As a result, several crania of Bison bison were exposed and secured for the University of Kansas. At the same time was found the partial skull 
which McClung made the type of his Bison kansensis. In 1910, at about the same place, was discovered the fine skull of a horse, which forms the type of Equus laurentius, a part of an antler of an elk, and a femur which Professor Roy L. Moodie regarded as that of a species of Smilodon. In the University of Kansas is a nearly complete skull of Bison occidentalis (lacking the lower jaw), found in 1903, along the river, near North Lawrence. This is described on page 193. It appears evident that there are deposits of very different ages along the river in that region.

Millwood, Leavenworth County (3).--In the U. S. National Museum (No. 1818 ) is a skull of an American bison, sent, in 1894, by Dr. A. G. Chase, of Millwood. The writer received a letter, dated October 16, 1916, from Henry S. Chase, of Easton, Kansas, saying that he found the skull in Stranger River, after a flood. It was, as he writes, in a bed of gravel about 25 feet underground. From this statement it is inferred that the bed of gravel was 25 feet below the top of the bank. The skull might have been buried near the top of the bank and fallen down. Moreover, it is possible that it had been carried some distance down the stream before it lodged in the bed of gravel. The locality is in the southwest quarter of section 6 , township 7 south, range 20 east.

Russell Springs, Logan County (4).-Charles W. Gilmore, of the U. S. National Museum, informed the writer that some years ago he helped to collect a considerable part of the skeleton of a bison near Smoky Hill River, at a point about 8 miles above Russell Springs. The place was in a gully 2 miles from the river and the bones were buried at a depth of about 8 feet. The remains are now in the Carnegie Museum at Pittsburgh. It is probable that the skeleton belonged to the existing bison.

COLORADO.

(Map 26.)

Gold Hill, Boulder County (1). - In the U. S. National Museum are 3 molar teeth of a bison, said to have been found in a gravel-bank 3 feet below the surface. There is nothing to show that the teeth are not those of Bison bison; the geological age may be Recent.

Wellington, Douglas County (2).-In the collection of the University of Colorado, at Boulder, are 2 teeth of a bison, found 2 miles north of Wellington, in fine sand, but nothing more is recorded regarding the geological conditions. They appear not to differ from those of Bison bison.

IOWA.

(Map 26.)

In this section it is proposed to put on record remains of the gellus Bison which appear to belong to the existing species and which were excavated under circumstances which show that they were buried for a long time. Some of these remains may reach back to late Pleistocene times.

Rock Creek Township, Jasper County (1).-Professor Lynds Jones, of Oberlin College, Ohio, informed the writer that in 1886 he found the skull of a bison 5 miles west of Grinnell; the exact location and depth of burial have not been recorded. The skull was put in the collection of the Agassiz Asso- 
ciation at Grinnell and is probably now in the collection of Grinnell College. While probably an ancient skull, one would not be justified in referring it with certainty to the Pleistocene.

Prairie Grove, Clarke County (2).-In Simpson College, Indianola, Iowa; is a part of the skull, with horn-cores, of Bison bison. It was found in washedout sands in a creek, by Will E. Sayres, in August 1910. The locality is in the northeast quarter of section 1, township 73 north, range 26 west, about midway between Prairie Grove and New Virginia. The bone is apparently somewhat mineralized and the skull must have been buried a long time; but one can not with certainty refer it to the Pleistocene.

Bear Grove, Guthrie County (3).- In the U. S. National Museum, No. 1600 , is a lower right first true molar sent to the museum by V. D. Merrill. It is well worn down and the animal matter is gone. It may belong to the Recent period, but it is quite as likely to belong to the Pleistocene and to be of some other species than $B$. bison. Bear Grove is situated just outside of the Wisconsin drift area. No details have been preserved as to the conditions under which the tooth was discovered.

Deloit, Crawford County (4).- In the National Museum (No. 2172) is the forehead, with horn-cores, of Bison bison. This was purchased of R. H. Childress, of Deloit. An account and a figure of this skull have been given by the present writer (Iowa Geol. Surv., vol. XxiII, p. 315, pl. xxxix, fig. 1). In a letter, written February 1901, Mr. Childress stated that the skull was found while he was excavating a canal along the railroad for the purpose of straightening a section of Boyer River. The skull was discovered at a depth of 18 feet below the surface, 6 feet below the bed of the river, and about 75 yards from the main channel. While one can hardly refer this skull to the late Pleistocene, it can not with certainty be denied that it belongs there.

Logan, Harrison County (5).-In volume $\mathrm{xx}$ of the Iowa Geological Survey, on pages 408 to 410, Professor Shimek recorded various localities in Harrison and Monona Counties where bison remains have been discovered. On his page 409 he states that there is an exposure along Hog Creek, on the farm of Lester Adams, in the northeast quarter of the southeast quarter of section 14 , township 79 north, range 42 west. This is about 5 miles north of east of Logan. Along the creek is a deposit of alluvium into which the present stream has cut a gully to the depth of from 8 to 12 feet. Many of the bison and elk bones were found sticking out about halfway up the bank. The bison skulls were largely those of males; and Professor Shimek thought that this indicated that the animals had been mired, the less heavily built cows having been able to extricate themselves. It is probable that these remains belong to the Recent epoch; but it would be interesting to know at what time the creek-bed had deposited that alluvium. From what Professor Shimek says of the next locality to be mentioned, it is probable that here also the cutting away of the alluvium had only recently commenced. He reported the finding of a part of a bison skeleton in section 24, township 80 north, range 42 west. This is a little southeast of Woodbine. Nothing is said about the conditions under which it was found.

Turin, Monona County (6).--Professor Shimek (op. cit., p. 408, pl. xxxII) has given an account of the discovery of many bones of the bison, the elk, 
and the Virginia deer at a locality near 'T'urin. 'The exposures extend along Beaver Creek for some distance, the best ones being in the northwest quarter of section 17, township 83 north, range 43 west, and in the southeast quarter of section 8 of the same township. Here in the alluvial deposits the creek has cut a gully about 18 feet deep with a width of about 35 feet. The lowest 4 fect of the alluvium consists of a tough blue-black clay; higher up the deposit becomes lighter both in color and texture. The bones were found in the upper part of the lowest tough stratum and in the lower part of the upper layer. At one point was observed an old beaver dam buried to a depth of about 12 feet. Professor Shimek presents a view of the stream and a reproduced photograph which shows the skulls and bones. He was informed that about 30 years ago there was no gully along this creek. The cutting has evidently been due to changes brought abcut by cultivation of the land.

The writer has quoted (Iowa Geol. Surv., vol. xxiII, p. 314) some remarks from a letter received from Professor Calvin regarding this locality. Professor Shimek informs the writer that this locality is on Beaver Creek and is the same that he described. Professor Calvin had evidently misapprehended the name of the creek. Henry McCall writes that many bison and elk horns had been picked up on his father's farm, 7 miles north of Moorhead, Monona County. This must be very near the locality described by Shimek and Calvin.

The history of Bison bison as known and the condition of the bones collected on Beaver Creek indicate that they are not older than late Pleistocene and that they may be wholly of Recent age. Judging from Shimek's description of the lower blue-black layer of alluvium, it would appear to have been derived from the earlier post-Kansan loess and to have been deposited before the younger yellow loess was laid down over that region. The upper and greates part of the alluvium appears to have been derived from this younger loess. The writer concludes, therefore, that just before, or not long after, the close of the Wisconsin stage, when bisons had begun to frequent this stream, through some change of level the more loamy alluvium began to be deposited and to hide the bones. Those which occur in the older alluvium may easily have been tramped into it by the herds.

Grimes, Polk County (7).-From Dr. James H. Lees, assistant state geologist of Iowa, the writer has received photographs of a part of a Bison bison skull, with horn-cores, together with both humeri and a part of a femur. These were found in 1910 in an old lake-bed, near Grimes, in the east half of section 20, township 80 north, range 25 west. The bones were not preserved by the finders. No records were kept of depth and kind of deposit. This lakelet was situated on an area which in Bain's report (Iowa Geol. Surv., vol. VII, map) is represented as being occupied by Wisconsin assorted drift. It is impossible to say whether or not the animal in question lived so long ago as the late Pleistocene; it might have been drowned not many years ago.

Hubbard, Hardin County (8). - In the collection at Grinnell College, Grinnell, Iowa, is a skull of Bison bison, found in digging a well near Hubbard. It was deposited in the collection by Dr. N. C. Morse, of Eldora, Iowa. He informs the present writer that the well was located in the northeast quarter of the southwest quarter of section 16 , township 86 north, range 21 west. It 
was from 12 to 14 feet deep and was dug near the base of a gravel hill. There is no stream near and the hills are not steep. The subsoil is gravelly. The region is occupied by Wisconsin drift. It is difficult to understand how this skull could have become buried there, unless glacial action of some kind was going on at the place.

Lehigh, Webster County (9).-Frank C. Wilder (Iowa Geol. Surv., vol. xII, p. 190) reported the presence of many bison remains, especially teeth, on the second terrace, at the mouth of a ravine, 2.5 miles north of Lehigh. With these were mingled articles of Indian workmanship. It was Professor Wilder's view that these bison remains were probably of late date. They were covered with 6 feet of silt, on which were growing trees of considerable size.

Laporte, Black Hawk County (10).-At Princeton University are 2 cervical and 3 dorsal vertebræ of Bison, labeled as taken from the bank of Cedar River. It is at present impossible to determine either the species or the geological age of these vertebræ.

Floyd, Floyd County (11).-Bones and teeth of probably Bison bison were reported by W J McGee (11th Ann. Rep. U. S. Geol. Surv., p. 43) as found near the top of a 25-foot section along Cedar River. The teeth were in a lightbrown loam, with univalve shells of Recent species and partly mineralized wood. They were buried at a depth of about 15 inches. There is nothing in the account that indicates any considerable age for these remains, except the mineralization of the wood.

\section{NEBRASKA.}

(Map 26.)

Omaha, Douglas County (1).- In the collection of the Iowa Geological Survey is an atlas of a bison, collected at Omaha by Professor Shimek. It has the number 66. It was found in a railroad cut near the line (perhaps south of it) which runs between Omaha and South Omaha. A considerable part of the skeleton was there, possibly the whole of it; but it was removed by unfavorable weather before it could be secured. The width of the bone across the wings, at the hinder end, is $210 \mathrm{~mm}$. The atlas of a specimen of Bison bison in the National Museum measures $223 \mathrm{~mm}$. in width. It appears probable that the skeleton in question was that of the existing bison, buried in a Recent deposit.

Winnebago Reservation, Thurston County (2).- - In the U. S. National Museum is a nearly complete skull, lacking the lower jaw, of Bison bison, sent to the museum many years ago by Dr. T. T. Minor. It is recorded as found in the "loess of Missouri," in the Winnebago Reservation. Probably the loess of the Missouri River was meant. The Winnebago Indian Reservation occupies the northern part of Thurston County and extends to Missouri River. As noted by Lucas (Proc. U. S. Nat. Mus., vol. XxI, p. 75\%), the skull is remarkable for the spread of the horns $(655 \mathrm{~mm}$.) and size of the teeth.

In this case, again, but little information has been furnished. If it were known exactly where the skull was found and the depth at which it was buried, someone might in the future determine approximately the geological age of the specimen. This knowledge might be the means of proving that the species had been present in the country before the close of the Pleistocene. It is probable that the skull is the one referred to by F. V. Hayden (Final 
Rep. U. S. Geol. Surv. Neb., 1872, p. 10) as having been found in the loess ("marl bluffs") near Dakota ("Dakota City") at a depth of 30 feet.

\section{WYOMING.}

(Map 26.)

Lance Creck, Converse County (1).-In the U. S. National Museum (No. 3032) are most of the bones of the left hinder limb of a bison, found by Doctors Knowlton and Stanton, in 1906, on Lance Creek. It had been buried in hard clay, in the bank of a gully, at a depth of 7 or 8 feet. During one of the occasional rains the bones had become exposed. The animal probably belonged to Bison bison; its geological age is late Pleistocene or Recent.

Henry's Fork, Uinta County (2).- - In the U. S. National Museum is a lower left hindmost molar of a bison, collected many years ago at Henry's Fork by Dr. F. V. Hayden. It is said to have been found at a depth of 4 feet. In this case, again, the species is probably Bison bison; the geological age is uncertain.

\section{MINNESOTA.}

\section{(Map 26.)}

Mora, Kanabec County (1).--In 1910 (Bull. Acad. Sci., vol. IV, p. 420, pl. $\mathrm{xI}$ ), Winchell reported the finding of 2 teeth of a bison near Mora. These were met with in making a drainage-ditch and were buried in several feet of tenacious clay. They were associated with several other teeth and bones, but only the 2 teeth were preserved. They were stained nearly black. Winchell concluded that they belonged to some extinct species and referred them with doubt to Bison latifrons. The teeth are not distinguishable from those of Bison bison. The deposit was certainly of post-Wisconsin or at most of late Wisconsin age, and as no bisons except Bison bison, B. sylvestris, and possibly $B$. occidentalis are known to have lived after the Wisconsin stage, the teeth probably belonged to the existing buffalo.

Crosby, Crow Wing County (2).- In the fall of 1921 the U. S. National Museum received from the John A. Savage Company at Crosby, through F. W. Uhler, chief engineer, a large lot of buffalo skulls and other bones. These had been found in the course of developing an iron-mine in section 19, township 46, range 29. This mine was overlain by about 30 feet of drift, and above this was from 6 to 8 feet of peat. The bones were exposed in hydraulicking off the peat and were at or near the bottom of this. Most of the bones belong to Bison occidentalis, but a nearly complete skull (Cat. No. 10544) and a maxilla (Cat. No. 10669) belong to B. bison. The drift, as the writer has been informed by Professor Frank Leverett, was laid down about the middle of the Wisconsin stage. How long it was after this that these bones were buried there it is impossible to say. The two species mentioned may have lived together or not. From the same deposit were secured an antler of Alces americanus and some antlers of a reindeer, probably Rangifer caribou. An account of this discovery and a description of some of the skulls were published by the writer in 1923 (Proc. U. S. Nat. Mus., vol. I.XIII, art. 5, pp. 1-8, pls. I, II ).

On Pine River, Beltrami County (3).-In 1889 (Can. Geol. Nat. Hist. Surv., vol. III, pt. 1, p. 172 F.), A. C. Lawson wrote that remains of Bos 
americanus (Bison bison) had been found at the first rapid on Pine River. It is not certain that they belong to the Pleistocene.

\section{SOUTH DAKOTA.}

Yankton, Yankton County.-From Mr. Doane Robinson, superintendent of the State department of history, at Pierre, the writer received, too late to be indicated on map 26, an account of the finding of a skull of Bison bison at Yankton. Superintendent Robinson sent drawings and measurements of the skull and the information that it was taken from the second pier from the north, evidently of a bridge, in the bed of Missouri River, at a depth of 38 feet below low water. The horn-cores are rather small. Their circumference at the base is 8 inches; the length of the concave curve, 6 inches; of the convex curve, 8.75 inches. The distance between the bases of the horn-cores is 12 inches; between the tips of the horn-cores, 19.5 inches. To what stage of the Quaternary this skull belongs cannot be determined. It may have been buried there during a time of scouring and refilling.

ALBERTA.

(Map 26.)

Red Deer, Red Deer County (1). - In the Victoria Museum, Ottawa, is a skull of a bison, labeled as found at a depth of 20 feet below the bed of Red Deer River, at the crossing of the Canadian Pacific Railroad. The measurements taken appear to indicate that the species is Bison bison. The distance between the tips of the horn-cores is $712 \mathrm{~mm}$.; the length on the concave curve of the horn-core is $242 \mathrm{~mm}$.; on the convex, $264 \mathrm{~mm}$. The horn-cores appear, therefore, to be too short for Bison occidentalis.

Coleman, Macleod County (2).- In the Summary Report of the Geological Survey of Canada for 1911, published in 1912, on page $34 \%$, an account is given of the discovery of bison remains a mile west of Coleman. They were identified as belonging to the existing bison; but the reasons therefor were not given. The remains consisted of portions of humerus, radii, and tibia. These were found in Pleistocene gravels along Crownest River. 


\title{
FINDS OF' THE GIAN'T BEAVER, CASTOROIDES, IN 'THE MIDDLE REGION OF' NORTH AMERICA.
}

\author{
TEXAS. \\ (Map 27.)
}

Dallas, Dallas County (1).-Dr. J. A. Allen (Mon. U. S. Geol. Surv. Terrs., vol. XI, p. 424) wrote as follows.

In the Museum of Comparative Zoology, Cambridge, Mass., are portions of several lower incisors and parts of several molar teeth, from Dallas, Dallas County, Texas, collected by Mr. Boll from alluvial deposits on the Trinity River, associated with remains of an extinct horse and the mastodon.

'The alluvial deposits mentioned belong certainly to the Pleistocene. The occurrence of Equus and of Elephas imperator in the same immediate region appears to indicate that these deposits and the contained fossils appertain to the early part of the Pleistocene. A list of the species of Pleistocene vertebrates found at Dallas is given on page 241 .

\section{OKLAHOMA.}

(Map 27.)

Afton, Ottawa County (1). - In the collection of the palæontological department of the U. S. National Museum is a fragment of an incisor of Castoroides, which was found near Afton and, so far as can be determined, belongs to $C$. ohioensis. For an account of the spring in which it was found and a list of the species of mammals found in it, see page 254. It is quite impossible to determine to which stage of the Pleistocene it belongs.

\section{KANSAS.}

(Map 27.)

Boicourt, Linn County (1).- In the Kansas University collection is a skull of Castoroides, which was found at Boicourt and which H. T. Martin described under the name of Castoroides kansensis (Kan. Univ. Sci. Bull., vol. vi, 1912, pp. 389-396, pls. 24-27). The specimen was found about the year 1900 while a coal-shaft was being sunk, 3.5 miles southwest of Boicourt, in the valley of Marais des Cygnes River. It was met with at a depth of 34 feet and lay in a deposit of bluish silt. This was underlain by a sandy conglomerate. Martin published a section taken at Trading Post, about 3 miles below Boicourt. Beginning above, there are 6 feet of black loam, then 12 feet of marly clay, followed by 12 feet of blue-and-yellow marl, itself underlain by 18 inches of the bluish silt, and this by 18 inches of conglomerate lying on limestone. It is evident that all above the limestone is a river deposit. The skull was kept for several years in a cigar store as a curiosity. It was secured by Dr. J. R. McLeland and presented to the University. The writer regards the skull as that of Castoroides ohioensis. The exact time during the Pleistocene when it lived can not be determined.

IOWA.

(Map 27.)

Oakland, Pottawattamie County (1). - In the collection of the State University of Iowa is an upper left incisor of Castoroides, which was, as stated by Calvin (Bull. Geol. Soc. Amer., vol. xxiI, p. 215, pl. xxIII), pumped up in 
sand from the bottom of the Nishnabotna River, near Oakland. There is no reason at present for supposing that it did not belong to $C$. ohioensis. This tooth was described and figured by the writer (Iowa Geol. Surv., vol. XxIII, pp. 82, 46\%, pl. LxxII, figs. 1-4). Calvin regarded it as evidence of the presence of Aftonian deposits at the locality; but, inasmuch as probably the same species lived on up to the end of the Pleistocene, the conclusion is not wholly justified.

Near Corley, Shelby County (2).-In July 1921, Ray Leonard sent to the U. S. National Museum two photographs of a skull of Castoroides, which had been found a short time before near Corley. The locality is on the Nishnabotna River. The skull lacks the lower jaw and a part of each zygomatic process. Both incisors are preserved and the 4 molars of the left side; also the front one of the set on the right side. The length from the snout to the rear of the occiput is given as 14 inches; the height from the alveoli to the top of the skull, 5.5 inches. Mr. Leonard has informed the writer that this skull was found in the southeast quarter of the southeast quarter of section 32, township 78, range 39 west. It will be described at length by Professor A. O. Thomas. He quotes from Dr. J. A. Udden (Iowa Geol. Surv., vol. xI, 1901, p. 266) regarding the filling of the valley, and Professor Thomas adds that this filling may well be post-Wisconsin. The age must at present be regarded as uncertain.

Turin, Monona County (3).-In the collection of the State University of Iowa is a fragment of a water-worn incisor of Castoroides ohioensis, which was found in the Elliott sand-pit at Turin. It was mentioned by Calvin in his second paper on the Aftonian fauna (op. cit., p. 215). The geology of this pit is described on page 29\%. The species must be credited to the Aftonian.

Des Moines, Polk County (4).-In 1921 (Science n. s., vol. LIV, p. 309), Professor A. O. Thomas, of Iowa University, reported that an incomplete incisor tooth of Castoroides ohioensis had been found at Des Moines. It was exhumed while excavations were being made in gravels of uncertain age near the western limits of the city.

\section{NEBRASKA.}

(Map 27.)

Peters, Sheridan County (1).- In 1902 (Bull. Amer. Mus. Nat. Hist., vol. XVI, p. 319), Matthew reported that there were in the American Museum of Natural History remains of Castoroides, which had been found in the so-called Hay Springs quarries. These quarries are, however, situated along the Niobrara River, near the post-village of Peters. The specimens include fragments of teeth, limb-bones, and astragali.

In the collection in the State University Museum, at Lincoln, is a small part of a lower jaw of Castoroides, attached to the right lower incisor. This was found somewhere in the region about Hay Springs or Peters. The grooves and ridges on this tooth appear to be more numerous and finer than on that of post-Wisconsin specimens. About 24 may be counted, whereas on the tooth of a specimen in the American Museum of Natural History, New York, found in Berrien County, Michigan, only 18 or 20 can be counted. Perhaps this is due to individual rariations. The portion of tooth at Lincoln has a fore-and- 
aft diameter of $25 \mathrm{~mm}$., a lateral diameter of $21 \mathrm{~mm}$, and a length of 137 mm.; but some part is missing from both ends of it. An incisor with numerous fine ridges has been described by the writer from Charleston, South Carolina (Pleistocene of North America, etc., 1923, p. 279). The deposits found near Peters form the type of the Sheridan beds.

Florence, Douglas County (2).-Dr. William C. Alden informed the writer that he collected, near Florence, a fragment of an incisor tooth of Castoroides ohioensis. It was found near the bottom of a deposit of loess 10 to 15 feet thick, non-calcareous and containing concretions of carbonate of calcium. The locality is just north of the waterworks above Florence.

\section{MINNESO'TA.}

(Map 27.)

Minneapolis, Hennepin County (1).--In 1879, while digging a cistern in Minneapolis, at the intersection of Washington and Fifteenth Avenues, J. G. Somers found, at a depth of 8 feet, a left mandibular ramus of a giant beaver. Accounts of this find were given by Professor N. H. Winchell in 1880 (8th Ann. Rep. Geol. Surv. Minn., pp. 181-183) and in 1888 (Final Rep. Geol. Nat. Hist. Surv. Minn., vol. II, p. 306). The jaw is stated by Professor Winchell to have been buried near the upper surface of the brick-clay which underlies the gravel of the plain between the bluffs of the river. He regarded the deposits as having been laid down near the close of the glacial period. The glacier may have still prevailed over the northern part of the State.

\section{SOUTH DAKOTA.}

\section{(Map 27.)}

Sioux Falls, Minnehaha County (1).-In the collection of the State University of Iowa is one of the three upper anterior grinding-teeth of a giant beaver, probably Castoroides ohioensis, found some years ago by Professor B. Shimek (Bull. Geol. Soc. Amer., vol. xxirr, 1912, p. 143). It was collected in the lower sand and gravel of the Collins sand-pit. It is believed to belong to the Aftonian interglacial stage. 


\section{ON THE PLEISTOCENE OF THE MIDDLE REGION OF NORTH AMERICA AND THE REMAINS OF VERTEBRATES OCCURRING IN IT.}

\section{LOUISIANA.}

The principal sources of information regarding the Pleistocene of Louisiana are the writings of the following authors:

F. V. Hopkins (1st, 2d, and 3d Ann. Rep's Geol. Surv. Louisiana, for 1869, 1870, and 1871).

E. W. Hilgard, Geology of Lower Louisiana and the Rock Salt Deposit of Petite Anse (Proc. Amer. Assoc. Adv. Sci., XuvirI, 1869, pp. 327-340) ; Results of a Geological Reconnaissance of Louisiana (Amer. Jour. Sci., vol. xLvIII, 1869, pp. 331-346) ; The Geology of Lower Louisiana (Smithson. Contrib. Knowl., vol. XXIII, 1872, art. III, pp. 1-34.

W J McGee, The Lafayette Formation (12th Ann. Rep. U. S. Geol. Surv., pt. I, pp. 430-439).

G. D. Harris, The Mississippi Embayment (Geol. Surv. Louisiana, pt. vi, 1902, pp. 1-39) ; Underground Waters of Southern Louisiana (U. S. Geol. Surv., Watersup. Pap., 101) ; Rock Salt in Louisiana (Geol. Surv. Louisiana, Bull. No. 7, pp. 1-259).

A. C. Veatch, The Five Islands (Geol. Surv. Louisiana, pt. v, 1899, pp. 209-262) ; Geography and Geology of the Sabine River (Geol. Surv., Louisiana, pt. vi, 1902, pp. 101-148) ; Geology and Underground Water Resources of Northern Louisiana (Geol. Surv. Louisiana, 1906, Bull. No. 4, pp. I-XII, 1-209) ; Underground Water Resources of Northern Louisiana, etc. (U. S. Geol. Surv., Prof. Pap. No. 46) ; Salines of Northern Louisiana (Bull. No. 7, Geol. Surv. Louisiana, 1902).

Harris and Veatch (Geol. Surv. Louisiana, pt. v, 1899, pp. 1-354).

In 1869 ( $2 \mathrm{~d}$ paper cited, pp. 331-336), Hilgard proposed the name Port Hudson for extensive deposits of clays found along the Mississippi and represented typically near Port Hudson, north of Baton Rouge. Two sections were described in detail in Hilgard's papers, especially in that of volume XXIII of the Smithsonian Contributions, as above cited. In the lowest stratum observed were numerous stumps of cypress trees. Above this was another which contained driftwood, leaves, and mastodon bones. This section and Hilgard's map of the embayment region are reproduced in the writer's work of 1923 on the Pleistocene, pages 387, 389. According to Hilgard, the Port Hudson belt enters the State from Florida and continues to the great river and northward to the southern boundary of Mississippi. It is represented as reappearing west of the river at Grand Lake and passing on around the Gulf to the Rio Grande. Hilgard recognized, further, that the Port Hudson extended northward along the Mississippi, as far north as Memphis, and up Red River to Shreveport, but overlain by alluvium and loess.

One of the latest papers dealing with the geology of Louisiana is Veatch's report on the "Geology and underground water resources of Northern Louisiana and Southern Arkansas" (Prof. Pap. U. S. Geol. Surv., No. 46, 1906). Veatch appears to hold the view that the Lafayette of the Pliocene was laid down at a time of submergence of the Coastal Plain beneath the sea. The writer has expressed his views on this theory of late Pliocene submergence in his work on the Pleistocene of North America, etc., 1923, page 346. The utter lack of any marine fossils in the Lafayette clays, sands, and gravels disproves this theory. 
Figure 1 is taken from Teatch's work quoted and is intended to show the way in which the Lafayette and the younger gravels pass beneath the Port Hudson in southern Louisiana. Veatch concluded that at the close of the Pliocene or early in the Pleistocene the land rose to a level about 100 feet above that of the present time. This led first to a deepening of the channels of the rivers and later to a widening of them. The early part of the Pleistocene is regarded as a long and complex period of erosion. At a later time the land became again depressed, so that fluvatile deposits were laid down along the rivers, partially filling the broadened valleys. Thus was initiated the Port Hudson. No divisions of this Port Hudson are recognized by Veatch. To it are referred the remains of Mastodon, Elephas, Mylodon, Megalonyx, Megatherium, and Glyptodon.

Harris appears likewise disposed to extend the Port Hudson over all Quaternary time. He expressed the opinion (Water-supply Pap., 101, p. 21)

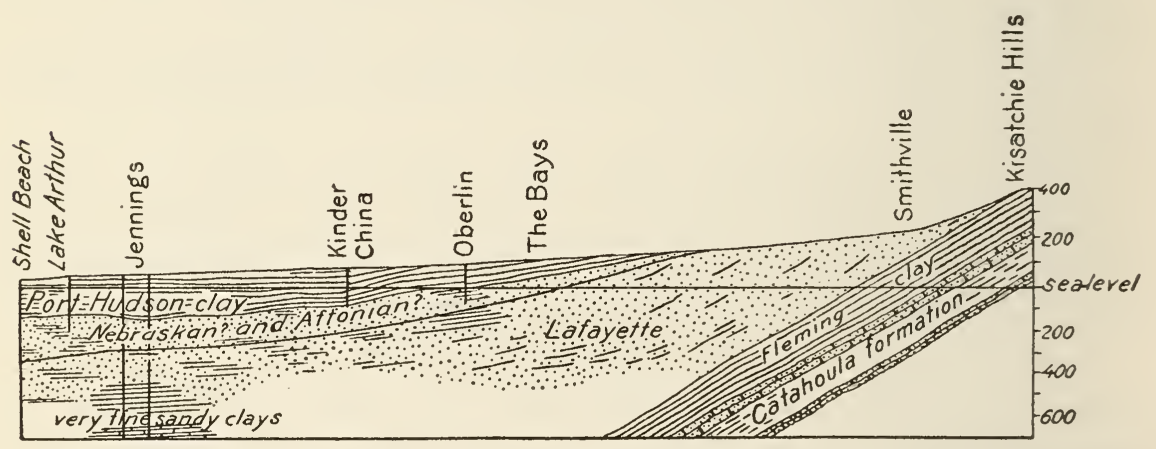

Frg. 1.-Section from Kisatchie Hills, Natchitoches County, southward to Shell Beach, Cameron County, showing Lafayette and early Pleistocene deposits passing beneath Port Hudson clays. Modified from Veatch, 1906.

that the longer the geology of southern Louisiana is studied the more futile appears the attempt to make in its Quaternary deposits satisfactory divisions that have any definite time or structural limits. All sorts of deposits, he thinks, have been produced at the same time and at all times even up to the present. That his views are largely correct is certainly true; also that, through the changing of the channels, great parts of the deposits of any stage have been reworked or removed. But the case does not appear so hopeless as Harris supposes. The deposits of any glacial stage, as the Illinoian, for example, may be broken up into a mosaic by changes in the courses of the rivers, but much remains undisturbed and may possibly be identified. The deposits of loess may be referred to one glacial stage, or possibly to two not widely separated stages, and this loess formation will serve to establish a division in the Pleistocene record. Palæontology may enable us to determine other divisions.

The type locality of the Port Hudson has furnished plants, but apparently no vertebrates except mastodons; the latter continued through the Pleistocene without apparent change, while the modifications of the plants, if any, have not been referred to their proper stages. On the other hand, the mammals in general underwent extraordinary changes during the Pleistocene, chiefly through immigration from foreign lands and through subsequent extinction 
of species. It is therefore through the study of mammalian fossils that the position of the Port Hudson in the Quaternary is to be established.

Near Baton Rouge and about 30 miles south of Port Hudson have been found a tooth of a horse, bones of a proboscidean, and fossil wood. Many years ago (p. 122) a tooth of a horse was found somewhere along Little Bayou Sara. The locality appears to be about 30 miles north of Port Hudson. In both cases the horse represented appears to have been Equus complicatus, a common species of about Sangamon times, which species existed earlier and possibly somewhat later, but was certainly extinct before the close of the last glacial stage.

Farther north, at Natchez, was discovered, long ago, a considerable fauna in a blue clay underlying many feet of loess. Here were found Equus complicatus and $E$. leidyi, 2 species of mylodons, 2 tapirs, an extinct tiger, and an extinct bear, none of which is known to have existed after the Sangamon stage. A tapir has been reported from a place 20 or 30 miles west of Opelousas.

It seems therefore justifiable to conclude that there is in the Mississippi embayment a widely extended deposit which approximates the age of the Illinoian glacial and the Sangamon interglacial. That this deposit does not belong to the earlier Pleistocene appears to be indicated by the fact that nowhere within Louisiana have there been discovered any remains of any vertebrates characteristic of the Aftontian stage, such as Elephas imperator, species of camels, species of Megatherium and of Glyptodon, and horses other than Equus complicatus and E. leidyi. The rare finds of the horse and of the tapir indicate that the Port Hudson extends up the Red River to the northwestern corner of the State and up the branches of the Nezpique.

No deposits in Louisiana of earlier stages of the Pleistocene than the Port Hudson have been recognized, but it appears possible that such may be hidden beneath the Port Hudson along the Mississippi, the Ouachita, the Red, and the Sabine rivers, or may form a part of the tracts between these streams and therefore some portions of the Port Hudson as mapped by Harris (Geol. Surv. Louisiana, pt. vI, 1902, pl. I).

Avery Island, or Petite Anse Island.-From the point of view of vertebrate palæontology, as well as that of Pleistocene geology, the most interesting locality in Louisiana is the tract named Avery Island, although it appears to be a body of elevated land surrounded by swamps. According to Veatch (Geol. Surv. La., pt. v, 1901, p. 237), this locality has borne the various names Thomas' Island, Marsh's Island, Salt Island, and Avery's Island, besides that of Petite Anse Island. Its area is about 1,640 acres. It is situated in the southeastern corner of township 13 south, range 5 east, extending into the next township east. It is distant about 10 miles south-southwest from New Iberia and 3 miles from the north shore of Vermillion Bay. There is here an extensive deposit of rock salt; this deposit was not discovered until May 1862; before that time salt springs were known to exist here and had been worked by the Indians in prehistoric times.

Richard Owen, of Indiana, was one of the first scientific men to make an examination of the salt deposits at Petite Anse. In 1863 (Trans. St. Louis Acad. Sci., vol. II, pp. 250-252), he published a report of his observations. He 
concluded that the accumulation of from 15 to 18 feet of clay, sand, and gravel overlying the rock salt had been the result of comparatively recent washings from the adjoining hills; also that the deposit of salt had been worked by the aborigines. He saw a basket, made of split cane, which had been obtained from the surface of the rock salt at a depth of 15 feet. $\mathrm{He}$ did not mention the discovery of any fossil bones.

Apparently the first notice published of the finding of fossil vertebrates here was that given by Dr. Joseph Leidy (Proc. Acad. Nat. Sci., 1866, p. 109). He stated that J. F. Clew (or (leu, as sometimes spelled), one of the proprietors of the salt mine at Petite Anse, had called on him announcing the donation of a mass of rock salt weighing 150 pounds. In digging to get a more abundant supply of salt brine the workmen had come upon a solid rock and this turned out to be pure salt. It was covered with 15 or more feet of soil composed mostly of sand and mud. Doctor Leidy was surprised to find grains of precious garnet and olivine in a sample of this soil. Mr. Clew added that in one of the pits, at a depth of from 10 to 15 feet, bones of elephants had been found and beneath them pieces of matting composed of tough, flexible split cane; also that pieces of the matting had been allowed to remain undisturbed and could yet be seen beneath the elephant bones. Doctor Leidy recommended that a competent person be sent to investigate the matter, but nothing more appears to have been done about it. Some of the matting which had been shown to Doctor Leidy was afterwards figured by J. W. Foster (Trans. Chicago Acad. Sci., vol. I, pl. xxiv). A brief paper on this subject was read by Professor Joseph Henry before the Chicago Academy of Science (Trans. Chi. Acad. Sci., vol. I, p. 223). Reference is made to this discovery by James C. Southhall in his book The Recent Origin of Man, 1875, page 322.

While the animal remains are referred to elephants, they were more probably mostly those of mastodons. There is, however, in the U. S. National Museum a much-worn lower tooth of an elephant from Petite Anse, which has very coarse plates. It is possible that it belongs to Elephas imperator, but it is on the map of undetermined species of elephants (No. 2, map 12). It probably belongs to $E$. columbi.

In 1867, Professor E. W. Hilgard made a geological examination of the salt deposits at Petite Anse under the auspices of the Smithsonian Institution. His report was published in 1872 (Smithson. Contrib. Knowl., vol. xxıII, No. 248, pp. 1-34, with illustrations). According to Hilgard's observations, parts of the island had suffered some disturbance which had produced tilting of the deposits and gravels, which belong to what he called Orange sand, a formation since come to be known as the "Lafayette formation of McGee." This formation was regarded as belonging to late Pliocene. More recent than this was a deposit of greenish clay which he referred to his Port Hudson formation. His profile, taken near the west side of the island, was as follows:

6. Light-brown loam f... feet.

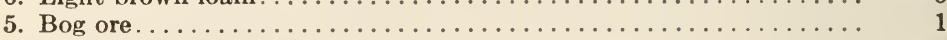

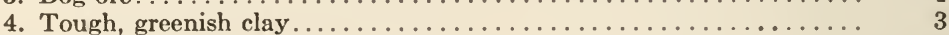

3. Sandy loam, or hardpan....................... 7

2. Heavy gray or greenish clay (Port Hudson).............. 15-20

1. Grayish sand? (doubtful) ..................... ? 
It appears that all the pits in which remains of fossil vertebrates have been found at Petite Anse are those which were sunk in what Hilgard calls detrital materials and which he supposed had been washed down from the surrounding hills and had partly filled the valley. In this deposit had been found, before Hilgard's visit, remains of mastodons, buffalo, deer, and other bones, besides Indian hatchets, arrow-heads, and rush baskets, but above all an incredible quantity of pottery fragments.

In 1872, Rev. Edward Fontaine, who apparently had considerable knowledge of the geology of Louisiana and Mississippi, published a book entitled: How the World was Peopled. On page 68, speaking of Petite Anse, he said:

The valley in which the bones and aboriginal works of art are found is alluvium, washed in from the surrounding hills, and the whole is not more than 16 feet thick. In this recent deposit they are so mingled that we can only infer that the men and the animals were probably coëval and that they lived and died in an age not far removed from our own.

The purpose of Professor Fontaine's book was to disprove the high antiquity of the human race.

In 1883, a collection of fossil bones made at this place was sent to the Smithsonian Institution by William Crooks, of the company which was then exploiting the salt mines. These fossils were described first briefly by Doctor Leidy (Proc. Acad. Nat. Sci. Phila., 1884, p. 22) and in 1889 more fully (Trans. Wagner Inst., vol. II, pp. 33-39, figs. 1-4). Among these he recognized remains of the mastodon (Mammut americanum), the ground sloth (Mylodon harlani), and the horse (Equus complicatus). The remains of horses have been examined by the writer. Among these are 8 upper and 5 lower grinding-teeth, besides a few incisors. The writer regards them as belonging to Equus complicatus. From letters which accompanied the collection, Doctor Leidy learned that the shaft sunk to the rock salt was in a ravine about 20 feet above mean tide and that the surrounding hills rose to heights varying from 20 to 50 feet greater. The surface of the bed of salt was about 20 below the general surface at that spot and thus at about the level of the sea. The following geological section was made out by Doctor Leidy:

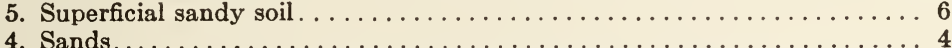
3. Black earth like that of neighboring bogs, containing fragments of pottery. 4

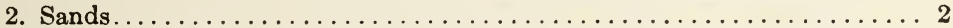
1. Dark coarse sand and gravel in contact with salt bed and varying from

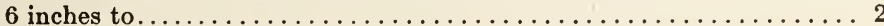

It was in the lowest layer, No. 1, that were found the bones, many of them close to, if not in contact with, the salt. As stated by Doctor Leidy, the bones, now in the U. S. National Museum, are stained chocolate-brown and black and are not rolled or water-worn.

In the early part of 1890 , Dr. Joseph F. Joor, of New Orleans, made a collection of archæological and palæontological specimens at Petite Anse for Tulane University. His account of this trip was not published until 1895 (Amer. Naturalist, vol. xxix, pp. 394-398). A new excavation had been made, whose form was rectangular, about 50 by 90 feet at the top and 30 by 70 feet at the bottom, with sloping sides. The depth to the salt bed varied 
from 16 to 25 feet. The materials of the slope varied in different parts. A section taken at one corner was as follows:

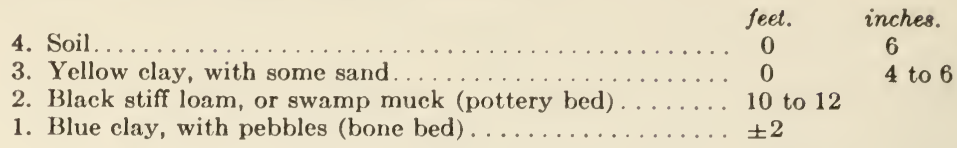

No. 1 rested on the uneven surface of the rock salt. Near one corner of the excavation a sort of trench had been cut across, apparently by human. hands. It was in the upper part of No. 2 and had a depth of from 3 to 4 feet. This trench was completely filled with ashes, containing thousands of bits of pottery. Inasmuch as the top of this trench was apparently covered by only a foot or less of soil and sand, no great age need be attributed to the ashes. Other somewhat similar trenches or gullies were found which contained sand, or sand with ashes and some fragments of pottery. A part of a cane basket was found which appeared to have come from the lower part of the loam, No. 2, and below the other human relics. Doctor Joor stated that not an arrow-head or tool was found in this excavation. In the blue clay, from 16 to 20 feet below the surface, was found an immense number of bones. As these were badly decayed and the clay very tenacious, most of them were destroyed. Nevertheless Doctor Joor secured several hundred teeth and fragments of bones; he stater that he obtained remains of mastodon, one or two species of Equus, giant sloths, a deer, and possibly an Elephas. He was shown a tooth of an elephant which he was told had been found in this shaft. An antler of a deer was found, but he was not certain from which deposit it came. However, some vertebræ which appear to belong to a very large deer and some teeth of some large herbivorous animal were found in the blue clay.

Doctor Joor's collection was studied by Professor Cope and reported on in 1896 (Proc. Amer. Philos. Soc., vol. XxxIv, pp. 458-468, pls. X-XII). He described a new horse, Equus intermedius, and 2 new species of Mylodon, $M$. renidens and $M$. sulcidens. M. harlani was recognized also. Professor Cope's new horse is now referred to Equus complicatus; and Stock has concluded that the new mylodons were variations of $M$. harlani. Professor Cope recognized also the mastodon, pronounced no judgment as to Elephas, and did not mention any other species of vertebrates.

So far as the writer can determine, the following is the list of species secured at Petite Anse: Megalonyx jeffersonii (p. 1), Mylodon harlani ( $\mathrm{p}$. 1), Equus complicatus (p. 122), Odocoileus virginianus (p. 170), Bison sp. indet. (p. 186), Mammut americanus (p. 11), Elephas sp. indet. (p. 216).

Of these, the first three are most important. There is no occasion to doubt that elephant remains have been found here. The presence of Mylodon and Equus appears to exclude any reference of the assemblage to the Wisconsin, early or late. All five have been found at Natchez. There is no species present, which compels us to refer the age of the deposits to early Pleistocene, but also none which prevents this reference. They may belong to the same epoch as do the species found at Natchez.

Apparently in 1900 Arthur C. Veatch published a special report on the Five Islands (Geol. Surv. La., part v, pp. 209-262, pls. XIX-XxxI). He pre- 
sented a history of the investigations made in the region. Pages 237 to 253 are devoted to Petite Anse. On page 260 the author thus expressed himself:

The gravel beds which overlie the salt are of decidedly uncertain date. If we accept the generally received opinion of the age of the southern gravel beds they are Lafayette or late Pliocene. This would make the salt bed pre-Pleistocene.

On his page 250 , Veatch wrote:

It is believed that the cypress-stump stratum which Hilgard found in the marshes surrounding the island, and which he represents in his cross-section as extending under the island, represents a stratum much younger than that seen at Port Hudson bluff. $*^{*} *$ Further, there is no evidence of the stump stratum in any of the borings yet made on the island.

In his report of 1908 on the rock salt of Louisiana (Bull. No. 7 Geol. Surv. La., p. 11), Dr. G. D. Harris stated that all the beds at Petite Anse are admittedly of Quaternary age; none contain anything that can not be referred to inter- or post-glacial times. He presented a section of a well made on the island which reached a depth of 2,729 feet. At a depth of 2,643 feet an old $\log$ of wood was struck. Gilbert believed that it was part of a cypress tree. This would indicate that the Pleistocene deposits at that place had a great depth. In speaking of the fossil bones found at Petite Anse, Veatch (as cited) says :

The vertebrate remains found in Mine Valley show no trace of erosion, so they can not be regarded as having been transported by the same agent that brought the gravel. The animals which the bones represent in all probability ventured into the valley for salt and became mired in the mud which surrounded the lick or spring. * * * The bone-bed was formed after the elevation of the island and the bones represent Pleistocene Mammalia.

Various authors had suggested that the bones had been washed down from the hills with the sand, clay, etc. It will be seen that Veatch did not attempt to assign these deposits to any particular part of the Pleistocene.

Veatch discusses briefly the archæology of Petite Anse. The formation of sink-holes around the mine made it possible to examine the deposits more thoroughly than before. He carefully searched the bone-bed for objects which could be unquestionably attributed to man, but he was unable to discover any. Numerous pieces of cane were found in this layer, which at first were thought to be artificial, but which turned out to be the result of weathering.

The writer has expressed his opinion as to the geologic age of the animals whose remains have been found in the pits and shafts at Petite Anse. An opinion must be expressed more guardedly respecting the age of the objects of human origin found there. It will not do to dismiss too lightly the statements of those who have affirmed that the human objects and the bones were intermingled before disinterment. There is no occasion to question the honesty of Mr. Clew, who affirmed that the basket-work had been found 2 feet below elephant bones and that there was more of the basket-work and bones for the examination of experts. However, it is possible that he was in some way mistaken as to the relative position of the materials and that others were mistaken as to the commingling of bones and pottery; or it may be that the artifacts in some unknown way got into their places in rather late times. The case offered here at Petite Anse is not greatly different from that which pre- 
sents itself at Natchez and at a considerable number of other localities in the United States.

Fossil vertebrates of the Pleistocene have been found in 10 of the parishes of Louisiana. Beginning in the northwest corner of the State, we learn ( $p$. 122 ) that at Shreveport, Caddo Parish, a tooth of Equus complicatus was found on a sand-bar in Red River. A little farther east, in Webster Parish, at the head of Bistineau Lake, were obtained remains of a proboscidean, supposed to be those of a mastodon (p. 10).

Near Castor, in the southwestern part of Bienville Parish, were found what appear to have been some bones and a tusk of a proboscidean (p. 10). A few miles farther east, at Rayburn's salt works, as reported by Hopkins, occurred bones of mastodon. The geology of this locality is describer by Veatch (Geol. Surv. La., pt. vi, pp. 71-75). He also stated that mastodon bones had been found here, but he relied probably on Hopkins.

From two localities in Winn Parish have been secured bones supposed to belong to mastodon, but, as in the cases noted above, they may have belonged to elephants. One lot of bones was discovered at Price's salt works (p. 10); another lot at Drake's salt works, about 6 miles south of Price's. The geology of this neighborhood is described by Veatch in the Geological Surrey of Louisiana, part vi, 1902, pages 51-64. In Bulletin No 7 of the Louisiana Survey, page 51, a section shows that in the uppermost 303 feet there were found muck, pebbles, and logs; below these was limestone. The geology in the vicinity of Price's salt works is described by Veatch (op. cit., pp. 61-70).

In St. Landry Parish, in 1839, a skull of a mastodon was reported as found a mile east of Opelousas. At an earlier date, 1804, mastodon remains were reported as exhumed somewhere near this city. For details regarding these finds, see page 11. Apparently in the southwest corner of the same parish, Professor W. M. Carpenter, in 1846, learned of the discovery of a tapir jaw, exhumed from a depth of 45 feet (p. 155).

Along Mississippi River, in West Feliciana Parish, on Little Bayou Sara, between Bayou Sara and the Mississippi, were found teeth of mastodons in two localities (p. 12). At another locality was discovered a tooth, supposed to belong to a mastodon, but which from its weight, 12 pounds, is believed to have belonged to an elephant (p. 12). In immediate association with this proboscidean tooth was discovered a tooth of Equus complicatus (p. 122). As stated on page 12, Hopkins reported remains of mastodons found at Alworth's, 6 miles from Baton Rouge; but more definite statements ought to have been offered.

In East Baton Rouge Parish, near Port Hudson, Hilgard, in 1872, discorered bones which he referred to mastodons (p. 12). What bones these were and on what characters he based his determinations is not known. The remains may have been those of elephants.

On page 123 is noted the discovery of teeth of a horse (Equus complicatus), mastodon bones, and fossil wood at a point about 2 miles north of Baton Rouge. The discovery of about 8 species of extinct vertebrates at Arery Island, Iberia Parish, is recorded and discussed on pages 216 to 219 .

Mastodon bones were, as long ago as 1871, reported from Côte Blanche, St. Mary Parish (p. 11). The island is described by Harris (Bull. No. 7, Geol. Surv. La., p. 27), but little is said about the Pleistocene geology. 
TEXAS.

\section{Remarks on the River Valleys and Terraces.}

It is doubtless true that, along the streams of Texas, especially the larger ones which have broad flood plains, deposition of silt, sand, and gravel is going on at the present time; and there is little reason to suppose that such deposits were not laid down during various epochs of the Pleistocene. However, even though late Pleistocene deposits of this kind may exist, they are shown to be such in only rare instances by vertebrate fossils. It is remarkable how few remains of existing species of vertebrates have been discovered in the Quaternary sediments of the State; also how frequently it happens that extinct species which elsewhere occur in middle and late Pleistocene deposits are in Texas either associated with species of early Pleistocene time or are found under conditions which indicate great age.

Various geologists have concluded that at least some of the important terraces found along the great rivers are not older than the middle Pleistocene and that the same is true of a broad belt which lies around the Gulf of Mexico. It is time to take these matters into consideration.

Elsewhere (p. 229) a brief description is given of the terraces on Colorado River in the vicinity of Austin, and reference is made to the works of Hill and Vaughan. The terraces along this river have been described also by Deussen (Profess. Pap. 126, U. S. Geol. Surv., pp. 115-116). The highest of these terraces, the Asylum, is about 215 feet above the present Colorado River. In other regions a corresponding terrace seems to be connected with deposits which are spread out on the divides between streams. Hill (21st Ann. Rep. U. S. Geol. Surv., pt. 7, pp. 353-354) stated that high terraces of this general character extend down Colorado, Brazos, and Trinity Rivers in widening belts and at length fan out and coalesce across the divides, so that an almost continuous belt of alluvial materials containing small pebbles extends across certain counties. Those mentioned are Caldwell, Travis, Wil liamson, Bastrop, Milam, Falls, Limestone, Navarro, and Henderson. This high-land alluvium forms usually only a veneer, but it may become as much as from 10 to 30 feet thick. According to Deussen (Water-supply paper 335, p. 82), similar high-land materials are found covering parts of Houston and Brazos Counties. These widely distributed upland deposits have not been well studied elsewhere, and without doubt they have a much wider extension. They probably belong to the Pleistocene, but, if so, to a very early stage, possibly Nebraskan glacial. They belong to a time when the whole country may have been standing at a higher level than it does to-day and when the rivers were at the level of the ligh terraces.

Below the very high terrace just described and its probably associated upland extensions are other terraces varying in number and importance at different places. Two of these appear to be pretty generally present; at Austin one is found at a level of from 100 to 130 feet above the river, a still lower one occurs at a height of from 60 to 80 feet. Still lower down is the present flood plain of the river. It is evident that, since the river deposited the silts, sands, and gravels of the upper terrace, the channel has been cut down many feet, and it is equally evident that each terrace is older than the one succeeding 
it below. It is pertinent to consider whether the troughs of the great rivers were excavated deep and wide early in the Pleistocene, or whether the trenching went on at intervals throughout this geological epoch. The writer believes that there is much evidence to show that these valleys were deeply and widely excavated at a very early stage in Pleistocene times. They may have been afterward refilled and reexcavated.

That at least some of the Pleistocene deposits of the State are old was recognized by the earlier observers. What was known as the Equus beds were at one time regarded by Cope and others as belonging to the Pliocene. Penrose (1st Ann. Rep. Geol. Surv. Texas, pp. 47-63, map) referred to the Tertiary, under the name Fayette beds, approximately the area designated by Deussen as Lissie; and Professor Cope (3d Ann. Rep. Geol. Surv. Texas, p. 251) indorsed this view.

Dr. E. T. Dumble (Trans. Amer. Inst. Min. Eng., vol. xxxıII, p. 985) gave it as his opinion that the Equus beds of southwestern Texas, although Pleistocene, were older than the Columbian formation of McGee. This formation, as mapped in Texas by McGee, included both the Beaumont and the Lissie of Deussen. According to Dr. G. B. Richardson (Folio No. 166, U. S. Geol. Surv.), an old structural depression at El Paso is filled up by 2,000 feet or more of unconsolidated materials, most of which belong to the Pleistocene. Into this the Rio Grande has cut down at least 250 feet (see p. 234).

That the excavation of wide and deep stream beds affected even the higher portions of probably every region of the State and that it occurred early in the Pleistocene is shown by the finding of remains of vertebrate animals of early Pleistocene age along small streams, even on the divides between river basins. A conspicuous illustration of this statement is found on the border of the Staked Plains in Swisher and Briscoe Counties. References to this region have already been made, and a list of the vertebrate fossils found there is given on page 239. The geology of this region has been studied by Dumble (4th Ann. Rep. Geol. Surv. Texas, p. 199) and by Gidley (Bull. Amer. Mus. Nat. Hist., vol. xix, p. 622). The latter obtained a geological section near the head of Tule Canyon and this is here presented (fig. 2, p. 232).

Of these divisions, No. 1 is Triassic and No. 2 is Miocene; the others belong to the Pleistocene. Gidley's figure shows the canyon at that point and the relative positions of the strata. According to Gidley's observations, the Pleistocene beds are of fluviatile origin and they lie in the channel of an old river. This channel must have been excavated late in the Pliocene or probably early in the Pleistocene. After various changes of level, mostly successive depressions, during which the Pleistocene sands, clays, and gravels, with their remains of vertebrates, were laid down, the region began to be elevated. The stream, now having become more vigorous, began to cut a deeper channel. At the point where the section is taken, the excavation went down through al] four of the Pleistocene beds, through the 60 feet of Miocene clay, and into the Triassic sandstone a depth of 20 feet. Cummins states that at the mouth of Rock Creek, the canyon is 340 feet deep, the creek having cut down into the Triassic beds a distance of 170 feet. This has been effected since those elephants, mastodons, horses, camels, and other species left their bones in the Pleistocene beds. It is not probable that the wearing down of the canyon 
went on steadily. The numerous benches and terraces along all the great rivers of the State prove that there were periods of relative inaction, followed by periods of greater activity.

Besides the testimony of the canyon itself to the time that must have elapsed since the deposition of the Pleistocene beds, there is to be considered that derived from the fossils. A list of the species found in Rock Creek is given on page 239. The mammals in general are such as are found in the type locality of the Equus, or Sheridan, beds in Nebraska, and such as have been collected in the Aftonian beds in Iowa, those beds which lie between the first and second drift sheets. Of the whole list, the only species that have been found in deposits later than the Aftonian are Mylodon harlani, Elephas columbi, Equus complicatus, Platygonus compressus, and Aenocyon dirus.

An instructive case is furnished by the discovery of a large part of a species of Glyptodon near Wolfe City, Hunt County. Hill (21st Ann. Rep. U. S. Geol. Surv., pt. 7, pl. LXvr) maps Pleistocene deposits along Middle Sulphur Creek, but not nearer to Wolfe City than about 12 miles. Not far from the sources of this creek, near the divide between it and the little tributaries of North Sulphur, at a depth of 9 feet, was found a skeleton of Glyptodon petaliferus. Inasmuch as this is in all probability an early Pleistocene animal, we conclude that in still earlier Pleistocene times the channel had been trenched out, that after the death of the glyptodon this channel became filled with clay to a depth of at least 9 feet, and that since then the old deposits have been cut into by the present creek.

On page 243 is an account of the terraces on Leon River, in Bell County, and mention is made of the vertebrate remains that have been discovered near Temple. They are indicative of early Pleistocene time, about that of the first interglacial. It seems to follow that, whatever the geological age of the terrace itself, the materials which inclosed those fossils belong to the early Pleistocene and equivalent, or nearly so, to the Sheridan beds. The explanation may be that late in the Pliocene, or more probably very early in the Pleistocene, a broad and deep valley had been excavated along Leon River. A period of depression began and continued until the materials of the highest Pleistocene terraces had been laid down and the old channel itself filled up. As the filling of the valley proceeded, animals were buried in the deposits. Although during a later period of elevation the river removed the greater part of the early sediments, some of these yet remain in the terraces. It seems to follow that possibly the fossils in such materials in the lower terraces are somewhat older than those of the upper terraces. It is to be remarked, however, that some parts of each terrace may belong to the time of the original excavation, others to the time of refilling, and others perhaps to the time of reexcavation.

The writer was informed by Dr. Charles L. Baker that streams in the region of San Antonio have cut deep and narrow trenches in the Pleistocene, which he regards as the equivalent of the Port Hudson. Leon Creek, in Bexar County, above its mouth, has cut a narrow trench 40 feet deep in this deposit.

The situation along the Brazos may be considered. At Hidalgo Falls there is apparently a single terrace above the present flood plain, about 2 miles 
from the river; at the town 3 or 4 miles higher up, the high terrace approaches the river (Navasota Quad. U. S. Geol. Surv.). At the top of the bluff, 100 or more feet above the river, were found long ago horse, elephant, mastodon, megalonyx, a land tortoise, and probably the alligator. The remains which represent all of these species might be as recent as the middle of the Pleistocene, although they are certainly older. Farther up the river, especially about Pittbridge, have been discovered forms which can belong only to the early Pleistocene, among them, Chlamytherium, Megatherium, Tetrameryx, Elephas imperator, and the mastodon Anancus brazosius, belonging to a genus that has until lately been supposed to have ceased to exist during the Pliocene.

Dr. Alexander Deussen (Prof. Pap. 126, U. S. Geol. Surv., p. 114) states that the second terrace on the Brazos ranges from 40 to 55 feet above the bed of the river and is composed largely of red sandy clay, but has more or less gravel in its basal part. A considerable vertebrate fauna has been collected from this terrace by Dr. Mark Francis. The specimens were found from 20 to 40 feet above the stream. A list of these species is presented on page These fossils appear to be at least as old as those of the high terrace at Hidalgo Falls.

At Waco, in gravel-pits 100 feet above the river, have been found Elephas imperator and one or more species of camels. In pits in a terrace about 55 feet above the river have been discovered Elephas imperator and a great tortoise whose shell reached a length of 5 or 6 feet. Hill (21st Ann. Rep. U. S. Geol. Surv., pt. 7, p. 353) expressed the opinion that the upper terrace at Waco is equivalent to the Asylum terrace at Austin and was laid down at the time when the Brazos, a few miles below, was scattering its débris over the interstream areas.

An alternative explanation for the cases cited above may be that the highest terraces and their fossils belong to the first glacial stage of the Pleistocene, the Nebraskan, and that it has happened that the few fossils found in the terraces belong to genera represented also in the succeeding stage, the Af tonian.

\section{In the Valley of Red River.}

On page 231 are described the fossil-bearing Pleistocene localities which lie about the headwaters of Red River. These localities are in Wheeler, Randall, Armstrong, Swisher, Briscoe, Motley, Cottle, Hardeman, Wilbarger, and Wichita Counties. At present no vertebrate fossils are known from Texan localities lower down in Red River Valley until Cooke County is reached. Nor has the writer found especial mention of Pleistocene deposits along the valley above Montague County; although there can be no doubt that they extend all along the river and up its small tributaries. Robert T. Hill (21st Ann. Rep. U. S. Geol. Surv., pt. 7, pl. Lxvi) maps Pleistocene deposits along Red River into Montague County; and Shumard (Geol. West. Texas, 1886, p. 125) describes Quaternary deposits in Grayson County. On page 30 he reported that remains of the mastodon had been found at Gainesville, Cooke County. Dr. Charles L. Baker informed the writer that along Red River, in northwestern Montague County, are two major terraces composed of Port Hudson deposits. The upper is much eroded.

The most recent map of this region known to the writer as showing the distribution of the Pleistocene is that of C. H. Gordon, forming plate I of 
Water-supply Paper 276 of the U. S. Geological Survey. According to that map, there is, along both sides of Red River, from the Arkansas line to Fannin County, a strip, from a mile to 10 miles in width, of Recent silts and clays. These form the present flood plain of the river. Beyond this flood plain, in Bowie County, between the Red and Sulphur Rivers, is a wide area which is mostly occupied by Pleistocene sands, silts, and clays. These are referred by Gordon to the Port Hudson formation. This area extends westward into Red River County. On the north side of Sulphur River, in Red River and Delta Counties, are other areas of this formation. Also, in Titus and Hopkins Counties, Pleistocene is found on both sides of White Oak Creek, a branch of Sulphur. Gordon stated (op. cit., p. 32) that along Red River, in Bowie and Red River Counties, the height of the upper terrace, that of the Pleistocene, is about 70 to 75 feet above the present flood plain, while about 30 or 40 feet below this another well-marked terrace was noted in places. Robert T. Hill (Bull. Geol. Soc. Amer., vol. v, pp. 312-313) stated that there can be little doubt that diuring the Pleistocene and late Tertiary this region was the scene of oscillation accompanying base-leveling and estuarine deposit. Ancient alluvial deposits found here were regarded by him as belonging to several well-defined epochs of base-leveling and erosion. These are represented by the terraces. These alluvial deposits along Red River sometimes extend 15 miles from the stream.

At a point still farther down Red River Basin, about the year 1888, Dr. T. W. Vaughan, of the U. S. Geological Survey, found some teeth and bones of Elephas imperator, near Blocker, Harrison County. Doctor Vaughan informed the writer that the bones were buried at a depth of only 3 or 4 feet in a stiff alluvium in the second terrace of a nameless stream which enters Caddo Lake; this lake discharged its waters into Red River. Gordon's map does not extend far enough south to take in the locality; he does not represent any Pleistocene nearer than about 15 miles. If, as the writer believes, the elephant discovered by Doctor Vaughan lived during the early Pleistocene, an illustration is furnished showing the small amount of sediment that has been deposited along that river since the animal died.

\section{In the Valley of Netches River North of the Lissie Formation.}

In the Third Annual Report of the Geological Survey of Texas, on pages 64-67, William Kennedy gave a brief account of his observations on the Pleistocene deposits along a line run from Terrell, in Kaufman County, to Sabine Pass. According to him, the deposits of the Quaternary cover a large part of the region east of Trinity River and are composed mostly of sands and gravel, these rarely reaching a thickness of 90 feet. Ferruginous sands and gravels and siliceous pebbles are said to be found everywhere capping the highest hills as well as extensive areas of the low lands. It is evident that Mr. Kennedy here included the late Pliocene deposits which have been known as the Lafayette furmation; in western Texas as the Uvalde formation. We are, therefore, not able to distinguish the deposits which represent the Pleistocene from the older ones. The writer regards it as safe to say that the Pleistocene is represented everywhere along the river and its tributaries. The only fossil material that is mentioned by Mr. Kennedy is wood. This appears to be quite abundant in places. 
In the same volume of the 'Texas Survey, on pages 9-14, William Kennedy describes the Quaternary of Houston County. 'This county extends from Netches River to the 'Trinity. 'There appears here the same inclusion of the I afayette with the Pleistocene. Dr. Charles L. Baker has communicated to the writer some of the results of his examination of certain counties along Netches River: Tyler, Jasper, and Angelina. The Lafayette was recognized and Baker expressed the opinion that it is a subaerial formation. In the counties named, along the Nctches, a second bottom is usually found elevated a few feet above the present flood plain. The higher terrace he correlates with the Port Hudson. The only Pleistocene vertebrate fossil from the basin is a mastodon tooth said to have been found near Denning in San Augustine County.

\section{In tife Valley of Trinity River North of tife Lissie Formation.}

Trinity River takes its rise in Archer County, just east of the area occupied by the Seymour beds of Professor Dumble. Some of its tributaries drain the southern borders of the counties lying south of Red River as far east as Fannin County.

At Fort Worth, 'Tarrant County, Elephas imperator, E. columbi, and Mammut americanum have been found. 'The writer has not learned at what levels all of these remains were met with. Hill (21st Ann. Rep. U. S. Geol. Surv., pt. 7, pp. 349-354) reported that at this place at least three terraces may be counted. North of the river is an alluvial plain 75 feet above the river and nearly a mile wide; other gravel-beds east of the town are situated at a level of 100 feet above the river. Professor W. M. Winton informed the writer that a jaw of Elephas columbi and one of a mastodon were found on the north side of Trinity River, in a terrace 45 feet above the river.

At Dallas, in the gravels and sands along Trinity River, have been discovered a considerable number of vertebrates. Hill (21st Ann. Rep. U. S. Geol. Surv., pt. 7, p. 353) reported that there is in the northern and eastern parts of Dallas a terrace at a height of about 100 feet above the streamway. The fossils were found in a lower terrace at a height of about 50 feet above the river.

Professor R. S. Isull (Amer. Jour. Sci., ser. 5, vol. II, pp. 159-172) published an account of the mammals found in the Lagow gravel-pit, in the 50foot terrace in East Dallas. A list of these will be found on page 241. All of the species except possibly a deer, are extinct. They appear to belong to the Aftonian fauna.

Professor Lull published (Science, n. s., volume Lrir, page 332) a geological section taken in the I agow pit by Professor Shuler. It is as follows:

Top soil, medium-grained sandy loam. Dark red to black............ about

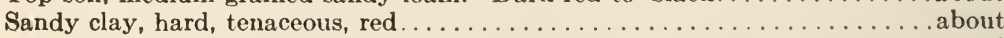

Fine sandy clay with light calcareous segregations and streaks. Texture of sand varies. Color yellow. Fossils: antelope, bison, mammoth.......... about

Fine to coarse clean white sand and gravel. Gravel usually under one inch, crossbedded. Forest beds not over 12 to 14 inches, usually 3 to 4 inches. Fossils usually found at bottom, especially larger bones. Bones clean and usually white or cream in color. Elephant, camel, Tetrameryx shuleri........ about

$\begin{array}{cc}\text { feet. } & \text { inches. } \\ 2 & 7 \\ 3 & \\ 2 & 10 \\ & \\ & \\ & \end{array}$
Austin chalk.... 
Doctor Baker has reported to the writer his studies of the valley of 'Trinity River from Trinity County southward. At Drews Landing, San Jacinto County, had been found mastodon remains under 30 feet of supposed Port Hudson, underlain by 4 feet of Lafayette. Other vertebrate remains, he wrote, had been found in Trinity, Walker, and Polk Counties, but details were not given. He stated that since the Port Hudson had been laid down it had been greatly eroded. This is an indication of the considerable lapse of time.

Professor E. T. Dumble (Univ. Texas Bull. No. 1869, pp. 266-269) discussed the geology along Trinity River, in Houston, Trinity, and San Jacinto Counties. He found remains of undetermined species of Elephas (p. 105) and Equus (p. 126) at White Rock Shoals, on the first bottom, and mastodon teeth and bones at Drews Landing. He referred the Pleistocene to the Port Hudson.

\section{In the Basin of Brazos River, Nortil of the Lissie formation.}

The sources of Brazos River are found in Lamb and Hale Counties, on the plateau of the Staked Plains. Scanty remains of vertebrates have been found on McDonald's Creek, Crosby County, near Knox City, and at a place 14 miles east of Benjamin, Knox County. No other Pleistocene vertebrates have been reported from Brazos Valley until Hood County is reached. Near Lipan, in a ravine, probably tributary to Kickapoo Creek, has been found a tooth of a mastodon. This seems to be fully 10 miles from Brazos River. Along Paluxy Creek, apparently about 12 miles or more from Brazos River, have been discovered Elephas imperator and Mammut americanum. The occurrence of these shows that early Pleistocene deposits were laid down on what are now high levels. Robert T. Hill (21st Ann. Rep. U. S. Geol. Surv., pt. 7, p. 351) reported that the Brazos, in Hood and Parker Counties, shows at least two distinct terraces of old alluvial formation. Terraces are seen at Granbury at a height of fully 100 feet above the present stream.

Many interesting species of fossil vertebrates have been reported from McLennan County, mostly from the vicinity of Waco. Robert J. Potts sent the writer a map of the county and blue-prints of a detailed survey of a part of East Waco and vicinity. At Waco there are at least three terraces. The lowest has an elevation of about 30 or 40 feet above estimated low-water $(360$ feet above sea), its elevation being thus from 390 to 400 feet. On the right side of the river, below Waco, this terrace may have a width of nearly a mile. The elevation of the second terrace is about 415 feet, approximately 55 feet above low-water. The greater part of Waco is built on it. The third terrace is about 465 feet above sea and about 100 feet above low-water. Hill, in his report of 1901, already so often quoted, refers on page 353 to this high terrace at Waco. In a gravel-pit on the second terrace, on the west side of the river, near a cemetery, has been found a tooth of Elephas columbi. On the same terrace, on the left side of the river, north of East Waco, and 2 or 3 miles from the center of Waco, the Potts-Moore Company has gravel-pits. The elevation of these pits is 415 feet. In these have been found fragments of teeth of Elephas imperator and bones of a great land tortoise, probably Testudo annce. On this terrace, near Paul Quin College, was found a tooth referred to Elephas imperator (p. 88). At a point higher up the river, about 5 miles from the center of Waco, on the left bank and near the mouth of White Rock 
Creek, are the pits of the White Rock Gravel Company. The elevation of the terrace is 465 feet. This is the highest of the three terraces. In these pits have been discovered remains of Elephas columbi, E. imperator, one or more species of camels, and a large unidentified cat-like animal, probably a Smilodon.

Near Speegleville, a town about 7 miles west of Waco, have been found, along Hog Creek, Mylodon harlani, Mammut americanum, and a tooth originally referred to Gomphotherium elegans, but which is now referred to Anancus brazosius. It is interesting because it shows that mastodons with teeth presenting trefoils as they become worn, abundant during the Tertiary, continued on into the lower Pleistocene. On page 243 will be found a list of the species of vertebrates which have been discovered in McLennan County. An elephant tooth believed to belong to Elephas imperator was found near Chilton, Falls County (p. 87).

In Bell County, Leon and Lampasas Rivers unite to form Little River. On Leon River, a mile above Shallow Ford, have been found vertebrate remains which appear to belong to the early Pleistocene. A list is presented on page 243. The writer learned from W. S. McGregor, of Temple, that the gravel-pit from which these remains were collected is in the first terrace, above the flood plain of the river, at an clevation of about 40 feet above the normal water-line and at a distance of about half a mile from the river. Hill (21st Ann. Rep. U. S. Geol. Surv., pt. 7, p. 349) wrote that on Nolan Creek, between Belton and Temple, are to be seen three terraces above the present flood plain. The first of these is about 30 feet above the river and 100 yards or more in width. At a level of 50 feet above the river is another. Half a mile away from the river is a third, at a height of 150 feet. Hill (p. 354) regards this terrace as corresponding to the Asylum terrace at Austin. The fossils collected at Temple were therefore in the lowest terrace.

In Robertson County, opposite Port Sullivan, were found by William Kennedy, the geologist (4th Ann. Rep. Geol. Surv. Texas, p. 67), a part of the lower jaw and teeth of an extinct horse. The following is Mr. Kennedy's section taken at this place, on the east side of the river. The strata are numbered from below upward:

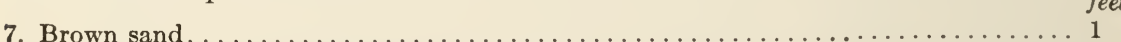

6. Laminated chocolate-colored and yellow stratified sandy clay, with humus at base... 2

5. Dark-brown or chocolate-colored sandy clay ..................... 8 to 10

4. Dark bluish-gray sandy clay, weathering yellow and containing fragments of bone and

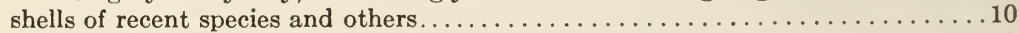

3. Indurations of sand and soft sandstones in the form of boulders $\ldots \ldots \ldots \ldots \ldots \ldots \ldots 1$ to 2

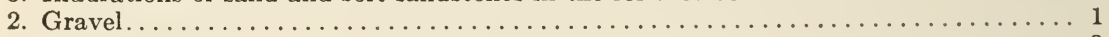

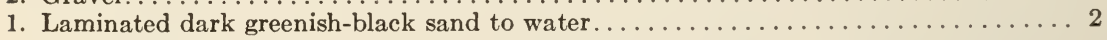

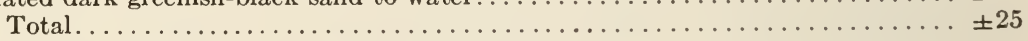

The jaw of the horse was found in No. 4 .

On page 66 of the renort above cited is giren a section found at Curley Shoals, 6 miles west of Calvert. In a conglomerate 10 or 15 feet above the river were found fragments of a tibia of a horse. On page 223 mention has already been made of the Pleistocene deposits at high and at low levels along Brazos River, from Pittbridge, Brazos County, to Hidalgo Falls.

\section{In the Basin of Colorado River.}

The main stream of Colorado River rises in Dawson County, in a canyon which it has cut for itself in the Tertiary strata of the Staked Plains. On 
the north side some small tributaries come in from the border of the elevated region just mentioned. On the south side is Spring Creek, which extends through Dawson County into Lynn. Concho River receives waters from far back on the Staked Plains, in Gaines and Andrews Counties, also from the region lying southeast of the Plains. In his report of 1892 (3d Ann. Rep. Geol. Survey Texas, pl. Iv), Cummins indicated the presence of considerable deposits of Pleistocene and Recent epochs in Sterling, Irion, and. Tom Green Counties, along the North and South Forks of Concho River. Somewhere about San Angelo, in Torn Green County, have been found teeth of Mammut americanum and Elephas imperator, a mastodon at Oatman, near Llano, Llano County, and Elephas columbi in Gillespie County. Elephas imperator points to an early stage of the Pleistocene.

The geology about Austin has been investigated by Doctors Hill and Vaughan (Folio No. 76 U. S. Geol. Surv.; 18th Ann. Rep. U. S. Geol. Surv., pt. 2, p. 247 ; see also Hill, 21st Ann. Rep. U. S. Geol. Surv., pt. 7, pp. 345361). A large part of the city is built on Pleistocene deposits. These present a number of terraces, each of which rises but little above its successor. The highest of these Pleistocene benches is known as the Asylum terrace; it has an elevation of about 215 feet above the river and about 635 feet above sealevel. Omitting a number of minor benches, the next one below is the Capitol terrace, having an elevation of from 105 to 130 feet above the river. Lower down, at elevations of from 60 to 80 feet, is the "depot group." The present flood plain is from 5 to 15 feet above ordinary water and is perhaps partly of Pleistocene age. Along Onion Creek is a deposit of Pleistocene marl which has been called by Hill the "Onion Creek formation." At its mouth it is 130 feet above Colorado River. He regarded it as being of the same age as the Equus beds. Above the Asylum terrace are considerable areas which are covered by coarse deposits composing the Uvalde formation, probably of late Pliocene age.

\section{In the Basin of Guadalupe and San Antonio Rivers North of the Lissie.}

Guadalupe River rises in Kerr County and joins the San Antonio in San Antonio Bay. Mastodons, elephants, a horse, and other vertebrates have been collected in the basin at a number of localities from Kerrville, at an elevation of 2,000 feet, to De Witt County. These are described in their proper places. They show that Pleistocene deposits are present along the river and far back on the divides on each side. The terraces along this river are described in Deussen's paper of 1924 (Profess. Pap. 126, U. S. Geol. Surv., p. 11\%).

San Antonio River, under the name of Bandera, rises in Bandera County, where the elevation is about 2,000 feet. In this county, possibly within the drainage of some tributary of Frio River, have been found remains of the early Pleistocene elephant Elephas imperator. Near Bulverde, Bexar County, many species have been collected in a cave. Other early Pleistocene fossils have been found farther down the river, showing that the Pleistocene is widely distributed in the basin, not merely along the stream itself.

The Pleistocene geology of Bexar County was described by Dr. F. H. Sellards in 1919 (Univ. Texas Bull. No. 1932, pp. 64-76). He recognized a complicated and extensive series of river flood plains, and these he divided 
into two groups. The first included the higher and older terraces not obviously associated with the existing streams; these he referred to the early Pleistocene or to even an earlier time. These deposits he regarded as belonging to the Uvalde formation, and in this no fossils have been found. Sellards referred a formation and plain of intermediate height, with a question, to the Leona, and he mentions vertebrate fossils found at San Antonio. He concluded that the position of these fossils was not sufficiently well determined. The terrace which lies just above the present flood plain of the rivers, especially well developed along Medina River, is believed by him to belong to late Pleistocene time. Inasmuch as the lower terraces of nearly all of the large rivers of Texas have furnished numerous remains of Elephas imperator, of various species of horses, camels, and ground sloths, the present writer believes that these terraces belong to the early Pleistocene, perhaps to the Aftonian interglacial stage.

\section{IN the Basin of Nueces River.}

Nueces River has its source in Edwards County, at an elevation of 2,000 feet above the sea. Several affiuents rise in Bandera County. Another, Atascosa Creek, rises in the northermmost corner of Atascosa County. A detailed description of the terraces along the Nueces at and immediately south of the Edwards plateau has been given by Hill and Vaughan (18th Ann. Rep. U. S. Geol. Surv., pt. 2, p. 253 ; folios Nos. 42 and 64, U. S. Geol. Surv.), also by Deussen (Profess. Pap. 126, U. S. Geol. Surv., p. 117). About the confluence of Nueces and Leona Rivers is a terrace of Pleistocene, at a lower level than the Pliocene Uvalde formation, and to this Pleistocene is given the name Leona formation. This was regarded as probably of the same age as the Onion Creek formation, near Austin, and that is itself equivalent to the beds elsewhere referred to the Equus or Sheridan beds, unless it is possibly as old as the Nebraskan stage.

The basin of Atascosa Creek was investigated by Dr. E. T. Dumble in 1903 (Trans. Amer. Inst. Min. Engineers, vol. xxxIII, pp. 913-987). The greater part of the area studied is occupied by deposits of Tertiary and Quaternary ages. The latest deposits belonging to the Tertiary and coming into contact with the Pleistocene are those called "Reymosa" by Doctor Dumble. They belong probably to McGee's Lafayette and Hill's Tralde and are of late Pliocene age. On both sides of Atascosa Creek this stream and its tributaries were examined and sections were obtained from just below Castroville, Medina County, to Oakville and then down the Nueces to the northern border of Nueces County. The Pleistocene deposits observed were regarded by Doctor Dumble as belonging to the Equus beds. They did not exceed 20 feet in thickness and appeared to be in detached or irregular basins, usually connecter directly with some drainage-channel, present or past. Near the mouth of Weedy Creek, in Live Oak County, the following section was taken. It indicates the kind of materials of which the Pleistocene is romposed:

5. Soil fect.

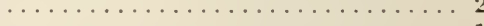

3. Mottled, sandy clay, with numerous land shells; passing below into $2 \ldots \ldots . . . . . . .2-8$

2. Cross-bedded ashy-gray sands; sands with pockets of gravel, lime concretions toward

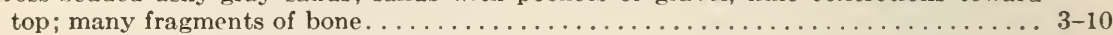

1. Reynosa lime and sand to creek 
Here, as elsewhere, the Pleistocene lies unconformably on the Reynosa. A considerable number of vertebrate fossils have been found in Atascosa County (p. 248).

We pass now into the valley of Frio River, some of whose tributaries rise in the southern border of Bandera County, on the Edwards plateau. For a knowledge of the geology of the region reference may be had to Hill and Vaughan's work mentioned above. As stated on page 88, possibly within the drainage of Frio River, has been found a tooth of Elephas imperator. In the northern part of Medina County, ou Verde Creek, in the basin of Frio River, have been found remains of mastodons. Besides these fossils, none are known to the writer as having been collected in the Nueces basin above the mouth of Frio River. Those found lower down will be mentioned in the discussion of the Lissie and Beaumont formations.

No Pleistocene vertebrates are known to the writer from La Salle and McMullen Counties, both of which are traversed by Nueces River and its tributary, Frio River. However, along both rivers, in both counties, are found deposits which, with a good deal of certainty, belong to the Pleistocene. The geology of the region has been studied by Deussen and Dole (Watersupply paper $375, \mathrm{pp} .141-179$ with map, pl. viIr, 1916). On their page 149 are recognized along the rivers three distinct Pleistocene terraces. On some of the higher lands, especially in the northern part of McMullen County, at heights of from 150 to 200 feet above the rivers, are patches of coarse gravels which belong to the Uvalde formation. This is usually referred to the Pliocene, but the authors indicate that it may belong to the Pleistocene.

\section{In the Region of the Staked Plains.}

An account of this region was given by Dr. W. F. Cummins in $1892(3 \mathrm{~d}$ Ann. Rep. Geol. Surv. Texas, pp. 129-223, pl. Iv and 8 text-figs.). The map (his plate IV) indicates the boundaries of the region. Beginning at Big Springs, in Howard County, the eastern border passes through Howard, Mitchell, Borden, Garza, Crosby, Dickens, Motley, Briscoe, Armstrong, and Gray Counties. Thence it turns west parallel with Canadian River, from 10 to 20 miles south of it, and then enters New Mexico. In this State it runs south parallel with Pecos River and reenters Texas in Loving County, passing into Ward County. The southern boundary is somewhat indefinite; but the others are marked by bold, precipitous escarpments, ranging as stated by Doctor Cummins, from 150 to 400 feet in elevation. It is an immense plateau which slopes gently from northwest to southeast and is extremely flat. The greatest elevation in Texas is found at Odessa, Ector County, where it is 3,100 feet. In this great plain some of the headwater streams of Red, Brazos, and Colorado Rivers take their rise. According to Cummins's map the greater part of this plain is occupied by Tertiary deposits. On page 169 he states that at many places on the top of the Staked Plains there are found beds of sand, gravel, and boulders, much water-worn. These beds he referred to the Quaternary. On pages 181-200 he gives a brief description of the counties of the region, especially with reference to the water-supply; little or nothing is said about the Pleistocene or the Recent deposits; and inasmuch as it has been but little explored by others, few of the Quaternary areas can be located. 
However, the writer has learned from Dr. Charles L. Baker, the geologist, that he has collected, along South Tule Creek, in the southeastern part of Swisher County, remains of Equus. In Hale County he has obtained remains of Elephas at Running Water and at Plainview, both places on Blanco (or White) Fork of Brazos River. Both South Tule and White Fork are mere "draws" from 20 to 30 feet deep, bordered by Pleistocene deposits.

On the eastern border of the Staked Plains the rivers have cut deep canyons into the escarpment and carried them back sometimes many miles. Along these canyons are found here and there Pleistocene deposits of river origin, which sometimes contain fossils. One of these canyons appears to be situated in Howard County. It was mentioned by Doctor Cummins in his report published in 1893 (4th Ann. Rep. Geol. Surv. Texas, p. 182). The canyon has been cut to a depth of more than 100 feet by Wild Horse Creek. This appears to be in Borden County. Here he collected shells, remains of 2 species of horses, and remains of a proboscidean. The bed was at a height of 20 feet above the present bed of the creek. The locality was said to be about 15 miles east of north of Big Springs.

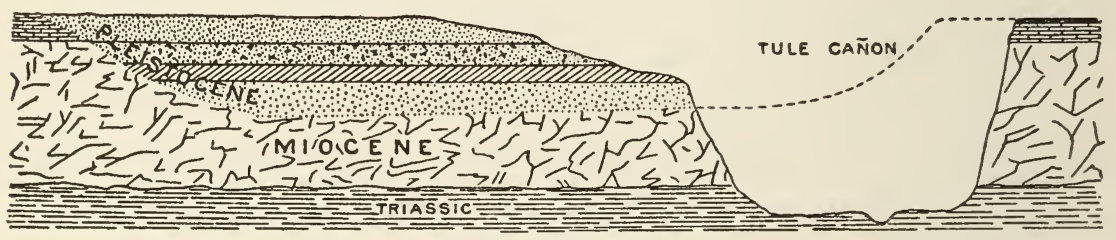

Fig. 2.-Diagrammatic section across Tule Canyon, to show position of the Sheridan beds and the underlying strata. The Pleistocene beds, taken together, are about 90 feet thick, and extend back from the canyon a little more than a mile. After J. W. Gidley, 1903.

Another of the canyons is that in which arises Salt Fork of Brazos River. This is in Dickens and Crosby Counties. Doctor Cummins wrote (Report of 1892, p. 144) that in all the valleys of all the creeks is a bed of Quaternary conglomerate. No fossils are mentioned; but in a later account (4th Geol. Surv. Texas, p. 185) he reported the finding of a fragment of an elephant tooth on McDonald's Creek, in Crosby County. Farther north, in Motley County (pp. 144, 145), similar deposits were found. A little farther north, on or near Tom Ball Creek, Case found teeth of a fossil horse.

It appears that Doctor Cummins did not visit Tule Canyon on his trip of 1891, but in 1893 (4th Ann. Rep. Geol. Surv. Texas) he and Professor Cope entered it and collected vertebrate fossils (op. cit., pp. 199-200). Professor Cope referred the beds to the Equus horizon. The fossils collected were described by him in a separate paper which is quoted as belonging to the Fourth Annual Report of the Texas Survey, pages 1-87, but it is not included in the main report.

Tule Canyon, in Briscoe and Swisher Counties, has been cut by Tule Creek. The canyon heads about 10 miles east of Tulia, the county seat of Swisher County. On each side the bluffs rise abruptly to a height of 400 or 500 feet. There are lateral canyons, the most noted of which is that made by Rock Creek, 
in Briscoe County, opening on the south side of Tule Canyon. A section made somewhere in the vicinity is as follows:

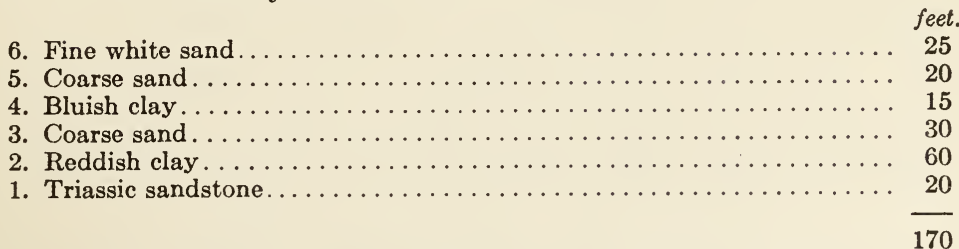

Of these strata, Nos. 3 to 6 are Pleistocene. No. 3 of this section (coarse sand) and No. 6 (a fine sandy clay) furnished Pleistocene vertebrates. Professor Cope's list of fossils found here (Vert. Paleont. Llano Estac., p. 87) includes 2 species of Testudo, elephant, 4 species of Equus, and 2 species of camels. To this region the American Museum of Natural History, New York, sent three expeditions, 1899, 1900, 1901. These were under the direction of J. W. Gidley; his report appeared in 1903 (Bull. Amer. Mus. Nat. Hist., vol. XIX, pp. 617-634, pls. LII-LVII, text-figs. 1-4). Text-figure 2 presents a diagrammatic section across Tule Canyon; it corresponds to Professor Cummins's section heretofore given. The Pleistocene does not extend far out over the country, but was laid down in an old valley excavated in the Miocene. To Professor Cope's list Gidley added Elephas imperator and a peccary. For a list of the species found here, see page 239.

\section{Region Immediately East of the Staked Plains.}

In 1893, Professor W. F. Cummins investigated also the region in Texas which lies immediately east of the Staked Plains. At various places Pleistocene deposits were encountered and in some places vertebrate fossils were collected. In his report (4th Ann. Rep. Geol. Surv. Texas, p. 181) he described deposits which he regarded as belonging to the Pleistocene and which he called the "Seymour beds," from the type locality, Seymour, Baylor County. These beds are said to extend from the Cretaceous hills south of the Texas and Pacific Railroad northward entirely through the State. They are well presented on a broad level plateau west of Sweetwater, in Nolan County. The deposits are described as varying in range from a few feet to 50 feet in thickness. They are composed of unstratified beds of sandy clay resting on the red-beds of the Permian. The formation has been cut across by the streams which flow eastward. The deposits appear, therefore, to occupy the higher lands. Professor Cummins believed that they had been laid down in an inland lake. He does not record any fossils from Nolan County, but elsewhere are described remains of Elephas columbi and of an unidentified species of Bison, both of which were found in the banks of Icemgood Creek, in this county. $\mathrm{He}$ wrote that his Seymour beds are well represented in Baylor and Knox Counties, especially north of Brazos River. The Seymour beds have been further described by C. H. Gordon (U. S. Geol. Surv. Water-supply paper 31\%, p. 30). His map (his plate I) shows the distribution of these beds in Harde. man, Foard, Knox, Haskell, Wilbarger, Baylor, and Throckmorton Counties. The beds occupy the highlands between the streams and have a thickness varying from 10 to 60 feet. Doctor Gordon adopts the view of W. D. Johnson 
(21st Ann. U. S. Geol. Surv., pt. 4, 1901, p. 655) that they are the result of branching streams of desert habit.

Farther north, on Groesbeck Creek, in Hardeman County, Professor Cummins made a small collection west of Quanah. Here were found, 25 feet above the stream, horse teeth referred by the present writer to Equus francisi; also remains of elephant and beaver. Doubtless the Pleistocene continues to Red River. Baker informed the writer that the same beds are found in Foard County.

In the southwest part of Cottle County, about 10 miles below the hear of Good Creek, at a height of about 25 feet above the present channel of the stream, Professor Cummins found (Report of 1893, p. 185) the bones of an animal as large as an elephant, but not otherwise determinable. This locality is a few miles west of his Seymour plateau.

Professor Cummins (op. cit., p. 185) found what is probably Pleistocene deposits on the eastern side of Brazos River, in Stonewall County. Shells were taken from a bluish clay situated about 20 feet above the present river. The water does not reach this level to-day.

A locality not exactly determined and which may be distant from the plateau of the Staked Plains as much as from 35 to 55 miles lies somewhere in Wheeler County. From it was obtained, a good many years ago, a skull of one of the ground sloths belonging to the genus Nothrotherium.

\section{The Region Bordering on the Rio Grande.}

A good idea of the geology of the region lying between Rio Grande and Pecos Rivers may be obtained from two folios of the U. S. Geological Survey, Nos. 166 and 194. Both are based on the investigations made by Dr. G. R. Richardson.

Folio 166 describes the geology of the El Paso quadrangle. In this the Quaternary includes river alluvium and bolson. The former probably belongs to the Recent, the bolson, at least the upper portion, to the Pleistocene. The alluvium lies along the river, is composed of gravel, sand, and clay, and has an estimated thickness of about 100 feet. To the Recent must be referred likewise some of the outwash found on the slopes of the mountains. The bolson deposits cover the greater portion of the El Paso quadrangle, filling deeply a structural trough between mountain ranges. It consists of materials, coarse and fine, that were borne by torrential streams from the bordering mountains. The general elevation is about 4,000 feet. The bolson is mostly flat, but rises somewhat as it approaches the mountains. At least the upper part belongs to the Pleistocene, as shown by the occurrence of Pleistocene vertebrates. Through this bolson the Rio Grande, in the late Tertiary or early Pleistocene, cut its channel to a depth of several hundred feet. Later, this was partially refilled, so that the river runs many feet above its ancient bed. Doctor Richardson records the construction of a well which appeared, from the report rendered, to have reached a depth of over 2,200 feet without striking bed-rock.

In folio 194, Doctor Richardson described the Tan Horn quadrangle, which forms the southwestern part of Culbertson County. One part of the quadrangle is covered by bolson, another by unconsolidated gypsum. A part, at 
least, of each belongs to the Pleistocene. No fossil rertebrates have been discovered. Figure 3, reproduced from this folio, is a generalized geological map of a belt extending from the Rio Grande to the Pecos and shows the disposition of the Quaternary deposits.

Farther down the Rio Grande, in Valverde County, there are, according to Hill and Vaughan (p. 253), deposits of Pleistocene to be found on Devils River. The extent of these is not known. According to the same authors (p. 251) there is a succession of terraces, which extend along the Rio Grande from Del Rio, Valverde County, to Laredo, Webb County. Some of these are to be referred to the Pleistocene. Above all is the Uvalde formation, supposed to have been laid down late in the Pliocene; the Pleistocene is more or less overlain by Recent ailuvium. The geology of the region along the lower

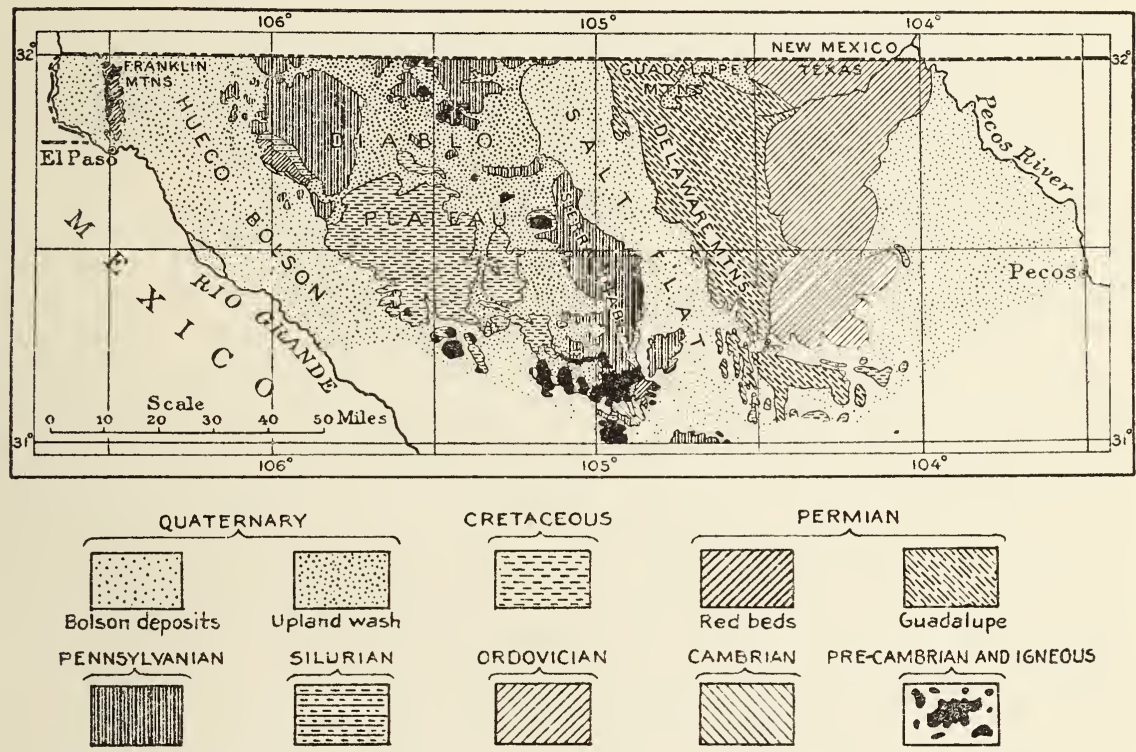

Fig. 3.-Generalized geological map of region between Rio Grande and Pecos River, to show the Quaternary deposits. Adapted from Richardson (Folio 194, U. S. Geol. Surv.).

Rio Grande, from Marerick County to the mouth of the river and northward from this to the northern borders of Kenedy, Brooks, and Jim Hogg Counties, has been studied by A. C. Trowbridge (Prof. Paper 131, U. S. Geol. Surv., pp. 85-117).

In Zavalla County is mapped an area of a few square miles occupied by the Leona formation. A few patches of the same are found farther down along the river as far as Hidalgo County. This formation, found as noted above, had been recognized in the terraces of upper Nueces River, the San Antonio, and elsewhere. It is regarded by Deussen and Trowbridge as corresponding to the Equus beds. No Lissie was observed by Trowbridge, but he thought it might be hidden by later deposits. A considerable part of Hidalgo County is occupied by the Beaumont. Cameron and Willacy Counties, and a part of 
Hidalgo County along the Rio Grande, are covered by fluviatile deposits, supposed to belong to the Recent.

\section{The Pleis'ocene of the Gulf Coastal Plain.}

A very important part of the Quaternary deposits of 'Texas, if not the most important, is that forming a belt, approximately 100 miles wide, along the Gulf of Mexico, from Sabine River to the Rio Grande. About one-half of this, that extending from Sabine River to longitude $97^{\circ}$, was mapped by Alexander Deussen in his paper on the "Geology and Underground Waters of the Southeastern Part of the Texas Coastal Plain" (Water-supply Paper 335, U. S. Geol. Surv., pl. I, 1914). The same geologist has described and mapped this Coastal Plain from the Brazos to within a few miles of the Rio Grande (Profess. Pap. 126, U. S. Geol. Surv., pp. 108-114, map pl. viII). The whole belt was mapped also by J. A. Udden, C. L. Baker, and Emil Böse in their Review of the Geology of Texas (Bull. Univ. Texas, 1916, No. 44, 1916). The boundaries as laid down by Udden and his associates do not exactly coincide with those of Deussen, but as nearly so as can be expected in the present state of investigation.

Deussen recognizes three formations: One lies immediately along the coast, is about 10 miles wide, and is continued far up all the rivers. It is regarded as belonging to the Recent epoch. North of this is the Beaumont formation, or the Beaumont clay, whose northern boundary passes north of Beaumont, in Jefferson County, crosses Trinity River just north of Liberty, in Liberty County, passes just north of Houston, and immediately north of Richmond, on Brazos River, and a short distance north of Wharton, on Colorado River, and continues through Victoria. The Beaumont is composed mostly of clays and clayey sands. Its width varies from 30 to 40 miles throughout its extent in the State. According to Deussen's map of the Coastal Plain west of the Brazos (Profess. Pap. 126, 1924, pl. viri), the Beaumont and the Lissie, in Jim Hogg, Brooks, and Keane Counties, are overlain by dune sands. Remains of vertebrated animals have been discovered at numerous localities in the Beaumont area. In his paper of 1914, just cited, on page 111, Deussen stated that vertebrate fossils, especially of Elephas and Equus had been found in the Beaumont formation; but he thought that they may have been eroded out of the Lissie gravels. However, the discovery of whole skulls or large parts of them and of the skeletons shows that the remains had not been disturbed after burial.

North of the Beaumont is the Lissie. According to Deussen's maps (Watersup. Pap. 335, U. S. Geol. Surv., 1914, pp. 78-80, pl. I ; Profess. Pap. 126, U. S. Geol. Surv., 1924, pp. 108-110) it is about 40 miles wide on Sabine River, but narrows until north of Victoria it is only 10 miles wide. In Jim Wells County the width is about 15 miles. It is composed of gravels, sands. and some sandy clays, the materials being mostly coarse. Deussen expressed the opinion that the Lissie gravels represent the time equivalent of the middle terrace (pp. 78, 82), or gravel portion, and the lower part of the lowest of the three Pleistocene terraces, and that these belong probably to the early and middle parts of the Pleistocene. He held also the riew that at a late time the Lissie was submerged beneath the sea. 
An important locality in the Lissie belt is Sour Lake, in Hardin County. The geology of the district was described by Hays and Kennedy in 1903 (Bull. U. S. Geol. Surv. 212, pp. 113-119, figs. 5, 6). From their general section of the oil-producing region, on their pages 19-21, the following section is made up. The thicknesses given were intended to represent the least and the greatest occurring.

1. Recent. Low coastal marshes. Along rivers and small lakes occur beds of shells of Rangia cuneata and species of Ostrea........... 5 to 25

2. Pleistocene.

a. Beaumont clays of various colors. Sands with great quantities of cypress wood and recent shells................... 25 to 400

b. Columbia sands. Sands and clays of various colors with some decayed wood. In the clays belonging to these beds at Sour Lake have been found the species of vertebrates mentioned on page 242. Followed below by Tertiary and finally Cretaceous. 50 to 200

Udden and his associates have not differentiated the elements of the Quaternary in their text or on their map. Indeed, they include, with some reservations, under the Pleistocene (their page 91 and the map) also the Lafayette, the Reynosa, and the Uvalda, all three being probably equivalent in age. Those deposits, which without any question, these authors refer to the Pleistocene, are called the "Port Hudson" and the "Columbia" formations, the latter defined as forming the materials of the second bottom terraces of the main streams. The Port Hudson is regarded as being equivalent to the Equus beds.

In the discussion of the Pleistocene geology of Louisiana the writer has presented reasons for believing that the Port Hudson beds are more recent than the so-called Equus beds, that they belong somewhere about the Illinoian and Sangamon stages, while the Equus beds belong to the first interglacial. The fauna which is represented at Peters, Nebraska ("Hay Springs"), Fossil Lake, Oregon, and in the Aftonian interglacial deposits in Iowa reveals itself in the Beaumont at various places, among them Keeran Point, Victoria County, where close to tide-level have been found remains of a camel, besides elephant and mastodon. About 15 miles north of Galveston, at the level of high tide, skulls and tusks of elephants in nearly complete condition, together with fragments of bones of horses, have been collected. The occurrence of species peculiar to the Aftonian fauna, such as Elephas imperator, glyptodons, and camels ceases as the Mississippi embayment is approached, but there is a reoccurrence of these in Alabama and Florida. The writer holds, therefore, that the Beaumont belongs to the first interglacial stage.

The Lissie gravels are of course older than the Beaumont clays. They belong to a time when the region occupied by the plains and the Rocky Mountains was rising and the hastened streams were bearing coarse materials toward the Gulf. It seems probable that the Lissie belongs to some part of the first glacial stage, the Nebraskan, when the channels of great streams of Texas were just beginning to be excavated and when in times of freshets the water overflowed the banks and carried gravel and sand across the divides. It is possible that the third terraces, at a height of about 100 feet belong to this time instead of the Aftonian. The species of vertebrates which have been collected within the area of the Lissie are not numerous and it is possible that 
some of them really belong to a somewhat later time. One, however, the little and rather primitive horse, Equus francisi, certainly belongs to the Lissie, being found in the gravels at a depth of 25 feet.

It seems that even yet some of the writers on the Quaternary of Texas assume that the sea, during the deposition of the Quaternary formations, occupied successively the areas of the Lissie and the Beaumont. Inasmuch as the laying down of these formations must have required many thousands of years, as there was a considerable variety of materials and as the climate was favorable for the production of marine life, one might expect to find in both the Lissie and the Beaumont many shells of mollusks, the bones of fishes, porpoises, and whales. Instead of these, there are found such land animals as ground sloths, glyptodons, elephants, mastodons, horses, and bisons. It is true that in the Beaumont, in a very few places, have been found occasionally shells of the oyster and of the genus Rangia; but these may be accounted for without supposing that there was any'hing like an inundation of the Beaumont area by the sea (see Hay, Jour. Wash. Acad. Sci., vol. xIv, pp. 255-264).

\section{Distribution of Pleistocene Vertebrates in Texas.}

On preceding pages the writer has described the discovery of certain species of vertebrates in Texas, giving such details regarding the identification of the remains, the localities, and conditions of burial as could be secured and showing the localities on maps. The forms recorded are those occurring in considerable numbers. These are as follows: The Xenarthra (p. 1, map 1); Elephas boreus (p. 47, map 5); Elephas columbi (p. 57, map 8); Elephas imperator and $E$. francisi (p. 85, map 11) ; Elephas sp. indet. (p. 102, map 13) ; Equidce (p. 123, map 16); Odocoileus (p. 170, map 21); Bison, extinct species (p. 186, map 25) ; Bison bison (p. 201, map 26) ; Castoroides ohioensis (p. 210, map 27); and mastodons (p. 12, map 3).

A number of other species have been mentioned incidentally. It is thought well to consider now the fossils in a way to bring together those which occur in the same locality or in the same vicinity. In doing this citations will be made to pages where details may be given regarding the fossils and the geological features. Inasmuch as on the maps the counties are indicated by numerals, these numerals are inserted in parentheses.

An undetermined species of Elephas has been reported (p. 102) from Tascosa, Oldham County (11) ; also teeth of a mastodon (p. 12). From Wheeler County (15) has been secured a remarkable xenarthrid, Nothrotherium texanum (p. 1). In Randall County (17) have been found, in Palo Duro Canyon, a mastodon (p. 12) and teeth of an undetermined species of horse (p. 123). In Armstrong County (18) there have been collected, near Paloduro, remains of Elephas columbi (p. 57).

An interesting region for the rertebrate palæontologist is found on the border of the Staked Plains, in Swisher and Briscoe Counties. A brief account of the geology of the region is given on page 231. Not many species have been reported from Swisher County (23), but Gidley found, at the head of Tule Canyon, Elephas imperator (p. 85), and both he and Baker have reported remains of unidentified species of Equus (p. 124). 
Briscoe County (24) has been more prolific of fossil vertebrates. The Pleistocene deposits along Rock Creek have been examined by Cummins, Cope, Gidley, and collectors from Yale University, under the direction of Professor R. S. Lull. In 1884 (Prelim. Rep. on Vertebrate Paleont. Llano Estacado, p. 87), Cope presented the following list of fossil vertebrates as found in the Equus beds of the Staked Plains:
1. Testudo hexagonata.
6. Equus semiplicatus.
2. T. laticaudata.
7. E. tau.
3. Mylodon sodalis?
4. Elephas primigenius.
8. E. major.
5. Equus excelsus.
9. Holomeniscus sulcatus.
10. H. macrocephalus.

Of these species it is not definitely stated that Nos. 6, \%, 8, 9 were discovered in Briscoe County. To this list, Gidley (Bull. Amer. Mus. Nat. Hist., vol. XIx, p. 624) added Equus scotti and Platygonus sp. indet. The materials collected by Professor Lull's party were described in 1915 (Amer. Jour. Sci., ser. 4, vol. $\mathrm{xxxIx}$, pp. 613-638, with illustrations). The following is Troxell's list:
Equus scotti.
E. calobatus n. sp.
Auchenia hesterna.
Eschatius conidens.
E. macrocephalus?
Canis dirus.
Canis texanus n. sp.

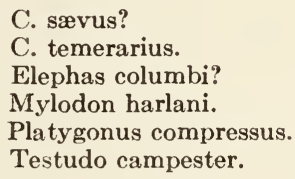

In 1917 (Scient. Monthly, vol. IV, p. 89), Troxell reported also Glyptodon. Inasmuch as Aelurodoi scevus and Canis temerarius are Upper Miocene species and as 'Troxell's identifications were made on what seem to be insufficient materials, their presence in the Pleistocene is regarded as very doubtful. The writer is inclined to revise as follows the lists above presented. In the list is included Elephas imperator, found by Gidley in Swisher County, not far from the western border of Briscoe, and possibly also by Troxell (op. cit., pp. $616,636)$.
Testudo hexagonata Cope.
T. laticaudata Cope.
T. campester? Hay.
Mylodon harlani Owen.
Glyptodon sp. indet.
Elephas imperator Leidy.
E. columbi Falconer.
Equus complicatus Leidy.
E. scotti Gidley.
E. semiplicatus Cope.
E. calobatus Troxell.
E. tau? Owen.

It will be observed that the list contains not a single species that still exists. One might be justified in regarding the fauna as somewhat older than that found along Niobrara River, near Peters, Sheridan County, Nebraska, and believed to belong to the typical Equus beds.

At a point about 10 miles from Childress, Childress County (26), were found remains recorded (p. 102) under Elephas sp. indet., but which may well be $E$. imperator. At two places in Hale County (29), Running Water 
and Plainview, have been found remains of undetermined species of elephants (p. 102). In Motley County (31), near White Flat, teeth of Equus complicatus have been collected (p. 124). From McDonald's Creek, Crosby County (40) have been secured remains of an undetermined species of elephant (p. 102). In Dickens County (41), near Spur, was found a skull which is identified as Bison bison (p. 201). Near Post, in Garza County (58), was discovered a tooth of mastodon, Mammut americanum (p. 19). In Jones County (79), near Hawley, were discovered some of the peculiar dermal plates of a glyptodon (p. 2). Found at a depth of 56 feet, these may have been buried in Pliocene deposits, but more probably in early Pleistocene beds. Along Wild Horse Creek, in Howard County (97), Professor Cummins found teeth of what he regarded as two species of horses ( .125$)$. In the same canyon he found remains of what he supposed was an elephant or a mastodon. Somewhere near Colorado, Mitchell County (98), a humerus and a lower molar of an elephant (p. 102), which may have belonged to Elephas imperator, were discovered. Near Sweetwater, Nolan County (99), on Icemgood Creek, have been found teeth of Elephas columbi (p. 58) and a tooth of an extinct bison (p. 186). In Tom Green County (141), near San Angelo, have been discovered remains of mastodon (p. 14), and of E. imperator (p. 88).

Coming back to the Red River country, we find that in Hardeman County (33) Professor Cummins collected, on Groesbeck Creek, west of Quanah, remains of a small horse which appears to belong to Equus francisi (p. 125), of an undetermined species of elephant (p. 103), and of a beaver, probably Castor canadensis. In Foard County (34), near Foard City, a tooth of Elephas columbi was discovered (p. 57). Near Vernon, Wilbarger County (35), Elephas columbi (p. 58) and remains that appear to belong to the existing bison (p. 201) were secured.

In Wichita County (36), near Burkburnett, were discovered remains that belonged to an undetermined elephant ( $p .103$ ) and to a probably extinct species of bison (p. 190). From near Bridgeton, in the same county, the writer has seen a tooth of a camel, probably Camelops huerfanensis (p. 161), which was buried in a gravel-pit 70 feet above Red River. At or near Gainesville, Cooke County (48), R. 'T. Hill found some remains of mastodon (p. 13). In Grayson County (49), Stephenson found, 6 miles east of Sherman, a vertebra of what is taken to be an extinct species of bison (p. 190). Near Tulip, Fannin County (50), considerable remains of probably Elephas columbi (p. 58) have been found. Near Wolfe City, Hunt County (68), was discovered several years ago a considerable portion of the skeleton of Glyptodon petaliferus (p. 2). It must be regarded as belonging to an early part of the Pleistocene. Near the eastern border of the State, in Harrison County (94), near Blocker, were discovered parts of the skeleton of Elephas imperator (p. 86).

Five miles east of Denton, Denton County (66), have been found remains of an elephant (p. 103) and at or near the same locality teeth belonging to Equus complicatus (p. 125). On Panther Creek, near Rock Hill, Collin County (67), was found a tooth which probably belongs to Elephas columbi (p. 58), but possibly to $E$. imperator. At McKinney, Collin County, was secured a 
tooth, which may belong to E. columbi (p. 58). At and near Fort Worth, Tarrant County (84), have been collected at least three species of Pleistocene proboscideans. One of these is Elephas imperator (p. 85) ; at least two specimens of Elephas columbi are reported (p. 58); and a jaw of $E$. columbi and a tooth of Anancus gratus (p. 13) were found along Trinity River, at an elevation of about 45 feet above the present river.

Dallas, Dallas County (85), is one of the important points in Texas for the occurrence of Pleistocene vertebrates. The geology of the vicinity is discussed on page 226.

In 1921 (Amer. Jour. Sci. ser. 5, vol. II, p. 160), Lull presented a list of fossil vertebrates which had been collected in the Lagow gravel-pit. It is as follows :

Felidæ:

Trucifelis fatalis (Leidy).

Cervidæ:

Odocoileus, sp. indet.

Antilocapridæ:

Bovidæ:

Tetrameryx shuleri Lull.

Bison alleni Marsh.
Camelidæ:

Camelops huerfanensis dallasi Lull.

Equidæ:

Camel, gen. and sp. indet.

Elephantidæ:

Elephas columbi Falconer.

It is worthy of mention that Professor E. H. Shuler, in 1923 (Science, n. s., vol. LVII, p. 333), reported the occurrence of human bones in the Lagow pit in the same deposits that had furnished the list reported by Lull.

To these the writer believes may be added the following which have been found in or close to the city:

Bison occidentalis (p. 186).

Equus sp. indet. (p. 126).

Mammut americanum (p. 13).

Elephas imperator (p. 85).

Castoroides ohioensis (p. 210).

Homo sp. indet.

At Carrollton, on Trinity River, in the northern part of Dallas County, has been found a scapula of a very large species of Testudo, T. annce? (Hay, PanAmerican Geologist, vol. xxxix, p. 116). At Wilmer, 5 miles south of Dallas, a tooth of a mastodon has been secured (p. 13).

The species of vertebrates which have been reported from the Pleistocene deposits in Dallas County, mostly in the terraces along Trinity River, appear to be as follows:

\author{
Testudo annæ? \\ Equus leidyi? \\ Equus sp. indet. \\ Camelops huerfanensis dallasi. \\ Camelops sp. indet. \\ Odocoileus sp. indet. \\ Tetrameryx shuleri.
}

\author{
Bison alleni? \\ Bison occidentalis. \\ Mammut americanum. \\ Elephas columbi. \\ E. imperator. \\ Castoroides ohioensis. \\ Trucifelis fatalis. \\ Homo sp. indet.
}

Near Waxahatchie, Ellis County (107), have been discovered Elephas columbi and E. imperator (p. 59). In the northern part of Bosque County (12\%) a skull referred to Bison bison was found (p. 202), and from Clifton a tooth of Elephas columbi was sent to the American Museum in New York (p. 60). Remains of probably Elephas columbi (p. 104) have been reported from the vicinity of Mount Calm and Hubbard, Hill County (128). In 
Navarro County (129) remains of a not certainly identified elephant, probably Elephas imperator, were dug up (p. 103). Elephas columbi has been collected near Corsicana (p. 59). From somewhere about Palestine, Anderson County (130), a tooth of Equus semiplicatus was sent to Professor Cope (p. 126).

Trinity County (153) has furnished a number of fossil mammals. At Clapp's Ferry was picked up a tooth of Mammut americanum (p. 19). At White Rock Shoals were found the tooth of a horse (p. 126) and teeth and bones of an undetermined elephant (p. 105). From Leota, Madison County (172), has been reported a tooth of Mammut americanum (p.19). From near Drew's Landing, San Jacinto County (174), Baker reported an undetermined species of elephant (p. 105) and Dumble many teeth and bones of mastodons (p. 19). From Onalaska, Polk County (175), the writer has received photographs and a specimen showing the discovery there of both Elephas columbi and $E$. imperator (pp. 59, 89). Dr. Mark Francis has a mastodon tooth (p. 19) sent to him from Denning, San Augustine County (155).

At Sour Lake, Hardin County (192), the vertebrates named below have been found. Sour Lake lies near the southern border of Deussen's Lissie formation, the border overlapped by the Beaumont.

Many years ago bones and teeth were discovered near Sour Lake, in a stratum of clay overlain by a bed of asphalt, which furnished Leidy (Contrib. Ext. Vert. Fauna, 1873, p. 260) the following Pleistocene vertebrates: Mastodon, Megalonyx, Equus, Trucifelis, Emys petrolei, and two undetermined bones. Later the writer described, from the same collection, the terrapin Trachemys? trulla, and referred a horse tooth to Equus littoralis.

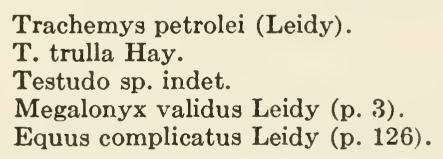

E. leidyi Hay (p. 126).

E. littoralis Hay (p. 126).

Mammut americanum (Kerr) (p. 20).

Trucifelis fatalis Leidy.

The two undetermined bones figured by Leidy, as cited above (plate xxxiIr, figs. 20, 21), appear to belong to a very large species of Testudo, probably to either $T$. francisi or T. annœ. The bone of Leidy's figure 20 is probably a dermal bone from the hinder part of the thigh, while the bone 21 is a terminal phalange. The geology of the locality is described on page $23 \%$.

A tooth of a mastodon (p. 19) was washed up on shore at Port Arthur, Jefferson County (209). On the banks of Buffalo Bayou, near Harrisburg, Harris County (20\%), were found fragments of a mastodon tooth (p. 20) and at Houston a tooth of Elephas columbi (p. 63). Important vertebrate fossils have been found around Galveston Bay, probably in Galveston County (222). Long ago Leidy described a tooth of Equus complicatus (p. 12\%), which had been picked up in a gully of the bay. At San Iieon, on the western shore, have been unearthed Elephas imperator (p. 63), E. columbi (p. 63), and a species as yet undetermined, possibly Elephas francisi; also an undetermined species of horse (p. 12\%).

Cummins found, in his Seymour beds, at a locality $1 t$ miles east of Benjamin, Knox County (43), probably on the Brazos, remains of a mastodon 
(p. 12) and of an undetermined horse (p. 125). Pleistocene vertebrates have been reported from at least three localities in Hood County (104). A mastodon was discovered on Kickapoo Creek, near Lipan, in the northwestern part of the county (p. 14). Near Granbury were found molars of a mastodon (p. 14) and a tooth and jaw of an undetermined species of elephant (p. 104). Along Paluxy Creek, in the southwestern corner of the county, have been collected Elephas imperator (p. 86) and a tooth which is referred to Elephas columbi (p. 60). In deposits along Indian Creek, in Comanche County (125), were found some remains of a mastodon (p. 14).

McLennan County (148) has furnished a considerable number of Pleistocene vertebrates. As already stated, there are at Waco three terraces at heights of about 35 feet, 55 feet, and 100 feet above the river, or, respectively, 360, 415 , and 465 feet above sea-level. In the lowest terrace have been found Elephas columbi; in the second, Elephas imperator and the great dry-land tortoise, probably Testudo annce; in the third, Alligator, Elephas columbi, E. imperator, Camelops hesternus, and a great felid, probably Smilodon sp. indet. A bone of an undetermined species of Equus was discovered in either the second or third terrace. Along Hog Creek, at Speegleville, near Waco, have been collected Mylodon harlani, Mammut americanum, and a mastodon tooth, which on wear presented trefoils. This was referred to Gomphotherium elegans, but really belongs to Anancus brazosius. At or near Crawford, in McLennan County, hare been found some bones of a probably extinct bison and of Mammut americanum (pp. 186, 16). The fossil vertebrates, collected within McLennan County, are as follows:

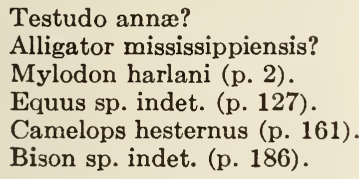

Testudo annæ?

Alligator mississippiensis?

Equus sp. indet. (p. 127)

Bison sp. indet. (p. 186).
Mammut americanum (p. 16).

Anancus brazosius (p. 16).

Elephas columbi (p. 60).

E. imperator (p. 88).

Smilodon? sp. indet.

It will be observed that all of these species are extinct, except probably the alligator. The tortoise, the camel, the species referred to Anancus, and Elephas imperator indicate the Aftonian interglacial stage; none of the others testify against it.

An important collection of fossil vertebrates has been secured along Leon River. in Bell County (168), mostly between Temple and Belton.

Testudo francisi Hay.

Mylodon harlani Owen (p. 2).

Equus semiplicatus Cope (p. 129).

Tapirus sp. indet. (p. 155).
Camelops macrocephalus Cope (p. 161).

Mammut americanum Kerr (p. 17).

Elephas imperator Leidy (p. 87).

Elephas columbi? Falconer (p. 61).

These species and most of the genera are extinct. The tortoise was described by the writer in 1923 (Pan-Amer. Geol., vol. xxxix, p. 116, pl. xIII). At Sparta, in Bell County, has been found a tooth of a mastodon (p. 16).

At several places in Falls County (169) have been collected Pleistocene vertebrates. At or near Marlin were found the type specimen of Elephas francisi (p. 8\%), also E. columbi (p. 61), probably E. imperator. At Reagan was found a tooth referred to Equus semiplicatus (p. 12\%); at Satin Falls, 
Elephus columbi (p. 61); at I)enny, Mammut americanum (p. 17); and at Chilton, Elephas imperator (p. 87).

On page 90 is recorded the finding of an elephant tooth, not certainly determined, which came from Cameron, Milam County (170), on page 17 a fragment of a mastodon tooth at Buckholts, same county, on pages 17, 18 the finding of Mammut americanum and a fine lower jaw of Anancus brazosius. A skull of Bison bison found there may belong to the Recent epoch or not. From Port Sullivan Shoals, Robertson County (171), five lower teeth of Equus complicatus came to the University of Texas (p. 127).

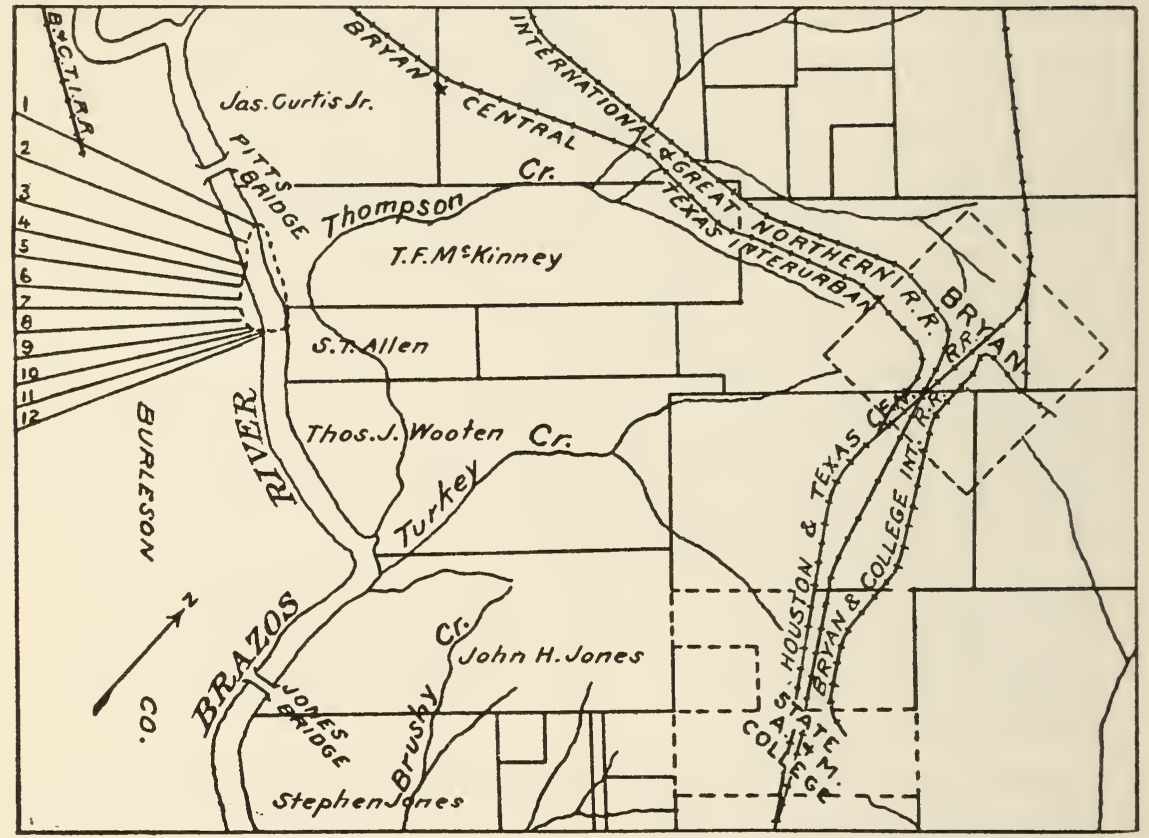

Fig. 4.-Map of Brazos River opposite Bryan, Brazos County, with list of important Pleistocene vertebrates collected near Pittbridge:

1. Elephas columbi.

2. E. imperator.

3. Mammut americanum.

4. Anancus gratus.

5. Chlamytherium septentrionale.

6. Equus complicatus.
7. Camelops huerfanensis?.

8. Megatherium mirabile.

9. Mylodon sp. indet.

10. Bison latifrons?

11. Tetrameryx shuleri.

12. Testudo annae.

Many fossil vertebrates have been collected along Brazos River, from Hidalgo Falls, Washington County, northward to Pittbridge. Dr. Mark Francis, of the Agricultural and Mechanical College, at College Station, deserves most of the credit for discovering and otherwise securing Pleistocene fossils in this region. His collection is a large and valuable one and contains specimens from nearly all parts of Texas. Most of those secured near College Station have been collected at Pittbridge, the crossing over the Brazos. Some of the materials were found on the Burleson County (186) side of the Brazos, others on the Brazos County (18\%) side (see fig. 4). 
At Munson's Shoals, 2 or 3 miles below Pittbridge, have been recovered remains of Mammut americanum and Elephas columbi. The list to be accredited to Pittbridge is as follows:

\section{Testudinata:}

Amyda emoryi?

Chrysemys belli.

Terrapene whitneyi.

T. impressa n. sp.

Testudo annæ.

Xenarthra:

Mylodon, sp. indet. (p. 3).

Megatherium mirabile (p. 3). Equidæ:

Chalmytherium septentrionale (p. 3).

Equus complicatus (p. 128).
Camelidæ:

Camelops huerfanensis? (p. 162).

Antilocapridæ:

Tetrameryx shuleri.

Bovidæ:

Bison latifrons (p. 187).

B. sp. indet. (p. 187).

Elephantidæ:

Anancus gratus (p. 18).

Mammut americanum (p. 18).

M. progenium (p. 18).

Elephas imperator (p. 89).

E. columbi (p. 61).

In 1923, Dr. Mark Francis sent the writer the front half of the plastron of a species of box tortoise which he found at Pittbridge. This appears to have characters indicating an undescribed species. It is proposed to call it Terrapene impressa and a figure of it of natural size is furnished (fig. 5). The plastron is characterized by the deeply and sharply impressed sulci which separate the horny plates. The greatest width is $82 \mathrm{~mm}$.

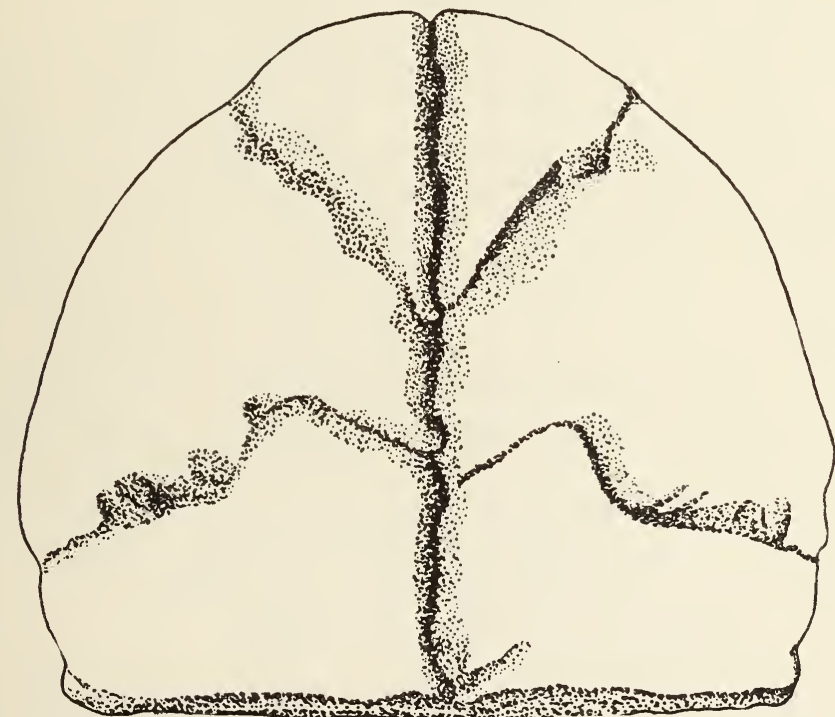

Fig. 5.-Terrapene impressa n. sp. Front of plastron, $\times 1$.

A vertebra was found in Brazos River, east of Lyons, Burleson County (186), which the writer referred provisionally to Elephas imperator (p. 89). A large tibia believed to belong to Elephas imperator (p. 90) was found near Millican, Brazos County. An elephant of unidentified species was found (p. 105) at Iola, Grimes County (188).

At or near Hidalgo Falls, Washington County (189), have been discovered remains of a supposed crocodile (p. 18), Mammut americanum (p. 18), Elephas columbi (p. 62), Elephas sp. indet. (p. 105), and Equus sp. indet. 
(p. 128). Elephas columbi reported from Navasota was probably found on the Brazos opposite Hidalgo Falls (p. 62). From Navasota, Doctor Francis reports the finding of teeth of Alligator. Mammut americanum (p. 19) was found in Brazos River, near Chapel Hill. A molar of Elephas imperator was reported from near Brenham (p.90). A tooth of Elephas columbi (p. 62) was secured at Big Spring for the U. S. National Museum. In the same museum are teeth of a bison, found near Burton (p. 188) and at some unknown point in the county a tooth of Equus complicalus (p. 128) was found.

At San Felipe, Austin County (205), have been collected a considerable number of species of Pleistocene mammals. The following list is believed to include all:

Mylodon sp. indet. (p. 3)

Equus leidyi (p. 129).

Tapirus sp. indet. (p. 156).

Camelops huerfanensis? (p. 162).

Bison regius? (p. 189).
Mammut americanum (p. 20).

Anancus brazosius (p. 20).

Elephas columbi (p. 62).

E. imperator (p. 92).

A part of a horn-core of a bison, apparently Bison latifrons (p. 188) and a tooth of Elephas imperator (p. 93) were found at Wallis Station, in the southwestern corner of the county. Somewhere about Eagle Lake, in the southwestern corner of the county, near Colorado River, was found a large femur which is not certainly identified (p. 106), but may belong to Elephas imperator. A number of vertebrate fossils have been found in Brazos River, opposite San Felipe, at or near McDowell, Austin County (205). Those known are Elephas columbi, Elephas imperator, and Mammut americanum. Equus sp. indet. was found north of Brookshire (p. 129), and Elephas columbi somewhere near the same town (p.63). According to Deussen (Profess. Pap. 126, U. S. Geol. Surv., p. 108, pl. viri) the fossils found at San Felipe, in the vicinity of Wallis, and at McDowell, belong to the Lissie formation.

A little farther down the Brazos, perhaps in Fort Bend County (220), "50 miles above the mouth of Brazos River," were discovered long ago remains of Mammut americanum (p. 20), Elephas, sp. indet. (p. 106), and Megatherium, sp. indet. (p. 3). Teeth of a camel were discovered in Brazos River, near Richmond (p. 162). At the same place was found a femur of an elephant, unidentified (p. 106), but probably Elephas imperator. The animals said to have been discovered in Fort Bend County were possibly found in Brazoria County (221). Remains of an unidentified elephant (p. 106) have been collected along San Bernardo River, Brazoria County. Near Alvin were discovered teeth and bones of Elephas columbi. In San Bernardo River between Wallis and Chesterville, probably in Austin County, was found a tooth of Elephas imperator (p. 93).

Cherry Springs, Gillespie County (181), is to be credited with Elephas columbi (p. 64). In Llano County (166), near Llano, were found remains of a mastodon ( $p .14)$. Near Marble Falls, Burnet County (16\%), have been secured Mammut americanum (p. 14) and Elephas columbi (p. 64). Important vertebrate fossils have been discovered in Williamson County (183) in three places: At Bartlett was collected Equus giganteus? (p. 130) ; at Georgetown, Elephas imperator (p. 88); and at Liberty Hill, Elephas sp. indet. (p. 104). 
In Travis County (184), at Austin, have been found Terrapene whitneyi, Equus excelsus? (p. 130), and Elephas sp. indet. (p. 104) ; on Cedar Creek, Mammut americanum (p. 16) ; and near Pilot Knob, Bison latifrons? (p. 189).

At Bastrop, Bastrop County (203), or near there, have been collected Mylodon (p. 3), Equus (p. 130), Bison bison (p. 202), Mammut americanum (p. 16), Elephas columbi (p. 64), and Elephas sp. indet. (p. 104). What seemed to be a nearly complete skeleton of Bison bison (p. 202) was discovered near Nash's Ferry, near Goodman, 7 or 8 miles above Bastrop.

Near Luling, in Caldwell County (202), have been discovered Elephas columbi (p.65), in Guadalupe County, teeth of Equus (p. 131). Fayette County (204) has furnished an undetermined species of horse near Colorado River (p. 130) and an extinct species of Bison somewhere along O'Quinn Branch (p. 188). In Wharton County (219) was discovered, at Lissie, the type of Equus francisi (p. 130); at Egypt, Equus complicatus (p. 130); and at Wharton, Elephas columbi (p. 63).

Elephas imperator was discovered near Buckeye (p. 92), in Matagorda County (232) and near Bay City a tibia believed to belong to an elephant (p. 106).

At Kerrville, Kerr County (197), were found some remains of an elephant (p. 105), not certainly identified but belonging probably to Elephas columbi. In Cibolo Creek, Kendall County (199), was discovered a tooth of a mastodon (p. 15). Bandera County (198) has furnished a specimen of Elephas imperator (p. 88).

Pleistocene vertebrates have been discovered at a number of places in Bexar County (213). A collection of vertebrates, from a cave near Bulverde was secured; this cave and the fossils obtained from it were described by the writer in 1920 (Proc. U. S. Nat. Mus., vol. LviII, pp. 129-143, with pls.). The following is a list of the species:

\section{Pisces.}

Alisodon mirus Hay.

Reptilia.

Terrapene whitneyi Hay

T. bulverda Hay

Gopherus atascosæ? Hay

Crotalus atrox? Baird and Girard.
Mammalia.

Didelphis virginiana Kerr.

Bison sp. indet.

Mammut americanum (Kerr).

Elephas boreus Hay (E. primigenius of authors).

Peromyscus sp. indet.

Geomys texensis? (Merriam)

Perodipus sp. indet.

Sylvilagus sp. indet.

Ursus americanus Pallas.

Canis latrans Say.

Aenocyon dirus? (Leidy).

Dinobastis serus Cope.

Felis sp. indet.

Inasmuch as the entrance to the cave near Bulverde is a perpendicular shaft more than 30 feet deep, open at the top, animals have for a long period been liable to fall into it. The species, therefore, probably do not all belong to the same Quaternary time. Apparently the only ones that require reference to early Pleistocene time are the wolf Aenocyon dirus? and the sabre-tooth Dinobastis serus; but the extinct fish Alisodon mirus and the three extinct tortoises probably belong to the earlier half of the Pleistocene.

Near Elmendorf was found a tooth that is believed to belong to Elephas imperator (p. 88). From probably somewhere near Helotes was sent to Cope 
remains of Mammut americanum (p. 15). In the vicinity of Leon were found remains of an elephant, recorded on page 66 as Elephas columbi but which may belong to $E$. imperator. At San Antonio have been collected remains of Mammut americanum and Elephas columbi (pp. 16, 65); also Elephas columbi southeast of San Antonio, on Salado Creek. Apparently on Rosillo Creek an undetermined species of Equus (p. 131) was collected. Baker found a tooth of an elephant (p. 10\%) on Parita Creek. On Medina River some teeth and bones of an undetermined species of elephant were found (p. 10\%).

Comal County (200) has contributed only a mastodon, found near New Braunfels (p. 16). In Hays County (201), near San Marcos, were found bison remains that appear to belong to the existing species, Bison bison ( $p$. 201). A nearly complete skull of an alligator is in the U. S. National Museum, reported as found in Blanco River, 15 miles above San Marcos, on the Edwards plateau; it was thought to occur in the Cretaceous limestone. While the animal matter is all gone, the bones do not appear to be mineralized. It is not certain that it is as old as the Pleistocene.

In Guadalupe County (215), Eleplias columbi has been discovered near Marion (p. 65), and Equus complicatus at an uncertain place called "Screwbean bridge" (p. 131). Gonzales County (216) has furnished, at Ottine, Elephas columbi (p. 65) and E. imperator (p. 91).

In Atascosa County (226), somewhere along Gallinas Creek, were collected some fragments of molar teeth of Elephas imperator. From the "Equus beds" of this county, but with no definite localities given, have been collected three species of tortoises, Trachemys bisornata (Cope), Terrapene marnochii (Cope), and Testudo (Gopherus) atascose Hay. These are described in the writer's Fossil Turtles of North America (1908, pp. 353, 362, 464). A mastodon (p. 21) was found near Ezzell, Lavaca County (21\%).

Mammut americanum (p. 21) was discovered on Clear Creek, near Cuero, De Witt County (228), and the same species (p. 21) was found near Berclair, Goliad County (229). A number of important species have been collected in Victoria County (230). At Inez an elephant molar (p. 10\%), not seen by the writer but believed by Dr. Mark Francis to belong to Elephas columbi, was discovered. At Keeran Point, on Lavaca Bay, have been collected remains of a camel (p. 163), an elephant which is referred (p. 64) to Elephas columbi, and a mastodon (p. 21) which the writer has called Anancus brazosius. A number of interesting species have at various times been collected in the vicinity of Beeville, Bee County (23\%), but the exact localities are not recorded. The species are Mammut americanum (p. 21), Elephas columbi (p. 66), E. imperator (p. 91), Elephas sp. indet. (p. 108), Bison latifrons and B. regius (p. 190).

From near Skidmore was sent to Dr. Mark Francis an elephant tooth which is referred to Elephas columbi (p. 66). In Live Oak County (236), Elephas imperator has been discovered on Sulphur Creek (p. 90); an undetermined species, probably Elephas columbi, at George West (p. 10\%); and an extinct bison (p. 189) near Oakville.

From the region about San Diego, Dural County (242), and from Nueces County (244), or a former part of it, perhaps now Jim Wells County (243), Cope reported five species of horses (p. 131), Mammut americanum (p. 22), 
and the tortoise Terrapene marnochii. The latter was found on San Diego Creek (Hay, Fossil Turtles N. A., p. 362). The locality must have been in either Duval County or what is now Jim Wells County. From Robstown, Nueces County, has come a molar tooth of Elephas imperator (p. 93). A tooth of an unidentified horse has been discovered 20 miles south of west of Corpus Christi (p. 133). The type of Glyptodon petaliferus (p. 4) was reported from Nueces County. It may have been found along San Diego Creek, in Duval or Jim Wells County. Cope reported also a tusk of an elephant, not otherwise identified (p. 66), from southwestern Texas. It was probably found in the region about San Diego. From Alfred, Jim Wells County, came a part of a tooth of Elephas columbi (p.66). On page 108 is recorded the discovery of a tooth of Elephas sp. indet. near Brownsville, Cameron County (353). All of these specimens come from localities belonging in the area of the Lissie (Deussen, Profess. Pap. 126, U. S. Geol. Surv., p. 110, pl. viII).

In Maverick County (223), Doctor C. L. Baker found teeth of the horse Equus complicatus (p. 134). In Brewster County (159), near Terlingua, were collected bones of Nothrotherium (p. 2) and a horse (p. 134). Near El Paso, El Paso County (113), were discovered Equus complicatus (p. 134), Tapirus haysii (p. 155), Elephas columbi (p. 66), and a mastodon belonging to another genus than Mammut (p. 22).

\section{ARKANSAS.}

L. W. Stephenson and A. F. Crider have studied the geology of the part of Arkansas most important as regards the Pleistocene; and for its distribution their map may be consulted (U. S. Geol. Surv. Water-supply Paper, 399, 1916, pp. 1-315, with pls. I-XI and 4 text-figs.). According to them (op. cit., p. 13), the State may ba divided into two physiographic regions by drawing a line from the northeastern corner of Randolph County southwestward to Arkadelphia, Clark County, and thence westward to the State line. The portion of the State north and west of this line belongs to the Ozark Province; that part east and south of the line, to the Gulf Coastal Plain. The latter embraces about 27,500 square miles, the former about 25,000. The Ozark province is rough and mountainous; the Coastal Plain is less diversified and much of it is low and flat. Nearly all of the Pleistocene deposits that are capable of being mapped are found in this Coastal Plain.

The Gulf Coastal Plain in Arkansas and southeastern Missouri is bounded on the east by Mississippi River; on the west and northwest by the highlands of the Ozark Province; on the southwest by the highlands of Arkansas River. Its greatest width, over 100 miles, is in the latitude of Little Rock. It is divided into approximately equal parts by an elevated tract, Crowleys Ridge, which begins near Helena and runs northward bearing westward about 40 miles, then northward bearing eastward, into Stoddard County, Missouri. The lowland lying west of this ridge is known as the Advance lowland; that east of it as the Mississippi lowland. The latter expands in width northward, the former southward. The Mississippi lowland has been described at length by R. Ellsworth Call (Arkansas Geol. Surv., vol. II, 1891), and by Stephenson and Crider (U. S. Geol. Surv. Water-sup. Pap. 399, 1916). The portion of it 
situated in Missouri has formed the subject of an investigation by C. F. Marbut (Univ. Missouri Studies, vol. I, No. 3, 1902).

In Arkansas, Crowleys Ridge varies in width from 0.5 to 12 miles; in Missouri its greatest width is 18 miles. Its height above the lowlands ranges from 100 feet at the south end to 260 feet in Missouri. Crowleys Ridge is composed of Tertiary rocks (Wilcox, Claiborne, Jackson, and Lafayette) largely overlain by loess. It has been determined that the ridge is the result of erosion of the Tertiary formations mentioned above, which occupied the regions east and west of the ridge. The theory is that, at some time during the later part of the Tertiary, Ohio River found its way toward the Mississippi embayment, east of Crowleys Ridge, and the Mississippi its way along the west side, the two streams meeting south of the ridge. These positions of the rivers continued until after the deposition of the loess (Stephenson and Crider, op. cit., p. 129). This, according to present views, was late in the Iowan glacial stage or in the Peorian.

According to Marbut (op. cit., p. 62), the Mississippi was diverted into the Ohio, first near New Madrid and later at a point near Commerce, Missouri. While the two rivers were following separate courses, each constantly changing its channel, was eroding a broad valley and laying down abundant deposits, that of the old Mississippi forming the Advance lowland, that of the Ohio the one now called the Mississippi lowland. Inasmuch as, according to Stephenson and Crider, the Mississippi abandoned its ancient course late in the Pleistocene, it is probable that deposits belonging to all of the Pleistocene stages exist in the Advance lowlands. The deposits of the lowlands east of Crowleys Ridge likewise belong probably to various stages of the Pleistocene. According to Marbut and Call, as cited, the course of events in this interesting region was somewhat different; but both were working on the theory then held by glaciologists that the loess had been deposited during the first glacial stage and through the action of water. Stephenson and Crider's report leaves out of the account the carbonaceous clay that Call reported from Helena. This underlies the loess and may be regarded as belonging to the Port Hudson formation.

Crowleys Ridge is occupied by considerable deposits which belong to the so-called Lafayette formation. It is not even yet certain whether this formation belongs to the late Pliocene or to the early Pleistocene. Salisbury has discussed this subject (Arkansas Geol. Surv., vol. II, pp. 240-242 ; Stephenson and Crider, op. cit., pp. 98-99). His investigations showed that in these gravels are found no pebbles of northern origin. They occur in the course of the Mississippi, coming down from regions occupied by glacial till. If the Lafayette gravels had been laid down after the beginning of the Pleistocene, they could hardly have failed to be, in some part at least, composed of glacial materials. This fact appears to indicate clearly that the Lafayette does not belong to the Pleistocene. Probably it is to be referred to the latest Pliocene.

The deposits of loess are now regarded as laid down at the close of the Iowan glacial stage or during the Peorian interglacial. In the loess of Crowleys Ridge, as in the loess of other localities, are found numerous shells of land mollusks. How are these related to those now living in the same localities? Dr. Bohumel Shimek has offered a valuable contribution to the subject (Science, n. s., vol. xxxvir, 1913, pp. 506-50s; Stephenson and Crider, op. 
cit., p. 113). "Southward along the Mississippi the loess molluscan fauna changes in essentially the same manner as the modern fauna of the surface." He has found, too, that in Iowa the mollusks of the loess are identical with those now living in the same region. These facts appear to show that the loess must have been deposited, not during some part of the glacial, but during a warm interglacial, stage.

For information regarding the Pleistocene deposits of southwestern Arkansas the reader may consult Veatch's Geology and Underground Waters of Northern Louisiana and Southern Arkansas (U. S. Geol. Surv. Prof. Paper No. 46, pp. 46-55, pl. III) and C. H. Gordon's Geology and Underground Waters of Northeastern Texas (U. S. Geol. Surv. Water-supply Paper, 276, pp. 31-32, pl. I). In this region there appears to be no loess present. The Pleistocene deposits forming terraces along the rivers are probably of early or middle Pleistocene time and they are referred by Veatch and Gordon to the Port Hudson. No vertebrate fossils are known from this part of Arkansas.

The Ozark region has offered little opportunity for the deposition of Pleistocene alluviums. In the four quadrangles for which up to this time folios have been published by the U. S. Geological Survey, no mention is made of Pleistocene deposits and none are mapped. Nevertheless, that region has furnished, at one locality, a large Pleistocene fauna. This place is located about 4 miles west of the town of Willcockson, in Newton County. In this Ozark region there are some limestones in which have been excavated caves and fissures.

In one of these fissures near Willcockson were secured, by Barnum Brown, of the American Museum of Natural History in New York, 51 species of mammals, besides some remains of birds, reptiles, and amphibians. The fissure is on a hill about a mile north of Buffalo River. It must therefore be in the southern part of township 17 north, range 21 west. For a description of the fissure and for descriptions and figures of the fossils, the reader may consult Mr. Brown's paper (Mem. Amer. Mus. Nat. Hist., vol. Ix, 1908, pp. 157208 , with pls. XIV-XXv and 3 text-figs). The fissure was excavated to a depth of 25 feet and was 12 feet in length and 7 feet in width. Some thousands of bones, skulls, and teeth were secured. The bones of the limbs and trunks were scattered; only rarely were two or more of those of the same skeletons associated. The following is the list of the species as determined by Mr. Brown; but the names have been changed in some cases to conform to present usage. Those preceded by the asterisk are extinct:

\section{MAMMALIA.}

Equidæ:

*Equus scotti?.

Tagassuidæ:

*Mylohyus browni Gidley (sp. $a$ of Brown).

*Mylohyus sp. indet.

*Mylohyus sp. indet.

Cervidæ:

Cervus canadensis?.

Odocoileus hemionus?.

Bovidæ: Odocoileus virginianus?.

*Symbos australis.
Geomyidæ.

Sciuridæ:

Marmota monax.

*Tamias nasutus.

Citellus 13-lineatus?.

Sciurus hudsonicus.

Castoridæ:

Cricetidæ:

*Reithrodontomys simplicidens.

Peromyscus, sp. indet.

* Neotoma ozarkensis.

Microtus ochrogaster.

*Ondatra annectens. 
Erethizontidæ:

Erethizon dorsatum.

Leporidæ:

Sylvilagus floridanus?.

Lepus americanus?.

*Lepus giganteus.

Talpidæ:

Scalopus aquaticus.

Soricidæ:

-Blarina brevicauda ozarkensis.

Sorex personatus.

*Sorex personatus fossidens.

Sorex obscurus?

Sorex fumeus?

*Microsorex minutus.

Vespertilionidæ:

*Eptesicus fuscus grandis.

Myotis subulatus?.

Procyonidæ:

Ursidæ:

Procyon lotor.

Ursus americanus.

Mustelidæ:

*Mephitis newtonensis.

Spilogale interrupta?.
Mustelidæ:

* Brachyprotorna pristina.

* Brachyprotoma spelaea.

Martes pennanti.

Mustela vison.

* M. cicognanii angustidens.

* Mustela gracilis.

Canidæ:

Canis occidentalis?.

Vulpes fulva?

Felidæ:

Urocyon? sp. indet.

* Lynx compressus.

Lynx rufus?.

Felis cougar?.

*Felis longicrus.

*Smilodontopsis troglodytes.

*Smilodontopsis conardi

AVES.

Meleagridæ:

Meleagris gallopavo?.

Crotalidæ:

REPTILIA.

Crotalus sp. indet.

Besides the forms recorded above, Mr. Brown recognized remains of a lizard, several undeterminable species of snakes, some caudate amphibians, bones of a frog or two, and other bones thought to belong to the genus Bufo. At whatever time in the Pleistocene these animals lived, they undoubtedly represent only a small part of the vertebrates then living in that immediate region. In the neighborhood of that fissure there must have been in existence ground sloths, more than one species of horse, probably tapirs, species of Bison, mastodons, and elephants, besides many species of birds and reptiles.

Counting the new subspecies, but not the doubtful species (except Equus scotti) collected by Brown, there are 24 forms extinct among the mammals. This amounts to 47 per cent of the whole number, 51. In case the North American species of mammals became extinct somewhat gradually during the Pleistocene, and in case, further, that the numbers of the extinct and of the yet existing species collected in the fissure are in proportion to the extinct and the yet existing of the fauna then living in that region, the percentage appears to indicate a time about the middle of the Pleistocene. Inasmuch, however, as the larger species of mammals appear to have suffered extinction to a greater degree than the smaller ones, and as the larger ones are not well represented in the collection, it seems possible that the percentage of extinct species is too low. Mr. Brown concluded (op. cit., p. 169) that the fauna represented by his collection had lived there during one of the glacial stages. A number of the species now live considerably farther north, and some of his new forms are most closely related to boreal species. As such boreal species may be mentioned Sciurus hudsonicus, Erethizon dorsatum, Lepus americanus, Mustela pennanti, $M$. cicognanii angustidens, Sorex fumeus, S. obscurus, $S$. personatus, and Microsorex minulus. Taking into consideration the high percentage of extinct species and subspecies, and the fact that the glacial sheet of the Illinoian stage approached that region more closely than did any other glacial sheet, the writer is inclined to refer the age of the fauna to the Illi- 
noian stage. 'There is no sufficient evidence, moreover, that any of the horses or of the saber-tooth tigers existed up to the time of later glacial stages.

From near 'Trumann, Poinsett County, the writer has seen a fragment of a tooth and a dorsal vertebra of Mammut americanum. It was found in a small stream, at a depth of about 12 feet (p. 22). The locality is in the southeast quarter of section \%, township 12 north, range 5 east. This is therefore about 5 miles from Trumann and in what is put down on Stephenson and Crider's map as the Bay of St. Francis River and about 5 miles east of Crowleys Ridge. The region is mapped as being occupied by Recent alluvium, but including possibly some Pleistocene alluvium. The occurrence of the mastodon remains appears to confirm the presence of Pleistocene of an undetermined stage. Frank Janes, who sent the tooth, reported that the deposit was a waxy soil, called there "gumbo."

According to Dr. R. E. Call (Ann. Rep. Ark. Geol. Surv., 1899, vol. II, p. 39 ), some bones that were supposed to belong to a mastodon were found at Helena, at some unnoted time before he wrote. These were buried below the base of a cliff of loess that appears to have had a thickness of from 50 to 80 feet and at a distance of 25 feet from the face of the cliff. This is near the southern end of Crowleys Ridge. Beneath the loess was a deposit of a stiff blue-black carbonaceous clay of a fetid odor, and in this clay were the bones. There is nothing in the account to indicate that the bones may not have been those of one of the elephants. They are said to have been sent to the Smithsonian Institution, but the writer has never seen them. Whether they were those of a mastodon or of an elephant it is to be noted that, being in a clay beneath the loess, they antedate the loess. One may conclude that such a deposit probably corresponds in age to the clays which underlie the loess at Natchez and other localities in Mississippi and Louisiana, and which have been called the Port Hudson clays.

The writer has seen a tooth of a mastodon from Mississippi River, Chicot County, which was received at the U. S. National Museum in 1922 (p. 22). It had been discovered in a carload of gravel dredged up from the river, probably on the Mississippi side, but possibly on the Arkansas side. Some Pleistocene deposit was evidently being attacked by the river.

\section{OKLAHOMA.}

Not much appears to have been written on the Pleistocene geology of Oklahoma and it is of a very general nature. The known Pleistocene deposits lie mostly along the rivers and their tributary streams. These are, however, so numerous and often have such broad valleys that Pleistocene deposits are certain in time to be found in abundance.

The most interesting locality in Oklahoma, as regards vertebrate palæontology, is Afton, in the southwestern corner of Ottawa County, on the St. Louis and San Francisco Railway. Near this place, between it and Miami, is a spring in which, about 1900 , Dr. R. H. Harper, of Afton, discovered remains of mastodons and mammoths in close association with flint implements. At his solicitation the Smithsonian Institution sent a member of the department of palæontology to examine the place for the purpose of getting mantodon and mammoth remains; later, Professor W. H. Holmes visited the 
locality and made extensive excavations and the results of his work were announced in 1901 (Amer. Anthropologist, vol. IV, pp. 108-129, pls. XI-XII). In 1903 (Ann. Rep. Sinithson. Inst. for 1901, U. S. Nat. Mus., pp. 237-252, pls. I-XXVI), the report, with many illustrations, was republished. Professur Holmes secured from the spring large numbers of flint implements, arrowheads, spear-points, krives, and scrapers, together with implements made o! bone, and antlers. These are preserved in the department of anthropology in the U. S. National Museum. In the same spring were found large numbers of bones and teeth, which, in the reports mentioned, were referred to Elephas primigenius, E. imperator, buffalo, deer, elk, and horses, domestic and extinct. The country in this region appears to be very flat and to consist superficially of sandy and gravelly materials. It is underlain by rocks of Carboniferous age.

A study of the fossil remains appears to show that deposits are here found which belong to the so-called Equus beds, but that overlying these are probably thin deposits of all succeeding stages of the Pleistocene and of the Recent. Certainly some of the remains found in the spring, such as a skull of a bison and one of a wolf, appear not to have been buried there during the Pleistocene.

According to Holmes's account (1903, p. 240), the spring does not vary in its outflow from season to season, appearing thus to have a deep origin; in summer its waters disappear from sight a few hundred yards from the source. Beginning at the surface, there is a muck-bed about 2 or 3 feet in depth. This, however, is found only close around the spring and changes to sandy loam not far away. Beneath this muck is a bed of sand, said to be 3 or 4 feet thick, but increasing to 10 feet or more at a distance of 20 feet. Towards the lower part this bed becomes more or less gravelly. The excavation made by Holmes penetrated to a depth of only 13 feet; but a soundingrod indicated at least 16 feet of comminuted deposits. Later other excarations were made near the spring, but nothing more of special interest was discovered.

The bones and teeth of mammals which were secured at Afton are preserved partly in the department of anthropology and partly in the department of vertebrate palæontology at the U. S. National Museum. The writer has examined these and found remains which represent the following species:

\footnotetext{
*Castoroides ohioensis-A fragment of an incisor (p. 210).

*Equus complicatus-Many teeth upper and lower (p. 135).

*E. laurentius-Teeth (p. 136).

*E. holmesi-Teeth (p. 136).

*E. excelsus-Teeth (p. 136).

*E. hatcheri-One upper tooth; perhaps some lower teeth (p. 136).

*Camelops kansanus?-Upper and lower teeth (p. 163).

*Camelops nitidus-Two teeth (p. 164).

Cervus canadensis-Tooth and fragment of antlers (p. 173).

Odocoileus virginianus-Teeth and part of antler (p. 170).

Alces americanus-Lower molars in part of the jaw.

*Cervalces roosvelti?-Teeth.

*Symbos promptus-Atlas and teeth (p. 178).

Bison bison-Skull and teeth (p. 203).

*B. sp. indet.-Many teeth (p. 190).

*Elephas columbi-Teeth (p. 66).

*E. imperator-Teeth (p. 94).

*Mammut americanum-Many teeth (p. 23).

Canis nubilus-Skull, many teeth and several bones.

C. latrans-Axis.
} 
The species preceded by an asterisk are extinct. This collection was described by the writer in 1920 (Proc. U. S. Nat. Mus., vol. LviII, pp. 117-128).

The presence of camels, of extinct horses, and of Elephas imperator indicates with certainty the presence of early Pleistocene deposits at this locality. Probably many or all of the proboscidean remains belong to about the same period, but some may be of a later time. The less thoroughly fossilized teeth of Equus complicatus may belong to the middle of the Pleistocene, about the Sangamon. The musk-ox (Symbos promptus) may be as old as this.

Holmes concluded that the flint implements had been thrown into the spring by Indians of comparatively recent times in the observance of religious ceremonies. This appears to be the most reasonable explanation. Holmes thought that this was the most plausible theory to account for the presence of the bones and teeth also, and he notes the fact that most of these were found very close to the spring funnel. To the present writer this theory does not seem probable. One feature in the explanation of such cases appears not to have been taken into consideration, and that is the constant but slow removal of the materials forming the walls of the funnel. A stream of water can not fail to carry away such materials, and sometimes the amount of this will be extensive. Holmes says (1903, p. 243) that "the finely comminuted materials, the sand and clay, would be carried away by the strong flow of water and the great teeth and the coarse gravel would remain in the basin." $\mathrm{He}$ also reported the fact that a year or two previous to his visit to Afton, and during a wet season, a body of liquid and semi-liquid material suddenly broke through the surface of the ground near the spring like a bursting bubble, leaving a little hillock which was yet visible when he was there. Now, the removal of the materials from the walls of the funnel does not mean an increase in the diameter of the funnel, nor does the eruption of masses of mud and sand mean the production of permanent cavities in the earth. As the funnel is worn, the surrounding earth slowly presses in and occupies the place of the part swept away. Examples of such movements of the earth may be seen in many passageways to basements and cellars, where even the retaining-wall becomes displaced. As this spring at Afton has probably been flowing for thousands of years, teeth and bones have been steadily moved toward it and thus concentrated. As a result of such movements some of the more recent species buried in the upper layers might get low down in the spring.

Near Fort Gibson, Muskogee County, was found the type specimen of the musk-ox Symbos cavifrons (p. 179). Near Peno, Le Flore County, a jaw of a mastodon was discovered (p. 23). In the same general region remains of an extinct bison (p. 203) and a part of a skull of Symbos cavifrons (p. 179) were collected. A tooth belonging probably to Bison bison was found in the vicinity of Pickwick, Bryan County (p. 203). From a point near Kinlock, Marshall County, the State University, at Norman, received a remarkable palate of Elephas imperator (p. 94). From Avery, Lincoln County, the U. S. National Museum received a tooth of Elephas columbi (p. 6\%). Not far from Mulhall, Logan County, have been reported a number of species of Pleistocene vertebrates. From Professor C. N. Gould, former State Geologist of Oklahoma, the writer learns that the locality is about 5 miles southwest of Mulhall, not far from Ephraim Creek. A farmer, H. F. Sears, in 1911, was making an 
excavation for a tank, when he discovered some bones. Professor Gould visited the locality, but found the bones in poor condition and apparently many of the better pieces had been carried away by curious visitors. Dr. E. T. Troxell informed the writer that he visited the locality in 1916. In 1917 (Bull. Geol. Soc. Amer., vol. xxvirI, p. 212) he published a brief abstract, stating that he had recognized remains of a tapir, a bison whose horn would measure about 3 feet from tip to tip, mastodon, mammoth, deer, and a giant sloth. Nothing further has been published on the collection. The tapir appears to carry the age of the deposit back to at least the Sangamon stage; but it may have been older.

Professor Cope secured, 8 miles west of Hennessey, Kingfisher County, teeth believed to belong to Elephas columbi (p. 67) and a canine tooth of the saber-tooth tiger Dinobastis serus. A tooth of Elephas columbi (p. 67) was found in Canadian River, just south of Norman, Cleveland County. In the same river, near Walker, Cleveland County, was discovered a tooth of a mastodon (p. 23). A femur supposed to belong to Elephas imperator (p. 94) was discovered, probably near Okeene, Blaine County. A molar believed to belong to Elephas imperator has been found near Kingfisher, Kingfisher County (p. 95).

\section{NEW MEXICO.}

New Mexico is one of the States which have furnished abundant rertebrate fossils of Tertiary times and but few belonging to the Pleistocene. In only about twelve places have Pleistocene vertebrates been reported from the State, and in only one case have there been as many as four species found associated. In at least the western two-thirds of the State the deposits of this time are scattered along the streams and between the mountains. The eastern third no doubt may furnish more extended areas, but it has not yet been investigated; neither, indeed, is the rest of the State well surveyed.

'The impression that one obtains on reading the geological literature pertaining to this part of our country is that it is a region of high mountains and deeply cut canyons, of arid and desert-like mesas and bolsons, of rolcanic peaks and crater pits, of plains of sand and gravel, and of lava outflows. Up to the present time the U. S. Geological Survey has published folios for only six quadrangles: No. 199, the Silver City folio, by Sidney Paige; No. 207, the Deming folio, by N. H. Darton; and No. 214, the Raton-Brilliant-Koehler folio, by Willis T. Lee. The results secured by their work will be considered below.

The Raton, Brilliant, and Koehler quadrangles are included almost wholly in Colfax County, in the northeast corner of New Mexico, and belong in the transitional zone between the Rocky Mountains and the Great Plains. As said by Lee, the highlands occupy most of the Brilliant quadrangle; both highlands and lowlands are represented in the Koehler quadrangle; while in the Raton quadrangle the most conspicuous features are the mesas and plains. So far as Pleistocene geology is concerned, at present the Raton quadrangle alone offers any interest, and this not much. On the Johnson mesa are two areas of high-level gravels which are recorded as belonging to the Quaternary. These gravels lie on a basalt sheet which caps the mesa; on this and some of 
the other mesas, beds of gravel are found between sheets of basalt. The gravels are known to vary from 10 to 70 feet in thickness, and some are probably thicker. The place of these basalts and gravels in the geological column is not well known, but they are probably Quaternary. On one mesa, in a well, a limb-bone 6 to 8 inches in diameter was found. It was supposed to belong to a Pleistocene mastodon, but it may have belonged to one of the late Tertiary species. No other vertebrate fossils have been reported from Colfax County.

In Harding County, on Carisso Creek, near Albert, was found a part of a skeleton of an undetermined species of elephant, probably either Elephas imperator or E. columbi (p. 108). At Taos, in Taos County, Professor E. D. Cope, in 1874, saw a tooth of Mammut americanum, found in the clay along Rancho Creek. There has been but one other specimen of this species reported from the State. Of itself, the tooth tells us merely that there are in that region some Pleistocene deposits; but whether early or late one can judge only from what is learned elsewhere.

Members of the Wheeler Survey found some vertebrate fossils 1.5 miles north of Ildefonso, Santa Fé County, and later Professor Cope collected there a considerable number of species. Those obtained by him, as well as most of the other specimens, belong to species now referred to the Upper Miocene or Lower Pliocene. However, in the lot was a tooth or a bone which Professor Marsh referred to Equus. If no mistake was made in the identification, we may be quite sure that it was found in a Pleistocene deposit somewhere thereabouts. Lee (Bull. Geol. Soc. Amer., vol. xviri, p. 215) says that some of the Santa Fé marls resemble closely the Pleistocene deposits of southwestern New Mexico.

Somewhere near Santa Fé, many years ago, was found a tooth of Elephas columbi (p. 69), which was described by Dr. Joseph Leidy, though he presented no details regarding the history of the tooth. A tooth of the same species was found by Professor Cope near the town of Placita, in Sandoval County (p. 68). Along Placita Creek he found deposits which he named the Placita marls and in these the tooth was obtained. The town and creek are not far from Albuquerque, and Reagan (Amer. Geologist, vol. xxxI, pp. 67111) has described and mapped the geology of the region. Pleistocene deposits occur on both sides of the Rio Grande for many miles above and below Albuquerque. Reagan states (pp. 89-90) that the Rio Grande marls are identical with the Placita marls and that one can be traced intu the other without breaks. Teeth of elephants (p. 108) have been found at Bernalillo, in Sandoval County, according to Herrick and Johnson (Bull. Denison Univ. Labs., vol. XI, p. 224), in the flood plain of the Rio Grande; it appears probable that this flood plain is of Pleistocene age. In these Rio Grande marls, at Pena Blanca, have been found, according to Reagan, remains of Elephas columbi (p. 68) and of other Pleistocene animals not identified. Pena Blanca is on the Rio Grande, about 40 miles above Albuquerque, in township 16 north, range 6 east.

From the mountainous region of Lincoln County, not far from Fort Stanton, there have come to the U. S. National Museum teeth of Elephas columbi (p. 68). The exact locality of one tooth is not known; the other was found about 5 miles north of Fort Stanton (p. 68). With the latter specimen were 
discovered a tusk and some of the skeleton. The pleistocene deposits here indicated are doubtless distributed along some of the stream courses. From some point still farther south, in the Sacramento Mountains, in Otero County, there was sent to the U. S. National Museum, in 1919, a large tooth which is referred to Elephas columbi (p. 67). The writer has received no further information regarding the discovery.

In the description of the Pleistocene geology of the valley of the Rio Grande, as shown in Texas (p. 66), reference has been made to the finding, in a gravel pit at El Paso, of Elephas columbi, another proboscidean supposed to be a species of mastodon, apparently not Mammut, Equus complicatus, and Tapirus haysii. These are regarded as indicating deposits of early or middle Pleistocene times. Coming across the Rio Grande, at Mastodon, Donna Ana County, on the Southern Pacific Railroad, we learn that remains referred to Equus complicatus (p. 137) and to Mammut americanum (p. 24) have been discovered. Near Afton, in the same county, some remains of a horse ( $p$. $137)$ were found in the Kilburn crater.

A discussion of the deposits of this region by Dr. Willis T. Lee may be consulted (Bull. Geol. Soc. Amer., vol. xvirr, pp. 211-220). According to Doctor Lee the Rio Grande had at one time, probably in the late Tertiary, excavated in the region a deep and broad gorge. In the early Pleistocene, some change occurred which led to a filling of the gorge with sand and gravel to a depth of about 1,000 feet. Again the flow of the river was accelerated and a channel was excavated to such a depth that the ancient filling of the gorge stands above the river at a height of 300 or 400 feet. The deposition of the old filling and all of the down-cutting of the channel must have occurred since these horses, tapirs, elephants, and mastodons lived.

Still farther toward the northwest, somewhere near Deming, Luna County, was found a vertebra of an unidentified species of elephant (p. 108). No details have been furnished regarding the locality or formation. The character and the distribution of the Pleistocene deposits of this region may be learned from Bulletin No. 618 of the U. S. Geological Survey and from Folio No. 207 , the author of both of which is Dr. N. H. Darton. Much of the country is covered by tracts called "bolsons," which form smooth desert plains, occupying the greater part of Luna County and are a part of the great plain which extends from the Rio Grande to and over the Continental Divide. It is in this plain that the river excavated its channel. Here, as nearer the river, the deposit is composed of clay, sand, and gravel. Borings have passed through sheets of basalt. Probably in this bolson deposit was found the elephant vertebra which was sent to the U. S. National Museum.

Silver City is situated about 125 miles northwest of El Paso and has given name to the quadrangle which is described in the U. S. Geological Survey's Folio 199, prepared by Sidney Paige. About 460 square miles of this quadrangle are occupied by bolson plains, the materials of which have been derived from the surrounding mountains. Paige concluded that the bolsons correspond in age to the Gila conglomerate of G. K. Gilbert (Rep. Exped. W. 100 Merid., vol. III, p. 540). No fossils were met with, but Paige heard reports of the occurrence of bones in the grarels at Santa Rita, a town about 12 miles east of Silver City. About 100 miles north of Silver City is Datil, in Socorro 
County. Just east of this place are the San Augustine plains, probably bolsons, lying as elsewhere between the mountains of the region. C. L. Herrick and D. W. Johnson (Bull. Denison Univ. Labs., vol. xI, p. 224) reported that large numbers of teeth and bones of elephants (p. 108) had been found. It is not known what became of these remains.

In the extreme western part of the State, near Zuni, McKinley County, a few important fossil vertebrates have been found. At Black Rocks, a few miles east of Zuni, a reclamation reservoir was being constructed. In the excavations were found a toothless jaw and a pelvic bone of a horse (p. 138), a part of a scapula of a camel (p. 164), two molar teeth of Elephas columbi (p. 69), and the type skull of the musk-ox Gidleya zuniensis. Apparently no geological observations were made during the execution of this enterprise. The presence of the horse and the camel indicate an early Pleistocene deposit. The occurrence of the musk-ox skull shows that at even this early time representatives of the Ovibovinæ had entered the continent. This has been confirmed by the discovery of a musk-ox skull in the Cox gravel pit at Missouri Valley, Harrison County, Iowa.

\section{MISSOURI.}

A brief account of the Pleistocene geology of Missouri will be presented. Only the northern part of the State was subjected to glaciation. Missouri River may be taken as approximately the southern limit of the glaciated part. Undoubtedly the ice sheet passed in some places beyond this river, but the extreme extension has not been determined. The Pleistocene geology of the glaciated portion of the State was described in detail by Professor J. E. Todd in 1896 (Geol. Surv. Missouri, vol. x, pp. 113-217). Doubtless some opinions there expressed, as regards the origin of the loess, for example, have undergone modification in the author's mind. The till covering the region in question belongs, mostly at least, to the Kansan stage, but beneath this there is probably some Nebraskan. This conclusion becomes apparent when one considers the presence of this drift sheet along the southern border of Iowa. The Wisconsin ice sheet did not reach Missouri.

In 1923 (Bull. Geol. Suc. Amer., vol. xxxıv, p. 91), Professor Frank Leverett reported the finding of boulders and smaller erratics from 10 to 30 miles south of the definite Kansan till sheet. Hannibal, Jefferson City, and Tipton were mentioned as localities. In volume $\mathrm{xxxv}$ of the same journal, on page 69 , is an abstract of a paper by Professor Leverett. He reported that this old glaciation, probably the Nebraskan, had extended from southern Illinois into Missouri as far south as Cape Girardeau. Still farther south, near Commerce, were found evidences that Lafayette materials had been reworked by the drainage from the Nebraskan ice sheet.

The Kansan till in this State does not contain many boulders except in the northern part. Todd states that its thickness rarely exceeds 40 feet and is most frequently less than 5 feet. In Putnam County it has the unusual thickness of 200 feet. Few forest beds and old soils have been discovered. Nearly everywhere the Kansan drift is overlain by loess and this reaches a great thickness along the large rivers. Along the Missouri, in Atchison County, it has been reported to have a depth of 200 feet or more, but Todil regarded the estimate as too high. 
'The region south of Missouri River and away from the lowlands along the Mississippi is covered mostly by soils resulting from the decay of the underlying rocks. As these rocks are often limestone, in them may occur caves, and in these are sometimes to be found remains of vertebrated animals. Along the streams are found deposits of alluvium which may sometimes be of Pleistocene age. When one considers the great width of the trough cut by Mississippi River, the depth of this trough, and the facility with which the river changes its channel, one can realize that in this valley must be deposits laid down during each of the glacial stages. On account of the frequent changes of the channel these deposits have doubtless been converted into discontinuous patches.

In the southeastern corner of the State the Pleistocene forms a continuation of the lowlands of eastern Arkansas. For a description of the latter, see page 249. The lowlands of Missouri were described by Marbut in 1902 (Univ. Missouri Studies, vol. I, pp. 1-63, with maps). As in Arkansas, the lowlands are divided into two portions by an elevated tract called Crowleys Ridge. At the extreme north of this is Benton Ridge, once a part of Crowleys Ridge. Between Crowleys Ridge and the Mississippi is the Morehouse lowland, and on the opposite side of Crowleys Ridge is the Advance lowland. The origin of the ridge and of the lowlands is described in Marbut's excellent paper. As this was written when it was believed that the loess was deposited during the very early part of the Pleistocene, Marbut's paper needs to be read in connection with later productions, as Stephenson and Crider's work (U. S. Geol. Surv. Water-supply Pap. 399).

The St. Louis quadrangle has been described by N. M. Fennemann (U. S. Geol. Surv. Bull. 438). The late Pliocene and the Quaternary are treated on his pages 30-34, 44-49. Inasmuch as, according to Fennemann, St. Louis and vicinity form a somewhat critical locality with respect to Pleistocene deposits, it will be considered here briefly. West of St. Louis, within the quadrangle, are found a number of deposits of gravel which are referred to the Lafayette, of the late Pliocene. They occupy the more elevated areas (Fennemann, op. cit., p. 30 ).

During two stages of the Pleistocene the region lay near the border of two distinct ice sheets. One was the Kansan, approaching from the northwest; the other the Illinoian, coming from the northeast. Fennemann states that some Kansan deposits, probably water-lain, are found near the northern boundary of the quadrangle, but it can not be affirmed that there are any ice-laid deposits. The Illinoian ice sheet appears to have crossed the Mississippi for a short time and left drift materials that have been found beneath the loess. The loess covers all of the uplands of the quadrangle (Fennemann, op. cit., p. 33). On the eastern bluffs of the Mississippi it may be 50 feet thick. West of the river the thickness is much reduced. On the flood plain of the Mississippi the alluvium varies from 60 to 150 feet in thickness, composed of fine clay or sand above; of gravel, cobblestones, and boulders below. Fennemann states (op. cit. p. 48) that east of the present channel is an older one filled with alluvium and 100 feet deeper than the rock surface beneath the present one. 
Folio 206 of the U. S. Geological Survey should be mentioned here. In this Henry Hinds and F. C. Greene describe the Leavenworth quadrangle situated partly on the Kansan side of the Missouri, but mostly on the Missouri side; also the Smithville quadrangle, which adjoins the Leavenworth quadrangle on the east. They found in both areas glacial drift of Kansan age; beneath this were observed gravels which the authors referred provisionally to the Aftonian. Over the Kansan is an accumulation of loess. No fossils were found in the Pleistocene.

Missouri has not furnished a great number of Pleistocene vertebrates, although it was one of the first to secure a wide-extended reputation for such fossils. This happened especially through the publications of the enterprising but somewhat unreliable procedures and publications of Albert Koch, in the years from 1839 to 1858 .

Most of the animals discovered have been described in their proper places on preceding pages, but in a rapid review those found at the various localities will be recalled and considered in connection with the associated fossils and their geological relations. Those found in the glaciated region will be first mentioned.

On page 32 is mentioned the finding of mastodon teeth in a creek near Clarksville, Pike County. Although these well-preserved teeth were at first supposed to belong to a European species, they were quite certainly those of Mammut americanum. The animal probably lived after the Kansan glacial stage; but at a point so near Mississippi River that there is a possibility that the creek had cut down into an older deposit.

On page 109 mention is made of the discovery of two teeth referred to Elephas boreus which long ago were found in the loess somewhere along Bonne Femme Creek, Howard County. In case they were embedded in the loess the elephant belonged to either the end of the Iowan stage or to the Peorian. The geologist Broadhead reported (Kansas City Review Sci., etc., vol. Iv, 1881, p. 521) that a mastodon tooth had been found in Caldwell County. The geological age of the beast was probably post-Kansan.

On page 32 is recorded the finding of a large tooth of a mastodon on Line Creek, Platt County. It is impossible to determine the Pleistocene stage to which it belonged; the probability is that it is post-Kansan, but as the region is not from Missouri River the tooth may have been embedded in a preKansan deposit. On page 32 is mentioned a mastodon tooth which was found somewhere near St. Joseph, Buchanan County.

Several species of fossil vertebrates were found in a gravel pit in section 22, township 64 north, range 41 west (Calvin, Bull. Geol. Soc. Amer., vol. xxII, p. 210), about 5 miles south of Rockport and on Nishnabotna River. The forms collected were a horse (p. 139), which the writer referred to Equus niobrarensis (Iowa Geol. Surv., vol. xxIII, p. 201) ; a Hipparion, resembling H. gratum; an unidentified camel (p. 164), which may belong to Camelops kansanus (Iowa Geol. Surv. as cited above, p. 243, pl. xxxI, fig. 4); and Elephas columbi (p. 69). Calvin regarded the deposit as belonging to the Aftonian, and this appears to be confirmed by the occurrence of the horse, the hipparion, and the camel. 
On page 31 is noted the discovery of two teeth of a mastodon in St. Louis, some time before 1855. G. C. Swallow, the geologist, reporter that they harl been found in making a sewer, in loess, at a depth of 16 feet. On page 181 is described a skull of Symbos cavifrons, which was found some time before 1869 in St. Inuis. It appears that with the skull was a large part of the skeleton, but this apparently was not preserved. If found really in loess it appears to belong to the Iowan or to the Peorian. On page 139 is noted the finding of a tooth of Equus complicatus on the "Illinois Bluffs," 6 miles west of St. Louis in the "bluff formation." If we may rely on the statement made, we must conclude that the horse too had lived during the late Iowan or the Peorian. As regards the locality it is pretty certain that it was east of $\mathrm{St}$. Louis, on the Illinois side of the Mississippi.

Kimmswick, Jefferson County (11).- In his "Short Description of Fossil Remains found in the State of Missouri," published at St. Louis in 1840, Albert Koch gave an account of fincling mastodon remains in the vicinity of Sulphur Springs, on Little Rock Creek, 22 miles south of St. Louis, near the present village of Kimmswick. At the union of Little Rock Creek with Rock Creek there is formed a triangle nearly surrounded by walls of rock from 30 to 40 feet high. "Immediately under the foot of the west corner from these bluffs is the place on which it is supposed that many large animals of different kinds and sizes found their deaths."

Koch stated that the lowest stratum found there consisted of bluish sand, such as is often seen on the bottom of the Mississippi. On this lay a bed of gravel about 1.5 feet thick; above it a stratum whose thickness was not given and which consisterl of large and small pieces of rocks, mostly fragments of limestone. These rocks varied in size from a weight of several tons to only several pounds, and were bound together by a limestone cement and blue clay. Mingled with the gravel and the broken rocks were at least two skulls and great quantities of other bones, some of which had been ground to powder. Above these bone-bearing strata was a layer of blue clay varying from 2 to 4 feet in thickness. Over all was the soil. "The whole described mass forms a sloping hill, coming down from the foot of the 30 to 40 feet wall of rocks descending toward the creek."

In these deposits Koch found the head of an animal which he named Missourium kochii and the head of another animal which he did not name and which lie stated exceeded the elephant in size from four to six times. Both of these have been shown to be remains of the American mastodon. Here Koch found likewise what he regarded as a part of the antlers and two teeth of "the antediluvian reindeer that has belonged to a creature of gigantic size." It appears quite probable that he had found the antlers of a species of Cervalces. He discovered also a tooth of an antediluvian horse at Kimmswick.

Shumard in 1873 (Geol. Surv. Mo., 1855-1871, p. 305) recalled that Drs. Koch and McDowell, of St. Louis, had disinterred from alluvium near Sulphur Springs some mastodon bones. They were found in a dark loam, mixed with a great deal of humus, at the base of some high bluffs of limestone.

At a meeting of the American Philosophical Society, October 2, 1840 (Proceedings, vol. I, p. 279), W. E. Horner made a report on a collection of mastodon bones, secured for the Society from Doctor Koch. It is stated that 
this collection consisted of 200 or more teeth of the mastodon and of the American elephant, obtained principally from the locality south of St. Louis and from Gasconade County. Among other things in the collection was the "nondescript skull" mentioned above which Koch found on Rock Creek, below St. Louis. The condition and the identity of this was discussed by Horner. It was regarded as being a mastodon. In the collection were an ulna and a humerus of probably a megalonyx, but it was not stated where they were found. Since the time when Koch made his excavations there, other persons have engaged in the same work, and large quantities of bones have been taken out; but they have been mostly scattered or destroyed. About 1902, Alban Stewart of the U. S. National Museum spent some time at Kimmswick and succeeded in getting some proboscidean materials. At St. Louis University there is a lower right second molar which was found at Kimmswick and presented by Omer Little. This was identified by the present writer as Taurotragus americanus. In the U. S. National Museum (No. 4988) is a left third premolar of this species which was collected by Stewart at Kimmswick.

In the possession of Mr. C. W. Beehler, of St. Touis, the writer has seen a portion of a horn-core which resembled that of Boötherium bombifrons. Mr. Beehler found large numbers of small tusks in his excavations at Kimmswick; probably these were shed lower tusks of the mastodon. Professor W. C. Mills, of the State University of Ohio, on a visit to the locality, found a number of these. They had a length of 5 to 6 inches and the diameter of a man's thumb. Professor Mills showed the writer 2 teeth of a Megalonyx jeffersonii which he secured at Kimmswick. Dr. W. F. Parks, of St. Louis, in 1921, sent to the U. S. National Museum a small collection in which were found 6 teeth of an extinct bison, 3 teeth which, because of their imperfect fossilization, are thought to belong to Bison bison, an upper molar referred to Symbos cavifrons, a second phalange which appears to belong to the Virginia deer, 8 teeth of Megalonyx jeffersonii, and a well-preserved upper molar of Equus complicatus. The following is a list of the Pleistocene species which appear to have been found at Kimmswick:

$\begin{array}{ll}\text { Megalonyx jeffersonii. } & \text { Symbos cavifrons. } \\ \text { Equus complicatus. } & \text { Bison sp. extinct. } \\ \text { Odocoileus virginianus. } & \text { Bison bison. } \\ \text { Cervalces? sp. indet. } & \text { Anancus? sp. indet. } \\ \text { Taurotragus americanus. } & \text { Mammut americanum. } \\ \text { Boötherium bombifrons?. } & \text { Elephas sp. indet. }\end{array}$

In the collection sent by Mr. Parks is the distal end of a remarkable tusk which in the list is referred to Anancus?, sp. indet. The fragment is 140 min. long. The diameter at the proximal end was at least $35 \mathrm{~mm}$. but some layers of the dentine are missing. The tusk is gently curved. On a part of the concave face the dentine layers are missing, varying from a thickness of $8 \mathrm{~mm}$. distally to $3.5 \mathrm{~mm}$. proximally, thus exposing a deeper part of the tusk: 'This deeper portion is broadly oval in section and rises to a sharp edge. The angle between the two sides bounding the edge is somewhat more than a right angle. The remarkable feature of the tusk is that the distal end was covered by a cap of enamel to a distance of about $95 \mathrm{~mm}$. above the tip. The upper part of this enamel has scaled off, but at a distance of from 65 to $75 \mathrm{~mm}$. 
it is present halfway around the tusk and evidently continued all around it. At its upper border it is $1.5 \mathrm{~mm}$. thick. Patches of it are seen on the dentine $90 \mathrm{~mm}$. above the tip. On one side of the fragment, toward the left when the tusk is held with the concave face upward and the tip away from the observer, is a channel $10 \mathrm{~mm}$. or more wide and as much as $1.5 \mathrm{~mm}$. deep. Beneath the enamel everywhere the dentine presents the usual ridges and grooves. That the covering described is enamel and not the usual outer layer of dense dentine is indicated by its highly polished surface, by its hardness, and by its structure. It is with difficulty scratched by a point of steel. The dentine is far softer. It is impossible at present to assign the possessor of this tusk to its proper place in the system.

As to the stage of the Pleistocene to which these fossils (except $B$. bison) belong, the presence of a horse, the Taurotragus, and an extinct bison, is compatible with a reference to the Sangamon stage. The list may be compared with that of the species found at Alton, Illinois (Hay, Pleistocene of N. A., east of Miss. R., 1923, p. 339). On page 29 is given an account by Albert Koch of the discovery of mastodon bones somewhere along Bourbeuse Creek in Gasconade County. All of that account which can be relied on is probably the statement that mastodon remains were met with. On page 31 is noted the finding of a tooth of Mammut americanum somewhere near Fertile, Washington County. It was discovered at a depth of 18 feet, evidently in a yellow sandy clay. The stage to which it belonged can not be determined.

On page 180 is recorded the discovery of a part of a skull of Symbos cavifrons somewhere near Cape Girardeau. It is impossible to determine the Pleistocene stage during which this skull became entombed, but the probability is that it was in late Pleistocene time. On page 179 the occurrence of Symbos cavifrons somewhere in the vicinity of New Madrid, New Madrid County, is noted and its age is discussed. It may be as old as the Illinoian glacial stage or as recent as the Wisconsin. On page 109 is mentioned the finding of elephant teeth, about 1820, 3 miles below New Madrid. At that time the announcement was of more value than at present. On page 31 is reported the occurrence of mastodon teeth at Arrowrock, Saline County. It is impossible to determine the stage during which this individual mastodon lived. It seems possible that it was as early as the Aftonian or as late as the close of the Wisconsin. On page 31 mention is made of some mastodon remains which were found many years ago on Blackwater Creek, near the mouth of Ferris Creek in Saline County. One can not, from the information given, determine the Pleistocene stage to which these remains belonged. The recording of the location is exact enough that a geologist, at some time, might determine the age of the deposit; or other species might be found there which would solve the problem.

The discovery of a skull of Symbos cavifrons at Wellington, Lafayette County, is reported on page 181. On page 32 is noted the finding of teeth of Mammut americanum in the loess of Kansas City. On page 192 is reported the discovery of a tooth of a probably extinct species of Bison in the loess. The occurrence of the mastodon and of a bison in the late Iowan stage or in the Peorian appears thus to be established. 
On page 69 is reported the finding of a tooth of probably Elephas columbi at a point about 30 miles southeast of Kansas City in Jackson County. The geological age of this specimen can not be determined from the information furnished. The discovery, by Broadhead, the geologist, of a tooth of probably an extinct bison at Pleasant Hill, Cass County, is mentioned on page 192. The Pleistocene stage to which the animal belonged can not be determined from the information conveyed; possibly in the future some geologist may be able to identify the age of the gravels.

In the University of Missouri, at Columbia, is a fine collection of mastodon bones, which were discovered in the winter of 1879 and 1880 about 4 miles southeast of Sedalia (p. 29). No other species were discovered, so far as the present writer knows. No facts are known which help in determining the Pleistocene stage when these mastodons lived; possibly further search might furnish some species which would decide the case. On page 25 is given an account of the discovery, at various times, of mastodon bones and teeth near Avery, Hickory County, on Pomme de Terre River.

Harlan reported that in the Koch collection were more than 300 mastodon

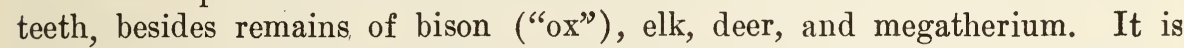
extremely doubtful that so many mastodon teeth were found at this locality; most of them had probably been secured elsewhere. Both Harlan (Amer. Jour. Sci., vol. xLIV) and Leidy (Smithson. Cont. Knowl., vol. vir, art. 3, p. 48) believed that Mylodon harlani had been collected on the Pomme de Terre. Leidy had nothing to say about the megatherium which Harlan said was in the collection, and the specimen may have belonged to some other animal. The deer, the elk, and the bison may well enough have been secured in the Missouri locality. As to the Pleistocene stage to which the remains belonged one must be uncertain. The Mylodon appears to indicate a pre-Wisconsin time. If Megatherium had really been obtained there the present writer would be inclined to refer the deposit to the Aftonian.

On page 28 is detailed the finding of mastodon remains at a point on Osage River which the writer has been informed is near Tackner. Besides the mastodon, there have been reported Symbos cavifrons (p. 180), Elephas columbi (p. 69), Platygonus compressus (p. 15\%), and Equus (p. 139). The securing of horse remains indicates that the deposits, or some of them, belong to a pre-Wisconsin stage, possibly as early as the Aftonian. It is probable that further explorations along the Osage in that region would result in the discovery of still other species. On page 25 is mentioned the discovery of tusks of a proboscidean near Springfield, Greene County. While referred provisionally to the mastodon they may have belonged to some of the elephants. On page 138 is given what is known about the discovery of a tooth of an undetermined species of Equus near Papinsville. Considering the depth at which the tooth was buried and the character of the deposits, likewise the fact that the locality is not far from places in Oklahoma where Aftonian deposits appear to be present, we seem to be justified in concluding that this individual horse lived during the first interglacial stage. On page 25 is mention of a tusk, supposed to be that of a mastodon, which was found in gravel somewhere about Papinsville. The known facts regarding the deposit containing the tusk are too meager to permit a decision regarding its place in the Pleistocene. On 
page 29 is a statement regarding the finding of a tooth of a mastodon at Osceola, St. Clair County. 'The Pleistocene stage can not, at present at least, be determined. 'Three species of mammals have been found in what appears to have been a cave in limestone near Joplin, Jasper County. 'The species are Elephas columbi (p. 69), Mammut americanum (p. 24), and Bison sp. extinct (p. 191). The conditions in which they occurred appear to indicate an early Pleistocene stage. On page $2 t$ is presented an account of the finding of a mastodon skeleton near Galena, Stone County. It seems probable that the deposits containing the remains belong to an early Pleistocene stage.

\section{KANSAS.}

Much remains to be done on the geology of Kansas; and this is especially true of the Pleistocene. The distribution, the composition, and the divisions of the deposits of this epoch are therefore imperfectly known. They overlie a great variety of older formations. A geological map of the State showing well the formations which underlie the Pleistocene deposits is found in Watersupply Paper 273 of the U. S. Geological Survey, by Horace N. Parker. The map forms plate $\mathrm{I}$. The older formations are not everywhere concealed by Pleistocene deposits. For illustration of this statement see Robert Hay in his Geology of Southwestern Kansas (Bull. No. 57, U. S. Geol. Surv., pl. II; Bull. Geol. Soc. Amer., vol. III, p. 519).

A formation often mentioned in palæontological literature, is that called by Cope the Equus beds; later by Scott, the Sheridan formation. It was described by Cope (Amer. Naturalist, vol. xxix, pp. 593-599) as occupying the Plains region from Mexico to the Dakotas; also parts of Oregon, Nevada, and Washington. He stated that the most eastern station was in western Nebraska. Although the name Equus beds was applied because of the frequency of remains of horses, Cope (Geol. Surv. Texas, vol. IV, p. 70) thought that they are always to be distinguished by the presence of Elephas primigenius. Under this name he included the species now called $E$. columbi, E. boreus and $E$. imperator.

In western Kansas the Equus beds are regarded as occupying the high country between the main water courses (Darton, Profess. Paper No. 32, p. 155). Darton defines them as consisting of sands and sandy clays; while the loess, composed of fine sandy loam of a pale brownish-buff color is regarded as overlying it. Probably the two deposits are not always to be distinguished; the loess appears to be the more important of the two. Darton expresses the Quaternary stratigraphy as follows: Sand hills, alluvium, loess, Equus beds.

Robert Hay (Bull. 57 U. S. Geol. Surv., p. 35) gives as the average thickness of the loess on the high lands, as shown by wells which penetrate it, from 100 to 180 feet. Probably the average thickness is less, as in Nebraska, where it arerages from 40 to 50 feet (Emmons, Monogr., xxvir, U. S. Geol. Surv., p. 26t). In eastern Colorado the average thickness is given as about 125 feet. From the higher lands of Kansas this loess may be followed down the slopes, even to the river valleys. In the middle and eastern parts of the State there are, especially along the larger streams, abundant deposits of loess. For example, at Fort Riley (R. Hay, Bull. 137 U. S. Geol. Surv., p. 12) the bluffs of Republican River are capped by loess and this extends back on the 
highlands. In the valley of Kansas River at this place the loess is overlain by alluvium.

'The origin of the loess of the Equus beds has perhaps not been wholly agreed upon; but it is now generally believed to be composed of fine wind-swept sand and dust, which have been mostly blown up from the dried mud banks along the streams. Doubtless some of it has been blown from regions farther west.

The most complete account that we have of any Equus beds in Kansas has been given by Haworth and Beede (Univ. Kansas Geol. Surv., vol. II, pp. 285-296) and by Beede (Trans. Kansas Acad. Sci., vol. XI, pp. 104-110, pls. II, III, VI). In these papers is described a formation covering about 800 square miles in McPherson, Marion, Harvey, and Reno Counties. The deposits consist of alternating layers of clay and sand, with a stratum of volcanic ash in a part of the northern area. Near the bottom is a layer of waterbearing gravel. At McPherson this stratum lies at a depth of 150 or more feet. These materials are laid down in a deep and wide channel which had been carved out of the Permian shales and Dakota sandstones. They were deposited by running water, but it is not yet decided where the stream originated and emptied.

As already stated, Cope held that the Equus beds might be recognized by the presence of Elephas primigenius, under which name he included the species $E$. columbi and $E$. boreus. Inasmuch, however, as these species existed in our country from the Aftonian to post-Wisconsin times, the test is not applicable. Not even the presence of remains of horses serves to differentiate the Equus beds; for species of the genus Equus continue from the Nebraskan to the Sangamon, possibly to the Peorian.

Opinions have differed as to the age of the Equus beds. Cope (as cited above) appears to have thought they belonged to the middle part of the Pleistocene, being pre-Champlain. That would relegate them to a time after the Glacial stages. Williston held the view that the Equus fauna existed during a time of depression which marked the Champlain and that this was during late Pleistocene time. Osborn (Age of Mammals, p. 454) concluded "that the so-called Equus zone faunas in different localities are not synchronous but represent an enormously long period of time, some of early and some of mid-Pleistocene age." He accordingly divided the "Equus zone" into (1) early phases and (2) late phases. It is probable that even on the high plains there are deposits which belong to very different stages of the Pleistocene; Scott took as the type of his Sheridan beds those found in Sheridan County, Nebraska, and especially the fossil-bearing sands in the region south of Hay Springs along Niobrara River. These show by their fossils and by the fact that farther north they pass beneath what is probably Kansan drift that they belong to early Pleistocene. They appear to be equivalent to Aftonian. The use of the name Equus beds ought to be abandoned.

Knowledge regarding the geology of the northeastern portion of Kansas is furnished principally by the late Professor James E. Todd. He devoted his attention especially to the origin and distribution of the drift sheets. Reference may be made to papers published in the Transactions of the Kansas Academy of Science, volume XxII, pp. 10\%-110, and in volumes xxIII and xxiv. More recently, 1918, appeared (Trans. Kan. Acad. Sci., vol. xxvirr, 
pp. 33-47, map 1; 187-203, maps 2-4) Todd's interesting summary of the glacial geology of northeastern Ḱansas.

In the northeastern corner of the State is a considerable area covered by Kansan drift. In general, this area is bounded on the south by Kansas River; on the west by Big Blue. Doubtless at some points it will be found that the Kansas glacial ice extended somewhat beyond these rivers. Robert Hay reported (Bull. 137, U. S. Geol. Surv., p. 25) that glacial boulders were found near Junction City. In 1892 (8th Bienn. Rep. Kan. Board Agricult.) he placed the limit of the drift just north of Wakarusa Creek. Todd (Trans. Kansas Acad. Sci., vols. Xxil-Xxir, p. 211) has shown that the Kansan ice at one time dammed the course of Kansas River and compelled the water to discharge through Wakarusa Creek. In 1922 (Pan-Amer. Geologist, rol. xxviII, pp. 378-382) Schoewe reported deposits of drift at a point some miles south of Robert Hay's line. It has not yet been shown that the Kansan drift sheet, in Kansas, is underlain by the earlier Nebraskan. In consideration of the finding of Equus laurentius near Lawrence, the writer believes that in the valleys of the Kansas River and Wakarusa there exist deposits of Aftonian age.

Brief reference will be made to the Pleistocene vertebrates which have been found in Kansas and to the localities where discovered, with citations of pages where fuller information is furnished. So far as the writer knows, such fossils have been found in about 40 counties. In several cases a number of species have occurred together.

Near Palermo, Doniphan County, have been discovered the following species: Equus niobrarensis (p. 140), Elephas columbi (p. 69), Mammut americanum (p. 34). The locality is in township 4 south, range 21 east. The last two species are not distinctive, for they occur also in the post-Wisconsin; but Equus niobrarensis is known only from the Sheridan and its equiralent, the Aftonian. Professor J. E. Todd made the bare statement that a mammoth has been found near Hiawatha, Brown County (p. 110), and a bison (p. 193) near Atchison, Atchison County. It appears to be implied that the remains occurred in Aftonian deposits. Near Millwood, Leavenworth County, a shull of Bison bison (p. 204) was discovered many years ago. There is no indication of any considerable geological age. At North Lawrence, Jefferson County, along Kansas River, after freshets, the following species were collected: Equus laurentius (p. 34), Bison occidentalis (p. 193), B. bison (p. 203), Cervus canadensis (p. 173), Odocoileus virginianus? (p. 171), Smilodon?, sp. indet. Near Argonia, Sumner County, were found teeth of Elephas columbi (p. 71).

The horse and the supposed Smilodon indicate Aftonian age. Bison occidentalis may have lived later. The others may be Recent or late Pleistocene.

On the opposite side of Kansas River, on Wakarusa Creek, Douglas Countr, have been collected the following species: Mammut progenium (p. 33), Bison bison (p. 203), Cercus canadensis (p. 174), and Antilocapra americanna. The last three species were believed by the finders to have been buried in deposits of late origin, probably of the Recent period. The mastodon jaw was supposed to have been fossilized and to have been carried by running water into the Recent deposits. It could not have been transported far without injury; 
and even if the clay in which it was lying is not of Pleistocene age, such deposits must exist not far away. The jaw is referred to $M$. progenium because of the large lower tusks. The type of the species is from the Aftonian of Iowa; but the species occurs in deposits overlying the Wisconsin drift (Hay, Pleistocene N. A., etc., 1923, p. 10\%).

Near Seneca, Nemaha County, have been discovered remains of a mylodon, probably Mylodon harlani (p. 5). At St. George, Pottawatomie County, a tooth of Elephas boreus was found (p. 48). Near Marysville, Marshall County, many years ago was discovered a tooth of a horse, Equus complicatus (p. 140). Along Blue River, apparently near Manhattan, Riley County, was collected the horn-core which form sthe type of Bison alleni (p. 193). In the vicinity of Minneapolis, Ottawa County, was discovered a tooth of Equus complicatus (p. 141). A tooth of a mastodon has been reported from Jewell County ( $p$. 35). Near Osawatomie, Miami County, a jaw of a mastodon containing teeth was discovered (p. 33). In Eight-mile Creek, Franklin County, were found remains of mastodons (p. 33). At Ottawa were collected remains of Elephas columbi; also near Rantoul (p. 70). At Ottawa many bones and some teeth of an unidentified elephant (p. 110) were found in a well. Near Boicourt, Linn County, was secured a skull of Castoroides (p. 210); it forms the type of $C$. kansenis Martin. In Bourbon County, mastodon teeth (. . 33) were collected somewhere in Little Osage River, and remains of Elephas columbi (p. 70) near Hammond. In Cherokee County, Crawford township, a skeleton of a bison, possibly of an extinct species, was found in the bank of Republican River (p. 192). A bone of another bison was found at Oswego, Labette County (p. 192). Near Buffalo, Wilson County, fine jaws and teeth of Mammut americanum were found (p. 33). In Coffey County were secured, at Burlington, a lower jaw of a species of bison (p. 192) and a tooth of Elephas columbi (p. 70 ), and at Leroy a bone of a camel, probably a species of Camelops (p. 165), which appears to indicate the presence of Aftonian deposits there. Near Emporia, Lyon County, was found a mastodon tooth (p. 33). In Cowley County remains of Elephas columbi have been collected at Arkansas City (p. 70). From Sumner County, near Argonia, have been collected teeth referred to Elephas columbi (p. 71). From McPherson County, mostly from near McPherson, have been obtained the following species: Megalonyx leidyi (p. 5), Equus complicatus? (p. 141), Camelops? sp. indet. (p. 165), Bison sp. indet. (p. 194), Anancus mirificus (p. 35), Elephas columbi (p. 71).

The presence of camel and of Anancus mirificus remains appears alone to establish the early Pleistocene age of the beds. McPherson is one of the localities selected by Osborn (Age of Mammals, p. 461) to illustrate late phases of the Equus zone.

From near Wilson, Ellsworth County, have been secured a part of a skull believed to belong to Symbos cavifrons (p. 181). Rush Center, Rush County, has furnished a tooth which belongs either to Elephas columbi or E. imperator (p. 111). Near Ellis, Ellis County, were found remains supposed to belong to Bison occidentalis (p. 194). Near Ness City, Ness County, was collected a lower jaw believed to belong to Elephas imperator (p. 95). The presence of early Pleistocene is indicated. The type skull of Bison regius was found near Hoxie, Sheridan County (p. 194). From the "elephant bed," about 7 miles 
northeast of Pendennis, Iane County, have been obtained the following marnmals: Equus niobrarensis (p. 142), Camelops? sp. indet. (p. 165), Elephas boreus (p. 48), E. columbi (p. 71), Canis occidentalis?

The horse and the camel remains appear to establish the Sheridan age of the deposits.

T'welve-mile Creek, Logan County.-The following species were found at the mouth of Twelve-mile Creek or not far from it: Camelops?, sp. indet. (p. 165), Equus laurentius (p. 143), Bison occidentalis (p. 194), Canis occidentalis?, Canis, sp. indet, Taxidea taxus?.

The deposits furnishing these fossils certainly belong to the Sheridan beds. From Russell Springs, in the same county, have been reported camel remains (p. 165), Bison bison (p. 204), and Elephas of undetermined species (p. 111). Along Republican River, Cheyenne County, were exhumed remains of a probably extinct bison (p. 195). Not far from Goodland, Sherman County, were obtained skeletons of the peccary, Platygonus leptorhinus Williston (p. 158). The depth at which they were buried, 9 feet, appears to indicate an age earlier than late Pleistocene. Near Sharon Springs, Wallace County, was found a tooth of Elephas columbi (p. 72). From Wellington, Sumner County, have been reported Elephas imperator (p. 95) and Bison alleni (p. 193). These appear to indicate Sheridan, or Aftonian, times. Near Hutchinson, Reno County, was found a part of a tooth of Elephas columbi (p. 71). In the vicinity of Attica, Harper County, in the "earlier gravels," was discovered teeth of an undetermined species of Elephas (p. 110). Another undetermined elephant has been reported from Medicine Lodge, Barber County (p. 110). Teeth of an undetermined horse have been reported from Kiowa Creek, Comanche County (p. 142).

Clark and Meade Counties may be considered together. For our knowledge of the vertebrates found here and for the geology, we are indebted mostly to Dr. F. W. Cragin. The following species are noted in his collection (Hay, Kansas Univ. Bull., vol. x, pp. 31-34) :

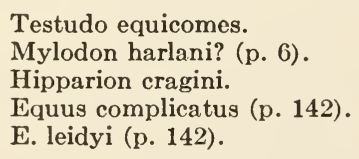

The hipparion and the camel suffice to determine the early Pleistocene age of the beds; the other species support the conclusion. The species of Mylorion was referred by Cragin to Megalonyx, but the teeth are those of a mylodon, probably Mylodon harlani.

In a survey of later geological formations in Clark and Meade Counties, Cragin recognized three terranes, all of which he regarded as parts of the Equus beds of Cope. The lowermost of these was the Kingsdown marls, named from the town of Kingsdown, in Ford County, a station on the Rock Island Railroad. Vanhem no longer appears on the maps, but was probably in the northern part of Clark County. In this county the marls attain a thickness of 100 feet and more than twice that thickness at certain localities on the divides westward. These marls are said to be rarely fossiliferous. The second member of the series named by Cragin is the Pearlette, consisting of 
deposits of volcanic ash. In Meade County, near Meade Center, the bed is said to attain a thickness of 13 feet. It occurs also in Clark County. 'The Pearlette rarely contains fossils and, when found, they do not differ from those of the underlying Meade formation. The Meade gravels have for their type locality Meade Center, Meade County. Cragin stated that the gravels are mostly unconsolidated, but frequently contain hard ledges. They vary in thickness from 10 to 40 feet.

\section{COLORADO.}

As is well known, Colorado is made up of two very different regions. The eastern two-fifths consists of the high dry plains, sloping toward the east and drained by the South Platte and Arkansas Rivers. 'The affluents of these rivers are rather unimportant streams. The western three-fifths presents a tangle of high mountain ranges, in which arise rivers flowing in deep canyons and emptying into the Gulf of Mexico on one side and into the Gulf of California on the other. As regards Pleistocene vertebrate palæontology neither of these regions has, up to the present time, proved to be of great importance. It is a very narrow strip lying between these two regions that has furnished the greater part of the Pleistocene vertebrate remains.

The plains region is to a great extent covered with a layer of loess. However, the writer is assured by geologists that the loess is found mostly along the rivers, and that deposits of gravel are common on the highlands. At present the best description of this deposit in Colorado is that of Dr. S. F. Enımons (Monog. Xxvir, U. S. Geol. Surv., 1896, pp. 261-269). The loess is found at levels below 5,800 feet, and it extends eastward and northward into Kansas and Nebraska. The deposit thickens eastward to the State line, where it may reach 225 feet (Emmons, loc. cit. p. 264). Near the Front Range its thickness is greatly reduced, being nowhere more than 40 feet, and usually less. As regards its composition it appears to contain less argillaceous and more calcareous material as the distance from the mountains increases. The color changes in the same direction from ash-brown or reddish-buff at Denver to light buff or colorless on the Plains. The size of the component grains of sand diminishes from $1 \mathrm{~mm}$. at the west to about $0.1 \mathrm{~mm}$. at the eastern border; but much of the loess is still finer. Emmons discussed the origin of the loess on his pages 274 to 278 ; and he was inclined to attribute it to deposition of fine materials in widely extended lakes of quiet fresh water. Nevertheless, he recognized the difficulties that oppose themselves to this theory. To the present writer it appears more probable that by far the greater part of it is composed of wind-blown sand and dust.

Extremely few remains of vertebrate animals have been found in the loess of Colorado. Emmons (op. cit., p. 264) mentions a number of species, but all of these were found near Denver. These will be considered on page 274 . At Old Fort Lyon, in Bent County, about 1872 (Amer. Jour. Sci., ser. 3, vol. III, pp. 302, 373), Messrs. Berthoud and Woodhull found and excavated a tusk of a proboscidean, whether of an elephant or of a mastodon is uncertain; but this was within a few yards of Arkansas River and the tusk may have been buried in river alluvium. About 1875, Mr. N. M. Tabor, of Denver, discovered and placed in the collection of the State Historical and Natural His- 
tory Society, a tootl of a mastodon which he had found about 15 miles northeast of Pueblo; but no record was left of the exact locality and the character of the deposit. 'The tooth may have been buried in alluvial deposits along Chico Creek or some of its branches. The writer knows of no other vertebrate fossils that have been found in the Pleistocene of the high plains of Colorado, beyond a few miles away from the Front Range. If the loess had been deposited in shallow lakes, one would expect to find some remains of freshwater mollusks and bones of fishes; but none are known. If we suppose that the loess deposit was built up slowly by fine wind-blown dust it is not difficult to understand why bones and teeth are wanting, since skeletons lying exposed on the surface are almost certain to perish within a few years. Without doubt all this region throughout the whole of Pleistocene time was the home of many species of vertebrates.

The mountainous area of Colorado has been the subject of much more active exploration than the eastern part of the State. This has been because of the more interesting and intricate geography and topography of the region, the necessity of finding routes for wagon roads and railroads, the search for valuable minerals, the study of the geology, and the desire to know the character of the animals and plants, living and extinct. The region is noted for its peaks, which rise to a height of 14,000 feet or more, and for its deep gorges. Although lying far south of the limit of continental glacier sheets, there existed local glaciers. These prevailed at an earlier and at a later epoch; but they have not yet been synchronized with the continental ice sheets. Inasmuch as no vertebrate fossils have been found in these glacial deposits or between them, they do not require attention here. In a region where denudation has greatly exceeded deposition, few Pleistocene fossils are to be expected and these only along stream courses where alluvium has been laid down, or possibly in caves and fissures.

The attention of the reader may be called to a paper published in 1912 (Jour. Geol., vol. xx, pp. 385-409) by Atwood and Mather. The title is "The evidence of three distinct glacial epochs in the Pleistocene history of the San Juan Mountains, Colorado." Two glacial epochs had previously been recognized in several of our western mountain groups. In the San Juan Mountains, Atwood and Mather discovered evidence of a glacial stage far older than those previously known. Remnants of its deposits now lie from 1,000 to 2,000 feet above the present streams and extend several miles beyond the mountains. They lie on the divides between the present drainage channels, and on hills isolated from the mountains by deep canyons. Details can not be given here, but it would be a matter of the highest interest if vertebrate fossils could be found in any outwash deposits that may yet exist high above the streams of the region.

Well toward the western part of the State, at South Canyon, near Glenwood Springs, were discorered some years ago a humerus of an extinct species of bison (p. 196), a part of a tooth of Elephas imperator (p. 97), and a much worn tooth of a horse (p. 145). These were found in making a tramway in gravel about half a mile up the canyon and at a depth of about 8 feet. The presence of Elephas imperator indicates a geological time about that of the Aftonian and of the Equus beds of the plains. The horse and the bison do 
not contradict this conclusion. A tooth of Elephas columbi (p. 74) was found many years ago along Bear Creek, near Hayden, Routt County; but nothing is known about the nature of the deposit in which it was buried.

Not until we near or pass the Front Range do we learn of the discovery of additional vertebrate fossils. Some years ago 3 teeth of a camel (p. 167) were found in a well at the depth of between 15 and 25 feet, in Custer County, within the limits of the town of West Cliff. These teeth were probably buried in an early Pleistocene alluvium. Nearby, in the vicinity of Silver Cliff, were found, in 1898, 4 teeth of the early Pleistocene horse Equus laurentius (p. 144). The animals are indicative of early Pleistocene and not of a later time.

By far the larger number of vertebrate fossils of the Pleistocene liave been found in a narrow strip which runs north and south across the State, between the Plains on the east and the mountains on the west. The strip is prohably only about 15 miles wide and may reach into the Plains on one side and the mountains on the other. South of Pueblo this strip is crossed by Arkansas River and its affluents coming down from the mountains. North of Pueblo, Fountain Creek flows southward after leaving the mountains at Colorado Springs. From this city the strip follows along Monument Creek to the northern border of El Paso County. Here the drainage is taken up by Plum Creek, then by South Platte River and carried northward until this river suddenly turns eastward at Greeley. North of this town the strip includes the lower part of Big Thompson, Cache de Poudre, and Long Creeks.

Somewhere in Huerfano County, along Muddy Creek, a branch of Huerfano River, was found a part of the camel (p. 166) which was described by Professor F. W. Cragin. This is now known as Camelops huerfanensis. With it was found a fossil tooth of a horse (p. 143). From Rouse, in the same county, there are in the U. S. National Museum 4 teeth of Equus laurentius (p. 143). At Laveta, in Huerfano County, was found a palate of the elephant Elephas imperator (p. 96). At Walsenburg was discovered a fine skull of Mylodon harlani (p. 6). All of these belong to the early Pleistocene fauna.

El Paso County has furnished a considerable number of species of fossil vertebrates. At Callan, in the northeastern corner of the county, a metatarsal bone of a horse was found at a depth of 60 feet (p. 144). At Colorado Springs there have been collected Elephas imperator (p. 96), an undetermined species of a horse (p. 114), a metatarsal bone of a camel (p. 166), a musk-ox (p. 182), possibly Ovibos, some fragments of bones of Bison (p. 195), and a bone of a deer-like animal. All, except the elephant, had been discovered in gravel pits. In Colorado City, just west of Colorado Springs, a tooth of Elephas columbi (p. 72) was found along a creek at a depth of 8 feet. A few miles further west, in a cave near Manitou, was discovered a tooth of a horse ( $p$. 144) and a bone of a goat-like antelope, regarded as Ncemorhedus.

In Douglas County, fossil vertebrates have been discovered in several places. As reported by Dr. G. P. Richardson (U. S. Geol. Surv. Folio 198), a tooth of Elephas columbi (p. 73) was found half a mile west of Cherry Creek near Parker. We can not be certain of the geological age of the tooth from our knowledge of the alluvium or of the species. In a tunnel, at Newlin Gulch, were found some vertebræ of a species of bison (p. 195) probably extinct. Near the Isone Tree schoolhouse, not far from Dawson Butte, were found 
tusks and teeth of an unidentified elephant (p. 111). Somewhere near Palmer or Husted was found a tooth of Elephas columbi (p. 73). Other remains have been discovered in the county, but details regarding them are wanting. In Elbert County, a few vertebræ of an elephant (p. 72) were found in the banks of Running Creek, 4 miles southwest of the town of Elbert. All that can be concluded from this discovery is that there is some kind of Pleistocene deposit along that creek. The jaw of a young horse (p. 144) has been found at some undesignated locality in the same county, at a depth of 25 feet. It is unfortunate that no details of the discovery have been left on record.

At Denver have been found remains of horses (p. 145), extinct bisons ( $p$. 195), Elephas columbi (p. 73), E. imperator (p. 96) and Camelops huerfanensis (p. 166), besides remains of smaller animals; but the latter, mostly rodents, may have been intrusions of recent species into the deposits. Teeth of $E$. columbi have been found in gravel pits, in one case at a depth of 25 or 30 feet. Another tooth was found in gravel in the construction of the Alameda Street subway. Professor George L. Cannon sent bones and teeth of horses, camels, and bisons to the U. S. National Museum which are understood to have been found in Pleistocene so-called loess deposits along Platte River (Hay, Proc. U. S. Nat. Mus., vol. LIx, p. 599). Emmons (see p. 599 Monogr. U. S. Geol. Surv., vol. xxxviI, p. 264) reported parts of six or more skeletons of horses that had been found in the loess. Elephas imperator appears to have been found in or close to the city. In Arapahoe County remains of an unidentified elephant (p. 112) were found near Melvin in the bed of Cherry Creek, and a tooth of a horse (p. 144) about 3 miles northeast of Littleton. It was taken from a gravel formation 25 feet from the surface.

Two miles north of Golden, in Jefferson County, have been found 2 teeth of Elephas columbi (p. 74 ); 5 miles above Golden, on Clear Creek, a tusk supposed to belong to an elephant, and a tooth of a mastodon (p. 35) found in Quaternary gravel at or near the town. Details are rather meager. At Gold Hill, near Boulder, at a depth of 3 feet, some teeth of a bison ( $p$. 204) have been found. These are possibly those of the existing bison, but one can not be certain. At Lovers Hill a tooth of Elephas imperator (p. 97 ) was discovered; but under what conditions is not known.

In Larimer County fossil vertebrate remains have been discovered at three places. At Longmont* a tooth referred to Equus complicatus (p. 145) was found in gravel at a depth of 15 or 20 feet. This indicates a Pleistocene not later than the Sangamon interglacial, but probably earlier. Two miles north of Wellington, were found two teeth of a bison (p. 204) which appear not to differ from the existing bison; but also they are not to be distinguished from those of some of the early Pleistocene species. It is not known at what depth they were found; consequently the deposit throws no light on the identity of the species, nor the species on the age of the deposit. At Fort Collins, one mile due east of the college, in gravel, at a depth of 15 feet, were found teeth of Elephas imperator (p. 74) and E. columbi (p. 97). The first mentioned species is regarded as indicative of early Pleistocene.

At Greeley, Weld County, there were collected within the limits of the town teeth of Elephas columbi (p. 74) and Equus complicatus (p. 145). Both

* An error. Longmont is in Boulder County. 
species were buried in gravel, those of the horse at a depth of 19 feet. Somewhere along Big Thompson Creek, either in Weld or in Larimer County, was found a tooth of Elephas columbi (p. 74); but it appears to have been lying in loose sand.

So far as the writer knows the following list covers the species of vertebrates found in the Pleistocene of Colorado up to the present time:

Mylodon harlani.

Elephas columbi.

E. imperator.

Mammut americanum.

Equus complicatus.

E. laurentius.
Camelops huerfanensis.

Ovibos? sp. indet.

Bison bison?.

B. sp. extinct.

Naemorhedus palmeri.

Of these it is possible that the remains identified as Bison bison? are really those of some extinct species, and should be left out of consideration. The species of most importance are the first seven of the list; all of these, except Equus laurentius, have been found in the strip already referred to. Of the other six species, Elephas columbi and Mammut americanum may also be ignored, because they existed during the whole known Pleistocene. Elephas imperator and Camelops are known from only the early Pleistocene, while Equus complicatus and Mylodon harlani are known from the Aftonian, the so-called Equus beds, and the Sangamon interglacial of other regions. It appears certain, therefore, that the deposits in which are found not only Elephas imperator and Camelops huerfanensis and whatever other camels may be represented there, but also the whole list given above, except possibly Bison bison? belong to that fauna which has been known as that of the Equus beds. The remains found in the few localities in the mountain region may safely be referred to the same stage of the Pleistocene. Silver Cliff has furnished Equus laurentius (p. 144), an Aftonian species, and West Cliff, not far away, has given a camel (p. 16\%). Glenwood Springs, Garfield County, has contributed Elephas imperator (p. 9\%). It is possible of course, that those localities which have furnished only Mylodon harlani, Elephas columbi, Mammut americanum, Equus complicatus, and the bisons are of somewhat later date; but this is doubtful.

At Denver, where camels, horses, and elephants have been found, some occur in what has been called loess, and this loess has been supposed to cover much of the Plains region and to connect with the loess along the Missouri and Mississippi Rivers. Now, the loess deposits along these rivers and that covering much of the State of Iowa are referred to the Sangamon and later interglacial stages. The loess of the Denver region, if loess, must be much older. To the writer it seems most probable that it is a fine alluvium which was laid down during a period of depression and of full and sluggish rivers. This followed the time of elevation which gave rise to the cutting of canyons and gorges in the mountains. Since that time of depression there has been some elevation and a removal of some of the fluvatile deposit.

IOWA.

As regards the geology and the vertebrate palæontology of the Pleistocene epoch, Iowa is one of the most interesting States of North America. Within its limits are found beds of till laid down by all five of the glacial stages. There are likewise deposits belonging to all of the four interglacial stages, the Af- 
tonian, the Yarmouth, the Sangamon, and the Peorian. Excepting a narrow strip in the northeastern rorner of the State, extending southward along Mississippi River into the northern part of Jackson County, the whole of the State has been subjected to glacial action. 'The strip referrel to forms a part of the Driftless Area (Geol. Surv. Iowa, xxvi, pl. XIv). Furthermore, the glacial drift in Iowa has been laid down on various older deposits, those of the Palæozoic, the Cretaceous, and possibly of some Tertiary. The rocks of all of these ages have had their influence on the composition, the thickness, and the arrangement of the glacial drift. It is proposed to consider briefly the Driftless Area and the character and distribution of the various glacial and interglacial deposits.

\section{The Driftless Area.}

The Driftless Area was long ago (1885) described by Chamberlin and Salisbury (6th Anm. Rep. U. S. Geol. Surv., pp. 199-322, with maps and illustrations). 'The greater part of this region is situated in Wisconisn, but there are, besides the strip in Iowa, a small area in northwestern Illinois and a narrow strip in southeastern Minnesota. It has been subject to the agencies of degradation, such as heat, cold, chemical changes, and the erosive action of running water during at least the latter part of the Tertiary, the Pleistocene, and the Recent. It stands as an illustration of the appearance which the surface of Iowa would now present had it not been for the work of the successive ice-sheets. In this Driftless Area deposition could occur only sparsely along streams and through the action of winds bearing thither the dust which forms the thin mantle of loess. Being thus a region in which deposits were being removed, instead of being laid down, few fossils of any kind are found. Chamberlin and Salisbury present a list of the mollusks found in the loess (thenr page 286), and other lists are found in Folio 200 of the U. S. Geological Survey, prepared by Shaw and Trowbridge. A comparison of the map of the Driftless Region as represented by Chamberlin and Salisbury (op. cit., pl. xxviI) with the one found in Folio 200 of the U. S. Geological Survey, shows that in Iowa glaciai drift has been traced farther east than at the earlier date, thus reducing considerably the width of the strip devoid of drift west of Mississippi River.

Vertebrates are known only from a few localities in the Driftless Area of Iowa. An elephant of undetermined species has been found in Allamakee County. A mastodon has been reported from near Garber, in Clayton County. In Dubuque County have been discovered elephant remains and probably remains of a peccary and of a megalonyx. Details regarding these will be found recorded on their proper pages.

\section{The Nebraskan Giacial Stage.}

This, so far as known, is the earliest glacial stage and its till the first product of the Age of Ice. Unlike the similar deposits of the succeeding glacial stages, the Nebraskan drift is almost everywhere overlain by more recent deposits and in Iowa is detected only where streams have cut through the later drifts, or in railroad cuts, or in wells and other excarations. How widely in North America this earliest drift is distributed is not yet known. A thin sheet of old drift in New Jersey, the Jerseyan, and others in Pennsylvania, 
south of the Wisconsin moraine, may be coëval with it, but the correlation has not been established. One can hardly doubt that in Minnesota and northward and north-westward it will be found underlying the later drift sheets.

The identification of the Nebraskan drift depends usually on its relation to the overlying Aftonian, itself a deposit of sands, gravels, old soils, and peatbeds, and on its relation to the Nebraskan gumbotil, a formation to be described below.

The thickness of the Nebraskan drift varies from nothing to perhaps as mucl as 200 feet. Carman (Iowa Geol. Surv, vol. Xxvi, pp. 415 to 416) concluded that in northwestern Iowa the major portion of the 200 or more feet of Pleistocene material is Nebraskan drift. When this drift was laid down the face of the country must have been very uneven and the tendency was toward filling up first the lowlands and valleys. During the Aftonian stage the surface of the Nebraskan undoubtedly underwent more or less erosion and trenching.

The presence of Nebraskan till has been recognized in many places in the eastern, the southwestern, and the western parts of the State. Within a few years, however, doubt has been thrown on the age of certain deposits of till in the counties lying along Missouri River and formerly confidently referred to the Nebraskan. This matter will be discussed below.

An interesting and important discovery has been made by Professor George F. Kay, State Geologist of Iowa. At the top of the Nebraskan till is a tough, sticky, pebbly clay, which has received the popular name of gumbo. This clay has sometimes been regarded as loess. Kay (Iowa Geol. Surv., vol. xxvi, pp. 216-231) and Kay and Pearce (Jour. Geol., vol. xxviri, pp. 89-125) liave shown that it has resulted from the weathering of the upper part of the Nebraskan drift. The lime rocks were dissolved out through the solvent and chemical action of percolating water, while the granites and greenstones were slowly decomposed and carried away. The resultant soil and subsoil have been called by Kay gumbotil. The materials from which were derived the Nebraskan gumbotil were laid down during the Nebraskan glacial stage and they must be taken as evidence of this stage wherever found. On the other hand, the modifications which these materials suffered were the result of chemical and physical changes effected during Aftonian times and are to be regarder as evidence of a long period between the Nebraskan and the Kansan glacial stages. This interval constitutes the Aftonian stage. A similar gumbotil overlies the Kansan and the Illinoian drift sheets. For an opinion in opposition to this explanation of the origin of gumbotil the reader may consult an article by Charles Keyes (Pan-Amer. Geologist, vol. xxxviıI, pp. 403-408).

Remains of animal life are likely only rarely to be buried in any glacial till and few cases, in fact, have been established. For our knowledge of the vertebrates which lived diaring the Nebraskan stage we must depend, mostly at least, on collections made in deposits laid down south of the glaciated region. When found, these may be expected to consist to a considerable extent of remains of genera and species which had persisted from Pliocene times and might therefore be wrongly credited to the Pliocene. With these would be invaders from Asia and South America. The Nebraskan evidently occupied a long lapse of time and must have filled up chronologically and biologically 
a considerable part of the gap between the Blanco, hitherto supposed Middle Pliocene, and the Aftonian, hitherto supposed earliest Pleistocene.

\section{The Aftonian Intergiacial Stage.}

The Aftonian interglacial stage is that which intervened between the $\mathrm{Ne}$ braskan and the Kansan glacial stages. The deposits consist of sand, gravel, silt, old soils, and beds of peat. Nebraskan gumbotil, wherever found, may likewise be taken as evidence of the stage. Usually, of course, these materials overlie the Nebraskan till, but they may repose on older rocks, as those of the Cretaceous or the Palæozoic. Beneath a till, usually the Kansan, in most localities gravels or old soils or deposits containing wood have been discovered.

The investigations of the Iowa Geologist have shown that Aftonian deposits occur over nearly the whole State. Along the Missouri bluffs deposits which have been hitherto regarded as Aftonian are exposed along streams and in railroad cuts and in sand and gravel pits; and in these there have been discovered a rather large mammalian fauna. Professor Bohumil Shimek and the late Dr. Samuel Calvin are to be credited with this discovery. The fossil remains recovered are described on other pages. Unfortunately the specimens are usually fragmentary; nevertheless they indicate sufficiently well the animals to which they belonged. The most important are several species of horses and a hipparion, ground-sloths, camels, mastodons, and elephants, among the latter Elephas imperator. This fauna, as was pointed out by Calvin and Shimek, is equivalent to that found on the Great Plains, especially on Niobrara River, near the post office Peters, Sheridan County. The discovery made by these geologists has been supposed to determine the geological level occupied by the Sheridan County collection, other collections made at Fossil Lake, Oregon, on the Plains of Texas as far as the Gulf of Mexico, around the Gulf to Florida, and north on the Atlantic coast to northern New Jersey. Away from the Missouri Valley hardly any Aftonian vertebrate fossils are found in Iowa. Some bones of Hipparion, believed to belong to the Aftonian, were discovered near Thayer, Union County. In this supposed Aftonian of western Iowa, Shimek brought to light a considerable molluscan fauna consisting of both fresh-water and terrestrial species (Bull. Geol. Soc. Amer., vol. xxI, p. 121). Apparently all are living to-day in Iowa.

Only vegetable materials, mosses, grasses, and forest trees have been found in the Aftonian in the greater part of the State; but they suffice to show that the State was occupied by meadows and forests. In such a land vertebrate animals must have been abundant. During most of the time the climate was not greatly different from that of to-day. With regard to the supposed Aftonian deposits found near Afton, Union County, and in the Counties lying along Missouri River, the opinions of the Iowa geologists, under the leadership of Dr. George F. Kay, have been undergoing a change, which will be observed on reading pages 4 to 6 of volume xxvin of the Iowa Geological Survey, and pages 132 to 133 of volume xxxI of the Bulletin of the Geological Society of America. Again, in 1923, Dr. Kay read a paper before the Geological Society of America, in which he presented the results of his latest investigations. This paper will be found in volume xxxiv of the Bulletin of the Geological Society 
of America. It is necessary here to condense greatly Doctor Kay's latest paper and the reader must consult the original document.

1. In recent field work Doctor Kay has traced the Nebraskan and Kansan tills, separated by gumbotil, peat, and soil zones, as far west as Crawford and Shelby Counties, less than 25 miles from Missouri River. Moreover, he has found, in Council Bluffs, the two drifts, separated by leached Nebraskan till. He regards this discovery as indicating that the two tills extend to Missouri River and probably into Nebraska.

2. He has found that in western Iowa the two tills can not be distinguished by difference in color, texture, lithological composition, or degrees of weathering. It can be done only through the recognition of the gumbotils or of other interglacial materials whose age is known.

3. The sands and gravels of western Iowa hitherto supposed to belong to the Aftonian interglacial are interpreted by Doctor Kay as not a distinctive stratigraphic horizon, but as lenses and irregularly shaped masses of gravels and sands within one or both of the two tills. The gravels and sands are unleached and appear to be of the age of the associated tills.

4. Doctor Kay concludes that the numerous mammals found in the sands and gravels lived in front of an advancing glacier, either the Nebraskan or the Kansan, and were buried in the glacial outwash. Later the glacier overrode and incorporated the fossil-bearing sands and gravels. Whether this advancing glacier was the Nebraskan or the Kansan, or both in succession, can not at present be determined; nor, as a consequence, the exact age of the mammals. Kay grants that the mammals belong certainly to the early Pleistocene, and were associated with the early advance of the Nebraskan ice-sheet, or with that of the Kansan, or with both.

The writer regrets that he can not accept Doctor Kay's opinion that all those animals whose remains have been found in early Pleistocene deposits in western Iowa lived in the immediate vicinity of an ice-sheet and were buried in the till. It is not improbable that the proboscidean Elephas boreus and the musk-ox Symbos did live there and sometimes left their remains in the glacial outwash and escaped pulverization; but this is hardly probable with respect to other species. The writer can not look upon the glacial front as offering a pleasant summer resort where musk-oxen and ground-sloths could browse together in comfort. The acceptance of Doctor Kay's conclusions would not, however, greatly affect the writer's views of the geological age of those mammals. If their bones are entombed in the Kansan drift, their ancestors, hardly different in any way, must have lived in that region during the Aftonian interglacial stage. If those remains are found in the Nebraskan the animals must have been in the region when the Nebraskan glacier arrived. In this case, however, one might expect to find among the fossils more genera and species that lived during the late Pliocene.

The theory held by Doctor Kay and not a few others impels us to consider, not so much the questions whether the animals found in the deposits heretofore called Aftonian could endure a climate a little more or less unfavorable or whether the climate was more or less unfavorable, as it is to determine whether or not the climate was such that it was impossible for them to exist there. No one, the writer believes, will contend that the ma- 
jority of the animals and plants native to western Iowa could live in the aretic and subarctic regions of North America or that the majority of the animals and plants of these northern regions could exist in western Iowa.

It is certain that the distribution of animals and plants is determined largely by climate, especially by temperature. It is equally certain that many animals and plants can endure a wide range of climatic conditions. The bison was formerly distributed from northern Mexico to near the Arctic Circle. The beaver, the muskrat, and the black bear range from the southern states north to the limit of forests. On the other hand, many species of both animals and plants occupy very restricted areas. Many are confined to regions which lie north of the United States; others to our southern States. Sometimes closely related species require very different enviromments. Again, all the species of a genus or of a family may affect a warm habitat; those of other genera and families, one that is cold. Furthermore these peculiarities persist indefinitely, so that, with all freedom for the organisms to occupy new territory having a different climate, the opportunity may be refused. These statements will probably be accepted by all persons concerned.

In the great stretch of country extending from the Arctic Ocean into some of our northern states, there are, besides species of both animals and plants which have a range much further south, numerous species which are restricted to the more northern area. Some of these species are found in similar climates in the Old World; others are known from no other region than that now nourishing them.

Considering the small amount of change undergone by our North American plants and animals since the beginning of the Pleistocene, we may confidently believe that the bulk of those species now living in the region between Hudson Bay and the Rocky Mountains lived at the beginning of the Pleistocene, somewhere in the northern hemisphere. Without doubt, too, many plants and animals at that early time inhabited the central and northern part of British America. It is furthermore very probable that, in general, the same species of animals and plants lived there in the early Pleistocene that live there now, besides others which have since perished.

Now what happened to that northern fauna and flora, when the Nebraskan ice-sheet began to form and to advance southward? Those plants and animals could not live under the glacier or on top of it. Those which did not perish were compelled to move southward in front of the glacier. In order to continue existence the members of both kingdoms were obliged to seek in front of the ice a climate not much different from that in which they had been bred; hence, when the Nebraskan ice-sheet reached its southern limit, there must have been in front of it a belt having an arctic climate and beyond that another belt with a subarctic climate. In these belts lived the plants which had migrated from far north; and the animals lived there which in the far north had subsisted on those plants. There were musk-oxen, the reindeer, the northern elephant, probably ptarmigans, arctic jays, and arctic owls; also a host of arctic fresh-water fishes, and numerous species of insects, many of which must have required its own particular food plant. That these animals and plants did not, in general, become adapted to a temperate climate and remain in their new homes when the glacier retired is shown by the fact that 
they are not there now and that they are in the far north. In some cases certain species both of animals and plants escaped the moderating climate by migrating to the tops of mountains.

If what has just been written is a correct interpretation of events during the Nebraskan stage, it follows that a similar migration and return were made by the animals and plants of the northern regions four or five times, a journey and return for each glacial stage; and now we find that the species which escaped extinction are back in their original homes without having undergone important changes in either form, structure, or habits. Among mammals wlich appear always to have sought a cool or cold climate are the musk-oxell, the reindeer, the moose, the hairy elephant, the arctic fox, and the walrus. However often they have been exiled from the northern regions they have returned thither, unwilling to remain in a warmer climate and a more fertile land.

The writer holds that the reasoning here employed has shown that as each continental ice-sheet advanced there was developed in front of it an arctic climate and beyond this a sub-arctic. Further south and west of these cold belts the climate was cooler than in the same regions to-day, but warmer than near the glacial front; and into these regions the animals loving a temperate climate could escape. Furthermore they moved away from the glacier front, not only because of the lowered temperature, but because they no longer found there their favorite food plants. As to those that left their bones in the gravels of western Iowa the writer believes that they lived there during an interglacial time, not during a glacial. When the gravels of those pits were deposited, the climate was much like it is to-day. This is made probable by the character of the mammals, the elephants, the mastodons, the camels, the horses, and especially the ground sloths; but it is made almost certain by the collections of mollusks made by Doctor Shimek in various gravel and sand pits of that region.

In 1910 Doctor Shimek (Bull. Geol. Soc. Amer., vol. xxi, pp. 119-140) reported the discovery of land or fresh-water mollusks or both in at least five sand and gravel pits in which there were also remains of vertebrates. Mollusks were found in six or more pits, apparently of the same geological age, but in which no bones had been found. In all, Shimek recorded 16 aquatic species and 10 terrestrial species of mollusks from deposits which he and Calvin at that time regarded as belonging to the Aftonian interglacial. In the Elliott pit near Turin, Monona County, were collected horses, camels, elephant, and mastodon, and 20 species of mollusks. On his page 121 Shimek wrote that the mollusks found in these pits are identical with those which inhabit Iowa to-day and the habits of which are definitely known. The evidence then is to the effect that, when those ground sloths, camels, mastodons, elephants, and numerous mollusks inhabited Iowa, there prevailed a temperate climate; and that when the glacial deposits overlying them were being laid down there prevailed an arctic climate.

Glaciologists have, it is believed, usually held the opinion that the advance of an ice sheet was accompanied by a colder climate, resulting in the introduction of boreal species of animals and plants and the retreat of the former occupants of the region. The writer will restrict himself to a quotation from 
Professor Ernst Antevs, a Swedish geologist who has occupied himself with Pleistocene glacial problems. In his paper on The Recession of the last Icesheet in New England (Amer. Geograph. Soc. Research, series No. 11, p. 89) he wrote:

The climate was not arctic, for the melting of the ice in many zones was quite rapid. Since, however, a vast amount of heat was used in the melting of the ice and heating the cold ice-water, the temperature remained comparatively low in a belt off the ice front. The arctic to subarctic zone shifted northward as the ice front withdrew. It doubtless accommodated an arctic and subarctic fauna and flora, about which, however, very little is yet known.

In this connection Professor Antevs mentioned a number of plants which had remained on the summits of mountains.

To sum up in a sentence the writer believes that, with few exceptions, the vertebrate remains found along the Missouri in Iowa, South Dakota, and Nebraska belong to the Aftonian interglacial stage.

\section{The Kansan Glacial Stage.}

The Kansan glacial stage is the name applied to the time of the second glaciation. The ice-sheet which proceeded from the Keewatin center was one of wide extent. The drift laid down by it occupied nearly the whole of Iowa, parts of Missouri, Kansas, Illinois, and Nebraska, and probably the region northward into British America. Probably from the Labradoran center an ice-sheet spread over the east of Canada and our northeastern States a drift of corresponding age, but the correlation has not been definitely determined.

Dr. William C. Alden, who has been investigating the glacial border in North Dakota and Montana, informs the writer that the Kansan drift probably does not extend so far westward as was formerly supposed and as was indicated on the distribution maps used in the writer's volume of 1922 (Carnegie Inst. Wash., Pub. No. 322). From somewhere in South Dakota westward the drift appears to belong to a younger stage. In the present volume it is mapped as Pre-Wisconsin.

In Iowa the Kansan drift appears to have been laid down over the whole of the State, except along Mississippi River in the northeast corner. In the southeast corner of the State, along the Mississippi, the Kansan is overlain by the Illinoian; in the northeast quarter of the State the Kansan is widely overlain by the thin sheat of Iowan. From Minnesota a broad tongue-shaped lobe of Wisconsin drift overlies the Kansan as far south as Des Moines. In addition to these glacial sheets which more or less conceal it, the Kansan drift is covered widely by a deposit of loess. On map 4 is indicated the distribution of that part of the Kansan which is not hidden by younger drift sheets. Since the close of the stage the Kansan drift has suffered weathering and erosion, with the result that where not covered by later deposits the surface is rolling and completely drained. The formation of Kansan gumbotil is discussed below.

One can hardly expect to find fossils in glacial drift, but it is not impossible. Proboscidean remains have been reported, but the deposit may have been misinterpreted. Some wood has been reported. This may have been derived from forests overwhelmed by the advancing glacier. Undoubtedly logs of wood can better resist the abrading and fracturing actions of moving glacial 
ice than can the bones of even large vertebrates. On account of the general lack of fossils we need not deal at length with the Kansan stage; it seems certain, however, that its rigors led to the extinction of many species of vertebrated animals.

\section{The Yarmouth Interglacial Stage.}

The Yarmouth interglacial stage includes the time between the close of the Kansan and the beginning of the Illinoian glacial stage. The type locality is Yarmouth, Des Moines County. A geological section obtained in a well at this place was published by Leverett in 1899 (Monogr. U. S. Geol. Surv., vol. XXXVIII, p. 42). It is here reproduced:

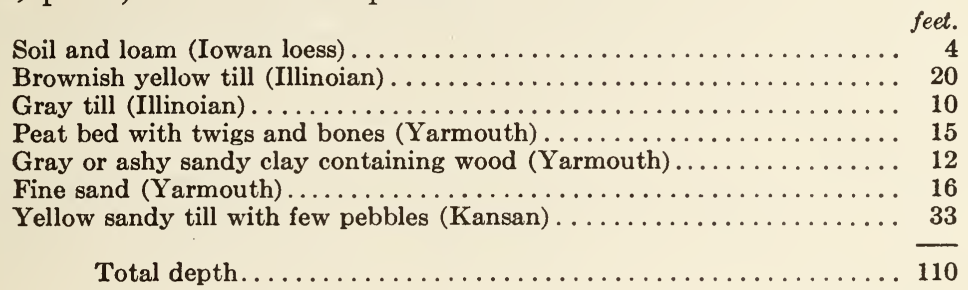

The bones found in the Yarmouth were identified as those of a rabbit, Lepus sylvaticus, and of a skunk, Mephitica mephitica. Both species are now living in that region, but for nomenclatural reasons the rabbit is now called Lepus floridanus and the skunk Mephitis putida. Although other species of vertebrates have not yet been identified from deposits recognized as Yarmouth, we may be sure that there were numerous animals occupying those prairies and forests. Ground sloths, elephants, mastodons, horses, bisons, peccaries, besides other mammals now no longer existing, had not yet become extinct in Yarmouth times. Remains of these, or some of these, will certainly be recovered.

It appears that the Yarmouth has at the type locality a thickness of 43 feet. Leverett states that beds of peat occur all over the portion of southeastern Iowa which was invaded by the Illinoian ice-sheet. He does not, however, regard these peat beds and old soils as better evidence of a long period of interglacial time than is afforded by the general weathering which the Kansan drift suffered during the Yarmouth stage. This drift had been deprived of its lime constituents to a depth of from 4 to 6 feet and probably some part of leached materials had been removed by erosion.

Professor G. F. Kay has discovered (Kay and Pearce, Jour. Geology, vol. xxviII, pp. 83-103) that the upper part of the Kansan drift, as well as that of the Nebraskan, had been converted into a fine sticky clay which he called gumbotil. This Kansan gumbotil had been formed before the deposition of the Iowan drift and the Iowan loess. In one section (Kay, op. cit., p. 220) the gumbotil was found to be 20 feet thick and the overlying loess 25 feet thick. The conversion of the drift into gumbotil probably occupied three Pleistocene stages: the Yarmouth, the Illinoian, and the Sangamon. Of the 20 feet one may credit 6 or 7 feet to the Yarmouth. It would evidently require much longer time to convert drift materials into gumbotil than to remove from the same number of feet the calcareous materials. Evidently the Yarmouth stage was a very long one. 


\section{T'he Illinoman Glacial Stage.}

Illinoian drilt is confined in Iowa to a narrow strip along Mississippi River extending from the northern edge of Scott County to Fort Madison, Lee county. An interesting fact is that the western border of the Illinoian icesheet pushed across the valley of the Mississippi and compelled the river to follow a channel west of the foot of the glacier (see map 4). For an account of ancient lake Calvin, existing here until the invasion of the Iowan ice-sheet, the reader should consult an article by $\mathbb{W}$. H. Schoewe (Bull. Geol. Soc. Amer., vol. xxxiv, p. 93).

On occupying the eastern border of Jowa the Illinoian ice-sheet and its included drift buried deep the Yarmouth forests. During the Illinoian stage the remainder of Iowa was apparently exposed to the weathering influences of a cold climate. Probably all vertebrates, except the most hardy, were driven far to the soutli.

Kay and Pearce (Jour. Geology, vol. xxvir, p. 100) have shown that the Illinoian drift is covered with a sheet of gumbotil, as are the Nebraskan and the Kansan. In Lee County in two sections the gumbotil has a thickness of 4 feet 6 inches.

\section{'The Sajganon Interglacial Stage.}

At the end of the Illinoian glacial stage the Sangamon interglacial began, and it ended at the begimning of the Iowan glacial. If anywhere Iowan drift were found lying over Illinoian drift, one might hope to find Sangamon interglacial between them; but no contact between these two drifts is known, inasmuch as they occupy different regions. 'The loess of eastern Iowa and western Illinois is now believed to be of late Iowan or early Peorian age. Hence any old soils, peat beds, or fossils found between the Illinoian drift and the loess might safely be referred to the Sangamon, and any such materials found in or above the loess might be referred to the Peorian interglacial. However, it is not certain that no loess was deposited during the Sangamon; Dr. William C. Alden informs the writer that there is in Illinois, Missouri, and Iowa an older reddish loess which may be of Sangamon age; this wherever found might contain or underlie old soils and fossils. Moreover, the loess is not found everywhere, and where found it is often a thin sheet; also it seldom contains vertebrate fossils, while the mollusks often present are not good time markers. In many cases therefore it is difficult or impossible to refer old soils and vertebrate fossils with certainty to any one of the three stages, the Sangamon, the Iowan, or the Peorian.

\section{The Iowan Glachll Stage.}

'The area occupied by the Iowan drift sheet is shown on map 4 . The deposit is a relatively thin one. The latest investigations of the Iowan were made by Doctors W. C. Alden and M. M. Leighton (Iowa Geol. Surv, rol. xxvi, 1915, pp. 49-212, with maps and figures). They concluded that such a drift sheet really exists and that it was laid down long after both the Kansan and the Illinoian drifts. At some localities a Kansan gumbotil is found below the Iowan till and occasionally there are traces of a black soil. Fossils are rare in the deposits of the Towan stage. At Clermont, Fayette County, wero 
found a part of a skull of the musk-ox Ovibos moschatus (Iowa Geol. surr., vol. xxiri, pp. 433, 434) and a tooth of Elephas boreus. Alden and Leighton (op. cit., p. 134) concluded that these fossils were probably found in outwash gravels of Iowan age.

A widespread deposit in Iowa is that known as loess. It is strongly developed along Missouri River, thinning out further east, but most of the Kansan drift has a mantle of it. It occurs over the driftless region, also along the Mississippi in Iowa and Illinois and far down this river. It is now generally agreed that it is an accumulation of wind-blown dust. It has considerable thickness around the border of the Iowail drift sheet and overlaps it. As shown by Alden and Leighton, this loess deposit was closely related to the closing stages of the Iowan glacial occupation or to the early Peorian. 'The loess of northeastern Iowa is discussed by Alden and Leighton, as citerl. Professor Shimek studied the loess of lowa and that found at Natchez. Mississippi, and gave special attention to the fossil mollusks found in them; the present writer in 1914 gave a list of Shimek's papers (Iowa Geol. Surv., vol. XxIII, pp. 94-95). In some of these papers will be found lists of the species occurring in the loess, besides interesting observations on their distribution and habits. Most of the mollusks collected in the loess belong to terrestrial species. and in general these species live in the same localities to-day. Shimek concluded that the climate, during the time of the formation of the loess, was not greatly different from that of the present. This fact appears to indicate that the loess was laid down during the warm Peorian stage.

It is remarkable that, while the most delicate snail shells have been prestrved in the loess, few bones or teeth of the vertebrates have been discorered; also that few plant remains have been preserved. This may be due to the fact that the loess was deposited very slowly, so that plants and remains of the large animals decayed before they were covered up; yet one might suppose that burrowing animals, dying in their nests, would have been preserved. Again, in the loess of the Rhine, many mammals, large and small, have left their bones. The conditions under which the loess in the two countries accumulated must have been different. It seems that the preservation of bones, especially in the early stages of their fossilization, is dependent on the more or less continuous presence of water.

\section{The Prorian Stage.}

The Peorian interglacial stage takes its name from a locality a few miles east of Peoria, Illinois. For a description of this the reader may consult Leverett's work on the Illinois Glacial Lobe (Monogr. xxxvir,, U. S. Geol. Surv., pp. 185-189). Here beneath the oldest Wisconsin drift was found a bed of fossiliferous loess 8 to 12 feet thick, and below this is 100 feet of Illinoian drift. In places the upper part of this loess presented a darker brown color than the lower part. It was agreed by the geologists who visiter the locality that the weathering which this loess indicated was less than might be expected in the case of a loess laid down in Sangamon times.

Inasmuch as the Iowan drift passes beneath the eastern border of the Des Moines lobe of the Wisconsin drift, one may hope to find Peorian interglacial old soils somewhere in Worth, Cerro Gordo, or Franklin Counties, but none are 
known. As stated above, the loess was probably laid down during the early part of the Peorian stage.

\section{The Wisconsin Glacial Stage.}

The Wisconsin stage is represented in Iowa by the Des Moines lobe, which projects southward far beyond the general border of the Wisconsin drift in Minnesota and westward. A glance at map 4 shows that the area is mostly drained by Des Moines River. It is bordered on the east and west by conspicuous moraines. No lengthy description of the Wisconsin stage need be presented, inasmuch as few vertebrate fossils have been discovered within the area of this lobe. The characteristics of this drift sheet have, as found in Illinois, been detailed by Leverett (Monogr. xxxvin, U. S. Geol. Surv.). The geologists of Iowa have described the Des Moines lobe in the surveys made of the various counties occupied by it. In volume XXIII of the Iowa Geological Survey the writer, in 1914, briefly considered the features of the Wisconsin stage.

If we hold that the Pleistocene epoch came to an end when the glaciers had retired to their centers of radiation and that such animals as two or three species of elephants, one or two species of mastodons, at least one species of peccary, the giant beaver, and the megalonyx had become extinct at that time or earlier, then we have proof of the existence of a large fauna during the Wisconsin glacial stage and within the glaciated area. That is, this fauna is, in part at least, one of a glacial stage. It appears probable that such a statement may be true of the known faunas of other supposed interglacial stages. It would, however, be difficult or impossible to prove whether any collection of fossils belonged rather to a late part of a glacial stage or to the early part of the succeeding interglacial.

The Pleistocene Vertebrates of Iowa, their Distribution, and their Rejation to the Geology.

Having described the different geological stages of the Pleistocene epoch in Iowa the writer proposes to consider the various localities where vertebrate fossils have been discovered and to determine as far as possible the Pleistocene stages to which these fossils belong. On previous pages this has been done for the species of Xenarthra, the mastodons, the various species of elephants, the horses, the peccaries, the camels, the deer of the genus Odocoileus, the elk, the reindeer, the musk-oxen, the bisons living and extinct, and the giant beaver. To save space, reference to those pages will be made; citations are also made to the writer's work on the Mammals of the Pleistocene of Iowa, published in 1914, in the twenty-third volume of the Iowa Geological Survey. It is proposed to begin in the northeastern corner of the State where are found the Driftless Area, the Iowan and the Kansan glacial deposits, and to work southward over the Kansan, Iowan, and Illinoian areas, then westward to Missouri River and northward to the Iowa-Minnesota line. Lastly will be described the few occurrences of fossils in the area covered by the Wisconsin drift.

In the bank of Yellow River, 4 miles north of Postville, were found, in 1904, by Thomas French, teeth and some bones of an undetermined species of elephant. The region is within the driftless area. The age of the deposit 
has not been determined (page 117 ; also pages 76,427 of volume XxIII of Iowa Geological Survey). On page 150 is an account of a tooth of a horse, Equus niobrarensis, which was found in washed-out sand and gravel, in Otter Creek, Lincoln Township, Winneshiek County. The writer has recorded the finding of teeth of elephants of undetermined species in sections 5, 16, and 23 of Wagner Township (Tp. 94 north, range 5 west), Clayton County; also a mastodon. No details are known (page 117; also Iowa Geol. Surv., vol. xxIII, pp. 83, 130). For a mastodon tooth found in a gravel pit 2 miles east of Garber, Clayton County, see page 40 ; also page 381 of the Iowa Geological Survey, volume xxirI. From the knowledge we have we may conclude that the mastodon lived during the Kansan glacial stage or the Iowan. Perhaps during the summers mastcdons ventured close to the foot of the glacial wall. This supposition implies that suitable food was to be found there.

A considerable number of fossil vertebrates have been discovered in Iowa in the region about Dubuque. In the case of other remains we can not be certain that they were not found in either Illinois or Wisconsin. On page 7 is given an account of the finding of some teeth of megalonyx in a flat crevice in the Galena limestone, near Dubuque. They were discovered in clay at a depth of 10 feet and associated with peccary teeth (Iowa Geol. Surv., vol. xxIII, p. 127). The peccary appears to have belonged to Tagassu lenis. Other peccary remains were found in a crevice near Dubuque, on the Mississippi, a few rods below Lorimiai furnace and were referred to Platygonus compressus. For these peccary remains see page 159 ; also Iowa Geol. Surv., vol. XxIII, pages 82, 214. At Horse Shoe Bluffs, 3 miles below Dubuque, a large elephant tooth was found, but the species is not known. Teeth of Elephas boreus have been secured near Center Grove and at another point near there, 11 miles west of Dubuque, measured along the railroad (page 55; also pp. 82, 433, Iowa Geol. Geol. Surv., vol. xxIII). All of these fossils are within the driftless area as laid down on plate XIV of the twenty-sixth Annual Report of the Iowa Geological Survey. The Pleistocene stage or stages to which these belong has not been determined with certainty. Formerly (Profess. Paper 106, U. S. Geol. Surv., pp. 346-347) the writer expressed the opinion that the fossil vertebrates found in the lead crevices of Iowa, Wisconsin, and Illinois belonged to post-Wisconsin times. Now he is inclined to believe that they are older. The fossils themselves appear to be such as might be found in either pre-Wisconsin or in post-Wisconsin; or, perhaps better said, in the closing stages of the Wisconsin. If these lead crevices are filled up with Iowan loess or covered over with it, it seems probable that the fossils belong to the Sangamon stage or to the Peorian. On page $20 \%$ is recorded the finding of bones and teeth of a bison near the top of a 25-foot section along Cedar River near Floyd, Floyd County. The animal was probably Bison bison. It occurred within about a foot of the surface and may belong to the Recent epoch. (Iowa Geol. Surv., vol. xxIIr, pp. 85, 316). On page 54 is an account of the finding of teeth of Elephas boreus in the glacial valley-train of probably the Wisconsin stage. The writer published a more detailed account of this discovery in 1914 (Iowa Geol. Surv., vol. xxIII, pp. 60, 434). Other teeth from the same locality are referred to Elephas columbi (p. 78).

On page $\mathbf{5 4}$ is recorded the discovery of a tooth of Elephas boreus near Beed's Lake, not far from Hampton. The animal belongs probably to the 
Wisconsin glacial stage (Iowa Geol. Surv., vol. xxir, pp. 8t, 434). Along 'T'urkey River, near Clermont, Fayette County, in gravel terraces belonging probably to the Iowan glacial stage (Alden and Leighton, Iowa Geol. Surv.. vol. xxvi, pp. 133-134), was found a tooth referred by the writer to Elepliris. boreus (Towa Geol. Survey, vol. xxiII, pp. 81, 433). Near the same place was discovered a part of a skull of Ovibos moschatus (p. 183; also Iowa Geol. Surv., vol. xxin, pp. 81, 297). These were fit companions to haunt the foot of a glacial sheet. A large tusk, that of a mastodon or elephant, was founr in a gravel pit at Clarksville, Butler County. 'The locality is on Cedar River and within the area of the Iowan drift. Whatever proboscidean it was that is represented by the tusk it may have lived during the Iowan glacial stage or the early Peorian (Iowa Geol. Surv, vol. xxiII, p. 86). On page 53 is described three large teeth found in a gravel pit at Waterloo, Black Hawk County, believed to belong to Elephas boreus. The region is covered by Kansan drift, overlain by Iowan drift; over this is nearly everywhere a few feet of loess. However, in the present state of knowledge, it is not possible to say definitely to what Pleistocene stage the animal belonged; quite certainly it lived after the Kansan stage or near its close (Iowa Geol. Surv., vol. Xxin, pp. 75, 428). From the banks of Cedar River, at La Porte, Plack Hawk County, was sent to Princeton University a tooth of a bison, possibly the existing one; or it may have belonged to an extinct species of some preWisconsin stage (see p. $20 \%$; also Iowa Geol. Surv., vol. XxIII, pp. 8t, 316).

Many years ago, Professor Samuel Calvin secured the head of a femur of a proboscidean at a place 5 miles east of Winthrop, Buchanan County. and probably not far from Cedar Creek. It was found in a peaty layer, but the exact geological position of this was not recorded (Iowa Geol. Surr., vol. xxiII, p. 85). On page 149 is given an account of a tooth of an undetermined species of horse found near Sandspring, Delaware County. It is beliered to belong to the Aftonian interglacial stage (Iowa Geol. Survey, rol. xxuI, p. 178). In Iowa River at Albion, Marshall County, was discovered a large molar of an undetermined species of elephant (see p. 113 ; also Iowa Geol. Surv., vol. vII, p. 231, for geologic section; Iowa Geol. Surv., vol. xxIII, pp. 70, 441). The Pleistocene stage to which the tooth belonged is uncertain. A tooth of Elephas columbi was found in the alluvium along Iowa River at Tama, Tama County (p. is; also Iowa Geol. Surv., rol. xxiII, p. 44\%). The Pleistocene stage to which it belongs is not known.

A mastodon tooth was found in the alluvium of a creek 3 miles northwest of Shellsburg, Benton County (p. 42; also Iowa Geol. Surv., vol. xxirI, pp. $80,380)$. The geological age is not known, beyond that it is probably postKansan. Is recorded on page 42 two mastodon teeth were reported as found on or in Iowan drift near Springville, Limn County. They may be referred probably to the early Peorian interglacial stage. A tooth of Elephas boreus was pumped up from the bed of Cedar River at Cedar Rapids, Linn County (p. 53 ; also Iowa Geol. Surv., vol. xxin, pp. 80, 438). The Pleistocene stage can not be determined.

On page 40 is recorded the finding of some proboscidean remains near Maquoketa, Jackson County. Whether these belonged to a mastodon or to an elephant, has not been determined. The Kansan drift occupies the region. 
On page 40 is given an account of the finding of a tooth of Mammut americanum near Bryant, Clinton County. The region is occupied by Kansan drift and the age of the fossil may be regarded as post-Kansan (Iowa Geol. Surv., vol. XxIII, pp. 80, 381). In the vicinity of Clinton, Clinton County, have been found remains of Elephas columbi (p. 75), of an undetermined species of elephant (p. 115), and of a mastodon (p. 40). See also pages 75, 381,430 of the twenty-third volume of the Iowa Geological Survey. In the case of none of the fossils collected near Clinton can the exact geological age be determined.

Some teeth of an elephant were found in a small creek about 4 miles southeast of Clarence, Cedar County, some time before 1901. They had probably been washed out of a bed of gravel. The Pleistocene stage to which the teeth belonged can not be determined with certainty; but it is probably post-Kansan (p. 116; also Iowa Geol. Surv., vol. xxIII, pp. 7\%, 428). An account is given on page 78 of the discovery somewhere near Big Rock, Scott County, of a tooth referred to Elephas columbi (Iowa Geol. Surv., vol. xxiII, pp. 75, 447).

Remains of Elephas boreus have been found at Davenport. The region about this city is of great interest to geologists and palæontologists; the Pleistocene geology has been discussed by many writers. McGee (11th Ann. Rep. U. S. Geol. Surv., p. 491, fig. 7\%) describes a geological section found there. Leverett (Monogr. xxxviII, U. S. Geol. Surv., pp. 45, 128, 167) presents and discusses three sections, including the one observed by Pratt. See also Leverett (Zeitschr. Gletscherkunde, vol. vi, p. 296), Calvin (Bull. Geol. Soc. Amer., vol. xx, p. 143), Shimek (Bull. Lab. Nat. Hist. Iowa, vol. v, p. 361 ; Iowa Geol. Surv., vol. xx, p. 376), Norton (Iowa Geol. Surv., vol. Ix, p. 471), Hay (Iowa Geol. Surv., vol. xxirI, pp. 62-64). According to Norton, no exposure of pre-Kansan (Nebraskan) drift has been found, but it has been detected in wells. The Aftonian seems to be represented by old soils and deposits of muck. The Kansan is the surface drift in the northeastern parts of Scott County and probably underlies the Illinoian at Davenport. The Yarmouth interglacial appears in exposures in Davenport and vicinity and well records show the presence of forest beds. The Illinoian drift occupies the greater part of the county. The Sangamon interglacial is believed to be revealed in various well records and in a railroad cut west of Davenport. Iowan drift appears only on the northern border of the county. With the exception of the Iowan drift area and the alluvial bottom lands the county is covered with a layer of loess which may attain a thickness of 30 feet or more. There are apparently two distinct beds of this loess.

In 1876 (Proc. Davenport Acad. Sci., vol. I, p. 96, pl. XxxII) W. H. Pratt published a description of a section observed in a railroad cut just west of Davenport. This presented the following deposits, numbered from above downward:

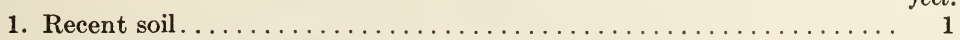

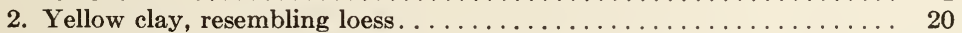

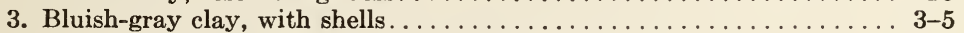

4. Brown peat, with moss and coniferous wood . . . . . . . . . . . . . 1

5. Ancient soil, rich vegetable mould . . . . . . . . . . . . . . . . . . 2

6. Boulder drift............................... 18

It appears to be. agreed that Nos. 2 and 3 are beds of true loess. 'The boulder clay, No. 6, extended on below the level of the railroad cut. 
In 1899 (Monogr. xxxvir, p. 45) Iseverett published two sections studied by him in Davenport. One of these, numbered from above downward, was as follows:

\section{Section at Sixth and Harrison Streets, Davenport.}

1. Iowan loess partly eroded feet.

2. Black soil 1 foot, with Illinoian till surface leached and reddened to a depth of 3 feet during the Sangamon; total . . . . . . . . . . . . . . . . . . . . . . .

3. Brown calcareous, characteristic Illinoian till......................

4. Brown till, calcareous; a characteristic oxidized Kansan till .................. 8-10

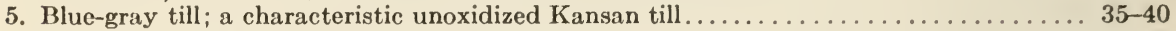

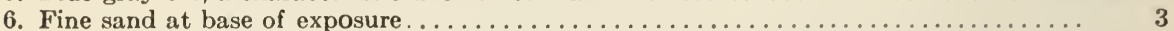

In another section there was found, interposed between Nos. 3 and 4, from 2 to 3 feet of gummy clay, with black humus-like streaks, which Leverett referred to the Yarmouth. This may be Kansan gumbotil. In Pratt's section there appeared only one drift sheet No.6. If this is Kansan the Illinoian is missing; if it is Nebraskan both the Kansan and the Illinoian are missing. It appears far more probable that Pratt's No. 6 is Illinoian drift; his 4 and 5, different manifestations of the early Sangamon; while the No. 3 may be Sangamon loess of a somewhat later time. Leverett (Monogr. xxxviI, p. 127) regarded the Davenport peat, No. 4, as belonging to the Sangamon interglacial. The yellow loess, Pratt's No. 2, may be of Iowan or Peorian age.

It was in the cut which Pratt described that a tusk, several molars, and some bones of an elephant were exhumed by a steam shovel. Pratt states that these were found at the junction of the yellow and the blue clays; that is, between the two sheets of loess. Leverett thinks it possible that the skeleton had been derived from the Sangamon soil (Pratt's No. 5) and redeposited in the basal portion of the loess. This does not appear probable, on account of the number of bones associated. These elephant remains are now preserved in the collection of the Davenport Academy of Sciences, where the writer has been permitted, through the kindness of the curator, Mr. J. H. Paarmann, to examine them. The writer sees no reason for doubting that the animal was Elephas boreus. Now this species is usually found in close proximity to the border of some glacial ice sheet. Why then may we not suppose that the individual in question lived on the site of Davenport at a time when the Iowan ice sheet was on the northern border of the county? Possibly a part of the loess overlying the elephant bones was deposited during the Iowan stage, some of it during the Peorian.

On page 116 is described the finding, many years ago, of an elephant near Bluegrass, Scott County. The region is underlain by Illinoian drift, covered by loess of Iowan age. Beneath this is a Sangamon soil and weathered zone (Leverett, Monogr. xxxvir, p. 46). At a depth of 10 feet, the depth of the elephant remains, the loess was probably late Iowan or early Peorian. For a tooth of Elephas boreus found at Buffalo, Scott County, see page 53 .

Vertebrate fossils have been found at several localities in Muscatine County. All occurred within the area of the Illinoian drift. On page 41 is an account of a supposed mastodon which was long ago found near Wilton, Muscatine County, along Mud Creek, a tributary of Cedar River. It is probable that this animal lived during the Sangamon interglacial stage. Reference is made to page 115 where is recorded the finding of elephant bones in the northeast 
corner of Sweetland township, Muscatine County (Iowa Geol. Surv., vol XXIII, pp. 64, 442). The remains are believed to belong to the Sangamon interglacial stage. The geology of the vicinity of Muscatine has been studied by several geologists. McGee (11th Ann. Rep. U. S. Geol. Surv., pt. 1, pp. 491-493, pl. L) described sections; Leverett (Monogr. xxxvIII, pp. 47, 48) presented three geological sections; Calvin (Bull. Geol. Soc. Amer., vol. xx, p. 143) and Shimek (Bull. Geol. Soc. Amer., vol. xxI, p. 139) contributed to our knowledge of the locality. Leverett found here Nebraskan till, Aftonian peaty soils, Kansan till, and silts and sands that appear to belong to the Yarmouth; also Illinoian till, Sangamon soil, and loess referred to the Iowan. According to Shimek, Professor F. M. Witter found a tooth of Elephas boreus at the top of Aftonian gravels. Another elephant tooth was found by F. M. Van Tuyl along Mud Creek, in gravel (p. 116; also Iowa Geol. Surv., vol. xxIII, pp. 61, 443). An important discovery at Muscatine is that of a reindeer (Rangifer muscatinensis). For details regarding this see page 176 (also pages 34, 278, vol. xxIII, Iowa Geol. Surv.). The time of the animal's existence appears to have been at the close of the Illinoian glacial stage or at the close of the Iowan.

In Louisa County fossil vertebrates have been reported from five localities; but these fossils comprise only elephants and a deer. The Pleistocene geology was described by J. A. Udden (Iowa Geol. Surv., vol. XI, pp. 101-114). 'The greater part of the county is within the area of the Illinoian drift. Udden reported the presence of Nebraskan, Kansan, and Illinoian drifts and interglacial deposits belonging to the Aftonian, the Yarmouth, and the Sangamon, besides Iowan loess. The loess averages about 8 feet in thickness, but it may be as much as 18 feet. It seems not improbable that some part of this loess belongs to the Sangamon stage.

On page 50 are given the details of the discovery of remains of Elephas boreus in section 34 of Union Township, 6 miles west of north of Columbus Junction. The writer's work of 1914 may be consulted (Iowa Geol. Surv., vol. Xxirr, pp. 84, 438). Udden (Iowa Geol. Surv., vol. xI, p. 104, fig. 3) presented a section observed about 2 miles north of the elephant locality. In this were seen supposed Nebraskan till, Kansan till, Sangamon leached soil, and loess ; from which of these, if any, the elephant was derived, it is impossible to say. On page 115 is mentioned a tooth of an undetermined species of elephant found in a shallow well in section 28, near Grandview, Louisa County. Udden (Iowa Geol. Surv., vol. XI, pp. 110 ; Hay, Iowa Geol. Surv., vol. xxIII, pp. 68, 439) concluded that the tooth had been buried in Sangamon interglacial deposits. On page 171 is recorded the finding of antlers of a deer, probably Odocoileus virginianus, in section 23, township 74 north, range 3 west, known as Port Louisa township. The antlers were supposed by Udden to have been derived from the Sangamon interglacial deposits (Hay, Iowa Geol. Surv., vol. XxIII, pp. 71, 252). On page 53 is brief mention of a tooth of Elephas boreus found somewhere near Wapello. The stage of the Pleistocene to which it belonged cannot be determined (Iowa Geol. Surv., vol. XxIII, pp. 70, 71, 438). The discovery of an elephant of undetermined species near Morning Sun is recorded on page 115. Udden, as there cited, regarded it as found in Sangamon soil (Hay, Iowa Geol. Surv., vol. XxIII, pp. 72, 73, 439). 
On page 283 is presented an account of the type locality of the Yarmouth interglacial stage and the discovery, in a bed of peat, at a depth between $3 t$ and 54 feet, of bones of a skunk and a rabbit (Iowa Geol. Surv., vol. xxiII, pp. 27, 62, 472, 480). The locality is at Yarmouth, Des Moines County. In the High School at Burlington, Des Moines County, are a bone and a tusk supposed to belong to a mastodon. The tusk was found within the city; the bone, a part of the pelvis, was discovered in making a bridge across Skunk River (Iowa Geol. Surv., vol. XxiII, p. 58). On page 52 is a brief reference to a tooth of Elephas boreus found somewhere about Burlington. Its exact geological age can not be determined (Hay, op. cit., pp. 5\%, 432). On page 41 is a description of a mastodon tooth said to have been collected at Burlington.

On page 77 is recorded the discovery in Flint Creek, at Burlington, of a tooth of Elephas columbi. It can be referred no more exactly than to the Pleistocene. A species of peccary, probably Platygonus compressus, was long ago found somewhere about Burlington (p. 158; also Iowa Geol. Surv., vol. XXIII, pp. 58-217).

Lee County is occupied partly by the Illinoian drift and partly by the Kansan. Only a few vertebrate fossils have been reported from this county. They are here recorded. On page 41 are mentioned proboscidean bones found in Lost Creek about 2 miles from Denmark, but they furnish little valuable information. On page 40 is a note on a mastodon found 3 miles west of Fort Madison. It is at present impossible to determine the stage to which this mastodon belongs. On page 145 is mentioned the discovery of a tooth of an unidentified species of horse near Montrose, at a depth of 25 feet. An Aftonian deposit is indicated. From Sugar Creek, near Montrose, was obtained, as reported, a tooth of Elephas boreus, but the identification is to be doubted (Iowa Geol. Surv., vol. XxIII, pp. 77, 437). On page 74 is recorded the discovery of a tooth of Elephas columbi somewhere about Keokuk, but nothing is known regarding the exact level where it was buried.

The writer has learned of only two occurrences of Pleistocene vertebrate fossils in Johnson county. On page 113 is recorded the finding, near Iowa City, of remains of an elephant of undetermined species, although it has been referred to Elephas boreus. It is impossible to determine the Pleistocene stage to which it belonged. The river valley is widely filled by alluvium of supposed Recent times. The region about Iowa City is occupied by Kansan drift overlain by Iowan loess. In the northern part of the county is some Iowan drift. According to Calvin (Iowa Geol. Surr., vol. vir, p. 83) no older drift than the Kansan appears at the surface. Leighton (Iowa Geol. Surv., vol. $\mathrm{xxv}, \mathrm{pp}$. 112-116) concluded from data derived from well-borings that both Nebraskan and Aftonian deposits were present in the county. On page 113 is a brief notice of the finding of a proboscidean tusk in Iowa River at River Junction. At present, at least, it furnishes little valuable information.

On page 50 is presented an account of the finding of a tooth of Elephas boreus along Bear Creek, near Marengo, Iowa County (Iowa Geol. Surv., vol. xxiII, pp. 74, 404, 436, pl. Iv, fig. 2). From the same gravels near Marengo was secured a lower jaw of an elephant (Iowa Geol. Surv., vol. xxiII, pp. it, 436). These remains seem to belong to an Iowan or post-Iowan deposit. In 
Grinnell, Poweshiek County, have been found Elephas boreus and E. columbi (pp. 50, 75; also Iowa Geol. Surv., vol. xxIII, pp. 74, 444). These remains appear to have been buried in the Peorian loess.

On page 204 is recorded the finding of a skull of Bison bison by Professor Lynd Jones at a point 5 miles west of Grinnell. This was probably in Rock Creek township, and along Sugar Creek, in Jasper County. The skull may or may not belong to the late Pleistocene. The vertebrate fossils found in Mahaska County do not contribute much to exact information. A supposed elephant pelvis has been found near Oskaloosa (p. 113; also Iowa Geol. Surv., vol. XXIII, pp. 79, 440, pl. LIx, figs. 4, 5) ; a mastodon tooth somewhere in the county (p. 3\%; also Iowa Geol. Surv., vol. xxIII, pp. 79, 386). The information is not exact, and of none of these can one determine the exact Pleistocene age. At Eddyville, in Mahaska County, possibly in Wapello County, was found in a gravel pit a skull of a deer, Odocoileus virginianus. It belongs possibly to the Recent epoch, but may have lived during the late Wisconsin (p. 171).

On page 49 is recorded the discovery of considerable parts of Elephas boreus in Brighton township, Washington County. The age of the remains may be regarded as post-Kansan but can be hardly more definitely determined. Probably an examination by an expert glacialogist might solve the problem. On page 74 is a statement regarding the finding of teeth of Elephas columbi about a mile southwest of Trenton, Henry County, along a little stream. No details are known as to the depth and kind of deposit. The region is occupied by Kansan drift covered over by loess (Iowa Geol. Surv., vol. xII, pp. 289-294). The age of the fossils is probably post-Kansan. Somewhere near Trenton, possibly near the same stream, was found a tooth of a mastodon (p. 36). On page 36 is a notice of the finding of mastodon bones in a well in or near Mount Pleasant, Henry County. They appear to have been buried in Aftonian deposits (Iowa Geol. Surv., vol. xxiII, pp. 80, 384). On page 36 is recorded the discovery of teeth of Elephas columbi near Mount Pleasant. Mastodon remains have been reported from the southwestern corner of Henry County. Leverett reported mastodon teeth from the vicinity of Salem. J. M. Shaffer stated that mastodon teeth had been dug up near the bank of Skunk River (p. 36; also Iowa Geol. Surv., vol. xxIII, pp. 81. 385). The Pleistocene stage to which these belonged can not be determined; but it was probably post-Kansan. In Walnut township, Jefferson County, was found a lower jaw of an undetermined species of elephant (p. 112; Iowa Geol. Surv., vol. XxIII, pp. 76, 437). To which stage of the Pleistocene this belonged could not be determined. Remains of mastodons have been discovered in two localities in Van Buren County, Selma and Milton. The known facts regarding these fossils are presented on page 37 (also Iowa Geol. Surv., vol. xxiII, pp. 80, 81, 391). The Pleistocene stage to which these remains belonged can not be determined. Remains be longing apparently to the mastodon have been found at three places in Wapello County: Ottumwa, 6 miles south of Ottumwa, and near Eldon (p. 37; also Iowa Geol. Surv., vol. xxıI, pp. 78, 79, 86, 391). Their place in the Pleistoeene can not be determined with any exactness, but the animals in all probability lived after the close of the Kansan stage, possibly as late as near the 
end of the Wisconsin. For known details regarding the discovery of probuscidean remains in Des Moines River in Davis County see page 113 (also Iowa Geol. Surv., vol. xxiII, pp. 81, 432).

On page 113 will be found an account of the discovery of a vertebra of an elephant near Indianola, Warren County. At present the Pleistocene stage to which it belongs is in doubt (Iowa Geol. Surv., vol. xxiII, pp. 84, 447). Near Indianola (p. 182) was found an atlas, probably of Symbos cavifrons. The deposit containing it may be as old as the Aftonian (op. cit., p. 307). For an account of a proboscidean found by Dr. G. F. Kay buried in Kansan drift at Osceola, Clarke County, consult page 114. Near Liberty Center, Warren County, in a well, was found a thigh bone of a proboscidean. It was referred by Professor Tilton to the Aftonian (Iowa Geol. Surv., vol. XxiII, pp. 87, 448). On the page last cited the township was erroneously given as $7 \%$ north instead of 74 north. A mastodon tooth was long ago found near New Virginia, Warren County (p. 37; also Iowa Geol. Surv., vol. xxıI, pp. 78, 391). The exact age of the deposits can not be determined.

On page 146 is given an account of the finding of some teeth and bones of a Hipparion of undetermined species, 4 miles east of Afton, Union County (Iowa Geol. Surv., vol. xxiIr, pp. 52, 150). These were found in the type locality of the Aftonian interglacial deposits. As regards this locality the reader should consult a statement made by Dr. G. F. Kay (Iowa Geol. Rep., vol. Xxvir, 1920, p. 5). In 18\%0, from a well at Blanchard, Page County, at a depth of $\mathbf{5} 4$ feet, were brought up some large bones which Calvin (Iowa Geol. Surv., vol. xI, p. 413) regarded as those of an elephant or a mastodon. These remains evidently belonged in Aftonian deposits (Iowa Geol. Surv., vol. XxIII, pp. 78,388$)$. On page 75 is mentioned a tooth believed to belong to Elephas columbi which was brought up in a pump from the bottom of Nishnabotna River, near Red Oak, Montgomery County. The age is uncertain.

Mills County.-Fossil vertebrates have been found in several localities in this county. Shimek (Iowa Geol. Surv., vol. xIII, pp. 1\%0, 1\%1) presented lists of the mollusks found in the loess of three localities in the county. For a claw of a megalonyx see page 6 , also Iowa Geol. Surv., vol. xxirr, p. 129. It appears to have been derived from the Aftonian sands. Interesting species have been reported from the vicinity of Henton (see pages 147, 167). These are all regarded as having been buried in Aftonian deposits. They consisted of Elephas columbi? (possibly E. imperator), two undetermined camels, and Equus complicatus and E. laurentius (Iowa Geol. Surv, vol. xxıI, pp. 53, $83,177,208,241,242,441,442)$. On page 53 of the paper just cited is an account of a tooth of Elephas columbi which was found apparently at or just north of Henton. Its exact geological age is uncertain. On page 171 is noted the discovery of bones of a deer near Folsom. Considering that a heavy deposit overlay that from which the remains were obtained one must conclude that they belonged to one of the Pleistocene stages. Near Pacific Junction were found remains of an elephant of undetermined species (p. 114; also Iowa Geol. Surv, vol. xxiı, pp. $\% \%, 441)$. The animal lived at some time between the close of the Kansan glacial stage and the carly Peorian. If the lower part of the loess belonged to the Sangamon stage the animal did not live there at a later time than this stage. On the pages cited above is noted 
the discovery of teeth, tusks, and bones of an undetermined species of elephant at the bottom of the loess at Malvern. The statements concerning the elephant remains found near Pacific Junction apply to those here considered. On page 147 is recorded the finding of the upper and the lower grinding teeth and parts of the skeleton of Equus complicatus in Lyons Township. The deposit is a fine blue clay or silt which is regarded as Aftonian (Iowa Geol. Surv., vol. XxIIr, pp. 58, 168). Inasmuch as various parts of the skeleton were present, they could rot have been redeposited from an older formation.

On page 196 is presented an account of the finding of a skull of a bison, probably $B$. occidentalis, in section 28 of James Township, Pottawattamie County. Inasmuch as the skull was found at a depth of 14 feet in loess the animal may be referred to the late Iowan or the early Peorian (Iowa Geol. Surv., vol. XxiIr, pp. 69, 322). On page 210 is recorded the finding of an incisor tooth of Castoroides near Oakland. Calvin thought that this tooth belonged to the Aftonian, but this can hardly be regarded as certain (Iowa Geol. Surv., vol. XxIII, pp. 82, 466). As stated on page 115, remains supposed to belong to an elephant were once found in section 34 of Washington township. The matter of interest is that they were apparently buried in the loess; in the same county wood and peat have been found in the loess (Udden, Iowa Geol. Surv., vol. xI, p. 260). As recorded on page 183 a skull of the musk-ox Symbos cavifrons was long ago found at Council Bluffs. MeGee reported it as coming from a depth of 12 feet in the loess. If this is correct the time in which the animal lived was probably near the close of the Iowan stage or in the early Peorian. If the deposit is what Shimek called Loveland the existence of the animal is carried back to about the close of the Kansan.

The finding of a skull of Castoroides near Corley, Shelby County, is recorded on page 211. As in the case of the tooth of Castoroides found at Oakland, Pottawattamie County, the Pleistocene stage in which the animal lived is uncertain.

From Guthrie County have been recorded a fragment of a tusk of a proboscidean (Iowa Geol. Surv., vol. xxiII, p. 85) and of a tooth of a bison (op. cit., pp. 85, 316). Neither of these objects furnish much information.

Sand and gravel pits in the vicinity of Pisgah, Harrison County, have furnished several interesting species of Pleistocene vertebrates, all referable to the Aftonian interglacial stage. The Peyton pit is situated a mile southwest of Pisgah, in the northeast quarter of section 23, township 81 north, range 44 west. This pit and its fossils have been described by Calvin (Bull. Geol. Soc. Amer., vol. xx, pp. 343, 344, 350, 351, 352), Shimek (Bull. Geol. Soc. Amer., vol. Xxi, pp. 133, 134, Iowa Geol. Surv., vol. xx, p. 339, 340), and Hay (Iowa Geol. Surv., vol. xxiri, p. 56). Here the Aftonian rises about 40 feet above Soldier River, is 30 feet thick, and overlain by Kansan till. There is said to be a blue clay underlying the Aftonian and to be probably Nebraskan till. In this pit have been found Mammut progenium, Elephas imperator, Equus complicatus, and an undetermined species of camel. In the Kress pit nearby was discovered a tooth of Elephas columbi. In another pit, situated in the northwest quarter of section 26 of the same township, were found 2 teeth of Equus complicatus (Hay, op. cit., pp. 56, 1\%1). Unfortunately on the page cited these teeth are said to have been found in the 
Peyton pit. Also on page 56, the introduction of a sentence stating correctly the locality of these teeth has produced some confusion with regard to the origin of certain species found in the Peyton pit, Marmmut progenium, Elephas imperator, and a camel. These fossils, found near Pisgah, were described by the writer in 1914 (Iowa Geol. Surv., vol. xxıI, pp. 56, 240, 242, $244,260,384,425,436)$. All these species are mentioned in the present work on pages $38,9 \%, 147,168$.

On page 183 is recorded the finding of a lower jaw at Woodbine, Harrison County, and provisionally referred to Symbos cavifrons. At present it is impossible to determine the geological age of the fossil, but inasmuch as it was in or below the loess covering the bench, or terrace, it must be as old as the early Peorian. Possibly some day the jaw itself will be recovered and identified. On page 76 a statement is made regarding the finding of a molar of Elephas columbi in the Peckenbaugh sand and gravel pit at Logan, Harrison County. In a well near the pit was secured a bone that appeared to belong to a horse. At this place the Aftonian rests on Missouri limestone (Hay, Iowa Geol. Surv., vol. Xxiır, pp. 54, 417, 436). On Hog Creek, about 5 miles east of Logan were found many bones of the existing bison (Shimek, Iowa Geol. Surv., vol. xx, p. 409). Whether these belong to the late Pleistocene or to the Recent is at present doubtful.

Near Missouri Valley, Harrison County, in the northeast quarter of section 24, township 78 north, range 44 west, in the southeast bluffs of Boyer River, is the Cox sand-and-gravel pit, one of the most important of the Aftonian exposures. A detailed description of the section exposed here has been given by Professor Shimek (Iowa Geol. Surv., vol. xx, pp. 333-334). At the base are sands and gravels about 35 feet thick and these are regarded as Aftonian. Overlying this interglacial deposit is typical bluish calcareous Kansan till 13 feet in thickness; then what Shimek regards as Loveland; and capping this on the ridge nearby is loess. Unfortunately the deposit on which the Aftonian rests is not exposed. Shimek has given a list of the rarious specimens found; below is a list of the species as identified by the present writer :

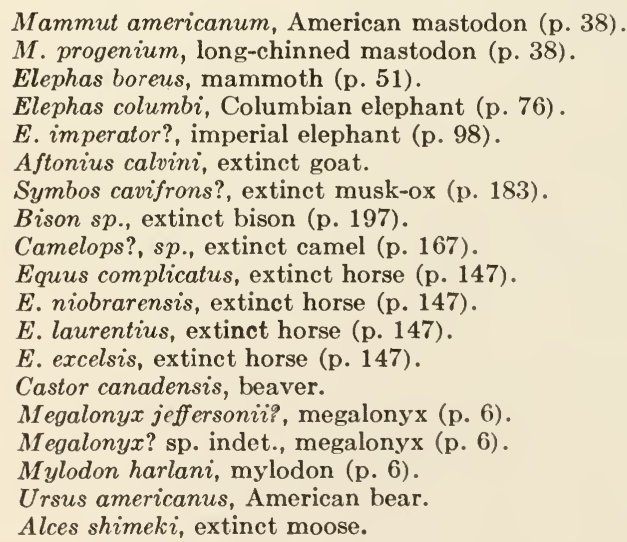

It will be observed that of the 19 species of the list all are extinct except two, the beaver and the bear, the forms no longer living constituting about 
90 per cent of the whole number. This high ratio is probably due to the fact that the bones all belong to the larger species. The animal catalogued as Megalonyx? sp. indet. is the one represented by figure 30 on page 130 of volume XxIII of the Iowa Geological Survey.

The geology of this county was studied by Doctor Shimek (Iowa Geol. Surv., vol. $\mathrm{xx}$ ) and his observations on the Pleistocene geological sections were reported on pages $340-34 \%$. In most of the sections no vertebrate fossils were found. In the loess of a number of the exposures mollusks were obtained, partly fresh-water, partly land species. The Aftonian deposits usually consist of sand and gravel. On page 97 is noted the finding of a part of a tooth of Elephas imperator in a well near Mapleton, buried in Aftonian deposits. In another well was found a large tusk of a proboscidean (Iowa Geol. Surv., vol. xxIII, pp. 59, 60, 387). The Elliott gravel pit, in Turin, has furnished an important collection of vertebrate remains. The pit and its fossils were reported on by Calvin (Bull. Geol. Soc. Amer., vol. xx, pp. 344, 345), by Shimek (Bull. Geol. Soc. Amer., vol. xxi, p. 129; Iowa Geol. Surv., vol. xx, p. 340) and by Hay (Iowa Geol. Surv., vol. xxiII, p. 59). The following are the species that have been identified:

1. Megalonyx jeffersonii (Iowa Geol. Surv., vol. xxırı, p. 129).

2. Equus complicatus (op. cit., pp. 167, 175-177).

3. E. niobrarensis (op. cit., pp. 198, 200).

4. E. excelsus (op. cit., p. 191).

5. Camelops, sp. indet. (op. cit., pp. 241, 243, 244).

6. Mammut americanum (op. cit., p. 387).

7. Elephas columbi (op cit., p. 442).

8. Castoroides ohioensis (op. cit., p. 466).

These species are treated on the following pages: 1 , page 7 ; 2 , page 148 ; 3 , page $148 ; 4$, page $148 ; 5$, page $168 ; 6$, page $38 ; 7$, page $7 \% ; 8$, page 148 .

The writer was in error when he reported that Calvin had found here a tooth of Elephas imperator (op. cit., p. 59). All the species found here are extinct. All were likewise large animals whose bones could endure deposition in gravel. Collections of mollusks, some of fresh-water habit, others terrestrial, were secured. All are of living species.

According to Shimek, as just cited, the Aftonian sands, gravels, and silt combined, have a thickness of 12 feet. The gravel is mostly near the bottom of the stratum and in this were discovered the bones and teeth. Overlying the Aftonian was Kansan drift, Loveland (probably gumbotil), and loess. In a boring made below the Aftonian a layer of tough clay, with boulders, was penetrated a distance of 4 feet. Shimek regarded it as Nebraskan till.

The fossils listed above belong to the first interglacial stage. At another locality in Monona County have been found three species of a much more advanced time, possibly of the Recent epoch. These species are the existing bison (p. 206), the elk (p. 174), and the white-tailed deer (p. 172). Large numbers of their bones were found on Beaver Creek, which appears to be about 5 miles east of Turin. By mistake Doctor Calvin called this stream Cedar Creek (Iowa Geol. Surv., vol. xxırı, p. 314). At Denison, Crawford County, have been examined two sand-and-gravel pits; one is near the town and close to Boyer River. A geological section was published by Shimek in 1909, (Bull. Geol. Soc. Amer., vol. xx, p. 405) who referred the deposit of 
sand and gravel to the Aftonian. In 1910 (same Bull., vol. xxi, p. 13\%) he expressed doubt as to the assignment. In 1911 (same Bull., vol. XxiI, p. 212) Calvin stated that the stratigraphic position of these gravels had not been determined with certainty. Attention must be called to Dr. James H. Lees' paper on the valley gravels of Crawford County (Bull. Geol. Soc. Amer., vol xxxıI, p. 49). They are regarded as being pre-Kansan and post-Kansan. The other pit is about a mile further down the river on a terrace and at a lower level than the upper pit. The terrace consists of deposits laid down probably by outwash from the Wisconsin ice-sheet, 10 or 15 miles away. At Denison have been found Mammut americanum (p. 38), Elephas boreus (p. 51), Bison occidentalis? (p. 197), and Cervalces roosevelti. It appears that these species were discovered in the lower pit and are thus to be accredited to the Wisconsin stage, in case the geology of the locality has been correctly determined (Lees, op. cit.; also Hay, Iowa Geol. Surv., vol. xxiı, pp. 55, 267, 325, 382, 431). Here may be mentioned a skull referred to the existing bison (p. 205) which was found at Beloit, 6 miles above Denison, on Boyer River. It possibly belongs to the Recent epoch (Hay, op. cit., p. 56).

On page 116 is mentioned the discovery of part of a scapula in a gravel-pit near Lake View, Sac County. It probably belonged to one of the elephants and the animal lived during some part of the Wisconsin stage (Iowa Geol. Surv., vol. xxiII, pp. 76,446$)$. A tusk of an elephant or of a mastodon was discovered at Ida Grove, Ida County, but no details are known as to the geological conditions (p. 115; also Iowa Geol. Surv., vol. xxiII, p. 86).

The Anderson sand-pit in the southeast quarter of the northwest quarter of section 13, township 89 north, range 48 west, near Sioux City, Woodbury County, was described by Shimek in 1910 (Bull. Geol. Soc. Amer., vol. XxI, p. 128). The locality is north of North Riverside. Shimek's geological section abridged is as follows:

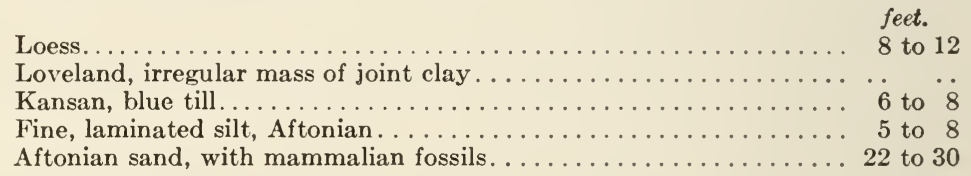

The owner reported that large boulders and gravel under the sand rested on rock. This stratum belongs probably to the Nebraskan. The following species of vertebrates were collected in this pit:

Megalonyx jeffersonii (Iowa Geol. Surv., vol. xxiII, p. 128).

Equus complicatus (op cit., pp. 57, 177).

E. laurentius (op, cit.,pp. 57, 207).

Mylohyus? temerarius (op. cit., p. 227).

Professor J. E. Todd had previously collected somewhere about Sioux City some horse vertebræ. In the Sioux City Academy of Sciences is a tooth referred to Equus niobrarensis. It is said to have been found in a sand-pit on Big Sioux River. The species named here are further mentioned on page 148 .

At Correctionville, Woodbury County, have been found Elephas boreus (Iowa Geol. Surv., vol. xxiII, pp. 74, 449), Rangifer (op. cit., pp. 75, 281), Bison occidentalis (op. cit., pp. $74,325,449$ ) and a tooth of a horse. For 
details on these species see pages 52, 176, 19\%. Carman (op. cit., p. 410) wrote that a few miles south of Correctionville, in the valley of the Little Sioux, from the Gilleas gravel-pit, had been taken antlers of deer (p. 172) besides a skull of a buffalo (p. 197), and a worn tooth of Elephas boreus (p. 52). The geologic age of these is probably the same as those of the preceding paragraph; that is (Carman, op. cit., p. 412) post-Kansan and pre-loess. Apparently this would mean the Yarmouth or the Sangamon.

In a well near Akron, Plymouth County, in the northeast quarter of section 33, township 93 north, range 48 west, two molars of the mastodon Anancus (Stegomastodon) mirificus were found. The well was 24 feet deep, reaching down to hard-pan regarded by Shimek as Nebraskan. Aftonian sand and gravel overlie this, and in this Aftonian at a depth of 20 feet, lay the mastodon remains. Above the Aftonian is Kansan drift. Besides the mastodon, a bone belonging probably to Megalonyx jeffersonii was found ( $p$. 7, 39 ; also Iowa Geol. Surv., vol. XxIIr, pp. 58, 131, 388). For our knowledge of the geology in the vicinity of Le Mars, Plymouth County, we are indebted to Bain (Iowa Geol. Surv., vol. virr, p. 338) and to Carman (Iowa Geol. Surv., vol. xxvi, np. 394, 409, 412). On the last page cited Carman concluded that the valley gravels which furnish the fossils are "post-Kansan and pre-loess, which probably means pre-Iowan." The discovery of horse teeth in the gravels makes it probable that the gravels are not younger than the Sangamon interglacial. Besides the teeth of horses (p. 149), there have been found bones of proboscideans (p. 39 ; also Iowa Geol. Surv., vol. xxIII, pp. 69, 389) and antlers of deer (p. 172). Doctor Carman has sent the writer shattered enamel plates of Elephas boreus (p. 52) dredged from the deep pit just northwest of Le Mars; also from one of the pits a well-fossilized calcaneum of a deer of the genus Odocoileus (p. 172) but apparently not $O$. virginianus.

The Pleistocene geology of Cherokee County was described by Professor Macbride (Iowa Geol. Surv., vol. xII, pp. 31\%-324). Kansan drift covered by loess is everywhere present; Wisconsin outwash and Recent alluvium are found along Little Sioux River. The valley gravels of northwestern Iowa have received the special study of Dr. Ernest Carman (Iowa Geol. Surv., vol. xxvi, pp. 234-445, with map). The pits which have furnished fossils are about 3 miles north of Cherokee and are situated on a high bench (Carman, op. cit., pp. 372-379, 399-401, 409). The gravel, according to Carman, was laid down at the foot of the Kansan ice-sheet; at a later time the Little Sioux cut its valley in the till above these gravels. The present valley was afterwards cut into and through the gravel deposit, leaving a bench now from about 50 to 100 or more feet above the stream. A lower gravel terrace within the valley is interpreted by Carman as belonging to the Wisconsin. On page 77 is described a tooth of Elephas columbi, which was found in one of the pits excavated in the Kansan drift. Inasmuch as the gravel is brought up from considerable depths by scoops it is impossible to determine at what depth the tooth was embedded in the deposit. It nevertheless appears necessary to admit that the Kansan ice-sheet was not far away when the elephant tooth was buried there. 
Near Hartley, O'Brien County, a molar of an elephant was discovered which is referred to Elephas columbi (p. 77). Its exact geological age is unknown beyond that it is Pleistocene.

On page 149 is a notice of a fragment of a horse tooth found about a mile east of Granite, Lyon County and referred to the Aftonian. On the same page is given a geological section observed by Shimek. Near Doon, in Lyon County, were found two large proboscidean tusks in gravel at a depth of about 25 feet. They are supposed to have been unearthed from Aftonian deposits (Iowa Geol. Surv., vol. xxıII, pp. 83, 386). On page 52 is recorded the finding at Rock Rapids, Lyon County, of an atlas which the writer referred to Elephas boreus. The animal is believed to have lived at some time during the Wisconsin stage (Hay, Iowa Geol. Surv., vol. xxiı, pp. 7\%, 386, 439, 446 ; Carman, Iowa Geol. Surv., vol. Xxvi, pp. 382, 410).

Near Irvington, Kossuth County, was discovered a part of a skull bearing fine antlers of Cervus canadensis (p. 175). These may belong to the Recent epoch. Teeth believed to belong to Elephas boreus have been found at two places in Cerro Gordo County, Clear Lake and Mason City. Clear Lake (p. 54) lies within the border of the Wisconsin area, and the elephant, Elephas boreus, probably lived at a time near the close of the Wisconsin stage. Mason City is within the Iowan area on Shell Rock River. In the Gabler gravel pit east of Mason City has been found a tooth of Elephas boreus (p. 54; also p. 85, vol. xxiII, Iowa Geol. Surv.). Professor A. O. Thomas informs the writer that the gravel is part of a valley train from the Wisconsin ice-sheet. This being the case the ice-front was not far away when the elephant died, and the region must have furnished sufficient food to invite the presence of elephants.

At Webster City, Hamilton County, was found in a gravel bar in Boone River a part of a skull with a horn-core which the writer identified as Bison occidentalis (p. 197; also pp. 82, 323, Iowa Geol. Surv., vol. xxIII). The age of the bison skull is uncertain. Unidentified bones have been reported from gravel pits. In Harden County near Hubbard, a skull of Bison bison was found by a man digging a well. The skull is probably of late Wisconsin time, but it is well mineralized (p. 206 ; also Iowa Geol. Surv., vol. xxiIr, p. 315). At Carroll, Carroll County, has been found the distal end of a left tibia of an elephant or mastodon. As the locality is at the border of the Wisconsin drift lobe, it is probable that the animal lived during the latter part of this stage (see Hay, Iowa Geol. Surv., vol. xxıII, pp. 65, 381). Somewhere near Rippey, Greene County, were found a scapula and a humerus belonging probably to a mastodon, which are referred to the Wisconsin stage, most likely to the latter part of it (p. 42 ; also pp. 78, 382, Iowa Geol. Surv., vol. xxIII).

Somewhere in Boone County were found parts of one or more mastodons. As the whole county is within the Wisconsin area the remains probably belong to the last part of the Wisconsin stage (p. 43; also pp. 78, 380, Iowa Geol. Surv., vol. XXIII). At two places in Story County vertebrate fossils have been found. In 1894 Mr. M. Stalker, of Ames, exhumed some bones of a mastodon or an elephant (Iowa Geol. Surv., vol. xxiIr, pp. 82, 390) in Washington township. Near Nevada, many antlers of elk were plowed up and dug up (op. cit., p. 260). The whole county is within the area of the last drift, 
and the animals, elk, and proboscidean, doubtless lived near the close of the Wisconsin stage. A complete skeleton of a mastodon was found somewhere near Adel, Dallas County, as reported by Professor Samuel Calvin. It was buried in a peat deposit on the surface of the Wisconsin drift. The animal lived certainly near the close of the Wisconsin stage (p. 42; also Iowa Geol. Surv., vol. XXIII, pp. 78, 382).

A molar tooth of an elephant, called E. primigenius, was many years ago found near Polk, Polk County. As the region is within the Wisconsin drift area, the animal probably lived late in the Wisconsin stage (p. 116; also Iowa Geol. Surv., vol. XXIII, pp. 76, 444). On page 206 is noted the finding of parts of a skeleton of a bison, Bison bison, in an old lake-bed near Grimes, Polk County. The remains may belong to the late Pleistocene or to the Recent. At Des Moines, Polk County, have been discovered teeth of Elephas boreus, $E$. columbi, Mammut americanum, and a tooth of a bison of uncertain species (pp. 54, 78, 42, 197; also Iowa Geol. Surv., vol. xxiIr, pp. 65, 318, 389, 443). On page 211 is noted the discovery of a tooth of the giant beaver. Unfortunately in the case of none of these fossils can it be determined with certainty to which Pleistocene stage it belongs. As reported by Calvin (Bull. Geol. Soc. America, vol. xx, p. 148) Kansan drift, loess containing terrestrial mollusks of existing species, and Wisconsin drift are present in Des Moines. This has been confirmed by Lees (Proc. Acad. Sci. Iowa, vol. xxviII, pp. 5963). In the Peorian loess was found a tusk of an elephant or of a mastodon.

\section{NEBRASKA.}

Although Nebraska has been the subject of many geological and palæontological expeditions sent out by the United States government, by various eastern museums, and by the Geological Survey of the State itself, it lacks much of having been subjected to the detailed study which is to be desired. Many areas, occupied by Pleistocene deposits, are not yet mapped and their extent, thickness, and composition are not well known. The volumes of the Nebraska Geological Survey, issued by Dr. Erwin H. Barbour, have made valuable contributions to the geology and palæontology of the State. The most recent geological map of the State is that published by Doctor Barbour in 1903 (Nebraska Geol. Surv., vol. I, pl. x).

So far as known, the State was invaded by only two of the drift sheets of the Glacial epoch, the Nebraskan and the Kansan. The first of these rarely is seen, inasmuch as it is usually buried beneath more recent deposits, the Aftonian interglacial, by the Kansan drift, and the later accumulated loesses and alluvial materials. The Nebraskan is likely to be found exposed along the Missouri River where the later deposits have been removed. Shimek (Bull. Geol. Soc. Amer., vol. xx, p. 138) found Nebraskan drift in the Offerman sand and gravel-pit in South Omaha. The workmen had penetrated it to a depth of 16 feet; it was overlain by Aftonian.

The Kansan drift occupies a strip on the eastern end of the State about 80 miles wide on the parallel of $41^{\circ}$. At the southern boundary of the State the strip is wider. Beginning (Barbour, op. cit.) at the southwestern corner of Thayer County its western edge runs northeast to Seward County, so that 
the eastern two-thirds of this county is within the Kansan area. Here the border turns northward and runs west of north to Missouri River. Within Nebraska the Kansan drift is very thin; Barbour (op. cit., p. 166) states that it is seldom more than 1 or 2 feet thick, but in places it is thicker. Barbour published a view (his fig. 98), taken at Bennett, where Dakota sandstone is overlain by many feet of drift, full of boulders. His figure 103 represents the gravel pits of the Rock Island Railway near Fairbury. Here the drift gravel is from 20 to 40 feet thick. It is overlain by from 10 to 20 feet of loess.

The Kansan drift of Nebraska is charactertized by the presence of pink and purple boulders of Sioux quartzite which have been brought down from the vicinity of Sioux Falls, South Dakota. Some of these are of enormous size, as much as 20 feet long and 10 or 12 feet wide and thick. It is hardly probable that vertebrate fossils will be found in the drift; but this sheet, where present, will serve to differentiate the underlying Aftonian from the overlying loess. The drift clay is said by Barbour to be usually of a reddish buff color, and it sometimes merges into the overlying loess or "yellow clay." As in Iowa, it may sometimes be difficult to determine whether a fossil has been found in drift-clay or in loess.

There can hardly be a doubt that the Aftonian interglacial deposits are continued westward beyond the Kansan border and are equiralent to the Sheridan beds. Essentially the same genera and species occur in both. The most important and characteristic are horses of various species belonging to Equus, occasionally a Hipparion, Elephas imperator, and species of camels. All of these have been found in the Aftonian deposits of Iowa and in the Sheridan (Equus) beds of Kansas and Nebraska. The type locality of the Sheridan beds is near Grayson, on Niobrara River, in Sheridan County. A list of the fossils found there is presented on page 305 .

Near Seneca, Thomas County, Matthew found Equus beds which furnished camels, Mylodon, horses, etc.; and Leidy's type of Elephas imperator must have been found not far from that region. The same elephant has been discovered near Cody, in Cherry County. South of the Platte, E. imperator has been found at Wauneta, Chase County; and at Sutton in Clay County. Within the area of the Kansan drift the same elephant has been discovered at Pickrell, Gage County; at Fairbury and Reynolds, Jefferson County, accompanied at the latter locality by a camel. We may, therefore, conclude that the Sheridan beds are widely distributed over the State. In the southeastern half the Sheridan beds and the Kansan drift are mostly overlain by loess deposits. Widely distributed sand hills occur in a considerable portion of the northwestern part of the State.

The loess is mapped by Barbour as covering most of the eastern part of the State to nearly longitude $99^{\circ}$. Along Niobrara River it continues to longitude $100^{\circ}$. North of the Platte River is a wide extent of loess-covered country extending westward to about longitude $100^{\circ}$. South of the Platte the loess reaches longitude $102^{\circ}$. So far as the writer knows, the age of the loess of Nebraska has not been determined; but it is probable that it has been accumulating ever since the close of the Kansan ice stage. Few fossils are found in the loess. 
Pleistocene vertebrate fossils have been discovered in about 40 counties of Nebraska. In giving a summary of these a beginning will be made in the southeastern corner of the State; and pages will be cited where the finds are more fully described.

Somewhere about Pawnee City, Pawnee County, a part of a molar of Elephas columbi was found (p. 78). In the vicinity of Tecumseh, Johnson County, a claw bone was found which is supposed to belong to a species of Mylodon (p. 8). At an unknown point in the county, Hayden discovered a tooth which is referred to Elephas imperator (p. 98). Near Wyoming, Otoe County, a skull of the musk-ox Symbos cavifrons was discovered (p. 184). At Louisville, Cass County, a tooth was met with which appears to belong to Equus complicatus (p. 150), and somewhere in this county the humerus of a gigantic bear, Dinarctotherium merriami (Barbour, Neb. Geol. Surv., vol. IV, pp. 349, 353, figs. 4-6). Near Richfield, Sarpy County, a tooth was found which was supposed to belong to an extinct bison (p. 198).

In Douglas County, at Omaha, a bison skeleton was observed which was probably that of the existing bison ( $p .207$ ) ; also a vertebra of a proboscidean, supposed to be an elephant (p. 118). In the collection of the Academy of Natural Sciences, at Philadelphia, is a concretion of sand from which protrudes the lower jaw and two incisor teeth of Geomys bursarius, labeled as found at the mouth of Platte River. Just above Omaha, at Florence, was found a fragment of a tooth of the giant beaver Castoroides (p. 212). In the vicinity of Lincoln, Lancaster County, was collected a tooth referred to Elephas columbi (p. 79); and the same species was found at Martel (p. 79). At Pickrell, Gage County, a mastodon tooth was discovered (p. 43), and at Holmesville a tooth of $E$. imperator (p. 98).

Jefferson County has furnished several species. At Endicott was collected a part of a skull of Symbos cavifrons (p. 184); at Fairbury a molar of Elephas columbi and one of $E$. imperator (p. 98); at Reynolds teeth of $E$. imperator (p. 99), and bones of a camel (p. 168). In Saline County, at Wilber, a tooth of Elephas columbi (p. 79) was collected and at Crete a jaw of Elephas hayi (p. 101) and teeth of Equus niobrarensis (p. 151). At Seward, Seward County, a molar of Elephas columbi was found (p. 79). Near York, York County, a molar of Elephas boreus was discovered (p. 55); and at Grafton, Filmore County, a molar of E. columbi (p. 80).

In the vicinity of Hebron, Thayer County, a tooth of Elephas imperator was met with (p. 99); along Oxbow Creek, Nuckols County, a molar of Elephas columbi (p. 80). Near Sutton, Clay County, a lower jaw of Mammut americanum (p. 43) and one of Elephas imperator (p. 99) were obtained. At Brickton, Adams County, was found a molar of Elephas columbi (p. 80). Near Red Cloud, Webster County, a humerus of a species of Mylodon (p. 8) was collected. At an undefined locality in Buffalo County, Hayden discovered a mastodon tooth (p. 43). A molar of Elephas columbi was found near Ravenna, Buffalo County (p. 80). Near Cambridge, Furnas County, a part of a skull of Symbos cavifrons (p. 184) was discovered; and somewhere in the same county a jaw of a camel (p. 168). At an unknown locality in Gosper County an undetermined species of elephant (p. 117) was found. At 
Indianola, Redwillow County, a tusk supposed to belong to an elephant ( $p$. 118) was exhumed. Somewhere along Medicine Creek, Frontier County, a lower jaw of Elephas columbi (p. 80) was secured. Near Hayes Center, Hayes County, a molar referred to Elephas boreus (p. 56) was collected. Somewhere in Hitchcock County, a horn-core was found which is referrerl with some doubt to Bison latifrons. Near Benkelman, Dundy County, a lower jaw was obtained which is referred to Elephas columbi (p. 81). In Chase County, near Wauneta, a molar of Elephas imperator was discovered. At Sidney, Cheyenne County, a tooth of Elephas columbi (p. 81) was found in a deep well.

Coming back to the eastern part of the State, north of Platte River, we find that at Pender, Thurston County, a skull of a mastodon (p. 43) with a remarkably long straight tusk was found. In the Winnebago Reservation was discovered a skull of Bison bison (p. 207). In Nance County, at Fullerton, evidence was obtained of an undetermined species of horse (p. 152). At Dannebrog, Howard County, was found a molar of Elephas boreus (p. 55). In Custer County, at Broken Bow, molars of Elephas columbi (p. 81) were found, and a part of a skull of Bison occidentalis (p. 198).

Along the Middle Loup River, west of Seneca, Thomas County, collectors from the American Museum of Natural History, New York, obtained, in 1916, materials which Dr. W. D. Matthew (Bull. Amer. Mus. Nat. Hist., vol. xxxviII, pp. 227-228) reported on as follows:

\footnotetext{
Equus sp. cf. niobrarensis, teeth and foot bones.

Camelid cf. Camelops, 2 species, foot bones.

Platygonus, 2 species, jaw fragments.

Megalonychid indet., part of scapula.

Thomomys sp. indet., several lower jaws.

Cynomys sp., indet., lower jaw.

Scalops sp. indet., lower jaw.

Lutra, jaw fragments, no teeth.
}

According to Matthew this is the region where Hayden, in 1858, obtained the species described by Leidy as Elephas imperator, Equus excelsus, and possibly an undetermined species of Hipparion. It was probably in this same region that the type of Stegomastodon mirificus was discovered (p. 44). In Cherry County, remains of Mammut americanum (p. 44) were reported from Valentine; from near Corly, a limb bone supposed to belong to Elephas imperator (p. 100).

Many species of fossil rertebrates have been taken on Niobrara River, near a place now known as Old Grayson, not far from the present town of Grayson, from excavations known in the literature as the "Hay Springs quarry." The locality is said to be along a ravine about a mile away from Niobrara River, and south of it. The fossils were found in a deposit of sand at an elevation between 50 and 100 feet above the river. Collections were made for Professor O. C. Marsh by J. B. Hatcher; for Princeton University by J. B. Hatcher and J. W. Gidley; and for the American Museum of Natural History by Hatcher, Gidley, O. A. Peterson, W. D. Matthew and Albert Thomson. Following is a list of the fossil vertebrates found near Grayson, Sheridan County. This is taken mostly from Matthew's list published in 1918 (Bull. Amer. Mus. Nat. Hist., rol. 38, pp. 226-227). 
Canidæ:

Canis occidentalis?.

C. latrans.

Ursidæ:

Arctotherium sp. indet.

Felidæ:

Smilodon nebrascensis.

Sciuridæ:

Cynomys ludovicianus?.

Muridæ:

Ondatra nebracensis.

Microtus sp. indet.

Castoroididæ:

Castoroides sp. indet (p. 211).

Geomyidæ:

Thomomys sp. indet.

Megalonychidæ:

Mylodon nebrascensis = M. harlani (p. 8).

Megalonyx sp. indet. (p. 8).
Equidæ:

Equus niobrarensis (p. 152).

E. excelsus (p. 152).

Elephantidæ:

Elephas columbi (p. 81).

E. imperator (p. 100).

Tagassuidæ:

Platygonus sp. indet. (p. 160).

Camelidæ:

Camelops kansanus (p. 168).

C. vitakerianus (p. 168).

C. (Camelus) americanus (p. 168).

Antilocaprinæ:

Antilocapra americana?

Capromeryx furcifer.

Emydidæ:

Chrysemys timida.

The identity of this fauna with that of the Aftonian interglacial of Iowa was recognized by Matthew (op. cit., p. 22\%).

Near Agate, Sioux County, was found a molar of an elephant which the writer regards as Elephas boreus (p. 56). Its geological age is uncertain. At Morrill, in the same county, was found a part of a skull of a musk-ox, probably Ovibos moschatus (p. 185).

\section{WYOMING.}

Wyoming, which has furnished such abundant collections of fossil vertebrates belonging to the Tertiary and to earlier periods, has afforded only meager representatives of Pleistocene animals. A single horse tooth, of undetermined species (p. 152), has been found somewhere about Bridger, Uinta County. Elephas columbi (p. 81) has been discovered in two localities, somewhere in Converse County and at Buffalo, Johnson County; and Elephas imperator ( $p .101)$ somewhere along Powder River. In no one of these three cases do we have exact records regarding the locality or the formation. Elephants of undetermined species ( $p$. 118) have been met with in the region of Raw Hide Butte, Converse, or Laramie Counties; somewhere about Casper, Natrona County; and in Laramie Canyon, Albany County.

Bison remains, possibly those of Bison bison (p. 208) have been found along Lance Creek, Converse County; and on Henry's Fork, Uinta County. These bison finds are really of little importance. From the others we learn simply that during the Pleistocene, or some part of it, horses and elephants were able to exist in that mountainous region.

The geological history of the State during the Pleistocene is itself interesting; but it is not necessary to dwell on it here. It may be read in Darton's work on the geology of the southern half of the Black Hills (Ann. Rep. U. S. Geol. Surv., vol. xxI, pt. IV, pp. 489-599) and in the various folios which have been issued by the U. S. Geological Survey. In brief, there prevailed during the early Quaternary an epoch of high elevation and abundant preciptation; and these conditions led to the erosion of canyons and gorges. About this time also there were formed great glaciers which distributed rock materials along their valleys in the form of moraines. At a later time, probably during the Wisconsin, there was a renewal of glacial conditions. The glaciers of this 
time swept away a large part of the ancient moraines and deposited new ones. Along the rivers and small streams were laid down alluvial deposits; but these are difficult to distinguish from those of Recent times. There are present above this alluvium at a height of from 50 to 100 feet, terraces of fine but mostly coarse materials which were laid down at an earlier epoch, possibly during the earlier glaciation. For a conspicuous display of both the earlier and the later deposits folio 173 describing Laramie County may be consulted.

It may well be imagined that in this mountainous region during periods of general glaciation few species of vertebrates, and of these only the inost hardy, would have been able to exist. When, however, the warm interglacial periods had come on, the mountains were repopulated; and it was during some of these milder times when the elephants and horses left their bones and teeth in the soil.

\section{MINNESO'TA.}

The geology of the Pleistocene epoch is to be learned especially from the publications of the Minnesota Geological Survey. The rolumes of N. H. Winchell's Final Reports, besides presenting a general account of the Pleistocene, deal with the details of the various counties. More recent discussions of the Pleistocene of the State are to be found in three Bulletins of the Minnesota Geological Survey. These are Bulletin 12, 1915, by Frank Lererett, and Bulletins 13 and 14 by Frank Leverett and Frederick W. Sardeson. The U. S. Geological Survey has published three folios, a part of each of which is devoted to the Pleistocene. Folio 117 by C. M. Hall and D. E. Willard described two quadrangles in the region about Fargo, North Dakota, and Moorhead, Minnesota. A part of the Fargo quadrangle lies in Minnesota along Red River. Folio 210, 1919, by Sardeson, details the geology of two quadrangles lying further south and a little further east than those of Folic, 11\%. Most of Douglas and Pope Counties are included in these quadrangles. Sardeson has given the details of the region around St. Paul and Minneapolis in Folio 201, 1916. The same geologist presented in 1922 a concise and interesting account of the glacial drift sheets in Minnesota (Pan-Amer. Geolngist. vol. xxxviI, pp. 383-402, with 3 maps).

With the exception of a small area in the southeastern corner of the State which includes a little of the "driftless region," the whole State is covered by deposits of drift, which belong to different Pleistocene stages. Nebraskan drift (pre-Kansan) is recognized as present in exposed remnants.

Interglacial deposits have been discovered in nearly every county of the southern tier and in some farther north. These have in many cases furnished peat and wood and gasteropod mollusks (Final Rep. Geol. Surr. Minn., rol. I). Upham recalls these occurrences and believes that the deposits belong to the Aftonian (Bull. Geol. Soc. Amer., rol. xxxir, p. 49\%). An "old gray drift" referred to the Kansan stage occupies a considerable area in the southeastern corner of the State and a smaller area in the southwestern corner (Leverett and Sardeson, Bull. 11, Minn. Geol. Surv., fig. 2, pp. 13, 46; Sardeson, Folio 201 U. S. Geol. Surv., p. $\%$ ).

South of St. Paul have been observed deposits believed to belong to the Illinoian stage. On Map 29 this is "old red drift" orer "old gray drift" (Lev- 
erett and Sardeson, p. 48.) The rest of the State is overlain by deposits belonging to the Wisconsin stage. As stated by Sardeson (Folio 210, p. 2) Minnesota was twice invaded by the ice during the Wisconsin stage, first by a sheet coming from the north, and later by two sheets, one coming from the northeast and another from the northwest. A large part of the northeastern corner of the State, the central part south to about $45^{\circ}$ is occupied by a red drift of about middle Wisconsin age. The rest of the Wisconsin-covered area is of later date and furnished the "young gray drift," overlying partly the "red drift." For the distribution of the various drift sheets, Leverett and Sardeson may be consulted (op. cit., pp. 45-58).

As the late Wisconsin ice retired a lake began to form along its southern edge and the water escaped down Warren River, now the Minnesota. As the ice continued to withdraw, the lake increased in size until it occupied the northern and northwestern parts of Minnesota, a strip of eastern North Dakota, and a wide area, in British America north to about $55^{\circ}$ of latitude. The surface covered was about 110,000 square miles, an area greater than that of the five great lakes drained by the St. Lawrence. At length the drainage was diverted into Hudson Bay. Lake Agassiz, as it is called, is now represented only by small lakes in northern Minnesota and a number of larger ones in British America. The deposits of silt and sands carried into Lake Agassiz now form an immense level plain.

The Pleistocene deposits of Minnesota have not made any greatly important contributions to vertebrate palæontology. So far as the writer has been able to learn only seven determinable genera of vertebrates have been met with in the Pleistocene beds of the State: Bison, Ovibos, Rangifer, Alces, Elephas, Megalonyx, and Castoroides. All of these lived on until near the close of the glacial period; the first 4 still exist, Ovibos and Rangifer being confined to the shores and islands of the Arctic Ocean, Bison and Alces yet living in the United States and in Europe. Elephas is now native to Africa and Asia. The others are extinct. From the geological conditions in which the fossils referred to have been found it is quite certain that all, except possibly the musk-ox (Ovibos), had lived in Minnesota during, or not long after the close of, the Wisconsin ice stage, for the remains have been discovered in deposits laid down by that glacial sheet or by outflows of water from its borders. The musk-ox found in the driftless region, somewhere between Wabasha and Theilman, in Wabasha County, was believed by Winchell (Bull. Minn. Acad. Sci., vol. Iv, p. 419) to have lived possibly during the time of the Iowan loess period; but not unlikely during the Wisconsin.

The most northern point where vertebrates of Pleistocene age have been discovered is Pine River, Beltrami County (p. 208) and it is not certain that the bison there observed is not of Recent times. At Crosby, Crow Wing County, many bones of Bison occidentalis and some of Bison bison (p. 208) were found in a peat bed overlying drift of middle Wisconsin age. With these were found also some antlers of Alces americanus and of Rangifer, probably $R$. caribou (p. 17\%).

At Mora, Kanabec County, were found remains of a bison, probably of the existing species (p. 208). At Fairhaven, Stearns County, a tooth was found which was supposed by N.H. Winchell to be that of an elephant ( $p$. 
$119)$; but which seems quite as likely to be that of a mastodon. At Stillwater, Washington County, was found a tusk which was thought to be that of a mastodon (p. 44), but it also may have been that of an elephant. In Anoka County, 5 miles north of Minneapolis, a tusk and a tooth of an undetermined species of elephant (p. 119) were found in the gravel terrace, on the east side of Mississippi River. Various proboscidean remains have been met with in the vicinity of Minneapolis; but most of them may belong to either the mastodon or to two or three species of elephant. In Yale University there is, however, from Minneapolis, a tooth which is certainly that of Elephas boreus (p. 56) ; here too has been discovered a jaw of the giant beaver, Castoroides ohioensis (p.212). Of still more interest is the discovery, within the city, of a caudal vertebra believed to belong to the ground-sloth Megalonyx, probably $M$. jeffersonii. This affords further evidence that this genus of ground-sloths continued on after the retirement of the Wisconsin ice and that the climate was warmer than at the present time.

At Wabasha, Wabasha County, a tooth of Elephas boreus (p. 56) has been found in the gravel terrace along Mississippi River. As already stated, a part of a skull of Ovibos (p. 185) probably the existing species, was found somewhere west of Wabasha, along Zumbrota River. In Rice County, at Northfield, a tusk was found that was referred to the mastodon ( $p .45$ ), but it may quite as well have been that of an elephant. At Mankato, Blue Earth County, the writer has seen a part of a jaw of a mastodon (p. 45) and a part of a tooth of Elephas boreus (p. 45). Coming farther south we find reported from Minnesota City, Winona County, the discovery of a tusk of which one can say safely only that it was that of a proboscidean. In the town of Stockton, in this county, was found many years ago a remarkable tooth of an elephant, the details of which are presented on page 119. From Albert Lea, Freeborn County, the writer has received evidences of the presence of an elephant tooth, probably that of Elephas boreus (p. 56) ; from the same place has been reported a jaw of a mastodon ( $p .45)$, but it is not certain that the man who reported it knew the differences between a jaw of a mastodon and that of an elephant. At some point in Nobles County, not indicated, a large elephant tooth (p. 119) was unearthed from a depth of $2 \%$ feet. After this page was put in type Dr. C. R. Stauffer published (Science, n. s. vol. Lx, p. 41) additional finds of proboscideans in Minnesota.

\section{SOUTH DAKOTA.}

That part of South Dakota which lies east of Missouri River is in general covered by Wisconsin drift. Around the borders of this late drift, along the Big Sioux and Missouri Rivers, are found remains of one or more older drift sheets, and here and there traces of interglacial deposits. That part of the State which lies west of Missouri River has escaped direct glacial action; but during the Pleistocene, it was subjected to erosion, to the deepening of the channels of its streams, and to the laying down of sands, gravels, and soils as terraces along water courses; these terraces are now found often far above the present beds of the streams. The Edgemont folio (No. 108) and especially the Oelrichs folio (No. 85) show the distribution and character of these terraces. 
A series of quadrangles has been studied and mapped by Professor J. E. Todd, which cover a strip of country from the southeast corner of the State to near its northern boundary and through which flows James River. From these folios may be learned the changes which were brought about by the advance, the persistence, and the final recession of the Wisconsin ice sheet. The folios are known as the Elk Point (No. 156); the Parker (No. 97); the Olivet (No. 96); the Alexandria (No. 100); the Mitchell (No. 99); the DeSmet (No. 114); and the Huron (No. 113).

Inasmuch as no vertebrate fossils have been, so far as the writer knows, found in the State in deposits overlying or in Wisconsin drift, except, perhaps an elephant met with at Sioux Falls, also a musk-ox found near there, it will not be necessary to consider any further this drift sheet. Todd's work on the moraines of southeastern South Dakota must be examined (Bull. U. S. Geol. Surv. No. 158) ; for the musk-ox see his page 85 .

Nebraskan glacial deposits and Aftonian interglacial soils, sands, and gravels are found well displayed along Big Sioux River in Iowa. One naturally would expect the same deposits to occur on the western side of the river. Aftonian and Kansan have been recognized by Shimek in Union County, South Dakota, and probably Aftonian and Nebraskan at Fairview, Lincoln County.

From Dr. Wm. C. Alden the writer learns that the drift deposits indicated on the maps as lying on each side of Missouri River in Montana, North Dakota, and South Dakota are of uncertain age, being probably younger than Kansan. On the maps this drift is identified simply as pre-Wisconsin.

In the Elk Point folio, page 4, Todd stated that a geological section found at Otis Mills, in the southwest quarter of section 29, township 94 north, range 48 west, presented the following Pleistocene deposits:

1. Ieet.

1. Loess slope..................................... 55

2. Gravelly slope ............................. 45

3. Till slope.................................... 22

4. Dark clayey silt with many fresh-water shells and a lower jaw of a fossil horse.................................. 6

The latter lay on Cretaceous clay. The horse was identified as Equus complicatus or $E$. scotti (p. 153).

Todd was disposed to regard the silt as of comparatively recent origin and as having been covered by the caving down of the overhanging cliff. Shimek has, however, taken a different view regarding the age of the silt (Bull. Geol. Soc. Amer., vol. xxiII, p. 140); and he interprets it as belonging to the Aftonian. It is overlain by a stratum of gravel and on this is a thick bed of Kansan drift; this in its turn is covered by loess. From the same locality Dr. N. H. Darton sent to the U. S. National Museum 2 upper teeth of a horse (p. 153) which the writer identifies as Equus laurentius. Under what circumstances they were found is not known, but the species is regarded as of Aftonian age.

Farther north, at Sioux Falls, Minnehaha County, Todd found a vertebra of a horse (p. 153), some bones of a mammal about as large as a rabbit, and bones of an unidentified turtle. At the same place, in the Collins sand pit, Shimek got some teeth of a giant beaver (p. 212). Shimek believed that the 
beaver belonged to the Aftonian; and probably the remains found by 'Tordd belonged to the same Pleistocene stage. At Sioux Falls have been found Elephas columbi (p. 82) and possibly E. boreus; but the age of the deposits containing them is not well known. The remains referrer to $E$. boreus are described by Todd in 1894 and again in 1899 (Bull. U. S. Geol. Surv., No. 158, p. 85). They are said to have belonger to the mammoth Elephas americanus. Tusks, teeth, and some bones were met with in the loam capping the high terrace which rises about 60 feet above the present stream. Todd appears to refer the formation of the terrace to the time when the Wisconsin ice occupied the region. Some bones supposed to belong to a mastodon had previously been found there at a lower level; from this level is supposed to have come also the skull of a musk-ox. Horse remains have been secured at Sioux Falls and in Union County (p. 153).

At or near Yankton, a tooth of Elephas columbi (p. 82) was found many years ago, but lack of details regarding the geology renders the find of little importance. Two foot-bones of an indeterminable species of horse (p. 153) were found on the surface, somewhere near Fort Pierre, Stanley County. Further west, in Stanley County, at Philip, situated on Bad River, a finely preserved femur of Megalonyx (p. 9) was found in 1908 and sent to the University of Nebraska. No records are known to the writer regarding the geological age of the deposits that contained it. From the southwestern corner of the State, near Pine Ridge, Shannon County, a tooth of Mammut americanum (p. 45) was sent to the U. S. National Museum, but nothing is known as to the age of the beds in which it was buried. A tooth of an elephant (p. 120) has been reported from the "Black Hills" but the information is not of much value. Dr. C. C. O'Harra has sent to the writer a photograph of a tooth of Elephas columbi which appears to have been found near Cheyenne River, southeast of the Black Hills. A tooth of Mammut americanum (p. 45) was found in Perkins County; also a fine skull of Bison occidentalis at Pierre (p. 19?).

\section{NORTH DAKOTA.}

Only a brief statement need be made regarding the Pleistocene geology of North Dakota, inasmuch as up to the present the contributions of the State to the list of Pleistocene vertebrates is a small one. For an outline of the geological history of the State during the Quaternary the reader is referred to an article by Dr. A. G. Leonard, Director of the Geological Survey of North Dakota (Quart. Jour. Univ. N. Dak., rol. vir, pp. 233-235). Nearly the whole of that part of the State which lies east of Missouri River is covered by a sheet of drift that was laid down during the Wisconsin glacial stage. Near its close there was an ice barrier in the valley of Red River which prevented the water from escaping toward the north, and resulted in forming a body of water that has been called Lake Agassiz. According to Leonard's map this occupied a strip nearly 40 miles wide across the whole eastern end of the State. In the beach of this lake, near Ripon, Cass County, there was found, some time before 1896, a part of the skeleton of an elephant (p. 120). It is not known to what species it belonged, nor what became of the specimen. 
The animal had died and been buried there at some time after the glacial ice had withdrawn toward the north but while the lake yet existed. Another part of Lake Agassiz is described and mapped on folio No. 11\%. The southern border of the Wisconsin drift is marked conspicuously by the Altamont moraine.

West of the Missouri there are evidences of the prevalence of an older glacial stage. This is referred by Leonard provisionally to the Kansan stage; but Doctor W. C. Alden now regards it as probably younger than the Kansan, but its age is not yet exactly determined. Traces of this drift are met with from 40 to 60 miles west of the Missouri. During this glacial stage Missouri River was forced to flow along a bed lying considerably farther west than the one now occupied. This old, mostly abandoned, valley had a length of $\mathbf{1 5 5}$ miles. In the deposits laid down along this valley it may be possible yet to find the remains of middle Pleistocene vertebrates, especially mammals.

The Bismarck folio, No. 181 of the U. S. Geological Survey, illustrates the Pleistocene geology of this region. The Missouri flows diagonally across the quadrangle. The Altamont moraine, the supposed limit of the Wisconsin ice sheet, does not enter the quadrangle. Morainic deposits, glacial till, glacial outwash, and terraces appear to belong to an older drift, formerly supposed to be the Kansan. At Bismarck it has been found that Missouri River once flowed at a level of 100 feet or more below the present bed. It is supposed that the filling occurred during the Wisconsin stage.

\section{MONTANA.}

From North Dakota the glaciated area continues into Montana and on into Washington. Across Montana it follows the Missouri until the river turns to the southward. As in North Dakota, the Wisconsin approaches the Missouri but does not cross it. On each side of the river is an older drift, referred usually to the Kansan, but which is now believed to be younger. The Fort Benton quadrangle extends somewhat north of the river. Darton, in Folio No. 55, reported that the whole half of the quadrangle was covered by an almost continuous sheet of drift, but he did not identify the stage. It appears to belong to the older drift, rather than to the Wisconsin. Beds of loess up to 100 feet in thickness were found.

Besides glacial materials laid down by the ice sheets that came down from the north, deposits were made by local glaciers. These, too, appear to belong to earlier and later stages. Such deposits were found in the Philipsburg quadrangle (Folio No. 196). Rowe and Wilson (Univ. Montana Studies, ser. No. 1, pp. 26-29) reported terraces along the rivers up to 1,000 feet above the present level of the streams.

The Philipsburg quadrangle includes parts of Granite, Deer Lodge, and Powell Counties. F. C. Calkins and W. H. Emmons found in this quadrangle evidences of at least two periods of glaciation. During the first stage, glaciers had descended into the valleys from the mountains and left their moraines; but these were later nearly all swept away or covered by a second glaciation. The moraines of this period of cold have been little eroded and their materials have undergone relatively little change; on the other hand, certain boulders of the earlier drift have suffered extensive decay. The authors 
concluded that a long interval had passed between the two stages. No determination of the age of the deposits was made.

Alden (Bull. Geol. Soc. Amer., vol. xxiIr, pp. 687-708) has discussed the Quaternary geology of Glacier Park. 'T'his lies just south of the outermost moraine laid down by any of the general ice sheets. Glaciers that originated in the Lewis Range, probably during the Wisconsin stage, carried drift materials eastward and laid them down in the Blackfoot Indian reservation. Besides these, there were found patches of an older drift on higher level. The exact age of this drift was not determined.

In this State have been found few fossil vertebrates of Pleistocene age. Only elephants, mastodons, a horse, and possibly a camel appear to have been reported; and the scanty information that has accompanied these fossils renders them of comparatively little value.

Bringing together in one paragraph the discoveries of Pleistocene vertebrates one learns that a tooth belonging to a camel (Camelops?) and taken from Pleistomene deposits was found near Flaxville, Sheridan County (p. 169). In Dawson County, Elephas columbi has been found at Axtell, and at Glendive. Somewhere near Kimball, Custer County, were picked up teeth of Elephas columbi. The same species has been identified from Ashland and Rosebud in Rosebud County (p. 83). Mammut americanum was reported from Pryor Creek, Crow Reservation (p. 46). Long ago Elephas columbi was found near Virginia City, Madison County (p. 84). A tooth of Elephas columbi (p. 84) and a molar of a mastodon (p. 46) were discovered near Diamond, Broadwater County. In the vicinity of Helena, Lewis and Clark County, have been found Elephas columbi (p. 84), Elephas imperator (p. 101), and an undetermined species of elephant (p. 120). Near Valier, Pondera County, has been discovered Elephas imperator (p. 101). Elephas columbi is known from the vicinity of Havre, Hill County (p. 83). From near Lovejoy, Phillips County, has been reported the discorery of a tooth of an undetermined species of Equus.

In 1918 (Profess. Pap. 108-J, pp. 179-184, with map) A. J. Collins and W. T. Thom published a paper on the geology of an area extending from near the eastern boundary of Montana to about longitude $111^{\circ}$, a distance of 175 miles. This area is bounded on the south by the line of $48^{\circ}, 20^{\prime}$, and on the north by the line $49^{\circ}$. Their map represented, in its western half, likewise the surface geology of Canada north to latitude $50^{\circ}$. Here is shown the Oligocene of the Cypress Hills. At a lower level is found a deposit consisting mostly of sand and gravel, and varying in thickness from a few feet to 100 feet. This rests on Fort Union, Lance, and Bear Paw formations. In these Flaxville gravels Collins and Thom collected many fragmentary fossils and teeth of vertebrates, none of which could be identified as to species, many of them as to genus only provisionally. There were recognized by Gidley horses belonging to Hipparion, Protohippus, and Merychippus; camels belonging to Procamelus, and apparently to Camelops; a rhinoceros (Teleoceras? or A phelops?), some remains of Merycodus, a metapodial bone of a saber-tooth tiger, a piece of jaw-bone of a dog-like carnivore, a species of Ceratogaulus (horned gopher) and a rabbit. On the basis of this fauna the beds were regarded as belonging to the late Miocene or early Pliocene. The conclusion is apparently 
justifiable; but the fact remains that some of these genera, as Hipparion, Procamelus, and Camelops, are known to enter the Pleistocene; others, as Teleoceras, appear to do so; and it is possible that all may be found to have existed in the very earliest, or Nebraskan, Pleistocene. Mr. Gidley concluded that the well-preserved tooth referred to Camelops was apparently a Pleistocene species. The details regarding the tooth are given on page 169 of the present work.

After the deposition of the Flaxville beds there followed a long interval, during which the gravels were deeply eroded. The streams which accomplished this work left scattered beds of silt and interstratified gravels. 'Two localities are mentioned in the report referred to, in which these deposits were 25 feet thick. In one such outcrop, near Lovejoy, was found a tooth of Equus (see p. 153). These deposits, are therefore, by the geologists referred to the late Pliocene or early Pleistocene. To the present writer it appears safe to refer all such Equus-bearing beds to the Pleistocene until Equus shall have been found in some known Pliocene deposits.

Whatever be the exact geological age, the streams of this region have since that time eroded their valleys from 100 to 500 feet below these silts and gravels. Milk River, or as thought, the ancient Missouri River, eroded a valley from 1 to 5 miles wide before the oncoming of the Wisconsin drift. Along this river and its affluents are alluvial deposits of late Pleistocene time. As noted on page 83 there has been found at Havre, in Hill County, on Milk River, a tooth of Elephas columbi, but whether in late or early Pleistocene is not known.

\section{MANITOBA, SASKATCHEWAN, ALBERTA.}

As a basis of a knowledge of the Pleistocene from Lake of the Woods to the Rocky Mountains must be taken G. M. Dawson's paper of 1875 (Rept. on Geol. and Resources 49th parallel, Geol. Surv., Canada, pp. 203-268, with map). His observations were of great value but of necessity of a general nature. He ascribed the deposition of the glacial drift mainly to floating ice in a great inland sea. The time had not come in Canada for a recognition of glaciation by continental ice sheets and for a differentiation of glacial and interglacial stages.

In 1884 (Rept. Geol. Nat. Hist. Surv. Canada for 1882-1884 C. pp. 139 152) Dawson reported on the superficial deposits and glaciation of the southern part of Alberta. He found the region in general deeply covered with glacial deposits, a special character of which was their persistence and similarity over immense areas. He concluded that in the region east of the Porcupine Hills the glacial drift probably averaged over 100 feet. On page 140 he presented a Pleistocene section beginning above, as follows:

Stratified sands, gravels, and silts.

Upper boulder clay.

Interglacial deposit with peat.

Lower boulder clay.

Quartzite shingle and associated beds.

At points the interglacial deposit was marked by a bed of lignite more or less impure. It became evident, therefore, that two glacial stages and one interglacial are represented in that region. He held that the quartzite shingle 
was preglacial and was derived entirely from the Palaxozoic rocks of the Rocky Mountains, but pointed out that, because of the discovery, by R. G. McConnell and J. B. 'Tyrrell, of 'Tertiary (Miocene) conglomerate containing similar quartzite pebbles in Cypress and Hand Hills, it was possible the quartzite shingle was derived in fact from these 'Tertiary outliers. He described the terraces along Bow River west of Calgary and at other places, and the occurrence of Laurentian erratics up to heights of 5,280 feet. He noted that no Laurentian erratics occur along Bow River west of Calgary, but found them at other places farther west. Moraines showed that local mountain glaciers extended from the mountains down the valleys but these glaciers had retreated somewhat "before at least the final period of dispersion of Laurentian erratics, for these have been found overlying distinct morainic material of Rocky Mountain origin." He still believed that the theory of floating ice best accounted for the facts of glaciation but admitted that the presence of abandoned river channels favored the view of continental glaciation, for these could otherwise be explained only on the supposition of considerable relative changes of level, of which there was little definite evidence.

In 1885 R. G. McConnell in describing the geology of the Cypress Hills region in southern Alberta and southwest Saskatchewan (Report on the Cypress Hills Wood Mountain and Adjacent Country, Geol. and Nat. Hist. Survey, Canada, Ann. Report, vol. I, 1885, pp. 71-76 C.) named the quartzite gravels underlying the glacial drift, the South Saskatchewan gravels, and regarded them as probably of Pliocene age. He noted that they contain, in a few places Laurentian pebbles but that as a rule they are distinct from the glacial drift. He found only one boulder clay sheet and no interglacial deposits. The upper 400 feet of the Cypress Hills were unglaciated and the maximum depth of the glacial sea or continental glacier on the plains surrounding the Cypress Hills was 2,000 feet, the average being about 1,500 feet. He also described the abandoned river channels and regarded them as due to normal stream erosion during a period of a greater rainfall than the present.

In 1887 (Geol. Nat. Hist. Surv. Canada, vol. II, E. pp. 139-147) J. B. Tyrrell published the results of his observations on parts of northern Alberta and Saskatchewan. He concluded that the glacial drift would not arerage more than 20 or 30 feet in thickness. He stated that in the western part of the area two boulder clays could be distinguished. A thin seam of lignite intercalated with boulder clays was found at one locality, but, in general, interglacial deposits appeared to be lacking and in the eastern part of the area the boulder clay must be regarded as forming one sheet. Following McConnell he referred the quartzite gravels at the base of the glacial drift to the Pliocene. He described the ancient river channels, now occupied by small streams, and stated that the ancient flow was apparently towards the south or southeast, whereas the flow of the present streams is north or northeast.

In 1889 (Bull. Geol. Soc. Amer., vol. I, pp. 395-410) Tyrrell described several of the moraines in Manitoba, Saskatchewan, and Alberta and referred them to a continental ice-sheet advancing from the north and northeast. He pointer out that stratified silts, probably of interglacial age, and holding 
numerous fresh-water shells and plant and fish remains, occur near the north end of Duck Mountain in Manitoba. He held that, in the plains region as a whole, there is evidence of three distinct boulder clays, two formed by the continental glacier moving southward, and the third or upper formed by local glaciers.

In 1892 R. G. McConnell (Ann. Rep. Geol. Surv. Canada, vol. v, part D, pp. 59-63) briefly described the glacial geology of part of the Athabasca district in northern Alberta. He observed boulder clays underlain by stratified sands and gravels of the age of the Saskatchewan gravels. The boulder clay was divided into two parts, a lower of a distinct reddish tint, and an upper of dark gray. In one place the two were separated by stratified sands and gravels. Masses of tar sands were found to be included in the sands and gravels above the boulder clay and he concluded that they had been derived from the Cretaceous beds and had been transported upward through a vertical interval of several hundred feet by a glacier, the center of dispersion of which lay somewhere in the region between the east ends of Lakes Athabasca and Great Slave and Hudson Bay. In the same volume (part E, pp. 215-218) J. B. Tyrrell reported on the Pleistocene geology of northwestern Manitoba. He recorded a list of the diatomaceæ, plants and mollusks found in stratified sands and silts near the north end of Duck Mountain. The beds are $\% 0$ feet or more thick, are overlain by till, and are probably interglacial in age.

The greater part of Manitoba is covered by deposits in the ancient glacial Lake Agassiz, formed during the retreat of the last ice-sheet. The prime source for information regarding this lake and its deposits is Warren Upham's great work (Monogr. U. S. Geol. Surv., vol. xxv, 1895). Upham described in detail not only the deposits of Lake Agassiz but discussed much of the literature and many of the problems connected with the glaciation of North America. He considered that all the northern part of North America east of the Rocky Mountains had been covered by a vast ice-sheet, to which G. M. Dawson had applied the name Laurentide glacier, and that Lake Agassiz came into existence during the time of final retreat of this ice-sheet. Upham also pointed out what is now generally recognized as the true explanation of many of the ancient river channels in the Great Plains region, namely that they were associated with the retreat of the last ice-sheet, and that the diversion of the flow in many cases was due to ponding of the glacial drainage waters by the ice-sheet.

J. B. Tyrrell in 1895 (Geog. Jour., vol. vi, p. 439) after his second expedition through the Barren Grounds of northern Canada applied the name Keewatin glacier to the great ice-sheet, which had its center west of Hudson Bay and which at its greatest extension spread over a large part of the Great Plains region. In later papers (Jour. Geol., vol. IV, 1896, pp. 811-815; Geol. Surv. Can., vol. vir, part 8, 1895; Geol. Surv. Can., vol. Ix, part F, 1896) he applied the name Labradorian Glacier to the ice-sheet which had its center east of Hudson Bay, thus dividing the Laurentide glacier into two parts and still added a third, the Patrician glacier south of Hudson Bay (Compte-Rendu, Congrès Géologique International XII ${ }^{\mathrm{e}}$ Session Canada, 1913, pp. 523-534; Roy. Soc. Canada, Series III, vol. x, sec. IV, 1916, pp. 1-27). Tyrrell argued that the Cordilleran ice-sheet of British Columbia attained its greatest extent earliest and that it, as well as the Keewatin glacier, had largely disappeared 
before the Isabradorean glacier $g \quad N$ to its maximum extent. But Upham has pointed out (Fields of Outflow of the North American Ice-sheet, Congrès Géologique International, Canada, 1913, Compte-Rendu, pp. 151-522) that the distribution of the very old glacial drift and the terminal moraines in the United States imply similar conditions of glaciation within both the Keewatin and Labradorean area.

In 1895 (Bull. Geol. Soc. Amer., vol. vis, pp. 31-66), G. M. Dawson discussed the glacial deposits of southwestern Alberta, in the vicinity of the Rocky Mountains. He republished the Pleistocene section, which has already been given. In his summary (p. 65) he referred to Chamberlin's glacial stages and suggested that the lower boulder clay of Alberta corresponds to the Kansan stage, and the interglacial to the post-Kansan interval, the upper boulder clay to the Iowan. The Wisconsin drift he supposed had not extended so far west. The Saskatchewan gravels and boulder clays from the west were believed by him to belong to an earlier and unnamed stage, and for this he proposerl the name Albertan.

In 1910 Dr. A. P. Coleman (Trans. Roy. Soc. Canada, ser. 3, vol. III, sec. 4, pp. 3-10) presented a valuable and interesting paper on the relation of the Cordilleran and Keewatin drifts of Alberta. An older drift adranced eastward from the Rocky Mountains a distance of from 40 to $\% 0$ miles. On the retreat of this an interglacial interval ensued. Later the Keewatin drift reached and overlapped to some extent the Cordilleran drift. Great glacial lakes formed in front of the Keewatin ice-sheet, spreading silt and clay and floated boulders. Coleman did not refer the deposits to special stages.

In 1913 Alden, associated with Stebinger (Bull. Geol. Soc. Amer., vol. xxIv, pp. 529-606), dealt in considerable detail with the glacial geology of southwestern Alberta, in connection with that of the Glacial National Park in Montana. In their summary ( $p$ p. 569-572) they reported in that region a preWisconsin drift and a drift of Wisconsin age. They concluded also that the Saskatchewan gravels, supposed by Dawson, McConnell, and Tyrrell to lie at the base of the Pleistocene, probably belong to an interglacial stage. To which of the Pleistocene stages the lower boulder deposits are to be referred is not yet determined, but Alden and Stebinger say that it probably is the Nebraskan.

W. A. Johnston in 1915 (Memoir No. 82, Geol. Surv. Canada) described the geology of the Rainy Lake district, which included a part of southeastern Manitoba. He recognized at least two distinct till sheets. The uppermost, a clay containing many boulders of limestone, was brought from the northwest by a lobe of the Keewatin glacier. Beneath this is a sandier clay without limestone boulders. It bears the name red till and it came from the Labradorean center. Both of these are regarded as belonging to the Wisconsin stage. Beneath this red till have been observed small quantities of another calcareous drift whose age has not been determined. Usually the Wisconsin drifts are overlain by the lacustrine deposits of Lake Agassiz.

The geology of Wood Mountain area in southern Saskatchewan has been described by Bruce Rose (Memoir No. 89 Geol. Surv. Canada, 1916). The glacial phenomena are briefly described on his pages 18 to 23 and 46 to 50 . He especially noted the many abandoned river valleys now occupied or not by 
small streams and long narrow lakes. He did not identify the ages of the glacial deposits.

For much of the information regarding the Pleistocene geology of this region the writer is indebted to Mr. W. A. Johnston, of the Geological Survey of Canada.

Comparatively few vertebrate fossils of the Pleistocene epoch have been discovered in western Ontario, Manitoba, Saskatchewan, and Alberta. The pages are here cited on which these fossils and their geological environment are described.

In Manitoba, at York Factory, on Hudson Bay, at the mouth of Nelson River, was discovered a skull of a horse, not certainly fossil (p. 154). In Manitoba remains of extinct bisons have been found at three localities. At Aweme, Beautiful Plains County, and at Douglas Station, Norfolk County, were secured skulls of Bison occidentalis (p. 200); at Arden, Beautiful Plains County, were found some parts of an undetermined species of bison (p. 200). At Moose Jaw, Saskatchewan, two teeth of Elephas columbi have been found (p. 84). Near Fort Pelly a proboscidean shoulder-blade, referred to an elephant, was discovered in 1854 (p. 121). In Alberta, at Edmonston, were discovered a tooth referred to Elephas columbi (p. 84) and a skull of a musk-ox, probably Ovibos moschatus (p. 185). On the bank of Loon River was obtained a tooth of an unidentified elephant, perhaps $E$. boreus (p. 121). At Empress, Medicine Hat County, was found a tooth of an undetermined horse (p. 154). Remains belonging apparently to Bison bison have been discovered at Red Deer, Red Deer County, and at Coleman, Macleod County (p. 209). 


\section{lixplanation of Map 1.}

Numbers indicating locallties In Mississippi, Tennessee, and Illinols are explained in PubLouisianA :

1. Petite Anse, Iberia Parish, Mylodon harlani (p. 1) ; Megalonyx sp. indet. (p.1). Texas:

1. Wheeler Co., Nothrotherium texanum (p.1).

2. Rock Creek, Briscoe Co., Mylodon sodalis?, M. harlani (p. 1).

3. Terlingua, Brewster Co., Nothrotherium sp. indet. (p. 2).

4. Wolfe City, Hunt Co., Glyptodon petaliferus (p. 2).

5. Speegleville, McIennan Co., Mylodon harlani (p. 2).

6. Pittbridge, Burleson or Brazos Co., Megatherium sp. indet. and Chlamy. therium septentrionale (p. 3).

7. Hidalgo Falls, Washington Co., Megalonyx sp. indet. (p. 3).

8. Sour Lake, Hardin Co., Megalonyx validus (p. 3).

9. San Felipe, Austin Co., Mylodon sp. indet. (p. 3).

10. Fort Bend? Co., Megatherium sp. indet. (p. 3 ).

11. Nueces Co., Glyptodon petaliferus (p. 4).

12. Hawley, Jones Co., Glyptodon petaliferus? (p. 2).

13. Bastrop, Bastrop Co., Mylodon sp. indet. (p. 3 ).

14. Temple, Bell Co., Mylodon sp. indet. (p. 2).

15. Quinlan, Hunt Co., Megalonyx jeffersonii (p. 2). OKLAHOMA :

1. Mulhall, Logan Co., "giant sloth" (p. 4).

Missouri :

1. Pomme de Terre River, Benton or Hickory Co.. Mylodon harlani and Mega. therium? (p. 4).

2. Kimmswick, Jefferson Co., Megalonyx jeffersonii (p. 5). Kansas :

1. Seneca, Nemaha Co., Mylodon harlani? (p. 5).

2. Harper township, McPherson Co., Megalonyx leidyi (p. 5).

3. Meade or Clark Co., Mylodon harlani (p. 6).

Colorado:

1. Walsenlurg, Huerfano Co., Mylodon harlani (p. 6). Iow :

1. Mills Co., Megalonyx sp. indet. (p. 6).

2. Missouri Valley, Harrison Co., Megalonyx sp. indet. (p. 7) ; Mylodon harlani (p. 6).

3. Turin, Monona Co., Megalonyx jeffersonii (1. 7 ).

4. Sioux City, Woodbury Co., Megalonyx jeffersonii (1) 7 ).

5. Akron, Plymouth Co., Megalonyx? sp. indet. (p. 7 ).

6. Dubuque, Dubuque Co., Megalonyx sp. indet. (p. 7 ).

7. Aroca, Pottawattamie Co., Megalonyx jeffersonii (p.6).

8. Wayland, Henry Co., Megalonyx jeffersonii (p. 7 ).

Nebraska :

1. Tecumseh, Johnson Co., Mylodon sp. indet. (p. S).

2. Red Cloud, Webster Co., Mylodon sp. indet. (p. 8).

3. Grayson, Sheridan Co., Mylodon garmani (p. 8).

4. Box Butte Creek, Sherislan Co., Megalonyx leidyi? (p. 9). MINNESOTA:

1. Minmeapolis, Hennepin Co., Megalonyx sp. indet. (p. 9).

Souti DAкота:

1. Philip, Stanley Co., Megalonyx jeffersonii? (p. 9). 


\section{MAP 1.}
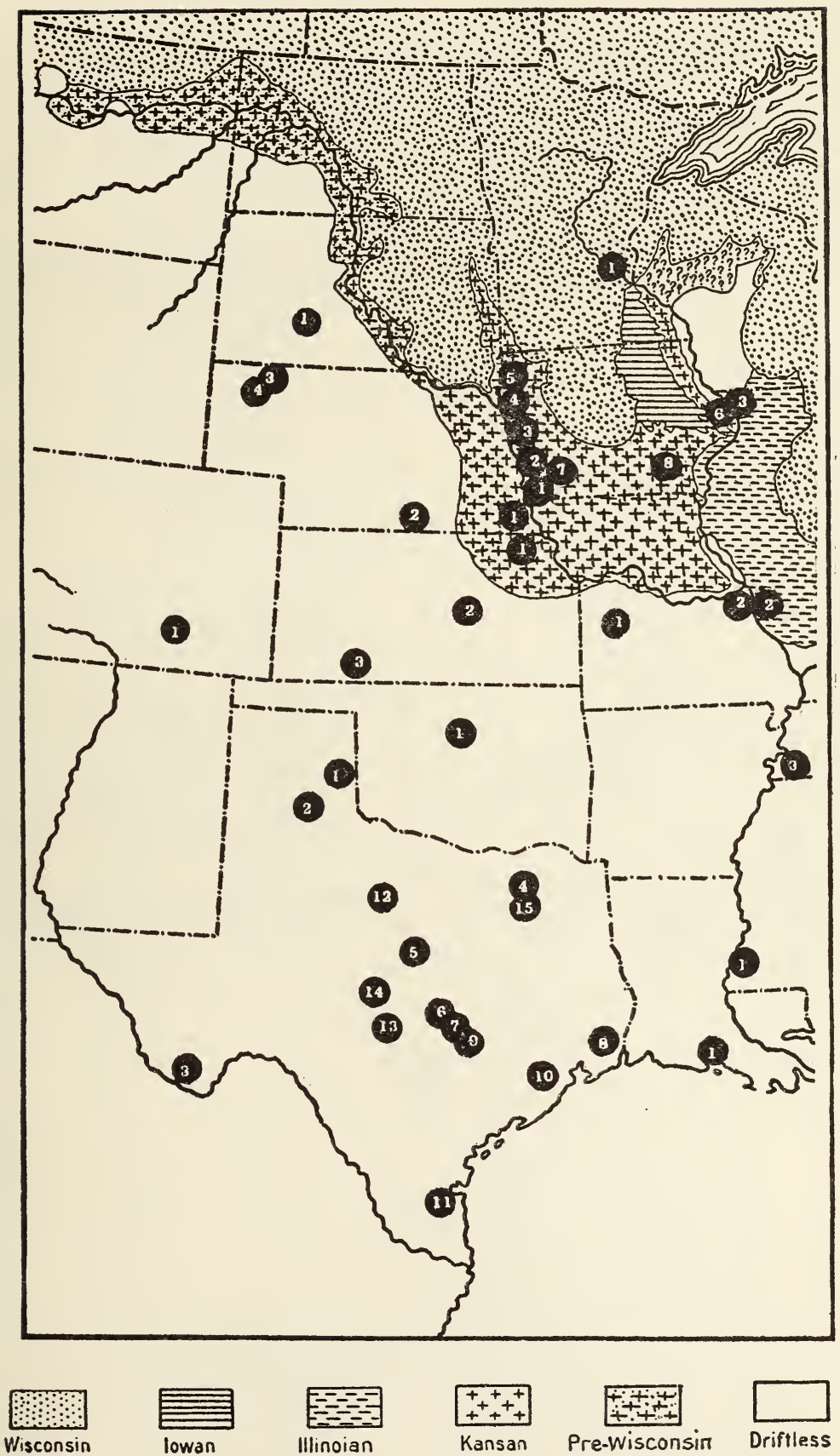

Location of finds of Xenarthra in Middle Region of North America. 


\section{Fixpanation of Map 2.}

Unless another name is used after the localities, Mammut americanum is to be understood.

Numbers indicating localities in Mississippi, Tennessee, Illinois, and Wisconsin are explained in Publication No. 322 of Carnegie Institution of Washington.

LOUISIANA :

1. Bistineau Iake, Webster Parish (p. 10).

2. Castor, Bienville Parish (p. 10).

3. Rayburn's Salt Works, Bienville Parish (p. 10)

4. Price's Salt Works, Winn Parish (p. 10). Drake's Salt Works, Winn Parish (p. 10).

5. Opelousas, St. Landry Parish (p. 11).

6. Petite Anse, Iberia Parish (p. 11).

7. Côte Blanche, St. Mary's Parish (p. 11).

8. Little Bayou Sara, West Feliciana Parish (p. 12).

9. Port Hudson, East Baton Rouge Parish (p. 12).

10. Alsworth, East Feliciana Parish (p. 12).

11. Baton Rouge, East Baton Rouge Parish TExas : (p. 12).

See explanation of Map 3 .

ARKANSAS :

1. Helena, Phillips Co. (p. 22).

2. Truman, Poinsett Co. (p. 22).

3. In Mississippi River, Chicot Co. (p. 22). OKLAHOMA:
1. Afton, Ottawa Co. (p. 23).
2. Peno, Le Flore Co. (p. 23).
3. Walker, Cleveland Co. (p. 23).
4. Citra, Hughes Co. (p. 23).
5. Mulhall, Logan Co. (p. 23).

New Mexico:

1. Taos, Taos Co. (p. 24).

2. Mastodon, Donna Ana Co. (p. 24). Missour I

1. Galena, Stone Co. (p. 24).

2. Joplin, Jasper Co. (p. 24)

3. Springfield, Greene Co. (p. 25)

4. Papinsville, Bates Co. (p. 25).

5. Pomme de Terre River, Benton Co. (p. 25).

6. Tackner, Benton Co. (p. 28).

7. Osceola, St. Clair Co. (p. 29).

8. Sedalia, Pettis Co. (p. 29)

9. Bourbeuse Creek, Gasconade Co. (p. 29).

10. - Ste. Genevieve Co. (p. 31).

11. Kimswick, Jefferson Co. (p. 31)

12. St. Louis, St. Louis Co. (p. 31).

13. Arrowrock, Saline Co. (p. 31).
Missour I-Continued:

14. Kansas City, Jackson Co. (p. 32).

15. Line Creek, Platt Co. (p. 32 ).

16. Caldwell Co. (p. 32).

17. St. Joseph, Buchanan Co. (p. 32).

18. Clarksville, Pike Co. (p. 32)

19. Fertile, Washington Co. (p. 31).

Kansas :

1. Little Osage River, Bourbon Co. (p. 33).

2. Fmporia, Lyon Co. (p. 3.3).

3. Franklin Co. (p. 33).

4. Osawatomie, Miami Co. (p. 33).

5. Lawrence, Douglas Co., Mammut progenium (p. 33).

6. Palermo, Doniphan Co. (p. 34).

7. Manhattan, Riley Co. (p. 35).

8. - Jewell Co. (p. 35).

9. McPherson, MePherson Co., Anancus mirificus (p. 35).

10. Buffalo, Wilson Co. (p. 33). Colorado:

1. Golden, Jefferson Co. (p. 35).

IowA: See Map 4.

Nebraska :

1. Pender, Thurston Co. (p. 43).

2. Pickrell, Gage Co. (p. 43).

3. Sutton, Clay Co. (p. 43).

4. Buffalo Co. (p. 43).

5. Valentine, Cherry Co. (p. 44).

6. Seneca, Thomas Co., Anancus mirificus (p. 44).

Minnesota :

1. Fairhaven, Stearns Co. (p. 44).

2. Stillwater, Washington Co. (p. 44).

3. Northfield, Rice Co. (p. 45).

4. Mankato, Blue Earth Co. (p. 45).

5. Albert Lea, Freeborn Co. (p. 45)

6. Minnesota City, Winona Co. (p. 45). SOUTH DAKOTA :

1. P'ine Ridge, Shannon Co. (p. 45).

2. Perkins Co. (p. 45). Number not on Iap 2.

Montana :

1. Prior Creek, Crow Reservation (p. 46).

2. Diamond City, Broadwater Co. (p. 46). 
MaP 2.
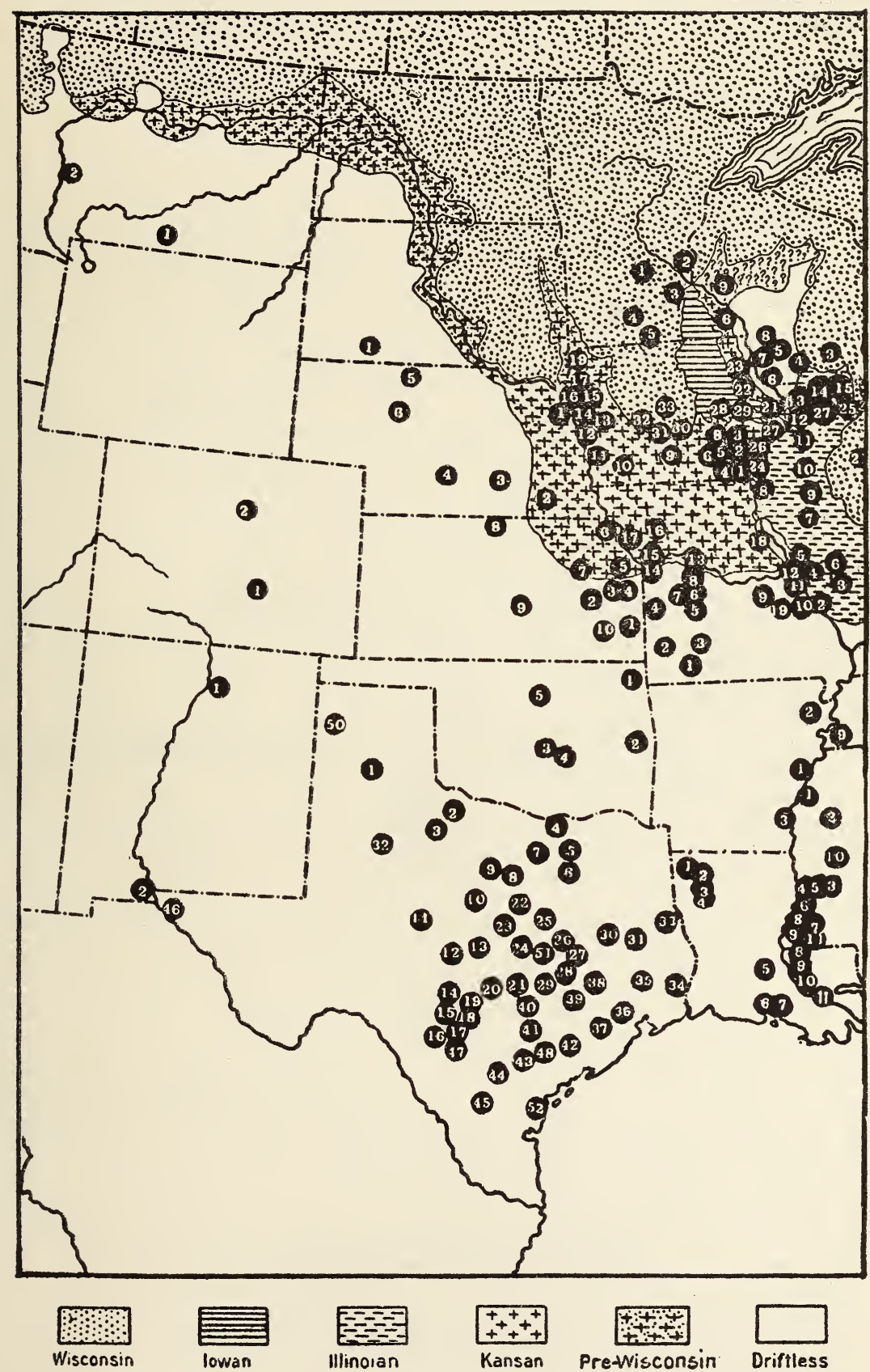

Location of finds of Mastodons in Middle Region of North America. 


\section{hiplanation of Map 3.}

Unless another name is used after the localities, Mammut americanum is to be understood.

Texas :

1. Palo Duro Canyon, Randall Co. (p. 12).

2. Benjamin, Knox Co. (p. 2).

3. Knox City, Knnox Co. (p. 13).

4. Gainesville, Cooke Co. (p. 13).

5. Dallas, Dallas Co. (p. 13).

6. Wilmer, Dallas Co. (p. 13).

7. Fort Worth, Tarrant Co. (p. 13).

8. Lipan, Hood Co. (p. 14).

9. Granbury, Hood Co. (p. 14).

10. Indian Creek, Comanche Co. (p. 14).

11. San Augelo, Tom Green Co. (p. 14).

12. Oatman Creek, Llano Co. (p. 14).

13. Marble Falls, Burnet Co. (p. 14).

14. Kendalia, Kendall Co. (p. 15).

15 Cibola Creek, Kendall Co. (p. (15).

16. Medina Co. (p. 15).

17. Helotes?, Bexar Co. (p. 15).

18. Bulverde, Bexar Co. (p. 15).

19. New Braunfels, Comal Co. (p. 16).

20. Cedar Creek, Travis Co. (p. 16).

21. Bastrop, Bastrop Co. (p. 16).

22. Speegleville and Crawford, McLennan Co. (p. 16).

23. Sparta, Bell Co. (p. 16).

24. Belton, Bell Co. (p. 17).

25. Denny, Falls Co. (p. 17).

26. Munson Shoals, Brazos Co. (p. 18).

27. Pittbridge, Brazos Co., and Burleson Co., Mammut americanum, M. progenium, Anancus gratus (p. 18).

28. Hidalgo Falls, Washington Co. (p. 18).

29. Chapel Hill, Washington Co. (p. 19).

30. Leota, Madison Co. (p. 19).

31. Clapps Ferry, Trinity Co. (p. 19).

32. Post, Garza Co. (p. 19).

33. Denning, San Augustine Co. (p. 19).

34. Port Arthur, Jefferson Co. (p. 19).

35. Sour Lake, Hardin Co. (p. 20).

36. Harrisburg, Harris Co. (p. 20).

37. Brazos River, Fort Bend? Co. (p. 20 ).

38. McDowell, Austin Co. (p. 20).

39. San Felipe, Austin Co. (1. 20).

40. Ezzell, Lavaca Co. (p. 21).

41. Cuero, De Witt Co. (p. 21.)

42. Keeran Point, Victoria Co. (p. 21).

43. Berclair, Goliad Co. (p. 21).

44. Beeville, Bee Co. (1). 21).

45. Duval Co., Jim Wells Co., or Nueces Co. (p. 22).

46. El Paso, El Paso Co., Anancus? sp. indet. (p. 22).

47. San Antonio, Bexar Co. (1) 1(i).

48. Coleto Creek, Victoria Co., Anancus brazosius (p. 21).

49. Drew's Landing, San Jacinto Co. (p. 19).

50. Tascosa, Oldham Co. (1). 12).

51. Cameron, Milam Co., Mammut americanum, Anancus brazosius (p. 17).

52. Corpus Christi, Nueces Co., Anancus brazosius (p. 21). 
MAP 3.

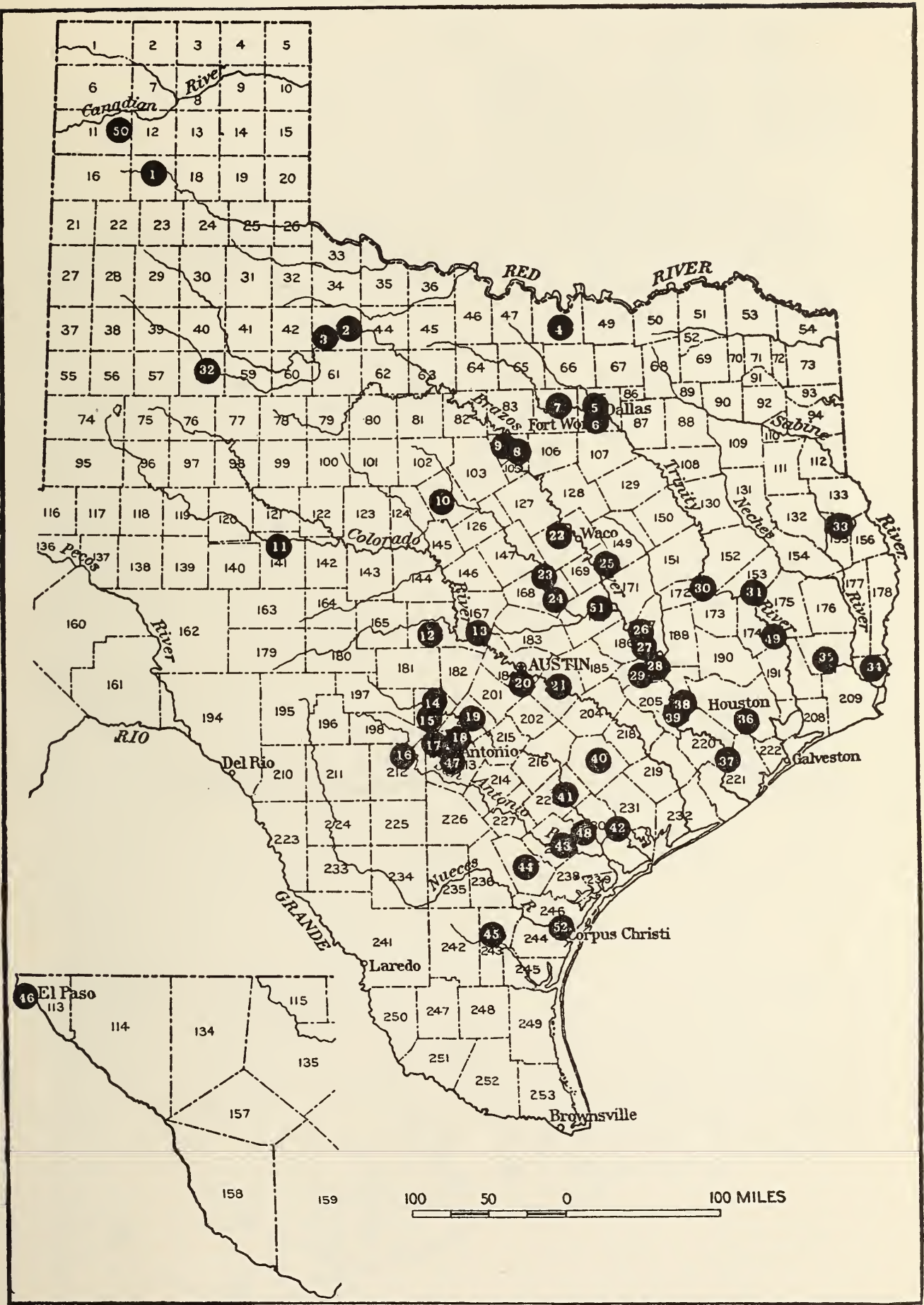

Location of finds of Mastodons in Texas. 


\section{Explanation of Map 4.}

IowA :

1. Salem, Henry Co. (p. 36).

2. Mount Pleasant, Heury Co. (p. 36).

3. Trenton, Henry Co. (p. 36).

4. Milton, Van Buren Co. (p. 37).

5. Selma, Van Buren Co. (p. 37).

(i. Eldon, Wapello Co. (p. 37 ).

7. Ottumwa, Wapello Co. (p. 37 ).

8. Mahaska Co. (p. 37).

9. New Virginia, Warren Co. (p. 37 ).

10. Clarinda, Page Co. (p. 38).

11. Missouri Valley, Harrison Co., M. americanum, M. progenium (1). 38).

12. Mt. Pisgah, Harrison Co., M. progenium (p. 38).

13. Denison, Crawford Co. (p. 38).

14. Turin, Monona Co. (p. 38).

15. Castanea, Monona Co. (p. 39).

16. Mapleton, Monona Co. (p. 39).

17. Le Mars, Plymouth Co. (p. 39 ).

18. Aklon, Plymouth Co., Anancus mirificus (p. 39).

19. Doon, Lyon Co. (p. 40 ).

20. Clinton, Clinton Co. (p. 40).

21. Bryant, Clinton Co. (p. 40).

22. Maquoketa, Jackson Co. (p. 40).

23. Garber, Clayton Co. (p. 40).

24. Fort Madison, Lee Co. (p. 40).

25. Lost Creek, Iee Co. (p. 41).

26. Wilton, Muscatine Co. (p. 41).

27. Davenport, Scott Co. (p. 41).

28. Shellsburg, Benton Co. (p. 42).

29. Springville, Linn Co. (p. 42).

30. Des Moines, Polk Co. (p. 42).

31. Adel, Dallas Co. (p. 42 ).

32. Rippey, Greene Co. (p. 42 ).

33. —— Boone Co. (p. 43).

34. Mount Pleasant, Henry Co. (p. 36).

35. Burlington, Des Moines Co. (p. 41). The number is not on Map 4. 
MaP 4.

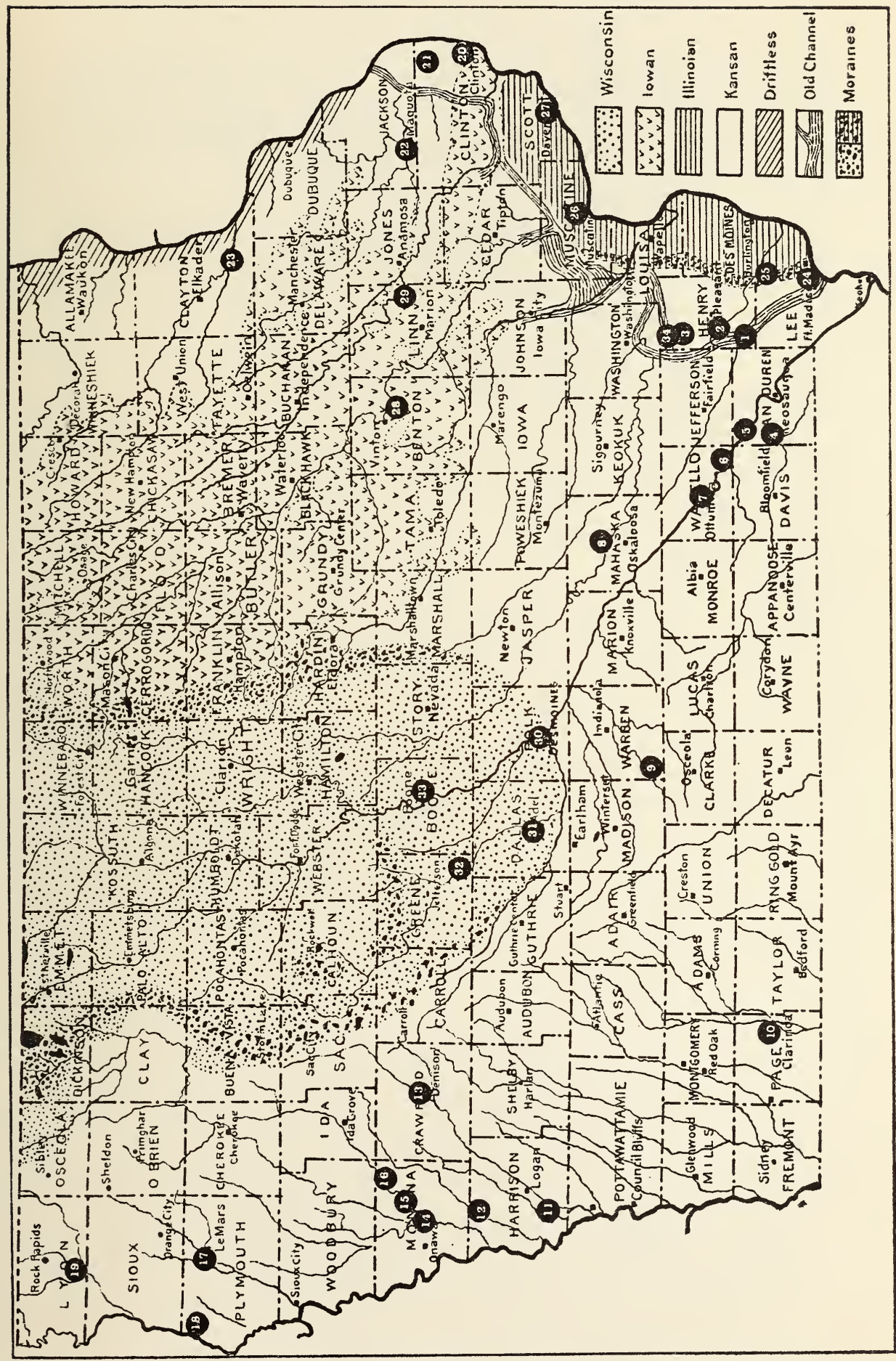

Location of finds of Mastodons in Iowa. 


\section{Explanation of Map 5.}

Texas :

1. Temple, Bell Co. (p. 47).

2. Bulverde, Bexar Co. ( ). 47).

Missouri :

1. Osage River, Benton Co. (p. 47).

KANSAS :

1. St. George, Pottawatomie Co. (p. 48).

2. Pendennis, Lane Co. (p. 48).

Iowa : See Map 6.

Nebraska :

1. York, York Co. (p. 55).

2. Dannebrog, Howard Co. (p. 55).

3. Hayes Center, Hayes Co. (p. 56).

4. Agate, Sioux Co. (p. 56).

Minnesota :

1. Minneapolis, Hennepin Co. (p. 56).

2. Wabasha, Wabasha Co. (p. 56).

3. Mankato, Blue Earth Co. (p. 56). 


\section{MAP 5.}

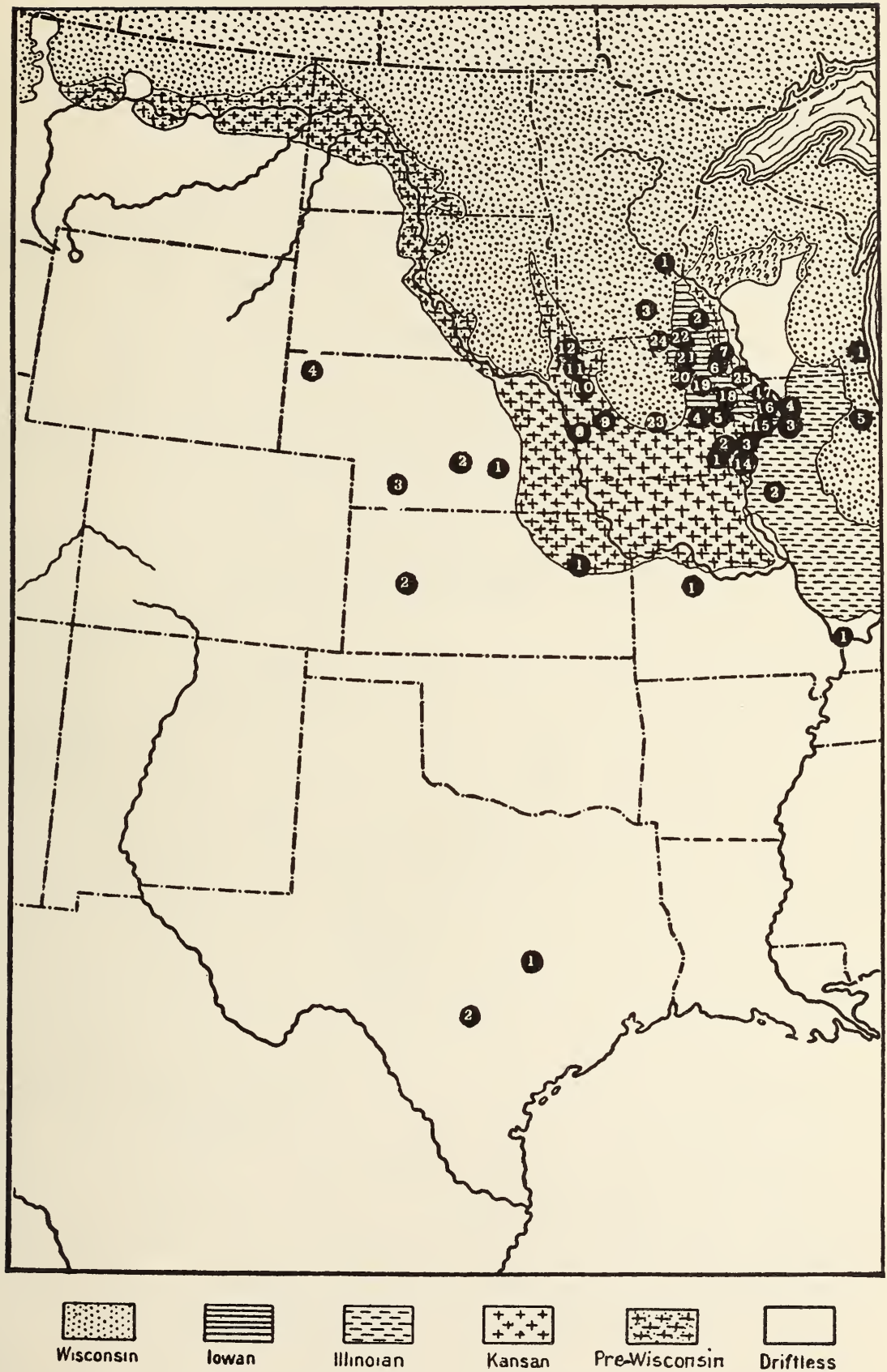

Jocation of finds of Elephas boreus in Middle Region of North America. 


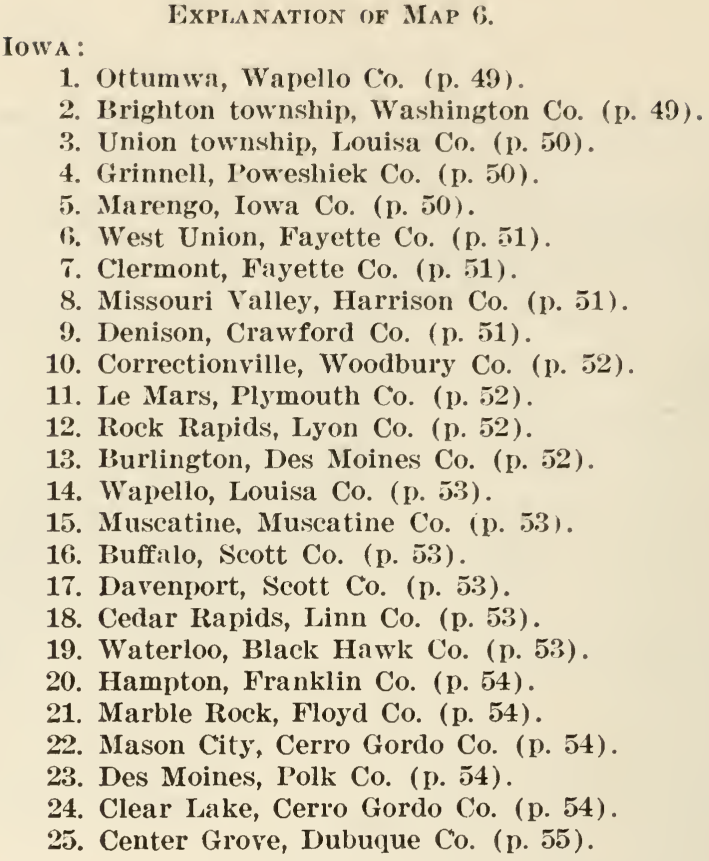


MAP 6.

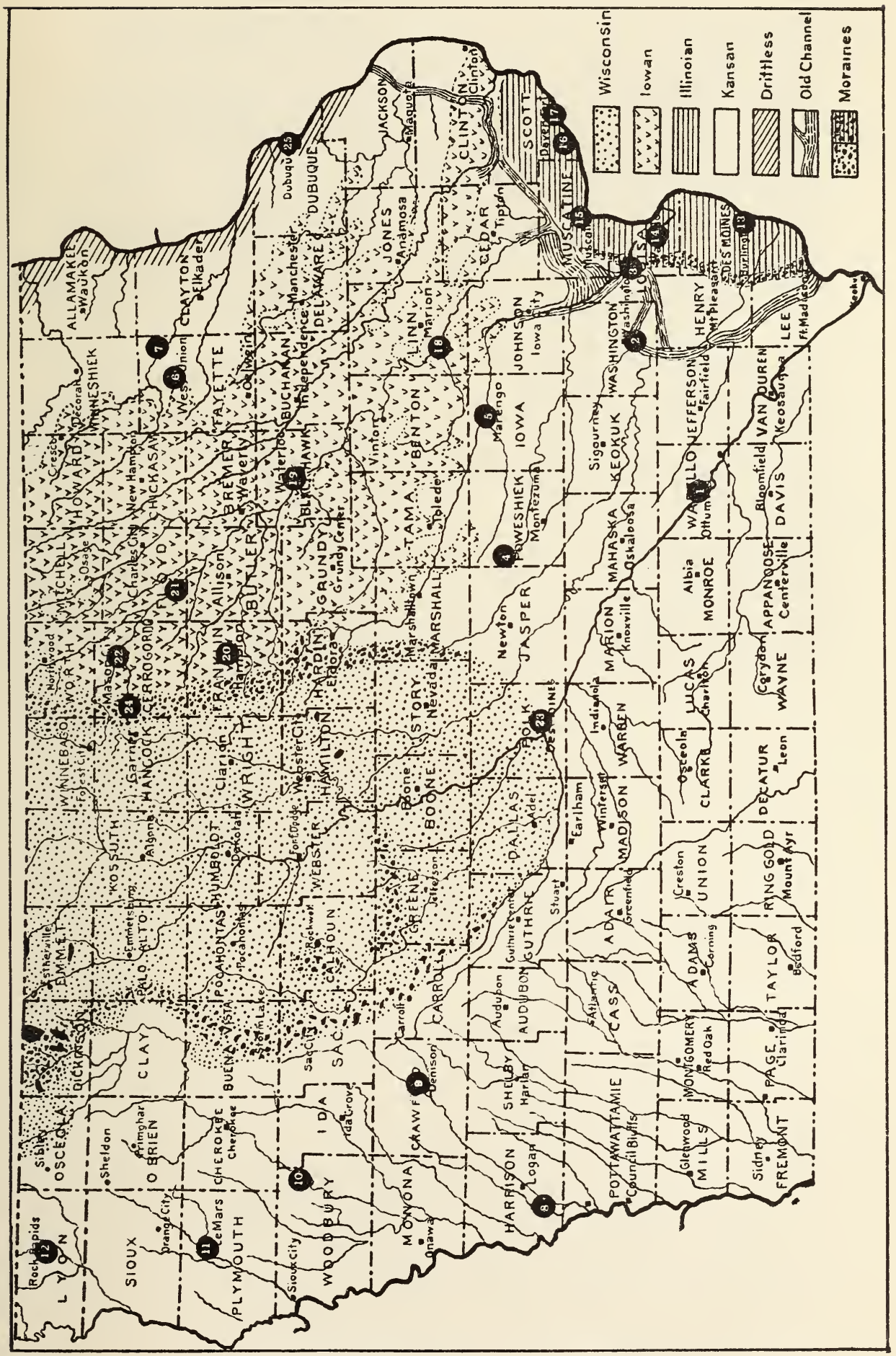

Location of finds of Elephas boreus in Iowa. 


\section{mxplanation of Map 7.}

LOUISIANA :

1. Petite Anse, Iberia Parlsh (p. 57). Texas: (See Map 8).

OKLAHOMA :

1. Afton, Ottawa Co. (p. 66).

2. Avery, Lincoln Co. (p. 67).

3. Hennesey, Kingfisher Co. (p. 67).

4. Norman, Cleveland Co. (p. 67).

New Mexico:

1. Sacramento Mts., Otero Co. (p. 67).

2. Capitan, Lincoln Co. (p. 68).

3. Albuquerque, Bernalillo Co. (p. 68).

4. Placita, Sandoval Co. (p. 68).

5. Las Vegas, San Miguel Co. (p. 68).

6. Santa Fe, Santa Fe Co. (p. 69).

7. Black Rocks, McKinley Co. (p. 69).

MIssouri :

1. Joplin, Jasper Co. (p. 69).

2. Tackner, Benton Co. (p. 69).

3. Rockport, Atchison Co. (p. 69).

4. Jackson Co. (p. 69).

KANSAS

1. Palermo, Doniphan Co. (p. 69).

2. Hammond, Bourbon Co. (p. 70)

3. Burlington, Coffey Co. (p. 70).

4. Arkansas City, Cowley Co. (p. 70).

5. McPherson, McPherson Co. (p. 71).

6. Hutchinson, Reno Co. (p. 71).

7. Pendennis, Lane Co. (p. 71)

8. Sharon Springs, Wallace Co. (p. 72)

9. Ottawa, Franklin Co. (p. 70).

10. Rantoul, Franklin Co. (p. 70).

11. Argonia, Sumner Co. (p. 71). Colorado :

1. Grass Valley, Teller Co. (p. 72).

2. Colorado City, El Paso Co. (p. 72).

3. Elbert, Elbert Co. (p. 72).

4. Parker, Douglas Co. (p. 73).

5. Denver, Denver Co. (p. 73).

6. Golden, Jefferson Co. ( $p_{\text {. 74) }}$.

7. Greeley, Weld Co. (p. 74).

8. Big Thompson Creek, Weld Co. or Larimer Co. (p. 74).

9. Ft. Collins, Larimer Co. (p. 74).

Colorado-Continued:

10. IIayden, Iroutt Co. (p. 74).

11. Calhan, El Paso Co. (p. 72).

12. Monument, Fi Paso Co. (p. 73).

Iowa: (See Map 9.)

NeBraSKA :

1. Pawnee City, Pawnee Co. (p. 78).

2. Faírbury, Jefferson Co. (p. 79).

3. Wilber, Saline Co. (p. 79).

4. Lincoln, Lancaster Co. (p. 79).

5. Martel, Lancaster Co. (p. 79).

6. Seward, Seward Co. (p. 79).

7. Grafton, Fillmore Co. (p. 80 ).

8. Oxbow Creek, Nuckolls Co. (p. 80).

9. Brickton, Adams Co. (p. 80).

10. Ravenna, Buffalo Co. (p. 80 ).

11. Lurnas Co. (p. 80).

12. Broken Bow, Custer Co. (p. 81)

13. Benkelman, Dundy Co. (p. 81).

14. Sidney, Cheyenne Co. (p. 81).

15. Peters, Sheridan Co. (p. 81)

16. Medicine Creek, Frontier Co. (p. 80).

WYOMING :

1. Caryhurst, Converse Co. (p. 81).

2. Buffalo, Johnson Co. (p. 82).

SOUTH DAKOTA :

1. Sioux Falls, Minnehaha Co. (p. 82).

2. Yankton, Yankton Co. (p. 82).

3. Cheyenne River, Black Hills (p. 82)

4. Pierre, Hughes Co. (p. 82). Number not on Map 7.

Montana:

1. Axtell, Dawson Co. (p. 83)

2. Glendive, Dawson Co. (p. 83).

3. Kimball Post Office, Custer Co. (p. 83).

4. Ashland, Rosebud Co. (p. 83).

5. Rosebud, Rosebud Co. (p. 83).

6. Havre, Choteau Co. (p. 83).

7. Diamond City, Broadwater Co. (p. 84).

8. Virginia City, Madison Co. (p. 84).

9. Helena, Lewis and Clark Co. (p. 84).

SASKATCHEWAN :

1. Moose Jaw (p. 84). 
MAP 7 .

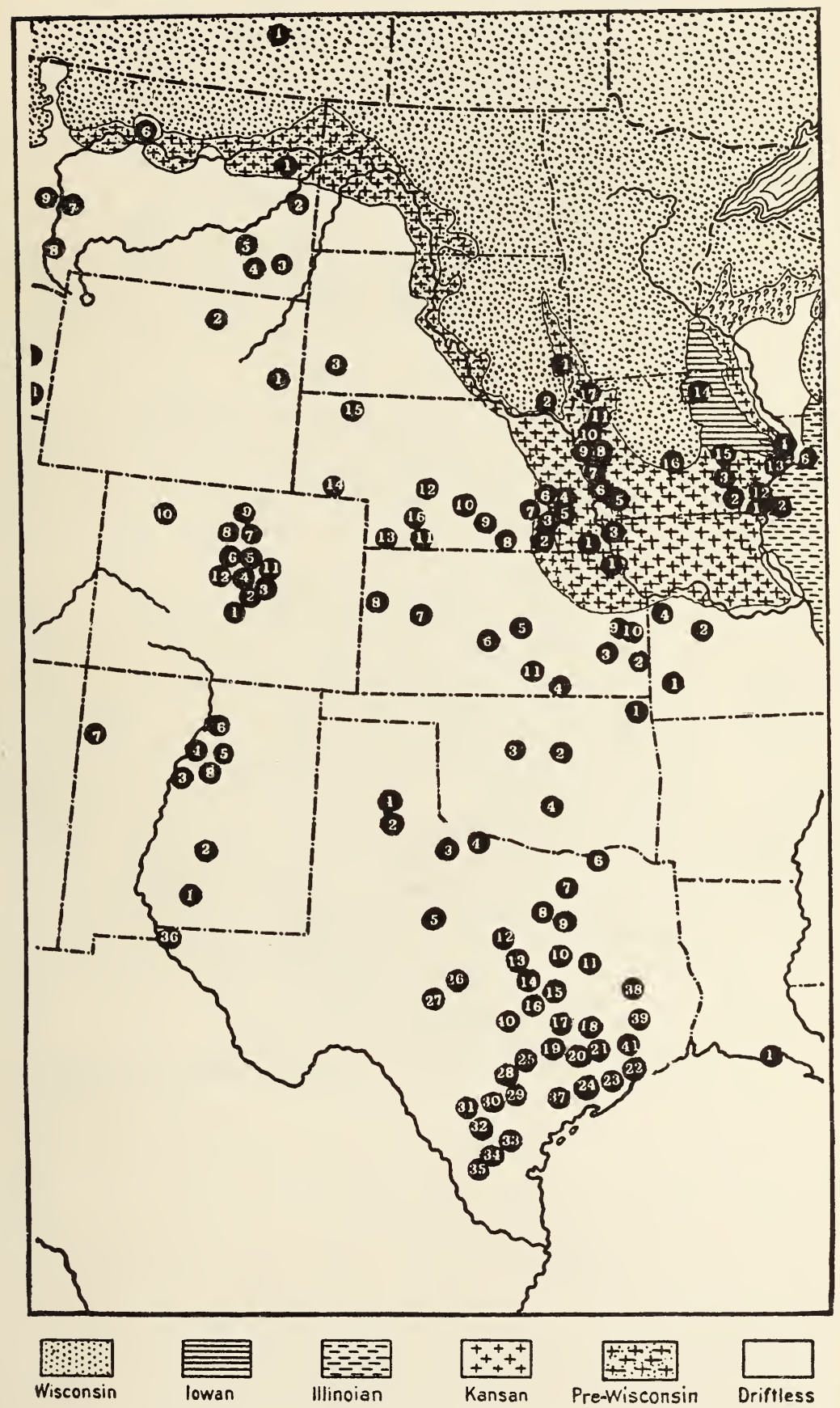

Location of finds of Elephas columbi in Middle Region of North America. 
TExas :

hxplayation of Map 8.

1. Paloduro, Amstrong Co. (1). 57).

2. Rock Creek, Brisco Co. (p. 57).

3. Foard City, Foard Co. (p. 57).

4. Vernon, Wilbarger Co. (p. 58).

5. Sweetwater, Nolan Co. (p. 58).

6. Tulip, Fannin Co. (p. 58).

7. Rock Hill, Collin Co. (p. 58).

8. Fort Worth, Tarraut Co. (1. 58).

9. Dallas, Dallas Co. (p. 58).

10. Waxahatchie, Ellis Co. (p. 59).

11. Corsicana, Navarro Co. (p. 59).

12. Paluxy Creek, Hood Co. (p. 60).

13. Clifton, Bosque Co. (p. 60).

14. Waco, McLenuan Co. (p. 60).

15. Marlin, Falls Co. (p. 61).

16. Satin, Falls Co. (p. 61).

17. Pittbridge and Munson Shoals, Brazos Co. (p. 61).

18. Navasota, Grimes Co. (p. 62).

19. Big Spring, Washington Co. (p. 62).

20. San Felipe, Austin Co. (p. 62).

21. McDowell, Austin Co. (p. 63).

22. San Leon, Galveston Co. (p. 63).

23. Alvin, Brazoria Co. (p. 68).

24. Wharton, Wharton Co. (p. 63).

25. Bastrop, Bastrop Co. (p. 64).

26. Marble Falls, Burnet Co. (p. 64).

27. Cherry Spring, Gillespie Co. (p. 64).

28. Luling, Caldwell Co. (p. 65).

29. Ottine, Gonzales Co. (p. 65).

30. Marion, Guadalupe Co. (p. 65).

31. San Antonio, Bexar Co. (p. 65).

32. Leon, Bexar Co. (p. 66).

33. Beeville, Bee Co. (p. 66).

34. Alfred, Jim Wells Co. (p. 66).

35. San Diego, Duval Co. (p. 66).

36. El Paso, El Paso Co. (p. 66).

37. Keeran Point, Victoria Co. (p. 6t).

38. Trinity, Trinity Co. (p. 59).

39. Onalaska, Polk Co. (p. 59).

40. Temple, Bell Co. (p. 61).

41. Houston, Harris Co. (p. 63).

42. Rock Hill, Collin Co. (p. 58). Number not on Maps 7, 8. 
MAP 8.

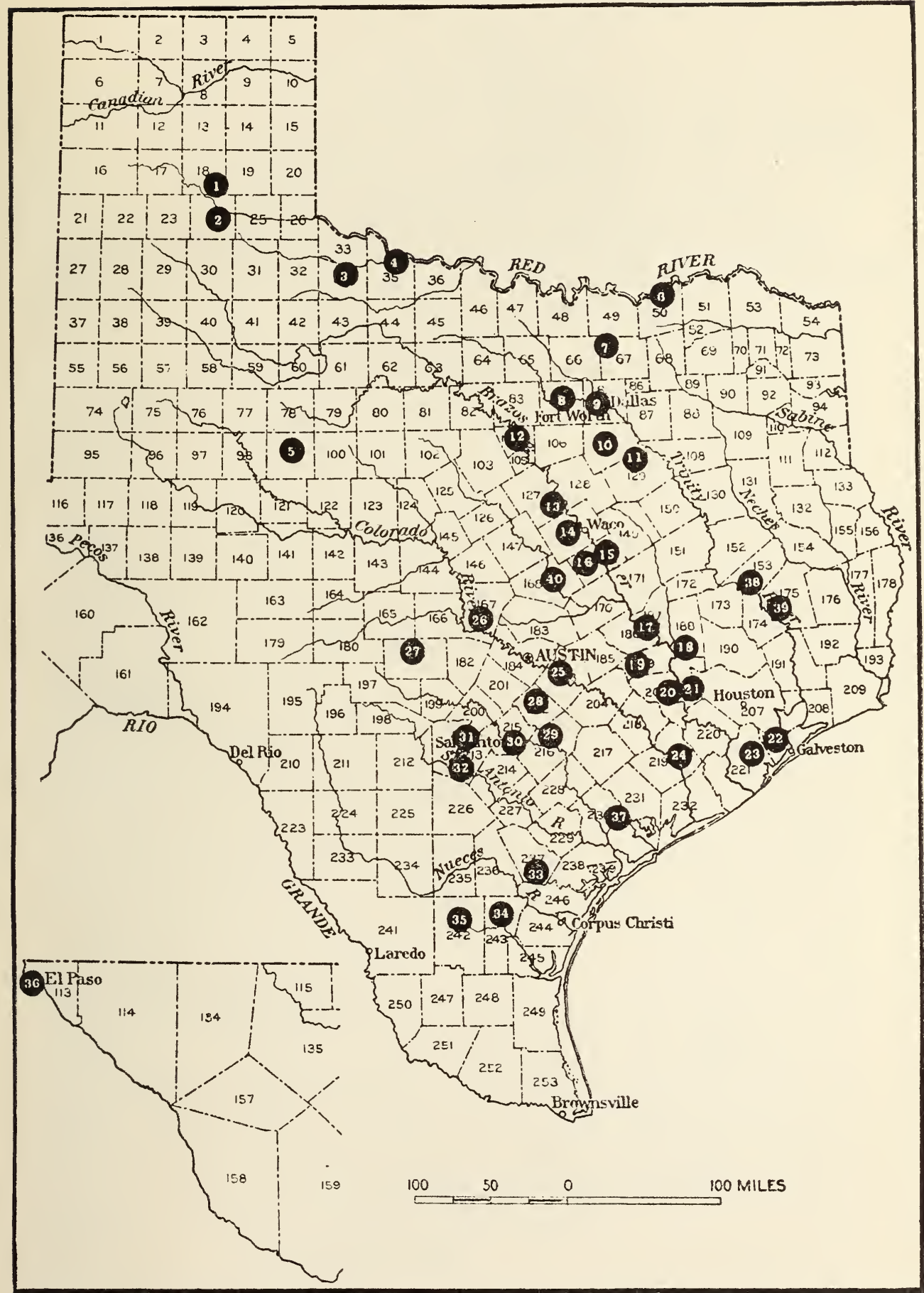

Jocation of finds of Elephas columbi in Texas. 


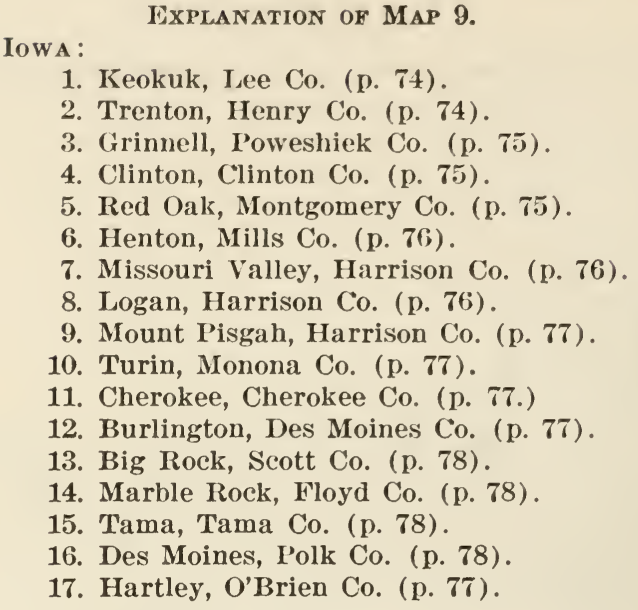


MAP 9.

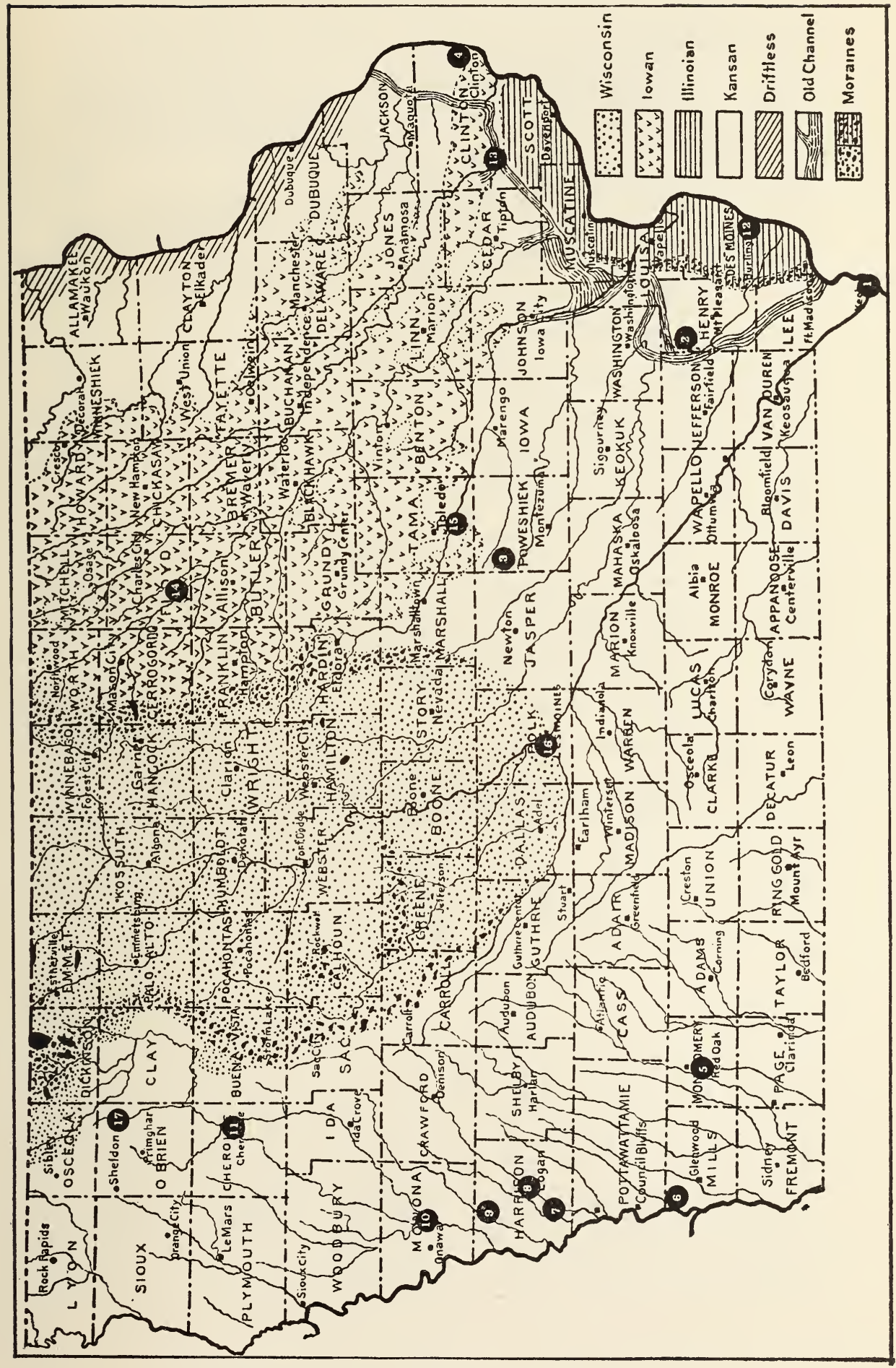

Location of finds of Elephas columbi in Iowa. 
Fxplanation of Map 10.

Texas: (See Map 11).

OKLAHOMA:

1. Afton, Ottawa Co. (1. 94).

2. Kinlock, Marshall Co. (p. 94).

3. Okeene, Blaine Co. (p. 94).

4. Kingfislier, Kingfisher Co. (p. 95). Number not on Map 10. KANSAS :

1. Wellington, Sumner Co. (p. 9.5).

2. Ness City, Ness Co. (p. 95).

3. Russell, Russell Co. (1. 95). Number not on Map 10. Colorado :

1. Laveta, Huerfano Co. (1. 96).

2. Colorado Springs, El Paso Co. (p. (H).

3. Denver, Denver Co. (p. 96).

4. Boulder, Boulder Co. (p. 97).

5. Fort Collins, Larimer Co. (p. 97).

6. Glenwood Springs, Garfield (o. (p. 97).

IowA :

1. Mt. Pisgah, Harrison Co. (p. 97).

2. Mapleton, Monona Co. (p. 97).

Nebraska :

1. Johnson Co. (p. 98).

2. Holmesville, Gage Co. (p. 98).

3. Fairbury, Jefferson Co. (p. 98).

4. Reynolds, Jefferson Co. (p. 99).

5. Waumeta, Chase Co. (p. 99).

6. Seneca, Thomas Co. (p. 100).

7. Cody, Cherry Co. (p. 100).

8. Grayson, Sheridan Co. (p. 100).

9. Hebron, Thayer Co. (p. 99).

10. Sutton, Clay Co. (p. 99).

WYOMING :

1. Powder River, Johnson Co.? (p. 101). Montana :

1. Helena, Broadwater Co. (p. 101).

2. Valier, Pondera Co. (p. 101). 
MAP 10.

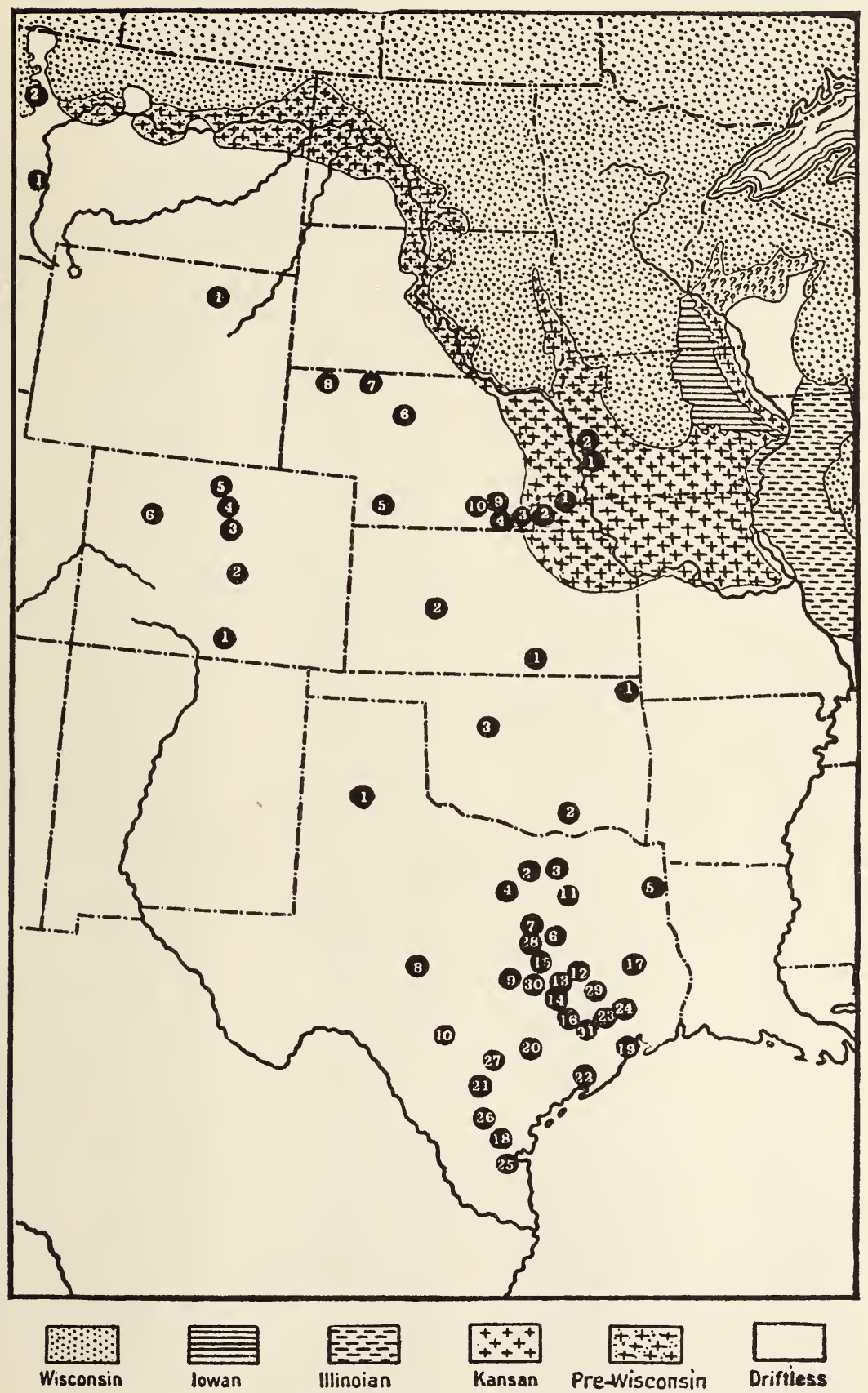

Location of finds of Elephas imperator in Middle Region of North America. 


\section{Exirianation of Map 11.}

Trixas:

1. Tule Canyon, Swislier Co. (p. 85).

2. Fort Worth, Tarrant Co. (p. 85).

3. Dallas, I oallas Co. (p. 85).

4. Paluxy Creek, Hood Co. (p. 86).

5. Hlocker, Harrison Co. (p. 86).

6. Marlin, Falls Co. (p. 87).

i. Waco, McIennan Co. (p. 88).

8. San Angelo, Tom Green Co. (p. 88)

9. Georgetown, Williamson Co. (p. 88).

10. - Bandera Co. (p. 88).

11. Waxahatchie, Ellis Co. (p. 86).

1.. Bryan, Brazos Co. (p. 89).

13. Iittbridge, Brazos Co. (p. 89)

14. Lyons, Burleson Co. (p. 90)

15. Cameron, Milam Co. (p. 90).
16. Inrenham, Washington Co. (p. 90).

17. ()nalaska, I'olk Co. (p. 8\%).

18. Heeville, Bee Co. (p. 91).

19. San Iaon, Galveston Co. (p. 92).

20. Ottine, Gonzales Co. (p. 91).

21. Gallinas Creek, Atascosa Co. (p. 92)

22. Buckeye, Matagorda Co. (p. 92).

23. San Felipe, Austin Co. (p. 92).

24. McDowell, Austin Co. (p. 9.3)

25. Robstown, Nueces Co. (p. 93).

26. Sulphur Creek. Live Oak Co. (p. 90).

27. Himendorf, Bexar Co. (p. 88)

28. Chilton, Falls Co. (p. 87).

29. Millican, Brazos Co. (p. 90).

30. Temple, Bell Co. (p. 87 ).

31. San Bernard River, Austin Co. (p. 93).

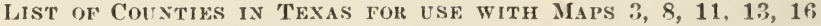

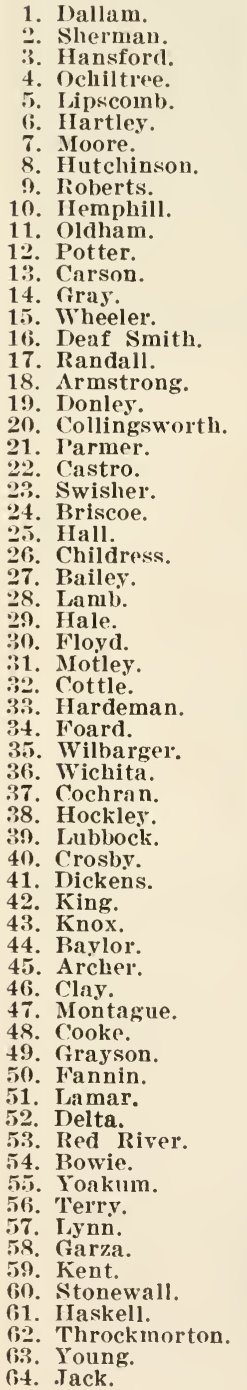

1. Dallam.

(i.). Wise.

(i6. Denton.

67. Collin.

68. Hunt.

(i). Hopkins.

70. Franklin.

71. Titus.

72. Morris.

73. Cass.

74. Gaines.

75. Dawson.

77. Scurry.

78. Fisher.

79. Jones.

80. Shackelford

81. Stephens.

82. Palo Pinto.

83. Parker.

84. Tarrant.

85. Dallas.

86. Rockwall.

87. Kaufman.

88. Van Zandt.

89. Rains.

90. Woort.

91. Camp

92. Upshur.

g:3. Marion.

94. Harrison

9.). Andrews.

96. Martin.

97. Howard.

98. Mitchell.

9?. Nolan.

100. Tavlor.

101. Callahan

10:. Eastland.

10.3. Erath.

104. Hood.

105. Somervell.

106. Johnson.

107. Ellis.

108. Henderson.

109. Smitl.

110. Fregg.

111. Rusk.

112. Panola.

113. El Paso.

114. Inspeth.

115. Loving.

116. Winckler.

117. Ector.

118. Midlind.

119. Glasscock.

120. Sterling.

121. Coke.

12.2. Runnels.

123. Coleman.

124. Brown.

125. Comancle.

126. Iamilton.

12\%. Bosque.

128. Hill.
129. Navarro.

130. Anderson.

131. ('herokee.

132. Nacogdoches.

13.3. Shelby

134. Culbertson.

135. Reeves.

136. Ward.

137. Crane.

138. Upton.

139. Reagan.

140. Irion.

141. Tom Green

142. ('oncho.

143. McCulloch.

144. San Saba.

145. Mills.

146. Lampasas.

147. Coryell.

148. McLennan.

149. Limestone.

150. Freestone.

151. Leon

152. Houston.

15:3. Trinity.

154. Angelina.

15.5. San Augustine.

156. Sabine

157. Jeff Davis.

1.58. Presidio.

159. Brewster.

160. Pecos.

161. Terrell.

162. Crockett.

163. Schleicher.

164. Menard.

165. Mason.

166. Llano.

167. Burnet.

168. Bell.

169. Falls.

170. Milam.

171. Robertson.

172. Madison.

173. Walker.

174. San Jacinto.

175. Polk.

176. Tyler.

177. Jasper.

178. Newton.

179. Sutton.

180. Kimble.

181. Gillespie.

182. Blanco.

18.. Williamson.

184. Travis.

18.). I ce.

186. Burleson.

187. Brazos.

188. Frimes.

18?. Washington.

190. Montgomery.

191. I.iberty.

1.9. IIardin.
193. Orange

194. Valverde.

195. Hdwards.

196. Real.

197. Kerr

198. Bandera.

199. Kendall.

200. Comal.

¿01. Hays.

202. Caldwell.

203. Bastrop.

204. Fayette.

205. Austin.

206. Waller.

207. Harris.

208. C'hambers

209. Jefferson.

-10. Kinney.

211. Uvalde.

212. Medina.

213. Bexar.

214. Wilson.

215. Guadalupe

216. Gonzales.

217. Iavaca.

218. Colorado.

219. Wharton.

2:0. Fort Bend.

221. Brazoria.

222. Galveston.

223. Maverick.

224. Zavalla.

225. Frio.

226. Atascosa

227. Karnes.

228. De Witt.

229. Goliad.

230. Victoria.

231. Jackson.

232. Matagorda.

233. Dimmit.

234. Iasalle.

235. McMullen

236. Live Oak

237. Bee.

238. Refugio.

239. Aransas.

40. Calhoun.

241. Tebb.

242. Duval.

243. Jin Wells.

244. Nueces.

245. Kleberg.

246. San Patricio.

247. Jim Hogg.

248. Brooks.

249. Kenedr.

250. Zapata.

251. Starr.

วล2. Hidaigo.

253. Cameron. 
MaP 11.

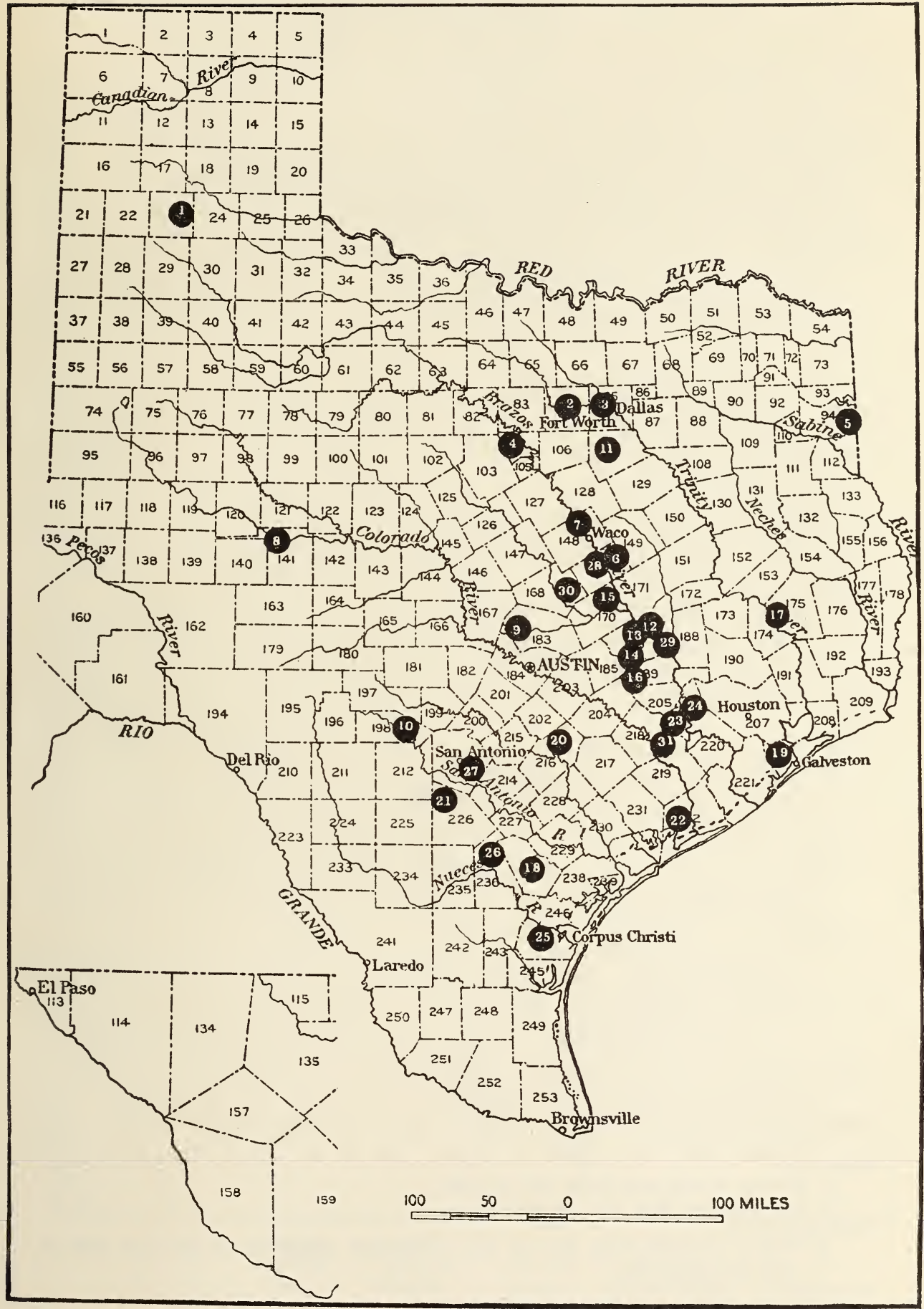

Location of finds of Elephas imperator in Texas. 
Explanation of Map 12.

Numbers indicating localities in Mississippi and Illinois are explained in Publication No. LOUISIANA : 322 of Carnegie Institution of Washington.

1. Little Bayou Sara, West Feliciana Parish (p. 102).

Texas: (See Map 13.)

OKLAHOMA :

1. Mulhall, Logan Co. (p. 108).

2. Lawton, Comanche Co. (p. 108).

New Mexico:

1. Deming, Luna Co. (p. 108).

2. Bernalillo, Sandoval Co. (p. 108).

3. Datil, Socorro Co. (p. 108).

4. Albert, Harding Co. (p. 108).

Missouri :

1. Kimmswick, Jefferson Co. (p. 109).

2. Bonne Femme Creek, Howard Co. (p. 109).

3. New Madrid, New Madrid Co. (p. 109).

4. Wellington, Lafayette Co. (p. 110). KANSAS :

1. Ottawa, Franklin Co. (p. 110).

2. Hiawatha, Brown Co. (p. 110).

3. Attica, Harper Co. (p. 110).

4. Medicine Lodge, Barber Co. (p. 110).

5. Vanhem, Clark Co. (p. 110).

6. — Meade Co. (p. 110).

7. Rush Center, Rush Co. (p. 111).

8. Russell Springs, Logan Co. (p. 111).

9. Manhattan, Riley Co. (p. 111).

10. Twelve-mile Creek, Smith Co. (p. 111).

Colorado :

1. Old Fort Lyon, Bent Co. (p. 111).

2. Dawson Butte, Douglas Co. (p. 111).

3. Melvin, Arapahoe Co. (p. 112).

4. Golden, Jefferson Co. (p. 112).

5. Denver, Denver Co. (p. 112).

IowA: (See Map 14.)

NeBraska :

1. - Gosper Co. (p. 117).

2. Indianola, Red Willow Co. (p. 118).

3. Crawford, Dawes Co. (p. 118).

4. Omaha, Douglas Co. (p. 118).

5. - Saline Co. (p. 118).

WYOMING:

1. Raw Hide Butte, Laramie Co. (p. 118).

2. Caspar, Natrona Co. (p. 118).

3. Dover, Albany Co. (p. 118).

Minnesota :

1. Fairhaven, Stearns Co. (p. 118).

2. Near Minneapolis, in Anoka Co. (p. 119).

3. Stockton, Winona Co. (p. 119).

4. Albert Lea, Freeborn Co. (p. 119).

5. — Nobles Co. (p. 119).

South Dakota :

1. Sioux Falls, Minnehaha Co. (p. 120).

2. Black Hills (p. 120).

NorTh DAKota :

1. Ripon, Cass Co. (p. 120).

Montana :

1. Helena, Lewis and Clark Co. (p. 120).

2. Butte, Silver Bow Co. (p. 120).

SASTatchewaN :

1. Region of Pelly, Pelly Co. (p. 121). 'The spot should be on the west side of the boundary line.

ALBERTA :

1. Calgary (p, 121).

Loon River (1). 121). Locality not on the map. 


\section{MAP 12.}

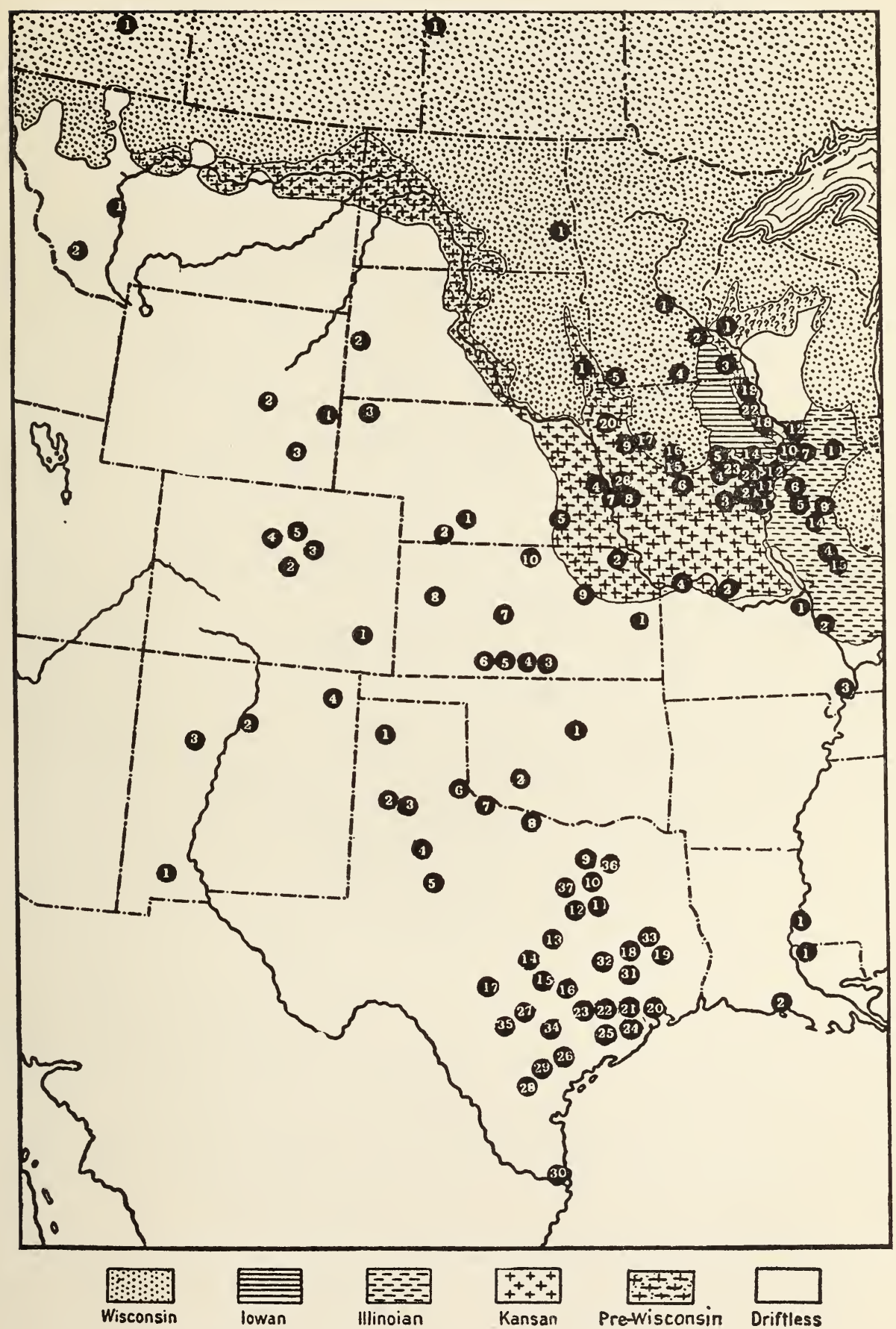

Location of finds of elephants of undetermined species in Middle Region of North America. 
Explanation of Map 13.

Texas :

1. Tascosa, Oldham Co. (p. 102).

2. Running Water, Hale Co. (p. 102).

3. Plainview, Hale Co. (p. 102).

4. McDonald's Creek, Crosby Co. (p. 102).

5. Colorado, Mitchell Co. (p. 102).

6. Tell, Childress Co. (p. 102).

7. Quanah, Hardeman Co. (p. 103).

8. Burkburnett, Wichita Co. (p. 103).

9. Denton, Denton Co. (p. 103).

10. Dallas, Dallas Co. (p. 103).

11. Dawson, Navarro Co. (p. 103).

12. Hubbard and Mountcalm, Hill Co. (p. 104).

13. Temple, Bell Co. (p. 104).

14. Liberty Hill, Williamson Co. (p. 104).

15. Austin, Travis Co. (p. 104).

16. Bastrop, Bastrop Co. (p. 104).

17. Kerrville, Kerr Co. (p. 105).

18. Iola, Grimes Co. (p. 105 ).

19. Drews Landing, San Jacinto Co. (p. 105).

20. San Leon, Galveston Co. (p. 105).

21. Brazos River, Fort Bend? Co. (p. 106).

22. Richmond, Fort Bend Co. (p. 106).

23. Eagle Lake, Austin Co. (1. 106).

24. San Bernardo Creek?, Brazoria Co. (1) I(mi).

25. Buckeye, Matagorda Co. (p. 106).

26. Inez, Victoria Co. (p. 107).

27. Parita Creek, Bexar Co. (p. 107).

2S. George West, Live Oak Co. (p. 107).

29. Beeville, Bee Co. (p. 108).

30. Brownsville, Cameron Co. (p. 108).

31. Navasota, Grimes Co. (p. 105).

32. Pittbridge, Brazos Co. (1. 105).

33. White Rock Shoals, Trinity Co. (p. 105).

34. Hallettsville, Lavaca Co. (p. 107 ).

35. Medina River, Bexar Co. (p. 107).

36. McKinney, Collin Co. (p. 103).

37. Granbury, Hood Co. (p. 104). 
MaP 13.

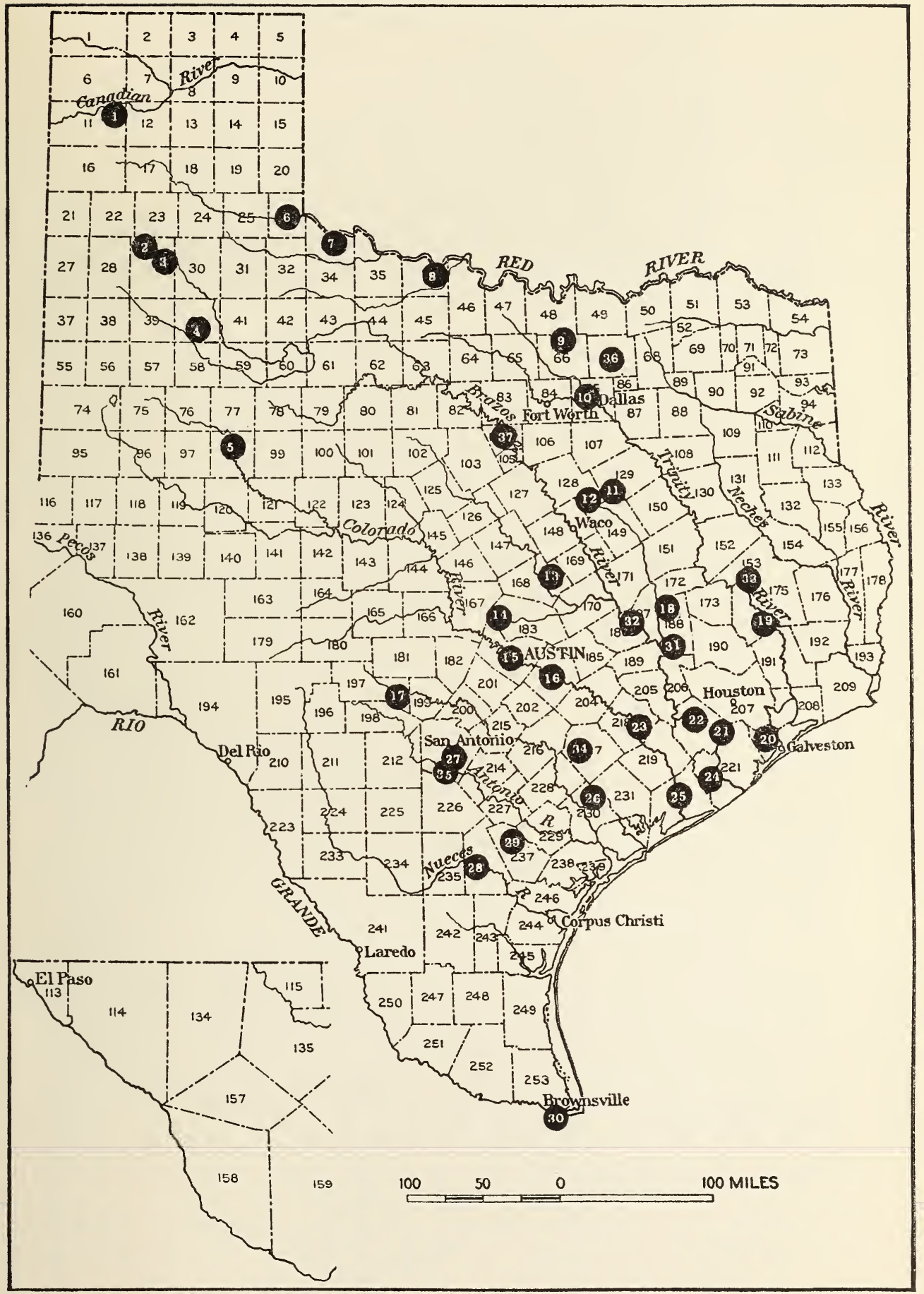

Location of finds of elephants of undetermined species in 'Texas. 
Explanation of Map 14.

Iow A :

1. Sugar Creek, Ice Co. (p. 112).

2. Walnut township, Jefferson Co. (p. 112).

3. Floris, Davis Co. (p. 113).

4. Oskaloosa, Mahaska Co. (p. 114).

5. Albion, Marshall Co. (p. 113).

6. Indianola, Warren Co. (p. 113).

7. Pacific Junction, Mills Co. (p. 114).

8. Malvern, Mills Co. (p. 114).

9. Ida Grove, Ida Co. (1). 115).

10. Clinton, Clinton Co. (p. 115).

11. Morning Sun, Louisa Co. (p. 115).

12. Sweetland township, Muscatine Co. (p. 116).

13. Blue Grass, Scott Co. (p. 116).

14. Clarence, Cedar Co. (p. 116).

15. Raccoon River, Polk Co. (p. 116).

16. Polk, Polk Co. (p. 116).

17. Lake View, Sac Co. (p. 116).

18. Dubuque, Dubuque Co. (p. 117).

19. Postville, Allamakee Co. (p. 117).

20. Le Mars, Plymouth Co. (p. 115).

21. Muscatine, Muscatine Co. (p. 115).

22. Wagner township, Clayton Co. (p. 117).

23. Iowa City, Johnson Co. (p. 113).

24. River Junction, Johnson Co. (p. 113).

25. Osceola, Clarke Co. (p. 114).

26. Washington township, Pottawattamie Co. (p. 115).

27. Grandview, Louisa Co. (1). 115). 
MaP 14.

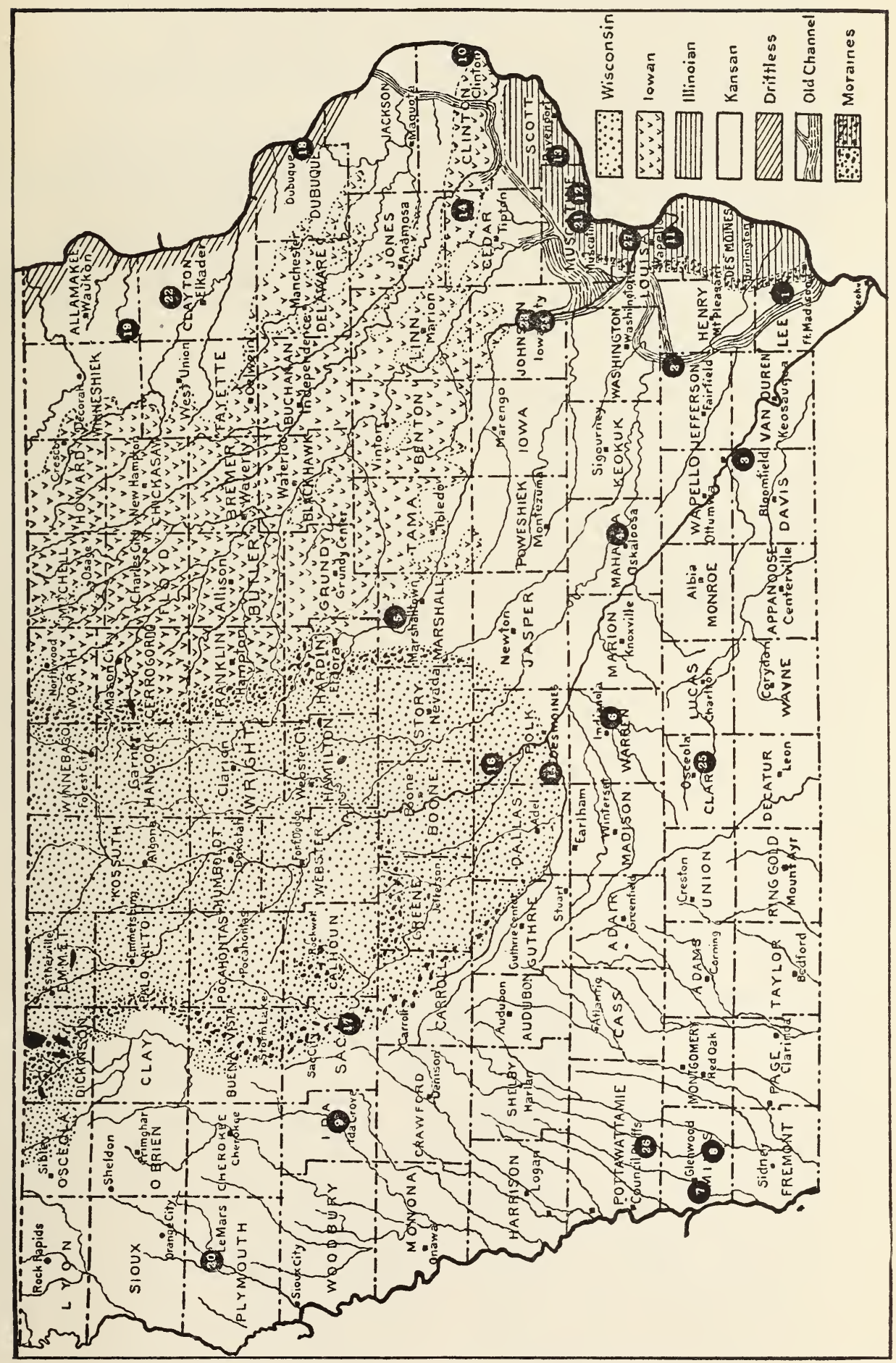

Location of finds of elephants of undetermined species in Iowa. 
Exilanation of Map 15.

Numbers iudicating localities in Mississippi and Illinois are explained in Publication No. 322 of Carnegie Institution of Washington.

LOTISIANA:

1. Shreveport, Caddo Parish (p. 122).

2. Little Bayou Sara, Feliciana Parish (p. 122).

3. Petite Anse, Iberia Parish (p. 122).

4. Iaton Rouge, East Baton Rouge Parish (p. 123).

Trias: (See Map 16).

AHKANSAS :

1. Willcockson, Newton Co. (p. 134).

OKLAHOMA

1. Afton, Ottawa Co. (p. 135).

New Mexico:

1. Mastodon Station, Donna Ana Co. (p. 137).

2. Afton, Dona Ana Co. (p. 137).

3. Black Rocks, McKinley Co. (p. 138).

4. Ildefonso, Santa Fé Co. (p. 137). MISSOLRI :

1. Papinsville, Bates Co. (p. 138).

2. Osage River, Benton Co. (p. 139).

3. Kimmswick, Jefferson Co. (p. 139).

4. Opposite St. Louis, in Illinois (p. 139).

5. Rockport, Atchison Co. (p. 139).

IiANSAS :

1. Palermo, Doniphan Co. (p. 140).

2. Marysville, Marshall Co. (p. 140)

3. Harper township, McPherson Co. (p. 141).

4. Minneapolis, Ottawa Co. (p. 141).

5. Bluff Creek, Clark Co. (p. 141)

6. Meade, Meade Co. (p. 142).

7. Kiowa Creek, Comanche Co. (p. 142).

8. Pendennis, Lane Co. (p. 142).

9. Twelve-mile Creek, Logan Co. (p. 143).

10. Atchison, Atchison Co. (p. 140).

\section{Ka.vsas-Continued:}

11. Russell, Russell Co. (p. 141).

12. North Lawrence, Jefferson Co. (p. 268). Not on the map. Colorado:

1. Rouse, Huerfano Co. (p. 143).

2. Gardner, Huerfano Co. (p. 143).

3. Silver Cliff, Custer Co. (p. 144).

4. Colorado Springs, El Paso Co. (p. 144).

5. Manitou, El Paso Co. (p. 144).

6. Calhan, El Paso Co. (p. 144).

7. Elbert Co. (p. 144).

8. Littleton, Arapahoe Co. (p. 144).

?. Denver, Denver Co. (p. 145).

10. Longmont, Boulder Co. (p. 145).

11. Greeley, Weld Co. (p. 145).

12. Glenwood Springs, Garfield Co. (p. 145).

IOWA: (See map 17).

NeBraska :

1. Louisville, Cass Co. (p. 150).

2. Fullerton, Nance Co. (p. 152).

3. Seneca, Thomas Co. (p. 152).

4. Peters, Sheridan Co. (p. 152).

5. Crete, Saline Co. (p. 151).

WYOMING :

1. Bridger, Uinta Co. (p. 152).

SOLTH DAKOTA :

1. Sioux Falls, Minnehaha Co. (p. 153).

2. Otis Mill, Union Co. (p. 153).

3. Fort Pierre, Stanley Co. (p. 153).

4. Runkel, Lawrence Co. (153).

Montava :

1. Phillips Co. (p. 153).

ALBERTA :

1. Fimpress (p. 154).

MANiTOBA:

1. York Factory (p. 154). 


\section{MAP 15.}
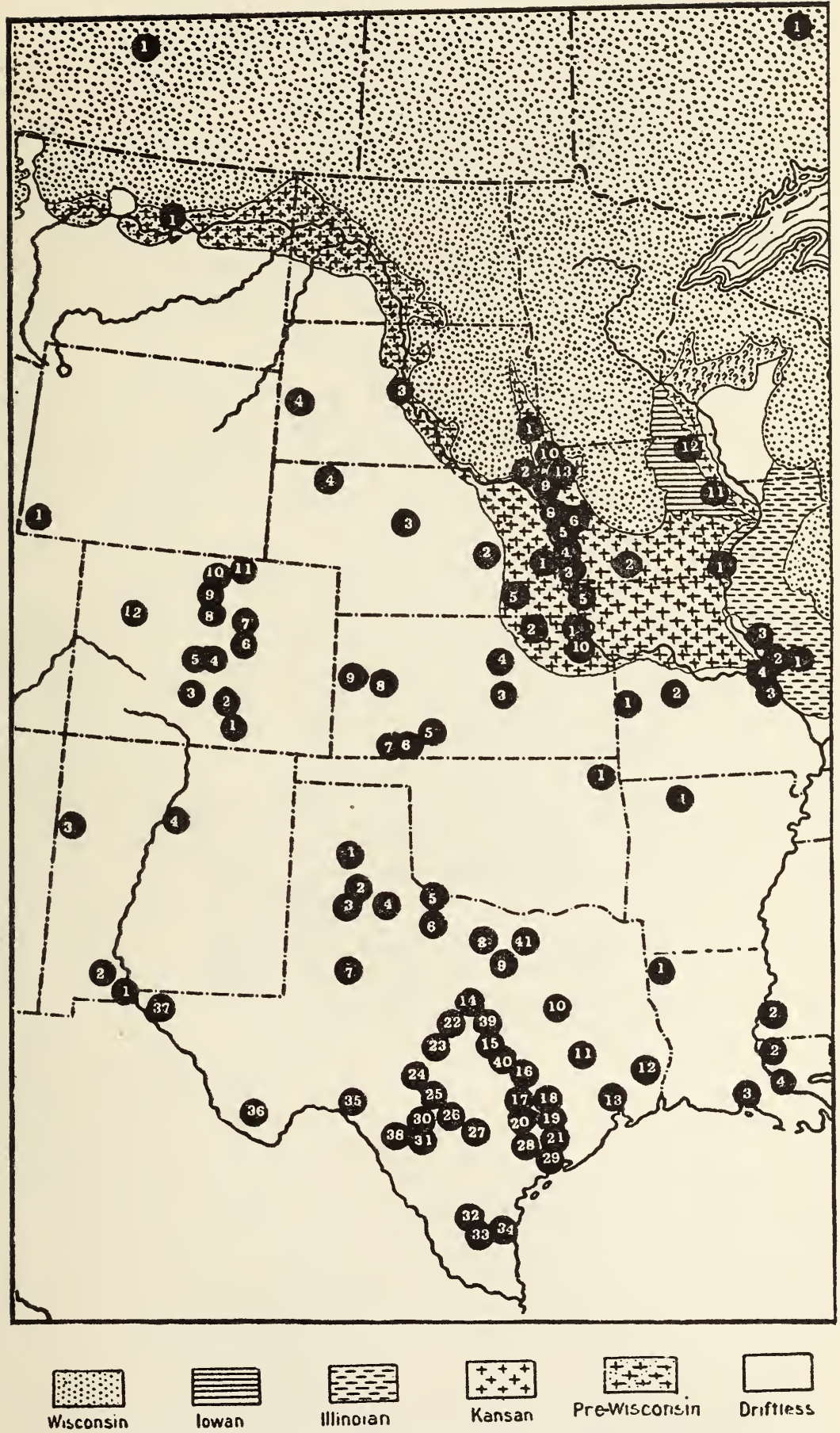

Location of finds of horses, Equidæ, in Middle Region of North America. 
Texas :

\section{Explanation of Map 16.}

1. Palo Duro Canyon, Randall Co. (p. 123).

2. Rock Creek Canyon, Briscoe Co. (p. 123).

3. South Tule Creek, Swisher Co. (p. 124).

4. White Flat, Motley Co. (p. 124).

5. Quanah, Hardeman Co. (p. 125).

6. Benjamin, Knox Co. (p. 125).

7. Wild Horse Creek, Howard Co. (p. 125).

8. Denton, Denton Co. (p. 125).

9. Dallas, Dallas Co. (p. 126).

10. Palestine, Anderson Co. (p. 126).

11. White Rock Shoals, Trinity Co. (p. 126).

12. Sour Lake, Hardin Co. (p. 126).

13. Galveston Bay, Galveston? Co. (p. 127).

14. Waco, McLennan Co. (p. 127).

15. Reagan, Falls Co. (p. 127).

16. Port Sullivan Shoals, Robertson Co. (p. 127).

17. Pittbridge, Brazos Co. (p. 128).

18. Hidalgo Falls, Washington Co. (p. 128).

19. Washington Co. (p. 128).

20. San Felipe, Austin Co. (p. 129).

21. Brookshire, Waller Co. (p. 129).

22. Temple, Bell Co. (p. 129).

23. Bartlett, Williamson Co. (p. 130).

24. Austin, Travis Co. (p. 130).

25. Delvalle, Travis Co. (p. 130).

26. Bastrop, Bastrop Co. (p. 130).

27. Colorado River, Fayette Co. (p. 130).

28. Lissie, Wharton Co. (p. 130).

29. Egypt, Wharton Co. (p. 130).

30. Seguin, Caldwell Co. (p. 131).

31. Guadalupe Co. (p. 131).

32. San Diego, Duval Co. (p. 131).

33. - Nueces Co., or Jim Wells Co. (p. 133).

34. Nueces Co. (p. 133).

35. - Maverick Co. (p. 134).

36. Terlingua, Brewster Co. (p. 134).

37. El Paso, El Paso Co. (p. 134).

38. Near San Antonio, Bexar Co. (p. 131).

39. Marlin, Falls Co. (p. 127).

40. Curley Shoals, Robertson Co. (p. 127).

41. Quinlan, Hunt Co. (p. 125). 
MAP 16.

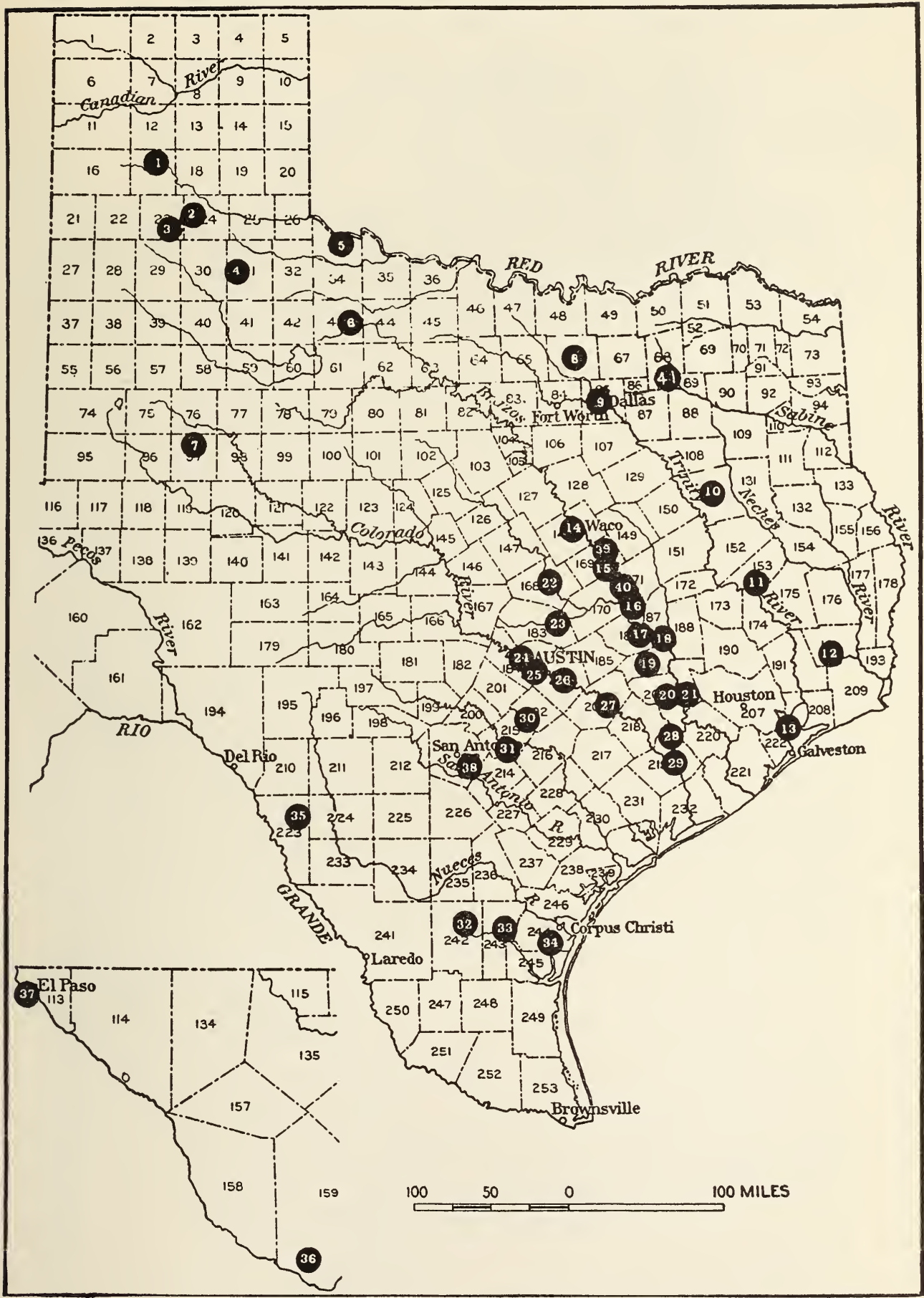

Location of finds of horses, Equidæ, in Texas. 
IowA :

$$
\text { Fxplanation of Map } 17 .
$$

1. Montrose, Lee Co. (p. 14:i).

2. Afton Junction, Union Co. (p. 146).

3. Lyons township, Mills Co. (p. 147).

4. Hinton Station, Mills Co. (p. 147).

5. Missouri Valley, Harrison Co. (p. 147).

6. Logan, Harrison Co. (p. 147).

7. Pisgah, Harrison Co. (p. 147).

8. Turin, Momona Co. (1. 148).

9. Sioux City, Woodbury Co. (p. 148).

10. Granite, Lyon Co. (p. 149).

11. Sand Spring, Delaware Co. (p. 149).

12. Ridgeway, Winneshiek Co. (p. 150).

13. Ie Mars, Plymouth Co. (p. 149).

14. Correctionville, Woodbury Co. (p. 52). Not on map 17. 
MAP $1 \%$.

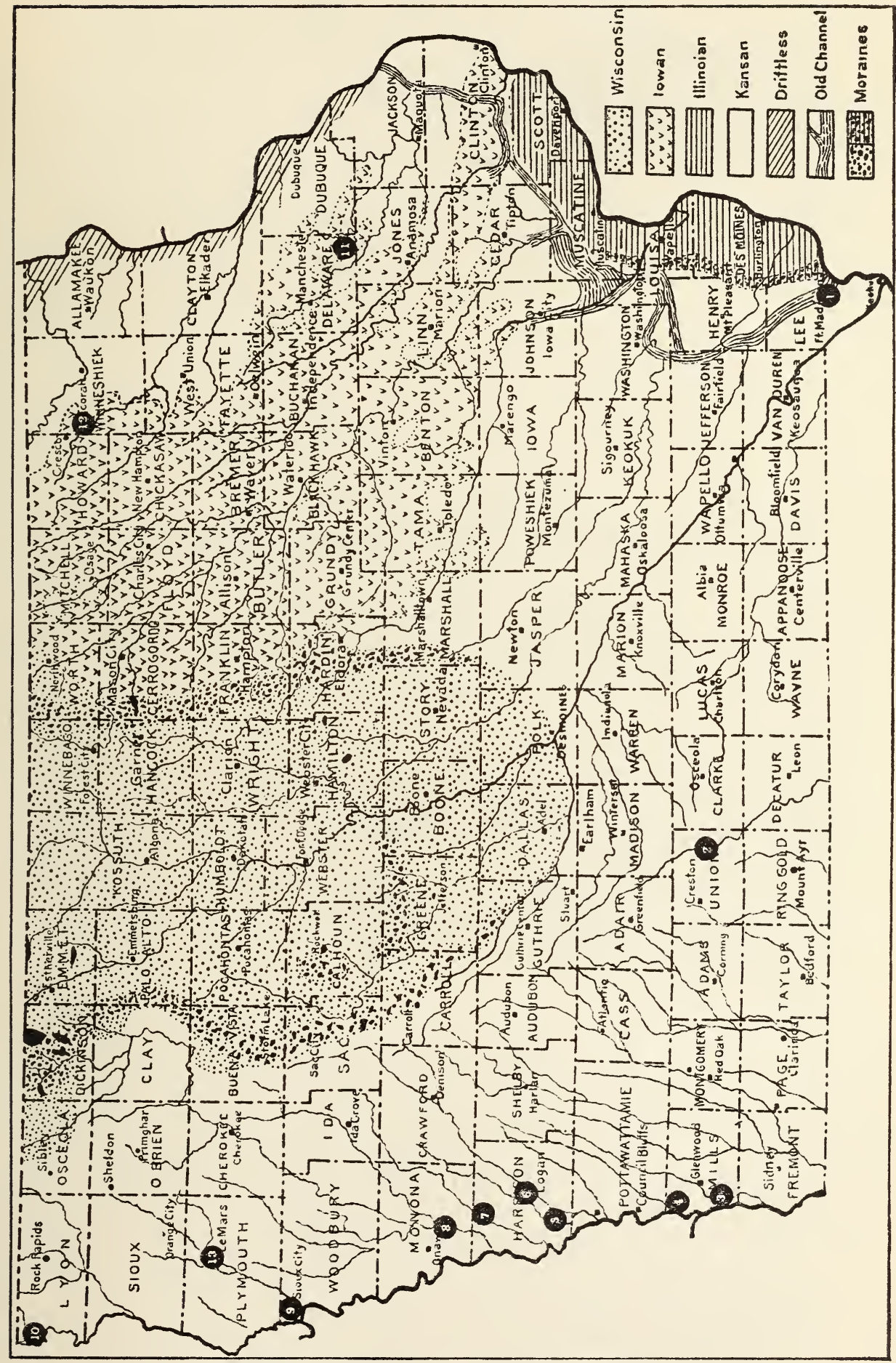

Location of finds of horses, Equidre, in Iowa. 
Expianation of MaP 18.

\author{
I,OUISIANA : \\ 1. - St. Landry Parish (p. 155). \\ Texas: \\ 1. El Paso, El Paso Co. (p. 155). \\ 2. Temple, Bell Co. (p. 155). \\ 3. San Felipe, Austin Co. (p. 156). \\ OKIAHOMA : \\ 1. Mulhall, Logan Co. (p. 156).
}

Explanation of Map 19.

The numbers of localities in Illinois and Wisconsin are explained in Publication No. 322 of Carnegie Institution of Washington.

Texas :

1. Rock Creek, Briscoe Co. (p. 157).

Arkansas :

1. Willcockson, Newton Co. (p. 157). MISSOURI :

1. Tackner?, Benton Co. (p. 157).

KANSAS :

1. Goodland, Sherman Co. (p. 158).

Iow A :

1. Sioux City, Woodbury Co. (p. 158).

2. Burlington, Des Moines Co. (p. 158).

3. Dubuque, Dubuque Co. (p. 159).

Nebraska :

1. "Niobrara River" (p. 159).

2. Seneca, Thomas Co. (p. 159).

3. Peters, Sheridan Co. (p. 160). 
MAP 18.

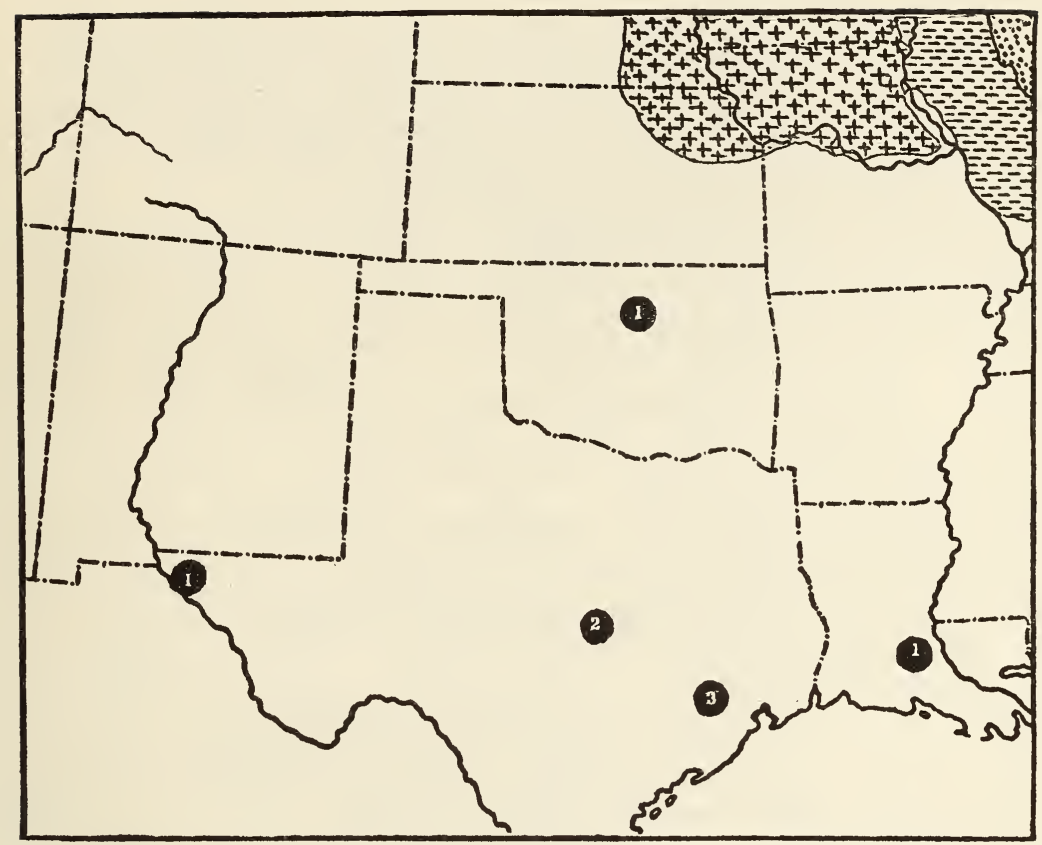

Location of finds of Tapiridæ in Middle Region of North America.

MAP 19.

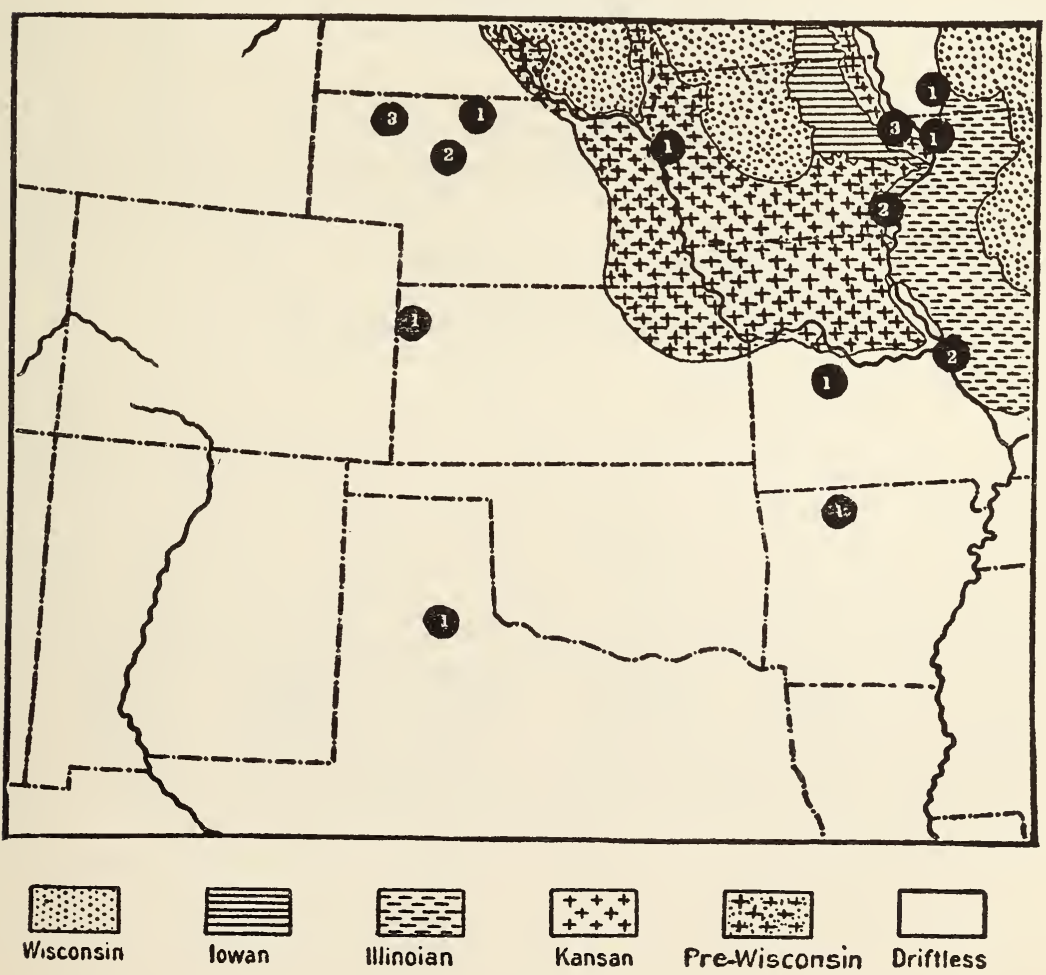

Location of finds of peccaries, Tagassuidx, in Middle Region of North America. 
Explanation of Map 20.

Texas :

1. Rock Creek, Briscoe Co. (p. 1fi1).

2. Waco, McIennan Co. (p. 161).

3. Temple, Bell Co. (p. 161).

4. San Felipe, Austin Co. (p. 162).

5. Richmond, Fort Bend Co. (p. 162).

6. Keeran Point, Victoria Co. (p. 163).

7. Pittbridge, Brazos Co. (1) 162).

8. Bridgeton, Wichita Co. (p. 161).

9. Dallas, Dallas Co. (p. 161).

OKLAHOMA :

1. Afton, Ottawa Co. (p. 163).

New Mexico:

1. Black Rocks, McKinley Co. (p. 164). Missouri :

1. Rockport, Atchison Co. (p. 164).

KANSAS :

1. McPherson, McI'herson Co. (p. 165).

2. Meade, Meade Co. (p. 165).

3. Pendennis, Lane Co. (p. 165).

4. Russell Springs, Logan Co. (p. 165).

5. Leroy, Coffey Co. (p. 165).

Colorado :

1. Gardner, Huerfano Co. (p. 166).

2. Colorado Springs, El Paso Co. (p. 166).

3. Denver, Denver Co. (p. 166).

4. West Cliff, Custer Co. (p. 167).

IowA :

1. Hinton Station, Mills Co. (p. 167).

2. Missouri Valley, Harrison Co. (p. 16i7).

3. Pisgah, Harrison Co. (p. 167).

4. Turin, Monona Co. (p. 168).

Nebraska :

1. Reynolds, Jefferson Co. (p. 168).

2. Seneca, Thomas Co. (p. 168).

3. Peters, Sheridan Co. (p. 168).

4. - Furnas Co. (p. 168).

South Dakota :

1. Irene, Clay Co. (p. 168).

Montana :

1. Flaxville, Sheridan Co. (p. 1(i9). 
MAP 20.

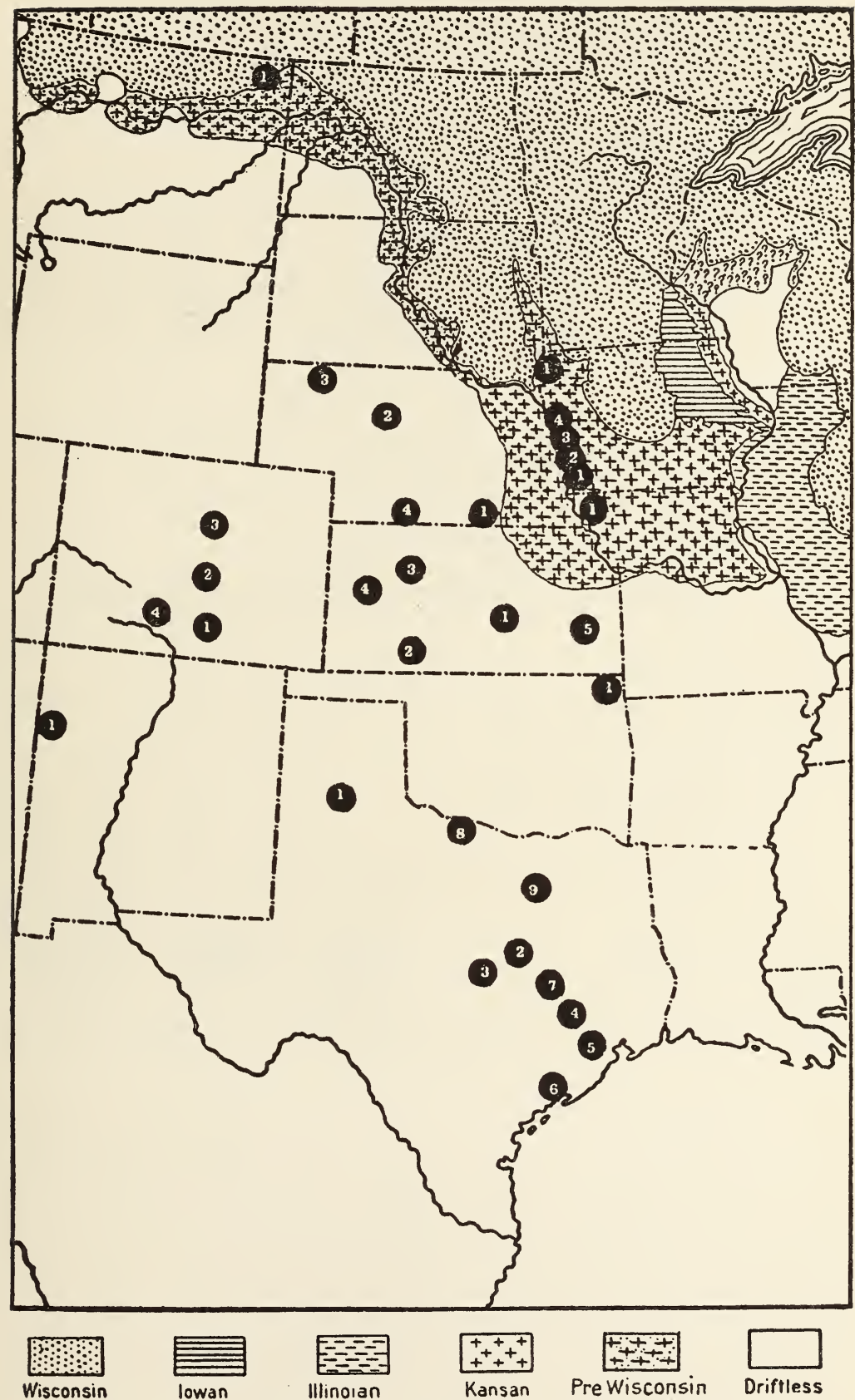

Location of finds of Camelidæ in Middle Region of North America. 
Explanation of Map 21.

Numbers indicating localities in Mississippl, Illinois, and Wisconsin are explained in Publication No. 322 of Carnegie Institution of Washington.

I.OUISIANA :

1. Petite Anse, Iberia Parish (p. 170). Texas :

1. Wast Dallas, Dallas Co. (p. 170).

ArKansas :

1. Willcockson, Newton Co. (p. 170).

OKLAHOMA :

1. Afton, Ottawa Co. (p. 170).

2. Mulhall, Jogan Co. (p. 170).

Missouri :

1. Pomme de Terre River, Hickory Co. (p. 171).

2. Kimmswick, Jefferson Co. (p. 171).

KANSAS :

1. North Lawrence, Jefferson Co. (p. 171). Iow A :

1. Wapello, Louisa Co. (p. 171).

2. Folsom, Mills Co. (p. 171).

3. Turin, Monona Co. (p. 172).

4. Le Mars, Plymouth Co. (p. 172).

5. Eddyville, Mahaska? Co. (p. 171).

6. Correctionville, Woodbury Co. (p. 299). Not on map 21. 
MAP 21.
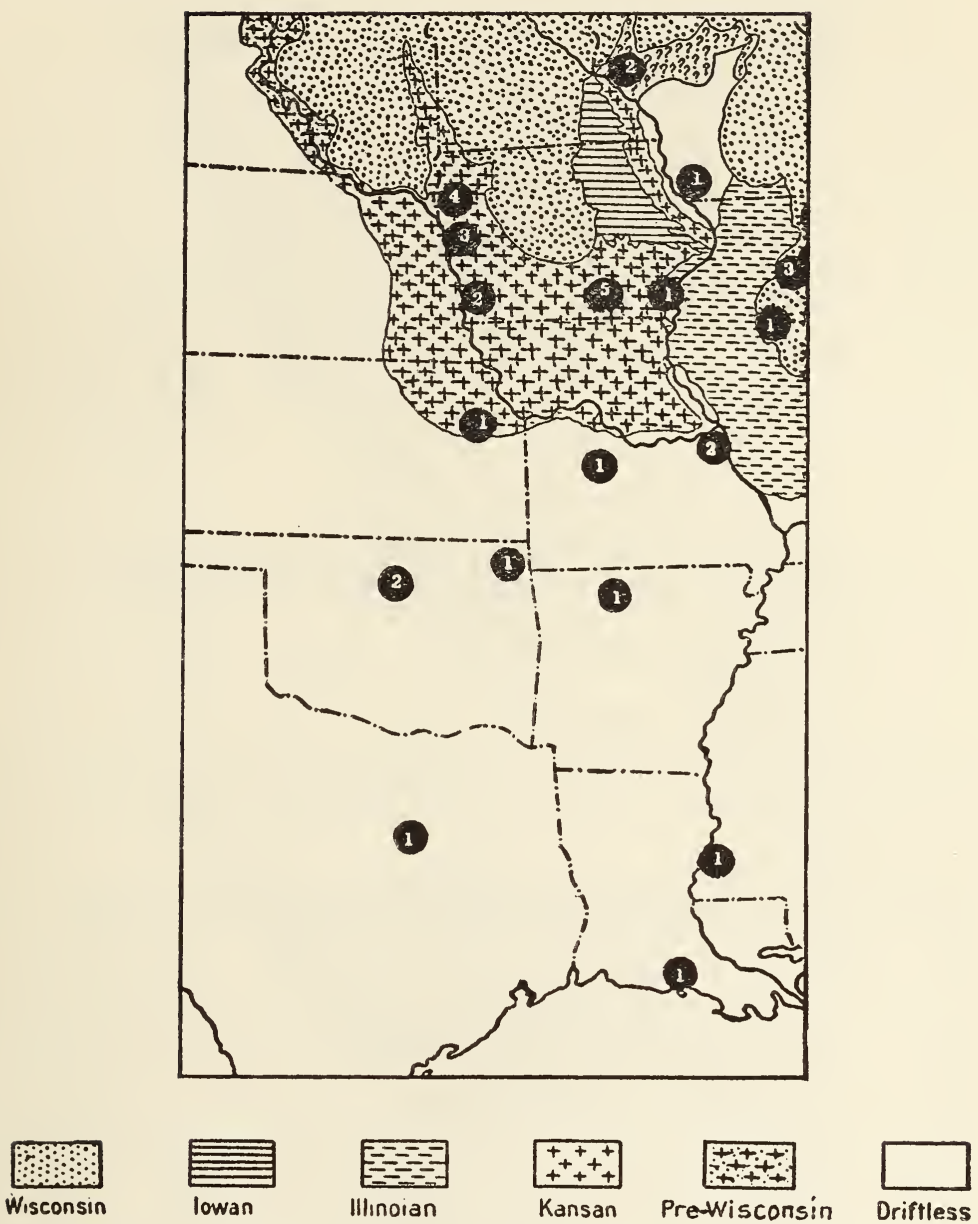

Location of finds of deer, Odocoileus, in Middle Region of North America. 


\section{Explanation of Map 22.}

The numbers of localities in Illinois and Wisconsin are explained in Publication No. 322 of Carnegie Institution of Washington.

MINNESOTA :

1. Crosby, Crow Wing Co. (p. 177). Iow A :

3. Correctionville, Woodbury Co. (p. 176).

2. Avon, Polk Co. (p. 176).

1. Muscatine, Muscatine Co. (p. 176).

Explanation of MaP 23.

The numbers of localities in Illinois and Wisconsin are explained in Publication No. 322 of Carnegie Institution of Washington.

Arkansas :

1. Willcockson, Newton Co. (p. 173).

Orinahoma :

1. Afton, Ottawa Co. (p. 173).

2. Guthrie, Logan Co. (p. 173).

Missouri :

1. Pomme de Terre River, Hickory Co. (p. 173). KaNSAS :

1. North Lawrence, Jefferson Co. (p. 173).

2. Wakarusa Creek, Douglas Co. (p. 174).

Iow A :

1. Near Logan, Harrison Co. (p. 174).

2. Turin, Monona Co. (p. 174).

3. Nevada, Story Co. (p. 174).

4. Irvington, Kossuth Co. (p. 175). 
MaP 22.

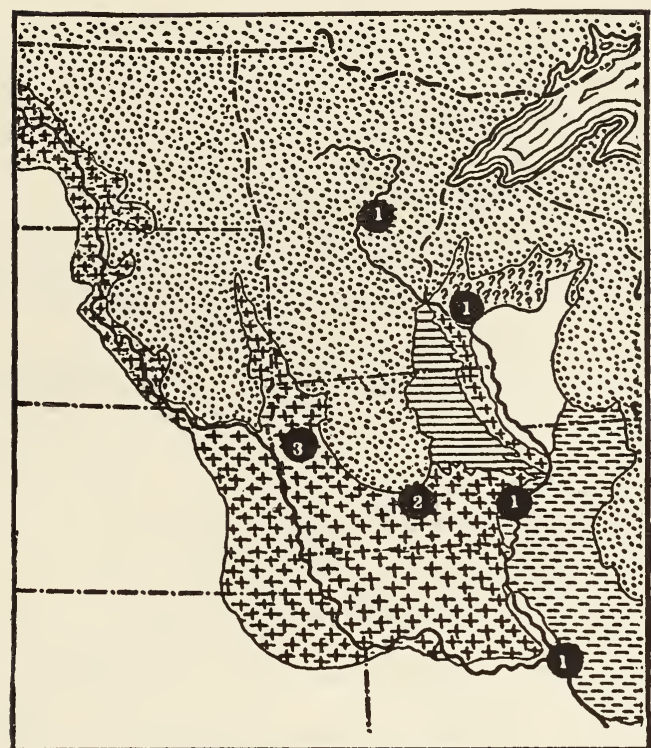

Location of finds of reindeer, Rangifer, in Middle Region of North America.

MAP 23.

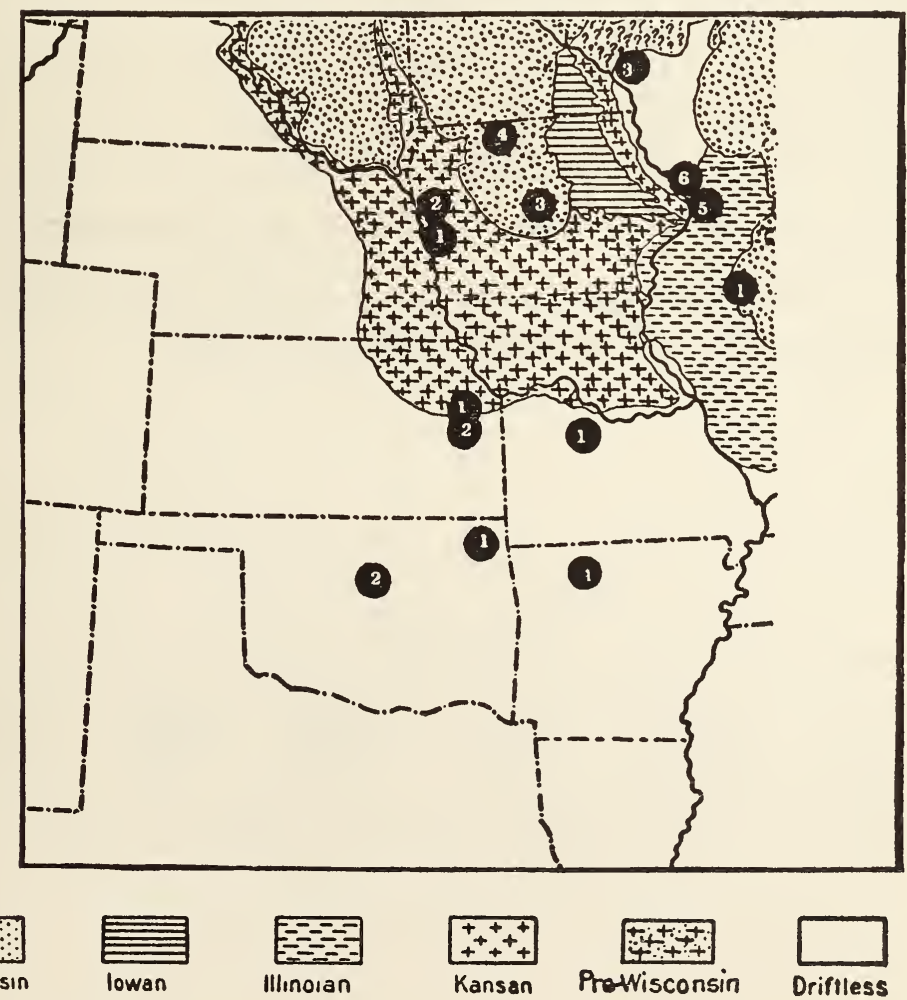

Location of finds of Cervus canadensis in Middle Region of North America. 


\section{mxplanation of Map 24.}

The numbers of localities in Mississippi and Illinois are explained in Pubication No. 322 of Carnegie Institution of Washington.

Arikansas:

1. Willcockson, Newton Co., Symbos australis (p. 178).

Orentioma :

1. Afton, Ottawa Co., Symbos promptus (p. 178).

2. Fort Gibson, Muskogee Co., Symbos cavifrons (p. 179).

3. Braden?, Le Flore Co., Symbos cavifrons (p. 179).

New Mexico:

1. Black Rocks, MeKinley Co., Gidleya zuniensis (I. 179). Missouri :

1. New Madrid, New Madrid Co., Symbos cavifrons (p. 179).

2. Cape Girardeau, Cape Girardeau Co., Symbos cavifrons (p. 180).

3. Tackner?, Benton Co., Symbos cavifrons (p. 180).

4. Kimmswick, Jefferson Co., Symbos cavifrons (p. 181) ; Boötherium bombifrons? (p. 181).

5. St. Louis, St. Louis Co., Symbos cavifrons (p. 181).

6. Wellington, La Fayette Co., Symbos cavifrons (p. 181). KANSAS :

1. Wilson, Ellsworth Co., Symbos carifrons (p. 181).

Colorado:

1. Colorado Springs, El Paso Co., Ovibos moschatus (p. 182).

Iow A :

1. Ottumwa, Wapello Co., Oribos sp. indet. (p. 182).

2. Indianola, Warren Co., Symbos cavifrons? (p. 182).

3. Council Bluffs, Pottawattamie Co., Symbos cavifrons (p. 183).

4. Woodbine, Harrison Co., Symbos cavifrons (p. 183).

5. Missouri Valley, Harrison Co., Symbos? sp. indet. (p. 18?).

6. Clermont, Fayette Co., Ovibos moschatus (p. 183).

Nebraska :

1. Wyoming, Otoe Co., Symbos cavifrons (p. 184).

2. Endicott, Jefferson Co., Symbos cavifrons (p. 184).

3. Cambridge, Furnas Co., Symbos cavifrons (p. 184).

4. Morrill, Sioux Co., Ovibos moschatus (p. 185).

Minnesota :

1. Between Wabasha and Theilman, Wabasha Co., Ovibos moschatus (p. 185).

South DaKota :

1. Sioux Falls, Minnehaha Co., "Musk-ox" (p. 310). Not on map 24. Almerta :

1. Edmonton, Edmonton Co., Oribos moschatus? (p. 185). 
MAP $2 t$.

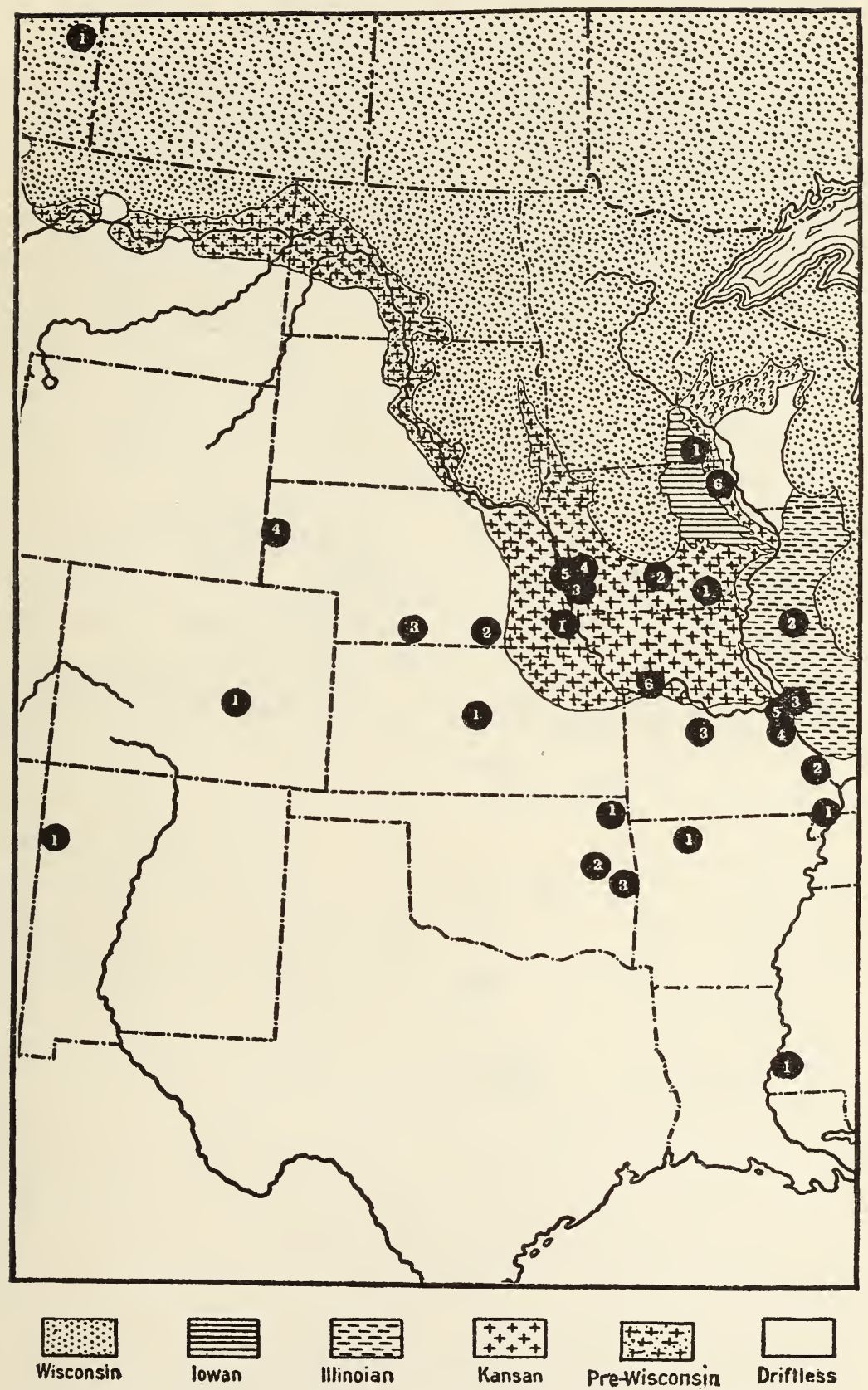

Location of finds of musk-oxen, Ovibovinæ, in Middle Region of North America. 


\section{Explanation of Map 25.}

The numbers of localities in Mississippi, Illinois, and Wisconsin are explained in Publication No. 322 of Carnegie Institution of Washington.

\section{LOUISIANA :}

1. Petite Anse, Iberia Parish (p. 186). Toxas :

1. Sweetwater, Nolan Co. (p. 186).

2. Crawford, McLennan Co. (p. 186).

3. Big Flm Creek, Falls ? Co. (p. 186)

4. Pittbridge, Brazos Co. (p. 187 ).

5. Burton, Washington Co. (p. 188).

6. San Felipe, Austin Co. (p. 189).

7. O'Quinn Branch, Fayette Co. (p. 188)

8. Pilot Knob, Travis Co. (p. 189).

9. Oakville, Live Oak Co. (p. 189).

10. Beeville, Bee Co. (p. 190).

11. Burkburnett, Wichita Co. (p. 190).

12. Near Sherman, Grayson Co. (p. 190).

13. Bulverde, Bexar Co. (p. 190).

14. Wallis Station, Austin Co. (p. 188).

15. Dallas, Dallas Co. (p. 186)

16. Fifth Creek, Cooke Co. (p. 186).

OKLAHOMA :

1. Afton, Ottawa Co. (p. 190).

2. Braden?, Le Flore Co. (p. 191).

3. Mulhall, Logan Co. (p. 191).

4. Fentress, Okfuscee Co. (p. 191). MISSOURI :

1. Joplin, Jasper Co. (p. 191).

2. Pomme de Terre River, Hickory Co. (p. 191).

3. Pleasant Hill, Cass Co. (p. 192).

4. Kimmswick, Jefferson Co. (p. 192)

5. Kansas City, Jackson Co. (p. 192). KANSAS :

1. Crawford township, Cherokee Co. (p. 192).

2. Oswego, Labette Co. (p. 192)

3. Burlington, Coffey Co. (p. 192).

4. North Lawrence, Jefferson Co. (p. 193).

5. Manhattan, Riley Co. (p. 193).
Kansas-Continued :

6. Wellington, Sumner Co. (p. 193).

7. McPherson, McPherson Co. (p. 194)

8. Ellis, Ellis Co. (p. 194).

9. Hoxie, Sheridan Co. (p. 194).

10. Twelve-mile Creek, Logan Co. (p. 194).

11. Cheyenne Co. (p. 195)

12. Atchison, Atchison Co. (p. 193). Colorado:

1. Colorado Springs, El Paso Co. (p. 195).

2. Parker, Douglas Co. (p. 195).

3. Denver, Denver Co. (p. 195). IowA :

4. Glenwood Springs, Garfield Co. (p. 196).

1. Avon, Polk Co. (p. 196)

2. James township, Pottawattamie Co. (p. 196).

3. Denison, Crawford Co. (p. 197).

4. Correctionville, Woodbury Co. (p. 197).

5. Des Moines, Polk Co. (p. 197).

6. Webster City, Hamilton Co. (p. 197)

7. Missouri Valley, Harrison Co. (p. 197).

8. Galva, Ida Co. (p. 198). NEBRASKA :

1. Richfield, Sarpy Co. (p. 198).

2. Broken Bow, Custer Co. (p. 198).

3. Hitchcock Co. (p. 198).

Minnesota :

1. Crosby, Crow Wing Co. (p. 199).

SoUth DAKOTA :

Pierre, Hughes Co. (p. 199). Number not on map.

Manitoba :

1. Aweme, Glenwood Co. (p. 200).

2. Douglas Station, Norfolk Co. (p. 200).

3. Arden, Beautiful Plains Co. (p. 200). 
MaP 25.

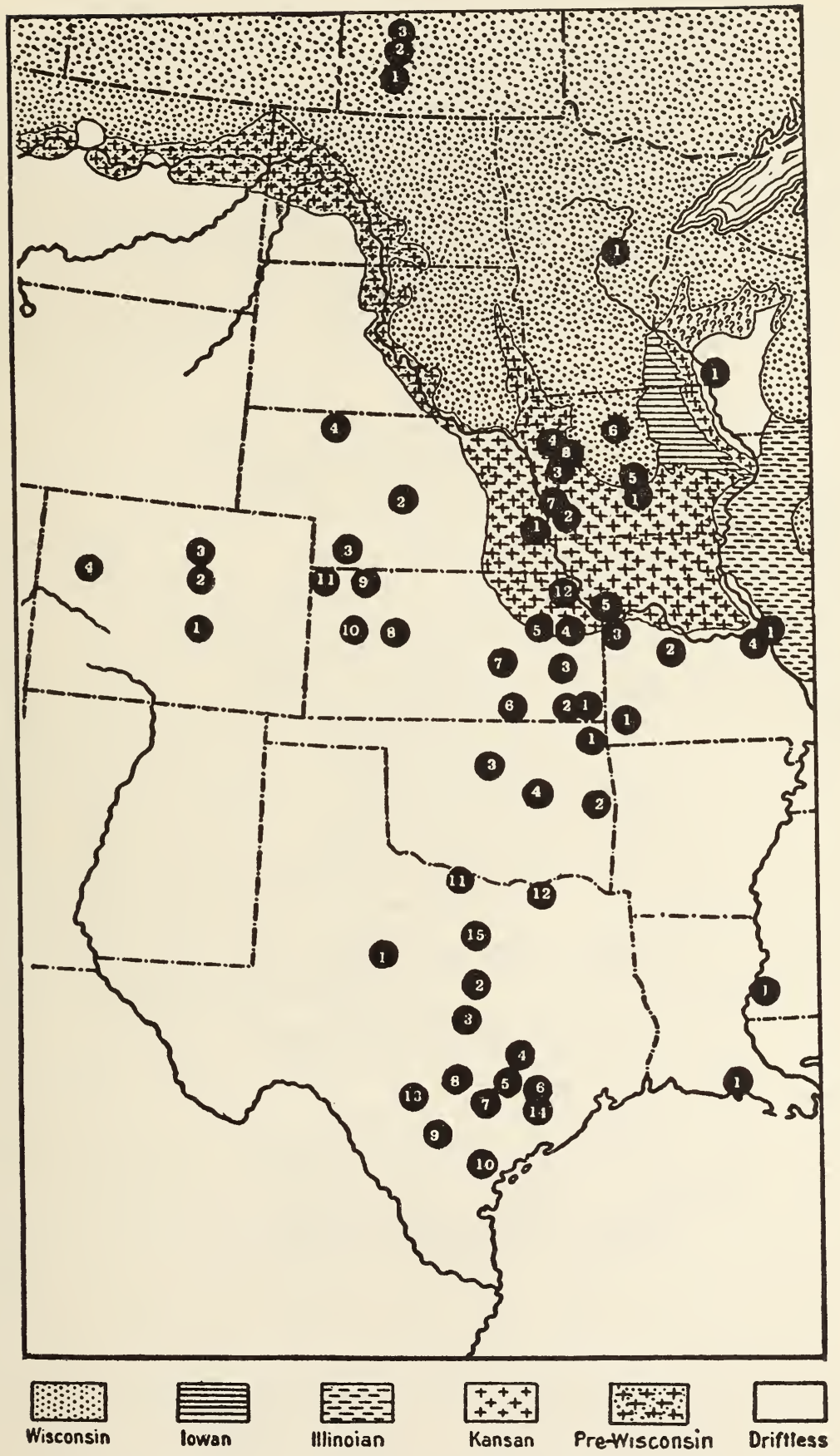

Location of finds of extinct Bisons in Middle Region of North America. 


\section{Explanation of Map 26.}

Numbers indicating localities in Illinois and Wisconsin are explained in Publication No. 322 of the Carnegie Institution of Washington.

Texas :

1. Crosby Co. (p. 201).

2. Vernon, Wilbarger Co. (p. 201).

3. San Marcos, Hays Co. (p. 201).

4. Nash's Ferry, Bastrop Co. (p. 202).

5. Bastrop, Bastrop Co. (p. 202).

6. Hill Creek, Bosque Co. (p. 202).

7. Cameron, Milam Co. (p. 203).

OKLAHOMA :

1. Afton, Ottawa Co. (p. 203).

2. Pickwick, Bryan Co. (p. 203).

MISSOURI :

1. Kimmswick, Jefferson Co. (p. 203).

KANSAS :

1. Wakarusa Creek, Douglas Co. (p. 203).

2. North Lawrence, Jefferson Co. (p. 203).

3. Millwood, Leavenworth Co. (p. 204).

4. Russell Springs, Logan Co. (p. 204).

Colorado :

1. Gold Hill, Boulder Co. (p. 204). IowA :

2. Wellington, Douglas Co. (p. 204).

1. Rock Creek Township, Jasper Co. (p. 204).

2. Prairie Grove, Clarke Co. (p. 205).

3. Bear Grove, Guthrie Co. (p. 205).

4. Deloit, Crawford Co. (p. 205).

5. Logan, Harrison Co. (p. 205).

6. Turin, Monona Co. (p. 205).

7. Grimes, Polk Co. (p. 206).

8. Hubbard, Hardin Co. (p. 206).

9. Lehigh, Webster Co. (p. 207).

10. Laporte, Black Hawk Co. (p. 207).

11. Floyd, Floyd Co. (p. 207).

NEBRASKA :

1. Omaha, Douglas Co. (p. 207).

2. Winnebago Reservation, Thurston Co. (p. 207). WYOMING :

1. Lance Creek, Converse Co. (p. 208).

2. Henry's Fork, Uinta Co. (p. 208).

Minnesota :

1. Mora, Kanabec Co. (p. 208).

2. Crosby, Crow Wing Co. (p. 208).

3. Pine River, Beltrami Co. (p. 208).

Alberta :

1. Red Deer, Red Deer Co. (p. 209).

2. Coleman, Rocky Mountain Co. (p. 209). 


\section{MaP 26.}

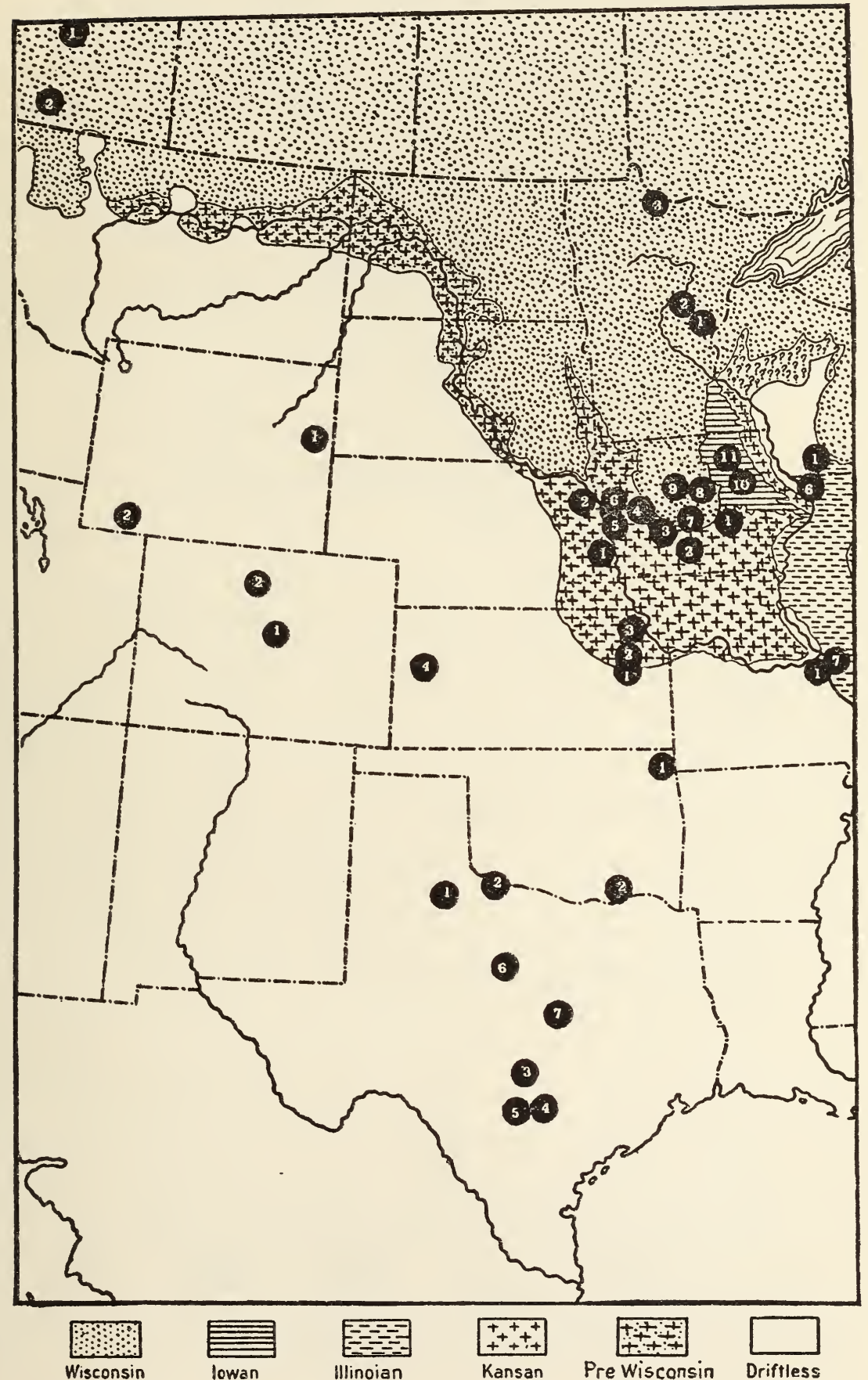

Location of finds of Bison bison in Middle Region of North America. 


\section{Fxplanation of Map 27.}

Numbers indicating localities in Mississippi, Tennessee, and Ililnois are expiained in Publication No. 322 of the Carnegie Institution of Washington.

TExas :

1. Dallas, Dallas Co. (p. 210). OKLAHOMA :

1. Afton, Ottawa Co. (p. 210).

KANSAS :

1. Boicourt, Linn Co. (p. 210). Iow A :

1. Oakland, Pottawattamie Co. (p. 210).

2. Corley, Shelby Co. (p. 211).

3. Turin, Monona Co. (p. 211).

4. Des Moines, Polk Co. (p. 211). NeBraska :

1. Peters, Sheridan Co. (p. 211).

2. Florence, Douglas Co. (p. 212).

Minnesota :

1. Minneapolis, Hennepin Co. (p. 212). South DAKota :

1. Sioux Falls, Minnehaha Co. (p. 212). 


\section{MaP $2 \%$}

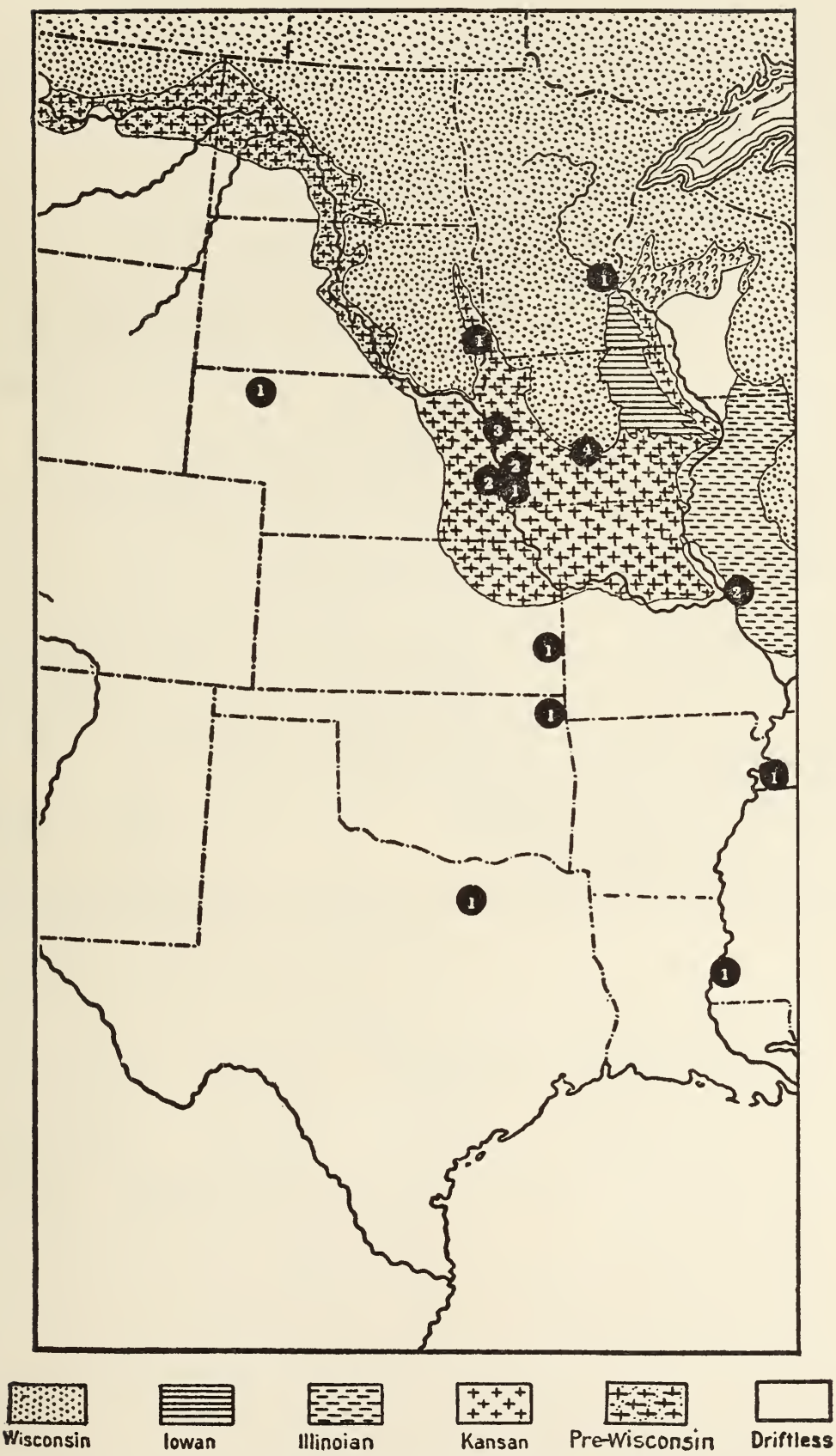

Location of finds of giant beaver, Castoroides, in Middle Region of North America. 


\section{Explanation of Map 28.}

Geological map of Louisiana and part of Mississippi: Intended to show especially the areas covered hy the Lafayette, the Port IIudson, and alluvium overlying Port Hudson along the rivers and the Gulf Coast. Shows also localities where Pleistocene vertebrate fossils have been found. Based on Harris's map of 1902 (Geol. Surv. Louisiana, part VI).

1. Shreveport, Caddo Parish, Equus complicatus (p. 122).

2. Bistineau Lake, Webster Parish, Mammut? (p. 10).

3. Castor, Bienville Parish, Mammut? (p. 10).

4. Rayburn's Salt Works, Bienville Parish, Mammut? (p. 10).

5. Price's Salt Works, Winn Parish, Mammut? (n. 10).

6. Drake's Salt Works, Winn Parish, Mammut? (p. 10).

7. Opelousas, St. Landry Parish, Mammut? (p. 11).

8. - St. Landry Parish, Tapirus sp. indet. (p. 155).

9. Little Bayou Sara, West Feliciana Parish, Mammut (p. 12). Elephas sp. indet. (p. 102), Equus complicatus (p. 122).

10. Alsworth's, East Feliciana Parish, Mammut? (p. 12).

11. Port Hudson, East Baton Rouge Parish, Mammut? (p. 12).

12. Baton Rouge, East Baton Rouge Parish, Mammut americanum (p. 12); Equus complicatus (p. 123).

13. Petite Anse, Iberia Parish, eight species (p. 218).

14. Côte Blanche, St. Mary Parish, Mammut? (p. 11). 
MAP 28.
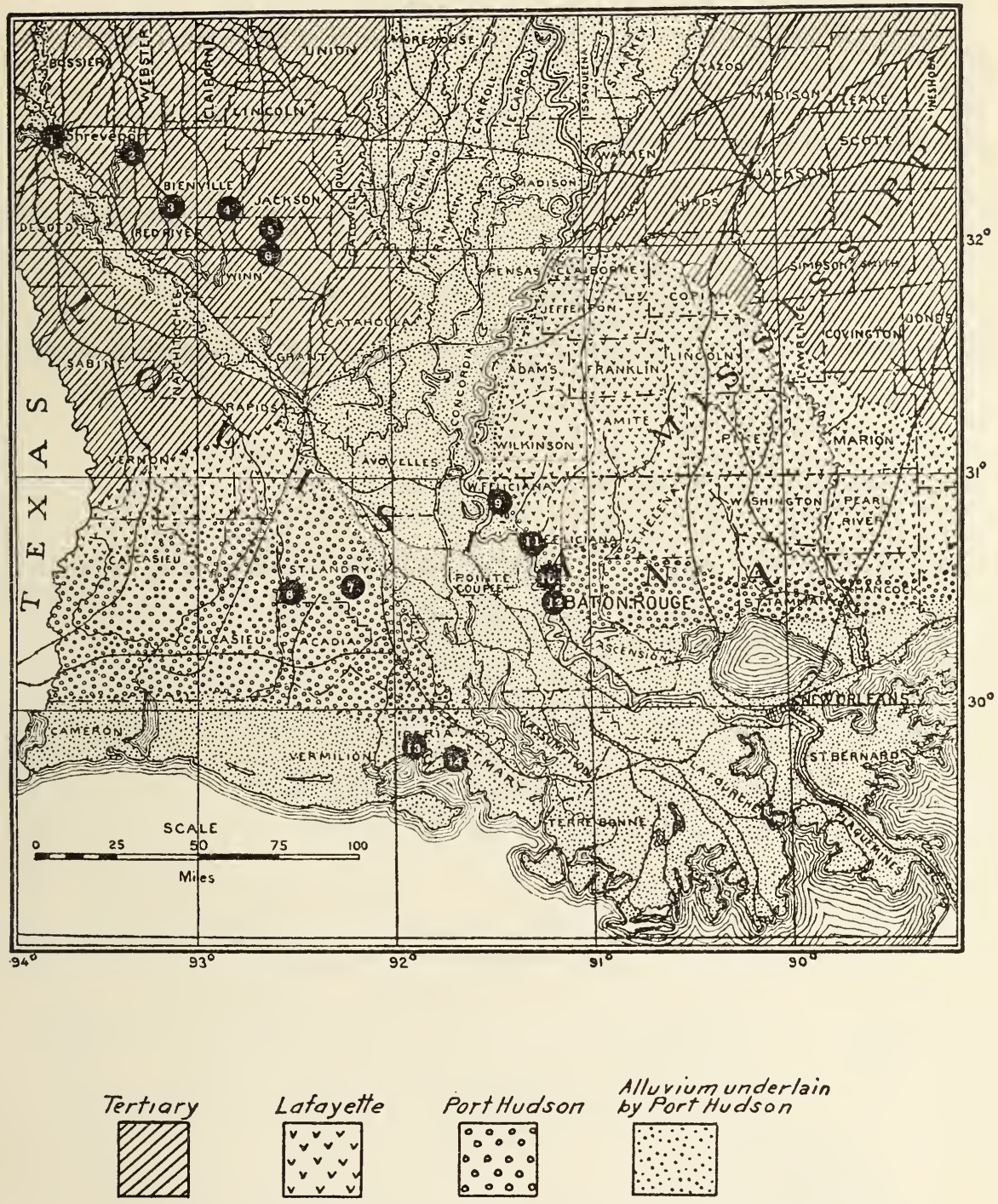

Pleistocene geology and palæontology of Louisiana. 


\section{Explanation of Map 29.}

Pleistocene map of Minnesota: Shows the driftless region, the glacial lakes, and the areas covered by the glacial drifts and the loess. The drift sheet, distinguished as the "old gray," is partly covered by loess, partly not. It belongs to the Kansan stage. The "old red" drift is determined as Illinoian. The "young red" drift and the "young gray" drift belong to the Wisconsin stage. Pleistocene vertebrates have been discovered in the following localities:

1. Pine River, Beltrami Co., Bison bison? (p. 208).

2. Crosby, Crow Wing Co., Bison occidentalis and B. bison (pp. 199, 208) ; Alces americanus (p. 208) ; Rangifer caribou? (p. 177).

3. Mora, Kanabec Co., Bison bison? (p. 208).

4. Fairhaven, Stearns Co., Elephas? sp. indet. (p. 118).

5. - Anoka Co., Elephas sp. indet. (p. 119).

6. Minneapolis, Henuepin Co., Elephas boreus (p. 56) ; Castoroides ohioensis (p. 212) ; Megalonyx jeffersonii (p. 9).

7. Stillwater, Washington Co., Mammut? (p. 44).

8. Wabasha, Wabasha Co., Elephas boreus (p. 56).

9. Zumbrota River, Wabasha Co., Ovibos moschatus (p. 185).

10. Minnesota City, Winona Co., Mammut? (p. 45).

11. Stockton, Winona Co., Elephas sp. indet. (p. 119).

12. Northfield, Rice Co., Mammut? (p. 45).

13. Mankato, Blue Earth Co., Elephas boreus (p. 56) ; Mammut americanum (p. 45).

14. Albert Lea, Freeborn Co., Mammut? (p. 45).

15. - Nobles Co., Elephas sp. indet. (p. 119). 
MAP 29.

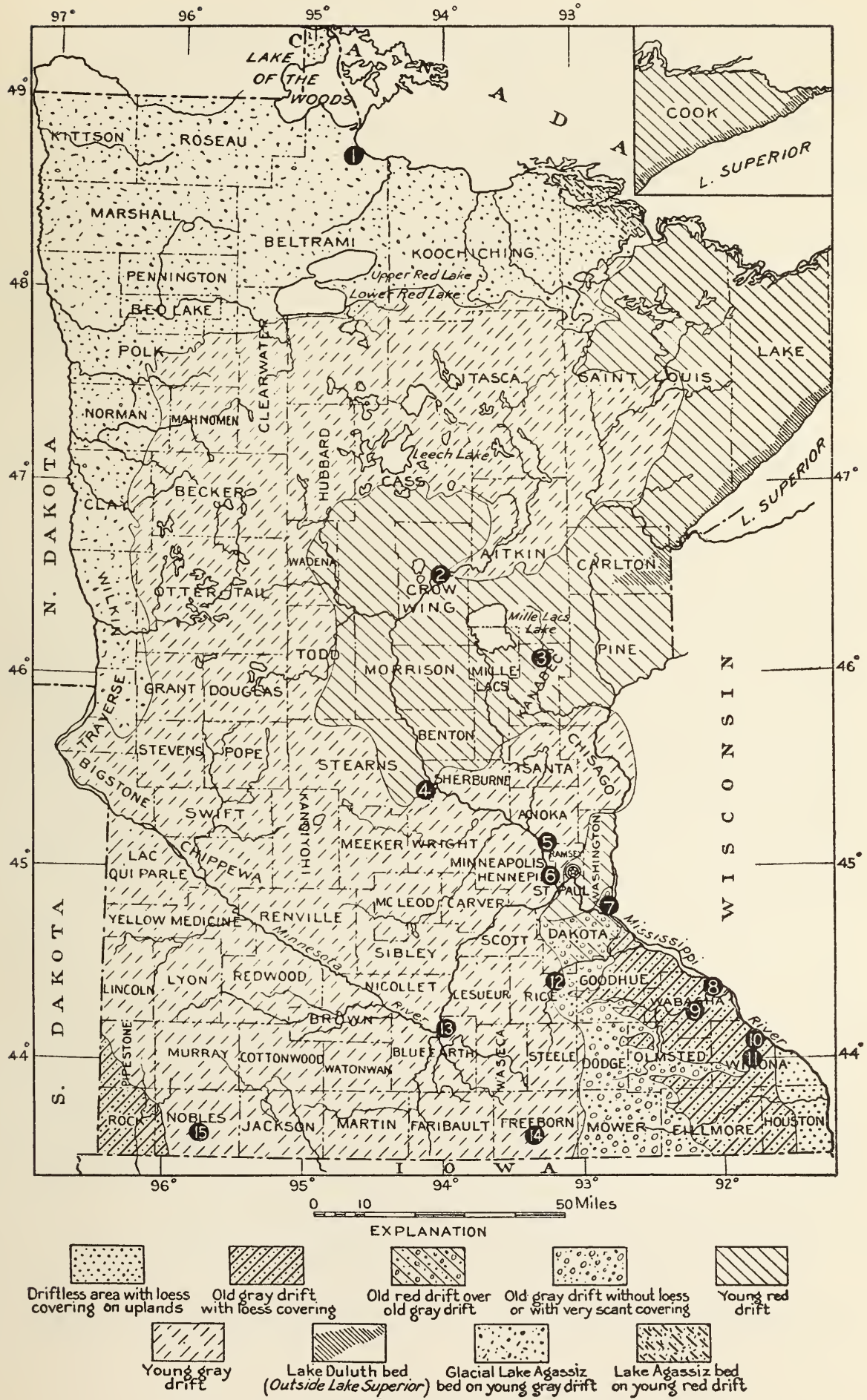

Pleistocene geology and palkontology of Minnesota. 



\section{INDEX.}

Academy of Natural Sciences Philadelphia, 179 Adams Co., Nebraska, 80

Adel, Dallas Co., Iowa, 42, 300

Advance lowland in Arkansas, 250; in Missouri, 260

Aelurodon sævus in Texas, 239

Aenocyon dirus in Texas, 223, 239, 247

Afton, Donna Ana Co., New Mexico, 137, 258

Afton, Ottawa Co., Oklahoma, 23, 66, 94, $135,163,170,173,178,190,203,210$, 253; Union Co., Iowa, 294

Afton Junction, Union Co., Iowa, 146

Aftonian interglacial stage and deposits, 6 , $7,8,34,36,38,39,40,75,76,95,98$, 146 ; in Iowa, 276, 277, 278; in Minnesota, 306 ; in Missouri, 261; in $\mathrm{Ne}$ braka, 301, 302; in South Dakota, 309; in Texas, 237

Aftonius calvini in Iowa, 296

Agassiz, L., 179

Agate, Sioux Co., Nebraska, 56, 305

Agricultural and Mechanical College, Texas, 87

Akron, Plymouth Co., Iowa, 7, 39, 299

Albany Co., Wyoming, 118, 305

Albert, Harding Co., New Mexico, 108, 257

Albert Lea, Freeborn Co., Minnesota, 45, 119 308

Alberta, Bison bison in, 209 ; Elephas columbi in, 84: Equidx in, 154; Ovibovinæ in, 185; Pleistocene geology of, 313 ; undetermined elephants in, 121

Albion, Marshall Co., Iowa, 113, 288

Albuquerque, Bernalillo Co., New Mexico, 68, 257

Alces americanus in Minnesota, 177, 199, 208 ; in Oklahoma, 254

Alces shimeki in Iowa, 296

Alden, W. C., 51, 148, 183, 184, 200, 212, $282,284,285,309,311,312,316$

Alden and Leighton, 288

Alfred, Jim Wells Co., Texas, 66, 249

Alisodon mirus in Texas, 247

Allamakee Co., Iowa, 117, 276, 286

Allen, G. M., 5, 8

Allen, J. A., 126, 181, 193, 210

Alligator mississippiensis in Texas, 243, 248 ; sp. indet. in Texas, 3, 246

Alsworth's, East Feliciana Parish, Louisiana, 12

Altamont moraine in North Dakota, 311

Alvin, Brazoria Co., Texas, 63, 246

American Museum of Natural History, 48 , $60,66,71,85,95,101,126,131,133$, $151,181,182,194,201,211,241,251$

Amyda emoryi in Texas, 245

Anancus brazosius in Texas, 16, 18, 20, 21 $22,64,129,163,224,228,243,244,246$, 248 ; A. gratus, $13,18,241,244,245$; A. hyodon, 17 ; A. mirificus, 16,35 ; in Iowa, 39, 299 ; in Kansas, 71, 269 ; in Nebraska, 44, 168; A. sp. indet. in Texas, 66 ; in Missouri, 263

Anderson Co., Texas, 126

Anoka Co.. Minnesota, 119, 308

Antelope, 174, 203

Anters, Ernst, on glacial problems, 282

Antilocapra americana in Kansas, 268; in Nebraska, 305

Arapahoe Co., Colorado, 112, 144, 274

Arctic climate in Iown, 280, 281

Arctotherium sp. indet. in Nebraska, 305

Arden. Portage la Prairie Co., Manitoba, 200, 317

Argonia, Sumner Co., Kansas. 71, 268, 269

Arkansas, Cervus in, 173; Equidæ in, 134 mastodons in, 22: Ovibovinæ in, 178; peccaries in, 157; Pleistocene geology of, 249

Arkansas City, Cowley Co., Kansas, 70, 269

Armstrong Co., Texas, 57, 224, 238

Arrowrock, Saline Co., Missouri, 31, 264
Ashland, Rosebud Co., Montana, 83, 312 Assiniboine River, 200

Atascosa Co., Texas, 92, 230, 231, 248

Atascosa Creek, Texas, 230

Atchison Co., Kansas, 140, 193, 268 ; Missouri, 69, 139, 164, 261

Atchison, Atchison Co., Kansas, 140, 193, 268

Attica, Harper Co., Kansas, 110, 270

Atwood and Mather, 272

Auchenia hesterna in Texas, 239; A. huerfanensis in Colorado, 143, 166; in Iowa, 168 ; in Kansas, 165

Aughey, in

Austin, Travis Co., Texas, 104, 130, 229, 247 Austin Co., Texas, 3, 62, 63, 92, 93, 106, 131, $156,162,188,189,246$

Avery, Hickory or Benton Co., Missouri, 171, 173. 265

A very, Lincoln Co., Oklahoma, 67, 255

Avery Island, Louisiana, 215

Avoca, Pottawattamie Co., Iowa, 6

Avon, Polk Co., Iowa, 176, 196

Aweme, Portage la Prairie Co., Manitoba, 200,317

Axtell, Dawson Co., Montana, 83, 312

Badger, 165

Bain, H. F., 299

Baker, C. L., 65. 88, 102, 107, 124, 134, 190 , $201,223,224,226,227,232,236,238$, $242,248,249$

Baker, F. C., 42, 115

Bandera Co., Texas, 88, 229, 230, 247

Bandera River, Texas, 229

Barber Co. Kansas, 110, 270

Barbour, Carrie A., 118

Barbour, E. H., 50, 55, 75, 79, 80, 98, 101, $108,117,118,151,152,185,301,302$

Bartlett, Williamson Co., Texas, 130, 246

Barton, B. S., 25

Bastrop, Bastrop Co., Texas, 3, 16, 64, 104, $130,202,247$

Bastrop Co., 'Texas, 3, 16, 64, 130, 202, 221, 247

Bates Co., Missouri, 25, 138, 265

Baton Rouge, Louisiana, 12, 123, 213, 214

Bay City, Matagorda Co., Texas, 106, 247

Baylor Co. 'Texas, 233

Baylor University, Texas, 1, 2, 16, 60, 93

Bayou Sara, Louisiana, 220

Bears (See Ursus and Arctotherium)

Bear Grove, Guthrie Co., Iowa, 205

Beaumont formation in Texas, 4, 92, 222, 236,237

Beautiful Plains Co., Manitoba, 200, 317

Beaver in Texas, 103, 125, 240; in Iowa, 174,205

Beaver Creek, Monona Co., Iowa, 297

Becker, F., 183

Bee Co.. Texas, 66, 91, 108, 190, 248

Beede, J. W., 266

Beeville, Bee Co., Texas, 21, 66, 91, 108, 190, 248

Bell, Robert, 119

Bell Co., Texas, 2, 16, 17, 47, 87, 104, 129, $155,161,223,228,243$

Beloit, Crawford Co., Iowa, 298

Belton, Bell Co., Texas, 17

Beltrami Co., Minnesota, 208, 307

Bender, Thurston Co., Nebraska, 304

Benjamin, Knox Co., Texas, 12, 125, 242

Benkelman, Dundy Co., Nebraska, 81, 304

Bent Co., Colorado, 111, 271

Benton Co., Iowa, 42, 288: Missouri, 4, 25, $28,29,47,69,139,157,180,191,265$

Berclair, Goliad Co., Texas, 21, 248

Bernalillo Co., New Mexico, 68

Bernalillo, Sandoval Co., New Mexico, 108, 257

Berthoud, E. L., 271

Bertram, Linn Co., Iowa, 42

Bexar Co., Texas, 15, 16, 47, 65, 88, 107, 131, $190,229,230,247,248$ 
Beyer, S. W., 175

Bienville Parish, Louisiana, 10

Hig Blue River, Kansas, 268

Hig Llm Creek, Falls Co., Texas, 186

Big Rock, Scott Co., Iowa, 78, 289

Hig Spring, Washington Co., Texas, 62, 246

Big Thompson Creek, Weld Co., Colo., 74

Bison (See Bison bison and Extinct bisons)

Bison alleni, 187, 188; in Iowa, 197; in

Kansas, $95,193,269,270$; in Texas, 186 , 241 ; B. antiquus, 189,196 ; B. bison,

$178,186,189,192,193,195,197 ;$ in

Alberta, 209, 317 ; in Colorado, 204, 275

in lowa, 204, 287, 293, 297, 298, 301 :

in Kansas, $173,203,268,270$; in Minnesota, 177, 199, 208, 307; in Missouri $203,263,264$; in Nebraska, 207, 304: in Oklahoma, 203, 254, 255'; in 'Texas, $201,238,240,244,247,248$; in Wyom ing, 208, 305; B. crampianus, 95 : $\mathrm{B}$. ferox, 199 ; B. kansensis, 193,$204 ;$ B. latifrons, 186, 193, 196; in Colorado, 195 ; in Nebraska, 199, 304; in Texas, $156,187,188,189,190,244,245,246$ 247,248 ; B. occidentalis, 187,189 ; in Iowa, 52, $177,198,295,298,300$; in Kansas, $143,157,165,174,193,194$ $196,197,204,268,269,270$; in Manitoba, 200,317 ; in Minnesota, 199,208 , 307 ; in Nebraska, 111, 304; in South Dakota, 310; in Texas, 186, 241; $\mathrm{B}$. regius, in Kansas, 194,269 ; in Texas, $189,190,195,246,248 ; \mathrm{B}$. sp. indet. in Colorado, 97, 145, 166, 167, 195, 196, $272,273,274,275$; in Iowa, 196, 197 $288,296,299,301$; in Kansas, 171, 174 $192,268,269,270$; in Louisiana, 186, 218 ; in Manitoba, 317 ; in Missouri, 24 $25,27,69,171,191,192,263,264,265$ 266 ; in Niebraska, 198,303 ; in Oklahoma, $179,254,255,256$; in Texas, 103 . $186,187,189,190,233,240,243,245$, 247 ; B. sylvestris, 198,208

Bistineau Lake, Louisiana, 10, 220

Black Hawk Co., Iowa, 53, 207

Black Hills, South Dakota, 82,120 , 310 $138,164,179,259$

Blackwater Creek, Saline Co., Missouri, 264

Blaine Co., Oklahoma, 94

Blake, Charles, 92

Blanchard, Page Co., Iowa, 38, 294

Blarina brevicauda ozarkensis in Arkansas, 252

Blocker, Harrison Co., Texas, 86, 240, 225

Blue Farth Co., Minnesota, 45, 56

Blue Grass, Scott Co.. Iowa, 116, 290

Bluff Creek, Clark Co., Kansas, 141

Boicourt, Linn Co., Kansas, 210

Boone Co., Iowa, 43, 300

Bonne Femme Creek, Howard Co., Missouri, 109,261

Boötherium bombifrons in Missouri, 5, 181 , 263 ; B. cavifrons in Missouri, 139 ; in Oklahoma, 179

Borden Co., Texas, 232

Bos americanus in Minnesota, 208 ; B. cram pianus, 193 ; B. pallasii, $180 ;$ B. scaphoceras, 189

Böse, Emil, 236

Bosque County, Texas, 60, 202, 241

Boulder Co., Colorado, 97, 145, 204, 274

Boulder, Boulder Co., Colorado, 97, 274

Bourbeuse, Gasconade Co., Missouri, 29, 264

Bourbon Co., Kansas, 33, 70, 269

Bowie Bend, Austin Co., Texas, 131, 162

Bowie Co., Texas, 225

Boxbutte, Sheridan Co., Nebraska, 9

Brachyprotoma spelæa in Arkansas, 252

Braden, Le Flore Co., Oklahoma, 179, 191

Brazoria Co., Texas, 63, 106, 246

Brazos Co., Texas, 18, 61, 89, 90, 105, 128, $162,187,221,244,245$

Brazos River, terraces of, 221, 22:. 227

Brenham, Washington Co., Texas, 90, 246

Brewster Co., Texas, 2, 134, 249
Brickton, Adams C'o., Nebraska, 80, 303

Bridger, Uinta Co., Wyoming, 152, 305

Bridgeton, Wichita Co.. Texas, 161, 240

Brighton Township, Washington Co., Iowa, 49,293

Briscoe Co., Texas, 1, 57, 123, 157, 161, 222, $224,232,238,239$

Broadhead, G. C.. 25, 28, 32, 109, 138, 261

Broadwater Co., Montana, 46, 84, 312

Broken Bow, Custer Co., Nebraska, 81, 198, 304

Brookshire, Waller Co., Texas, 63, 129, 246

Brown, Barnum, 134, 157, 170, 173, 178, 251

Brown Co., Kansas, 110, 268

Brownsville, Cameron Co., Texas, 108, 249

Bryan, Brazos Co., Texas, 89

Bryan Co., Oklahoma, 203, 255

Bryant, Clinton Co., Iowa, 40, 289

Buchanan Co., Iowa, 288: Missouri, 32

Bucholtz, Milam Co., Texas, 244

Buckeye, Matagorda Co., Texas, 92, 106, 247

Buckley, S. B., 19, 20, 104, 128

Buffalo (See Bison)

Buffalo Co., Nebraska, 43, 80, 303

Buffalo, Johnson Co., Wyoming, 82, 305; Scott Co., Iowa, 53, 290; Wilson Co., Kansas, 33

Bufo sp. indet., in Arkansas, 252

Bulverde, Bexar Co., Texas, 15, 47, 190, 229, 247

Burkburnett, Wichita Co., Texas, 103, 190, 240

Burks, F. M., 59

Burleson Co., Texas, 3, 90, 224, 244, 245

Burlington, Coffey Co., Kansas, 70, 192, 269 ; Des Moines Co., lowa, 41, 52, 77, 158, 292

Burnet Co., Texas, 14, 64, 246

Burton, Washington Co., Texas, 188, 246

Butte, Silver Bow Co., Montana, 120

Caddo Parish, Louisiana, 122, 220

Caldwell Co., Missouri, 32, 261 ; Texas, 65, $131,221,247$

Calgary, Alberta, 121

Calhan, El Paso Co., Colorado, 72, 144, 273

Call, R. E. 249,253

Calvin, Samuel, 6, 38, 41, 42, 51, 69, 75, 97, $148,150,167,168,172,174,197,210$, $211,261,278,288,289,291,292,294$, $295,297,301$

Cambridge, Furnas Co., Nebraska, 184, 303

Camels in Colorado, 143, 166, 167, 182, 195, 273 ; in Iowa. 167, 168, 278, 294, 295; in Kansas, $143,165,195$; in Missouri, $69,140,164$; in Nebraska, $79,168,303$; in New Mexico, 69, 138, 164, 179; in Oklahoma, 163: in South Dakota, i6s; in Texas, 21,47,64,129, 161, 163, 246 (See also Camelidx, Camelops, Camelus)

Camelidx in Colorado, 166; in Iowa, 167; in Kansas, 165 : in Missouri, 164; in Montana, 169; in Nebraska, 168; in New Mexico, 164 ; in Oklahoma, 163 ; in South Dakota, 168; in Texas, 161

Camelops hesternus in Texas, 131, 161, 162. 239,243 ; C. huerfanensis, 163,164 ; in Colorado, 166, 273, 274, 275: in Kansas, 165, 270: in Texas. 161, 239, 240, 241, 244, 245, 246: C. dallasi in Texas, 161, 162,241 ; C. kansanus in Iowa. 167 ; in Missouri, 165, 261; in Nebraska, 168 , 305 ; in Oklahoma, 163, 254; C. macrocephalus in Texas, $155,161,162,239$, 243 ; C. nitidus in Oklahoma, 164, 254; $\mathrm{C}$ sp indet in Colorado, 167 ; in Iowa, 167. 168, 296, 297; in Kansas, 269, 270; in Missouri, 69 : in Montana, 169,312 , 313 : in Nebraska, 100, 152, 159, 304; in South Dakota, 168; in Texas, 145, $162,241,246$; C. sulcatus in Texas, 161; C. vitakerianus in Nebraska, 168. 305

Camelus americanus in Nebraska, 16S, 305 ; C dromedarius, 165

Cameron Co., Texas, 108, 249
Cameron, Milam Co., Texas, 17. 90, 203, 244

Campbell, Franklin Co., Nebraska, 79 
Canis dirus in Texas, 239 ; C. latrans in Nebraska, 305 ; in Oklahoma, 254, 255 ; in Texas, 247 ; C. nubilus in Oklahoma, 254 , 255 ; C. occidentalis in Arkansas, 252; in Kansas, $71,143,165,195,270 ;$ in Nebraska, 305 ; C. Sæevus in Texas, 239 ; C. sp. indet. in Kansas, 270 ; in Nebraska, 100, 152, 159, 168; C. temerarius in Texas, 239 ; C. texanus, in Texas, 239

Cannon, George L., 145, 166, 274

Cape Girardeau, 180, 264

Cape Girardeau Co., Missouri, 180, 264

Capitan, Lincoln Co., New Mexico, 68

Capromeryx furcifer in Nebraska, 305

Caribou, 176, 177 (see Rangifer)

Carman, J. E., 52, 149, 277, 299

Carpenter. W. M., 11, 102, 122, 156, 189, 220

Carroll, Carroll Co., Iowa, 300

Carrollton, Dallas Co., Texas, 241

Caryhurst, Converse Co., Wyoming, 81

Case, E. C., 124, 232

Caspar, Natrona Co., Wyoming, 118, 305

Cass Co., Missouri, 192, 265 ; Nebraska, 150 , 303 ; North Dakota, 120, 310

Castanea, Monona Co., Iowa, 39

Castor, Bienville Parish, Louisiana, 10

Castor canadensis in Iowa, 296; in Texas, 240

Castoroides in Iowa, 210, 211, 295; in Kansas, 210 ; in Minnesota, 212 ; in $\mathrm{Ne}$ braska, 211, 303 ; in Oklahoma, 210 ; in South Dakota, 212, 309: in Texas, 210 , 238 ; C. kansensis in Kansas, 210, 269 C. ohioensis in Iowa, 210, 211, 297, 301; in Kansas, 210 ; in Minnesota, 212, 308; in Nebraska, 211, 212; in Oklahoma, 210, 254 ; in South Dakota, 212 ; in Texas, 210,241 ; C. sp. indet. in Nebraska, 305 Cedar Co., Iowa, 116, 289

Cedar Creek, Travis Co., Texas, 16, 247

Cedar Rapids, Linn Co., Iowa, 53, 288

Center Grove, Dubuque Co., Iowa, 55, 287

Ceratogaulus, sp. indet. in Montana, 169

Cerro Gordo Co., Iowa, 54, 300

Cervalces roosevelti in Iowa, 298; in Oklahoma, 254; C. sp. indet. in Missouri, 262

Cervus canadensis in Arkansas, 173, 251; in Iowa, 175, 300 : in Kansas 268; in Oklahoma, 173, 254; C. sp. indet. in Arkansas, 173 ; in Iowa, 174 ; in Kansas, 173 : in Missouri, 25, 173; in Oklahoma, 173

Chamberlin and Salisbury, 55, 276

Chambers Co., Texas, 127

Chapel Hill, Washington Co., Texas, 19, 246

Charlton, O. C., 70

Chase Co., Nebraska, 99, 302, 304

Cherokee, Cherokee Co., Iowa, 77, 299

Cherokee Co., Iowa, 77, 299; Kansas, 192, 269

Cherry Co., Nebraska, 44, 100, 302, 304

Cherry Creek, Douglas Co., Colorado, 273

Cherry Spring, Gillespie Co., Texas, 64, 246

Cheyenne Co., Kansas, 195, 270; Nebraska, 81,304

Cheyenne River, South Dakota, 310

Chicot Co., Arkansas, 22, 253

Childress, Childress Co., Texas, 239

Childress Co., Texas, 102, 239

Chilton, Falls Co., Texas, 87, 228

Chlamytherium septentrionale in Texas, 3 , $224,244,245$

Choteau Co., Montana, 83

Chrysemys belli in Texas, $245 ;$ C. timida in Nebraska, 305

Cibolo Creek, Kendall Co., Texas, 15. 247

Cistudo marnochii in Texas, 131, 132

Citellus tridecemlineatus in Arkansas, 251

Citra, Hughes Co., Oklahoma, 23

Clapps Ferry, Trinity Co., Texas, 19, 242

Clarence, Cedar Co., Iowa, 116, 289

Clarinda, Page Co., Iowa, 38

Clark Co., Kansas, 6, 110, 141, 270

Clarke Co., Iowa, $114,205,294$
Clarksville, Butler Co., Iowa, 288; Pike Co., Missouri, 32, 261

Clay Co., Nebraska, 43, 99, 302, 303; South Dakota, 168

Clayton Co., Iowa, 40, 117, 276, 287

Clear Lake, Cerro Gordo Co., Iowa, 54, 300

Clermont, Fayette Co., Iowa, 51, 183, 284, 288

Cleveland Co., Oklahoma, 23, 67, 256

Clew, J. F., 57, 216, 219

Clifton, Bosque Co., Texas, 60

Clifton Co., 'Texas, 241

Clinton Co., Iowa, 40, 75, 115, 289

Clinton, Clinton Co., Iowa, 40, 75, 115, 289

Cockerell, T. D. A., 6, 145

Cody, Cherry Co., Nebraska, 100, 302, 304

Coffey Co., Kansas, 70, 165, 192, 269

Coleman, A. P., 316

Coleman, Macleod Co., Alberta, 209, 317

Coleto Creek, Victoria Co., Texas, 21

College Station, Texas, 87

Collier, A. J., 153

Collin Co., Texas, 58, 103, 240

Collins, A. J., 312

Colorado, Bison bison in, 204; Camelidæ in, 166 ; Elephas columbi in, 72 ; Elephas imperator in, 96 ; Equidæ in, 143 ; extinct bisons in, 195 ; mastodons in, 35 ; Ovibovinæ in, 182; Pleistocene geology of, 271 ; undetermined elephants in, 111; Tenarthra in, 6

Colorado, Mitchell Co., Texas, 102, 240

Colorado City, El Paso Co., Colorado, 72, 273

Colorado College, 96

Colorado River, Fayette Co., Texas, 130 ; terraces of, 221, 228

Colorado Springs, El Paso Co., Colo., 96, 144, $166,182,195$

Comal Co., Texas, 248

Comanche Co., Kansas, 142, 270 ; Oklahoma, 108 ; Texas, 243

Conard fissure, Arkansas, 134

Concho River, Texas, 229

Converse Co., Wyoming, 81, 208, 305

Cook, Harold, 56,118

Cooke Co.. Texas, 13, 186, 224, 240

Cope, E. D. 15, 67, 68, 86, 122, 123, 126, 131 , $132,133,160,161,162,180,181,182$, $193,218,222,232,233,239,249,256$,

corley, Shelby Co., Iowa, 211, 295

Corpus Christi, Nueces Co., Texas, 21, 249

Correctionville, Woodbury Co., Iowa, 52, 176, 197,298

Corsicana, Navarro Co., Texas, 59, 242

Côte Blanche, St. Mary's Parish, Louisiana, 11,220

Cottle Co., Texas, 224, 234

Council Bluffs, Pottawattamie Co., Iowa, 183, 295

Cowley Co., Kansas, 70, 269

Cox gravel pit, 6, 167, 183, 197, 296

Cragin. F. W., 110, 131, 141, 142, 165, 166, $167,270,271,273$

Crawford, Dawes Co., Nebraska, 118; McLennan Co., Texas, 16, 186

Crawford Co., Iowa, 38, 51, 197, 205, 297, 298

Crawford township, Cherokee Co., Kansas, 192

Crete, Saline Co., Nebraska, 101, 151, 303

Criddle, Stuart, 200

Crider, A. F. 249, 250

Cripple Creek, Teller Co., Colorado, 72

Crocodilus sp. indet. in Texas, 3, 18, 128

Crosby, Crow Wing Co., Minnesota, 177, 199, 208,307

Crosby Co., Texas, 102, 201, 227, 240

Crotalus atrox in Texas, 247 ; C. sp. indet. in Arkansas, 252

Crow Reservation, Montana, 46, 312

Crow Wing Co., Minnesota, 177, 199, 208, 307

Crowleys Ridge in Arkansas, 249, 250; in Missouri, 260

Cuero, De Witt Co., Texas, 21, 248 
Cunnnins, W. F., 102, 103, 123, 125, 161, 222, $229,231,232,233,234,240$

Curley Shoals, Robertson Co., Texas, 127,

Custer Co., Colorado, 144, 167, 273; Montana, 83 ; Nebraska, 81, 128, 304

Cutler, W. E., 154

Cynomys ludovicianus in Nebraska, 305; sp. indet. in Nebraska, 304

Cypress Hills, Alberta, 314

Dallas Co., Iowa, 42; Texas, $13,58,85,103$, $126,161,170,186,210,241,226$

Dallas, Dallas Co., Texas, 13, 58, 85, 103, $125,161,186,210,226,241$

Dannebrog, IIoward Co., Nebraska, 5.5, 304

Darton, N. H., 15\%, 256, 258, 266, 305, 309

Datil, Socorro Co., New Mexico, 108, 258, 259

Davenport, Scott Co., Iowa, 41, 53, 289, 290

Davenport Academy of Science, $53,75,78$

I)avis Co., Iowa, 113, 294

Dawes Co., Nebraska, 118

Dawson, G. M., 185, 313, 315, 316

Dawson Butte, Douglas Co., Colorado, 111, 273

Dawson Co., Montana, 83

DeKay, J. E., 104,179

De witt Co., Texas, 248

Deer in Arkansas, 170 ; in Iowa, 115, 171, $172,205,294,297,299$; in Kansas, 171 ; in Louisiana, 170 ; in Missouri, 4, 27, $171,173,265$; in Oklahoma, 170 ; in Texas, 170

Delaware Co. Iowa, 149, 288

Deloit, Crawford Co., Iowa, 205

Delta Co., Texas, 225

Delvalle, Travis Co., Texas, 130

Deming, Luna Co. New Mexico, 108, 258

Dennison, Crawford Co., Iowa, 38, 51, 197, 297

Denmark, Lee Co., Iowa, 292

Denning, San Augustine Co., Texas, 19, 242

Denny, Falls Co., Texas, 17, 244

Denton Co., Texas, 103, 125, 240

Denton, Denton Co., Texas, 103, 125, 240

Denver, Colorado, $73,96,112,145,166,274$

Denver Co., Colorado, 73, 96, 112, 145, 166, 274

Des Moines, Iowa, 42, 54, 78, 197, 211, 301

Des Moines Co., Iowa, 41, 52, 77, 158, 283, 292

Des Moines River, Davis Co., Iowa, 294

Deussen, Alex, 21, 62, 129, 130, 188, 202, 221, $222,224,231,236,246,249$

Diamond City, Broadwater Co., Montana, 46 , 84,312

Dickens Co., Texas, 240

Dicotyles compressus. 157, 158; D. costatus, $157 ;$ D. lenis, $159 ;$ D. torquatus, 159

Didelphis virginiana in Texas, 247

Dinarctotherium merriami in Nebraska, 303

Dinobastis serus in Oklahoma, 67,256 ; in Texas, 247

Doniphan Co. Kansas, 34, 69, 140, 268

Donna Ana Co., New Mexico, 137, 258

Doon, Lyon Co., Iowa, 40, 300

Douglas Co., Colorado, 73, 111. 195, 204, 273 ; Kansas, 33, 174, 203, 268: Minnesota, 306: Nebraska, 118, 207, 212, 303

Douglas Station, Brandon Co., Manitoba, 200, 317

Dover, Albany Co., Wyoming, 118

Drake's Salt Works, Louisiana, 10, 220

Drew's Landing. San Jacinto Co., Texas, 19, $105,227,242$

Driftless area in Iowa, 276

Dubuque, Iowa, $7,117,159$

Dubuque Co., Iowa, 7, 55, 117, 159, 276, 287

Dumble, F. T., 19, 20, 66, 90, 105, 126, 131, $132,162,188,189,201,222,227,230$

Dundr Co.. Nebraska. 81

Duvai. II. H., 3, 64, 130, 202

Nuval Co.. Texas, 66. 131, 249. 249

Duval, Jim Wells Co., Texas, 22

Fagle Lalie, Austin Co.. Texas, 106, 246

Fast Raton Rouge Parish, Louisiana, 12, 220

Last Dallas, Dallas Co., Texas, 170
Eddyville, Mahaska Co., Iowa, 171, 293

Edmonton, Alberta, 84, 185, :317

Eimonton Co., Alberta, 185

Egypt, Wharton Co., Texas, 130, 247

Eight-mile Creek, Franklin Co., Kansas, 269

El Paso, Texas, 22, fifi, 134, 15.5, 249

El Paso Co., Colorado, 72, 73, 96, 144, 166, $182,195,273$; Texas, 22, 66, 1:34, 155, 249

Elbert, Elbert Co., Colorado, 72, 274

Eilbert Co., Colorado, 72, 144, 274

EIdon, Wapello Co., Iowa, 37, 293

Elephants of undetermined species in Alberta, 121: in Colorado, 111; in Iowa, 112 ; in Kansas, 110 ; in Louisiana, 102 ; in Minnesota, 118; in Missouri, 109; in Montana, 120; in Nebraska, 117; in New Mexico, 108; in North Dakota, 120; in Oklahoma, 108; in Saskatchewan, 121; in South Dakota, 120 ; in Texas, 102 ; in Wyoming, 118

Elephas americanus, $84,111,114,118,120$ 192,310 ; E. boreus in Alberta, 121,317 ; in Colorado, 74; in Iowa, 49, 50, 51, $113,114,116,117,278,285,287,288$, $289,290,291,292,293,296,298,299$, 300,301 ; in Kansas, 48, 72, 111, 142, $266,267,270$; in Minnesota, 56,119 , 308 ; in Missouri, $47,109,261$; in Nebraska, 55, 303, 304, 305; in South $\mathrm{Da}$ kota, 310 ; in Texas, 47, 64, 66, 238, 247 ; E. columbi in Alberta, 84, 317; in Colorado, $72,96,97,273,274,275$; in Iowa, 51, 74, 97, 115, 116, 147, 167, 287, $288,289,292,293,294,295,296,297$ $299,300,301,303$; in Kansas, 34,69 , $95,110,111,140,142,157,192,194$, $266,267,268,269,270$; in Louisiana, 57, 216; in Missouri, 24, 25, 28, 69, 109 , $140,164,191,265,266$; in Montana, $46,83,101,312,313$; in Nebraska, 78 , $118,198,303,304$; in New Mexico, 67, $108,138,257,258,259$; in Oklahoma $66,254,255,256$; in Saskatchewan, 84 , 317 ; in South Dakota, 82, 120, 310; in Texas. $13,14,20,21,57,89,90,92,93$, $103,104,105,106,107,134,155,162$, $186,223,226,227,228,229,233,238$, $239,240,241,242,243,244,245,246$, $247,248,249$ : in Wyoming, 81, 305; F. francisi in Texas, $61,64,87,89,90$, $106,107,238,242,243$; E. havi in Nebraska, 99, 101.303: E. imperator in Colorado, $96,145,272,273,274,275$; in Iowa $76,97,278,294,295,296,297$ : in Kansas, 95, 110, 111, 141, 194, 266, 269,270 ; in Louisiana. 102, 216 ; in Montana. $83.101,312$; in Nebraska, 43. $79,98,152,168,302,303,304 ;$ in New Mexico, 109 : in Oklahoma, 67, 94, 254 , 255,256 : in Texas. $58,59,60,61,63$, $64,85.103,105,106,107,210,224,225$. $226,227,228,229,230,231,238,239$. $240,241,242,243,244,245,246,247$. 248,249 : in Wroming, 101, 305: F. mammonteus, $87:$ E. primigenius, 37,41 , 47. $48,49,67,80,84,87,95,109,111$, 112, 116, 121, 239, 247, 254, 266 (See E. boreus): E. roosevelti, 48 : F. rupertianus, 121; E. sibiricus, 121: E. sp. indet. in Colorado, 274: in Iown. 276 . $\begin{array}{lllllllll}286 & 257 & 288 & 289 & 290 & 291 & 292 & 293\end{array}$ 294. 295: in Kansas. 269, 270 : in Louisiana. 214. 218 : in Minnesota. 1S1, 30s: in Missouri, 263, 264: in Montan?. 312: in Nebraska, 303, 304: in New Mexico, 257. 258: in North Dakota, 310. 311: in South Dakota, 30?, 310: in Texas, 3. 4. 18. $156,190,227,232$. 238, 230. 240. $242,243,244,246,247,248,249:$ in Wyoming. 305 : E. texianus, 92,93

Flk in Arkansas, 173 ; in Iowa, $172,174,175$, $297,300 \cdot$ in Kansas, $34,173,174,203$; in Missouri, 4, 27, 171, 191, 265 (See also Cervus) 
Elliott gravel pit in Iowa, 168, 211, 297

Ellis, Ellis Co., Kansas, 194, 269

Ellis Co., Kansas, 194, 269 ; Texas, 59, 86, 241

Ellsworth Co., Kansas, 181, 269

Elmendorf, Bexar Co., Texas, 88, 247

Emmons, S. F., $97,112,145,167,195,196$, 271

Emporia, Lyon Co., Kansas, 33, 269

Empress, Redcliffe Co., Alberta, 154

Empress, Alberta, 317

Endicott, Jefferson Co., Nebraska, 184, 303

Eptesicus fuscus in Arkansas, 252 ; E. fuscus grandis in Arkansas, 252

Equidæ in Alberta, 154; in Arkansas, 134 ; in Colorado, 143 ; in Iowa, 145 ; in Kansas, 140 ; in Louisiana, 122 ; in Missouri, 138 ; in Montana, 153; in Nebraska, 150; in New Mexico, 137; in Oklahoma, 135; in Ontario, 154; in South Dakota, 153; in Texas, 123; in Wyoming, 152

Equus americanus, 122 ; E. barcenæi, 4, 131, 132 ; E. calobatus, 124,239 ; E. complicatus in Colorado, 145, 274, 275; in Iowa, $76,147,148,167,294,295,296$, 297,298 ; in Kansas, $140,141,142,269$ 270 ; in Louisiana, 12, 122, 123, 215, 217, 2.20 ; in Missouri, 31, 139, 262, 263 ; in Nebraska, 151, 152, 303; in New Mexico, 137, 258; in Oklahoma, 135, 254; in South Dakota, 153, 309; in Texas, $66,123-131,133,134,155,240,242,244$ 249 ; E. crenidens in Texas, 4, 131, 132, 133 ; E. curvidens, 141,142 ; E. excelsus in Iowa, 147, 148, 296, 297; in Kansas, 71 ; in Nebraska, $152,304,305$; in Oklahoma, $135,136,254$; in Texas, 123 , $124,130-133,239,247$; $\mathrm{E}$. fossilis, 18 , 128 ; E. francisi in Texas, $125,130,133$, $234,240,247$; E. fraternus, 131,132 , 241 ; E. giganteus in Texas, 130,133 , 246 ; E. hatcheri in Nebraska, 152; in Oklahoma, $135,136,254 ; \mathrm{E}$. holmesii in Oklahoma, $135,136,152,254$; E. intermedius in Louisiana, $122,123,218$; E. laurentius in Colorado, 144, 145, 273, 275 ; in Iowa, $76,147,148,167,294$, 296,298 ; in Kansas, 34, 143, 171, 174, 268,270 ; in Oklahoma, $135,136,254$; in South Dakota, 153, 309; E. leidyi, 215; in Kansas, 141, 142; in Texas, 126, 129, $241,242,246 ; \mathrm{E}$. littoralis in Texas, 126, 242 ; . major, $122,123,129,131,133$, $141,148,239 ; \mathrm{E}$. niobrarensis in Iowa, $147,148,150,287,296,297,298$; in Kansas, $34,69,71,140,142,143,268$, 270 ; in Missouri, 261 ; in Nebraska, 151 , $152,303,304,305$; E. occidentalis, 131 , 132 ; E. pectinatus, 140 ; E. scotti in Arkansas, 251; in Iowa, 147; in South Dakota, 153, 309; in Texas, 124,134 , 239 ; E. semiplicatus in Texas, 47, 123 $124,126,129,131,132,133,155,162$, $239,242,243$; $\mathrm{E}$. species indetermined in Alberta, 154, 317 ; in Arkansas, 134 ; in Colorado, 143, 144, 145, 272, 273, 274; in Iowa, 145, 147, 148, 149, 292, 296 299,300 ; in Kansas, $141,143,165,270$; in Manitoba, 154, 317; in Missouri, 25, $69,138,139,164,262,264,265$; in Montana, 153, 312, 313; in Nebraska, 100 $159,168,302,304$; in New Mexico, 69, $138,257,258,259$; in South Dakota, $153,309,310$; in Texas, 3, 12, 124-131, $134,210,227,228,232,238,240,243$, 246-249 ; in Wyoming, 153,305 ; E. tau in Texas, 4, 123, 124, 131, 132, 133, 239 Equus beds in Colorado, 275; in Kansas, 6 , $266,267,270$; in Nebraska, 43 ; in Texas, 2, 221, 222, 223, 232, 235 (See Sheridan formation)

Erethizon dorsatum in Arkansas, 252

Eschatius conidens in Texas, 161, 239
Extinct bisons in Colorado, 195; in Iowa, 196 ; in Kansas, 192 ; in Louisiana, 186; in Manitoba, 200; in Minnesota, 199; in Missouri, 191; in Nebraska, 198; in Oklahoma, 190; in South Dakota, 199; in Texas, 186

Ezzell, Lavaca Co., Texas, 21, 248

Fairbury, Jefferson Co., Nebraska, 79, 98, 302, 303

Fairhaven, Stearns Co., Minnesota, 44, 307

Falconer, Hugh, 92

Falls Co., Texas, 17, 61, 87, 127, 186, 221 , 228,243

Fannin Co., Texas, 58, 225, 226, 240

Fargo, North Dakota, 306

Fayette beds in Texas, 222

Fayette Co., Iowa, 51, 183, 284, 288; Texas, $130,188,247$

Feliciana I'arish, Louisiana, 122

Felis cougar in Arkansas, 252; F. longicrus in Arkansas, $252 ; \mathrm{F}$. sp. indet. in Texas, 247

Fenneman, N. M., 260

Fentress, Okfuscee Co., Oklahoma, 191

Fertile, Washington Co., Missouri, 31

Field Museum of Natural History, 56,59

Fifth Creek, Cooke Co., Texas, 186

Fillmore Co., Nebraska, 80, 303

Finlay, G. I., 96

Five Íslands, Louisiana, 218, 219

Flaxville, Sheridan Co., Montana, 169, 312

Flaxville gravels, Montana, 312,313

Florence, Douglas Co., Nebraska, 212, 303

Floris, Davis Co., Iowa, 113

Floyd Co., Iowa, 78, 207, 287

Floyd, Floyd Co., Iowa, 207, 287

Foard Co. Texas, 57, 234

Foard City, Foard Co., Texas, 57

Folsom, Mills Co.s Iowa, 172, 294

Ford Co., Kansas, 270

Fort Bend Co. Texas, 3, 106, 162, 246

Fort Collins, Larimer Co., Colorado, 74, 97, 274

Fort Gibson, Muskogee Co., Oklahoma, 179, 255

Fort Madison, Lee Co., Iowa, 40, 146, 292

Fort Pelly, Saskatchewan, 121, 317

Fort Pierre, Stanley Co., South Dakota, 153, 310

Fort Stanton, Lincoln Co., New Mexico, 257

Fort Worth, Tarrant Co., Texas, 13, 58, 85, 226,241

Fossil wood in Louisiana, 220

Foster, J. IV., 216

Francis, Mark, 2, 3, 12, 13, 14, 17, 18, 19, $20,21,59,60,61,62,63,66,87,88,89$, $92,93,102,103,104,105,107,108,127$, $128,129,131,133,155,161,162,163$, $186,187,188,201,202,203,224,242$, $244,246,248$

Franklin, Canada, 121

Franklin Co., Iowa, 54, 287 ; Kansas, 33, 70, 110,269 ; Nebraska, 79

Freeborn Co., Minnesota, 45, 119

Frontier Co., Nebraska, 80, 304

Fullerton, Nance Co., Nebraska, 152, 304

Furnas Co., Nebraska, 80, 168, 184, 303

Tage Co.. Nebraska, 43, 98, 303

Gainesville, Cooke Co., Texas, 13, 240

Galena, Stone Co Missouri, 24, 266

Gallinas Creek, Atascosa Co., Texas, 92, 248.

Galva, Ida Co., Iowa, 198

Galveston Bay, Texas, 127, 242

Galveston Co., 'Texas, 63, 92, 105, 127, 242

Garber, Clayton Co., Iowa, 40, 276, 287

Gardner, Huerfano Co., Colorado, 143, 166

Gardner, J., 191

Garfield Co., Colorado, 97, 145, 196, 272

Garman, Samuel, 8

Garza Co., Texas, 19, 240

Gasconade Co., Missouri, 4, 29, 264

Geomys bursarius in Nebraska, 303

Geomys parvidens in Arkansas, 251

Geomys texensis in Texas, 247

George West, Live Oak Co., Texas, 107, 248

Georgetown, Williamson Co., Texas, 88, 246 
Giant beaver (Sre Castoroldes)

Gidley, J. W., 8., 124, 130, 131, 133, 137 $152,154,157,169,179,222,233,238$, (3) 304,312

Gidleya zuniensis in New Mexlco, 69, 138, i64, 179,259

Gilbert, G. K'., 138, 258

Gillespie Co., Texas, (j4, 229, 246

Gilmore, C. W., 108, 204

Gladwin, E. I., 147

Glendive, Dawson Co., Montana, 83, 312

(ilenwood Co., Manitol)a, 200, 317

Glenwood springs, Garfield Co., Colorado, 97, $145,196,272,275$

Glyptodion petaliferus in Texas, 2, 4, 223 , 240, 249: G. sp. indet. in Texas, 214, $215,239,240$

Gold Hill, Boulder Co., Colorado, 204

Golden, Jefferson Co., Colorado, 35, 74, 112, 274

Goliad Co., Texas, 248

Gomphotherium elegans, 16, 35, 228 (See $\Lambda$ nancus mirificus); G. gratum, 18 ; G. sp. indet., 22

Gonzales Co." Texas, 65, 91, 248

Goodland, Sherman Co., Kansas, 157, 158, 270

Gopherus atascosæ in Texas, 247, 248

Gordon, C. H., 224, 233, 251

Gosper Co., N'ebraska, 117, 303

Fould, C. N., 108, 255, 256

Grafton, Fillmore Co.. Nebraska, 80, 303

Granbury, Hood Co., Texas, 14, 86, 104, 227, 243

Grandview, Louisa Co., Iowa, 115, 291

Granite, I,yon Co., Iowa, 149

Grass Valley, Teller Co., Colorado, 72

Grayson, Sheridan Co., Nebraska, 8, 81, 100 302, 304 (See Peters, Sheridan Co., Nebraska)

Grayson Co., Texas, 224, 240

Greeley, Weld Co., Colorado, 74, 145, 274

Greene Co., Iowa, 42, 300; Missouri, 25, 265

Grimes, Polk Co., Iowa, 206, 301

Grimes Co., Texas, 62, 105, 245, 246

Grinnell, Poweshiek Co., Iowa, 50, 75, 293

Grinnell College, Iowa, 204

Groesbeck Creek, Hardeman Co., Texas, 103 $125,234,240$

Ground-sloths (See Xenarthra)

Guadalupe Co., Texas, 65, 131, 248

Guadalupe River, Texas, terraces of, 229

Gulf Costal Plain, Texas, 236; of Arkansas, 249

Gumbotil, 277, 279, 283

Guthrie Co., Iowa, 205, 295

Guthrie, Irogan Co., Oklahoma, 173

Hale Co., Texas, 102, 232, 239

Hallettsville, Lavaca Co., Texas, 21, 107

Hamilton Co., Iowa, 197, 300

Hammond, Bourbon Co., Kansas, 70, 269

Hampton, Franklin Co., Iowa, 54, 287

Hardeman Co., Texas, 103, 125, 224, 234, 240

Hardin Co., Iowa, 206, 300; Texas, 3, 20, $126,237,242$

Harding Co., New Mexico, 108, 257

Harlan, Richard, 4, 27, 171, 191, 265

Harper Co., Kansas, 110, 270

Harper township, McPherson Co., Kansas, 5,141

Harris, G. D., 213, 219, 220

Harris and Veatch, 10

Harris Co., Texas, 20, 63, 242

Harrisburg, Harris Co., Texas, 20, 242

Harrison C'o., Iowa, 6, 38, 51, 76, 77, 97, 147 $167,174,183,197,205,295$; Texas, 86 $2.25,240$

Hartley, O'Brien Co., Iowa, 77, 300

Harvey Co., Ḱansas, 267

Hatcher, J.' B., 152, 304

IIavre, Hill Co., Montana, 83, 312, 313

Hawley, Jones Co., Texas, 2, 240

Haworth, E., 266

Hay, O. P., 97, 289

Hay, Robert, $95,110,111,142,193,194$, 266,268
IIay Springs, Nebraska, 5, 81, 100, 152, 160, 211, 304 (see Peters, Sheridan Co., Nebraska)

Iayden, F. V., 84, 98, 100, 159, 193, 303

Hayden, Routt Co., Colorado, 74, 27 ,

Hayes ('o., Nebraska, 56, 304

Iayes Center, Hayes Co., Nebraska, 56, 304

Hays, C. W., 237

IIays Co., Texas, 201

ILebron, Thayer Co., Nebraska, 99, 303

Helena, Arkansas, 22, 253; Montana, 84, $101,120,312$

IIelotes, Bexar Co., Texas, 15, 247

IIennepin Co., Minnesota, 9, 56, 212

Hennesey, Kingfisher Co., Oklahoma, 67, 256

IIenry Co., Iowa, 7, 36, 74, 293

Ilenry's Fork, Uinta Co., Wyoming, 208, 305)

IIenton, Mills Co., Iowa, 76,294 (See Hinton)

IIerrick, C. L., 108, 257

Hiawatha, Brown Co., Kansas, 110, 268

IIickory ('o., Missouri, 171, 173, 191, 265

Hidalgo Co., Texas, 235

Hidalgo Falls, Washington Co., Texas, 3, 18, $128,223,244,245$

IIilgnrd, E. W., 12, 170, 213, 216

Hill, Robert 'T., 13, 14, 189, 223, 231, 235, 240 ; on terraces of Texas rivers, 221

Hill Co., Texas, 104, 241

Hill Creek, Bosque Co., Texas, 202

Hills, R. C., 166

Ifinton, Mills Co., Iowa, 147, 167 (See Henton)

IIipparion cragini in Kansas, 140, 146, 270

IIpparion gratum, 140, 146

IIipparion sp. indet. in Iowa, 146, 278, 294 ; in Missouri, $69,164,261$; in Montana, $169,312,313$; in Nebraska, 304

IIitchcock Co., Nebraska, 198, 304

IIocketts, Custer Co., Montana, 83

Holmes, W. H., 23, 66, 94, 170, 178, 203, 253

IIolmesville, Gage Co., Nebraska, 98, 303

Iolomeniscus macrocephalus in Texas, 161, 162, 239; H. sulcatus in Texas, 161, 163,239

IIomo in Texas, 241

IIood Co., Texas, 14, 60, 86, 104, 227, 243

Hopkins, F. V.A 10, 11, 213, 220

Horner, W. E., 109, 262

Horses in Colorado, 143, 144, 145, 182, 195 , 196 ; in Iowa, 52, 77, 145, 278, 299, 300 ; in Kansas, 6, 141, 143, 165, 195; in Louisiana, 12,215 ; in New Mexico, 164, 179; in Texas, 2, 12, 61, 63, 92, $103,125,126,130,131,134,139,210$ (See Equidæ and Equus)

Houston, Harris Co., Texas, 63

Houston Co., Texas, 221, 226

Howard Co., Missouri, 109. 261: Nebraska, 55,304 ; Texas, 125, 232, 240

Hoxie, Sheridan Co., Kansas, 194, 269

Iloy, P. R., 26

Hubbard, Hardin Co., Iowa, 206, 300 ; Hil: Co., Texas, 104, 241

Huerfano Co., Colorado, 6, 96, 143, 166, $27{ }^{\circ}$

Hughes Co., Oklahoma, 23; South Dakota S:, 199

II unt Co., Texas, 2, 125, 223, 240

Hutchinson, Reno Co., Káansas, 71, 270

Iberia Parish, Louisiana, 1, 11, 57, 122, 170 186,220

Icemgood Creek, Nolan Co., Texas, 186, 233

Ida Co., Iowa, 115, 298

Ida Frove, Ida Co., Iowa, 115, 298

Ildefonso, Santa Fè Co., New Mexico, 138. $25 \%$.

Illinoian stage and deposits in Arkansas, 252 ; in Iowa, 40, 77, 282, 284, 290; in Minnesota, 306 ; in Missouri, 260

Indian Creek. Comanche Co., Texas, 14, 243 Indianola, Red Willow Co., Nebraska, 118, 304 ; Warren Co., Iowa, 113, 182, 294

Inez, Victoria Co., Texas, 107, 248

Iola, Grimes Co., Texas, 105, 245 
Iowa, Bison bison in, 204; Camelidæ in, 167 ; Castoroides in, 210, 211; Cervus in, 174 ; Elephas boreus in, 49; Elephas columbi in, 74; Elephas imperator in, 97 . Equide in, 145 ; extinct bisons in, 196; mastodons in, 36; Odocoileus in, 171; Ovibovinæ in, 182; peccaries in, 158 ; Pleistocene geology of, 275 ; Rangifer in, 176 ; undetermined elephants in, 112; Xenarthra in, 6

Iowa City, Johnson Co., Iowa, 113, 292

Iowa Co. Iowa, 50

Iowa State University, $\mathbf{7 7}, \mathbf{7 8}$

Iowan stage and deposits, 51, 53, 78, 150, 250,284

Irene, Clay Co., South Dakota, 168

Irvington, Kossuth Co., Iowa, 175, 300

Jackson Co., Iowa. 40, 288; Missouri, 31, $69,192,264,265$

Jackson Creek, El Paso Co., Colorado, 73

James township, Pottawattamie Co., Iowa, 196,295

Jaques, H. E., 36,49

Jasper Co., Iowa, 204, 293 ; Missouri, 24, 69, 191,266

Jefferson Co., Colorado, 35, 74, 112 ; Iowa, 112,293 ; Kansas, $171,173,193,203$, 268; Missouri, 5, 31, 109, 139, 171, 180 , 102,262 ; Nebraska, $79,98,99,168,184$ 303 : Texas, 19,242

Jewell Co., Kansas, 35, 269

Jim Hogg Co., Texas, 235

Jim Wells Co., Texas, 22, 66, 133, 236, 248, 249

Johnson Co., Iowa, 113, 292; Nebraska, 8 98 ; Wyoming, 82,305

Johnston, W. A., 200,316, 317

Jones Co., Texas, 2, 240

Joor, J. F., 1, 11, 57, 122, 170, 186, 217, 218

Joplin, Jasper Co., Missouri, 24, 69, 191, 266

Kanabec Co., Minnesota, 208, 307

Kansan stage and deposits, $36,43,49,77$ in Iowa, 146, 282; in Kansas, 268; in Missouri, 25:, 260; in Nebraska, 301. 302 ; in South Dakota, 309

Kansas, Bison bison in, 203; Camelidæ in, 165: Castoroides in, 210; Cervus in 173 Elephas boreus in, 48 ; Elephas columbi in, 69; Flephas imperator in, 95; Fquidre in, 140; extinct bisons in, 102: mastodons in, 33; Odocoileus in 171: Ovibovina in, 181; peccaries in, 157; Pleistocene geology of, 266 ; undetermined elephants in, 110 ; Xenarthra in, 5

Kansas Aqricultural College, 141, 142

Kansas City, Missouri, 31, 192, 264

Kay, G. F., $75,183,277,283,294$

Kay and Pearce, 277, 284

Kearney Co., Nebraska, 303

Keeran Point, Victoria Co., Texas, 21, 64, 163,248

Kendalia, Kendall Co., Texas, 15

Kendall Co., Texas, 15, 247

Kennedy, W., 127, 128, 225, 226, 237

Keokuk, Lee Co., Iowa, 74, 292

Kerr Co., Texas, 105, 229, 247

Kerrville, Kerr Co., Texas, 105, 247

Keyes, C. R. 77, 146, 277

Kimball, Custer Co., Montana, 83, 312

Kimmswick, Jefferson Co., Missouri, 5, 31 109. $139,171,180,192,262$

Kindle, E. M., 121

Kingfisher Co., Oklahoma, 67, 95, 256

King's Salt Works, Louisiana, 10

Kingsdown marls in Kansas, 270

Kinlock, Marshall Co., Oklahoma, 94, 255

Kiowa Creek, Comanche Co., Kansas, 142 270

Knox City, Crosby Co., Texas, 13, 227

Knox Co Texas, 12, 125, 233, 242

Koch, Albert, 4, 26, 29, 30, 47, 109, 139, 171 , $173,191,262,264.265$

Kossuth Co, Iowa, 175, 300

Kunz, G. F., 79, 91

La Porte, Black Hawk Co., Iowa, 288
Labette Co., Kansas, 192, 269

I afayette Co., Missouri, 110, 181

Lafayette formation in Arkansas, 250; in Louisiana, 213, 214 ; Texas, 225, 230 , 231

Lagow gravel pit, Dallas, Texas, 170, 186 , 226,241

Lake Agassiz in Manitoba, 200, 315; in Minnesota, 307 ; in North Dakota, 120, 310, 311

Lake Calvin, Iowa, 284

Lake View, Sac Co., Iowa, 116, 298

Lancaster Co., Nebraska, 79, 303 Lance Creek, Converse Co., Wyoming, 208,

Lane Co., Kansas, 48, 71, 142, 165, 270

Langford, G., 82, 84

Laporte, Black Hawk Co., Iowa, 207

Laramie Canyon, Albany Co., Wyoming, 305

Laramie Co., Wyoming, 118

Larimer Co., Colorado, 74, 97, 274

Las Vegas, San Miguel Co., New Mexico, 68

Lavaca Co., Texas, 21, 107, 248

Laveta, Huerfano Co.. Colorado, 96, 273

Lawrence, Kansas, 33

Lawrence Co., South Dakota, 153

Iawson, A. C., 208

Lawton, Comanche Co., Oklahoma, 108

Le Flore Co, Oklahoma, 179, 191, 255,

Le Mars, Plymouth Co., Iowa, 52, 115, 149 , 172,299

Lead crevices in Iowa, 287

Leavenworth Co.. Kansas, 204

LeConte, J. L., 157

Lee, W. T., 134, 137, 144, 256, 258

I.ee Co. Iowa, 40,74, 112, 145, 292

Lees, J. H, 42, 206, 298

Lehigh, Webster Co., Iowa, 207

Leidy, J., 3, 11, 57, 70, 93, 98, 122, 126 , $127,128,139,152,156,157,158,159$ $179,180,181,183,192,216,217,257$ Leighton, M. M., 51, 184, 284, 285, 292

Ieon, Bexar Co., Texas. 66

Leon River, Bell Co., Texas, 3, 14, 228, 243 ; terraces of, 223

Leona formation, Texas, 230

Leona River, Texas, 230

Leonard, A, G 310,311

Leota, Madison Co., Texas, 19, 242

Lepus americanus in Arkansas, 252; L, floridanus in Iowa, 283; L. giganteus in Arkansas, 252; L. sylvaticus in Iowa, 283

LeRoy, Coffey Co., Kansas, 165, 269

Leverett, Frank, 36, 259, 283, 285, 286, 289, $290,291,293,306$

Lewis and Clark Co., Montana, 84, 101, 120

Liberty Center, Warren Co., Iowa, 294

Liberty Hill, Williamson Co., Texas, 104, 246

Limestone Co., Texas, 221

Lincoln, Nebraska, 79, 303

Lincoln Co., New Mexico, 68, 257 ; Oklahoma, 67,255

Lincoln township, Winneshiek Co., Iowa, 287

Lindahl, J., 5

Line Creek, Platt Co., Missouri, 32

Linn Co., Iowa, 42, 288; Kansas, 210

Liops zuniensis, 179

Lipan, Hood Co., Texas, 14, 227, 243

Lissie, Wharton Co., Texas, 130, 247

Lissie formation, $4,93,130,222,235,236$, $237,246,249$

Lissops, 179

Little Bayou Sara, Louisiana, 12, 102, 122, 220

Little Osage River, Kansas, 33, 269

Littleton, Arapahoe Co., Colorado, 144, 274

Live Oak Co., Texas, 90, 107, 189, 230, 248

Llano Co, Texas, $14,229,246$

Loess in Arkansas, 250 ; in Colorado, 266, 271,275 ; in Iowa, 285, 290 ; in Kansas, 266 ; in Mississippi, 285; in Missouri, 260 ; in Nebraska, 302

Loew, O., 138 
Logan Co., Iowa. 296 ; Kansas, 143, 165, 194, 204, 270; Oklahoma, 4, 23, 108, 156, $171,173,191,255$

Logan, Harrison Co., Iowa, 76, 147, 174, 205,296

Longmont, Boulder Co., Colorado, 145, 274

Ioon River, Alberta, 121, 317

Iost Creek, I,ee Co.. Iowa, 41

Louisa Co., Iowa, 50, 53, 115, 171, 291

Louisiana, Elephas columbi in, 57 ; Equidre in, 122 ; extinct bisons in, 186: mastodons in, 10, 220; Odocoileus in, 170; Pleistocene geology of, 213; Tapiridæ in, 15.5; undetermined elephants in, 102; Xenarthra in, 1

Louisville, Cass Co., Nebraska, 150, 303

Iovejoy, Phillips Co., Montana, 153, 312, 313

Loveland formation in Iowa, 38, 183, 295, 296,298

Lucas, F. A., 94, 18 ?

Iuling, Caldwell Co., Texas, 65, 247

Lull, R. S., 2, 86, 124, 160, 161, 170, 186, $226,239,241$

Luna Co., New Mexico, 108, 258

Lutra sp. indet, in Nebraska, 304

Lydekker, R., 17, 156

Iynx compressus in Arkansas, 252; L. rufus in Arkansas, 252 Lyon Co., Iowa, 52, 149, 300 ; Kansas, 33,

Lyons, Burleson Co., Texas, 90, 245

Lyons township, Mills Co., Iowa, 147, 295

Macbride, T. H., 198,299

Mackensen, B., 15

Iracleod Co., Alberta, 209

Madison Co., Montana, 84; Texas, 19, 242

Mahaska Co., Iowa, 37, 113, 171, 293

Malvern, Mills Co., Iowa, 114, 295

Mammut americanum in Arkansas, 22, 253 ; in Colorado, 35, 272, 275; in Iowa, 36, $276,287-301$; in Kansas, $33,140,268$, 269 ; in Louisiana, $10,123,217,218$; in Montana, 46, 312; in Minnesota, 44, 307, 308 ; in Missouri, 24, 68, 191, 261-266; in Montana, 84, 312; in Nebraska, 43 99. 303, 304; in New Mexico, 24, 164, 257 ; in Oklahoma, 23, 191, 254, 255, 256 : in South Dakota, 45, 310 ; in Texas, $3,12,90,123,226,229,231,238,240$ 249

Mammut mirificum in Iowa, 7 (See Anancus mirificus) ; $\mathbf{M}$. progenium in Iowa, 38, 295,296 ; in Kansas, $33,174,203,268$ 269 ; in Texas, $18,21,245$

Manhattan, Riley Co., Kansas, 35, 111, 193 , 269

Manitoba, extinct bisons in, 200; Pleistocene geology of, 313, 316

Manitou, El Paso Co., Colorado, 144, 273

Mankato, Blue Earth Co., Minnesota, 45, 56, 308

Mapleton, Monona Co., Iowa, 39. 97, 297

Maquoketa. Jackson Co., Iowa, 40, 288

Marble Falls, Burnet Co., Texas, 14, 64, 246

Marble Rock, Floyd Co., Iowa, 54, 78

Marbut, C. F, 250

Marengo, Iowa Co., Iowa, 50, 292

Marion. Guadalupe Co., Texas, 65, 248

Marion Co., Kansas, 267

Marlin, Falls Co., Texas, 87, 127, 243, 244

Marmota monax in Arkansas, 251

Marnock, G. IV., 15

Marsh, O. C., 159, 193, 199, 304

Marshall Co., Iowa, 113, 288; Kansas, 140 269 : Oklahoma, 94, 255

Martel, Lancaster Co., Nebraska, 79, 303

Martes pennanti in Arkansas, 252

Martin, $H$. $T$, 143,165, 194, 210

Iarysville, Marshall Co. Kansas, 140, 269

Mason City. Cerro Gordo Co., Iowa, 54, 300

Mastodon, Dona Ana Co., New Mexico, 24 137,258

Mastodon americanus, $122,131,139$; M. andium, 17 ; M. cordillerum, 17 ; M. cuvieri, 28 ; Mr. humboldtii, 17; M. mirificus, 35,44 (See Anancus mirificus)
Mastorlons in Arkansas, 22, 253; in Colorado, 35, 273-275; in Iowa, 36, 278, 286301 ; in Kansas, $33,268,270$; in Louisiana, 10, 123, 214, 220; in Minnesota, $44,307,308$; in Missonri, 24, 171, 180, $191,261-266 ;$; in Montana, 46, 312 ; in Nebraska, 43, 302-30.5; in New Mexico, 24, 257-259; in Oklahoma, 23, 253-256: in South Dakota, 45, 310 ; in Texas, 3, $12,123,126,156,210,227,238-249$

Matagorda Co., Texas, 02, 106, 247

Matthew, W. D., 9, $100,152,158,159,160$, $168,211,304$

Maverick Co., Texas, 134, 23.5, 249

Merlung, C. E., 193, 20 ?

Ireconnell, R. G., 314, 315

IIcrourt. W. E., 139

IfDonall's Creek, Crosby Co., Texas, 102, $227,232,240$

McDowell, Austin Co., Texas, 20, 63, 93, 246

McGee, W. J., 149, 183, 207, 213, 222, 289, 291,295

Mcfregor, W. F., 155, 161

McKinley Co., New Mexico, 138, 164, 179, 259

McKinney, Collin Co., Texas, 58, 103. 240

McLennan Co., Texas, 2, 16, 60, 88, 127, 161 , 186. $225,228,243$

McMullen Co. Texas, 231

McPherson Co., Kansas, 5, 35, 71, 141, 165, $194,267,269$

IfcPherson, McPherson Co., Kansas, 35, 71, $165,194,269$

Leade Center, Meade Co. Kansas, 271

Meade Co., Kansas, 6, 110, 142, 165. 270, 271

Meade, Meade Co., Kansas, 142, 165

reade gravels in Kansas, 271

Medicine Creek, Frontier Co., Nebraska, 80, 304

Medicine Lodge, Barber Co., Kansas, 110, 270

Medina Co., Texas, 15

Medina River, Bexar Co. Texas, 107, 248

Megalonyx jeffersonii in Iowa, 6, 7, 296, 297 , 298,299 ; in Kansas, 5 ; in Louisiana, 1. 218; in Minnesota, 9, 308; in Missouri, 5,263 ; in South Dakota, 9 ; in Texas, 2, 125; M. leidri, in Kansas, 5 , 6. 141, 269; in Nebraska, 9: M. sp. indet. in Iowa, $7,39,148,276,287,294,296$; in Kansas, 6 ; in Louisiana, 1, 214; in Minnesota, 9; in Nebraska, 305 ; in South Dakota, 310; in Texas, 18, 128; M. validens in Texas, 3,242

Megatherium mirabile in Texas, 3, 244, 245 ; M. sp. indet. in Missouri, 4, 20, 171, 173,265 ; in Texas, $4,20,224.246$

Meleagris gallopavo in Arkansas, 252

Melville Island Canada, 121

Melvin, Arapahoe Co., Colorado, 112, 274

Memorial Museum, San Francisco, 86

Mephitis newtonensis in Arkansas, 252; M. putida in Iowa, 283

Merriam, John C 134

Mervchippus sp. indet. in Montana, 169, 312

Merycodus sp. indet. 169

Miami Co., Kansas, 33

Microsorex minutus in Arkansas, 252; M. ochrogaster in Arkansas, 251; M. sp. indet. in Nebraska, 305

Middle Loun Fork River, 159, 160

Iiddle Sulphur Creek, Hunt Co.. Texas, 223

Milam Co., Texas, 17, 90, 203, 221, 244

Villican, Brazos Co., Texas, 90, 245

Mills, W. C., 263

urills Co., Iowa, 6, 76, 114, 147, 167, 172, 294,295

Millwood, Leavenworth Co., Kansas, 204, 268

Milton, Van Buren Co., Iowa, 37, 293

Minneapolis, Minnesota, 9, 56, 212, 306, 30s ; Ottawa Co., Kansas, 141, 269

Minnehaha Co." South Dakota, 82, 120, 153, $212,309,310$

Minnesota. Bison bison in, 208; Castoroldes in, 212 ; Elephas boreus in, 56 ; extinct bisons in, 199 ; mastodous in, 44; Ovibovinx in 185: Pleistocene geology of, 306; Rangifer in, 177 ; undetermined elephants in, 118; Xenarthra in, 9 
Minnesota City, Winona Co., Minnesota, 45, 308

Mississippi lowland in Arkansas, 250

Mississippi River, union with Ohio, 250

Missouri, Bison bison in, 203; Camelidæ in, 164 ; Cervus in, 173; Elephas boreus in, 47 , 48; Elephas columbi in, 69 ; Equidæ in, 138 ; extinct bisons in, 191 ; mastodons in, 24; Odocoileus in, 171; Ovibovinæ in, 179 ; peccaries in, 157 ; Pleistocene geology of, 259 ; undetermined elephants in, 109; Xenarthra in, 4

Missouri River in North Dakota, 311

Missouri Valley, Harrison Co., Iowa, 6, 38, $51,76,147,167,183,197,296$

Missourium kochii, 262, 263 ; tetracaulodon, $26 ;$ M. theristocaulodon, 27

Mitchell Co., Texas, 102, 240

Mollusks in Arkansas, 251; in Iowa, 280, 285,297 ; in Louisiana, 11 ; in Minnesota, 306; in New Mexico, 68; in Texas, $102,232,234,237$

Monona Co., Iowa, 7, 38, 39, 77, 97, 147, $172,174,205,211,297$

Montague Co., Texas, 224

Montana, Camelidæ in, 169 ; Elephas columbi in, 83; Elephas imperator in, 101; Equidæe in, 153; mastodons in, 46; Pleistocene geology of, 311; undetermined elephants in, 120

Montgomery Co., Iowa, $\mathbf{7 5}, 294$

Montrose, Lee Co., Iowa, 145, 292

Monument, El Paso Co., Colorado, 73

Moorhead, Minnesota, 306

Moose Jaw, Saskatchewan, 84, 317

Mora, Kanabec Co. Minnesota, 208, 307

Morning Sun, Louisa Co., Iowa, 115, 291

Morrill, C. H., 9, 81, 98, 99

Morrill, Sioux Co., Nebraska, 185

Motley Co., Texas, 124, 224, 232, 240

Mount Calm, Hill Co., Texas, 104, 241

Mount Pisgah, Harrison Co., Iowa, 38, 77, 97 (See Pisgah)

Mount Pleasant, Henry Co., Iowa, 36, 293

Moyer, M. J., 82

Mudge, B. F., 33

Mulhall, Logan Co., Oklahoma, 4, 23, 108, $156,171,191,255$

Munson's Shoals, Brazos Co., Texas, 61, 245

Muscatine Co., Iowa, 41, 53, 115, 176, 290

Muscatine, Muscatine Co., Iowa, 53, 116, 176, 290

Muskogee Co., Oklahoma, 179, 255

Musk-ox, 183

Musk-oxen, see Ovibovinæ

Mustela cicognanii angustidens in Arkansas, 252 ; M. gracilis in Arkansas, 252 ; $\mathbf{M}$. vison in Arkansas, 252

Myers, M. T., 41

Mylodon garmani in Kansas, 5; in Nebraska, 8,$9 ;$ M. harlani in Colorado, 273,275 ; in Iowa, 296; in Kansas, 5, 6, 269, 270 in Louisiana, $1,122,217,218$; in Mis souri, 4, 5, 25, 27, 265; in Nebraska, 8 , 9,305 ; in 'Texas, $2,162,223,228,239$, 243 ; M. nebrascensis in Nebraska, 305 M. renidens in Louisiana, 1,218 ; $M$ sodalis in Texas, 1,$239 ; M$. sp. indet. in Kansas, 5 ; in Louisiana, 1, 214 ; in Missouri, 5; in Nebraska, 8, 302, 303; in Texas, 2, 3, 47, 244, 245, 246, 247 ; M. sulcidens in Louisiana, 1,218

Mylohyus browni in Arkansas, 157, 251; M. sp. indet, in Arkansas, 157, 251; $M$. temerarius, $148,158,298$

Myotus subulatus in Arkansas, 252

Næmorhedus palmeri in Colorado, 144, 273, 275

Nance Co., Nebraska, 152, 304

Nash's Ferry, Bastrop Co., Texas, 202, 247

Natchez, Mississippi, 215

Natrona Co., Wyoming, 118, 305

Navarro Co., Texas, 59, 221, 241, 242
Navasota, Grimes Co., Texas, 62, 105, 246

Nebraska, Bison bison in, 207 ; Camelidæ in, 168 ; Castoroides in, 211 ; Elephas boreus in, 55 ; E. columbi in, 78 ; E. imperator in, 98 ; Equidæ in, 150 ; extinet bisons in, 198; mastodons in, 43; Ovibovinæ in, 184; peccaries in, 159 ; Pleistocene geology of, 301 ; undetermined elephants in, 117; Xenarthra in, 7

Nebraska stage and deposits in Iowa, 146 $276,277,278$; in Minnesota, 306 ; in Kansas, 268; in Missouri, 259; in Nebraska, 301; in South Dakota, 200, 309; in Texas, 237

Nebraska State University, 185

Nemaha Co., Kansas, 269

Neohipparion gratum, 146

Neotoma ozarkensis in Arkansas, 251

Ness City, Ness Co., Kansas, 95, 269

Ness Co. Kansas, 95

Netchez River, terraces of, 225

Nevada, Story Co., Iowa, 174,300

New Braunfels, Comal Co., Texas, 16, 248

New Madrid Co., Missouri, 109, 179, 264

New Madrid, New Madrid Co., Missouri, 109 179,264

New Mexico, Camelidæ in, 164; Elephas columbi in, 67; Equidx in, 137; mastodons in, 24; Ovibovinæ in, 179; Pleistocene geology, 256; undetermined elephants in, 108

New Virginia, Warren Co., Iowa, 37, 294

Newlin Gulch, Douglas Co., Colorado, 273

Newton Co., Arkansas, 134, 157, 170, 173, 178,251

Nishnabotna River, 211

Noble, L. L., 98

Nobles Co., Minnesota, 119, 308

Nolan Co., Texas, 58, 186, 233, 240

Norfolk Co., Manitoba, 200, 317

Norman, Cleveland Co., Oklahoma, 67, 256

Norris, H. WV., 52

North Dakota, Pleistocene geology of, 310 ; undetermined elephants in, 120

North Lawrence, Jefferson Co., Kansas, 171, $173,193,203,268$

North Riverside, Woodbury Co., Iowa, 7, 298

North Sulphur Creek, Hunt Co., Texas, 223

Northfield, Rice Co., Minnesota, 45, 308

Norton, W. H., 40, 42, 116, 269

Nothrotherium sp. indet., 2, 134, 249 ; $\mathrm{N}$. texanum in Texas, $1,234,238$

Nuckolls Co., Nebraska, 80

Nueces Co., Texas, 4, 21, 93, 133, 230, 248, 249

Nueces River, Texas, terraces of, 230

Oakland, Pottawattamie Co., Iowa, 210, 295

Oakville, Live Oak Co., Texas, 189

Oatman Creek, Llano Co., Texas, 14

Oatman, Llano Co., Texas, 229

O'Brien Co., Iowa, 77, 300

Odocoileus hemionus in Arkansas, 170, 251 ; 0 . sp. indet. in Iowa, 171, 172, 299; in Missouri, 25; in Oklahoma, 170, 256; in Texas, 170, 238, 241; 0 . virginianus in Arkansas, 170, 251; in Iowa, 171. 172, 291,293 ; in Kansas, 171,268 ; in Louisiana, 170,218 ; in Missouri, 171, 263 ; in Oklahoma, 170, 254; 0 . whitneyi in Iowa, 172

O'Harra, C. C. 82

Ohio River, union with Mississippi, 250

Okeene, Blaine Co., Oklahoma, 94, 256

Okfuscee Co., Oklahoma, 191

Oklahoma, Bison bison in, 203; Camelidæ in, 163 ; Castoroides in, 210 ; Cervus in, 173 ; Elephas columbi in, 66 ; E. imperator in, 94; Equidæ in, 135; extinct bisons in, 190 ; mastodons in, 23 ; Odocoileus in, 170 ; Ovibovinæ in, 178 ; Pleistocene geology of, 253 ; Tapiridæ in, 156 ; undetermined elephants in, 108; Xenarthra in, 4

old Fort Lyon, Bent Co., Colorado, 111, 271

Old Grayson, Sheridan Co., Nebraska, 304 
Oldliam Co., Texas, 12, 102

Omalia, Douglas Co., Nebraska, 118, 207

Onaluska, I'olk Co., 'Texas, 59, 89, 242

Ondatra annectens in Arkansas, 251 . nebrascensis in Nebraska, 30\%

Onion Creok formation in Texas, 189, 229, 230

Opelousas, St. Landry Parish, Louisiana, 11, 220

O'Quinn Branch, Fayette Co., Texas, 188 Orycotherium, 3; 0 . missouriense, 4, 27

Osage, Benton Co., Missouri, 47, 139, 26.5

Osawatomie, Miami Co., Kansas, 33, 269

Osborn, H. F., 111, 151, 157

Osceola, Clarke Co., Iowa, 114, 294 ; St. Clair Co., Missouri, 29, 266

Oskaloosa, Malıaska Co., Iowa, 113, 293

Oswego, Labette Co., Kansas, 192, 269

Otero Co., New Mexico, 67, 258

Otis Mill, Union Co., South Dak., 153

Otoe Co. Nebraska, 184, 303

Ottawa, Franklin Co., Kansas, 70, 110, 269

Ottawa Co., Kansas, 141, 269; Oklahoma, 23, $66,94,135,163,170,173,178,190$, $203,210,253$

Ottine, Gonzales Co., Texas, 65, 91, 248

Ottumwa, Wapello Co., Iowa, 37. 293

Ovibos cavifrons in Missouri, 185; 0 . mos chatus in Alberta, 317 ; in Colorado, 182 in Iowa. $51,183,285,288$; in Minnesota, 185, 308; in Nebraska, 185, 305 O. sp. indet. in Colorado, 144, 166, 273 $2 \div 5$

Oviboving in Alberta, 185 in Arkansas, 178 in Colorado, 182; in Iowa, 182 ; in Kan sas, 181; in Minnesota, 18.5; in Missouri 179 ; in Nebraska, 184 ; in New Mexico, 179 ; in Oklahoma, 178

Owen, Richard, 215

$\mathrm{Ox}, 27$ (See Bison)

Oxbow Creek, Nuckolls Co., Nebraska, 80, 303

Ozark Province in Arkansas, 249, 251

Paarmann, J. H., 53

Pace, Lula, 88

Pacific Junction, Mills Co., Iowa, 114, 295

rage Co., Iowa, 38, 294

Paige, Sidney, 256, 258

Palermo, Doniphan Co., Kansas, 34, 69, 140 268

Palestine, Anderson Co., Texas, 126

Palmer, Douglas Co., Colorado, 274

Palo Duro, Armstrong Co., Texas, 57

Palo Duro Canyon, Randall Co., Texas, 12, 123,238

Paluxy, Hood Co., Texas, 86

Paluxy Creek, Hood Co., Texas, 60, 227, 243

Papinsville, Bates Co., Missouri, 25, 138, 265

Paramylodon nebrascensis, 6, 9

Parita Creek, Bexar Co., Texas, 88, 107

Parker, Douglas Co., Colorado, 73

Parker. H. N., geological map of Kansas by, 266

Parker Co., Texas, 227

Parks, W. F., 5, 139, 203, 263

Pauline, Adams Co. Nebraska, 80

Pawnee Co.. Nebraska, 78, 303

Pawnee City, Pawnee Co., Nebraska, 78, 303

Pearlette formation, Kansas, 270, 271

Peccaries in Arkansas, 157; in Iowa. 158. in Kansas. 157; in Missouri, 157; in Nebraska, 159; in Texas, 157

Pecos River, Texas, 234

Pelly, Pelly Co., Saskatchewan, 121

Pena Blanca, Sandoval Co., New Mexico, 68, 257

Pendennis, Lane Co., Kansas, 48, 71, 142, 165,270

Pender, Thurston Co., Nebraska, $4:$

Peno, La Flore Co., Oklahoma, 23, 255

Penrose, R. F. A., 131, 222

Peorian stage and deposits in Iowa, 250, 276,285

Perkins Co., South Dakota, 45, 310

Perodipus sp. indet. in Texas, 247

I'eromyscus sp. indet. in Arkansas, 251; in Texas, 247
Peters, Sheridan Co., Nebraska, 81, 100, 152, $160,168,211$ (See Grayson)

I'eterson, O. A., 304

I'etle Anse, Iberia I'arish, Iouisiana, 1, 11, $57,12 \%, 170,186,215$

Pettis Co., Missouri, 29, 26.5

I'eyton gravel-pit, Iowa, 97, 168, 295

Philadelphia Academy of Natural Siciences, 95

I'lilip, Stanley Co., South Dakota, 9, 310

Phillips Co., Arkansas, 22; Montana, 153, 312,313

l'ickrell, Ginge Co. Nebraska, 43, 302, 30:

I'ickwick, Bryan Co., Oklahoma, 203, 255

Pierre, Hughes Co., South Dakota, 82, 199, 310

Pike Co, Missouri, 32,261

Pilot Knol, Travis Co., Texas, 189, 247

Pine Ridge, Shannon Co., South Dakota, 45, 310

Pine River, Beltrami Co., Minnesota, 208, 307

Pisgah, Itarrison Co., Iowa, 147, 167, 295 (see Mount Pisgah)

Pittbridge, Brazos Co., Texas, 18, 61. 89, $105,128,162,187$; Burleson Co., Texas, $3,224,244$

Placita, Sandovai Co., New Mexico, 68, 257

Plainview, Hale Co., Texas, 102, 232, 240

I'lants, Pleistocene in Louisiana, 214

Platte Co., Missouri, 32

Platygonus compressus in Iowa, 287, 292 ; in Missouri, 265; in Nebraska, 159, 160 ; in Texas, 157. 223, 239: $\mathrm{P}$. leptorhinus in Kansas, $158,270: \mathrm{P}$. sp. indet. in Nebraska, 100, 152, 168, 304, 305; in Texas, 157,$239 ;$ P. striatus, $159 ; \mathrm{P}$. vetus, 160

Pleasant Hill, Cass Co., Missouri, 192, 265

Pleistocene geology of Alberta, 313; of Arkansas, 249 ; of Colorado, 271; of Iowa, 275 ; of Kansas, 266 ; of Manitoba, 313 : of Minnesota, $306:$ of Missouri, 259: of Montana, 311; of Nebraska, 301; of New Mexico, 256: of North Dakota, 310 : of Oklahoma. 25.3; of Saskatchewan, 313. 314,316 ; of South Dakota, 308 ; of Texas, 221 ; of Wroming, 305

Pleistocene of Louisiana, 213

Plymouth Co., Iowa, 7, 39, 52, 115, 149, 299

Pohlig, IIans, 101

Poinsett Co., Arkansas, 22

Polk, Polk Co., Iowa, 116, 301

Polk Co., Iowa, 42, 54, 78, 116, 176, 196, 197, $206,211,301$ : Texas, 59, 89, 242

Pomme de Terre River, Missouri, 4, 25, 171, $173,191,265$

Pondera Co., Montana, 101, 312

Pope Co., Minnesota. 306

Port Arthur, Jefferson Co., Texas, 19, 242

Port Hudson, I,ouisiana, 12

Port Hudson formation in Arkansas, 250 251. 253: in Jouisiana, 12, 213, 214: in Missouri. 180; in Texas, 223, 224. $225,227,237$

Port Lonisa township, Louisa Co., Iowa. 291

Port Sullivan, Robertson Co., Texas. 228

Port Sullivan Shoals, Robertson Co., Texas, 127,244

Post, Farza Co.. Texas, 1?, 240

Postrille, Allamaliee Co., Iowa. 117. 286

Pottawattanie Co., Iowa, 6, 183, 196, 210 , 295

Pottawatomie Co., Kansas, 48, 269

Potts. R. .., 227

Powder River, Johnson Co., Wyoming, 101, 305

Poweshiek Co, Iowa, 50, 75, 293

Prairie Grove, Clarke Co., Iowa, 205

Pratt. W. H., 53, 289

Price's Salt Works, I,ouisiana, 10, 220

Princeton Iniversity, New Jersey, 85. 207

Procamelus sp. indet, in Montana, 169, 312

Procyon lotor in Arkansas, 252

Protohippus sp. indet. in Montans, 169, 312

Pryor Creek, Crow Reservation, Montana, 46 , 312

Pueblo Co., Colorado, 35 
Quanah, Hardeman Co., Texas, 103, 125, 234,240

Quinlan, Hunt Co., Texas, 2, 125

Raccoon River, Polk Co., Iowa, 116

Randall Co., Texas, 12, 123, 224, 238

Rangifer caribou in Minnesota, 177, 199, 208 , 307 ; R. muscatinensis in Iowa, 176, 196 . $291 ; \mathrm{R}$. sp. indet. in Iowa, 52, 176, Rantoul, Franklin Co., Kansas, 70

Ravenna, Buffalo Co., Nebraska, 80, 303 Raw Hide Butte, Laramie Co., Wyoming, 118,

Rayburn's Salt Works, Louisiana, 10

Reagan, A. B., 257

Reagan, Falls Co., Texas, 127, 243

Red Cloud, Webster Co., Nebraska, 8, 303

Red Deer Co., Alberta, 209

Red Deer, Red Deer Co., Alberta, 209, 317

Red Oak, Montgomery Co., Iowa, 75, 294

Red River, terraces of, 224, 225

Red Willow Co., Nebraska, 118, 304

Reithrodontomys simplicidens in Arkansas, 251

Reno Co., Kansas, 71, 267

Reynolds, Jefferson Co., Nebraska, 99, 168 302,303

Reynosa formation, Texas, 230, 231

Rhabdobunus mirificus, 39 (See Anancus mirificus)

Rice Co., Minnesota, 45, 308

Richardson, G. B., 73, 112, 134, 155, 222, 234,273

Richardson, John, 121

Richfleld, Sarpy Co.. Nebraska, 198, 303

Richmond, Fort Bend Co., Texas, 106, 162, 246

Ridgeway, Winneshiek Co., Iowa, 150

Riley Co., Kansas, 35, 111, 193,269

Rio Grande in New Mexico, 222, 257, 258 in Texas, 234

Ripon, Cass Co., North Dakota, 120, 310

Rippey, Greene Co., Iowa, 42, 300

River Junction, Johnson Co., Iowa, 113, 292

Robertson Co., Texas, 127, 228, 244

Robinson, Doane, 45, 82, 199

Robstown, Nueces Co., Texas, 93, 249

Rock Creek, Briscoe Co., Texas, 57, 123, 124 $157,161,239$

Rock Creek Canyon, Texas, 1, 222

Rock Creek Township, Jasper Co., Iowa, 204,293

Rock Hill, Collin Co., Texas, 58, 240

Rock Rapids, Lyon Co., Iowa, 52, 300

Rockport. Atchison Co., Missouri, 69, 139, 164,261

Rose, Bruce, 316

Rosebud Co., Montana, 83, 312

Rosebud, Rosebud Co., Montana, 83, 312

Rouse, Huerfano Co., Colorado, 143, 273

Routt Co., Colorado, 74, 273

Rubey, W. W., 95

Runkel, Lawrence Co., South Dakota, 153

Running Water, Hale Co., Texas, 102, 232, 239

Rush Co., Kansas, 111, 269

Rush Center, Rush Co., Kansas, 111, 269

Russell Co., Kansas, 95, 141

Russell, Russell Co., Kansas, 95, 141

Russell Springs, Logan Co., Kansas, 111, 165, 204,270

Sac Co., Iowa, 116, 298

Sacramento Mountains, Otero Co., New Mexico, 67, 258

St. Augustine Co., Texas, 226

St. Clair Co., Missouri, 29, 266 St. George, Pottawatomie Co., Kansas, 48,

St. Joseph, Buchanan Co., Missouri, 32, 261

St. Landry Parish, Louisiana, 11, 155, 220

St. Louis, Missouri, 31, 181, 262

St. Louis Academy of Sciences, 179

St. Louis University, 84

St. Paul, Minnesota, 306

St. Genevieve Co., Missouri, 31
St. Mary Parish, Louisiana, 220

Salado Creek, Bexar Co., Texas, 65, 248

Salem, Henry Co., Iowa, 36, 293

Saline Co., Missouri, 31, 264; Nebraska, 79, $101,118,151,303$

Salisbury, R. T., 250

San Angelo, Tom Greene Co., Texas, 14, 88, 229,240

San Antonio, Bexar Co., Texas, 16, 65, 131, $223,230,248$

San Antonio River, Texas, terraces of, 229

San Antonio Scientific Society, 88

San Augustine Co., Texas, 19, 242

San Bernard River, Austin Co., Texas, 93

San Bernardo Creek, Brazoria Co., Texas, 106,246

San Diego Creek, Texas, 249

San Diego, Duval Co., Texas, 66, 131, 248

Sandoval Co., New Mexico, 68, 108, 257

Sandspring, Delaware Co., Iowa, 149, 288

San Felipe, Austin Co., Texas, 3, 20, 62, 92, $156,162,189,246$

San Jacinto Co., Texas, 19, 105, 227, 242

San Juan Mountains, Colorado, 272

San Leon, Galveston Co., Texas, 63, 92, 105, 127,242

San Marcos, Hays Co., Texas, 201, 248

San Miguel Co., New Mexíco, 68

Sangamon stage and deposits in Iowa, 52, $276,284,290$; in Louisiana, 215

Santa Fé Co., New Mexico, 69, 138, 257

Santa Fé, Santa Fè Co., New Mexico, 69, 257

Sardeson, F. W., 44, 306, 307

Sarpy Co., Nebraska, 198

Saskatchewan, Elephas columbi in, 84 ; Pleistocene geology of, 313, 314, 316 ; indet. elephants in, 121

Satin. Falls Co., Texas, 61, 243

Saunders, D. A., 2

Savage, .T., 174

Savage, T. E., $36,42,51,75,78$

Scalopus aquaticus in Arkansas, 252 ; S. sp. indet. in Nebraska, 304

Schoewe, W. H., 284

Sciurus hudsonicus in Arkansas, 251

Scott, W. B., 81, 266

Scott Co., Iowa, 41, 53, 78, 116, 289, 290

Screw-bean bridge, Guadalupe Co., Texas, 131

Sedalia, Pettis Co., Missouri, 29, 265

Seguin, Caldwell Co.. Texas, 131

Sellards, $\mathrm{E}, \mathrm{H}, 3,66,107,229$

Selma, Van Buren Co., Iowa, 37, 293

Seneca, Nemaha Co., Kansas, 269; Thomas Co., Nebraska, 44, 100, 152, 159, 168 302,304

Seward Co., Nebraska, 79, 303

Seward, Seward Co., Nebraska, 79, 303

Seymour beds in Texas, 201, 233, 242

Shannon Co., South Dakota, 45

Sharon Springs, Wallace Co., Kansas, 72, 270

Shelby Co., Iowa, 211, 295

Shellsburg, Benton Co., Iowa, 42, 288, 289

Sheridan Co., Kansas, 194, 269; Montana, 169 ; Nebraska, $8,9,81,100,152,160$, $168,211,302,304$

Sheridan stage and deposits in Kansas, 6, 95, 266 ; in Nebraska, $43,55,56,81,100$, 158. 302 ; in Texas, 2, 223 (See Equus beds)

Sherman, Grayson Co., Texas, 190, 240

Sherman Co., Kansas, 157, 158, 270

Shimek, $7,38,39,77,97,148,149,158,174$ $176,183,205,207,212,250,278,280$ $285,289,291,294,299,301,309$

Shreveport, Louisiana, 122, 220

Shuler, E. W., 86, 126, 226

Shumard, B. F., $139,224,262$

Sidney, Cheyenne Co., Nebraska, 81, 304

Silver Bow Co., Montana, 120

Silver Cliff, Custer Co., Colorado, 144, 273 , 275

Silverton, Briscoe Co., Texas, 123

Sioux City Academy of Science, 40

Sioux City, Woodbury Co., Iowa, 7, 148, 158, 298

Sioux Co., Nebraska, 56, 185, 305 
Sloux Falls, South Dakota, 82, 120, 153, 212, $309, \quad 310$

Skidmore, Bee Co., Texas, 66, 248

skunk IRiver, Henry Co., Inwa, 293

Similodon nebrascensis in Nebraska, 305; S sp. indet. in Kansas, 204, 268; in Texas, 228,243

Smilodontopsis conardi in Arkansas, 252; S. troglodytes in Arkansas, 252

Smitlı Co., Ḱansas, 111

Socorro Co., New Mexico, 108

Sorex fumeus in Arkansas, 252; S. obscurus in Arkansas, 252 ; S. personatus in Arkansas, 252: S. personatus fossidens, in Arkansas, 252

Sour Iake, IÍardin Co., Texas, 20, 126, 237, 242

South Canyon, Garfield Co., C'olorado, 145

South Dakota, Camelidre in, 168 ; Castoroides in, 212; Flephas columbi in, 82 ; Equidre in. 153; extinct bisons in, 199; mastodons in, 45 : Pleistocene geology of, 308 ; undetermined elephants in, 120; Xenarthra in, ?

South Tule Creek, Swisher Co., Texas, 124, 232

Southern Methodist University. 58, 85

Sparta, Bell Co., Texas, 16, 243

Speegleville, McIennan Co., Texas, 2, 16, 228,243

Spencer, J. W., 180

Spilogale interrupta in Arkansas, 252

Springfield, Greene Co., Missourt, 25, 265

Springville, Iinn Co.. Iowa, 42, 288

Spur, Dickens Co., Texas, 240

Staked Plains. Texas, 231

Stanley Co., South Dakota, 9, 153, 310

State Agricultural College, Colorado. 144

State Historical and Nat. Hist. Society of Colorado, 73,96

State Tniversity of Iowa, 148, 174, 210; of Ohio, 184: of Oklahoma, 94

Stearns Co., Minnesotn, 44

Stegomastodon mirificus in Iowa. 7, 299: in Kansas, 35: in Nebraska, 44, 100, 168 , 304 (See Anancus mirificiss)

Stephenson, I. W., 65, 190, 240, 249, 250, 260

Sternberg, C. H.. 48, 71, 95, 142, 165. 194

Stillwater, Washington Co., Minnesota, 44. 308

Stock, Chester, 6, 218

Stockton, Winona Co., Minnesota, 119, 308

Stone Co., Missouri, 24, 266

Stonewall Co., Texas, 234

Stort Co., Iowa, 174, 175, 300

Sugar Creek. Iee Co., Iowa, 112

Sulphur Creek, Live Oak Co., Texas, 90, 248

Sumner Co., Kansas, 95, 193, 268

Sutton, Clay Co.. Nebraska, 43, 99, 302, 303

Swallow, G. C., 31, 109, 140, 262

Sweetland township, Muscatine Co., Iowa, 115,291

Sweetwater, Nolan Co., Texas, 58, 186, 240 Swisher Co., Texas, 85, 124, 222, 224, 232, 238

Sylvilagus floridanus in Arkansas, 252; in Iowa, 276; S. sp. indet. in Texas. 247

Symbos australis in Arkansas, 178, 251; S cavifrons in Iowa, 182, 183, 294, 295, 296 ; in Kansas, 181, 269 ; in Missouri, $31,110,139,179,180,181,262,264$; in Nebraska, 184, 303; in Oklalıoma, 191. $255 ; \mathrm{S}$. promptus in Oklahoma, 178 , 254,255 ; S. sp. indet. in Iowa, 179

Tackner, Benton Co., Missouri, 28, 69, 157, 180,265

Tagassu lenis in Iowa, 159, 287

Tagassuidæ, 157

Trma Co., Iowa, 78, 288

Tama, Tama Co., Iowa, 78, 288

Tumias nasutus in Arkansas, 25

Taos Co. New Mexico, 24, 257

Taos, Taos Co., New Mexico, 24, 257
Tapir in Texas, 47, 129, 162 (See Tapirus) Tapiridis in Loufsians, 155; in Oklahoma, 156 ; in Texas, 155

Tapirus americanus in Louisiana, 155: In Texas, 156: T. haysli in Texas, 134, 155,$249 ; \quad T$. sp. indet. in Iouisiona, 215; in Oklahoma, 256; in Texas, 243, 246: $T$. terrestris in Iouislana, 15.)

Tarancahnus C'reek, Duval Co., Texas, 66, 131

Tarrant Co., Texas, 13, 58, 85, 226, 241

'Tascosa, Oldham Co., Texas, 12, 102

Taurotragus americanus in Missourf, 263, 264

Taxidea taxus in Kansas, 270

Taylor, William, 66

Tecumseh, Johnson Co., Nebraska, 8, 30?

Teleoceras in Montana, 312, 313

Tell, Chlldress Co., Texas, 102

Teller Co., Colorado, 72

Temple, Bell Co., Texas, 2, 47, 61, 87, 104, $129,155,161,228,243$

Terlingua, Irewster Co., Texas, 2, 134, 249

Terraces of Brazos River, 223, 227 ; of Colorado River, Texas, 221, 228, 229: of Guadalupe River, Texas, 229 ; of Lenn River, Texas, 223, 228: of Missouri River. North Dakota, 311 ; of rivers in Montana, 311; of Netchez River. Texas. 225 ; of Nueces River, Texas, 230; of Red River, Texas, 224: of San Antonio River, 229 ; of Trinity River, Texas, 226

Terrapene bulverda in Texas, 247 : $T$. impressa in Texas, 245 ; $T$. whitneyi in Texas, 245, 247

Testudo annæ in Texas, 227, 241, 245; $\mathrm{T}$. a tascosie in Texas, 248,249 ; $T$. campester in Texas, 239; T. equicomes in Kansas, 270 : $T$. francisi, $162,242,243: T$. hexagonata in Texas, 239 ; T. laticaudata in Texas, $239 ; \mathrm{T}$. sp. indet. in Texas, 3, $18,128,242$

Tetracaulodon collinsii, 28

Tetrameryx shuleri in Texas, 224, 226, 241, 244

Texas. Bison bison in, 201; Camelidæ in, 161 ; Castoroides in, 210 : Elephas boreus in, 47 : E. columbi in, 57 ; E. imperator in, 85: Equidx in, 123 ; extinct bisons in, 186 : mastodons in, 12 ; Odocoileus in, 170: peccaries in, 157 ; Pleistocene geology of, 221 ; Tapiridæ in, 155 ; undetermined elephants in, 102 ; Xenarthra in, 1

Thayer Co., Nebraska, 99, 303

Thayer, Union Co., Iowa, 278

Thom, W. T., 312

Thomas, A. O., 36, 40, 171, 175, 198, 211 , 300

Thomas Co., Nebraska, 44, 100, 152, 159, 302,304

Thomomys sp. indet. in Nebraska, 304, 305

Thomson, Albert, 81, 304

Thurston Co., Nebraska, 43, 207. 304

Tilton, John L., 38, 113, 172, $176,182,183$, 196,294

Tinsley, R. W., 88

Titus Co., Texas, 225

Todd, J. F., $6,34,110,114,120,141,148$, 153. 192, 193, 259, 267, 268, 298, 309 , 310

Tom Greene Co., Texas, 14, 88, 229, 240

Tongue River, Montana, 83

Trachemrs bisornata in Texas, 248 ; $\mathrm{T}$. petrolei in Texas, 242 ; $T$. trulla in Texas, 242

Travis Co., Texas, 16, 104, 130, 189, 221, 229,247

Trenton. Henry Co., Iowa, 36, 74, 293

Trinity Co., Texas, 19, 59, 105, 126, 242

Trinity River, terraces of, 221,226

Trinity, Trinity Co., Texas, 59

Trowbridge, A. C., 235

Troxell, I. L., 1, 4, 23, 108, 157, 171, 256

Trucifelis fatalis in Texas, 241, 242

Truman, Poinsett Co., Arkansas, 22, 253

Tulane University, 217 
Tule Canyon, Swisher Co., Texas, 85, 222, 232

Tulip, Fannin Co., Texas, 58, 240

Turin, Monona Co., Iowa, $7,38,77,147$, $168,172,174,205,211,297$

Turkey Creek. Clay Co., South Dakota, 168

Twelve-mile Creek, Logan Co., Kansas, 143, 194,270

Twelve-mile Creek, Smith Co., Kansas, 111

Tyrrell, J. B., 314,315

Udden, J. A., 14, 16, 40, 50, 75, 76, 112, 115 , $171,196,211,236,291$

Uhler, F. W., 199

Uinta Co., Wyyoming, 152, 208, 305

Union Co., Iowa, 146, 278; South Dakota, 153,309

Union Township, Louisa Co., Iowa, 50

U. S. Geological Survey, 106

U. S. National Museum, $65,66,68,69,81$, $82-84,94,106,127,152,153,166,188$, $190,192,197,199,201-205,208,211$, $258,263,274$

University of Colorado, 96, 97, 204; of $\mathrm{Ne}$ braska, 78 ; of Texas, 64,91

Upham, Warren, 120, 200, 306, 315, 316

Urocyon sp. indet. in Arkansas, 252

Ursus americanus in Arkansas, 252; in Iowa, 296 ; in Texas, 247

Uvalde formation in Texas, 229, 230, 235

Valentine, Cherry Co., Nebraska, 44, 304

Valier, Pondera Co., Montana, 101, 312

Valverde Co., Texas, 234

Van Buren Co., Iowa, 37, 293

Vanhem, Clark Co., Kansas, 110

Van Tuyle, F. M., 53

Vaughan, T. W., $86,225,229,230,231,235$

Veatch, A. C., $10,213,218,220,251$

Vernon, Wilbarger Co. Texas, 58, 201, 240

Victoria Co., Texas, 21, 64, 107, 163, 248

Virginia City, Montana, 84, 312

Virginia deer, 174 (See Odocoileus)

Vulpes fulva in Arkansas, 252

Wabasha Co., Minnesota, 56, 185

Wabasha, Wabasha Co., Minnesota, 56, 308

Waco, McLennan Co., Texas, 60, 88, 127 , $161,227,243$

Wagner Institute, Philadelphia, 133

Wagner township, Clayton Co., Iowa, 117, 287

Wakarusa Creek. Douglas Co., Kansas, 33 , $174,203,268$

Walker, Cleveland Co., Oklahoma, 23, 256

Walker, J. B., 162

Wallace Co., Kansas, 72, 270

Waller Co., Texas, 20, 63, 129, 246

Wallis Station, Austin Co.. Texas, 188, 246

Walnut Springs, Bosque Co., Texas, 202

Walnut township, Jefferson Co., Iowa, 112 , 293

Walsenburg, Huerfano Co., Colorado, 6, 273

Wapello Co., Iowa, 37, 171, 293,294

Wapello, Louisa Co., Iowa, 53, 171, 291

Warren Co., Iowa, 37, 113, 182

Warren, E. R., 144, 182, 195

Warren River, Minnesota, 307

Washington Co., Iowa, 293; Minnesota, 44, 308: Missouri, 31; Texas, 3, 18, 19, 62, $90,128,188,244,245,246$

Vashington township, Pottawattamie Co., Iowa, 114, 295 ; Story Co., Iowa, 175, 300

Waterloo, Black Hawk Co, Iowa, 53, 288

Wauneta, Chase Co., Nebraska, 99, 302, 304

Waxahatchie, Ellis Co., Texas, 59, 86, 241

Wayland, Henry Co., Iowa, 7, 36

Webster City, Hamilton Co., Iowa, 197, 300

Webster Co., Iowa, 207 ; Nebraska, 8, 303

Webster Parish, Louisiana, 10, 220
Weld Co., Colorado, 74, 145, 274

Wellington, Douglas Co., Colorado, 204 ; Lafayette Co. Missouri, 110, 181, 264;

Larimer Co., Colorado, 274 ; Sumner Co., Kansas, 95, 193,270

West, H. H., 32

West Cliff, Custer Co., Colorado, 167, 273, 275

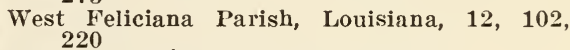

West Union, Fayette Co., Iowa, 50

Wharton Co., Texas, 63, 130, 247

Wheeler Co., Texas, 1, 224, 234

Whipple, S. H.. 28, 47, 69, 139, 180

White, C. A. 41

White Flat, Motley Co., Texas, 124, 240

White Rock Shoals, Trinity Co., Texas, 105, 126, 242; San Jacinto Co., Texas, 227

Whitney, F. L., 65, 91

Whitney, J. D., 7, 159

Wichita Co., Texas, 103, 161, 190, 224, 240

Wilbarger Co., Texas, 58, 201, 224

Wilber, Saline Co., Nebraska, 79, 303

Wilder, F. C., 207

Wild Horse Creek, Borden Co., Texas, 232; Howard Co., Texas, 125, 240

Willard, D. E., 306

Willcockson, Newton Co., Arkansas, 134, 157, $170,173,178,251$

Williamson Co., Texas, 88, 104, 130, 221, 246 Williston, S. W., 5, 33, 35, 71, 111, 142, 157 , $158,192,193,194$

Wilmer, Dallas Co., Texas, 13, 241

W'ilson Co., Kansas, 33, 269

Wilson, Eilsworth Co., Kansas, 181, 269

Wilson, W. B., 70

Wilton. Muscatine Co., Iowa, 41, 290

Winchell, N. H., 44, 45, 56, 83, 118, 119, $208,212,306$

Winn Parish, Louisiana, 10, 220

Winnebago Reservation, Thurston Co., Nebraska, 207, 304

Winneshiek Co., Iowa, 150, 287

Winona Co., Minnesota, 45, 119, 208

Winthrop, Buchanan Co., Iowa, 288

Winton, W. M., $14,58,226$

Wisconsin stage and deposits in Iowa, 42, 78,286 ; in Minnesota, 307 ; in Montana, 311,312 ; in North Dakota, 310 ; in South Dakota, 309

Wislizenius, A., 30

Witter, F. M., 176

Wolfe City, Hunt Co., Texas, 2, 223, 240

Woodbine, Harrison Co., Iowa, 183, 296

Woodbury Co., Iowa, 7, 52, 158, 176, 197, 298

Wortman, J. L., 71,168

Wyoming, Bison bison in, 208; Elephas columbi in, 81 ; E. imperator in, 101 : Equidæ in, 152; Pleistocene geology of. 305 ; undetermined elephants in, 118

Wyoming, Otoe Co., Nebraska, 184, 303

Wyman, Jeffries, 3, 20, 106, 158

Xenarthra in Colorado, 6; in Iowa, 6 ; in Kansas, 5 ; in Louisiana, 1 ; in Minnesota, 9 ; in Missouri, 4; in Nebraska, 7 ; in Oklahoma, 4; in South Dakota, 9 in Texas, 1,238

Yale Úniversity, 80,86

Yankton Co., South Dakota, 82, 310

Yarmouth, Des Moines Co., Iowa, 283, 292

Yarmouth stage and deposits in Iowa, 75, 276,283

York Factory, Manitoba, 154, 317

York Co.. Nebraska, 303

Zavalla Co.. Texas, 235

Zumbrota River, Minnesota, 185

Zuni, McKinley Co., New Mexico, 259 



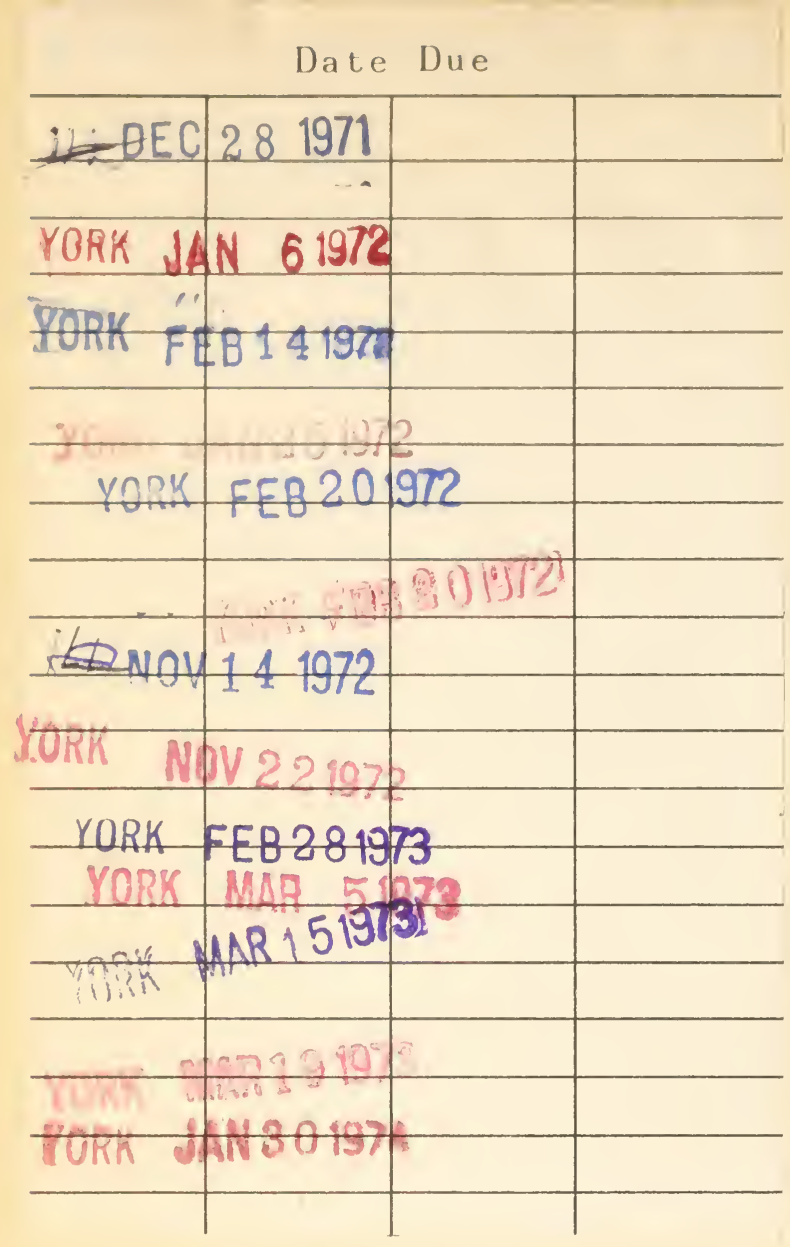




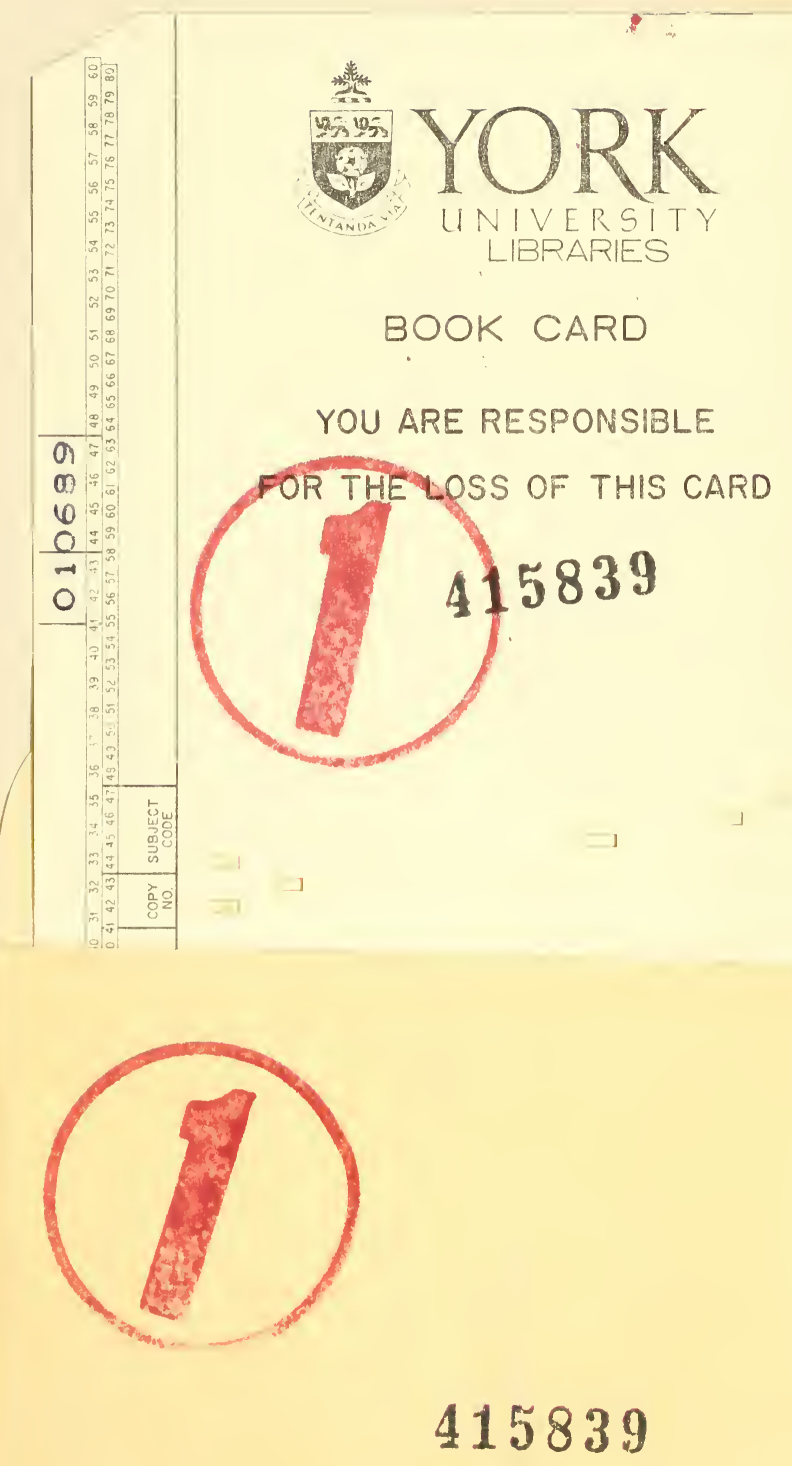


